JULIANA AUGUSTA MEDEIROS DE BARROS

\title{
A INTERPRETAÇÃO CONSTITUCIONAL EVOLUTIVA E A CIDADANIA SOCIAL: elementos para uma hermenêutica jurisdicional de implementação efetiva dos direitos fundamentais trabalhistas
}

\author{
TESE DE DOUTORADO
}

Orientador: Prof. DOUTOR Estévão Mallet 


\section{A INTERPRETAÇÃO CONSTITUCIONAL EVOLUTIVA E A CIDADANIA SOCIAL:} elementos para uma hermenêutica jurisdicional de implementação efetiva dos direitos fundamentais trabalhistas

Tese de Doutorado apresentada como requisito parcial para a obtenção do título de Doutor no Programa de Pós-Graduação da Faculdade de Direito da Universidade de São Paulo, pela doutoranda Juliana Augusta Medeiros de Barros

Orientador: Professor Doutor Estévão Mallet 


\section{A INTERPRETAÇÃO CONSTITUCIONAL EVOLUTIVA E A CIDADANIA}

SOCIAL: elementos para uma hermenêutica jurisdicional de implementação efetiva dos direitos fundamentais trabalhistas

Tese defendida e com média final igual a como requisito para a obtenção do título de doutor em Direito, área de concentração em Direito do Trabalho, junto à Faculdade de Direito da Universidade de São Paulo.

Belo Horizonte, 2011.

Prof. Doutor Estévão Mallet (Orientador) - USP 
Dedico essa tese ass trabalhadores brasileiros que têm muitos de seus direitos fundamentais trabalhistas nâo implementados efetivamente, seja pela ausência de his regulamentadoras on de politicas públicas, seja em virkude de uma akuação reskitiva dos órgãos do Poder fudiciário que, diversas vezes, se reskingem a interpretar involutivamente as normas que estabelecem tais direitos; ass empregados cujos direitos fundamentais não são obserwados pelos empregadores, sob o argumento de que as normas que os instituem não têm aplicabilidade alguma e, por isso, podem ser desprezados em toda a sua amplitude; e aos adrogados que pleiteiam judicialmente uma leitura dos diveitos fundamentais trabalhistas mais consentânea com a realidade social e aos juizes que têm atuado de modo a implementar, de forma ampliativa, esses diveitos constitucionais, concretizando o princípio da cidadania social do trabalhador.

Dedico o resultado dessa kese ass aplicadores do Direito que atuam na Iustica do Trabalho, on seja, ass adrogados, ass procuradores e, sobretudo, ass juizes do trabalho, para que possam interpretar as normas que estabelecem os direitos fundamentais do trabalhador, previstos na Constituicão Federal de 1988, valendo-se dos princípios e métodos da hermenêutica constitucional e pautando-se por uma interpretação "evolutiva" que leve em conta as alteraçôes ocorridas na realidade vivenciada pelos trabalhadores, garantindo, por meio de decisóes justas e fundamentadas, a máxima aplicabilidade das referidas normas e e exercicio efetivo de tais direitos sociais pelos cidadãos trabalhadores. 


\section{Agradecimentos}

Antes de tudo, agradeço à energia divina que denominamos Deus, por ter me dado forças nesses últimos anos para superar as adversidades que surgiram em meus caminhos, fazendo-me com que eu pudesse prosseguir.

Aos meus pais, exemplos de caráter e dedicação à família, agradeço imensamente por me propiciarem uma educação formal e informal pautada por valores como ética, humanidade e sensibilidade, que me tornaram a pessoa que sou hoje. Agradeço, também, por me apoiarem na decisão de optar pela continuidade dos estudos, minha eterna "paixão", mesmo tendo que abdicar, por uma vez, de um trabalho. E, ainda, por terem me mostrado, desde cedo, pelas suas próprias trajetórias de vida, que a profissão de professor e educador se revela da mais sublime importância para a formação do ser humano.

Ao meu irmão Fred e à Elisângela, por me abrigarem em sua casa durante a estada no Rio de Janeiro, antes de vir em definitivo para São Paulo. À minha irmã Germane e ao seu marido, pelas palavras trocadas e por acompanharem os meus passos. E ao meu irmão Gustavo, pelo companheirismo e pelas conversas durante esses anos de estudo.

Aos meus queridos Yuri e João Otávio, por me fazerem sorrir em muitos momentos pesados e difíceis.

Agradeço ao incentivo recebido dos professores do Mestrado, Márcio Túlio Viana, Mauricio Godinho Delgado e, especialmente, Luiz Otávio Linhares Renault, por trocar ideias sobre a intenção de cursar o Doutorado na USP, e José Roberto Freire Pimenta, que, ao saber do meu ingresso no curso, meu deu grande apoio.

Aos meus amigos, que sempre apóiam as minhas escolhas e me acompanham nessa trajetória de vida, compartilhando sonhos, tristezas e alegrias.

Agradeço, especificamente, a duas pessoas nessa trajetória do Doutorado. À Gesanne F. Gomes, pelo incentivo quando decidi tentar ingressar no curso de PósGraduação da USP, acreditando na minha capacidade e na minha vontade de prosseguir na vida acadêmica. E ao Guilherme De Marco F. Horta, que, nos últimos dois anos, em nenhum momento me deixou de estender as mãos e me ouvir com sensibilidade, mesmo nas horas mais dificeis e nos momentos mais pesados pelos quais passei e, ainda, pela ajuda com materiais essenciais para a feitura dessa tese.

Aos amigos e colegas, Andréa Cançado, Carolina Mesquita, Darlén Prietsch, Isabela Alcântara, Pedro Gontijo e Roberta Dantas, pelo auxílio com materiais imprescindíveis para a confecção desse trabalho.

Aos meus colegas de Doutorado, e especialmente, aos meus amigos de orientação, Francislene Souza, Luciano Martinez, Eduardo Arturo e Túlio Macedo Rosa, pelo apoio que me deram nas minhas rotinas de doutoranda e por trocarem ideias durante essa jornada. 
Aos professores do Doutorado, Doutores Estévão Mallet, Enoque Ribeiro dos Santos, Antônio Rodrigues de Freitas Júnior, Otávio Pinto e Silva, Paulo Eduardo Vieira de Oliveira, Jorge Luiz Souto Maior, André de Carvalho Ramos, Guilherme Assis de Almeida, Celso Lafer e Calixto Salomão Filho, dos quais tive o privilégio de ser aluna, por compartilharem o seu vasto conhecimento em sala de aula, fazendo-me aprender muito sobre o Direito do Trabalho, o Processo do Trabalho e os Direitos Humanos.

Agradeço, especialmente e de forma honrosa, ao Professor e Orientador Estévão Mallet, pela oportunidade de ser sua orientanda, aluna de pós-graduação e ouvinte das aulas de graduação, atividades essenciais para o meu engrandecimento acadêmico e profissional, e pela consideração durante esses três anos do Doutorado, sempre dispensando a atenção requerida e sendo solícito às minhas indagações, inclusive sobre a presente tese. Agradeço-lhe, ainda, pela convivência com um professor exemplar, pela inteligência e organização de suas aulas, cujo profissionalismo e seriedade na vida de advogado e docente me servem de modelo a ser constantemente perseguido.

Agradeço aos professores da banca de qualificação, pelas considerações, críticas e correções essenciais para a realização e bom andamento dessa tese de Doutorado, contribuições essas que acatei prontamente.

À Universidade de São Paulo, por ajudar a me propiciar uma educação pública e de qualidade.

Aos funcionários da Pós-Graduação da Faculdade de Direito da USP, pelo bom trabalho prestado nas atividades administrativas relativas ao Doutorado, essencial para a qualidade do Curso.

Agradeço, também, aos profissionais que me oportunizaram trabalhar no Gabinete n. 200 do TRT-MG, Desembargador Dr. Emerson José Alves Lage, Miriam Tonindadel, juíza Dra. Maristela Iris da Silva Malheiros, Ricardo Wagner Rodrigues de Carvalho e Andréa Aparecida Lopes Cançado, pelo profundo aprendizado que venho adquirindo, em termos práticos, sobre o Direito do Trabalho, pelo salutar compartilhamento da experiência e pela excelência do trabalho realizado no referido Gabinete. Agradeço, ainda, ao Dr. Emerson, à Miriam, às chefes de gabinete Denise e Nair e à assistente de gabinete Gislaine, pela compreensão e pelo apoio no que tange aos estudos do Doutorado, sem os quais teria sido impossivel concluir essa Pós-Graduação. E aos colegas assistentes, por terem me recebido de braços abertos.

Agradeço, por fim, aos meus ex-alunos da FAMIG e alunos do CEAJUFE, que foram e são essenciais para o meu aprimoramento enquanto professora e que sempre estão a me ensinar lições de vida, compartilhando, de forma frutífera, o dialético processo de ensino-aprendizagem. 
$\mathcal{O}$ Direito possui um fim belissimo em favor do qual devemos lutar: a realizacão da Gustiça. Mair do que um artista, o jurista pode talhar, sem retalhos, a solução - mãos justas e equânimes para determinada controvérsia. Sodavia, sem os fatos, sem a realidade, o Direito não tem vida; sua soma é nula, seu fim são fragmentos sem colagem.

Sulgar é um ato solitário, que requer ciência e consciência social. Recolhido em seu âmago, em seu interior, em seu intimo, em seu debate unilateral, em seu monólogo inquietante, em seu ventríloquo diálogo, o juiz não pode desprezar o mundo que o cerca - estar em si e fora de si, para realizar a justica em quem e para quem a pede. Oo momento do julgamento, o seu pensar tem de estar poroado pela realidade social, da qual é parke, agente e ator.

Duummond, num misto de lamento e de regozijo, acenou, em célebre poema, que: "kenho apenas anas mãos e o sentimento do mundo". Os juizes igualmente. Jềm eles o ordenamento juridico e o sentimento do mundo. Essa a matéria bruta com a qual lidam no seu dia a dia, para o desempenho de sua árdua Karefa de julgar. Os seus julgamentos, as suas decisêes, as snas sentenças são o reflexo do seu sentimento, da sua compreensão do Direito e do mundo em que vivem, krabalham, estudam, amam e desamam, se divertem, se alegram, se entristecem, riem e choram. Lapidar o Direito e es fatos é a sua karefa maior e mais nobre. Se as juizes não puderem estar mais-além do seu kempo, que pelo menos estejam no seu kempo; nunca aquém.

$\mathcal{O}$ mundo kransforma-se cada vez mais rapidamente. As leis muito lentamente. Quem avisa e akualiza o Direito, são os intérpretes. Ler é reler. É apreender o sentido de cada palavra, de cada frase e do conjunto. Ler é, portanto e acima de tudo, interpretar, compreender e atribuir um sentide social e atual ao que foi dito pelo legislador, visando as bem comum.

$\mathfrak{L i n}_{\text {ing }}$ Oásio Linhares Renault 


\section{RESUMO}

Os direitos sociais são fruto das lutas dos indivíduos por melhores condições de trabalho e de vida ao longo dos séculos XVIII e XIX, embora os direitos mínimos dos trabalhadores somente tenham sido sistematicamente inseridos nas Constituições e albergados pelos diplomas internacionais ao no decorrer do século XX. No Brasil, os direitos fundamentais do trabalhador foram elencados na Constituição Federal de 1934 e, a partir de então, foram sendo ampliados até a Constituição Federal de 1988, nomeada de "cidadã", que inaugurou um marco na constitucionalização desses direitos sociais, integrando-os efetivamente ao rol dos direitos fundamentais, conferindo-lhes aplicabilidade imediata e natureza de cláusulas pétreas. Toda essa sistemática traçada pelo legislador constituinte exige que os aplicadores do Direito tratem esses direitos trabalhistas como realmente fundamentais, inclusive no que tange às questões relativas à eficácia jurídica, efetividade e aplicabilidade. Ao lado do dilema da falta de efetividade das normas que estabelecem esses direitos, pela cultura de seu descumprimento reiterado pelos empregadores, existe outro problema igualmente grave: a ausência de implementação ou a implementação restritiva de vários direitos fundamentais trabalhistas, tanto pela ausência de leis infraconstitucionais que regulamentem as normas que os estatuem, quanto pela interpretação jurisdicional que lhes é conferida. Embora com alguns avanços no campo hermenêutico, a atuação do Poder Judiciário ainda tem sido insuficiente para a implementação plena dos direitos fundamentais sociais, tanto em virtude das resistências externas a uma postura mais ativa do Judiciário, quanto pela tendência de auto-restrição dos juízes em se aceitarem como órgãos legítimos para concretizar os direitos sociais esculpidos na Constituição. Ambos os problemas têm fulcro em uma concepção teórica restritiva de cidadania e, consequentemente, do exercício efetivo dos direitos fundamentais sociais pelos seus titulares, e em uma leitura desatualizada da teoria da separação dos poderes de Montesquieu, que desconsidera o Poder Judiciário como destinatário das normas de direitos fundamentais sociais. Sem embargo, a Constituição de 1988 adotou uma concepção de cidadania ampla, que pode ser denominada de cidadania "social", pois o cidadão tem não apenas a prerrogativa de exercer os seus direitos políticos e civis, como também os seus direitos sociais, além de poder requerer ao Judiciário a implementação dos direitos cujo exercício se encontra limitado, inclusive pela interpretação involutiva dos dispositivos constitucionais, totalmente desvinculada da realidade social. O cidadão tem garantido constitucionalmente o acesso a uma ordem jurídica justa, no sentido do acesso aos tribunais, do exercício do direito de ação, com todas as garantias concernentes ao devido processo legal, e de uma prestação jurisdicional adequada e em tempo razoável que concretize os direitos reconhecidos em juízo. Para isso, o juiz deve se valer não apenas da utilização de mecanismos processuais adequados, mas também, em se tratando de pleitos que envolvam direitos fundamentais, da interpretação evolutiva, isto é, da atribuição de novos conteúdos à norma constitucional, sem a alteração do texto do dispositivo constitucional, em virtude de mudanças sócio-econômico-políticas não previstas pelo constituinte. Embora existam exemplos de decisões, majoritárias ou pontuais proferidas por juízes ou pelos Tribunais do Trabalho, em que se vislumbra a interpretação constitucional evolutiva de alguns direitos fundamentais trabalhistas, para a implementação plena desses direitos a atuação desse ramo especializado do Judiciário deve ser mais incisiva e abrangente. Dessa forma, o intento da presente tese é demonstrar que, para garantir a implementação efetiva de vários direitos dos trabalhadores estabelecidos nos artigos $7^{\circ}$ a 11 da CF/88 e artigo 10 do ADCT, a Justiça do Trabalho deverá adotar uma hermenêutica jurisdicional pautada na interpretação evolutiva das normas constitucionais e na concepção ampliativa do exercício dos direitos fundamentais, fundada no princípio da cidadania social.

Palavras-chave: Direitos fundamentais trabalhistas. Interpretação constitucional evolutiva. Hermenêutica jurisdicional. Cidadania social. Justiça do Trabalho. Implementação efetiva dos direitos. 


\begin{abstract}
Social rights are the result of individuals' struggles for better working and living conditions in the eighteenth and nineteenth centuries, although the basic rights of workers have only been systematically inserted in the Constitution and encompassed by international treaties, covenants and declarations in the twentieth century. In Brazil, the fundamental rights of workers were listed in the Constitution of 1934 and, thereafter, have been extended to the Federal Constitution of 1988, referred to as "citizen", which represented a milestone for the constitutionalization of social rights, integrating them effectively to the role of fundamental rights and giving them instant applicability and the quality of entrenched clauses. The same procedure drafted by the constitutional legislators requires that lawenforcers see these labor rights as something really fundamental, including subjects related to the legal effectiveness, efficacy and applicability. Next to the dilemma of lack of effectiveness of the rules that determine these rights, that is to say the employers' culture of a repeated failure to comply with them, there is another equally serious problem: the lack of implementation or putting into effect, in a restrictive way, various fundamental labor rights, both because of the absence of infraconstitutional laws which regulate the rules that set them up, as well as the judicial interpretation they were given. Despite some advances in the hermeneutic field, the judiciary has still been not enough for the full implementation of fundamental social rights, both because of external opposition to a more active role of the judiciary, and by the self-restraint judges' tendency to accept themselves as a right and proper means for achieving the social rights guaranteed by the Brazilian Constitution. Both problems have a restrictive theoretical fulcrum conception of citizenship and, consequently, the effective exercise of fundamental social rights by their holders, and an outdated interpretation of the Montesquieu's theory of separation of powers, which disregards the judiciary as a recipient of the fundamental social rights standards. Nevertheless, the Constitution of 1988 adopted a broad conception of citizenship, which can be called "social" citizenship since citizens has not only the prerogative of exercising their civil and political rights, but also their social rights, as well as requesting the Judiciary for the implementation of rights which exercise is limited, even because of the involuting interpretation of constitutional provisions, totally divorced from social reality. Citizens have a constitutionally guaranteed access to a fair legal system in the sense of accessing courts, exercising the right of action, with all the guarantees pertaining to a due legal procedure and proper adjudication in a reasonable term that makes available the rights recognized in court. For that, judges must not only rely on the use of appropriate procedural mechanisms, but also, in case of claims involving fundamental rights, on the evolutionary interpretation, that is, assigning new content to the constitutional rules, without changing the text of the constitution because of socio-economic and political changes not foreseen by the constituent. Although there are examples of majoritarian or specific decisions taken by judges or by the Labor Courts, which are able to glimpse the evolving constitutional interpretation of some fundamental labor rights, for the full implementation of these rights, the performance of that specialized branch of the judiciary should be more incisive and comprehensive. Thus, the goal of this thesis is to demonstrate that to ensure the effective implementation of various workers' rights, as laid down in Articles 7 to 11 and Article 10 of CF/88 ADCT, the Labor Court should adopt judicial hermeneutics guided by the evolving interpretation of constitutional rules and the ampliative conception of exercising fundamental rights, based on the principle of social citizenship.
\end{abstract}

Keywords: Fundamental labor rights. Evolving constitutional interpretation. Judicial hermeneutics. Social citizenship. Labor Courts. Effective Implementation of rights. 


\section{RÉSUMÉ}

Les droits sociaux sont le fruit des luttes des individus pour de meilleures conditions de travail et de vie dès les XVIII ${ }^{\mathrm{e}}$ et XIX ${ }^{\mathrm{e}}$ siècles, bien que les droits minimaux des travailleurs n'aient seulement été insérés de manière systématique dans les constitutions nationales et reconnus par les conventions internationales qu'au cours du $\mathrm{XX}^{\mathrm{e}}$ siècle. Au Brésil, les droits fondamentaux du travailleur ont été considérés par la Constitution Fédérale de 1934 et, à partir de là, progressivement élargis jusqu'à la Constitution Fédérale de 1988, dénommée "citoyenne", qui est devenue un repère quant à la constitutionnalisation de ces droits sociaux en les inscrivant effectivement à la liste des droits fondamentaux, leur conférant une applicabilité immédiate et un caractère d'immuabilité. La systématique ainsi dessinée par le législateur constitutionnel exige que les droits du travail soient traités par les applicateurs du Droit comme droits fondamentaux vraiment, y compris en ce qui concerne les questions relatives à l'efficacité juridique, l'effectivité et l'applicabilité. Aux côtés du dilemme du manque d'effectivité des normes qui établissent ces droits de par la culture de leur inobservation réitérée de la part des employeurs, il existe un autre problème tout aussi grave : l'absence de mise en place, ou la mise en place restreinte, de nombreux droits fondamentaux des travailleurs, tout autant de par l'absence de lois infra-constitutionnelles réglementant les normes leur octroyant leur statut, que par l'interprétation juridictionnelle qui leur est attribuée. Bien que comptant quelques avancées dans le champ herméneutique, l'action du Pouvoir judiciaire a, jusqu'à maintenant, été insuffisante pour la pleine mise en œuvre des droits fondamentaux sociaux, tout autant de par des résistances externes à une posture plus active du Pouvoir judiciaire, que par la tendance à l'autorestriction des juges à s'accepter en tant qu'organe légitime pour concrétiser les droits sociaux inscrits dans la Constitution. Ces deux problèmes sont fondés sur une conception théorique restrictive de la citoyenneté et, en conséquence, de l'exercice effectif des droits fondamentaux sociaux de par ses titulaires, et d'une lecture outrepassée de la théorie de la séparation des pouvoirs de Montesquieu qui ne considère pas le Pouvoir judiciaire comme étant destinataire des normes de droits fondamentaux sociaux. Néanmoins, la Constitution de 1988 a adopté une conception ample de la citoyenneté, que l'on peut nommer de "citoyenneté sociale", où le citoyen n'a pas seulement la prérogative d'exercer ses droits politiques et civils, mais également ses droits sociaux, outre le fait de pouvoir saisir le Pouvoir judiciaire pour la mise en œuvre de droits dont l'exercice se trouverait limité, y compris dans le cas d'interprétation involutive des dispositions constitutionnelles, totalement déconnectée de la réalité sociale. Le citoyen possède la garantie constitutionnelle de l'accès à un ordre juridique juste, dans le sens de l'accès aux tribunaux, de l'exercice du droit d'action, et de toutes les garanties concernant une procédure légale correcte, ainsi que d'une prestation juridictionnelle adaptée et dans un délai raisonnable qui concrétise les droits reconnus par la justice. Pour ce faire, le juge doit faire valoir non seulement les mécanismes de procédure pertinents, mais également, s'agissant de revendications touchant aux droits fondamentaux, l'interprétation évolutive, c'est-à-dire l'attribution de nouveaux contenus à la norme constitutionnelle, sans altération des dispositions originelles, en vertu des changements socioéconomico-politiques non prévus dans les textes constitutionnels. Bien qu'il existe des exemples de décisions majoritairement ou isolément prononcées par des juges ou par les Tribunaux dans la Justice du travail, où l'on voit poindre une interprétation évolutive des normes constitutionnelles concernant certains droits fondamentaux des travailleurs, l'action dans cette branche spécialisée du Pouvoir judiciaire doit être plus large et incisive pour la pleine mise en œuvre de ces droits. C'est pourquoi l'intention de cette thèse est de démontrer qu'afin d'assurer la mise en place effective de certains droits des travailleurs, décrits aux articles $7^{\circ}$ à $11^{\circ}$ de la CF/88 et à l'article 10 de l'ADCT, la Justice du Travail devra adopter une herméneutique juridique orientée vers une interprétation évolutive des normes constitutionnelles et à partir d'une conception élargie de l'exercice des droits fondamentaux, fondée sur le principe de la citoyenneté sociale.

Mots-clés : Droits fondamentaux des travailleurs. Interprétation constitutionnelle évolutive. Herméneutique juridictionnelle. Citoyenneté sociale. Justice du Travail. Mise en place effective des droits. 
Abr. - Abril

Ago. - Agosto

Ampl. - Ampliada

Art. - Artigo

Arts. - Artigos

Atual. - Atualizada

Coord. - Coordenador

Dez. - Dezembro

Ed. - Edição

Fev. - Fevereiro

Jan. - Janeiro

Jun. - Junho

Jul. - Julho

Mar. - Março

N. - Número

Nov. - Novembro

Ns. - Números

Org. - Organizador

Out. - Outubro

Rel. - Relator

Rel $^{\mathrm{a}}$. - Relatora 
Rev. - Revisada

Set. - Setembro

Trad. - Tradução

V. - Volume 


\section{LISTA DE SIGLAS}

ADI - Ação Direta de Inconstitucionalidade

ADECON - Ação de Declaração de Constitucionalidade

ADPF - Arguição de Descumprimento de Preceito Fundamental

AIRR - Agravo de Instrumento em Recurso de Revista

AP - Agravo de Petição

CF/88 - Constituição Federal de 1988

CIPA - Comissão Interna de Prevenção de Acidentes

CLT - Consolidação das Leis do Trabalho

CPC - Código de Processo Civil

CPI's - Comissões Parlamentares de Inquérito

CUT - Central Única dos Trabalhadores

ED - Embargos de Declaração

EUA - Estados Unidos da América

MI - Mandado de Injunção

MTE - Ministério do Trabalho e Emprego

OJ's - Orientações Jurisprudenciais

ONG's - Organizações não Governamentais

RO - Recurso de Revista

RR - Recurso de Revista

STF - Supremo Tribunal Federal

TRT - Tribunal Regional do Trabalho

TST - Tribunal Superior do Trabalho 


\section{LISTA DE ANEXOS}

TABELA DE DIREITOS FUNDAMENTAIS TRABALHISTAS 350 


\section{SUMÁRIO}

1 INTRODUÇÃO 18

2 OS DIREITOS FUNDAMENTAIS TRABALHISTAS ......................................33

2.1 Escorço histórico dos direitos fundamentais ............................................................ 33

2.1.1 Origem dos direitos individuais: dos primórdios às "libertés publiques"............. 33

2.1.2 Do nascimento dos direitos trabalhistas: cerne dos direitos sociais ...................... 39

2.1.3 Da evolução dos direitos fundamentais: as dimensões de direitos ........................ 50

2.1.4 A importância da constitucionalização dos direitos fundamentais sociais e o fenômeno da constitucionalização dos ramos do Direito........................................ 56

2.1.5 A internacionalização dos direitos fundamentais .................................................60

2.2 Direitos fundamentais: definição e características ............................................... 69

2.3 Estrutura das normas de direitos fundamentais .................................................. 77

2.4 Os direitos fundamentais trabalhistas enquanto direitos sociais ....................... 81

2.5 Eficácia dos direitos fundamentais na relação de emprego: as peculiaridades dos destinatários das normas fundamentais trabalhistas .. 86

2.5.1 Eficácia, aplicabilidade e efetividade: distinção entre os conceitos ...................... 87

2.5.2 Eficácia vertical e horizontal dos direitos fundamentais trabalhistas .................. 90

2.6 Efetividade dos direitos fundamentais trabalhistas: a ineficácia social das normas decorrente do descumprimento reiterado dos direitos trabalhistas no Brasil ............................................................................................... 96

2.7. A ausência de implementação e a implementação restritiva dos direitos fundamentais trabalhistas diante da atuação da Justiça do Trabalho no Brasil ................................................................................................... 99

2.8 Os direitos fundamentais trabalhistas na Constituição de 1988 ....................... 101

2.8.1 Os direitos fundamentais trabalhistas estabelecidos nas Constituições brasileiras antes de 1988 ................................................................................... 101

2.8.2 A Constituição Cidadã de 1988 como marco dos direitos fundamentais

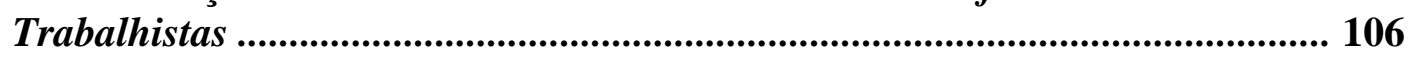

2.8.2.1 A sistemática dos direitos fundamentais na Constituição vigente ................... 106

2.8.2.2 Os direitos fundamentais trabalhistas na Constituição Federal de 1988 ....... 114

\section{A INTERPRETAÇÃO CONSTITUCIONAL EVOLUTIVA COMO} MECANISMO DA HERMENÊUTICA JURISDICIONAL ................................ 120

3.1 A hermenêutica e a interpretação: diferenciação ………………………………….... 120

3.2 Peculiaridades das normas constitucionais que influem na interpretação constitucional ..................................................................................................................... 122

3.3 Princípios da interpretação constitucional ................................................................ 125

3.4 Métodos de interpretação constitucional .................................................................. 126

3.4.1 Métodos clássicos ou tradicionais .................................................................. 126

3.4.2 Métodos modernos ........................................................................................................... 129

3.5 As mutações constitucionais ......................................................................................... 133

3.5.1 A rigidez e as mudanças na Constituição .................................................................. 133

3.5.2 Evolução do conceito de mutação constitucional ..................................................... 137

3.5.3 Fundamento jurídico-político das mutações constitucionais .................................. 148 
3.5.4 Características e pressupostos das mutações constitucionais ................................. 150

3.5.5 Modalidades de mutação constitucional ............................................................ 155

3.5.6 A interpretação constitucional evolutiva como modalidade de mutação constitucional via judicial ............................................................................... 164

3.5.6.1 Configuração ................................................................................................................... 164

3.5.6.2 Limites jurídicos à interpretação evolutiva .......................................................... 168

3.5.6.3 A interpretação constitucional evolutiva no Brasil pós-1988 ........................ 172

4 A CIDADANIA SOCIAL COMO FUNDAMENTO DA HERMENÊUTICA JURIDISCIONAL DE IMPLEMENTAÇÃO DOS DIREITOS FUNDAMENTAIS

4.1 Cidadania social e direitos fundamentais ............................................................. 182

4.1.1 A relação entre a concepção de cidadania e as teorias restritiva e ampliativa do exercício dos direitos fundamentais

4.1.2 Cidadania social e Constituição Federal de 1988 ............................................... 190

4.2 A atuação do Poder Judiciário para a concretização da cidadania social ........... 194

4.2.1 A teoria da separação dos poderes de Montesquieu e sua evolução no tempo .... 196

4.2.2 A releitura da teoria separação dos poderes no Estado Democrático de Direito Brasileiro

4.2.3 A postura do Poder Judiciário no tocante à efetivação dos direitos sociais: concepções possíveis e suas críticas

4.2.4 O Judiciário e a cidadania social: a observância do princípio de acesso à justiça

4.2.4.1 O acesso a uma ordem jurídica justa

4.2.4.2 A implementação dos direitos fundamentais sociais pelo Poder Judiciário em face da omissão do legislador e da linguagem aberta dos direitos fundamentais

4.2.5 A controvertida questão do ativismo judicial e a visão atualizada da teoria da separação dos poderes

4.2.5.1 A judicialização dos conflitos que demandam decisões de natureza política e o ativismo judicial: necessidade ou arbitrariedade

4.2.5.2 Possíveis limitações ao ativismo judicial 236

5 A INTERPRETAÇÃO CONSTITUCIONAL EVOLUTIVA E A CIDADANIA SOÇIAL: ELEMENTOS PARA A IMPLEMENTAÇÃO EFETIVA DOS DIREITOS FUNDAMENTAIS TRABALHISTAS PELA JUSTIÇA DO TRABALHO NO BRASIL

5.1 A Justiça do Trabalho no Brasil e a formação jurídica e humanista dos juízes trabalhistas

5.2 A cidadania social como elemento legitimador de uma Justiça Especializada comprometida com os direitos fundamentais trabalhistas

5.3 A interpretação evolutiva como mecanismo para a implementação dos direitos fundamentais trabalhistas pela Justiça do Trabalho 258

5.3.1 A interpretação constitucional evolutiva aplicada aos direitos fundamentais trabalhistas: exemplos da doutrina e da jurisprudência dos TRT's e TST e apresentação de propostas

5.3.1.1 Direitos relativos à relação de trabalho lato sensu ..................................... 266

5.3.1.2 Direitos relativos à proteção contra a dispensa e à estabilidade provisória,. 272 
5.3.1.3 Direitos relativos à remuneração e ao salário .......................................................... 293

5.3.1.4 Direitos relativos à jornada de trabalho .......................................................... 297

5.3.1.5 Direitos relativos à proteção à maternidade $\mathrm{e}$ à paternidade ............................ 301

5.3.1.6 Direitos relativos à não-discriminação ........................................................................ 304

5.3.1.7 Direitos relativos à saúde e segurança no trabalho............................................. 317

5.3.1.8 Direitos relativos à atuação sindical e à participação coletiva dos trabalhadores .................................................................................................. 321

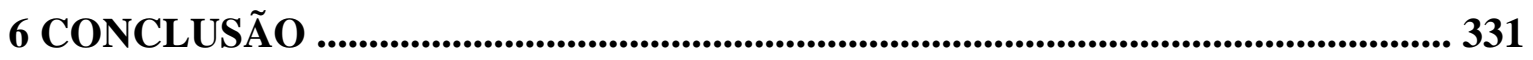

REFERÊNCIAS BIBLIOGRÁFICAS ......................................................................... 337

ANEXO - TABELA DE DIREITOS FUNDAMENTAIS TRABALHISTAS .......... 350 


\section{INTRODUÇÃO}

Um dos temas de maior destaque na atualidade é a problemática envolvendo a ausência de uma implementação efetiva cumulada com uma implementação, muitas vezes, restritiva dos direitos fundamentais dos trabalhadores esculpidos na Constituição Federal de 1988, sobretudo no que concerne aos métodos e mecanismos utilizados pela Justiça do Trabalho para a interpretação e concretização desses direitos humanos.

A terminologia "direitos fundamentais" somente passou a ser utilizada a partir do século XX, no contexto do movimento neoconstitucionalista, que elevou tais direitos à condição de normas essenciais dentro do sistema constitucional ${ }^{1}$, e do movimento de internacionalização desses direitos, após a Segunda Guerra Mundial. Sem embargo, a origem dos direitos hoje considerados "fundamentais" remonta ao jusnaturalismo, ganhando visibilidade e destaque com o movimento político e cultural que culminou com a Revolução Francesa e a decorrente Declaração dos Direitos do Homem e do Cidadão, de 1789. Esse documento, juntamente com a Declaração Americana, de 1776, consagrava como direitos de todos os homens os direitos de liberdade, segurança e propriedade, como uma resistência à opressão e aos excessos do regime absolutista, impondo limites à abusiva atuação do Estado. Nesse contexto, o primado da liberdade consistia na não-atuação estatal e a igualdade cingia-se apenas à concepção formal de todos os indivíduos perante a lei.

Sem embargo, a igualdade formal, ainda que estatuída nas Constituições, não foi suficiente para solucionar o grave quadro de desigualdade social e econômica decorrente das políticas adotadas no regime do Estado Liberal burguês.

Fazendo uma retrospectiva com o objetivo de situar os elementos desencadeadores do surgimento do Direito do Trabalho, retroage-se à dissolução do sistema feudal, momento em que as cidades passam a atrair uma massa de cidadãos pobres, que somente podem vender sua força produtiva para os detentores do capital. Nas grandes fábricas, homens, mulheres e crianças prestam sua mão-de-obra desqualificada, recebendo uma

\footnotetext{
${ }^{1}$ A grande inovação trazida pelo neoconstitucionalismo, no que tange aos direitos fundamentais, não foi a sua previsão nos textos constitucionais, visto que muitas das Constituições editadas a partir do movimento constitucionalista do século XVIII já traziam em seu bojo um rol de direitos e garantias hoje consideradas "fundamentais". O grande diferencial do movimento neoconstitucionalista foi elevar os direitos fundamentais à condição de normas essenciais dentro do sistema constitucional, com papel de destaque dentro do texto da Constituição, sendo consideradas materialmente superiores às demais normas constitucionais e dotadas de força normativa suficiente para pautar a forma de sua interpretação e aplicação.
} 
remuneração muito baixa, em virtude do excesso de oferta e da natureza braçal do trabalho desenvolvido.

A evolução da grande indústria passa pela intensificação da utilização das máquinas, da especialização e mecanização das tarefas, de modo a permitir o melhor aproveitamento do tempo e, consequientemente, maior eficiência e produtividade. Entretanto, os trabalhadores, encerrados durante horas nas fábricas, exerciam o seu labor em péssimas condições de higiene e salubridade, recebendo uma parca remuneração e sendo superexplorados e oprimidos.

É nesse contexto que nasce o Direito do Trabalho, inicialmente por meio de uma normatização esparsa, com o fim de proporcionar a proteção dos trabalhadores, assegurando patamares civilizatórios mínimos de contratação da força produtiva. O Estado passa a estabelecer normas que irão regular juridicamente a relação de emprego, de maneira a limitar a autonomia das partes na formação e estipulação do conteúdo contratual, fenômeno denominado "dirigismo contratual".

O discurso social da cidadania, sob a forte influência da concepção marxistaleninista, restou fortalecido após a Primeira Grande Guerra, daí resultando a Declaração dos Direitos do Povo Trabalhador, em 1918, e o leque de direitos estabelecidos na Constituição Mexicana, de 1917, na Constituição de Weimar, de 1919, e nas Constituições de vários países. A partir de então, o direito à abstenção converte-se em direito à atuação estatal voltada a prestações de índole social.

A primeira dimensão dos direitos humanos relativa às liberdades fundamentais foi, então, historicamente complementada pelos direitos sociais, culturais e econômicos considerados de segunda geração - como conquista dos desprivilegiados que reivindicavam o direito de participar do "bem-estar social", entendido, nas palavras de Celso Lafer, "como bens que os homens, por meio do processo coletivo, vão acumulando no tempo.",2

Mesmo nesse quadro de plena evolução de reconhecimento e proclamação dos direitos humanos, o regime nazista, que fundamentava na lei qualquer ação do Estado para justificar políticas de segregação e de violação de direitos humanos, implicou na ruptura do

\footnotetext{
${ }^{2}$ LAFER, Celso. A reconstrução dos direitos humanos - Um diálogo com o pensamento de Hannad Arendt. São Paulo: Companhia das Letras, 1999, p. 127.
} 
paradigma jusnaturalista, consistente na assertiva de que os direitos humanos decorrem da dignidade inerente a toda e qualquer pessoa humana. ${ }^{3}$

Diante do que resultou das atrocidades cometidas durante a Segunda Guerra Mundial, consolidou-se o consenso da comunidade internacional de que o ser humano tem direitos protegidos pelo direito internacional dos direitos humanos. Os direitos humanos são alçados à dimensão de soberania universal, constituindo preocupação internacional, independentemente da nacionalidade do indivíduo.

Com a Declaração Universal dos Direitos Humanos de 1948 - que mereceu aprovação unânime de quarenta e oito Estados, com oito abstenções - introduz-se uma nova linguagem de direitos, combinando-se o discurso liberal da cidadania com o discurso social da cidadania, o que resultou na celebração, em 1966, do Pacto Internacional de Direitos Civis e Políticos e do Pacto de Direitos Sociais, Econômicos e Culturais ${ }^{4}$.

Diante dessa nova perspectiva, busca-se evoluir da igualdade formal, antes conquistada e firmada na legislação interna dos países, para a igualdade material ou substantiva, quando os direitos humanos passam a constituir um complexo integral, único e indivisível.

Em virtude das modificações no cenário mundial, da tomada de consciência da existência de nações desenvolvidas e subdesenvolvidas e da deterioração da qualidade de vida humana, a referência individual do ser humano, até então considerada, não tem sido suficiente para atender às necessidades plenas das pessoas, razão por que, já no final da década de setenta, propugnou-se pelo alargamento da dimensão dos direitos humanos, para alcançar aqueles que se assentam sobre a fraternidade, ou seja, os denominados direitos de solidariedade. É nessa fase que são reconhecidos os direitos coletivos e difusos, como aqueles referentes ao desenvolvimento dos povos, ao meio ambiente, à paz, ao direito de comunicação, etc., direitos esses considerados de terceira dimensão. De acordo com Celso Lafer, "esses direitos têm como titular não o indivíduo em sua singularidade, mas sim grupos humanos, coletividades regionais étnicas e a própria humanidade". 5

Os direitos fundamentais trabalhistas, direitos sociais em sua gênese e natureza, só podem ser plenamente exercidos pelos seus titulares se direitos básicos de índole individual como o direito à liberdade e o direito à vida, por exemplo, estiverem garantidos.

\footnotetext{
${ }^{3}$ GOMES, Dinaura Godinho Pimentel. O processo de afirmação dos direitos fundamentais: evolução histórica, interação expansionista e perspectivas de efetivação. Revista de direito constitucional e internacional, São Paulo, v.11, n.45, out./dez. 2003, p. 124.

${ }^{4}$ Ambos os Pactos só foram ratificados pelo Brasil em 24 de janeiro de 1992.

${ }^{5}$ LAFER, Celso. Op. cit., p. 131.
} 
Da mesma forma, os direitos fundamentais trabalhistas, quando violados em massa, podem ser defendidos por meio das tutelas metaindividuais. ${ }^{6}$

No Brasil, a questão da efetividade dos direitos fundamentais trabalhistas pode ser observada em dois planos: o primeiro se relaciona à cultura ou hábito de violação reiterada dos direitos trabalhistas, por ser mais barato ${ }^{7}$ para o empregador do que cumprir devidamente os seus deveres, ainda que ele seja posteriormente acionado pelo trabalhador, e o segundo consiste na tentativa da Justiça do Trabalho em criar mecanismos que evitem a postergação ou precarização da reparação aos direitos violados.

Ao lado do problema da falta de efetividade dos direitos fundamentais, vislumbrase outro igualmente grave: a ausência de implementação ou a implementação restritiva de muitos dos direitos fundamentais esculpidos na Constituição Federal de 1988, pela interpretação jurisdicional que lhes é conferida ou pela ausência de leis infraconstitucionais que venham regulamentar alguns desses direitos constitucionalmente assegurados.

É necessário salientar que a tarefa de implementação dos direitos fundamentais não é realizada por meio do exercício exclusivo do magistrado, envolvendo também a Administração Pública, os advogados e procuradores. Não obstante, é no Poder Judiciário que tal empreitada se torna crucial para o trabalhador, tendo em vista que a atuação do juiz é um elemento chave na concretização dos direitos constitucionalmente estabelecidos.

\footnotetext{
${ }^{6}$ Segundo José Roberto Freire Pimenta, por um lado existem as lesões essencialmente metaindividuais, ou seja, agressões que atingem direitos difusos e coletivos em sentido estrito, que, por seu caráter indivisível, não podem ser objeto de ações estritamente individuais, em face da indeterminabilidade de seus titulares, e que devem ser defendidos por uma parte ideológica aparelhada para tanto, por meio de provimentos judiciais que dêem tratamento uniforme à controvérsia de natureza inibitória e mandamental, assegurando a tutela específica de direitos e interesses em jogo e evitando a perpetuação da prática do ilícito. De outro lado, existem lesões acidentalmente metaindividuais, isto é, cujo objeto são direitos individuais que tenham sido alvo de lesões ou ameaças de lesão de caráter massivo, por um fato de origem comum e por parte de um único empregador, e cujo enfrentamento processual por via coletiva é vantajoso, pois são situações jurídicas individuais, numerosas e homogeneizadas de grande importância social. Cf. PIMENTA, José Roberto Freire. A tutela metaindividual dos direitos trabalhistas: uma exigência constitucional. In: PIMENTA, José Roberto Freire; BARROS, Juliana Augusta Medeiros de; FERNANDES, Nádia Soraggi (Coords.). Tutela metaindividual trabalhista: a defesa coletiva dos direitos dos trabalhadores em juízo. São Paulo: LTr, 2009, p.39.

${ }^{7}$ Muitos empregados que têm seus direitos fundamentais trabalhistas lesados não se socorrem da Justiça do Trabalho ou por falta de conhecimento acerca dessas lesões ou mesmo por receio de não conseguirem mais emprego em seu ramo de atividade (em virtude das chamadas "listas negras" de empregados ou da propaganda negativa feita boca-a-boca entre as empresas). Outros empregados que ajuízam reclamações trabalhistas não recebem o que lhes é devido por fazerem acordos judiciais prejudiciais com o intuito de "receber menos mas receber rápido". E outros tantos trabalhadores esperam anos até que seus processos passem por todas as instâncias da Justiça do Trabalho, em virtude dos inúmeros recursos interpostos pelas empresas empregadoras para postergar ao máximo o pagamento das verbas trabalhistas ou das indenizações devidas.
} 
Em virtude do assoberbamento de processos, da morosidade e da falta de efetivação dos direitos materiais pela atuação do Poder Judiciário, têm sido desenvolvidos mecanismos procedimentais visando uma maior eficácia da tutela jurisdicional ${ }^{8}$.

As reformas processuais e os instrumentos postos a serviço de uma atuação mais efetiva do Judiciário e, consequentemente, de uma maior efetividade dos direitos fundamentais do trabalhador, tais como, por exemplo, a utilização em ordem crescente das tutelas antecipada, inibitória e específica no âmbito juslaboral, embora importantes não resolvem o problema da implementação restritiva dos direitos fundamentais trabalhistas pela Justiça do Trabalho ${ }^{9}$. E essa constatação se faz, analisando-se a matriz do ordenamento jurídico brasileiro, a Constituição Federal de 1988, que traz em seu texto os direitos fundamentais sociais dos trabalhadores urbanos e rurais.

\footnotetext{
${ }^{8}$ Em estudo conjunto, Mauro Cappelletti e Bryant Garth expuseram em detalhes o movimento mundial de reformas no processo contemporâneo levado a cabo a partir da segunda metade do século XX e que teve como objetivo, essencialmente, permitir um melhor acesso à justiça, por meio de um sistema processual acessível a todos e capaz de produzir resultados justos e efetivos através de três grandes ondas renovatórias. A terceira onda se caracteriza exatamente pelo novo enfoque do acesso à justiça, através da adoção de várias inovações procedimentais e no sistema judiciário com o fim de propiciarem um significativo aumento na efetividade dos direitos materiais e de sua respectiva tutela jurisdicional. Conforme CAPPELLETTI, Mauro; GARTH, Bryant. Acesso à justiça. Porto Alegre: Sérgio Antônio Fabris, 1988.

${ }^{9}$ Nesse ponto, é relevante observar que a atenção dada à temática da efetividade dos direitos fundamentais trabalhistas no Direito Pátrio diz respeito basicamente aos estudos da doutrina nacional sobre os procedimentos judiciais e as técnicas processuais aplicáveis ao processo do trabalho que propiciem a efetivação dos direitos do trabalhador (tutela antecipada, inibitória e coletiva dos direitos individuais, difusos, coletivos e individuais homogêneos e execução específica de direitos reconhecidos judicialmente, por exemplo). No tocante à implementação dos direitos fundamentais, mais raramente se observa o interesse dos juristas pela hermenêutica na seara juslaboral, além da pouca utilização, pelos aplicadores do direito, principalmente do Judiciário Trabalhista, dos métodos e mecanismos da interpretação constitucional moderna, fatores esses que vêm comprometendo seriamente a implementação de vários direitos fundamentais trabalhistas dispostos expressamente na Lei Fundamental.

Por outro lado, não obstante a grande produção de obras acerca da aplicabilidade e eficácia dos direitos sociais em geral pela doutrina brasileira e estrangeira, encontram-se em número bem menor os estudos referentes aos direitos sociais trabalhistas, que apresentam peculiaridades próprias referentes aos destinatários dessas normas constitucionais (normalmente os empregadores, embora também possa ser o Poder Público, em alguns casos), à sua eficácia na relação privada de emprego, à sua classificação em direitos de defesa e direitos prestacionais e ao enquadramento de algumas normas trabalhistas como normas programáticas.

$\mathrm{Na}$ realidade, percebe-se um vazio doutrinário no que tange ao estudo sistemático dos direitos constitucionais trabalhistas com base na teoria dos direitos fundamentais, pois os direitos trabalhistas insertos na Constituição Federal são direitos fundamentais sociais e deveriam ser tratados como tal, mesmo diante de algumas peculiaridades em relação aos seus destinatários e à sua eficácia. Normalmente, a doutrina existente estuda algum direito fundamental trabalhista, de forma mais aprofundada ou específica, ou realiza um estudo sistemático dos direitos dos trabalhadores dispostos na Constituição, porém não embasada na teoria dos direitos fundamentais.

Constata-se que não há no país obra completa e sistematizada acerca da implementação dos direitos fundamentais dos trabalhadores por intermédio das técnicas e métodos de interpretação constitucional moderna pela atuação do Judiciário trabalhista, nem a partir de uma matriz essencialmente teórica, nem, muito menos, por meio de análise teórico-prática de casos da jurisprudência trabalhista.

A partir dessa temática pouco burilada, a presente tese pretende trazer como contribuição original a proposição de uma hermenêutica jurisdicional trabalhista que tenha como elementos essenciais o mecanismo da interpretação constitucional evolutiva e o valor da cidadania social, com o objetivo de colaborar de forma eficaz para a implementação dos direitos fundamentais trabalhistas pela Justiça do Trabalho.
} 
No Brasil, embora desde 1934 já existissem alguns direitos trabalhistas previstos constitucionalmente, em conseqüência das rupturas democráticas ao longo do último século somente a partir de 1988 os direitos sociais do trabalhador foram estabelecidos como fundamentais na Constituição, nomeada de cidadã, que inaugurou uma nova ordem político-jurídica, qual seja, o Estado Democrático de Direito.

Nos países da Europa Central, em virtude da crise do Estado Liberal e dos movimentos sociais do final do século XIX e início do século XX, os direitos sociais encontraram no final da Segunda Grande Guerra o momento ideal para serem reconhecidos como fundamentais nas Constituições de vários países da Europa Central. ${ }^{10}$

Concomitantemente, a crise do positivismo jurídico ao fim da guerra - que na busca de uma ciência jurídica pura havia apartado o Direito da Moral e dos valores transcendentes como a justiça - abriu caminho para um conjunto amplo e inacabado de reflexões acerca do Direito, sua função e sua interpretação. Esse movimento denominado de pós-positivismo é a designação de um processo difuso, no qual se incluem a definição das relações entre valores, princípios e regras, aspectos da nova hermenêutica

\footnotetext{
${ }^{10}$ A Constituição alemã, de 1949, assegura a todos os cidadãos o direito de formar associações para manutenção e aperfeiçoamento das condições de trabalho e econômicas, sendo nulos todos os acordos e atos que visem a impedir o exercício desse direito. A Constituição espanhola, de 1978, prevê os direitos de sindicalização, de greve, de negociação coletiva entre representantes dos trabalhadores e dos empresários, direito à seguridade social e à uma remuneração suficiente para satisfazer suas necessidades e as de sua família, além de caber ao poder público zelar pela segurança e higiene do trabalho e assegurar o descanso necessário, mediante limitação de jornada e férias periódicas remuneradas. A Constituição francesa, de 1958, apenas se refere à competência do Parlamento para aprovar leis sobre o "direito ao trabalho, o direito sindical e a seguridade social (art. 34), mas afirma a superioridade dos tratados ratificados sobre as leis (art. 55), o que valoriza os princípios e normas constantes das Convenções da Organização Internacional do Trabalho. Na Itália, a Constituição de 1947 afirma que o país é uma República Federativa baseada no trabalho (art. $1^{\circ}$ ) e assegura os direito a salário suficiente para assegurar a existência livre e digna ao trabalhador e à sua família; jornada máxima de trabalho fixada em lei; repouso semanal remunerado e férias anuais remuneradas; idade mínima para o trabalho fixada por lei; proteção especial à mulher, para que possa exercer sua função familiar; isonomia de direitos por trabalho igual entre o homem e a mulher; proteção especial ao trabalho do menor, assegurada a equiparação salarial por trabalho igual ao adulto; seguros sociais contra doença, invalidez, velhice, acidente de trabalho e desemprego involuntário; liberdade sindical; direito de greve, em conformidade com a lei; colaboração dos trabalhadores com a gestão das empresas, nos termos da lei. Em Portugal, a Constituição de 1976, alterada por várias leis constitucionais posteriores, possui um largo capítulo sobre os direitos, liberdades e garantias dos trabalhadores. Além de proibir "os despedimentos sem justa causa ou por motivos políticos ou ideológicos", dispõe sobre as comissões de trabalhadores na empresa e as associações sindicais, fixando a competências dessas últimas e sua participação na celebração das convenções coletivas de trabalho. Prevê, ainda, o princípio da isonomia para trabalho igual e fixação e atualização do salário mínimo. Atribui à lei regulamentar sobre a prestação do trabalho em condições de higiene e segurança, a jornada de trabalho, o descanso semanal, as férias periódicas, os lazeres, a assistência aos desempregados e a autogestação. Por fim, estabelece o direito de todas à seguridade social. Cf. SUSSEKÏND, Arnaldo. Direito constitucional do trabalho. 2 ed. ampl. e atual. Renovar: São Paulo, 2001, p. $20-22$.
} 
constitucional, e a teoria dos direitos fundamentais, edificada sobre o fundamento da dignidade humana. ${ }^{11}$

Nesse sentido, tem sido grande o esforço dos estudiosos em criar um arcabouço teórico que transforme o avanço filosófico em um instrumental técnico-jurídico aplicável aos problemas concretos.

A partir das reflexões sobre a força normativa presente nas normas constitucionais e a conseqüente concepção dos princípios como espécie do gênero norma, a estruturação dos direitos fundamentais como normas principiológicas e as técnicas de solução de colisões entre princípios, constata-se que qualquer tentativa de implementação dos direitos fundamentais trabalhistas perpassa por uma nova hermenêutica jurisdicional.

Observando a realidade cotidiana das demandas que tramitam pela Justiça do Trabalho percebe-se que a interpretação dos magistrados, em prol da implementação efetiva dos direitos dos trabalhadores elencados nos artigos $6^{\circ}$ ao 11 da CF/88 e no 10 da ADCT, é ainda insuficiente, baseada em uma tendência de auto-restrição do Judiciário que tem fulcro em uma concepção teórica restritiva de cidadania e, conseqüentemente, dos direitos fundamentais sociais, e que está ainda atrelada à teoria da separação dos três poderes de Montesquieu ${ }^{12}$.

Assim, direitos fundamentais deixam de ser concretizados, por exemplo, por falta de lei infraconstitucional regulamentadora ${ }^{13}$ e por uma interpretação restritiva ou involutiva dos dispositivos constitucionais, totalmente desvinculada da realidade social e

11 BARROSO, Luís Roberto; BARCELlOS, Ana Paula. O começo da história. A nova interpretação constitucional e o papel dos princípios do Direito Brasileiro. Interesse Público, Sapucaia do Sul: Notadez, v.5, n.19, maio/jun. 2003, p.56.

${ }^{12}$ Em virtude da influência da doutrina tradicional da separação dos poderes, que prevalecia até meados do século XX, o papel dos juízes na criação e no desenvolvimento do direito ficava bastante reduzido, pois o direito era visto como produto exclusivo das leis aprovadas pelo Legislativo, restando ao Judiciário a função de aplicar por meio de subsunção a lei geral aos casos concretos. Com a intensificação da complexidade das relações econômicas e sociais, bem como da mudança do papel do Estado nessas relações, cada um dos três poderes passa a ser tido como complementar do outro, exercendo, inclusive em alguns casos, funções típicas dos demais poderes. Ademais, as normas editadas pelo Poder Legislativo passam a depender necessariamente da atuação dos outros dois poderes para serem concretizadas. Nesse contexto, é que se consolidou a idéia de que o Poder Judiciário pode participar, ainda que de modo supletivo, da atividade de criação do direito.

${ }_{13}$ Alguns direitos trabalhistas esculpidos na Constituição Federal de 1988, embora não requisitem gastos ou a criação de programas e sejam destinados ao empregador, necessitam de regulamentação por meio de lei a ser criada pelo Poder Legislativo. Nesse caso, a questão que se coloca é mais complicada, pois a aplicabilidade imediata desses direitos restaria subordinada à vontade do legislador infraconstitucional, caso se entenda que o Poder Judiciário não poderia, pelo exercício da função jurisdicional, implementá-los de forma alguma, em virtude do princípio da separação dos poderes. O problema envolve a legitimidade do Judiciário para a efetivação dos direitos fundamentais, por intermédio do estabelecimento de políticas públicas ou de leis, em sentido material; a necessidade de implementação dos direitos fundamentais que não podem ser exercidos por falta de regulamentação legal, em face da morosidade e dos interesses políticos do Poder Legislativo; e, ainda, o entendimento acerca do princípio da separação estanque ou não dos poderes. 
dos valores emergentes da Lei Maior, entre eles os princípios da dignidade da pessoa humana, do valor social do trabalho e da justiça social.

Em adição, a Constituição tem sido pouco utilizada como fundamento das decisões judiciais, como se os direitos mínimos dos trabalhadores não estivessem postos na Lei Maior e como se não devessem ser lembrados antes de qualquer norma heterônoma ou autônoma infraconstitucional, ainda quando essas são menos favoráveis ao trabalhador. Parece haver um hábito arraigado na Justiça do Trabalho em considerar os direitos fundamentais trabalhistas - direitos sociais por excelência - como direitos destituídos de normatividade, fundamentabilidade e eficácia. Assim, os direitos fundamentais laborais vão sendo desconstitucionalizados de duas maneiras: em primeiro lugar, pelo avanço dos ideais neoliberais de busca da diminuição do custo do trabalho, com a flexibilização e eliminação dos direitos dos trabalhadores ${ }^{14}$; e, em segundo lugar, pela própria postura da Justiça do Trabalho que se olvida que os direitos fundamentais dos trabalhadores - direitos mínimos - devem ser implementados efetivamente.

A Constituição Federal de 1988 adotou uma concepção de cidadania ampla, que pode ser denominada de "cidadania social", ou seja, o indivíduo, enquanto cidadão, não só tem a prerrogativa de exercer os seus direitos políticos como também de exercer os seus demais direitos de índole individual e os seus direitos sociais, além de poder requerer ao Judiciário a proteção dos direitos fundamentais violados pelo Estado ou por terceiros e a implementação dos direitos fundamentais cujo exercício se encontra limitado ou pela ausência de norma regulamentadora a ser criada pelo Poder Legislativo ou pela interpretação involutiva desses direitos realizada Poder Judiciário.

Em prol de uma atuação jurisdicional comprometida com a implementação dos direitos fundamentais e que está intrinsecamente relacionada com o processo interpretativo evolutivo, é imprescindível realizar uma análise das teorias sobre a amplitude do exercício dos direitos fundamentais, que estão intrinsecamente conectadas com a concepção de cidadania e a construção de teorias mais ampliativas ou restritivas no que tange ao exercício dos direitos fundamentais sociais. O Poder Judiciário, ao se filiar a uma ou outra teoria, pode comprometer a sua função de efetivar os direitos fundamentais sociais.

A denominada "cidadania social", para enfatizar o fato de que os cidadãos também têm direito a exercer efetivamente os direitos sociais, é a base para uma nova ideologia do Poder Judiciário desamarrada do dogma da separação estanque dos poderes e da tendência

\footnotetext{
${ }^{14}$ SOUTOR MAIOR, Jorge Luiz. A desconstitucionalização do Direito do Trabalho. Justiça do Trabalho: Doutrina, Jurisprudência, Legislação, Sentenças e Tabelas, Porto Alegre, v.18, n.213, set. 2001, p. 47.
} 
de auto-restrição jurisdicional que impinge aos magistrados a idéia de não haver legitimidade democrática para a tarefa de efetivar os direitos fundamentais sociais.

As teorias restritivas dos direitos fundamentais sociais, vinculadas a uma inspiração proveniente do Estado Liberal, são extremamente ligadas à concepção de cidadania como exercício dos direitos políticos, de modo que somente os direitos individuais poderão ser exercidos subjetivamente, ao passo que os direitos sociais podem ser suprimidos por meio de Emenda Constitucional. Ou, então, ampliam a concepção de cidadania, não a limitando a questões políticas, mas restringem a subjetividade dos direitos fundamentais sociais ao mínimo possível a ser pleiteado ao Poder Judiciário. ${ }^{15}$ Já a teoria ampliativa se pauta pela ótica do Estado Social e do Estado Democrático de Direito e se funda na concepção de cidadania social, incluindo o exercício dos direitos fundamentais sociais, buscando-lhes dar efetivação máxima ${ }^{16}$, inclusive por meio da atuação do Poder Judiciário.

O sistema adotado pelo constituinte brasileiro foi o correspondente a uma teoria realmente ampliativa do exercício dos direitos fundamentais, com alicerce na cidadania social, e que tem como um das formas da sua consolidação a busca do Judiciário como meio para a solução dos conflitos sociais. A Constituição Federal, ao proclamar direitos e garantias com forte conteúdo social, adquire forma que a coloca na condição de reguladora e garantidora da cidadania social.

No quadro filosófico e constitucional pós-positivista, a atuação dos magistrados reveste-se de uma importância substancial, visto que da simples tarefa de subsunção das regras jurídicas ao caso concreto passam a ser materializadores das normas constitucionais, especialmente das normas principiológicas.

O juiz, como intérprete dos dispositivos jurídicos em geral, incluindo os constitucionais, realiza atividade que antecede à aplicação da norma ao caso concreto, visto que cada caso a ser solucionado apresenta-se com distintas peculiaridades a serem sopesadas. Dessa forma, a interpretação consiste em ferramenta indispensável à compreensão da norma que compõe o ordenamento jurídico, visando, sobretudo, a atender os valores consubstanciados na Constituição como propiciadores da proteção aos direitos sociais do trabalhador e de sua dignidade como ser humano.

Nesse sentido, o intérprete das normas constitucionais deve adaptar o Direito às exigências sociais, fazendo uso, para tanto, dos mais variados métodos de interpretação

\footnotetext{
${ }^{15}$ ESTEVES, João Luiz M. Direitos fundamentais sociais no Supremo Tribunal Federal. São Paulo: Método, 2007, p. 39.

16 Ibidem, p. 39.
} 
que compõem a hermenêutica jurídica ${ }^{17}$, sejam os tradicionais ou os modernos, além dos princípios da interpretação constitucional.

Para uma implementação efetiva e ampliativa é necessário que a interpretação da norma seja feita em conformidade com a realidade social, mecanismo de mutação constitucional conhecido como interpretação evolutiva ${ }^{18}$. Na realidade, as constantes modificações das sociedades prescindem de uma Assembléia Constituinte em constante funcionamento, de modo que, em muitos casos, bastará que os operadores do direito busquem nas próprias normas constitucionais uma "reinvenção" do direito para os fatos cotidianos. $^{19}$

Atualmente, tendo em vista a consolidação da ideia de que as normas constitucionais são normas jurídicas especiais (normas vinculantes e obrigatórias, com um maior grau de abstração e generalidade, de modo a permitir uma maior abertura para reconhecer e aceitar as modificações ocorridas na sociedade), a mutação constitucional tem sido compreendida como o fenômeno por meio do qual são produzidas alterações de significado, de alcance ou sentido das normas constitucionais, desde que essas alterações sejam comportadas pelo "programa normativo", ou seja, que promovam o desenvolvimento, a complementação, o esclarecimento das normas constitucionais escritas, mas não violem nem a sua letra, nem tampouco o seu espírito.

A interpretação da Constituição é de extrema relevância para a constante adequação do direito à realidade social. Por isso, para que as normas constitucionais tenham força normativa não basta uma interpretação meramente literal. O próprio Konrad Hesse já diria que a força normativa da Constituição decorre da confluência dos dois fatores (realidade e norma) que a informam.

A interpretação deve, portanto, adequar as normas principiológicas constitucionais, que revelam os diversos valores apostos na Constituição, aos anseios sociais, a uma visão política e histórica contemporânea. E se os direitos fundamentais sociais, nos quais se

\footnotetext{
${ }^{17}$ A hermenêutica jurídica é o ramo do Direito que estuda os institutos, métodos e princípios da interpretação jurídica, seja ela realizada pelos entes estatais (Poder Judiciário, Administração Pública e Legislador), seja ela realizada por entes não-estatais, incluindo o povo, o cidadão, a opinião pública, etc.

${ }^{18}$ A interpretação evolutiva é uma modalidade de mutação constitucional, ou seja, um processo informal de mudança do texto da Constituição, em que a redação original do texto não é alterada, mas, sim, a interpretação desse texto. A mutação se difere da reforma constitucional que se trata de um mecanismo formal de alteração, previsto no texto constitucional, composto pelas emendas e revisões.

19 CORREIA, Marcus Orione Gonçalves. O postulado da razoabilidade e o Direito do Trabalho. In: CORREIA, Marcus Orione Gonçalves (Org.). Curso de Direito do Trabalho, v. 1 - Teoria geral do Direito do Trabalho. São Paulo: LTr, 2007, p. 119.
} 
incluem os trabalhistas, são normas com estrutura de princípio, conclui-se que a sua interpretação deve ser evolutiva, pois da sua própria essência.

Traçado o perfil de atuação do Judiciário trabalhista, percebe-se, portanto, que um grande obstáculo, no âmbito jurisdicional, para a implementação dos direitos fundamentais se encontra nos mecanismos utilizados pelos magistrados para a interpretação e aplicação desses direitos, incapazes de acompanhar as necessidades dos trabalhadores no atual contexto sócio-histórico-econômico do país.

A interpretação constitucional das normas constitucionais que encerram direitos fundamentais sociais é essencialmente uma interpretação de princípios, posto que aqueles se estabelecem por intermédio de normas de estrutura aberta. Por isso, para dar força normativa à Constituição, o juiz, especialmente em matéria de direito social, deve fazer um esforço interpretativo a que não está tão habituado, sendo necessária uma verdadeira revisão de conceitos e um reposicionamento do status conferido à interpretação dentro deste sistema.

Dessa forma, a presente tese ${ }^{20}$ pretende abordar como os direitos fundamentais trabalhistas, enquanto direitos sociais específicos, podem ser implementados, em progressão ampliativa, pela Justiça do Trabalho por meio de uma hermenêutica jurisdicional baseada na interpretação evolutiva das normas constitucionais e na cidadania social.

Assim, a tese se centra nos direitos trabalhistas típicos, elencados nos artigos $6^{\circ}$ ao 11 da Constituição Federal e no artigo 10 do Ato das Disposições Constitucionais Transitórias, ou seja, nos direitos trabalhistas enquanto direitos sociais, e não nos direitos

20 A presente proposta de tese de doutoramento teve com elemento propulsor a coordenação de um grupo de estudos, intitulado "A efetivação dos direitos fundamentais trabalhistas - estudos de casos através da jurisprudência do TST e dos TRT's” e composto por alunos da graduação em Direito e do mestrado, na área de concentração em Direito do Trabalho, da Pontifícia Universidade Católica de Minas Gerais. A proposta era a formação de um grupo de alunos interessados em analisar a jurisprudência do Judiciário trabalhista em um aspecto específico: a implementação dos direitos trabalhistas esculpidos nos artigos $7^{\circ}$ ao 11 da Constituição Federal e no artigo 10 do Ato das Disposições Constitucionais Transitórias.

Ao longo das reuniões e dos debates realizados entre os participantes, constatou-se que a inquietude original relativa à postura pouco vanguardista de implementação de vários dos direitos fundamentais trabalhistas pelo ramo judiciário especializado se confirmava. Ora as ementas ou acórdãos simplesmente se olvidavam de, ao menos, citar a fonte primordial do direito fundamental trabalhista, sua sede constitucional, ora se limitavam a dar ao direito uma interpretação restritiva, totalmente desvinculada da realidade social ou dos valores emergentes da Lei Maior no tocante à interpretação dos dispositivos constitucionais do trabalhador, entre eles o princípio da dignidade da pessoa humana, do valor social do trabalho e da justiça social.

Os poucos acórdãos ilustrativos de uma real implementação e ampliação dos direitos fundamentais trabalhistas serviram de incentivo para uma análise mais detida acerca dos motivos ensejadores de tal posicionamento pelas turmas de magistrados do TST e dos TRT's. E a conclusão foi a de que os métodos de interpretação utilizados em uma decisão influenciam sobremaneira na concretização dos direitos fundamentais laborais. 
fundamentais individuais que são aplicáveis à relação de emprego ${ }^{21}$, em virtude do fenômeno da eficácia direta dos direitos fundamentais nas relações privadas, tais como o direito à integridade física, à intimidade, à privacidade, à honra, entre outros. A pesquisa também não abarca direitos e princípios constitucionais aplicáveis ao Processo do Trabalho, nem demais direitos sociais correlatos às relações de trabalho, como o direito do segurado aos benefícios da Seguridade Social, por exemplo.

Nesse sentido, a título de organização da presente tese, em primeiro lugar será realizado um estudo específico sobre os direitos fundamentais trabalhistas, partindo-se de uma análise histórica dos direitos denominados "fundamentais" desde a origem dos direitos individuais, passando pelo surgimento dos direitos sociais até o aparecimento dos direitos metaindividuais, não se olvidando do movimento de constitucionalização e de internacionalização dos direitos fundamentais sociais. Em adição, serão apresentadas as características e a estrutura desses direitos e, em seguida, será trabalhada a noção dos direitos fundamentais enquanto direitos sociais, com suas peculiaridades próprias. Serão dissecadas, também, as questões envolvendo a eficácia jurídica das normas de direitos fundamentais trabalhistas e a vinculação dos particulares a esses direitos. Ainda nessa primeira parte da tese, será traçado o cenário nacional de inefetividade dos direitos fundamentais trabalhistas e da ausência de implementação de muitos desses direitos pela atuação da Justiça do Trabalho. Em último lugar, procurar-se-á demonstrar o processo de evolução na constitucionalização de direitos sociais no Brasil até a Constituição Federal de 1988, conhecida como Constituição Cidadã, e que sistematizou e aumentou consideravelmente o leque de direitos fundamentais trabalhistas.

À continuação, estudar-se-ão os princípios da interpretação constitucional, bem como os métodos tradicionais (método histórico, gramatical, sistemático e teleológico) e os métodos modernos (método cintífico-espiritual, método tópico, método normativoestruturante e método hermenêutico-concretizante) de interpretação das normas constitucionais.

Ainda nessa segunda parte, será dissecado o fenômeno de mudança constitucional denominado mutação constitucional, as suas características, o seu fundamento jurídicopolítico e as suas modalidades, incluindo a interpretação constitucional evolutiva. Abordar-

\footnotetext{
${ }^{21}$ A relação de emprego é uma relação jurídica privada em que incidem normas de ordem pública de forma a diminuir a desigualdade existente entre as partes contratantes. No caso específico dos direitos trabalhistas sociais, esses incidem diretamente na relação de emprego, não por força da teoria eficácia direta dos direitos fundamentais nas relações privadas, mas porque as normas que instituem aqueles direitos são justamente cogentes com o objetivo de mitigar o desequilíbrio da relação juslaboral.
} 
se-á, outrossim, os sujeitos que realizam as mutações constitucionais, sejam eles os entes estatais (Poderes Judiciários, Legislativo e Executivo), sejam eles os entes não-estatais (povo, opinião pública), dando ênfase à interpretação jurisdicional, em virtude do objeto da presente tese ser a implementação dos direitos fundamentais trabalhistas pela Justiça do Trabalho, por meio da interpretação evolutiva das normas constitucionais ${ }^{22}$. Serão trabalhados, ainda, os limites jurídicos à interpretação evolutiva e como essa modalidade de mutação vem sendo utilizada no Brasil pelo Poder Judiciário para interpretar as normas constitucionais.

Em seguida, a cidadania social será estudada como fundamento legitimador de uma interpretação jurisdicional comprometida com a implementação efetiva dos direitos fundamentais. Nesse sentido, inicialmente será traçado um paralelo entre a evolução da concepção de cidadania e as teorias restritivas e ampliativas de direitos fundamentais, chegando-se à concepção de cidadania adotada pela Constituição Federal de 1988. Em segundo lugar, será analisado o papel do Judiciário, de acordo com a teoria dos três Poderes desenvolvida por Montesquieu e conforme a releitura dessa teoria diante do paradigma do Estado Democrático de Direito. Serão, ademais, objeto de estudo as concepções da atuação do Poder Judiciário em relação à implementação dos direitos fundamentais sociais e a questão da concretização do princípio de acesso à Justiça, pelo prisma tanto do acesso ao Poder Judiciário, quanto da implementação dos direitos materiais pleiteados por meio do processo judicial, ainda que em face de complexas questões como a omissão do legislador em regulamentar direitos fundamentais sociais e a linguagem aberta dos direitos fundamentais. Ainda no terceiro capítulo será abordada a celeuma em torna do ativismo judicial diante de uma visão atualizada da teoria dos três poderes, analisando-se, por um lado, se a postura ativa do Judiciário é derivada de uma arbitrariedade ao entrar no domínio do Legislativo ou de uma real necessidade dos cidadãos e, por outro lado, se existem limites claros ao decisionismo judicial.

Em último lugar, buscar-se-á compreender como a cidadania social, atrelada a uma visão ampliativa dos direitos fundamentais, é a base essencial para uma posição mais atuante da Justiça do Trabalho no sentido de concretizar os direitos fundamentais trabalhistas. Ademais, por conceber a importância da utilização no plano fático de qualquer

${ }^{22}$ É necessário salientar que a jurisdição constitucional - a atividade de interpretação e aplicação da Constituição - é exercida tanto pelo Supremo Tribunal, guardião da Constituição e competente para o controle concentrado de constitucionalidade, quanto pelos demais juízes e tribunais em geral, inclusive da área trabalhista, no que tange ao controle difuso de constitucionalidade e à aplicação direta das normas constitucionais aos casos concretos. 
teoria apresentada no âmbito jurídico, tem-se como objetivo, nesse último capítulo, apresentar a aplicabilidade prática da interpretação constitucional evolutiva para a implementação dos direitos fundamentais do trabalhador no Brasil, partindo-se da análise da jurisprudência - tanto dos Tribunais Regionais do Trabalho, quanto do Tribunal Superior do Trabalho - e da doutrina nacionais no tocante à interpretação dos direitos trabalhistas constitucionalizados. Para sistematizar o estudo da interpretação dos direitos fundamentais trabalhistas, esses direitos serão divididos por grupos relativos à proteção contra a dispensa arbitrária ou sem justa causa, à não-discriminação do trabalhador, à remuneração e ao salário, à jornada de trabalho, à saúde e segurança no trabalho, à liberdade atuação sindical e à participação coletiva dos trabalhadores.

$\mathrm{O}$ que se tem como intento, portanto, na presente tese, é demonstrar que diante da falta de implementação efetiva e ampla de muitos dos direitos trabalhistas dispostos na Constituição, a atuação do ramo especializado do Judiciário torna-se essencial para garantir aos trabalhadores o mínimo necessário à sua condição de ser humano digno, princípio e valor fundamental do Estado Democrático de Direito. Isso porque o cidadão trabalhador vai ao Judiciário na esperança de ver reconhecido, garantido e efetivado um direito constitucionalmente positivado. A decisão da justiça, portanto, não deve frustrar a sua pretensão, pois pode comprometer a confiança na Justiça e nas bases do Estado Democrático de Direito.

A premente necessidade de implementação ampla dos direitos fundamentais trabalhistas carreados na Constituição cidadã é tarefa essencial e poder-dever da Justiça do Trabalho que não pode se furtar ao seu exercício jurisdicional sob pena de afronta ao princípio constitucional da inafastabilidade do Poder Judiciário em conhecer e julgar a lesão ou ameaça à direito trazida à sua apreciação.

As normas que estabelecem os direitos fundamentais trabalhistas estão postas na Constituição, ao mesmo tempo em que há no Brasil uma instituição democrática especializada apta a desempenhar o papel de interpretar e implementar os direitos constitucionais em questões sensíveis, tais como os direitos juslaborais. A questão crucial não está, portanto, na falta de dispositivos constitucionais a assegurar os direitos mínimos dos trabalhadores, nem nas opções políticas desempenhadas pelo parlamento brasileiro na elaboração das leis, mas substancialmente na interpretação constitucional dos direitos fundamentais trabalhistas realizada pelos juízes do trabalho. 
Somente a partir de um mecanismo de interpretação comprometido com os valores da cidadania e da evolução social será possível à Justiça do Trabalho implementar efetivamente vários dos direitos fundamentais dos trabalhadores.

Diante do exposto, propõe-se, como objetivo da presente tese, a adoção, pela Justiça do Trabalho, de uma hermenêutica jurisdicional trabalhista pautada na interpretação constitucional evolutiva, intrinsecamente vinculada às transformações sociais e aos anseios dos trabalhadores brasileiros, no atual contexto de violação dos direitos fundamentais trabalhistas, pelos empregadores, e da ausência de implementação ou implementação restritiva de vários desses direitos, pela Justiça do Trabalho. A atuação desse ramo especializado do Judiciário, com base em tal mecanismo de mutação constitucional, devese pautar em uma concepção ampliativa do exercício dos direitos fundamentais, fundada na cidadania social, extraída da Constituição Federal de 1988, que engloba a possibilidade de os cidadãos exercerem efetivamente os seus direitos individuais e sociais e na viabilidade de buscarem a materialização e implementação das conquistas constitucionalizadas. Ou seja, para que o trabalhador possa ser cidadão, no sentido que a própria Constituição lhe garante, ele deve poder exercitar subjetivamente seus direitos fundamentais individuais, sociais e metaindividuais. E esse exercício só será plenamente possível, por meio da implementação e concretização dos direitos sociais trabalhistas pela Justiça do Trabalho. 


\section{OS DIREITOS FUNDAMENTAIS TRABALHISTAS}

Os direitos fundamentais trabalhistas, enquanto direitos sociais, demandam o estudo da sua origem no contexto histórico e da sua evolução no tempo, perpassando pelos movimentos de constitucionalização e de internacionalização desses direitos, exigem a apresentação de suas características e da estrutura das normas constitucionais que os embasam, e implicam, ainda, a análise de intrincadas questões que lhe são atinentes, como a eficácia jurídica, a vinculação dos destinatários das normas fundamentais trabalhistas, a efetividade dessas normas no cenário nacional e a atuação da Justiça do Trabalho na implementação desses direitos.

\subsection{Escorço histórico dos direitos fundamentais}

Os direitos fundamentais, no qual se incluem os direitos fundamentais de índole social, podem ser definidos como o conjunto de direitos, garantidos na Constituição de um determinado ordenamento jurídico, que compõem o mínimo necessário para assegurar que o ser humano viva com dignidade.

Esses direitos são fruto de lutas ao longo da história que visaram garantir no plano formal e no plano fático o respeito, pelo Estado, da liberdade e igualdade entre os homens. Justamente por ser um produto cultural desenvolvido historicamente é que, em primeiro lugar, será feito um estudo histórico da evolução dos direitos fundamentais, desde a sua origem até os tempos atuais, por meio da clássica análise das gerações de direitos e dos movimentos de constitucionalização e internacionalização dos direitos fundamentais, para, em seguida, serem apresentadas, de forma mais pormenorizada e como decorrência das noções já apreendidas, a definição e as características desses direitos.

\subsubsection{Origem dos direitos individuais: dos primórdios às "libertés publiques"}

Os primeiros direitos, que posteriormente viriam a ser denominados de "fundamentais", não surgiram na antiguidade clássica, embora as primeiras noções sobre 
os valores da dignidade da pessoa humana, da liberdade e da igualdade tenham origem na filosofia antiga, especialmente na Greco-romana e no pensamento cristão.

Na Idade Média, desenvolveram-se postulados de caráter suprapositivo que atuavam como critério de exercício e de limitação do poder. Santo Tomás de Aquino, cujo pensamento teve grande influência nesse período, acreditava na existência de uma ordem formada pelo direito natural, como expressão da natureza racional do homem, e de outra constituída pelo direito positivo, de modo que a desobediência do direito natural por parte dos governantes poderia, em casos extremos, justificar até mesmo o exercício do direito de resistência da população. ${ }^{1}$ Também de grande relevância é o ponto de vista do italiano Pico della Mirandola que, com base no pensamento de Santo Tomás de Aquino, defendeu que “a personalidade humana se caracteriza por ter um valor próprio, inato, expresso justamente na ideia de sua dignidade de ser humano, que nasce na qualidade de valor natural, inalienável e incondicionado, como cerne da personalidade do homem". ${ }^{2}$

Em 1215, o rei João sem Terra da Inglaterra outorga a Magna Charta Libertatum ${ }^{3}$, que é considerado o primeiro ${ }^{4}$ documento que positiva e sistematiza formalmente os direitos individuais do povo inglês.

A Carta se ocupa dos direitos dos ingleses, consistindo na enumeração de prerrogativas garantidas a todos os súditos da monarquia e limitando o poder do Estado por meio da definição de proteções específicas em caso de violação desses direitos.

Portanto, não era o documento propriamente uma manifestação da ideia de direitos do homem inatos, mas a afirmação de direitos corporativos da aristocracia feudal em face do seu suserano. Estabelecia-se um modus vivendi entre o rei e os barões, que consistia fundamentalmente no reconhecimento de certos direitos de supremacia ao rei, em troca de certos direitos de liberdade estamentais consagrados nas cartas de franquia. Mas, apesar disso, significou uma abertura para a transformação dos direitos corporativos em direitos do homem ${ }^{5}$.

\footnotetext{
${ }^{1}$ PEREZ LUÑO, Antoine-Enrique. Los derechos fundamentales. 6 ed. Madrid: Ed. Tecnos, 1995, p. 30.

${ }^{2}$ SARLET, Ingo Wolfgang. A eficácia dos direitos fundamentais. 7 ed. rev. e ampl. Porto Alegre: Livraria do Advogado, 2007, p. 46.

${ }^{3}$ Manoel Gonçalves Ferreira Filho esclarece que a Carta Magna é um dentre os vários documentos em que os senhores feudais e reis escreviam direitos próprios e peculiares aos membros do grupo a que pertenciam, para que fossem conhecidos e respeitados. FERREIRA FILHO, Manoel Gonçalves. Direitos humanos fundamentais. 5 ed. rev. São Paulo: Saraiva, 2002, p. 11.

${ }^{4}$ Nesse período, outras cartas também foram editadas como a Bula de Ouro, em 1188, na Hungria, o Privilégio General outorgado por Pedro III, em 1283, em Zaragoza e os Privilégios da União Aragonesa, em 1283, em Aragão.

${ }^{5}$ CANOTILHO, J. J. Gomes. Direito constitucional e teoria da constituição. 3 ed. Coimbra: Almedina, 1999, p. 358 .
} 
Nesse instrumento legal, estão previstos a liberdade de ir e vir, a propriedade privada, a graduação da penas em relação à importância do delito, entre outros direitos ${ }^{6}$, que foram confirmados por documentos posteriores como a Petition of Rights, de 07 de junho de 1628, e o Bill of Rights, de 13 de fevereiro de 1689, e juntamente com a jurisprudência dos Tribunais ingleses deu origem ao rule of Law, ou seja, ao Estado de Direito como limitação do poder, inclusive das autoridades. Essas cartas receberam a influência da doutrina jusnaturalista, cujo ponto culminante de desenvolvimento ocorreu nos séculos XVII e XVIII, e que defende o reconhecimento dos direitos naturais aos indivíduos como expressão da liberdade e da dignidade da pessoa humana.

A Declaração de Direitos do povo da Virgínia, de 1776, é a primeira que marca a transição dos direitos de liberdade dos ingleses da lei para a Constituição. Essa Declaração incorporava os direitos e liberdades das Declarações sucessores inglesas, com a distinção de apresentar a característica da universalidade e da supremacia dos direitos naturais, sendo-lhes reconhecida eficácia inclusive em relação à representação popular, além vincularem os poderes públicos. Pela primeira vez, os direitos naturais do homem foram acolhidos como direitos constitucionais, ainda que esse status da fundamentalidade em sentido formal tenha sido definitivamente consagrado apenas a partir da incorporação de uma declaração de direitos à Constituição, em $1791 .^{7}$

A Declaração Francesa de Direitos, de 1789, é fruto da Revolução Francesa, que teve como motivos ensejadores o descontentamento com o modelo político absolutista, o contínuo desgaste do poder dos reis, a derrocada do mercantilismo e a contestação da discriminação fundada no nascimento que privilegiava nobres e clero. Com a Revolução, o antigo regime foi derrubado e instaurou-se a ordem burguesa na França.

As ideias defendidas pelos contestadores do antigo regime estavam embasadas nas teorias do liberalismo político e econômico e conseguiram se transmutar, ao longo do tempo, para o plano prático.

Surgido no final do século XVIII, em um momento de crise do modelo mercantilista, o liberalismo econômico, cujos principais teóricos foram François Quesnay,

\footnotetext{
${ }^{6}$ Os direitos individuais do homem somente passam a ser denominados de "fundamentais" com o processo de neoconstitucionalização e internacionalização desses direitos humanos no século XX. Ainda que inseridos nas primeiras Constituições do século XVIII, os direitos de índole individual não eram chamados de direitos fundamentais. A partir da intensificação do processo de constitucionalização dos direitos individuais e da inserção dos direitos sociais nas Constituições no século XX, passa-se a denominar de direitos formalmente fundamentais os direitos que são positivados nas Constituições e de direitos materiais fundamentais aqueles que, embora não positivados no texto constitucional, importam em prerrogativas mínimas sem as quais o homem não pode viver com dignidade.

${ }^{7}$ SARLET, Ingo Wolfgang. A eficácia dos direitos fundamentais. Op. cit., p. 52.
} 
Vincent de Gournay e Adam Smith, defendia a independência da economia em relação a qualquer interferência proveniente de outros meios, inclusive do Estado e a eliminação de medidas protecionistas e restritivas ligada à preservação dos mercados nacionais. $\mathrm{O}$ liberalismo econômico tinha como base o incentivo à liberdade de iniciativa econômica, à livre circulação de riqueza, à valorização do trabalho humano como fonte de toda riqueza e à economia de mercado pautada na livre concorrência e na lei da procura e da oferta como mecanismo de regulação de mercado.

A teoria do liberalismo político, por seu turno, foi gestada ao longo do século XVIII, mas a formação de suas ideias centrais remonta à transição do feudalismo para o capitalismo. Seus principais fomentadores foram os iluministas John Locke, Montesquieu e Anders Chydenius. Com a crise do poder dos reis absolutistas, começa a se formar o Estado Liberal, cujo pressuposto é o reconhecimento de que todos os seres humanos têm direitos naturais de índole individual, como a vida, a liberdade e a igualdade formal perante a lei, não podendo o poder estatal intervir e violar esses direitos. Por isso, os Estados teriam os poderes públicos subordinados às leis, sendo o governo baseado no livre consentimento dos governados e estabelecido por intermédio de eleições livres.

Também no período de gestação das ideias que culminaram na Revolução Francesa, o movimento iluminista estabeleceu as bases do conceito moderno de direitos do homem, a partir da compreensão de que esse é dotado de direitos inatos que precedem o Estado e a comunidade política, devendo ser respeitados e garantidos pelo Poder Público, concepção que encontrou no constitucionalismo a sua expressão jurídica mais clarividente.

A Declaração Francesa, de 26 de agosto de 1789, embora não tenha sido a primeira declaração existente, sendo antecedida pela da Virgínia, de 12 de junho de 1976, e da Declaração de Independência das Treze Colônias, de 4 de junho de $1776^{8}$, foi o principal modelo para a criação de outras declarações posteriores e serviu de norte para a formalização escrita de direitos fundamentais nas Constituições dos Séculos XVIII e XIX.

\footnotetext{
${ }^{8}$ A Constituição de 1787 que unificou as trezes colônias criando um Estado Federal, deixou de estabelecer, paradoxalmente, qualquer rol de direitos, omissão que veio a ser suprida em 1791, com a aprovação de dez emendas que consubstanciam o Bill of Rights, que elenca direitos de liberdade e garantia ao cidadão americano. Daniel Sarmento explicita que a contribuição mais valiosa para os direitos humanos, como limites impostos ao próprio legislador, é a de que o Judiciário pode fiscalizar a inobservância desses limites, por meio do controle de constitucionalidade dos atos normativos. Somente no século XX, após a criação de um modelo abstrato e concentrado de jurisdição constitucional, idealizado por Hans Kelsen, e depois das barbáries cometidas durante a segunda guerra sob o alvedrio da lei, é que a ideia de limitação do próprio legislativo pelos direitos fundamentais, por meio do controle de constitucionalidade das leis, começa a se expandir pelo continente europeu e pelo restante do mundo. Cf. SARMENTO, Daniel. Direitos fundamentais e relações privadas. 2 ed. Rio de Janeiro: Lumen Juris, 2006, p. 10-11.
} 
Paulo Bonavides esclarece que as Declarações anteriores de ingleses e americanos podiam até ganhar em concretude, mas perdiam em espaço de abrangência, porque se dirigiam ou à camada privilegiada dos barões feudais ou a um povo ou a uma sociedade que se libertava politicamente, como as antigas colônias americanas, "ao passo que a Declaração francesa de 1789 tinha por destinatário o gênero humano" ${ }^{9}$, apresentando uma formulação solene bastante abstrata acerca da liberdade. Foi, portanto, a Declaração de 1789 a primeira a ensejar a idéia de universalidade dos direitos humanos, advindo do racionalismo francês da Revolução.

Boutmy, citado por Bonavides, sintetiza a inovação da Declaração francesa: "Foi para ensinar o mundo que os franceses escreveram; foi para o proveito e comodidade de seus concidadãos que os americanos redigiram suas Declarações". ${ }^{10}$

A finalidade principal da Declaração foi instruir os indivíduos de seus direitos preexistentes e protegê-los contra atos do governo ${ }^{11}$. A ideia dos redatores do texto era de que os direitos naturais do homem, justamente pelo fato de serem intrínsecos à existência humana, não são criados, devendo apenas ser declarados. ${ }^{12}$

Para assegurar o exercício dos direitos pelos indivíduos, o Estado deveria reduzir ao mínimo a sua ação, para que a sociedade pudesse se desenvolver de forma harmoniosa, o que acabou gerando por um tempo considerável a dicotomia entre Direito Público e Direito Privado, como dois universos distintos e incomunicáveis.

Os direitos de liberdade e as garantias são considerados direitos universais, abstratos, imprescritíveis, inalienáveis e individuais, ou seja, existem para cada ser humano, independentemente da comunidade.

A Declaração trouxe basicamente duas categorias de direitos: as liberdades ligadas aos poderes de agir ou não agir, independentemente da ingerência do Estado - englobando a liberdade de locomoção, de opinião e de expressão, a propriedade, a legalidade processual, a presunção de inocência, dentre outros, e as liberdades relativas à participação política, entre eles o direito de participar da vontade geral, de escolher os seus

\footnotetext{
${ }^{9}$ BONAVIDES, Paulo. Curso de direito constitucional. 20 ed. São Paulo: Malheiros, 2007, p. 562.

${ }^{10}$ BOUTMY, Émile. La Déclaration des drois de l'homme, p. 139. BONAVIDES, Paulo. Curso de direito constitucional. Op. cit., p. 562.

${ }^{11}$ Para proteger os direitos de liberdade era necessário limitar o poder do Estado, com a atuação de apenas um governo moderado, intuito que foi alcançado com a teoria da separação dos poderes de Montesquieu, que será tratada de forma mais minuciosa no capítulo 4 dessa tese.

${ }^{12}$ Essa ideia de reconhecimento jurídico de direitos pré-existentes se contrapõe à visão positivista de que os direitos são apenas reconhecidos se postos na lei, se criados por lei. Assim, na Declaração a enumeração de direitos é apenas exemplificativa, pois não é necessário que os direitos estejam na Declaração para que sejam respeitados.
} 
representantes, de pedir contas da atuação dos agentes políticos, por exemplo. Ou seja, o documento englobava os direitos do homem enquanto tal, e os direitos do cidadão, pertencentes ao homem enquanto ser social, como indivíduo vivendo em sociedade, correspondendo à divisão do status negativus e do status activus de Georg Jellinek. ${ }^{13}$

As liberdades nada mais são do que direitos subjetivos oponíveis ao Estado de que são sujeitos ativos ou titulares cada um dos seres humanos e sujeitos passivos todos os indivíduos que não o titular, os entes públicos e privados. Manoel Gonçalves Ferreira Filho explica que o Estado deve abster-se de perturbar o exercício desses direitos, bem como evitar que eles sejam desrespeitados, além de atuar de forma repressiva, de modo a restaurá-los se violados, inclusive punindo os responsáveis por sua violação. ${ }^{14}$

Ademais, o texto da Declaração enumera vários princípios de organização política, como o da igualdade, a soberania da nação, a conservação de direitos e a existência de uma Constituição. Não obstante, os direitos políticos propriamente ditos foram conferidos apenas à burguesia, por meio da instituição do voto censitário.

A Declaração estipula, ainda, que a lei formal, ou seja, a editada pelo Poder Legislativo, deve regular o exercício dos direitos pelo homem e criar sanções para punir os abusos - por ser abstrata e derivada da vontade geral - e que todos os homem são iguais perante a lei, ou seja, há igualdade formal entre os seres humanos.

Sem embargo, a aparente neutralidade da lei em relação aos conflitos distributivos legitimou a dominação econômica sobre as classes mais desfavorecidas, fenômeno observado precipuamente a partir da denominada Revolução Industrial, ocorrida em virtude das alterações substanciais operadas sobre os meios de produção e sobre a forma de organização dos trabalhadores. Esses, que em sua grande maioria trabalhavam em relações ligadas ao sistema feudal e às corporações de ofício, passaram a se concentrar em grandes fábricas, fato que gerou profundas transformações sociais e econômicas. ${ }^{15}$

Assim, o mesmo legislador que "protegia a liberdade de contratar, negava-se a admitir a liberdade de associação dos trabalhadores, cujos sindicatos eram postos à margem da lei e sofriam implacável repressão." 16

Alguns outros direitos ficam fora do texto da Declaração, sendo estabelecidos apenas por instrumentos posteriores, como a liberdade econômica, que se vislumbra no

\footnotetext{
${ }^{13}$ JELLINEK, Georg. Sistema dei diritti pubblici subbietivi. Milano, 1910.

${ }^{14}$ FERREIRA FILHO, Manoel Gonçalves. Direitos humanos fundamentais. Op. cit., p. 30.

${ }^{15}$ MARTINEZ, Luciano. Curso de direito do trabalho: relações individuais, sindicais e coletivas de trabalho. São Paulo: Saraiva, 2010, p. 35.

${ }^{16}$ SARMENTO, Daniel. Direitos Fundamentais e Relações Privadas. Op. cit., p. 9.
} 
corolário da livre concorrência, determinada com a Lei Le Chapelier, de junho de 1791, a liberdade de comércio, indústria e profissão, com a Declaração de 1793, e a liberdade de trabalho, com o Decreto de 25 de fevereiro de 1848 e a Constituição do ano III, em seu Preâmbulo, item VII e artigo 13.

As declarações de direitos do homem influenciaram na confecção, pelos países, de constituições escritas, ou seja, leis escritas e superiores às demais normas do ordenamento jurídico, que tinham como objetivo estabelecer limites ao poder político, incorporando, por meio de normas jurídicas básicas, direitos subjetivos do homem e evitando-se, assim, que esses direitos se tornassem alvo do arbítrio do legislador infraconstitucional.

A positivação dos direitos do homem nas Constituições gerou a superação gradativa do jusnaturalismo, pois os direitos, antes inatos, passaram a ser acolhidos pela ordem jurídica dos Estados, movimento denominado de positivismo jurídico. ${ }^{17}$ A partir de então, é que os direitos individuais ou liberdades públicas são concebidos como direitos públicos subjetivos ${ }^{18}$ oponíveis ao Estado, gerador de pretensões do indivíduo em face do poder estatal que deveriam ser exercidas exclusivamente dentro dos limites traçados pelas leis.

\subsubsection{Do nascimento dos direitos trabalhistas: cerne dos direitos sociais}

A origem dos direitos econômicos e sociais está intrinsecamente relacionada com a passagem do Estado Liberal para o Estado de Bem-Estar Social, em virtude de diversos fatores encadeados que geraram a crise do liberalismo econômico e o quadro de extrema desigualdade econômica que se estabeleceu entre os trabalhadores assalariados ${ }^{19}$ - o proletariado - e a burguesia detentora dos meios de produção.

A lógica do modelo econômico baseado no laissez faire, ou seja, na mão invisível do mercado para resolver os problemas sociais, com o Estado protegendo apenas a

\footnotetext{
${ }^{17} \mathrm{O}$ positivismo jurídico identifica o Direito à lei posta pelo Estado, como medida de segurança jurídica, abdicando da ideia de justiça, como um valor metafísico e abstrato.

${ }^{18} \mathrm{O}$ principal jurista que formulou o conceito de direitos públicos subjetivos foi Georg Jellinek.

${ }^{19}$ Nos dizeres de Mauricio Godinho Delgado, no período da Revolução Industrial, após o processo de ruptura do sistema produtivo feudal, o trabalhador já não é mais servo ou escravo, ou seja, é juridicamente livre, pois separado dos meios de produção, mas está subordinado ao proprietário desses mesmos meios produtivos, o que configura um dos elementos mais importantes e diferenciadores da relação de emprego em relação às demais formas de relações de trabalho. Cf. DELGADO, Mauricio Godinho. Curso de direito do trabalho. 5 ed. São Paulo: LTr, 2006, p. 85.
} 
segurança interna e externa e a propriedade dos cidadãos, mostrou-se equivocada, pois acentuou o quadro de exploração do homem pelo homem. A distinção rígida entre sociedade e Estado acabou por separar a esfera das relações econômicas, que consagrava a exploração econômica capitalista, da esfera do poder político, que se democratizava aos poucos com a implantação paulatina do sufrágio universal. ${ }^{20}$

Nos dizeres de Eros Roberto Grau, a liberdade econômica levou à supressão da concorrência e a industrialização crescente, sem regulamentação estatal, gerou uma classe

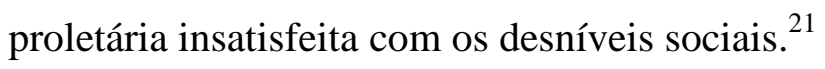

Nos países mais desenvolvidos da Europa Ocidental e nos Estados Unidos, a degradação das condições de vida e de trabalho do proletariado, em virtude de uma acumulação de riqueza sem precedentes dos grandes donos de fábricas, chega a um ponto crítico.

A grande massa de trabalhadores concentrada nas cidades europeias e norteamericanas leva a uma diminuição dos salários, paralelamente a uma redução de mão-deobra motivada pelo desenvolvimento das máquinas industriais. As condições de trabalho nas fábricas e minas eram extremamente ruins, com jornadas extenuantes, salários ínfimos, exploração da mão de obra dócil e barata, composta por crianças e mulheres, ausência de condições de segurança, saúde e higiene no local de trabalho, em virtude de um ambiente deveras insalubre pela umidade, falta de ventilação e de iluminação, sujeira e demais fatores dilapidadores da saúde dos trabalhadores. Diante do quadro externado, não é por acaso que os acidentes de trabalho, gerando mortes e mutilações, fossem bastante comuns e, juntamente com as condições degradantes, constituíram um dos elementos propulsores das revoltas, reivindicações e greves dos empregados.

Assim, a classe operária marginalizada começa a reagir contra a classe rica, por meio de revoltas ou de movimentos organizados, e a classe burguesa, com o receio do abalo às instituições liberais, passa a ter interesse em contornar a situação de crise mediante a adesão a teorias que buscavam uma maior harmonia entre o embate capital e trabalho.

Se o capitalismo mercantil e a luta pela emancipação da sociedade burguesa são inseparáveis da conscientização dos direitos do homem, de índole individualista, a luta de classes e as teorias socialistas põem em relevo a necessidade de completar os tradicionais

\footnotetext{
${ }^{20}$ SANTOS, Boaventura de Souza. Pela mão de Alice. São Paulo: Cortez Editora, 1995, p. 122.

${ }^{21}$ GRAU, Eros Roberto. A ordem econômica na Constituição de 1988. São Paulo: Malheiros, 2000, p. 15.
} 
direitos do cidadão burguês com os direitos do homem em sua integridade, o que só seria possível com uma nova organização da sociedade.

De um lado, havia a ideia de reconciliação do proletariado com as demais classes e o Estado, que se desenvolveu precipuamente nas teorias do socialismo cristão e do socialismo utópico. Por outro lado, outros grupos com ideias revolucionárias intentavam extinguir as classes exploradoras, por intermédio da abolição da propriedade privada dos meios de produção e da chegada ao poder do proletariado, como o socialismo científico de Marx e Engels, ou visavam extirpar o Estado e acabar com todas as classes, como pregavam os seguidores do movimento anarquista.

Segundo Marx, os direitos humanos do liberalismo compunham as bases da dominação econômica exercida pela burguesia sobre o proletariado, que só teria fim com a implantação final do comunismo, com a extinção das classes sociais. ${ }^{22}$

$\mathrm{Na}$ prática, o socialismo revolucionário somente chegou à experiência de concretização, ainda que distante das suas bases teóricas, com a Revolução Russa de 1917 e a criação posterior da União Soviética, que juntamente com outros seguidores da concepção político-econômica e social da forma de Estado Socialista, formaram um dos pólos da Guerra Fria.

Não obstante, o pensamento de Marx influenciou sobejamente no processo histórico de formação dos direitos sociais, embora fosse ele contrário à positivação desses direitos porque, uma vez ultrapassada a fase histórica caracterizada pela exploração do homem pelo homem, desnecessária é a produção de normas jurídicas, pois estas só se justificam pela diferença de condição material de vida entre as classes.

Por seu turno, o socialismo utópico, encabeçado por pensadores como Charles Fourier, Louis Blanc e Robert Owen, considerando o liberalismo incapaz de resolver a questão social, acreditava na possibilidade de convencimento da burguesia acerca da necessidade de reformas sociais. Essa corrente teve papel bastante relevante na criação do Direito do Trabalho. Owen, por exemplo, era um empresário inglês que implantou diversas medidas de proteção ao trabalho em suas fábricas, ainda no início do século XIX, difundiu ideias ligadas à proteção do trabalhador e teve grande influência na aprovação da primeira legislação social na Inglaterra. ${ }^{23}$

O socialismo cristão, consubstanciado na doutrina social da Igreja permeada pelas ideias de São Tomás de Aquino, criticava o individualismo exacerbado do liberalismo,

\footnotetext{
${ }^{22}$ SARMENTO, Daniel. Direitos Fundamentais e Relações Privadas. Op. cit., p. 16.

${ }^{23}$ SUSSEKIND, Arnaldo. Op. cit., p. 7.
} 
defendia um posicionamento mais ativo do Estado em defesa dos mais pobres, pregava uma vida digna para o ser humano, por meio da dignidade do trabalho e do trabalhador, e afirmava a existência de direitos que exprimissem as necessidades mínimas de uma vida digna consentânea com a dignidade de ser humano, criado à imagem e semelhança de Deus.

Essas ideias dispostas inicialmente na Encíclica Rerum Novarum, do Papa Leão XIII, de 1891, repercutiram ainda nas Encíclicas Quadragesimo Anno, de 1931, Mater et Magistra, de 1961, Pacem in Terris, de 1963, Populorum Progressio, de 1967, Humanae Vitae, de 1969 e Centesimus Annus, de 1991, essa última criada no papado de João Paulo II.

Justamente em virtude do embate entre o capital e o trabalho, vislumbrado no momento pós-Revolução Industrial, que levou à organização dos trabalhadores em sindicatos, ao fomento de novas ideologias, incluindo precipuamente o socialismo cristão e o científico e às lutas do proletariado é que emerge a preocupação do Estado em tentar conter as revoltas de classe justamente para manter a lógica do sistema capitalista. A atuação estatal, por meio da elaboração de leis que visavam proteger minimamente o trabalhador em prol de um maior equilíbrio entre o capital e o trabalho e que, em verdade, visa evitar um colapso do sistema, leva à emergência dos primeiros direitos sociais, quais sejam, os direitos do trabalhador. ${ }^{24}$ Esses, consequentemente, geraram a construção de outros direitos sociais básicos, como o direito à saúde, à assistência social, à educação, à moradia, à segurança, entre outros.

O Direito do Trabalho, dessa forma, pode ser considerado produto das transformações sócio-econômico-políticas ocorridas ao longo dos séculos XVIII e XIX que colocaram a relação de trabalho subordinado, ou seja, o trabalhador subordinado ao

\footnotetext{
${ }^{24}$ A formação e desenvolvimento do Direito do Trabalho, enquanto ramo do Direito, normalmente é sistematizada pelos autores da seara juslaboral em quatro fases: a primeira, denominada formação, que vai do início do século XVIII, com a publicação das primeiras normas trabalhistas, até 1848 , com a publicação do Manifesto Comunista; a segunda fase, conhecida como desenvolvimento, intensificação ou efervescência, que vai de 1848 até a edição da Encíclica Rerum Novarum, em 1891, caracterizada por muitas greves e pela criação e fortalecimento dos sindicatos; a fase de consolidação, de 1891 até a celebração do Tratado de Versalhes, após o final da Primeira Guerra Mundial, em 1919; e a fase de aperfeiçoamento ou autonomia, iniciada, com a criação da OIT, em 1919, e a promulgação das Constituições do México, de 1917, e da Alemanha, de 1919, e que vai até os dias atuais, tendo o seu pico no movimento do constitucionalismo social. Mauricio Godinho Delgado ainda acrescenta outra fase, a da crise e transição do Direito do Trabalho, marcada basicamente pelo questionamento, a partir do final da década de 70 , acerca da pertinência do direito do trabalho tal como construído até então, em face das alterações político-econômicas derivadas da crise do petróleo, da ascensão de regimes governistas conservadores, do neoliberalismo político e econômico e das inovações tecnológicas da era da informação. Cf. DELGADO, Mauricio Godinho. Curso de direito do trabalho. Op. cit., p. 86.
} 
detentor dos meios de produção, como núcleo essencial do processo produtivo característico da sociedade capitalista. ${ }^{25}$

As primeiras normas infraconstitucionais, com o objetivo de proteger o trabalhador e minimizar os efeitos sociais desoladores da Revolução Industrial, foram editadas na Inglaterra, na primeira metade do século XIX. Na Alemanha, Bismarck seguiu linha parecida nas décadas 60 e 70 do mesmo século, pretendendo impedir o avanço dos defensores do socialismo e alcançar a paz social, estabelecendo uma legislação inicial de proteção ao trabalhador e de assistência social.

Embora já houvesse nas Declarações do século XVIII certa preocupação social, prevendo a Declaração francesa de 1793, por exemplo, os socorros públicos e o direito à instrução, a Constituição francesa, de 4 de novembro de 1848 , foi a primeira a consagrar alguns direitos econômicos e sociais.

Precedida de um preâmbulo, a Constituição de 1848 contém um capítulo no qual se enunciam os direitos por ela garantidos, entre eles a proteção do cidadão na sua pessoa, sua família, sua propriedade, seu trabalho e a instrução indispensável, bem como a prestação de assistência para assegurar aos cidadãos necessitados ajuda na busca de trabalho, inclusive por meio de trabalhos públicos, ou socorros àqueles que não estão em condições de trabalhar. Implícitos, portanto, o direito ao trabalho e o direito à educação, ainda que timidamente.

Em 1889, o governo suíço propõe a realização de uma Conferência Diplomática em Berne, para fixar as bases de um acordo internacional sobre o trabalho nas fábricas. Sem embargo, somente com Guilherme II, Imperador da Alemanha, a iniciativa é tomada com a convocação, em Berlim, da primeira Conferência Internacional para o estudo da questão operária, que se realiza em 15 de março de 1891, com a presença de quatorze países, porém, sem nenhum sucesso, diante da impossibilidade de um entendimento diplomático. ${ }^{26}$

Em 25 de junho de 1900, realizou-se em Paris um Congresso Internacional para a proteção legal dos trabalhadores, do qual resultou a criação de uma Associação Internacional, integrada por políticos, empresários, professores e funcionários públicos que se instalou em Bale e passou a publicar um boletim mensal visando a incentivar a realização de novos congressos. Assim, em 1902, novo congresso foi realizado em Colônia, no qual se reconheceu a necessidade de uma intervenção legislativa no que tange

\footnotetext{
${ }^{25}$ DELGADO, Mauricio Godinho. Curso de direito do trabalho. Op. cit., p. 86.

${ }^{26}$ SOUTO MAIOR, Jorge Luiz; CORREIA, Marcus Orione Gonçalves. O que é direito social? Op. cit., p. 21.
} 
à proibição do trabalho de mulheres à noite na indústria e à utilização de fósforo branco na fabricação de palitos de fósforo. Mais duas conferências são realizadas, em maio de 1905 e em setembro de 1906, e dessa última resulta a proibição do trabalho de mulheres à noite nas fábricas, acatada por dezessete países e a interdição do fósforo branco em quatorze. ${ }^{27}$

Até a Primeira Guerra Mundial outros congressos são realizados, mas não surgem novas regulamentações do trabalho e, com o conflito armado, as reuniões são suspensas. Apenas após o final da Guerra é que a questão trabalhista passa a ser objeto de maior atenção, com a criação da Organização Internacional do Trabalho, pelo Tratado de Versalhes, com o intuito de desenvolvimento de uma legislação do trabalho.

É importante salientar que o movimento de positivação dos direitos sociais e econômicos, derivada da constatação da desigualdade de fato existente, visa proteger o mais fraco do mais forte, de modo a assegurar a igualdade materialmente e não mais somente do ponto de vista formal.

Paralelamente a essa análise do surgimento das primeiras leis trabalhistas, inclusive a nível mundial, é importante salientar que a extensão do sufrágio universal a cada vez mais parcelas da população acabou por exterminar com a hegemonia absoluta da burguesia no Parlamento, abrindo espaço, no plano político, para a reivindicação de direitos das camadas mais desfavorecidas do povo. Esse fator, juntamente com os problemas oriundos da Guerra, foi um dos responsáveis pelo surgimento, no século XX, do Estado de BemEstar-Social caracterizado pela ponte entre as liberdades já consagradas no modelo Liberal e os direitos sociais, estipulados constitucionalmente, a serem assegurados pelo Estado, por meio de prestações destinadas à garantia de condições mínimas de vida para a população, como saúde, educação e previdência.

Ainda antes do final da Guerra, foi promulgada a Constituição Política dos Estados Unidos Mexicanos, em 1917. Além de se referir à reforma agrária e ao nacionalismo, foi a primeira a atribuir expressamente aos direitos trabalhistas a qualidade de direitos fundamentais, juntamente com as liberdades individuais e os direitos políticos, trazendo um elenco dos direitos do trabalhador, entre eles o direito ao trabalho digno e socialmente útil, o direito de greve e de livre organização dos trabalhadores em sindicatos, jornada máxima de oito horas de trabalho, a proteção ao desemprego e à maternidade, a idade mínima de admissão de empregados nos trabalhos industriais e a vedação de trabalho noturno a menores na indústria.

\footnotetext{
${ }^{27}$ Ibidem, p. 21.
} 
Por seu turno, como fruto da Revolução Soviética de 1917, a Declaração dos Direitos do Povo Trabalhador e Explorado, de janeiro de 1918, de égide marxista-leninista, não elenca propriamente direitos, mas ações como a abolição da propriedade privada da terra, dos bancos e das empresas, colocando-os sobre o controle do partido dos trabalhadores, com a extirpação de todos os exploradores do Estado Social.

A influência da Constituição Mexicana, realmente precursora, fez-se sentir na Constituição de Weimar ${ }^{28}$, de 1919, ao fim da Primeira Guerra, e em todas as Convenções aprovadas pela recém-criada Organização Internacional do Trabalho, na Conferência de Washington no mesmo ano. A OIT foi estabelecida pelo Tratado de Versalhes, de 28 de junho de 1919, que visava definir as condições do pós-guerra entre os países aliados e a Alemanha e que estabeleceu os direitos sociais considerados fundamentais e de observância obrigatória para todos os países signatários do Tratado.

A Constituição de Weimar ${ }^{29}$, em sua primeira seção, tratou dos direitos do indivíduo, na segunda parte, da vida social, na terceira, da religião e das sociedades religiosas, na quarta, da instrução e dos estabelecimentos de ensino e na quinta, da vida econômica. A propriedade deve atender a sua função social, com base no interesse geral, na repartição de terras, na possibilidade de socialização das empresas, na proteção ao trabalho, no direito de sindicalização, na previdência social e na co-gestão das empresas.

As transformações sociais que se iniciaram como reação ao liberalismo se acentuaram após a Primeira Guerra Mundial em virtude dos desequilíbrios oriundos da livre concorrência, da concentração de capitais que gerou distribuição de renda injusta, salários baixos e preços altos e da opressão dos mais fracos economicamente pelos mais fortes, detentores dos meios de produção e das propriedades.

A crise do capitalismo, com a quebra da Bolsa de Nova Iorque, em 1929, evidenciou a necessidade de superação do modelo liberal de Estado, que não obstante foi ressuscitado em parte pelo modelo neoliberal, inicialmente implantado nos anos 80 do século XX. O período de depressão decorrente da quebra tornou patente a necessidade de intervenção estatal no mercado para implantar políticas econômicas e reduzir o desemprego. Essas idéias, defendidas pelo economista John Maynard Keynes, foram adotadas pelo Presidente Roosevelt por meio do New Deal, programa econômico e social

${ }^{28}$ A escolha da cidade de Weimar para a reunião da Assembléia Constituinte se deu em virtude da impossibilidade da cidade de Berlim, destruída pela Guerra, com suas instituições políticas em ruínas e uma situação social gravosa.

${ }^{29}$ A Constituição Alemã de 1919 serviu de modelo para a Constituição Espanhola de 1931 e a brasileira de 1934. 
desenvolvido pelos Estados Unidos na década de 30 para enfrentar a grave crise que se abateu sobre a economia norte-americana.

Os direitos sociais foram reafirmados e ampliados após a Segunda Guerra Mundial, sendo tratados de modo sistemático na Constituição brasileira de 1946, na italiana de 1947 e em todas as outras editadas após o conflito, implantando de vez o chamado Estado de Bem-Estar Social (Welfare State), nos países da Europa Ocidental, diante da necessidade clara de que o Estado não poderia mais apenas se abster de atuar para respeitar direitos de liberdade, mas deveria, concomitantemente, implementar as condições necessárias para a efetivação dos direitos sociais assegurados constitucionalmente.

Em 30 de maio de 1946, a OIT passa a fazer parte da Organização das Nações Unidas, criada ao fim da Guerra, como órgão permanente, reforçando a preocupação dos países com a questão da distribuição da renda e da fixação de condições dignas de trabalho em todo o mundo.

No Brasil, ao contrário do que aconteceu na Europa, não houve uma grande movimentação operária e popular que exigisse melhores condições de trabalho e de vida e que levasse à preocupação dos Estados em tentar amortecer as reivindicações por meio da criação de leis trabalhistas.

$\mathrm{O}$ movimento operário no Brasil, nas primeiras décadas do século $\mathrm{XX}$, quase não existia, pois não havia uma capacidade de organização e de pressão, justamente pela incipiência do número de trabalhadores, já que o país havia saído do regime da escravidão há muito pouco tempo (com a Lei Áurea, em 1888), passando por um processo de adaptação para o regime de trabalho livre e subordinado.

Embora já existisse alguma legislação social esparsa desde o final do século XIX, a partir da década de 30 o país acelera a atividade legislativa, regulando alguns assuntos de natureza trabalhista, incluindo a criação de sindicatos oficiais únicos, submetidos ao reconhecimento do Estado e colaboradores dele. A política corporativista sindical restou sedimentada com a Consolidação das Leis do Trabalho, em 1943, sepultando o desenvolvimento de um movimento operário forte e organizado, com consciência crítica da importância de sua atuação, pelo menos até a década de 1970, época do início do nascimento das lutas sindicais, ainda que mantidos os traços mais fortes do sistema corporativista pelo menos até a Constituição de 1988.

Ainda que a CLT tenha sido um importante passo na positivação dos direitos trabalhistas mais relevantes, seguida de inúmeras leis que, em seu conjunto, formaram um corpo legislativo de proteção aos trabalhadores no âmbito da relação de emprego e que 
permanece, em grande parte, até os dias de hoje, percebe-se que, no Brasil, a criação dos direitos trabalhistas se deu de cima para baixo, ou seja, da imposição do Estado para o povo, justamente para extirpar as primeiras tentativas de formação de um movimento operário consciente da força de sua atuação, inclusive na reivindicação de seus direitos.

Esmiuçados a origem e a evolução dos direitos sociais, cabe proceder à sua caracterização.

Na definição de Alexandre de Moraes, direitos sociais

\begin{abstract}
são direitos fundamentais do homem, caracterizando-se como verdadeiras liberdades positivas, de observância obrigatória em um Estado Social de Direito, tendo por finalidade a melhoria das condições de vida aos hipossuficientes, visando à concretização da igualdade social, e são consagrados como fundamentos do Estado democrático, pelo art. $1^{\circ}$, IV, da Constituição Federal. ${ }^{30}$
\end{abstract}

Os direitos sociais são direitos subjetivos e, em geral, ensejam poderes de exigir uma prestação concreta por parte do Estado na forma de um serviço ou de uma contrapartida em dinheiro, embora, em alguns casos, como o direito ao lazer, seja também um direito de agir. Ou seja, o Estado ou outros sujeitos passivos seriam os responsáveis por criar pressupostos materiais indispensáveis ao exercício desses direitos, tais como a construção de escolas e de hospitais para assegurar o direito à educação e o direito à saúde ou o estabelecimento de políticas governamentais que visem à criação ou ao aumento dos postos de trabalho para o exercício do direito ao trabalho. São direitos relacionados ao status positivus de Georg Jellinek, ou seja, direitos dos cidadãos às prestações necessárias ao desenvolvimento pleno da existência individual.

O sujeito passivo desses direitos é o Estado ou a sociedade ou às vezes pode ser até entes privados, como o empregador que se estrutura individualmente ou por meio de uma empresa. O fundamento dos direitos sociais está na sociabilidade inerente à própria natureza humana e, nesse sentido, são considerados direitos naturais, diferentemente dos direitos e liberdades individuais, advindos do homem enquanto indivíduo e, por isso, chamados naturais pelos jusnaturalistas e pelos que ainda defendem essa concepção.

O direito ao trabalho e os direitos dos trabalhadores são, portanto, direitos humanos sociais, eis que a sua origem é determinada pela luta pela dignidade da pessoa humana, merecendo ser tratados como tal, inclusive no que tange a sua irrenunciabilidade. Sem embargo, enquanto direitos sociais, sofrem com as mesmas argumentações teóricas que

\footnotetext{
${ }^{30}$ MORAES, Alexandre de. Direito constitucional. 7 ed. rev., ampl. e atual. São Paulo: Atlas, 2000, p. 190.
} 
tendem a enquadrá-los apenas como princípios sem normatividade ou normas sem aplicabilidade.

Realmente, muito já se questionou acerca da fundamentalidade e da aplicabilidade dos direitos sociais, visto que vários deles exigem do Estado determinadas prestações materiais nem sempre facilmente exeqüíveis, em virtude da escassez de meios e recursos para concretizá-los.

De fato, embora não exista hierarquia entre os direitos de índole individual e os direitos sociais, constata-se que esses ensejam maiores dificuldades para a sua afirmação concreta do que aqueles, por resistências ideológicas e por problemas operacionais.

\begin{abstract}
Pela sua vocação distributiva, os direitos sociais acenam para uma transformação do status quo, e por isso mobilizam contra si os interesses de extratos privilegiados da sociedade, que não desejam mudanças. [...] os direitos sociais, em razão da sua natureza eminentemente prestacional, carecem de recursos públicos que são escassos. Diante disso afirma-se que os direitos sociais estão sujeitos à reserva do possível, pois sua efetivação encontra obstáculos em limites fáticos muitas vezes insuperáveis. ${ }^{31}$
\end{abstract}

Argumenta-se, por exemplo, que esses direitos são formalmente reconhecidos, mas não poderiam ser acionados em juízo, ou seja, seriam desprovidos de adequadas garantias jurisdicionais que os tornassem aplicáveis mediante regras processuais estabelecidas.

Essa visão se embasava na ideia de que a Constituição continha apenas uma proclamação de princípios políticos, que dependeriam sempre do legislador para a produção de efeitos concretos e se dirigiriam ao Executivo e ao Legislativo, mas não ao juiz e ao cidadão. Ademais, sustentava-se que as declarações de direitos incorporadas às constituições teriam conteúdo exclusivamente moral, sem qualquer eficácia jurídica. ${ }^{32}$

Segundo Sarmento, com a adoção generalizada de instrumentos de controle de constitucionalidade em todo o mundo, ao longo do século XX, essa concepção foi se modificando, importando "na afirmação prática do valor jurídico e da superioridade normativa da Constituição". 33

31 SARMENTO, Daniel. Direitos fundamentais e relações privadas. Op. cit., 2006, p. 21.
32 CANOTILHO, Joaquim José Gomes. Op. cit., p. 1051-1052.
33 SARMENTO, Daniel. Direitos fundamentais e relações privadas. Op. cit., p. 51. O reconhecimento da
força normativa da Constituição implica na compreensão de que as normas constitucionais não são mais
apenas o limite para o legislador, mas também o norte da sua atuação e o centro unificador de todo o
ordenamento jurídico, inclusive das leis infraconstitucionais. Cf. HESSE, Konrad. A força normativa da
constituição. Tradução de Gilmar Ferreira Mendes. Porto Alegre: S. A. Fabris, 1991. Konrad Hesse foi o
precursor desse entendimento, a partir da elaboração da sua teoria da "força normativa da Constituição",
combatendo assim, a visão descrente de Ferdinand Lassale para quem as normas constitucionais não tinham
nenhum valor, equiparando-se a um mero pedaço de papel. Para Lassale, a Constituição verdadeira de um
Estado consiste exclusivamente nos "fatores reais de poder que regem uma nação"; assim, a lei constitucional 
Com a mudança do Estado Liberal para o Estado Social, as Constituições passam a consagrar não apenas os direitos individuais, mas também os direitos sociais e econômicos. Não obstante, o pensamento constitucional hegemônico do período atribui caráter vinculante apenas à parte da estrutura e organização do Estado e às normas consagradoras dos direitos individuais. As normas constitucionais que consagram os direitos sociais são rotuladas, durante boa parte do século $\mathrm{XX}$, como meramente programáticas, sem nenhuma força vinculante originária, dependendo do legislador e do administrador público para criar e implantar os programas que efetivem os comandos constitucionais. Caso o legislador ordinário ficasse inerte, restavam frustradas as potencialidades transformadoras da Constituição que, em verdade, constituíam risco para os interesses das classes hegemônicas.

Segundo Daniel Sarmento, esse posicionamento, ainda que enraizado nos operadores jurídicos, vai aos poucos sendo modificado, a partir da segunda metade do século XX, com a compreensão de que, ainda que existam gradações no tocante aos efeitos das normas constitucionais, todas elas possuem uma eficácia mínima, já que influenciam na “interpretação e integração do ordenamento jurídico, vinculam negativamente o legislador e a administração, que não podem agir de modo contrário à norma, e acarretam a não-recepção do direito anterior incompatível." 34

As normas programáticas geram, portanto, direito subjetivos negativos, não sendo possível ao Legislativo, ao legislar, nem ao Executivo, ao executar programas previstos constitucionalmente, atuar de forma contrária aos postulados da Constituição. O dispositivo constitucional, quando estabelece mesmo de forma genérica os seus propósitos, vincula os diversos agentes políticos para os fins impostos nos programas constitucionalmente estabelecidos.

Em adição, deve-se salientar que nem todos os direitos sociais são normas programáticas dependentes de regulamentação pelo legislador infraconstitucional para a plena eficácia jurídica, como vários dos direitos fundamentais trabalhistas estabelecidos na Constituição Federal de 1988 que não demandam regulamentação ${ }^{35}$, nem gastos para o erário (com exceção quando o próprio poder público é o empregador) para serem

só teria alguma eficácia se refletisse com fidelidade esses fatores. Cf. LASSALE. Ferdinand. A essência da constituição. Tradução de Walter Stones. Rio de Janeiro: Liber Juris, 1985.

${ }^{34}$ SARMENTO, Daniel. Direitos fundamentais e relações privadas. Op. cit., p. 53.

${ }^{35}$ Até porque vários dos direitos fundamentais trabalhistas, seja os que exigem lei infraconstitucional para a sua aplicabilidade direta, sejam os que não exigem, são regulados pela legislação infraconstitucional, o que rebate muitos dos argumentos que visam a não concretizar esses direitos. 
plenamente aplicáveis, enquanto alguns direitos de liberdade demandam a intervenção do legislador.

Andreas Krell defende, por seu turno, que os direitos sociais são dotados de várias garantias aptas a fazê-los valer em juízo:

[...] o fato de que os direitos sociais geralmente não são fruíveis ou exequiíveis individualmente não quer dizer que juridicamente não possam, em determinadas circunstâncias, ser exigidos como se exigem judicialmente outros direitos subjetivos. $^{36}$

Ademais, no que tange à questão da eficácia positiva das normas sociais consagradoras de prestações materiais, a compreensão de que essas normas são desvestidas de aplicabilidade encontra-se teoricamente ultrapassada, pois mesmo a doutrina mais liberal tem reconhecido alguma eficácia jurídica aos direitos sociais, ao menos no que tange à proteção do mínimo existencial, ou seja, à garantia das prestações materiais indispensáveis para a vida humana, sem as quais o usufruto das liberdades torna-se impossível $^{37}$, assunto que será melhor tratado ainda nesse capítulo.

\subsubsection{Da evolução dos direitos fundamentais: as dimensões de direitos}

Os direitos de primeira geração englobam os direitos e garantias civis, inclusive os direitos de nacionalidade, e os direitos políticos clássicos, ou seja, as chamadas liberdades públicas. São direitos que já se consolidaram em sua projeção de universalidade formal, não havendo Constituição que não os reconheça em toda a sua extensão.

Correspondem, respectivamente, à categoria do status negativus e do status activus da classificação de Georg Jellinek, traduzindo-se como as faculdades ou atributos dos indivíduos em opor ao Estado a não violação desses direitos, o que significa o reconhecimento de uma separação nítida entre a sociedade e o Estado.

Carl Schmitt, citado por Daniel Sarmento, entendia, inclusive, que os direitos fundamentais propriamente ditos eram apenas os direitos do homem livre e isolado em face do Estado, mais especificamente os direitos de liberdade, da pessoa particular,

${ }^{36}$ KRELL, Andreas J. Direitos sociais e controle judicial no Brasil e na Alemanha. Porto Alegre: Sergio Antonio Fabris, 2002, p. 102.

${ }^{37}$ SARMENTO, Daniel. Direitos fundamentais e relações privadas. Op. cit., p. 21. 
correspondendo ao conceito do Estado burguês de Direito, referente a uma liberdade, em princípio ilimitada diante de um poder estatal de intervenção limitado, mensurável e controlável. $^{38}$

Segundo o entendimento de Joaquim Gomes Canotilho, os direitos de primeira geração ou direitos de defesa têm como função a defesa dos cidadãos, sob uma dupla perspectiva:

constituem, num plano jurídico-objectivo, normas de competência negativa para os poderes públicos, proibindo fundamentalmente as ingerências destes na esfera jurídica individual; [...] implicam, num plano jurídico-subjectivo, o poder de exercer positivamente direitos fundamentais (liberdade positiva) e de exigir omissões dos poderes públicos, de forma a evitar agressões lesivas por parte dos mesmos (liberdade negativa). ${ }^{39}$

A primeira dimensão dos direitos humanos foi historicamente complementada pelos direitos sociais, culturais e econômicos considerados de segunda geração - como conquista dos desprivilegiados que reivindicavam o direito de participar do "bem-estar social", entendido, nas palavras de Celso Lafer, "como bens que os homens, por meio do processo coletivo, vão acumulando no tempo." 40

Fazendo um contraponto entre os direitos de primeira e segunda geração, Paulo Bonavides esclarece:

[...] na fase da primeira geração os direitos fundamentais consistiam essencialmente no estabelecimento das garantias fundamentais da liberdade [...] a partir da segunda geração passaram a compreender, além daquelas garantias, também os critérios objetivos de valores, bem como os princípios básicos que animam a lei maior, projetando-lhe a unidade e fazendo a congruência fundamental de suas regras. ${ }^{41}$

Os direitos fundamentais de segunda geração podem ser definidos como

[...] aqueles consagrados a partir do momento em que surgem reclamos da realização pelo Estado de maior justiça social, promovendo uma situação igualitária entre os indivíduos e setores da sociedade economicamente desnivelados. Esses seriam, portanto, direitos a determinadas prestações do Estado ao povo que o compõe $[\ldots]$. $^{42}$

\footnotetext{
${ }^{38}$ SCHMITT, Carl. Verfassungslehre. Berlin: Ducker \& Humblot, [s.d.], p. 164 apud BONAVIDES, Paulo. Curso de direito constitucional. 20 ed. atual. São Paulo: Malheiros, 2007, p. 561.

${ }^{39}$ CANOTILHO, Joaquim José Gomes. Direito constitucional. Op. cit., p. 383.

${ }^{40}$ LAFER, Celso. Op. cit., p. 127.

${ }^{41}$ BONAVIDES, Paulo. Curso de direito constitucioinal. Op. cit., p. 568.

42 GUERRA FILHO, Willis Santiago. Processo constitucional e direitos fundamentais. São Paulo: Celso Bastos, 1999, p. 112.
} 
Os direitos de segunda geração ou dimensão são os direitos sociais, econômicos e culturais e as liberdades coletivas, todos eles embasados no princípio da igualdade, já pronunciado na Revolução Francesa. Porém, somente a partir da ideologia antiliberal do final do século XIX e início do século XX, foram esses direitos positivados nas Constituições advindas a partir do final da Primeira Guerra, dominando por inteiro as Constituições do segundo pós-guerra.

A Declaração Universal dos Direitos do Homem, promulgada pela Assembléia Geral das Nações Unidas, em 10 de dezembro de 1948, é a afirmação da evolução dos direitos de primeira e segunda gerações, com a inclusão de novos direitos, como o direito de asilo, direito a uma nacionalidade, a liberdade de casar, e a sedimentação dos já existentes.

Os direitos chamados sociais englobam os direitos mínimos trabalhistas, os direitos à seguridade social, à saúde, à educação, à moradia, à alimentação, ao amparo na infância, na gravidez e na velhice, à segurança, ao acesso à cultura e ao lazer, à liberdade de associação, de reunião, à liberdade sindical e de greve, entre outros.

Esses direitos são chamados sociais, pois não são relativos a um indivíduo considerado abstratamente, mas sim à pessoa em sua relação no grupo em que convive, ao indivíduo considerado em concreto. Nas palavras de Romita

são os direitos pertinentes à teia de relações sociais formada pela pessoa no meio
em que atua, como trabalhador, como membro de comunidades, como
participante de coletividades sem as quais não poderia desenvolver suas
potencialidades nem usufruir os bens econômicos, sociais e culturais a que
aspira. ${ }^{43}$

Segundo Jorge Miranda, os direitos sociais decorrem da sociabilidade do ser humano e têm em vista objetivos de promoção, de comunicação e de cultura. ${ }^{44}$

Muitos dos direitos de segunda dimensão apresentam como característica principal a necessidade de uma prestação positiva do Estado, por meio de políticas públicas aptas a tornar efetivo o seu exercício, sujeitando-se, assim, à reserva do possível. Vários direitos sociais, não obstante, apresentam função eminentemente de defesa, como alguns direitos trabalhistas, entre eles o de greve e o de limitação de jornada de trabalho.

Celso Lafer destaca a complementaridade entre os direitos de primeira e de segunda dimensões, afirmando que os direitos sociais

${ }^{43}$ ROMITA, Arion Sayão. Direitos fundamentais nas relações de trabalho. 2 ed. rev. e aum. São Paulo: LTr, 2007 , p. 105.

${ }^{44}$ MIRANDA, Jorge. Manual de direito constitucional. T. IV. 2 ed. Coimbra: Coimbra Editora, 1993, p. 87. 
buscam assegurar as condições para o pleno exercício do primeiro, eliminando ou atenuando os impedimentos ao pleno uso das capacidades humanas. Por isso, os direitos de crédito, denominados econômicos, sociais e culturais, podem ser encarados como direitos que tornam mais reais direitos formais: procuram garantir a todos o acesso aos meios de vida e de trabalho num sentido amplo. ${ }^{45}$

Em virtude das modificações no cenário mundial, da tomada de consciência da existência de nações desenvolvidas e subdesenvolvidas e da deterioração da qualidade de vida humana, a referência individual, até então considerada, não tem sido suficiente para atender às necessidades plenas do ser humano, razão porque, já no final da década de setenta, muito se propugna pelo alargamento da dimensão dos direitos humanos, para alcançar aqueles que se assentam sobre a fraternidade, os denominados direitos de solidariedade. De acordo com Celso Lafer, "esses direitos têm como titular não o indivíduo em sua singularidade, mas sim grupos humanos, coletividades regionais ou étnicas e a própria humanidade". 46

Os direitos de solidariedade, também conhecidos como de fraternidade, em virtude da tentativa de materialização do terceiro princípio da Revolução Francesa, dizem respeito ao direito a um meio ambiente equilibrado, a uma qualidade de vida saudável, ao progresso, à paz, ao patrimônio comum da humanidade, à autodeterminação dos povos, ao direito de comunicação e demais direitos difusos - aqueles cuja titularidade é indeterminável e o objeto indivisível - e coletivos stricto sensu, que são titularizados por grupos de pessoas, ou seja, o sujeito é indeterminado, mas determinável, porém o objeto é indivisível.

A Constituição Brasileira de 1988 prevê alguns desses direitos, como, por exemplo, o direito à autodeterminação dos povos (art. $4^{\circ}$, III), o direito à paz (art. $4^{\circ}$, VI), o meio ambiente ecologicamente equilibrado (art. 225), o patrimônio comum da humanidade (art. 23, incisos III e IV) e o direito à defesa do consumidor (art. $5^{\circ}$, XXXII).

É importante salientar que embora os direitos de terceira geração se situem no plano difuso, isto não quer dizer que o mesmo não se dê com os direitos sociais, que podem ser exercidos na esfera individual, mas também de forma difusa. $\mathrm{O}$ tratamento coletivo para a tutela dos direitos humanos busca proteger os interesses essencialmente difusos e os direitos sociais, de uma forma geral, podem ser qualificados como tal, visto

${ }^{45}$ LAFER, Celso. A ruptura totalitária e a reconstrução dos direitos humanos: um diálogo com Hannah Arendt. Op. cit., p. 127.

${ }^{46}$ Ibidem, p. 131. 
que ligados, ainda que de forma indireta, à idéia que pauta a formação de dos direitos de terceira geração embasados no ideal de solidariedade. ${ }^{47}$

Alguns juristas ainda acrescentam ao estudo da evolução dos direitos fundamentais os direitos de quarta, quinta e sexta gerações ou dimensões. Paulo Bonavides entende que os direitos de quarta geração são aqueles advindos da globalização política, correspondendo à fase de institucionalização do Estado social, ou seja, são fruto da universalização de direitos no campo institucional. Cita como exemplo o direito à democracia, o direito à informação e o direito ao pluralismo. ${ }^{48}$

Arion Sayão Romita defende a existência da quarta dimensão ou família, englobando os direitos de manipulação genética e direito ao patrimônio genético relacionados com a biotecnologia, a bioengenharia e a bioética, tendo em vista as repercussões e perspectivas das novas descobertas científicas e de suas aplicações tecnológicas; da quinta família, formada pelos direitos de informática e cibernética, que transcendem as fronteiras tradicionais e possibilitam o surgimento de conflitos entre realidades sociais distintas, em virtude da revolução da informação que envolve o controle social de enormes massas de informação, proporcionadas pela conjugação da informática e das telecomunicações; e da sexta família, referente aos direitos da globalização, entre eles os mesmos citados por Bonavides, tais como o direito à democracia ${ }^{49}$ - pois, em um Estado Democrático de Direito exige-se o respeito aos direitos fundamentais, à informação correta - não como um direito individual ou profissional, mas como um direito da coletividade que só encontra sua plena realização em um regime democrático, e o pluralismo, que se opõe a uma concepção individualista da sociedade e do Estado, como o direito de todo o grupo humano a ser diferente e a ser tratado como igual.

Willis Santiago Guerra Filho nega a necessidade e mesmo a possibilidade teórica de se estender a enumeração dos direitos fundamentais além da terceira família, porque os novos direitos já estariam abrangidos nas dimensões anteriores. ${ }^{50}$

\footnotetext{
${ }^{47}$ PIOVESAN, Flávia. A proteção dos direitos sociais nos planos interno e internacional. In: GONÇALVES, Marcus Orione; CORREIA, Érica Paula Bacha (coords.). Direito previdenciário e constituição. São Paulo: LTr, 2004, p. 27.

${ }^{48}$ BONAVIDES, Paulo. Curso de direito constitucional. Op. cit., p. 570-571.

${ }^{49}$ A democracia, nos dizeres de Arion Sayão Romita, baseia-se na vontade humana livremente expressa pelo povo de determinar seus próprios sistemas políticos, econômicos, sociais e culturais e em sua plena participação em todos os aspectos de suas vidas. Cf. ROMITA, Arion Sayão. Op. cit. São Paulo: LTr, 2007, p. 126.

50 GUERRA FILHO, Willis Santiago. Dimensões dos direitos fundamentais e teoria processual da Constituição. In: SOARES, José Ronald Cavalcante (Coord.). Estudos de direito constitucional: homenagem a Paulo Bonavides. São Paulo: LTr, 2001, p. 49.
} 
É importante ressaltar que os direitos fundamentais evoluíram com o tempo, ao longo das Declarações de Direito e com os avanços nos estudos de sua normatividade, aplicabilidade e eficácia. Se no século XVIII e XIX os direitos individuais foram prestigiados, para proteger o indivíduo contra as arbitrariedades do Estado, sendo chamados de liberdades públicas negativas, no século XX eles foram remodelados, com o surgimento dos direitos de segunda e de terceira dimensão, ou seja, os direitos de natureza social e transindividual, sofrendo, assim, os devidos temperamentos.

Assim, adota-se, nessa tese, o entendimento de que as gerações de direitos explicitadas por Norberto Bobbio na verdade são melhor compreendidas como dimensões de direitos, visto que a expressão "geração de direitos" suscita a errônea ideia de exclusão dos direitos da geração anterior.

Cançado Trindade acredita que a concepção das gerações de direitos, defendida por Bobbio, é fragmentadora e atomizada, pois os direitos humanos não se sucedem ou substituem uns aos outros, mas se expandem, se acumulam e fortalecem.

Essa conceituação de que primeiro vieram os direitos individuais e, nesta ordem, os direitos econômico-sociais e o direito de coletividade, correspondem à evolução do direito constitucional. É verdade que isso ocorreu no plano dos direitos internos dos países, mas no plano internacional, os direitos que aparecem primeiros foram os econômicos e os sociais. [...] é uma construção perigosa, porque faz analogia com o conceito de gerações. O referido conceito se refere praticamente a gerações de seres humanos que se sucedem no tempo. Desaparece uma geração, vem outra geração e assim sucessivamente. Na minha concepção, quando surge um novo direito, os direitos anteriores não desaparecem. Há um processo de cumulação e expansão do 'corpus iuris' dos direitos humanos. Os direitos se ampliam, e os novos direitos enriquecem os anteriores. ${ }^{51}$

\section{Segundo Dinaura Godinho Pimentel Gomes}

[...] o reconhecimento de uma nova geração de direitos deve servir de fator de fortalecimento da geração ou dimensão anterior, que adquire uma nova roupagem que passa a interferir na sua interpretação, eis que representa o desencadeamento de mais uma faceta desses mesmos direitos consentânea com as aspirações e exigências decorrentes da realidade histórica compatíveis com a dignidade da pessoa humana. ${ }^{52}$

\footnotetext{
${ }^{51}$ Cançado Trindade no Seminário "Direitos humanos das mulheres: a proteção internacional", realizado no dia 25 de maio de 2000, na Câmara de Deputados Federais, Brasília, DF, esclarece que a tese de geração de direitos foi originalmente proposta por Karek Vasak, em conferência ministrada em 1979, no Instituto Internacional de Direitos Humanos, em Estrasburgo. Cf. CORREIA, Marcus Orione Gonçalves. Os direitos sociais enquanto direitos fundamentais. GONÇALVES, Marcus Orione; CORREIA, Érica Paula Bacha (coords.). Direito previdenciário e constituição. São Paulo: LTr, 2004, p. 25.

${ }^{52}$ GOMES, Dinaura Godinho Pimentel. Op. cit., p. 128.
} 
Dessa forma, não se pode falar em gerações de direitos no sentido da exclusão dos grupos anteriores, mas apenas para mostrar a evolução temporal dos direitos fundamentais ao longo do tempo. A segunda geração, de direitos sociais, não excluiu a primeira, e tampouco a terceira não suprimiu a segunda ou a primeira. São direitos que vão sendo acumulados, formando um corpo consistente de direitos fundamentais.

Após a análise da origem e da evolução dos direitos fundamentais, em torno da noção das dimensões de direitos, necessário se faz o estudo do processo de constitucionalização e de internacionalização dos direitos fundamentais sociais, como fenômenos que completam o escorço histórico desses direitos.

\subsubsection{A importância da constitucionalização dos direitos fundamentais sociais $e$ o fenômeno da constitucionalização dos ramos do Direito}

Os direitos da pessoa humana de índole individual foram sendo constitucionalizados, ou seja, dispostos no topo da pirâmide jurídica dos Estados, desde a Constituições Francesas de $1791^{53}$ e $1793^{54}$ e do Bill of Rights americano, ou seja, das Emendas Constitucionais de 1791 e seguintes à Constituição dos Estados Unidos da América de 1787.

Nas Constituições, sob influência das doutrinas liberais do século XVIII, os direitos positivados apresentavam o rótulo de direitos individuais ou direitos de liberdades "negativas", vistos como naturais, oponíveis à vontade do Estado, inalienáveis e imprescritíveis.

Apenas após a Primeira Grande Guerra é que começou o processo de constitucionalização sistematizada dos direitos sociais ${ }^{55}$, em virtude do discurso social da cidadania, sob a forte influência da concepção marxista-leninista, daí resultando a Declaração dos Direitos do Povo Trabalhador, em 1918. Esse novo leque de direitos transparece na Constituição Mexicana, de 1917, e na Constituição de Weimar, de 1919. A

\footnotetext{
${ }^{53}$ A primeira Constituição revolucionária francesa, de 03 de setembro de 1791 , não obstante, não encarta em seu texto cláusulas assecuratórias dos direitos do homem, mas, em seu preâmbulo, refere-se a eles.

${ }^{54}$ A Constituição de 24 de junho de 1793, intitulada de Acte Constitutionnel inseriu, ao final de seu texto, um tópico rotulado de De la garantie des droits, garantindo direitos como a igualdade, a liberdade, a segurança, a propriedade, o reconhecimento da dívida pública, o livre exercício de cultos, o reconhecimento a uma instrução comum e ao socorro público, a liberdade de imprensa, o direito de petição e o direito de se reunir em sociedades populares.

${ }^{55}$ A doutrina costuma utilizar a expressão "direitos sociais" de forma genérica, para se referir aos direitos econômicos, sociais e culturais.
} 
partir de então, os direitos à abstenção estatal passam a ser complementados com os novos direitos vinculados à atuação do Estado na elaboração de políticas públicas, criação de mecanismos e tomada de medidas efetivas para disponibilizar o exercício de direitos a todos os seres humanos. São direitos voltados a prestações de índole social estatuídos constitucionalmente.

A positivação constitucional dos direitos da pessoa humana é o passo inicial mais relevante para assegurar o reconhecimento jurídico e a proteção desses direitos e, também, o fundamento para instrumentalizar e concretizar o seu exercício.

A constitucionalização significa a incorporação de direitos do homem em normas constitucionais, normas formalmente básicas incorporadas na Constituição de um Estado, com o objetivo de subtrair do âmbito de atuação do legislador ordinário o reconhecimento e a disponibilidade desses direitos, bem como de protegê-los mediante o controle jurisdicional de constitucionalidade das normas que regulam esses direitos.

Nos dizeres de Canotilho, os direitos fundamentais precisam ser, então, compreendidos e interpretados como normas jurídicas vinculativas e não como "trechos ostentatórios" como os presentes nas "declarações de direitos". 56

Segundo o constitucionalista português, não basta a positivação dos direitos fundamentais, ou seja, a incorporação na ordem jurídica positiva dos direitos considerados naturais e inalienáveis dos indivíduos:

\footnotetext{
É necessário "assinalar-lhes a dimensão de Fundamental Rights colocados no lugar cimeiro das fontes do direito: as normas constitucionais. Sem esta positivação jurídica, os "direitos do homem são esperanças, aspirações, idéias, impulsos, ou, até, por vezes, mera retórica política", mas não direitos protegidos sob a forma de normas (regras e princípios) de direito constitucional. ${ }^{57}$
}

Carl Schmitt entende que os direitos fundamentais podem ser caracterizados como aquelas garantias e direitos nomeados e especificados no instrumento constitucional, recebendo um grau mais elevado de segurança, ou seja, ou são imutáveis ou pelo menos de mudança dificultada, com alteração permitida apenas mediante lei de emenda à Constituição. ${ }^{58}$

\footnotetext{
${ }^{56}$ CANOTILHO, Joaquim José Gomes. Direito constitucional e teoria da constituição. Op. cit., p. 354.

${ }^{57}$ Ibidem, p. 353.

${ }^{58}$ SCHMITT, Carl. Verfassungslehre. Berlin: Ducker \& Humblot, [s.d.], p. 163/173 apud BONAVIDES, Paulo. Curso de direito constitucional. Op. cit., p. 561.
} 
Alexy acredita que os direitos fundamentais assim o são por apresentarem uma fundamentalidade formal e uma fundamentalidade material. A fundamentalidade material está ligada diretamente à constitucionalização desses direitos, ou seja, as normas consagradoras de direitos fundamentais devem ser inseridas na Constituição por serem normas fundamentais e como tais estarão elas submetidas a procedimentos especiais de reforma. Ademais, muitas vezes as normas jusfundamentais passam a constituir limites materiais das reformas constitucionais e parâmetros materiais de escolhas, decisões e controle dos órgãos dos poderes legislativo, executivo e judicial.

A fundamentalidade material significa que o conteúdo dos direitos fundamentais é constitutivo das estruturas básicas do Estado e da sociedade, ou seja, existe uma relação intrínseca entre a fundamentalidade material e a formal. Assim, alguns direitos, ainda que não presentes formalmente em uma Constituição, podem ser considerados fundamentais e reconhecidos implicitamente pela Lei Maior, recebendo o mesmo tratamento que os direitos fundamentais formais, assim como novos direitos fundamentais podem a qualquer momento surgir e serem incorporados também.

Ao lado do processo da constitucionalização das normas de direitos fundamentais, nos últimos anos vêm ganhando espaço o fenômeno da constitucionalização dos diversos ramos do direito, sobretudo do Direito Privado, o que deve ser, ainda que brevemente, comentado.

A Constituição Brasileira de 1988 trouxe novas diretrizes sociais para o Brasil, estabelecendo parâmetros para a interpretação e aplicação do direito positivo pátrio. A Constituição vigente tem como diretriz a mescla de valores advindos do Estado Social de Direito com valores oriundos da Revolução Francesa que inspirou as Constituições de matriz liberal. Isso demonstra a complexidade dos valores contidos na Constituição de 1988 e a necessidade da utilização da técnica da ponderação dos princípios constitucionais para a solução de conflitos normativos.

$\mathrm{Na}$ verdade, nas sociedades pluralistas e modernas a diversidade de valores e idéias existentes no meio social acaba refletida no texto constitucional que acolhe normas potencialmente colidentes. Nessa linha de raciocínio, o princípio da unidade da Constituição, "obriga o intérprete a considerar a constituição ( sic) na sua globalidade e a procurar harmonizar os espaços de tensão existentes entre as normas constitucionais a concretizar". 59

\footnotetext{
${ }^{59}$ CANOTILHO, José Joaquim Gomes. Direito constitucional e teoria da constituição. Op. cit., p. 1097.
} 
A constitucionalização dos ramos do Direito significa que as normas infraconstitucionais de cada uma das áreas jurídicas devem ser lidas, interpretadas e aplicadas, conforme os princípios e seus valores emanados da Norma Fundamental, incluindo os valores irradiados pelas normas principiológicas de direitos fundamentais previstos constitucionalmente.

O fenômeno de constitucionalização do direito leva a uma unificação da ordem jurídica, visto que as normas constitucionais tornam-se progressivamente o fundamento comum dos diversos ramos do direito, relativizando a distinção entre direito público e direito privado.

O exemplo recente de maior visibilidade do procedimento de constitucionalização de um ramo jurídico está no Direito Privado, sobretudo com a vigência do Código Civil de $2002^{60}$. Este diploma e a Constituição passaram a interagir de uma forma totalmente nova, criando espaço para a consolidação do Direito Civil Constitucional. ${ }^{61}$

Sem embargo, é necessário ressaltar que, em se tratando do ramo jurídico trabalhista, ainda são incipientes os estudos dos juristas das áreas do Direito Constitucional e do Direito do Trabalho no que tange à constitucionalização do Direito do Trabalho, sobretudo por não haver uma conexão entre a teoria dos direitos fundamentais, desenvolvida pelos constitucionalistas, com os direitos fundamentais trabalhistas, normalmente tratados de forma mais sucinta e superficial pelos publicistas e abordada mais precipuamente pelos juristas da seara laboral, ainda que de forma incipiente.

O estudo por esses desenvolvido geralmente permeia mais a aplicação prática desses direitos ou dos direitos infraconstitucionais deles derivados nos casos concretos em que há controvérsia doutrinária e jurisprudencial, não adentrando nas possibilidades e peculiaridades desses direitos enquanto direitos fundamentais sociais.

Ademais, não se pode olvidar que o fato de os direitos trabalhistas mínimos estarem dispostos expressamente na Constituição torna-os obviamente direitos constitucionais fundamentais, ao contrário de vários direitos civis que estão dispostos apenas implicitamente na Constituição Federal. Assim, parece haver um desinteresse e uma falta de atenção à necessidade de um estudo pormenorizado dos direitos fundamentais trabalhistas enquanto direitos fundamentais sociais, sobretudo no que tange à interpretação desses direitos. Dessa forma, se nem os direitos fundamentais trabalhistas são burilados

${ }^{60}$ TEPEDINO, Gustavo. Temas de Direito Civil. Rio de Janeiro: Renovar, 2001 apud TARTUCE, Flávio. Direito Civil e Constituição. Disponível em: 〈www.flaviotartuce.adv.br〉. Seção artigos do professor. Acesso em: 10 out. 2010.

${ }^{61}$ TARTUCE, Flávio. Direito Civil e Constituição. Op. cit. 
devidamente pela doutrina e jurisprudência majoritárias como direitos fundamentais sociais, consequentemente, a tarefa de interpretar e aplicar os direitos trabalhistas infraconstitucionais sob a luz dos valores emanados pela Constituição Federal, em face da dimensão objetiva dos direitos fundamentais, dificilmente será incorporada pelos aplicadores do direito na seara laboral.

Urge, portanto, a conscientização dos juslaboristas em relação ao tratamento dado aos direitos fundamentais trabalhistas, que ordinariamente têm sido tratados como meros direitos infraconstitucionais, sendo, às vezes, mais relegados que os próprios direitos celetistas infraconstitucionais, de maneira que a influência benéfica trazida pelo movimento de constitucionalização do Direito Privado atinja também o Direito do Trabalho, que nada mais é do que um direito privado com incidência de normas de ordem pública.

\subsubsection{A internacionalização dos direitos fundamentais}

Diante dos resultados catastróficos das atrocidades cometidas durante a Segunda Guerra Mundial, consolidou-se o consenso da comunidade internacional de que o ser humano tem direitos que devem ser protegidos pelo direito internacional. Os direitos humanos são então alçados à dimensão de soberania universal, constituindo preocupação internacional, independentemente da nacionalidade do indivíduo. Segundo Flávia Piovesan,

\footnotetext{
fortalece-se, assim, a idéia de que a proteção dos direitos humanos não deve se reduzir ao domínio reservado do Estado, isto é, não deve se restringir à competência nacional exclusiva ou à jurisdição doméstica exclusiva, porque revela tema de legítimo interesse internacional. ${ }^{62}$
}

Em 10 de dezembro de 1948, a Assembléia Geral das Nações Unidas, mediante a Resolução n. 217, aprovou de forma unânime - com voto favorável de 48 estados e 8 abstenções - a Declaração Universal dos Direitos do Homem, que embora programática, estabeleceu valores e princípios sobre os quais se assentaram os direitos da primeira, segunda e terceira geração.

${ }^{62}$ PIOVESAN, Flávia. Introdução ao sistema interamericano de proteção dos direitos humanos. In: GOMES, Luiz Flávio; PIOVESAN, Flávia. (Coords.). O sistema interamericano de proteção dos direitos humanos o e o direito brasileiro. São Paulo: RT, 2000, p. 19. 
Tão importante quanto o ano de 1789 foi para a velha universalidade de inspiração liberal que teve como mérito o ponto de partida para a inserção de direitos de liberdade direitos civis e políticos - nas Constituições do século XIX, em um movimento progressivo de positivação formal ao qual sempre corresponderam os respectivos conteúdos materiais, o ano de 1948 o foi para a nova universalidade de direitos fundamentais, colocando-os num grau mais alto de juridicidade, concretude, positividade e eficácia, e fortalecendo os direitos da liberdade "com as expectativas e os pressupostos de melhor concretizá-los mediante a efetiva adoção dos direitos de igualdade e da fraternidade."63 O indivíduo, titular dos direitos de primeira, segunda e terceira gerações, antes de ser indivíduo de um país determinado, é pela sua condição de pessoa um ente qualificado por sua pertinência ao gênero humano.

Nessa nova perspectiva, busca-se passar da igualdade formal, antes conquistada, para a igualdade material ou substantiva, quando os direitos humanos passam a constituir um complexo integral, único e indivisível, agregando igualdade e liberdade, pois sem uma, não há a outra.

A Declaração de 1948, ademais, ao introduzir uma nova linguagem de direitos, combinando-se o discurso liberal da cidadania com o discurso social da cidadania, constituiu-se como o marco de criação do chamado "Direito Internacional dos Direitos Humanos", que é um sistema jurídico normativo de alcance internacional, com o objetivo de proteger os direitos humanos.

Após a aprovação da Declaração, com o intuito de assegurar a observância universal dos direitos nela previstos, prevaleceu o entendimento de que ela deveria ser juridicizada, sob a forma de tratado internacional, juridicamente obrigatório e vinculante no âmbito do Direito Internacional. Assim, em 19 de dezembro de 1966, esse processo de juridicização foi concluído com a celebração, pelas Nações Unidas, do Pacto Internacional de Direitos Civis e Políticos e do Pacto de Direitos Sociais, Econômicos e Culturais, tratados que incorporavam, com maior precisão e detalhamento, os direitos constantes da Declaração, sob a forma de preceitos juridicamente obrigatórios e vinculantes. Com a entrada em vigor em 30 de janeiro de 1976 - pois somente nesse data foi alcançado o número necessário de ratificações - a efetivação dos direitos sociais, econômicos e culturais passa a ser uma obrigação jurídica dos países que ratificarem ${ }^{64}$ o Tratado de 1966.

\footnotetext{
${ }^{63}$ BONAVIDES, Paulo. Curso de direito constitucional. Op. cit., p. 573.

${ }^{64}$ O Brasil ratificou ambos os Pactos por meio do Decreto n. 591, de 6 de junho de 1992, tornando-os lei vigente no Brasil.
} 
Assim, esses Estados devem adotar todas as medidas, principalmente nos planos econômicos e técnicos, até o máximo de seus recursos disponíveis, com vistas a alcançar progressivamente a completa realização desses direitos.

Não obstante, Flávia Piovesan ressalta que não somente os direitos sociais, mas também os direitos civis e políticos demandam do Estado prestações positivas, sendo equivocada e simplista "a visão de que os direitos sociais só demandariam prestações

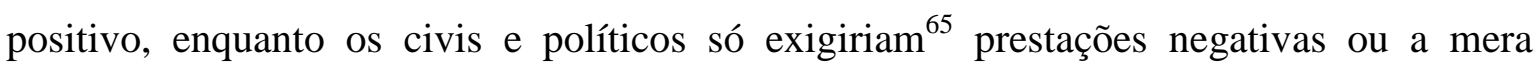
abstenção estatal". Como exemplos, a autora cita os custos com a segurança que asseguram os direitos de liberdade e de propriedade, o custo do aparato eleitoral para viabilizar os direitos políticos ou do aparato da justiça para viabilizar o direito de acesso ao judiciário.

Em relação à aplicação progressiva dos direitos sociais, culturais e econômicos, pode-se extrair o princípio da proibição do retrocesso, bem explicado por Canotilho:

o núcleo essencial dos direitos sociais já realizado e efetivado através de medidas legislativas deve considerar-se constitucionalmente garantido, sendo inconstitucionais quaisquer medidas que, sem a criação de esquemas alternativos ou compensatórios, se traduzam na prática em uma anulação, revogação ou aniquilação pura e simples desse núcleo essencial. A liberdade do legislador tem como limite o núcleo essencial já realizado. ${ }^{66}$

Assim, por exemplo, criado, por meio de lei, o direito ao seguro-desemprego, não pode mais o legislador extinguir esse direito, sob pena de violar o núcleo essencial do direito fundamental ao trabalho constitucionalmente protegido.

O Pacto Internacional dos Direitos Econômicos, Sociais e Culturais enuncia um extenso catálogo de direitos, que inclui o direito ao trabalho e à justa remuneração, o direito a formar e a filiar-se a sindicatos, o direito a um nível de vida adequado, o direito à moradia, o direito à educação, à previdência social, à saúde, entre outros. ${ }^{67}$ Deve-se relevar todavia que bem antes, mais precisamente após o final da Primeira Guerra Mundial, foi criada a Organização Internacional do Trabalho (OIT), pelo Tratado Versalhes de 1919, com o objetivo de promover parâmetros internacionais referentes às condições de trabalho e bem estar dos trabalhadores.

\footnotetext{
${ }^{65}$ PIOVESAN, Flávia. Introdução ao sistema interamericano de proteção dos direitos humanos. In: GOMES, Luiz Flávio; PIOVESAN, Flávia. (Coords.). Op. cit., p. 17.

${ }^{66}$ CANOTILHO, Joaquim José Gomes. Direito constitucional e teoria da constituição. Op. cit., p. 449.

${ }^{67}$ PIOVESAN, Flávia. A proteção dos direitos sociais nos planos interno e internacional. In: GONÇALVES, Marcus Orione; CORREIA, Érica Paula Bacha (Coords.). Direito previdenciário e constituição. São Paulo: LTr, 2004, p. 17.
} 
No âmbito americano, a Convenção Americana de Direitos Humanos ou Pacto de San José da Costa Rica, de 1969, além de declarar direitos, previu a criação da Comissão Interamericana de Direitos Humanos - que tem como uma de suas atribuições a de apreciar petições que contenham denúncias ou queixas de qualquer pessoa referentes à violação dos direitos declarados e encaminhar ao Estado as conclusões de seus trabalhos, com proposições e recomendações para que seja resolvido o problema e para que o Estado tome as medidas adequadas - e da Corte Interamericana de Direitos Humanos, que tem como função o julgamento de casos envolvendo a violação de um direito fundamental, reconhecido pela Convenção, para que o prejudicado possa gozar de seu direito.

No continente europeu, a Convenção Européia para a Proteção dos Direitos Humanos e Liberdades Fundamentais, de Roma, aprovada em 4 de novembro de 1950, teve o objetivo de declarar direitos fundamentais, como já feito na Declaração Universal de 1948, e de instituir a Comissão Européia de Direitos Humanos - que visa analisar os requerimentos de qualquer pessoa física ou entidade não governamental, por meio do Secretário-Geral do Conselho da Europa em relação à violação de direitos e enviá-los ao Comitê de Ministros que decidirá se houve ou não a violação e proporá uma conciliação amigável - e a Corte Européia de Direitos Humanos, cujo objetivo é julgar os casos em que não houve conciliação, determinando a sua correção ou concedendo uma reparação razoável.

A Carta Social Européia, de 18 de outubro de 1961, aprovada pelo Conselho da Europa, é um tratado que enuncia os direitos e as liberdades e estabelece um sistema de controle que garante o seu respeito pelos Estados membros. A entrada em vigor da Carta Social Européia revista, de 3 de Maio de 1996, pela Assembléia da República, n. 64-2001, produziu como efeito a cessação de aplicação das disposições da Carta de 1961. A versão revista proclama a unidade dos direitos humanos, bem como a defesa do direito ao emprego, à proteção contra a pobreza e exclusão social e do direito a uma habitação decente.

Em 27 de junho de 1981, a Carta Africana nos Direitos Humanos e dos Povos foi aprovada pela Conferência Ministerial da então Organização da Unidade Africana (OUA), em Banjul, na Gâmbia, sendo que em 27 de julho do mesmo ano, foi o documento adotado pela XVIII Assembléia dos Chefes de Estado e Governo da OUA - hoje chamada União Africana, em Nairóbi, no Quênia. Foi estabelecida também uma Comissão Africana dos Direitos Humanos e dos Povos para promover, proteger e interpretar as previsões de 
direitos humanas consagradas na Carta. Não obstante, apenas em 1986 é que a Carta entrou em vigor, atingindo em 1995 a ampla adesão dos cinquenta e três Estados Africanos.

A Carta de Banjul apresenta feições próprias e peculiares, distinguindo-se dos demais instrumentos internacionais e regionais de proteção aos direitos humanos, ao conferir importância às tradições históricas e aos valores da civilização africana, tratar do processo de libertação da África, da luta por independência e dignidade dos povos africanos, do combate ao colonialismo e neocolonialismo, da erradicação do apartheid, sionismo e quaisquer outras formas de discriminação. Ademais, a Carta Africana, que tem como desafio enfrentar graves e sistemáticas violações aos direitos humanos, adota uma perspectiva coletivista que dá ênfase aos direitos dos povos e é a partir dessa perspectiva que se transita aos indivíduos, considerando que os direitos civis, políticos, sociais, econômicos e culturais são indissociáveis tanto na sua concepção, como na sua universalidade e que a satisfação dos direitos econômicos, sociais e culturais garante o gozo dos direitos civis e políticos. ${ }^{68}$

A Declaração de Direitos de Viena, de 1993, reitera a concepção introduzida pela Declaração de 1948, de que todos os direitos humanos são universais, interdependentes e interrelacionados.

O Protocolo de San Salvador em matéria de direitos econômicos, sociais e culturais, que entrou em vigor em novembro de 1999 e foi ratificado pelo Brasil, reforça os deveres jurídicos dos Estados no tocante aos direitos sociais, que devem ser aplicados progressivamente, sem retrocessos, para que se alcance a sua plena efetividade. $O$ Protocolo elenca os direitos ao trabalho, à previdência social, os direitos sindicais, o direito à saúde, prevendo, inclusive, o direito de petição a instância internacionais para a defesa do direito à educação e dos direitos sindicais.

Outra importante instituição internacional criada com o objetivo de proteger os direitos humanos fundamentais é o Tribunal Penal Internacional, em 1998, pelo Tratado de Roma, sendo inclusive ratificado pelo Brasil e mais um grande número de Estados. O Tribunal visa julgar os crimes definidos no Tratado, incluindo os crimes de guerra, o genocídio e a escravização e submeter os condenados a sanções penais como a prisão, a multa e o perdimento de bens, dependendo da gravidade do crime e das circunstâncias pessoais do culpado.

68 PIOVESAN, Flávia. Carta africana dos direitos humanos e dos povos. Disponível em: http://www.esmpu.gov.br/dicionario/tiki-index.php?page=Carta+africana+dos+direitos+humanos+e+dos+ povos. Acesso: 30 set. 2010. 
Em relação à Organização Internacional do Trabalho, tendo em vista o seu importante papel no processo de internacionalização e universalização dos direitos fundamentais trabalhistas, por meio de um trabalho minucioso da criação de instrumentos internacionais, tais como convenções e recomendações, e do desenvolvimento de parcerias junto às entidades regionais e locais para a implementação de políticas de fomento à efetivação desses direitos, serão tecidas algumas informações complementares.

A OIT surgiu no contexto da Primeira Grande Guerra, sendo instituída pelo Tratado de Versalhes, de 1919. Arnaldo Sussekïnd explica que

\begin{abstract}
a primeira guerra transformou ou aboliu as mais radicais resistências à generalização das leis de proteção ao trabalho: destruição de grandes riquezas públicas e privadas, a morte de milhões de homens úteis, a bancarrota de numerosas empresas, a solidariedade das esferas sociais nos campos de batalha tudo veio a apaziguar o espírito sórdido de especulação e a luta desenfreada pela posse de bens. Algo assim como um sopro de purificação moral e de mútua compreensão passou pela Europa e quando os Governos comprovaram que as organizações operárias acudiram em defesa dos seus países ameaçados pelo flagelo mundial, esquecendo os ressentimentos internos e as lutas de classes, compreenderam que a paz e a guerra dependiam em grande parte da harmonia social. ${ }^{69}$
\end{abstract}

Naquele tempo, a Organização ainda não administrava os seus próprios recursos, uma vez que recebia da Sociedade das Nações, da qual era filiada, a receita destinada ao custeio de suas atividades. Somente em 1946, essa situação se altera, quando ganha personalidade jurídica de direito público internacional por meio da Carta das Nações.

Conforme Sussekïnd, a OIT é pessoa jurídica de direito público internacional, de caráter permanente, constituída de Estados que assumem, soberanamente, a obrigação de observar as normas constitucionais da entidade e das convenções que ratificam, integrando o sistema das Nações Unidas como uma das suas agências especializadas. A composição tripartida de sua Assembléia Geral (Conferência Internacional do Trabalho), do Conselho de Administração e de quase todos os seus órgãos colegiados, nos quais têm assento, com direito a voz e voto, representantes de Governos e organizações de trabalhadores e empregadores constitui uma das características marcantes da OIT e fator de relevo na formação do alto conceito que desfruta nos planos da cultura, da produção e do trabalho. ${ }^{70}$ Por isso, as decisões da Organização têm legitimidade indiscutível.

Entre os principais objetivos de sua criação estão o sentimento de justiça social por existirem, ainda, condições de trabalho que, para um grande número de pessoas, consistem

${ }^{69}$ SUSSEKÏND, Arnaldo. Op. cit., p. 88.
${ }^{70}$ Ibidem, p. 107. 
em miséria e privações; o perigo da injustiça social para a manutenção da paz em vista do descontentamento que gera; a similaridade das condições de trabalho na ordem internacional, a fim de evitar que os esforços de certas nações desejosas de melhorar a sorte dos seus trabalhadores possam ser obstados pela não-adoção, por outros países, de regimes de trabalho realmente humanitários.

Ademais, a OIT visa melhorar a condição humana em seu conjunto e não apenas as condições de trabalho; dá ênfase tanto à luta contra a necessidade, quanto aos valores da liberdade; não se limita à proteção dos trabalhadores propriamente ditos, porque alcança o conjunto dos seres humanos em suas relações com o trabalho; seus textos insistem na necessidade de um esforço concentrado, internacional e nacional, para promover o bem comum, isto é, assegurar o bem-estar material e espiritual da humanidade; a ação para melhorar as condições da humanidade não deve constituir um setor distinto das políticas nacionais ou da ação internacional, pois representa o próprio objeto dos programas econômicos e financeiros.

É necessário ainda dizer que a OIT aprova convenções e recomendações relativas ao trabalho, sendo que as primeiras constituem tratados multilaterais abertos à ratificação dos Estados-Membros que, uma vez ratificadas, integram a respectiva legislação nacional, e as segundas se destinam a sugerir normas que podem ser adotadas por qualquer das fontes diretas ou autônomas do Direito do Trabalho, embora visem, basicamente, ao legislador de cada um dos países vinculados à OIT. ${ }^{71}$

Uma vez aprovadas as Convenções pela Organização, os Estados passam a ter obrigação de apresentá-las às autoridades internas competentes para a sua ratificação. Para isso, a OIT conta com um sistema de comando único que busca impelir os Estados a proceder às ratificações. Ademais, a OIT regularmente revê a forma como as convenções estão sendo aplicadas e aponta as áreas onde há espaço para melhorias. Se surgir um problema relativo à aplicação das normas, a OIT busca ajudar os países por meio do diálogo e da assistência técnica.

Existem basicamente duas categorias de controle exercidos pela OIT: um regular e um especial. O primeiro tipo inclui a análise dos relatórios apresentados pelos EstadosMembros sobre as medidas tomadas para dar cumprimento às disposições das convenções ratificadas, bem como dos comentários recebidos acerca desse cumprimento pelas organizações de trabalhadores e empregadores. Esse controle é realizado pelo Comitê de

\footnotetext{
${ }^{71}$ Ibidem, p. 157.
} 
Peritos sobre a Aplicação das Convenções e Recomendações e pelo Comitê Tripartite sobre a Aplicação de Convenções e Recomendações da Conferência Internacional do Trabalho.

O segundo tipo de controle inclui um procedimento de denúncias ${ }^{72}$ e reclamações com um processo de aplicação geral ${ }^{73}$, além de um procedimento especial da liberdade de associação.

Não obstante, pode-se dizer que esses mecanismos da OIT não são suficientes e eficientes para gerar a adoção e o cumprimento das normas trabalhistas pelos países.

Em 18 de junho de 1998, com o objetivo de fomentar o respeito aos direitos fundamentais dos trabalhadores, a OIT assinou a Declaração sobre Princípios e Direitos Fundamentais do Trabalho e seu seguimento, estipulando a aplicação plena das convenções consideradas mais relevantes para a promoção daqueles direitos no que se refere aos Estados que as ratificaram, e a observância dos princípios nelas consagrados, no caso dos

\footnotetext{
${ }^{72}$ O processo de denúncia é regido pelos artigos 26 a 34 da Constituição da OIT, em que uma queixa contra um Estado-Membro, por não cumprimento de uma convenção que ratificou, pode ser apresentada por outro membro que tenha também ratificado a Convenção, um delegado para a Conferência ou o Corpo Governante Oficial. Após o recebimento da denúncia, o Conselho de Administração pode nomear uma comissão de inquérito composta de três membros independentes, cuja missão é realizar uma revisão profunda da denúncia para apurar os fatos e fazer recomendações de medidas para resolver os problemas. A comissão de inquérito é o mais elevado nível de investigação e geralmente é formado quando um Estado-Membro é acusado de violações graves e repetidas vezes se recusou a fornecer uma solução. Até a presente data, 11 comissões de inquérito foram criadas.

Quando um país se recusa a seguir as recomendações de uma comissão de inquérito, o Conselho pode tomar medidas nos termos do artigo 33 da Constituição da OIT. Esta seção dispõe que "Se um Estado-Membro não se conformar, no prazo prescrito, com as recomendações eventualmente contidas no relatório da Comissão de Inquérito, ou na decisão da Corte Internacional de Justiça, o Conselho de Administração poderá recomendar à Conferência a adoção de qualquer medida que lhe pareça conveniente para assegurar a execução das mesmas recomendações". O artigo 33 foi usado pela primeira vez na história da OIT em 2000, quando o Conselho de Administração solicitou à Conferência Internacional do Trabalho tomar medidas para pôr fim à utilização de trabalho forçado por Mianmar. Em 1996, uma reclamação ao abrigo do artigo 26 da Constituição foi apresentada contra o país por violar a Convenção (n. ${ }^{\circ}$ 29) 1930, e da Comissão de Inquérito, caso em que foi observada a "utilização generalizada e sistemática" do trabalho escravo no país. Conforme informações colhidas no site: http://www.ilo.org/global/What_we_do/InternationalLabourStandards/ApplyingandpromotingInternationalLa bourStandards/lang--fr/index.htm. Acesso em: 29 set. 2010. Entretanto, fica em aberto a pergunta: até que ponto uma advertência recebida por um Estado-Membro da OIT, em uma assembléia da Conferência Internacional do Trabalho, surte efeitos concretos para viabilizar o cumprimento das normas convencionadas?

73 O processo de reclamação é regidO pelos artigos 24 e 25 da Constituição da OIT. Ele dá o direito de organizações profissionais de empregadores ou de trabalhadores a apresentarem ao Conselho de Administração da OIT, uma denúncia contra qualquer membro que, em sua opinião, "não conseguiu assegurar um satisfatoriamente a execução de qualquer acordo a que tenha aderido. A comissão tripartida composta de três membros do Conselho será constituído para examinar a denúncia e que a resposta do governo. O relatório que a comissão apresente à Câmara aborda os aspectos jurídicos e práticos do processo, avalia as informações apresentadas e conclui com recomendações. Se a resposta do governo não parece satisfatória, o Conselho de Administração tem o direito de publicar a denúncia e a resposta dada. Conforme informações colhidas no site: http://www.ilo.org/global/What_we_do/InternationalLabourStandards/ApplyingandpromotingInternationalLa bourStandards/lang--fr/index.htm. Acesso em: 29 set. 2010.
} 
Estados que não as ratificaram, quais sejam, a liberdade sindical e o reconhecimento efetivo do direito de negociação coletiva; a eliminação do trabalho forçado ou obrigatório; a abolição efetiva do trabalho infantil; e a eliminação da discriminação em matéria de emprego e ocupação.

Esses quatro princípios estão dispostos em oito convenções (Convenção 29, sobre o trabalho forçado, de 1930; Convenção 87, sobre a liberdade sindical e a proteção do direito de sindicalização, de 1948; Convenção 98, sobre o direito de sindicalização e negociação coletiva, de 1949; Convenção 100, sobre remuneração, de 1951; Convenção 105, sobre abolição do trabalho forçado, de 1957; Convenção 111, sobre a discriminação no emprego e ocupação, de 1958; Convenção 138, sobre a idade mínima para admissão no emprego, de 1973; Convenção 182, sobre as piores formas de trabalho infantil), que se sujeitam a um procedimento de revisão e controle diferenciado em relação às demais convenções da OIT.

Nesse ponto, é necessário frisar que, ao contrário do modelo regular de controle exercido no tocante às outras convenções, no caso da Declaração são os Estados que não ratificaram alguma das normas internacionais que devem enviar anualmente um relatório esclarecendo questões de ordem formal - a incompatibilidade da convenção com o ordenamento jurídico interno - e questões de fato, relativas à observância daquele princípio no país. A cada ano, o Diretor Geral da OIT divulga um relatório global sobre um direito específico, retratando a observância daquele princípio em todo o mundo e ressaltando os casos mais difíceis. A Declaração, portanto, não conta com nenhum instrumento para impor o cumprimento desses princípios. ${ }^{74}$ Como se esclarece no Anexo da Declaração, a natureza desse procedimento de controle é estritamente promocional, permitindo a identificação das áreas nas quais a assistência da OIT, por meio de atividades de cooperação técnica, pode se revelar importante na implementação de direitos fundamentais.

\footnotetext{
${ }^{74}$ GOMES, Ana Virgínia Moreira; BERTOLIN, Patrícia Tuma Martins. O significado da Declaração de Princípios e Direitos Fundamentais dos Trabalhadores na posição da OIT como a organização internacional capaz de garantir um conteúdo laboral no processo de globalização. Revista de Direito do Trabalho. São Paulo: v.31, n.119, jul./set.2005, p. 29.
} 


\subsection{Direitos fundamentais: definição e características}

Perpassada essa importante análise da evolução dos direitos fundamentais, com a constatação de que formam, hoje, um conjunto de prerrogativas para o exercício de uma vida com dignidade pelos seres humanos, deve se passar para a definição e caracterização desses direitos.

No que tange às denominações direitos fundamentais e direitos humanos, ora elas são utilizadas como sinônimos, ora são diferenciadas, havendo certa tendência doutrinária e normativa, segundo Maria Garcia, a reservar o termo direitos fundamentais para designar os direitos positivados a nível interno e a expressão direitos humanos para se referir aos direitos naturais nas declarações internacionais, assim como aquelas exigências básicas relacionadas com a dignidade, liberdade e igualdade da pessoa que não tenham alcançado um estatuto jurídico-positivo. ${ }^{75}$

Canotilho entende que os direitos do homem são direitos válidos para todos os povos e em todos os tempos (dimensão jusnaturalista-universalista) e direitos fundamentais são os direitos do homem jurídico-institucionalmente garantidos e limitados espaçotemporalmente. $^{76}$

Já Paulo Bonavides esclarece que os termos direitos humanos e direitos do homem são mais comumente utilizados na literatura jurídica entre autores anglo-americanos e latinos, enquanto a expressão direitos fundamentais encontra a preferência dos publicistas alemães. $^{77}$

Não obstante as preferências e motivações dos juristas dos ramos constitucional e internacional, nessa tese adotar-se-á a posição de que, independentemente da nomenclatura, ou seja, da utilização das expressões "direitos fundamentais", "direitos fundamentais do homem", "direitos humanos", "direitos humanos fundamentais" ou "direitos do homem", todas os termos servem para designar aquele conjunto de direitos, sejam eles de índole individual, social ou transindividual, que constitui o mínimo necessário para que todo ser humano viva com dignidade e liberdade e que, em geral, estão previstos explícita ou implicitamente nas Constituições.

\footnotetext{
75 GARCIA, Maria. Mas, quais são os direitos fundamentais? Revista de direito constitucional e internacional, São Paulo, v. 10, n. 39, abr./jun. 2002, p. 115.

${ }^{76}$ CANOTILHO, Joaquim José Gomes. Direito constitucional e teoria da Constituição. Op. cit., p. 369.

${ }^{77}$ BONAVIDES, Paulo. Curso de direito constitucional. Op. cit., p. 560.
} 
De acordo com André de Carvalho Ramos, "os direitos humanos consistem em um conjunto mínimo de direitos necessário para assegurar uma vida do ser humano baseada na liberdade, na igualdade e na dignidade”. Estão formalmente garantidos ou expressos em normas superiores de um ordenamento jurídico determinado e são essenciais para a existência e para o conteúdo de outros direitos desse ordenamento. Ainda, segundo o autor, os direitos humanos estão inseridos nas Constituições ou nos tratados internacionais, compondo obrigações internacionais que devem ser cumpridas pelos Estados. ${ }^{78}$

Joaquín Herrera Flores acredita que os direitos humanos são um produto cultural, surgido como uma das formas de luta pela dignidade na modernidade ocidental capitalista, e não como um fenômeno natural ou metafísico transcendente:

[...] dos derechos humanos no son categorias previas ni a la acción política ni a las prácticas económicas. La lucha por la dignidad humana es la razón y la consecuencia de la lucha por la democracia y por la justicia. No estamos ante privilegios, meras declaraciones de buenas intenciones o postulados metafísicos de una naturaleza humana aislada de las situaciones vitales. Por el contrario, los derechos humanos constituyen la afirmación de la lucha del ser humano por ver cumplimentados sus deseos, sus necesidades en los contextos vitales en que está situado. $^{79}$

Arion Sayão Romita, baseado em uma visão que entende os direitos fundamentais como fruto do contexto histórico e dos valores de cada sociedade, superando, assim, a visão jusnaturalista centrada na natureza eterna e imutável do ser humano, considerado em abstrato, define os direitos fundamentais como

\begin{abstract}
os que, em dado momento histórico, fundados no reconhecimento da dignidade da pessoa humana, asseguram a cada homem as garantidas de liberdade, igualdade, solidariedade, cidadania e justiça. Este é o núcleo essencial da noção de direitos fundamentais, aquilo que identifica a fundamentalidade dos direitos. Poderiam ser acrescentadas as notas acidentais de exigência do respeito a essas garantias por parte dos demais homens, dos grupos e do Estado e bem assim a possibilidade de postular a efetiva proteção do Estado em caso de ofensa. ${ }^{80}$
\end{abstract}

Assim, os direitos fundamentais, como um produto histórico, são contemplados em normas jurídicas positivas, diferenciando-se da visão que os compreendia como direitos

\footnotetext{
${ }^{78}$ RAMOS, André de Carvalho. Direitos humanos na integração econômica: análise comparativa da proteção de direitos humanos e conflitos jurisdicionais na União Européia e no Mercosul. Rio de Janeiro: Renovar, 2008, p. 20.

${ }^{79}$ HERRERA FLORES, Joaquín. Los derechos humanos como productos culturales: crítica del humanismo abstracto. Madri: Los Libros de la Catarata, 2005, p. 14.

${ }^{80}$ ROMITA, Arion Sayão. Op. cit., p 45.
} 
subjetivos inerentes à pessoa humana pelo só fato de ela possuir racionalidade, ou seja, direitos que nascem com a pessoa humana e a acompanham em toda a existência.

Para Norberto Bobbio, os direitos ditos humanos são direitos históricos, produto da civilização humana que emergem gradualmente das lutas que o homem trava por sua própria emancipação e das transformações das condições de vida que essas lutas produzem. E justamente por serem históricos, esses direitos são mutáveis, ou seja, suscetíveis de transformação e de ampliação. ${ }^{81}$

Esses direitos têm como uma de suas principais características a universalidade, já analisada no tópico referente à internacionalização dos direitos fundamentais, porque o objetivo principal da sua inserção nos instrumentos internacionais é que todos os seres humanos, sem qualquer distinção, possam fazer jus a direitos mínimos que assegurem uma vida digna.

Romita, nesse ponto, esclarece que o conteúdo desses direitos não é invariável, dependendo das circunstâncias que distinguem umas sociedades das outras. Não obstante, a "existência de um mínimo de direitos é hoje reconhecida universalmente, a atestar o caráter de universalidade dos direitos fundamentais". ${ }^{82}$

Bobbio demonstra a trajetória evolutiva dos direitos humanos rumo à universalização. Em um primeiro momento, os direitos de índole liberal surgem em Declarações de cunho filosófico, de forma que a universalidade só alcançaria as liberdades negativas. Posteriormente, os direitos passam a ser positivados nas Constituições dos países, ganhando em concretização, mas perdendo em universalidade, pois valem apenas quando consagrados pelo ordenamento jurídico do Estado que os proclama. Finalmente, com a Declaração de 1948 inicia-se uma fase de universalização positivada e real, pois os destinatários dos direitos ali positivados não são mais apenas os cidadãos de um ou outro Estado, mas alcançam "os cidadãos da cidade que não tem fronteiras, porque compreende toda a humanidade" $" 83$

Diretamente relacionada com a universalização dos direitos fundamentais é a internacionalização e transnacionalização desses direitos, a partir da força persuasiva das Declarações internacionais e regionais, de modo que os indivíduos adquirem um status de sujeito de direitos no âmbito internacional.

\footnotetext{
${ }^{81}$ BOBBIO, Norberto. A era dos direitos. Trad. Carlos Nelson Coutinho. Rio de Janeiro: Campus, 2000, p. 32.

${ }^{82}$ ROMITA, Arion Sayão. Op. cit., p. 74

${ }^{83}$ BOBBIO, Norberto. Op. cit., p. 28-31.
} 
É necessário explicitar que a universalidade dos direitos humanos é contestada pela corrente que defende o relativismo cultural, pois esses direitos seriam uma expressão dos valores que embasam a civilização ocidental, em virtude da origem e desenvolvimento desses direitos no terreno sócio-político-cultural dos países ocidentais. Assim, não poderiam ser impostos a culturas diversas padrões de conduta com elas incompatíveis, típicas dos povos do Ocidente e de sua política expansionista e imperialista.

Nos dizeres de Romita, os relativistas sustentam que os direitos fundamentais estão relacionados com os padrões de cultura de cada povo, seu regime político, sua mentalidade, bem como o sistema moral e social e as tradições que formam a base cultural de cada sociedade. ${ }^{84}$

Longe de adentrar no embate entre o universalismo e o relativismo cultural, discussão que por si só já demanda um melindroso e complexo trabalho científico em virtude das inúmeras questões que estão diretamente relacionadas ao tema, adota-se, nessa tese, o entendimento de que independentemente da aceitação ou aplicação em maior ou menor grau dos direitos fundamentais nos diversos países, existem direitos que constituem um mínimo a ser observado em qualquer lugar do globo, pois têm como fundamento principal a dignidade da pessoa enquanto ser humano, não podendo ser vilipendiados por alegações atinentes à diversidade cultural, extraindo-se daí o seu caráter universal.

Outra característica dos direitos fundamentais é a indivisibilidade que se observa entre eles, pois todas as dimensões se completam. De acordo com Fábio Konder Comparato, "a liberdade individual é ilusória, sem um mínimo de igualdade social; e a igualdade social imposta com sacrifícios dos direitos civis e políticos acaba engendrando, mui rapidamente, novos privilégios econômicos e sociais". 85

Essa é a posição da ONU, adotada oficialmente no art. $5^{\circ}$ da Declaração de Viena, que assinala: “Todos os direitos humanos são universais, indivisíveis, interdependentes e interrelacionados. A comunidade internacional deve tratar os direitos humanos globalmente de maneira justa e equitativa, em pé de igualdade e com a mesma ênfase."

Nesse sentido, o próprio Comitê de Liberdade Sindical do Conselho de Administração da Organização Internacional do Trabalho já se pronunciou:

Um movimento sindical realmente livre e independente somente pode desenvolver-se dentro do respeito aos direitos humanos fundamentais. [...] A

\footnotetext{
${ }^{84}$ ROMITA, Arion Sayão. Op. cit., p 76.

${ }^{85}$ COMPARATO, Fábio Konder. A afirmação histórica dos direitos humanos. São Paulo: Saraiva, 1999, p. 20.
} 
liberdade sindical só pode ser exercida em uma situação em que sejam respeitados e garantidos plenamente os direitos humanos fundamentais, particularmente os relativos à vida e à segurança da pessoa. ${ }^{86}$

Assim, a efetiva liberdade sindical só restaria consolidada com o respeito e a efetivação dos direitos de reunião, livre manifestação do pensamento, de opinião, de inviolabilidade de correspondência e comunicação telefônica, entre outros, ou seja, direitos de liberdade relacionados nos documentos internacionais, da mesma forma que para a existência e efetividade das liberdades públicas e da democracia é essencial que haja liberdade sindical.

Os direitos fundamentais apresentam, ainda, como característica uma preponderância de função de defesa ou de função prestacional, mas não que essa função prevalecente seja a única a qualificar o direito em estribo. Qualquer direito civil, político, social, econômico ou cultural pressupõe um complexo de obrigações positivas e negativas do sujeito passivo, inclusive se for ele o Estado ou um particular.

Essa constatação é deveras importante, pois normalmente tende-se a veicular a idéia de que os direitos civis e políticos gerariam exclusivamente obrigações negativas ou de abstenção, enquanto que os direitos econômicos, sociais e culturais importam em obrigações positivas ou de prestação, comprometedoras do erário e, portanto, dependentes da disponibilidade para tanto.

Verifica-se que os direitos sociais não são puramente direitos a prestações, assim como também nem todas as liberdades e direitos políticos apresentam apenas a função de defesa. Um direito subjetivo determinado constitucionalmente que imponha aos destinatários passivos um dever de abstenção, ou seja, uma proibição de violação, geralmente está atrelado a um direito de defesa. Mas, não significa que esses direitos não possam ter uma dimensão positiva também, conducente ao reconhecimento de direitos a prestações.

Víctor Abramovich e Christian Courtis explicam que em grande parte dos direitos econômicos, sociais e culturais é possível reconhecer como faceta mais visível as obrigações de fazer, mas consegue-se vislumbrar, também, obrigações de não-fazer. Por outro lado, a efetividade de direitos civis e políticos importa, várias vezes, em obrigações

${ }^{86}$ ORGANIZAÇÃO INTERNACIONAL DO TRABALHO. La libertad sindical. 4 ed, p. 13 (n. 35) e p. 15 (n. 46). 
de fazer $^{87}$, em medidas positivas por parte do poder público que abrangem a alocação significativa de recursos materiais e humanos para sua proteção e efetivação.

O direito à vida, por exemplo, é um direito de defesa, de afirmar o direito de viver, com os correspondentes deveres jurídicos dos poderes públicos e dos outros indivíduos de não agredirem o bem "vida". Esse direito possui também uma dimensão protetiva, de modo que o Estado tem o dever de criar serviços de polícia, um sistema prisional e uma organização judiciária para proteger o direito à vida de todos os indivíduos. Todavia, o traço caracterizador do direito à vida é de direito de defesa o que justifica o seu enquadramento no catálogo das liberdades e direitos individuais.

Por seu turno, o direito à educação, ao contrário, estabelece necessariamente e primordialmente o dever do Estado de construir escolas e universidades, de organizar uma política de formação de professores, de criar diretrizes para os currículos escolares, entre outras medidas, mas os sujeitos titulares do direito à educação só terão condições de exercê-lo plenamente se tiverem liberdade de ir e vir, liberdade de pensamento e de opinião e se a sua vida e integridade física estiverem assegurados, sem agressões por parte do Estado e dos demais indivíduos.

Da mesma forma, no que tange aos direitos de terceira dimensão, pode-se fazer idêntico raciocínio. Não se pode garantir a paz internacional sem gastos com embaixadas, com despesas para os envolvidos com a realização dos acordos internacionais ou com a manutenção de representações junto a organizações internacionais.

É importante ressaltar que alguns direitos sociais, inclusive, apresentam a característica primordial de função de defesa, assemelhando-se tipicamente aos direitos de caráter negativo, como o direito fundamental à greve que estabelece uma posição dos sujeitos trabalhadores em face de seu empregador, seja ele o Estado ou particulares, de paralisarem as suas atividades, em virtude do descumprimento de outros direitos trabalhistas ou para reivindicação de melhores condições de trabalho, não podendo o empregador se imiscuir na esfera de liberdade dos empregados em iniciar e conduzir o movimento grevista, desde que atendidos determinados requisitos para evitar o abuso do direito em comento. Assim também ocorre com o direito de associação sindical e as garantias de proibições de discriminação entre os trabalhadores.

Pode-se dizer, então, que os direitos sociais abrangem tanto direitos prestacionais quanto direitos defensivos, com base na natureza da posição jurídica subjetiva reconhecida

\footnotetext{
${ }^{87}$ ABRAMOVICH, Víctor; COURTIS, Christian. Los derechos sociales como derechos exigibles. Madrid: Trotta, 2002, p. 25-32.
} 
ao titular do direito. Constata-se, ademais, que os direitos negativos apresentam uma dimensão positiva, ao passo que os direitos a prestações fundamentam também posições jurídicas subjetivas negativas, notadamente quando se cuida de sua proteção contra ingerências indevidas por parte dos órgãos estatais, de entidades sociais e também de particulares.

Ingo Wolfgang Sarlet esclarece que, a partir de um determinado texto há como extrair uma norma (ou normas) que pode (ou não) reconhecer um direito fundamental e atribuir uma determinada posição jurídica-subjetiva, sem prejuízo dos efeitos da dimensão objetiva, à pessoa (individual ou coletivamente), posição esta que poderá ter como objeto uma determinada prestação ou uma proibição de intervenção. ${ }^{88}$

Apesar da dimensão positiva dos direitos de defesa, observa-se que a imediata aplicação pelos órgãos do Poder Judiciário desses direitos nunca se pautou pelo fator "recursos disponíveis" para a negativa jurisdicional em efetivá-los, ao passo que em relação aos direitos sociais a prestações o fator "custo" assume especial relevância para a eficácia desses direitos, de modo que não é possível a realização efetiva das prestações sem a alocação de algum recurso.

A reserva do possível, cunhada na Alemanha, diz respeito à capacidade financeira do Estado para implementar direitos sociais a prestações materiais, por serem direitos fundamentais dependentes de prestação financiadas pelos cofres públicos, cuja disponibilidade está no campo discricionário das decisões do poder executivo e legislativo, no que tange ao orçamento público. ${ }^{89}$

Em relação aos direitos fundamentais sociais a prestações, há o problema em saber se o destinatário da norma se encontra em condições de dispor da prestação reclamada, ou seja, se existem meios suficientes para cumprir com a sua obrigação, ao mesmo tempo em que existe a questão da possibilidade jurídica de disposição, isto é, se o Estado pode dispor dos recursos existentes, em virtude da distribuição de receitas e competências tributárias, orçamentárias, legislativas e administrativas. A prestação requerida pelo sujeito ativo da norma deve corresponder, ainda, àquilo que é razoável que o Estado preste, ainda que a ideia de razoabilidade esteja também no âmbito da ponderação por parte do legislador.

De qualquer modo, órgãos estatais e agentes políticos devem ter como meta maximizar os recursos para minimizar o impacto da reserva do possível, assim como cabe

${ }^{88}$ SARLET, Ingo Wolfgang. Os direitos fundamentais sociais e os vinte anos da Constituição Federal de 1988: resistências e desafios à sua eficácia e efetividade. Revista do Instituto de Hermenêutica Jurídica, v. 1, n. 6, 2008, p. 168.

${ }^{89}$ Ibidem, p. 186. 
ao poder público o ônus da comprovação da falta efetiva dos recursos indispensáveis à satisfação dos direitos a prestações e da eficiente aplicação dos mesmos. ${ }^{90}$

Ao mesmo tempo, nos dizeres de Sarlet, cabe aos responsáveis pela efetivação de direitos fundamentais sociais a observância dos seguintes critérios:

\begin{abstract}
da adequação (aptidão do meio no que diz com a consecução da finalidade almejada), necessidade (menor sacrifício do direito restringido) e da proporcionalidade em sentido estrito (avaliação da equação custo-benefício [...]), respeitando sempre o núcleo essencial do(s) direito(s) restringido(s), mas também não poderão, a pretexto de promover algum direito, desguarnecer a proteção de outro(s) no sentido de ficar aquém de um patamar minimamente eficiente de realização e garantia do direito. ${ }^{91}$
\end{abstract}

O criador e o aplicador do direito devem se pautar primordialmente pela Constituição, como limites à sua atuação, bem como as decisões relativas a alocações de recursos devem ser feitas de modo o mais aberto possível, com garantia de informação à população.

As opções orçamentárias e a legislação relativa aos gastos públicos podem ser controladas pelo judiciário dentro, obviamente, de seus limites funcionais, em prol da implementação dos direitos fundamentais.

Sarlet pondera, ainda, que mesmo que o conteúdo judicialmente exigível dos direitos sociais como direitos a prestações não possa estar limitado à garantia do mínimo existencial, se ele estiver em causa, será plenamente exigível via jurisdicional, não podendo prevalecer objeções atreladas à reserva do possível, pois nesse caso estariam em jogo a vida e a dignidade da pessoa humana, ensejando, inclusive, o redirecionamento de prioridades em matéria de recursos materiais. ${ }^{92}$

Sem embargo, a eficácia jurídica e a efetividade dos direitos à prestação demandam um estudo mais pormenorizado que será realizado, caso a caso, no que tange aos direitos fundamentais trabalhistas que apresentam a função prestacional mais aguçada (assim como em relação aos que apresentam primordialmente a função de defesa), quando da análise da aplicação da interpretação evolutiva aos direitos constitucionais trabalhistas no último capítulo dessa tese.

Por ora, é necessário continuar o estudo dos direitos fundamentais, com enfoque especial para os direitos trabalhistas, passando-se, nesse momento, a analisar como se

\footnotetext{
${ }^{90}$ Ibidem, p. 191.

${ }^{91}$ Ibidem, p. 193.

${ }^{92}$ Ibidem, p. 198.
} 
apresenta a estrutura de uma norma constitucional que embasa um direito fundamental, para, posteriormente, se compreender como os direitos fundamentais podem ser fruto de uma interpretação constitucional de índole evolutiva, que é uma das formas de mutação de um texto constitucional.

\title{
2.3 Estrutura das normas de direitos fundamentais
}

Para entender como se estabelece a estrutura das normas de direitos fundamentais, é necessário contextualizar previamente o panorama jurídico-filosófico de sedimentação dos direitos fundamentais no Direito Constitucional.

No final do século XIX, a importação, pelo Direito, do positivismo filosófico resultou no positivismo jurídico, movimento que tinha como objetivo a criação de uma ciência jurídica, assim como já ocorria com as ciências exatas e naturais, e cujos principais elementos propulsores foram o surgimento do Estado Liberal, a consolidação dos ideais constitucionais em textos escritos e o êxito dos instrumentos codificados que, em seu conjunto suplantaram o jusnaturalismo.

De acordo com Luís Roberto Barroso

\begin{abstract}
O jusnaturalismo moderno, desenvolvido a partir do século XVI, aproximou a lei da razão e transformou-se na filosofia natural do Direito. Fundado na crença em princípios de justiça de justiça universalmente válidos, foi o combustível das revoluções liberais e chegou ao apogeu com as Constituições escritas e as codificações. Considerado metafísico e anticientífico, o direito natural foi empurrado para a margem da história pela ascenção do positivismo jurídico, no final do século XIX. ${ }^{93}$
\end{abstract}

O positivismo jurídico equiparou o Direito à lei, afastou-o da filosofia e das discussões relacionadas à legitimidade e à justiça e dominou o pensamento jurídico da primeira metade do século XX. O objetivo desse movimento era a separar o campo jurídico da moral, de modo que a atividade do aplicador do Direito, racionalmente empreendida, deveria cingir-se à subsunção do fato ao dispositivo normativo, não sobrando espaço para a interpretação das normas.

93 BARROSO, Luís Roberto. Neoconstitucionalismo e constitucionalização do Direito: o triunfo tardio do direito constitucional no Brasil. Revista de Direito Administrativo, Rio de Janeiro, n. 240, abr./jun. 2005 , p. 4. 
Nesse sentido, o Direito é compreendido como norma, ato emanado do Estado com caráter imperativo e força coativa. A ciência do Direito deve fundar-se em juízos de fato, que visam ao conhecimento da realidade, e não em juízos de valor, que representam uma tomada de posição diante da realidade. Assim, não é no âmbito do Direito que se deve travar a discussão acerca de questões como legitimidade e justiça. ${ }^{94}$

A decadência do positivismo jurídico é associada à derrota do fascimo na Itália e do nazismo na Alemanha, visto que esses regimes promoveram a barbárie, sob o manto da legalidade. Assim, ao fim da Segunda Guerra, a ética e os valores começaram a ganhar espaço, possibilitando o surgimento do movimento denominado pós-positivismo, que é uma forma de abordagem do Direito que une a noção de constitucionalismo com elementos morais, na denominada "volta aos valores" ou "virada Kantiana".

O pós-positivismo, nos dizeres de Luís Roberto Barroso

\begin{abstract}
busca ir além da legalidade estrita, mas não despreza o direito posto; procura empreender uma leitura moral do Direito, mas sem recorrer a categorias metafísicas. A interpretação e aplicação do ordenamento jurídico hão de ser inspiradas por uma teoria da justiça, mas não podem comportar voluntarismos ou personalismos, sobretudo os judiciais. No conjunto de idéias ricas e heterogêneas que procuram abrigo neste paradigma em construção incluem-se a atribuição de normatividade a princípios e a definição de suas relações com valores e regras; a reabilitação da razão prática e da argumentação jurídica; a formação de uma nova hermenêutica constitucional; e o desenvolvimento de uma teoria dos direitos fundamentais edificada sobre o fundamento da dignidade humana. Nesse ambiente, promove-se uma reaproximação entre o Direito e a filosofia. ${ }^{95}$
\end{abstract}

Nesse contexto, surgem as reflexões sobre a força normativa das Constituições, a conseqüente concepção dos princípios como espécie do gênero norma, a estruturação dos direitos fundamentais como normas principiológicas e as técnicas de solução de colisões entre princípios.

$\mathrm{Na}$ fase positivista, os princípios possuíam uma função subsidiária e supletiva na ordem jurídica, sendo aplicados apenas quando houvesse lacuna legal, como meio de integração do Direito.

Com a crise do positivismo, os princípios passam a ser reconhecidos como normas jurídicas, ultrapassando a noção de que teriam apenas uma dimensão puramente axiológica, ética, sem eficácia jurídica ou aplicabilidade direta e imediata. Assim, as

\footnotetext{
94 BARROSO, Luís Roberto; BARCELLOS, Ana Paula. O começo da história. A nova interpretação constitucional e o papel dos princípios do Direito Brasileiro. Revista Interesse Público, Sapucaia do Sul, v.5, n.19, maio/jun. 2003, p.55.

${ }^{95}$ BARROSO, Luís Roberto. Neoconstitucionalismo e constitucionalização do Direito: o triunfo tardio do direito constitucional no Brasil. Op. cit., p. 4-5.
} 
normas em geral e, particularmente, as normas constitucionais serão enquadradas em duas categorias distintas: os princípios e as regras. ${ }^{96}$

Segundo Barroso e Barcelos, na fase pós-positivista, a Constituição passa a ser compreendida "como um sistema aberto de princípios" e regras, permeável a valores jurídicos suprapositivos, no qual as idéias de justiça e de realização dos direitos fundamentais desempenham um papel fundamental" 98 .

Os direitos fundamentais caracterizam-se por regularem de maneira bastante aberta questões relativas à estrutura básica do Estado e da sociedade, de modo que os princípios serão a espécie de norma adequada para dar suporte estrutural-normativo à dinâmica e elasticidade dos dispositivos que estabelecem os direitos fundamentais. Portanto, esses direitos são positivados no ordenamento jurídico por meio de normas com estrutura de princípio, situando-se no ápice da pirâmide normativa, pois são normas constitucionais.

Cada direito fundamental pressupõe necessariamente uma norma jusfundamental que o reconheça, na lição do ilustre doutrinador alemão Robert Alexy. ${ }^{99}$ Do dispositivo constitucional (o texto) no qual se encontra enunciado o direito fundamental extrai-se, em geral, mais de uma norma, ou seja, um feixe de situações jurídico-subjetivas, como direitos, garantias e deveres fundamentais. Isto porque a norma não se confunde com o enunciado normativo, pois aquela apenas é o significado deste, de modo que uma mesma norma pode ser expressa por enunciados diferentes.

Alexy afirma que um princípio comanda a realização de um fim, constituído por um valor, que deverá ser buscado por meio de condutas, ou seja, ações e omissões. Assim, uma norma-princípio implica um conjunto de normas-regra que regerão as condutas capazes de realizar o fim prescrito naquele mesmo princípio. ${ }^{100}$

É importante salientar que embora sejam espécies do gênero norma, os princípios e as regras não se confundem, apresentando várias diferenças. Em relação à generalidade, as regras contêm relato mais objetivo, com incidência restrita às situações específicas às

\footnotetext{
${ }^{96}$ BARROSO, Luís Roberto; BARCELLOS, Ana Paula. Op. cit., p.56.

${ }^{97}$ Os princípios, pela plasticidade que lhes é inerente, têm como acomodar mais facilmente alterações em seu sentido, o que permite a atualização dos ditames constitucionais em virtude das mudanças que ocorrem na sociedade com o passar dos tempos.

${ }^{98}$ BARROSO, Luís Roberto; BARCELLOS, Ana Paula. Op. cit., p.57. De acordo com os autores, o sistema jurídico ideal se consubstancia em uma distribuição equilibrada entre princípios e regras, nos quais as regras desempenham o papel referente à segurança jurídica - previsibilidade e objetividade das condutas - e os princípios, com sua flexibilidade, dão margem à realização da justiça do caso concreto.

99 ALEXY, Robert. Teoría de los derechos fundamentales. Madri: Centro de Estudios Constitucionales, 1993, p. 62. Trad. Ernesto Garzón Valdés

100 Ibidem, p. 81.
} 
quais se dirigem, e os princípios têm maior teor de abstração e incidem sobre uma pluralidade de situações.

No que tange ao conteúdo, os princípios são normas que identificam valores a serem preservados ou fins a serem alcançados e as regras limitam-se a traçar uma conduta, cujos valores já foram traçados pelo legislador, não abrindo espaço ao intérprete.

Quanto à estrutura normativa, as regras jurídicas são normas de elevada densidade semântica que especificam os atos a serem praticados para seu cumprimento adequado, enquanto os princípios indicam fins, estados ideais a serem alcançados, não detalhando a conduta a ser perseguida para sua realização, de modo que a atividade do intérprete será mais complexa, pois a ele caberá a demarcação do conteúdo da norma.

E, finalmente, quanto ao modo de aplicação, entende-se que as regras são normas dotadas de uma estrutura fechada, nas quais uma conduta determinada é qualificada como obrigatória, proibida ou permitida ${ }^{101}$; veiculam mandados de definição de natureza biunívoca, isto é, só admitem duas espécies de situação: ou são válidas e se aplicam ou não se aplicam por serem inválidas, seguindo a modalidade do tudo ou nada (all or nothing) ${ }^{102}$; incidem pelo mecanismo tradicional da subsunção: enquadram-se os fatos na previsão abstrata e produz-se uma conclusão; o conflito entre regras gera uma antinomia jurídica que será solucionada por intermédio de critérios fornecidos pelo próprio sistema, qual sejam o hierárquico - pelo qual a lei superior prevalece sobre a inferior, o cronológico em que a lei posterior prevalece sobre a anterior e o da especialidade - em que a lei específica prevalece sobre a lei geral, sendo que, em qualquer dessas hipóteses, somente uma das regras será aplicada, excluindo-se a outra. ${ }^{103}$

Por seu turno, os princípios são normas dotadas de uma estrutura aberta, ou seja, são mandados de otimização, que "ordenam que se realize algo na maior medida possível, dentro das possibilidades jurídicas e reais existentes", limitadas por princípios opostos que procuram maximizar-se, impondo a necessidade de ponderação, e regras opostas que os excepcionam em algum ponto ${ }^{104}$; dos enunciados dos princípios não é possível estabelecer automaticamente as conseqüências jurídicas quando são satisfeitas as condições previstas

\footnotetext{
${ }^{101}$ Ibidem, p. 82-85.

102 DWORKIN, Ronald. Levando os direitos a sério. Tradução de Nelson Boeira. São Paulo: Martins Fontes, 2002, p. 43.

${ }^{103}$ Entretanto, não é correto dizer que a totalidade dos casos de incompatibilidade entre regras resulta na nulidade de uma delas, posto que há situações em que uma das regras conflitantes tem como núcleo normativo o estabelecimento de um limite ou exceção a outra, sendo, dessa forma, ambas válidas. Cf. HABERMAS, Jürgen. Direito e democracia: entre faticidade e validade. Rio de Janeiro: Tempo brasileiro, 1997, p. 70.

${ }^{104}$ ALEXY, Robert. Op. cit., p. 86.
} 
na norma, pois carecem de determinação com respeito aos princípios e regras opostos; os princípios contêm relatos com maior grau de abstração, não especificam a conduta a ser seguida e se aplicam a um conjunto amplo, por vezes indeterminado, de situações; podem ser cumpridos em diferentes graus, pois possuem uma dimensão de peso que as regras não têm, de modo que o aplicador do Direito, que irá resolver a colisão entre os princípios,

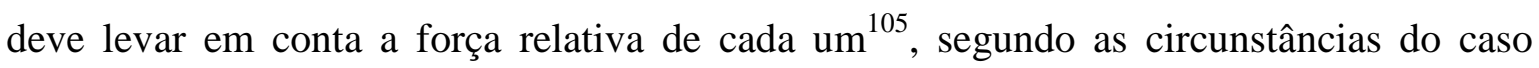
concreto, mediante a técnica da ponderação dos interesses; mesmo que um princípio venha a ceder diante do outro, ambos mantêm-se igualmente válidos.

Assim, pode-se afirmar que os direitos fundamentais sociais, dispostos na Constituição Federal de 1988, estão estabelecidos, como regra, em normas com estrutura principiológica, aberta, o que influenciará nos aspectos da sua aplicabilidade jurídica e sua efetividade ou eficácia social.

Após apresentar a caracterização dos direitos fundamentais e estudar a estrutura das normas que estabelecem esses direitos, serão dissecados especificamente os direitos fundamentais trabalhistas, enquanto direitos sociais com peculiaridades próprias, que, em alguns casos, se assemelham aos direitos sociais prestacionais e, em outros, estão mais próximos dos direitos de índole defensiva.

\subsection{Os direitos fundamentais trabalhistas enquanto direitos sociais}

Os direitos sociais englobam os direitos à saúde, educação, lazer, segurança, moradia, alimentação, seguridade social, ao trabalho, cujos destinatários são todos os indivíduos enquanto seres humanos que vivem em sociedade, bem como os direitos trabalhistas que se aplicam diretamente à relação de emprego, cujos sujeitos ativos são os empregados.

Não obstante a abrangência dos direitos de segunda geração, o objeto dessa tese engloba apenas o direito ao trabalho, previsto no art. $6^{\circ}$ da Constituição Federal, e especificamente os direitos fundamentais trabalhistas típicos, dispostos nos artigos $7^{\circ}$ ao artigo 11 da Constituição Federal e no artigo 10 do Ato das Disposições Constitucionais Transitórias, ou seja, os direitos trabalhistas enquanto direitos sociais, e não os direitos fundamentais individuais que são aplicáveis na relação de emprego, em virtude do

${ }^{105}$ DWORKIN, Ronald. Op. cit., p. 12. 
fenômeno da eficácia direta dos direitos fundamentais nas relações privadas, tais como o direito à integridade física, à intimidade, à privacidade, à honra, entre outros.

A relação de emprego é uma relação jurídica privada em que incidem normas de ordem pública de forma a diminuir a desigualdade existente entre as partes contratantes. No caso específico dos direitos trabalhistas sociais, esses incidem diretamente na relação de emprego, não por força da teoria da eficácia direta dos direitos fundamentais nas relações privadas, mas porque aquelas normas são justamente algumas das normas cogentes que têm como objetivo mitigar o desequilíbrio da relação juslaboral.

Portanto, pode-se dizer que os direitos fundamentais trabalhistas enquanto direitos sociais têm, como regra geral, eficácia direta e imediata na relação de emprego, pois esses direitos sociais são direcionados ${ }^{106}$ a reger especialmente essa relação jurídica.

Algumas vezes, entretanto, a aplicabilidade plena da norma de direito fundamental restará comprometida, tendo em vista, basicamente o destinatário da norma, como é o caso do direito ao trabalho, previsto no art. $6^{\circ}$ da $\mathrm{CF} / 88$, direito de índole precipuamente a prestações do Estado, ou seja, que depende de políticas públicas a serem desenvolvidas pelo aparato estatal de modo a possibilitar a introdução e manutenção das pessoas no mercado de trabalho e prepará-las para essa inserção.

Outras vezes, o empecilho principal para a aplicabilidade plena da norma do direito fundamental trabalhista deve-se à necessidade de regulamentação por meio de lei do preceito constitucional que o institui, ou seja, o direito não pode ser plenamente exercido e pleiteado judicialmente, pois o próprio texto constitucional prevê para isso a necessidade de criação de lei, atribuição de competência essencial do Poder Legislativo.

Não obstante, com ou sem a necessidade de lei infraconstitucional, o destinatário dessas normas, na maior parte das vezes, é o próprio empregador, que deverá observá-las e respeitá-las. Assim ocorre com o direito ao décimo terceiro salário (art. $7^{\circ}$, inciso VIII), direito ao repouso semanal remunerado (art. $7^{\circ}$, inciso XV), direito à remuneração de horas extraordinárias superior, no mínimo, $50 \%$ à hora normal (art. $7^{\circ}$, inciso XVI), direito de haver um representante dos empregados eleito para representar os interesses destes, em empresas com mais de duzentos empregados (art. 11), entre outros. Necessário esclarecer que essas normas se dirigem tanto ao empregador privado, quanto ao empregador público

\footnotetext{
${ }^{106}$ Existem discussões a respeito da incidência dos direitos fundamentais trabalhistas nas relações de trabalho lato sensu, que incluem, entre outras figuras, o autônomo e o trabalhador parassubordinado. Porém, nesse tópico, o objetivo é mostrar o objetivo da incidência das normas desses direitos fundamentais na relação de emprego, que por sua própria essência, é uma relação jurídica em que há um desequilíbrio entre os seus sujeitos.
} 
em se tratando de empregados públicos (que trabalham em empresas públicas e sociedades de economia mista e suas concessionárias) e servidores públicos detentores de emprego público (que laboram na administração direta, nas autarquias e fundações públicas).

De acordo com o art. 39, $\S 3^{\circ}$, da $\mathrm{CF} / 88$, vários incisos do art. $7^{\circ}$ se aplicam aos servidores públicos detentores de cargo público (que trabalham na administração direta, autarquias e fundações públicas), que, ademais, têm direito à livre associação sindical e ao exercício de greve, nos termos de lei específica, previstos nos incisos VI e VII do art. 37, caput, da $\mathrm{CF} / 88$, respectivamente. Não obstante, levando-se em conta que a presente tese têm como objeto principal o estudo da implementação dos direitos fundamentais trabalhistas típicos pela Justiça do Trabalho, no âmbito da relação de emprego, ou seja, da relação de trabalho que se caracteriza por ter como elementos a pessoalidade, a onerosidade, a não eventualidade, a subordinação e o trabalho prestado por pessoa física, e por ser regida pela Consolidação das Leis do Trabalho e demais leis infraconstitucionais, a concretização dos direitos fundamentais no âmbito da relação de trabalho estatutária dos servidores públicos detentores de cargo público foge aos limites dessa análise. Até mesmo porque procurar-se-á estudar a interpretação jurisdicional desses direitos realizada pelo Judiciário trabalhista que é competente para processar e julgar as controvérsias oriundas das relações de trabalho em geral (art. 114, I, CF/88), mas não para as relações de trabalho estatutárias - cujas demandas são de competência da Justiça comum, Federal ou Estadual, dependendo do ente empregador - segundo entendimento do Supremo Tribunal Federal e conforme posicionamento dominante dos Tribunais Regionais Federais e do Trabalho.

É importante ressaltar que alguns dos direitos previstos nos arts. $6^{\circ}$ ao 11 da Lei Maior têm como destinatário principal ora o Poder Público, como, por exemplo, a proibição de interferência do poder público na fundação e funcionamento de sindicato (art. $8^{\circ}$, inciso I), ora o empregador e o Poder Público ao mesmo tempo, como o direito ao salário mínimo capaz de atender às necessidades básicas do trabalhador (art. $7^{\circ}$, inciso IV), o direito ao trabalho (art. $6^{\circ}$ ), à licença-maternidade (art. $7^{\circ}$, inciso XVIII) e o direito à aposentadoria (art. $7^{\circ}$, inciso XXIV). Outros têm como destinatário os sindicatos como o art. $8^{\circ}$, inciso III, que traz as prerrogativas desse tipo de associação privada.

Todavia, como já afirmado, a maioria dos direitos fundamentais trabalhistas tem como destinatário o próprio empregador, seja ele o Poder Público - Administração Direta, autarquias e fundações para os servidores detentores de emprego público e empresas 
públicas e sociedades de economia mista para os empregados públicos ${ }^{107}$, as entidades privadas, incluindo as sociedades civis e empresárias, e os particulares, individualmente considerados.

A Constituição Federal de 1988 exige o requisito da aprovação em concurso público para preenchimento das vagas de emprego público, seja na Administração Direta ou Indireta e suas subsdiárias, nos termos do art. 37, inciso II. Ademais, estão os detentores de emprego público submetidos a algumas regras de ordem pública estabelecidas na Constituição - tais como a observância da regra da não acumulação de cargos, empregos e funções, da acumulação de proventos e remuneração da ativa e do teto remuneratório (com exceção das sociedades de economia mista e empresas públicas que não recebam recursos da União, Estados, Distrito Federal e Municípios para pagamento de pessoal ou custeio em geral) - e nas Leis de cada um dos órgãos ou entidades da Administração, normas essas não aplicáveis aos empregados de sociedades empresárias ou civis ou de particulares. Todos os empregados, públicos ou privados, não obstante, são regidos pela Consolidação das Leis Trabalhistas e demais leis infraconstitucionais que regulam a relação de emprego.

No que tange à classificação dos direitos fundamentais individuais e sociais, podese dizer que a clássica distinção entre eles, respectivamente, pela necessidade de o Poder Público apenas se abster de comportamentos que impeçam o exercício de direitos ou interfiram na liberdade de exercê-los (direitos de defesa ou direitos negativos) ou, em contrapartida, colocar em prática um dispositivo constitucional por meio de sua regulamentação e/ou da realização de gastos públicos para o implemento dos programas

\footnotetext{
${ }^{107}$ Essa divisão é feita por alguns doutrinadores administrativistas, enquanto outros juristas entendem que todos seriam empregados públicos. Em qualquer caso, a Constituição exige o requisito da aprovação em concurso público para que o empregado seja contratado pela Administração Pública, com a exceção dos contratos temporários realizados pela Administração Pública para atender a situação temporária de excepcional interesse público, nos termos do art. 37, inciso IX, da CF/88. O próprio Tribunal Superior do Trabalho, talvez se pautando na redação original do caput do art. 41 da Constituição Federal, cujo texto era "são estáveis, após dois anos de efetivo exercício, os servidores nomeados em virtude de concurso público" (não obstante os parágrafos do dispositivo constitucional já especificassem que se tratava de hipótese relativa a detentor estável de cargo público e a redação do artigo tenha sido alterado pela Emenda Constitucional n. 19/1998, anterior à criação das antigas OJ's que tratavam do mesmo assunto), estabeleceu na Súmula 390 a estabilidade do art. 41, após três anos de efetivo exercício e aprovação no estágio probatório, apenas para os servidores públicos celetistas da administração direta, autárquica ou fundacional, mas não para os empregados de empresas públicas e sociedades de economia mista. O TST também firmou o entendimento na OJ n. 247 da SDI-1, de que não é necessária a motivação do ato dispensa para os empregados de empresas públicas e sociedades de economia mista, excetuando-se os empregados da Empresa Brasileira de Correios e Telégrafos, cuja ato de dispensa está condicionado à motivação para sua validade, por gozar a empresa do mesmo tratamento destinado à Fazenda Pública em relação à imunidade tributária e à execução por precatório, além das prerrogativas de foro, prazos e custas processuais, na esteira do que entendimento do Supremo Tribunal no RE n 220.906-9-DF, que equiparou os Correios à Fazenda Pública.
} 
previstos $^{108}$ (direitos prestacionais ou positivos) não deve ser apreendida de forma absoluta. Realmente existem direitos fundamentais individuais que exigem a implementação de programas e gastos públicos ${ }^{109}$ (como, por exemplo, o direito de liberdade individual que para ser garantido necessita que o Estado coloque à disposição todo o seu sistema de repressão, inclusive o penal, se necessário) e, outrossim, direitos sociais que podem ser exercidos pelos cidadãos apenas por meio da não interferência do Estado.

A observação feita é importante, visto que vários direitos trabalhistas, enquanto direitos sociais, para serem aplicados não necessitam da realização de programas públicos com previsão orçamentária e dispêndio de dinheiro público, já que destinados exclusivamente ao empregador ou aos sindicatos. Essa constatação elimina grande parte das argumentações contrárias à aplicação direta e imediata dos dispositivos constitucionais que instituem esses direitos trabalhistas, mesmo sendo eles direitos sociais.

Ademais, deve-se ressaltar que nem todos os direitos trabalhistas direcionados ao Poder Público, enquanto não empregador, são de índole prestacional como se poderia erroneamente à primeira vista concluir, fazendo-se um contraponto com os direitos de defesa trabalhistas dirigidos precipuamente ao empregador público ou privado. A garantia de proibição de interferência do poder público na fundação e funcionamento de sindicato, esculpida no art. $8^{\circ}$, inciso I, da Lei Fundamental, apresenta-se tendencialmente como um direito de defesa, já que é dirigido à atuação negativa do Estado no sentido de não violar a liberdade de criação e organização dos sindicatos brasileiros. É claro que esse direito é limitado pela exigência do registro da criação do sindicato no órgão sindical, para fins de respeito à unicidade sindical (o que o torna, nesse aspecto um direito prestacional), e pela contribuição sindical compulsória, que como o próprio nome diz obriga todos os membros das categorias econômicas e profissionais (e não somente os associados aos sindicatos) a pagar anualmente uma contribuição obrigatória ao sindicato representante da respectiva categoria. Ambos os limites são resquícios do sistema sindical autoritário e corporativista implantado no Brasil desde a entrada em vigor da Consolidação das Leis Trabalhistas em 1943, que tomou como modelo a Carta del Lavoro italiana, criada sob os auspícios do regime fascista.

\footnotetext{
${ }^{108}$ É importante salientar que as normas constitucionais programáticas geram, ao menos, direitos subjetivos negativos, posto não ser possível quer ao legislativo, quer ao executivo, ao executar programas previstos constitucionalmente, atuar de forma contrária aos postulados ali dispostos.

${ }_{109}$ CORREIA, Marcus Orione Gonçalves. Os direitos sociais enquanto direitos fundamentais. Op. cit., p. 157.
} 
Alguns direitos trabalhistas fundamentais são primordialmente prestacionais como o próprio direito ao trabalho do art. $6^{\circ}$ da Constituição, exigindo a implementação, pelo Estado, de políticas econômicas e sociais que fomentem a criação de postos de trabalho (como, por exemplo, a reserva de verba econômica para incentivos fiscais oferecidos a empregadores que contratem empregados, conforme disposição de lei criada nesse sentido) e a qualificação de trabalhadores para preencher as vagas não ocupadas por falta de mãode-obra qualificada, além da atuação das próprias empresas por meio do oferecimento de vagas. Outros direitos de índole prestacional típicos são o salário mínimo capaz de atender às necessidades básicas do trabalhador a ser reajustado por meio de leis e pago pelo empregador, o direito à aposentadoria e o direito à licença-maternidade, pois dependem tipicamente da atuação positiva do Estado e, por vezes, do empregador para a eficácia jurídica plena dos dispositivos que os estabelecem.

Outros direitos, não obstante, embora não requisitem gastos ou a implementação de programas e sejam destinados unicamente ao empregador, necessitam de regulamentação por meio de lei a ser criada pelo Poder Legislativo. Nesse caso, a questão que se coloca é bem mais complexa, pois a aplicabilidade imediata desses direitos restaria subordinada à vontade do legislador infraconstitucional, caso se adote o posicionamento de que o Poder Judiciário não poderia, pelo exercício da função jurisdicional, implementá-los de forma alguma e em nenhum grau, em virtude do princípio da separação dos poderes. O problema envolve a legitimidade do Judiciário para a implementação dos direitos fundamentais, ainda que por intermédio da criação de políticas públicas ou de leis, em sentido material; a necessidade de implementação dos direitos fundamentais que não podem ser exercidos por falta de regulamentação legal, em face da morosidade e dos interesses políticos do Poder Legislativo; e, ainda, o entendimento acerca do princípio da separação estanque ou não dos poderes. Tais questões, que estão intimamente interligadas e são de índole complexa, serão analisadas, de forma pormenorizada, no capítulo 4.

\subsection{Eficácia dos direitos fundamentais na relação de emprego: as peculiaridades dos destinatários das normas fundamentais trabalhistas}

Nesse subitem serão estudadas as questões envolvendo a eficácia vertical e horizontal das normas de direitos fundamentais na relação de emprego, com ênfase para a 
questão da vinculação dos empregadores às normas que estabelecem direitos fundamentais individuais e direitos fundamentais sociais trabalhistas.

\subsubsection{Eficácia, aplicabilidade e efetividade: distinção entre os conceitos}

Os termos "vigência" e "validade", bem como "aplicabilidade", "eficácia" e "efetividade" costumam ser utilizados de forma pouco técnica e rigorosa, de modo que os conceitos são misturados, podendo levar a equívocos por parte do leitor pouco habituado com a linguagem jurídica. Por esse motivo, serão elucidados os referidos conceitos, visto que são eles essenciais para a compreensão da eficácia vertical e horizontal das normas de direitos fundamentais nas relações privadas e da vinculação dos particulares a essas normas.

Ingo Sarlet identifica a noção de existência da norma com a de sua vigência, de maneira que a vigência consiste na qualidade da norma que a faz existir juridicamente, tornando-se de observância obrigatória. Já a validade seria a conformidade da norma com os requisitos estabelecidos pelo ordenamento no que concerne à sua produção, ou seja, a norma pode existir e ser inválida. ${ }^{110}$

Para Sarlet, não há como dissociar a noção de eficácia jurídica da aplicabilidade das normas jurídicas, visto que a eficácia jurídica consiste justamente na possibilidade de aplicação da norma aos casos concretos, com a conseqüente geração dos efeitos jurídicos que lhe são inerentes. ${ }^{111}$

Segundo José Afonso da Silva:

[...] eficácia e aplicabilidade são fenômenos conexos, aspectos talvez do mesmo fenômeno, encarados por prismas diferentes: aquela como potencialidade; esta como realizabilidade, praticidade. [...] Esta se revela, assim, com a possibilidade de aplicação. Para que haja essa possibilidade, a norma há que ser capaz de produzir efeitos jurídicos. 112

\footnotetext{
${ }^{110}$ SARLET, Ingo Wofgang. A eficácia dos direitos fundamentais. 7 ed. rev., atual. e ampl. Porto Alegre: Livraria do advogado, 2007, p. 247.

${ }^{111}$ Ibidem, p. 248. Em relação a essa questão, Virgílio Afonso da Silva, entretanto, discorda ao apresentar uma nítida distinção entre eficácia e aplicabilidade de direitos. Segundo o autor, a norma aplicável é aquela que além de ser dotada de eficácia, ou seja, capacidade para produzir efeitos, possui um suporte fático que se conecta com os fatos de um determinado caso concreto. A norma pode ser eficaz, mas não ser aplicável a uma situação jurídica. Cf. SILVA, Virgílio Afonso da. A constitucionalização do direito: os direitos fundamentais nas relações entre particulares. São Paulo: Malheiros, 2005, p. 55.

${ }^{112}$ SILVA, José Afonso. Aplicabilidade das normas constitucionais. 4 ed. São Paulo: Revista dos Tribunais, 2000, p. 49-50.
} 
De acordo com Sarlet, enquanto a eficácia jurídica é a possibilidade de a norma vigente ser aplicada aos casos concretos e, na medida de sua aplicabilidade, gerar efeitos jurídicos, a eficácia social, ou efetividade, engloba tanto a decisão pela efetiva aplicação da norma juridicamente eficaz, quanto o resultado concreto decorrente ou não desta aplicação. $^{113}$

De forma simplificada, pode-se dizer que a eficácia jurídica é representada pela possibilidade de qualquer norma jurídica gerar efeitos. A aplicabilidade, por sua vez, é a possibilidade de aplicação da norma jurídica eficaz aos casos concretos. Já a efetividade significa a concreta realização dos efeitos jurídicos no plano dos fatos.

Segundo Luís Roberto Barroso:

\begin{abstract}
A efetividade significa [...] a realização do Direito, o desempenho concreto de sua função social. Ela representa a materialização, no mundo dos fatos, dos preceitos legais e simboliza a aproximação, tão íntima quanto possível, entre o dever ser normativo e o ser da realidade social. ${ }^{114}$
\end{abstract}

A efetividade, portanto, ultrapassa a noção de produção de efeitos para atingir a de qualidade de resultados, de eficiência. A efetividade equivale à ideia de eficácia social proposta por Miguel Reale, pois diz respeito à correspondência alcançada pela norma entre o que prescreve e os valores nos quais se funda a ordem jurídica e social no momento de sua aplicação, ou seja, “estabelece a perspectiva tridimensional da relação entre o fato (situação regida pela norma), a norma (texto) e o valor (padrões éticos estabelecidos para a nova ordem jurídica). ${ }^{115}$

A eficácia social das normas jurídicas, que será abordada no item 2.6, diz respeito à capacidade dessas normas, criadas pelo poder legislativo originário ou derivado, de serem efetivamente respeitadas pelos seus destinatários, por meio da incorporação, pela sociedade, dos valores que permearam o estabelecimento da norma no ordenamento jurídico, de maneira a tornar o mais natural possível o cumprimento e o respeito aos direitos nela esculpidos.

O estudo da eficácia jurídica das normas de direitos fundamentais trabalhistas é de suma importância, abrangendo tanto a análise da capacidade dessas normas produzirem efeitos jurídicos - em virtude da necessidade ou não de regulamentação da norma por

\footnotetext{
${ }^{113}$ SARLET, Ingo Wofgang. A eficácia dos direitos fundamentais. Op. cit., p. 249.

114 BARROSO, Luís Roberto. O direito constitucional e a efetividade de suas normas: limites e possibilidades da Constituição brasileira. Rio de Janeiro: Renovar, 1996, p. 83.

${ }^{115}$ REALE, Miguel. Filosofia do Direito. 19 ed. São Paulo: Saraiva, 2000, p. 598.
} 
legislador infraconstitucional, de modo a enfocar quais normas são auto-aplicáveis e quais têm aplicabilidade mediata ou não auto-executória - quanto o estudo da identificação dos destinatários das normas de direitos fundamentais, que deverão respeitá-los, observando-se sua incidência nas relações jurídicas travadas entre particulares (eficácia horizontal) e entre Estado e particulares (eficácia vertical).

$\mathrm{O}$ primeiro enfoque diz respeito à capacidade original das normas constituintes em produzir todos os efeitos jurídicos para os quais foram criadas. José Afonso da Silva tradicionalmente classifica as normas jurídicas, no que tange à aplicabilidade, em normas de eficácia plena, de eficácia contida e de eficácia limitada. ${ }^{116}$ As primeiras são aquelas que, desde a entrada em vigor da Constituição, têm possibilidade de produzir todos os efeitos jurídicos, relativamente a interesses, comportamentos e situações que o legislador quis regular, como, por exemplo, as normas que estabelecem os remédios constitucionais. As de eficácia contida são aquelas normas em que "o legislador constituinte regulou suficientemente os interesses relativos a determinada matéria, mas deixou margem à atuação restritiva por parte da competência discricionária do poder público, nos termos que a lei estabelecer" ${ }^{\prime 117}$ ou conforme os conceitos gerais nela enunciados. E, finalmente, as normas constitucionais de eficácia limitada são aquelas que somente incidem sobre os interesses que devem reger, após uma normatividade ulterior que lhes desenvolva a aplicabilidade ou, em outras palavras, são normas que necessitam de regulação pelo legislador infraconstituinte para que surtam todos os efeitos previstos pelo legislador constituinte. Por isso, são essas normas consideradas de aplicabilidade indireta, mediata ou reduzida, ao contrário das normas de eficácia plena e de eficácia contida que têm aplicabilidade direta e imediata.

O segundo enfoque será tratado no próximo item, por meio da análise da eficácia vertical dos direitos fundamentais trabalhistas, que se vislumbra entre Estado e indivíduos, e da eficácia horizontal das normas que embasam esses direitos entre particulares ou entre particular e Estado, enquanto empregador.

\footnotetext{
116 Outros autores trabalham a questão da eficácia jurídica das normas constitucionais, porém mantendo basicamente a mesma divisão classificatória. Assim, na presente tese, resumir-se-á a apresentar a classificação tradicional de José Afonso da Silva.

${ }^{117}$ SILVA, José Afonso. Op. cit., p. 89-91.
} 


\subsubsection{Eficácia vertical e horizontal dos direitos fundamentais trabalhistas}

De acordo com o disposto no art. $5^{\circ}$, $\S 1^{\circ}$, da Constituição brasileira de 1988 , os direitos e garantias fundamentais têm aplicabilidade imediata, independentemente do reconhecimento expresso por lei infraconstitucional, estando protegidos não apenas diante do legislador ordinário, mas também da ação do poder constituinte reformador, por integrarem o rol das denominadas cláusulas pétreas (art. 60, § $4^{\circ}$, inc. IV, da CF/88).

É necessário salientar que com esse dispositivo o constituinte quis dizer que a vigência das normas de direitos fundamentais é automática, ou seja, que elas têm autoaplicabilidade; não obstante, silenciou com relação em face de quem poderiam ser opostos os direitos fundamentais: se só contra o Estado ou se também nas relações jurídicas privadas, e em que medida. ${ }^{118}$

Nesse ponto, Virgílio Afonso da Silva entende que o fato desse dispositivo constitucional prescrever que os direitos fundamentais têm aplicação imediata não significa que essa aplicação deva ocorrer em todos os tipos de relação ou que todos os tipos de relação jurídica sofrerão algum efeito das normas de direitos fundamentais. ${ }^{119}$

Os direitos fundamentais sociais previstos constitucionalmente são normas de ordem pública, cogentes, ou seja, incidem nas relações entre o indivíduo e o Estado, independentemente da vontade desse último e nas relações entre particulares e entre indivíduo e Administração Pública, enquanto empregadora, em virtude da vocação original das normas que instituem direitos trabalhistas em diminuir a desigualdade entre as partes na relação jurídica empregatícia.

A relação de emprego, enquanto fenômeno sociojurídico, resulta da síntese de um diversificado conjunto de fatores ou elementos reunidos em um dado contexto social ou interpessoal.

De acordo com Maurício Godinho Delgado ${ }^{120}$, os elementos componentes da relação de emprego devem ocorrer de forma concomitante, sob pena de se descaracterizála, e são os seguintes: prestação de trabalho por pessoa física a um tomador qualquer, efetuada, com pessoalidade, onerosidade e não-eventualidade pelo trabalhador, sob

\footnotetext{
${ }^{118}$ GONÇALVES, Rogério Magnus Varela. Os direitos fundamentais e sua validade no âmbito das relações privadas. Revista Prim@ Facie, João Pessoa, v. 3, n. 5, 2004, p. 88.

${ }^{119}$ SILVA, Virgílio Afonso da. Op. cit., p. 58.

${ }^{120}$ DELGADO, Maurício Godinho. Curso de Direito do Trabalho. Op. cit., p. 287-305.
} 
subordinação ao tomador dos serviços. Esses elementos estão contidos em dois preceitos combinados da CLT: o caput dos arts. $2^{\circ}$ e $3^{\circ}$.

A própria relação de emprego tem como característica essencial o desequilíbrio entre as partes contratantes, o que demanda a incidência de normas de ordem pública, ou seja, normas cogentes, imperativas, invioláveis pelo empregado e empregador criadas pelo legislador como o objetivo de tentar reequilibrar essa relação jurídica privada.

A liberdade contratual se consubstancia na liberdade, de ambas as partes, de decidir celebrar o ajuste, celebrar o contrato, de escolher o outro contratante e de determinar o conteúdo do contrato, inclusive por meio da outorga, a um dos contratantes, do poder empregatício, por meio da organização, fiscalização, direção e disciplina do trabalho e do modo de produção.

Não obstante, no contrato de trabalho a vontade das partes é limitada e mitigada em virtude da incidência de normas de ordem pública, de índole constitucional ou infraconstitucional, com vistas a reduzir o desequilíbrio entre as partes, fenômeno conhecido como dirigismo contratual.

Realmente, a relação jurídica de emprego é uma relação privada em que existem dois sujeitos em situações desiguais: o empregador, que é a parte mais forte economicamente e, por definição, dirige a prestação pessoal dos serviços dos trabalhadores, e o empregado, que necessita alienar seu poder de dispor de sua própria força de trabalho para receber o salário como contraprestação. Dessa forma, devido à desigualdade entre as partes contratantes, a autonomia da vontade da parte mais fraca muitas vezes é mero pretexto para legitimação de imposições ditadas pela parte mais forte, tal como também acontece no Direito do Consumidor.

Em verdade, o empregador, sobretudo quando se constitui em empresa, representa um dos pólos de poder da sociedade enquanto força social e econômica, posto que há muito o poder não se encontra adstrito ao Estado. Dessa forma, a liberdade dos indivíduos necessita de proteção não somente contra os poderes públicos, mas também contra os particulares mais fortes.

Com o intuito de amenizar os efeitos do desequilíbrio entre as partes contratuais, a Constituição de 1988 apresenta em diversos artigos a decisão do legislador de garantir os direitos dos hipossuficientes, tais como os empregados na relação de emprego e o consumidor na relação de consumo, de forma a propiciar e assegurar o exercício da democracia nas relações privadas entre desiguais. 
Nesse contexto, a relação de emprego está sujeita a inúmeras normas de ordem pública, normas cogentes que vinculam as partes contratuais, independentemente de sua vontade, tais como as normas de saúde e segurança do trabalho, o salário mínimo para o trabalho em regime de 44 horas semanais, a irredutibilidade salarial, salvo negociação coletiva, entre outros direitos fundamentais sociais previstos nos arts. $6^{\circ}$ ao $11 \mathrm{da} \mathrm{CF/88} \mathrm{e}$ na CLT. O Direito do Trabalho se utiliza, também, de mecanismos e técnicas de julgamento de forma a equilibrar juridicamente a relação entre essas partes, tais como a presunção a favor do hipossuficiente em algumas situações ou a inversão do ônus da prova em desfavor do empregador, por exemplo. ${ }^{121}$

É importante lembrar que, embora existam mecanismos para tentar diminuir o desequilíbrio entre empregado e empregador como partes do contrato de trabalho, na realidade a relação de emprego nada mais é do que uma relação privada material e economicamente assimétrica em que incidem normas de ordem pública equalizadoras, justamente pelo fato de seus sujeitos encontrarem-se em uma relação de desigualdade jurídica.

Ante o exposto, constata-se que, na realidade, a eficácia das normas sociais relativas aos direitos fundamentais do trabalhador é naturalmente horizontal na relação de emprego, ou seja, essas normas incidem independentemente da vontade das partes, limitando a autonomia da vontade dos contratantes no que diz respeito ao mínimo a ser observado em termos de proteção estatal do empregado.

Obviamente que, na relação de emprego, não há como separar o trabalho da pessoa que o presta, pois na execução do contrato de trabalho, o empregado reúne a dupla qualidade de titular de direitos fundamentais aplicáveis estritamente no âmbito da relação de emprego e titular de direitos fundamentais que lhe assistem como cidadão. Os primeiros constituem os direitos sociais trabalhistas elencados na Constituição Federal (art. $6^{\circ}$ ao 11 da $\mathrm{CF} / 88$ e art. 10 do ADCT) e os segundos englobam todos os direitos fundamentais de índole individual ou transindividual que incidem direta e imediatamente na relação de emprego, em virtude do fenômeno da horizontalização dos direitos fundamentais nas relações privadas.

Essa eficácia direta e imediata é constatada por Romita ${ }^{122}$, ao explicar que a implicação da "pessoa do trabalhador na execução do contrato de trabalho afeta não só

\footnotetext{
${ }^{121}$ SARMENTO, Daniel. Direitos fundamentais e relações privadas. Op. cit. p. 262-264.

${ }^{122}$ ROMITA, Arion Sayão. Op. cit., p. 205.
} 
seus interesses profissionais (satisfação no trabalho, remuneração, carreira, etc.), mas também seus interesses pessoais (saúde, intimidade, integridade física, tempo livre, etc.)”.

Assim, os empregados, enquanto seres humanos que são, têm, sem sombra de dúvida, direitos à vida, à honra, à integridade física, à intimidade e à privacidade, entre outros, direitos esses que não se restringem ao âmbito de vida pessoal dos trabalhadores, incidindo na relação de emprego ${ }^{123}$.

Em virtude da desigualdade substancial entre as partes na relação de emprego, é necessário que a eficácia direta e imediata dos direitos individuais fundamentais seja mais intensa, visto que uma das partes tem a sua autonomia privada mitigada e, para fazer valer sua vontade, deverá poder exercer os seus direitos fundamentais em face do outro contratante que, por conseguinte, terá sua autonomia privada menos preservada. Esse entendimento encontra seu fundamento constitucional, inclusive, no art. $3^{\circ}$, incisos I e III, da Norma Fundamental, que dispõe, dentre os objetivos da República Federativa do Brasil, a redução das desigualdades sociais e a construção de uma sociedade justa e solidária.

Afinal, o contrato de trabalho não pode ser instrumento legitimador de violações ao exercício dos direitos fundamentais individuais constitucionalmente assegurados ao empregado como ser humano. Assim, ainda que no ambiente de trabalho, essa condição não poderá ser aviltada, admitindo-se apenas limitações razoáveis ao exercício desses direitos, desde que justificadas pela ponderação de tais interesses com outros direitos fundamentais em conflito.

A enorme discussão que se trava em relação à incidência das normas de direitos fundamentais nas relações privadas, ou seja, a celeuma em torno da eficácia horizontal de direitos fundamentais nas relações de índole privatística ${ }^{124}$, tem sentido, no Direito do

\footnotetext{
123 Vale esclarecer que os direitos e liberdades fundamentais não se aplicam somente aos trabalhadores subordinados, ou seja, aos empregados, mas aos trabalhadores autônomos, aos parassubordinados e a todos aqueles que exercem uma atividade remunerada por conta de outrem.

${ }^{124}$ Em relação aos particulares existem algumas teorias que buscam explicar o tipo de eficácia da norma de direito fundamental nas relações privadas, de maneira que as ideias acerca do assunto se cingem basicamente em torno de dois posicionamentos principais.

De acordo com a teoria da eficácia mediata e indireta dos direitos fundamentais nas relações travadas entre particulares, a vinculação do particular à norma de direito fundamental ocorre por meio da atuação do juiz, sobretudo por intermédio do preenchimento de lacunas jurídicas e de conceitos jurídicos indeterminados ou mesmo pela aplicação em um caso concreto do direito em foco, e também pela atuação do legislador, consoante a criação de leis que estabeleçam essa incidência de forma regrada. A teoria foi desenvolvida pelo alemão Dürig, sendo adotada pela maioria da doutrina alemã e pelo Tribunal Constitucional Alemão. Para maiores detalhes sobre a mencionada teoria, confira-se CANARIS, Claus-Wihelm. Grundrechte und privatrecht. AcP 184, 1984; SILVA, Virgílio Afonso da. A constitucionalização do direito: os direitos fundamentais nas relações entre particulares. São Paulo: Malheiros, 2005; HESSE, Konrad. Grundzüge des verfassungsrechts der bundesrepublik deutschland. 20 ed. Heidelberg: CF Muller, 1995; SARLET, Ingo Wolfgang. A eficácia dos direitos fundamentais. Op. cit., e SARMENTO, Daniel. Op. cit.
} 
Trabalho, apenas no que tange às normas de direitos fundamentais individuais na relação de emprego, que como se observou, nada mais é do que uma relação privada mitigada por normas de ordem pública, mas não se justifica em relação à eficácia de normas de direitos fundamentais laborais. Assim, quando se está a falar, por exemplo, dos direitos fundamentais à integridade física, à honra, à imagem, à intimidade e à privacidade dos empregados em seu ambiente de trabalho, é necessário que o aplicador do direito se posicione a favor da eficácia imediata e direta ou da eficácia mediata e indireta desses direitos fundamentais na relação de emprego, utilizando-se, caso adote a primeira corrente, dos parâmetros para realizar a ponderação entre os interesses em conflito, ou seja, entre o direito fundamental em apreço e os princípios da liberdade contratual e da livre concorrência, corolários da autonomia da vontade.

Esse tema, contudo, foge ao objeto da presente tese, que visa particularmente estudar a implementação dos direitos fundamentais trabalhistas, de índole intrinsecamente social, já que a eficácia jurídica horizontal desses direitos na relação de emprego já ocorre naturalmente, pois foram criados justamente para incidir nessa relação privada específica e diminuir o desequilíbrio reinante entre as partes contratuais.

A eficácia jurídica dos direitos sociais na relação de emprego, portanto, não pode ser rechaçada pelas partes, pois seriam direitos mínimos a ser assegurados, pelo empregador, seja ele privado ou público, para evitar o aviltamento da condição humana do ser obreiro. Essa noção constitui um dos elementos que propiciaram o nascimento do Direito do Trabalho e é estabelecida por meio de dois princípios pilares desse ramo jurídico, quais sejam, o princípio da imperatividade das normas trabalhistas e o princípio

A teoria da eficácia direta e imediata defende que as normas de direitos fundamentais incidem de forma direta na relação privada, sem a necessidade de intermediação pelo aplicador do direito ou pelo legislador, gerando o respeito e vinculação de uma das partes da relação jurídica à outra parte titular do direito fundamental em apreço. Ao se adotar a aplicabilidade imediata dos direitos fundamentais nas relações privadas, estar-se-ia prestigiando a supremacia das normas constitucionais, a sua força normativa e a unidade da ordem jurídica. A teoria da eficácia direta dos direitos fundamentais nas relações privadas é defendida na Alemanha por Hans Carl Nipperdey, embora não tenha logrado grande aceitação nesse país. Sem embargo, é considerada majoritária na Espanha e em Portugal. Confira-se, entre outros, NIPPERDEY, Hans Carl. Grundrechte und privatrecht. In: NIPPERDEY, Hans Carl (Hrsg.) Festschrift für Erich Molitor zum 75. Geburtstag. München. C.H. Beck, 1962; QUADRA-SALCEDO, Tomás. El recurso de amparo y los derechos fundamentales en las relaciones entre particulares. Madrid: Civitas, 1981; BILBAO UBILLOS, Juan Maria. La eficacia de los derechos fundamentales frente a particulares: Madrid: Centro de Estudios Constitucionales, 1997; NARANJO DE LA CRUZ, Rafael. Los límites de los derechos fundamentales en las relaciones entre particulares: la buena fe. Madrid: Centro de Estudios Políticos e Constitucionales, 2000; CANOTILHO, J. J. Gomes. Direito constitucional e teoria da constituição. Op. cit.; PRATA, Ana. A tutela constitucional da autonomia privada. Coimbra: Almedina, 1982; ABRANTES, José João Nunes. A vinculação das entidades privadas aos direitos fundamentais. Lisboa: Associação Acadêmica da Faculdade de Direito de Lisboa, 1990; e ANDRADE, José Carlos Vieira de. Os direitos fundamentais na Constituição Portuguesa de 1976. 2 ed. Coimbra: Livraria Almedina, 2001. 
da indisponibilidade, também nomeado por alguns doutrinadores de princípio da irrenunciabilidade dos direitos trabalhistas.

O princípio da irrenunciabilidade de direitos trabalhistas, segundo Alice Monteiro de Barros, tem como objetivo limitar a autonomia da vontade das partes, pois não seria possível que o ordenamento jurídico viabilizasse o despojamento desses direitos por parte do trabalhador, presumivelmente pressionado pelo temor de não obter um emprego ou de já o tendo, perdê-lo, caso não acatasse a renúncia. ${ }^{125}$

Ao lado da eficácia horizontal natural dos direitos fundamentais na relação de emprego - que tem como destinatários os empregadores privados, em se tratando de empregados privados, ou empregadores públicos, no caso de empregados públicos ${ }^{126} \mathrm{e}$ servidores públicos detentores de emprego público - é possível que se vislumbre a eficácia vertical dos direitos fundamentais trabalhistas, que se caracteriza por ensejar a vinculação do Estado aos direitos dos particulares. Como regra geral, em se tratando de direitos fundamentais, inclusive trabalhistas, as normas que os embasam têm eficácia direta e imediata perante o Estado ${ }^{127}$, pelo menos do ponto de vista negativo ou defensivo de não violação a esses direitos, mas também, em se tratando de normas constitucionais de eficácia limitada e aplicabilidade mediata, por meio do papel positivo do Estado pela regulamentação de direitos constitucionais que não prescindem de lei infraconstitucional para adquirir eficácia plena.

A eficácia vertical dos direitos fundamentais trabalhistas é facilmente vislumbrada, pois o Estado não pode agir de forma a desrespeitar esses direitos, seja por meio do poder legislativo, com a criação de normas que desrespeitem o patamar mínimo criado pelo

\footnotetext{
${ }^{125}$ BARROS, Alice Monteiro de. Curso de Direito do Trabalho. 3 ed. rev. e ampl. São Paulo: LTr, 2007, p. $182 / 183$.

${ }^{126}$ Para uma parte dos administrativistas, os servidores públicos detentores de emprego público seriam aqueles que trabalham na Administração Direta (o que engloba órgãos da União, dos Estados, Municípios e do Distrito Federal), e na Administração Indireta (Autarquias e Fundações Públicas) como os servidores públicos detentores de cargo público; porém, ao contrário desses, não ocupam cargo público, mas, sim, emprego público, regido predominantemente pela Consolidação das Leis do Trabalho, e de algumas normas de ordem pública, como a necessidade de aprovação em concurso público, por exemplo. Já os empregados públicos seriam aqueles que também ocupam emprego público, porém nas empresas públicos e sociedades de economia mista e suas concessionárias, as chamadas "empresas estatais", que fazem parte da Administração Indireta e podem tanto prestar serviços públicos, quanto desenvolver atividades econômicas de áreas estratégicas para o Estado, caso em que muito se assemelham às empresas privadas. Já outra parte dos administrativistas entende que todos os que ocupam emprego público na Administração Pública, seja na Administração Direta ou Indireta, seriam denominados empregados públicos.

127 Quando se está diante de um particular, há o questionamento acerca da eficácia da norma, se direta e imediata ou indireta e mediata, como já realçado, com exceção dos direitos fundamentais trabalhistas que se dirigem, em grande a parte, aos empregadores, públicos ou privados, e visam reduzir a desigualdade entre as partes da relação de emprego.
} 
legislador constituinte originário ${ }^{128}$ ou mesmo pelo legislador infraconstitucional, seja pela atuação do poder judiciário, de forma a não aplicar os direitos fundamentais pleiteados que foram cabíveis ou utilizando-se de interpretação que desprestigie uma atuação de efetivação dos direitos fundamentais, seja, ainda, pela administração pública que deve se pautar, em sua atuação, pelo respeito e não violação aos direitos fundamentais trabalhistas.

Deve-se salientar que tanto no caso quando os destinatários da norma de direito fundamental são os entes privados ou os particulares individualmente considerados, quanto quando o Estado é o empregador, está-se diante da eficácia horizontal natural das normas de direitos fundamentais trabalhistas na relação de emprego, como já esclarecido. Nessas situações, o Estado continuará com o papel de respeitar, por meio da atuação de suas instituições, os direitos fundamentais trabalhistas, em virtude da eficácia vertical das normas que estabelecem esses direitos.

Sem embargo, o Estado poderá ser o destinatário direto das normas que estabelecem esses direitos, mesmo quando não é o empregador, como, por exemplo, no caso do direito fundamental ao salário mínimo, fixado e alterado sempre por meio de lei, ou do direito à aposentadoria, pelo regime geral de previdência, administrado pelo Estado. Nessas situações, a eficácia, também vertical, se pautará não só por uma atitude defensiva do Estado, de não violação de direitos, mas também pelo dever de uma atuação positiva de maneira a implementar e efetivar os direitos fundamentais constitucionalmente por meio de programas governamentais e criação de legislação pertinente para a sua execução.

\subsection{Efetividade dos direitos fundamentais trabalhistas: a ineficácia social das normas decorrente do descumprimento reiterado dos direitos trabalhistas no Brasil}

A capacidade das normas jurídicas em serem absorvidas pelo corpo social de um país, ou seja, de após criadas serem efetivamente observadas e cumpridas pelos destinatários normativos, constitui a denominada eficácia social ou efetividade da norma jurídica.

\footnotetext{
${ }^{128}$ O princípio da vedação do retrocesso visa proibir que o legislador constitucional, por meio de emendas constitucionais, crie normas que diminuam o patamar de proteção já instituído, seja através da exclusão de normas que previam determinados direitos, seja modificando o texto constitucional, adotando redação mais restritiva.
} 
É pertinente observar que as normas que estabelecem os direitos trabalhistas, tanto as de patamar constitucional que entabulam os direitos fundamentais dos trabalhadores, quanto as infraconstitucionais, apresentam, no Brasil, um alto grau de ineficácia social ou inefetividade, derivada de uma cultura criada no seio das relações sociais de que descumprir os direitos trabalhistas é mais barato e mais lucrativo do que ser um empregador exemplar. Essa "cultura" caracterizada pela violação em massa de direitos fundamentais trabalhistas, foi sendo construída, conjuntamente, por vários fatores, que serão abordados a seguir, sem a pretensão de seu esgotamento, em virtude da amplitude do tema.

As relações entre o capital e trabalho têm sofrido a influência das alterações derivadas da globalização econômica e política, tais como o encurtamento das distâncias em virtude de meios de transporte cada vez eficientes; a quantidade de informações e a rapidez da sua transmissão; a intensificação das relações econômicas entre os países; a alteração das formas de produção, com a automação das linhas de produção, e o aumento do maquinário, pelos avanços da robótica, visando substituir o capital humano; e a globalização dos meios de produção e da mão-de-obra, com a busca pelas empresas multinacionais dos países onde se possa produzir a menor custo, de modo a fabricar em qualquer localidade do globo um produto para ser vendido em todos os cantos do mundo.

Diante desse cenário, mais do que nunca faz-se necessária a intervenção do Estado nas relações de trabalho no Brasil, não somente em face da ausência de emprego para todos, problema agravado diante das crises econômicas que atingem ciclicamente os países, mas, também, em virtude da prática de descumprimento reiterado dos direitos fundamentais trabalhistas. A ausência de dispositivos legais que assegurem segurança no emprego para que o empregado possa, no curso do pacto laboral, reclamar os direitos que estão sendo violados em virtude do receio de perder o posto de trabalho, conjugados com um prazo de prescrição trabalhista relativamente curto que não favorece a postulação de reclamações sobre direitos violados após cinco anos de contrato, em se tratando de ajuizamento de ação após a extinção do contrato, hipótese mais comum, ajudam a fomentar esse descumprimento pelos empregadores.

Outro fator que colabora para a violação de direitos trabalhistas são as ações judiciais que, em virtude da sistemática processual que permite a utilização pelos descumpridores de direitos de subterfúgios de vários tipos, inclusive recursais, somada à morosidade do Judiciário, levam, muitas vezes, anos para serem processadas e julgadas, sobretudo quando chegam ao Tribunal Superior do Trabalho. Muitos empregadores 
preferem se utilizar de todos os recursos existentes ao invés de pagar os valores devidos, pois ganham tempo e dinheiro até a decisão final do processo. Outras empresas, que reiteradamente "frequentam" a Justiça do Trabalho, sendo denominadas muitas vezes como "empresas clientes", utilizam-se dos acordos homologados judicialmente, com a famigerada cláusula de quitação geral, que extermina qualquer possível ação trabalhista futura, para pagar valores bem mais baixos do que seriam devidos caso o processo fosse julgado.

Ainda há a situação das empresas fornecedoras de trabalhadores terceirizados para as tomadoras de serviços, muitas daquelas sem um capital e um patrimônio suficientes para arcar com qualquer dívida trabalhista, posto que constituídas única e exclusivamente para fornecer mão-de-obra barata para empresas tomadoras e, outras vezes, agindo em conluio com as tomadoras para mascarar um verdadeiro vínculo de emprego.

Isso tudo sem contar que muitos trabalhadores, por não saberem que estão sendo lesados ou por temerem não ser novamente contratados, em setores da economia mais restritos em que a imagem do profissional facilmente se espalha pelas empresas do meio, não ajuízam reclamações trabalhistas.

Diante desse crítico cenário, não se pode perder de vista que o empregador, que acumula riquezas em função do trabalho alheio, tem uma responsabilidade deveras relevante em relação àquele que, com o seu trabalho, ajuda a manter a atividade econômica. O respeito aos direitos trabalhistas se impõe como fruto dessa responsabilidade e a agressão a esses direitos sociais precípuos constitui uma violação ao valor social do trabalho que movimenta e ajuda a manter o sistema capitalista.

O valor do trabalho não pode ser negado enquanto elemento essencial do modelo capitalista, até mesmo porque o sistema cria a necessidade de consumo e favorece a acumulação de riquezas, enquanto a retribuição pelo trabalho realizado funciona como uma forma de redistribuir a própria riqueza produzida pelos trabalhadores.

Jorge Luiz Souto Maior demonstra como funciona esse modelo integrado entre consumo, trabalho e responsabilidade social:

[...] quando nos beneficiamos de algum modo do modelo que está aí, quando adquirimos produtos que satisfazem as nossas necessidades de consumo [...] é sempre bom lembrar que por trás de tudo isto há trabalho, ou melhor, alguma pessoa que, pelo seu trabalho, nos possibilitou essa situação, e o mínimo que se exige, do ponto de vista de uma coesão social pautada pela ética de solidariedade social como valor jurídico, é que todas essas pessoas recebam, na integralidade, os seus direitos trabalhistas, numa perspectiva sempre integrativa e crescente, dos pontos de vista social e econômico. Há de se supor, ademais, que este é o 
desejo da sociedade, como ente ideal que visa ao bem comum, e, portanto, cabe aos profissionais do Direito exercer a sua função, fazendo com que tais direitos sejam respeitados (efetivamente, cumpridos). ${ }^{129}$

Deve-se frisar que ao lado da cultura arraigada nos empregadores de que vale mais descumprir direitos trabalhistas, o que é notório para qualquer um que analise mais detidamente a sistemática do processo do trabalho no Brasil, existe outro problema igualmente grave: a ausência de implementação e a implementação restritiva das normas que embasam esses direitos, em virtude da atuação pouco vanguardista da Justiça do Trabalho no que tange à interpretação e aplicação dos direitos fundamentais trabalhistas.

\subsection{A ausência de implementação e a implementação restritiva dos direitos fundamentais trabalhistas diante da atuação da Justiça do Trabalho no Brasil}

O papel da Justiça do Trabalho, no Brasil, é processar e julgar as ações decorrentes das controvérsias surgidas no seio das relações de emprego e de trabalho com a maior celeridade possível, em virtude da natureza alimentar dos créditos trabalhistas que estão presentes na maior parte dos feitos que correm nesse ramo judiciário especializado. Essa rapidez de tramitação, no entanto, vem sendo posta à prova em alguns tribunais do país em virtude do assoberbamento de processos e da falta de estrutura para dar conta do julgamento das ações nos prazos estipulados em lei.

Além da celeridade, deve a Justiça do Trabalho se pautar pela realização de julgamentos que venham concretizar os direitos materiais trabalhistas, de modo a funcionar, por um lado, como uma forma de contenção do descumprimento reiterado desses direitos sociais pelos empregadores e, por outro, como um meio para implementar, em sua plenitude, os direitos fundamentais do trabalhador dispostos na Constituição Federal de 1988, garantindo, assim, aos trabalhadores o patamar mínimo civilizatório estabelecido constitucionalmente.

O papel dos juízes trabalhistas é de importância ímpar para a implementação dos direitos constitucionalmente positivados e não apenas dos direitos infraconstitucionais dispostos na CLT e leis adjacentes e se configura como um dos mais importantes instrumentos viabilizadores da cidadania, enquanto pilar do Estado Democrático brasileiro.

129 SOUTO MAIOR, Jorge Luiz; CORREIA, Marcus Orione Gonçalves. O que é direito social? In: CORREIA, Marcus Orione Gonçalves (Org.). Op. cit., p. 32-33. 
Sem embargo, a realidade que vem sendo observada na atuação da Justiça do Trabalho na sua função de intérprete e aplicadora dos direitos fundamentais trabalhistas não é deveras animadora.

Por meio de uma análise da jurisprudência dos Tribunais Regionais do Trabalho, constata-se uma postura pouco vanguardista, quiçá possa-se dizer restritiva, de implementação dos direitos fundamentais trabalhistas, elencados nos artigos $6^{\circ}$ a 11 da CF/88 e no artigo 10 da ADCT. Em muitos acórdãos, simplesmente não se citam as fontes constitucionais dos direitos trabalhistas, mas apenas as infraconstitucionais, como se os direitos constantes da Constituição Federal não contivessem nenhuma força normativa, resumindo-se a uma mensagem estabelecida formalmente, sem valor jurídico. Outras vezes, a Especializada se limita a dar ao direito fundamental uma interpretação restritiva, ora desvinculada das mudanças ocorridas na sociedade e de suas reais aflições, ora desatrelada dos valores dispostos pelo constituinte originário.

Pode-se dizer que a função interpretativa dos dispositivos constitucionais tem sido pouco burilada pelos juízes no Brasil, que se deparam não mais apenas com a interpretação estabelecida pela base da subsunção do fato à regra jurídica existente, mas complementada com a complexidade da interpretação que envolve direitos constitucionais, muitos deles estabelecidos em normas de estrutura principiológica. E essa observação não tem sido diferente no que tange à atuação da Justiça do Trabalho.

A partir de pesquisa de jurisprudências nos Tribunais Regionais do Trabalho e no Tribunal Superior do Trabalho, constatou-se que poucos são os acórdãos que demonstram a utilização dos métodos, das técnicas e dos princípios da hermenêutica próprios para os direitos constitucionais em análise. A familiaridade dos magistrados com a interpretação em seu cotidiano de trabalho se resume, na grande maioria dos julgamentos, aos métodos de interpretação tradicionais, dando mais importância às normas heterônomas e autônomas infraconstitucionais do que para os dispositivos constitucionais que estabelecem direitos fundamentais do trabalhador, ainda que aqueles sejam menos favoráveis.

A distância existente na doutrina entre a teoria dos direitos fundamentais, tão bem trabalhada no Brasil pelos constitucionalistas, e os direitos fundamentais trabalhistas, normalmente estudada de forma desvinculada à sua matriz constitucional e voltada mais para a aplicação prática corriqueira, é observada também na jurisprudência, quando se percebe que a Justiça do Trabalho não tem desenvolvido eficazmente uma postura adequada para interpretar e aplicar os direitos fundamentais trabalhistas, sobretudo em relação às normas de eficácia plena que apresentam uma maior abertura interpretativa e 
àquelas que não atingem a eficácia plena pela falta de norma regulamentadora infraconstitucional.

Obviamente que a realidade social exige uma mudança de postura desse ramo jurídico especializado, sobretudo se levado em consideração que o material base de atuação da Justiça do Trabalho engloba basicamente relações jurídicas em que o valor trabalho é intrínseco, não podendo os magistrados se ater a uma interpretação das normas distanciada de uma pré-compreensão das questões sociais que existem no espaço exterior aos Tribunais, pois cada decisão proferida gera repercussões que envolvem vidas humanas.

\subsection{Os direitos fundamentais trabalhistas na Constituição de 1988}

Após o estudo de como os direitos fundamentais trabalhistas são tratados na sistemática dos direitos fundamentais, no que tange à evolução histórica, caracterização, estrutura das normas que os embasam, eficácia vertical e horizontal dessas normas, peculiaridades dos destinatários desses direitos, efetividade no cenário nacional e implementação restrita dessas normas pela Justiça do Trabalho, é necessário analisar quais os direitos fundamentais do trabalhador foram estabelecidos pelas Constituições brasileiras, inclusive a de 1988, e como esses direitos se inserem, enquanto direitos sociais, na Constituição Federal vigente, denominada de Constituição "Cidadã".

\subsubsection{Os direitos fundamentais trabalhistas estabelecidos nas Constituições brasileiras antes de 1988}

A constitucionalização de direitos, no Brasil, desde a primeira Constituição - a Constituição do Império, de 25 de março de 1824 - até a Emenda n. 01 de 1969 considerada por muitos juristas como uma nova ordenação constitucional, em virtude da alteração de grande parte da Constituição de 1967 e de algumas de suas bases estruturais mais importantes - se pautou pela positivação tópica dos direitos fundamentais no texto constitucional.

A Constituição de 1824 continha normas esparsas positivando direitos como os de nacionalidade no Título II ("Dos Cidadãos Brasileiros", artigos $6^{\circ}$ a $8^{\circ}$ ) e os direitos civis e 
políticos no Título VIII ("Das Disposições Gerais e Garantias dos Direitos Civis e Políticos dos Cidadãos Brasileiros”, artigo 179, com 35 itens). O texto, considerado avançado para o período histórico, assegurava direitos individuais como a liberdade de expressão, inclusive de imprensa, liberdade de convicção religiosa e de culto, ainda que adotasse a religião do Estado, igualdade de todos perante a lei, direito de petição e queixa, entre outros. Ademais, previa o direito à segurança e estabelecia, de forma embrionária, direitos sociais, tais como o direito à liberdade de exercício de trabalho, ao estabelecimento de indústria ou comércio, desde que não contrários à moral, saúde e segurança, à instrução primária gratuita para todos os cidadãos, aos colégios e universidades e aos socorros públicos.

A Constituição da República dos Estados Unidos do Brasil, de 24 de fevereiro de 1891, primeira Constituição Republicana do país, enumera no Título IV ("Dos Cidadãos Brasileiros") os direitos de nacionalidade e os políticos (na Seção I "Das Qualidades do Cidadão Brasileiro", arts. 69 a 71) e um rol de outros direitos (na Seção II "Declaração de Direitos", arts. 72 a 78). Além de manter vários direitos e garantias da Constituição do Império, foram acrescidos outros, incluindo a plena liberdade religiosa com a separação da Igreja e do Estado e abolição de religião oficial, a liberdade de associação, a ampla defesa aos acusados, o livre exercício de qualquer profissão moral, intelectual ou industrial, a garantia do habeas corpus. Sem embargo, não repetiu os dispositivos da instrução primária, dos socorros públicos e nem dos colégios e universidades.

Nessa Constituição é prevista, pela primeira vez, a cláusula que estabelece que a especificação de garantias e direitos expressos no texto constitucional não exclui outros direitos e garantias não enumerados, resultantes dos princípios que ela adota. Em todas as Constituições Brasileiras posteriores, os direitos fundamentais serão enumerados de forma exemplificativa, com a manutenção dessa cláusula.

A Constituição da República dos Estados Unidos do Brasil, de 16 de julho de 1934, estabelece em seu Título II ("Da Declaração de Direitos”) um capítulo sobre os direitos políticos (arts. 106 a 112) e outro sobre os direitos e garantias individuais (arts. 113 a 123), com nova redação para direitos já garantidos constitucionalmente e a introdução de outros direitos, como a proibição da prisão civil por dívidas, o direito à assistência judiciária para necessitados, a garantia do mandado de segurança e a menção expressa ao direito ao trabalho, a ser amparado pelo Poder Público (art. 113, item 34). A Constituição, sob a influência da Constituição de Weimar, inova ao estabelecer um título (Título IV) sobre a Ordem Econômica e Social, em que são estipulados direitos sociais, mais especificamente direitos dos trabalhadores, compendiados nos artigos 120 a 123 , incluindo o 
reconhecimento, por lei, de sindicatos e associações profissionais; proibição de diferença de salários, por motivo de sexo, idade, nacionalidade ou estado civil; direito ao salário mínimo regional capaz de satisfazer às necessidades normais do trabalhador; limite de jornada diária não excedente de oito horas, reduzíveis, mas só prorrogáveis nos casos previstos em lei; proibição de trabalho a menores de 14 anos; de trabalho noturno a menores de 16 e em indústrias insalubres, a menores de 18 anos e a mulheres; repouso hebdomadário, de preferência aos domingos; férias anuais remuneradas; indenização ao trabalhador dispensado sem justa causa; assistência médica e sanitária ao trabalhador e à gestante, assegurando a esta descanso antes e depois do parto, sem prejuízo do salário e do emprego, e instituição de previdência, mediante contribuição igual da União, do empregador e do empregado, a favor da velhice, da invalidez, da maternidade e nos casos de acidentes de trabalho ou de morte; regulamentação do exercício de todas as profissões; reconhecimento das convenções coletivas de trabalho; proibição de distinção entre o trabalho manual e o trabalho intelectual ou técnico, nem entre os profissionais respectivos; serviços de amparo à maternidade e à infância, referentes ao lar e ao trabalho feminino, incumbidos de preferências a mulheres habilitadas; previsão de lei específica para regulamentar o trabalho agrícola, com a adoção, quando possível das disposições constitucionais dos trabalhadores urbanos; a abertura constitucional para outros direitos trabalhistas a serem especificados em lei. A CF/34 institui a Justiça do Trabalho e estipula ainda equiparação dos profissionais liberais aos trabalhadores, para fins de benefícios da legislação social.

A Constituição de 1937, assimilando elementos da onda autoritária que se estabeleceu em alguns Estados europeus, refletiu-se no tratamento e na concepção dos direitos inseridos no texto, fortemente constrangidos durante o período de vigência do Estado Novo. Nos artigos 115 a 121, estabelece direitos de nacionalidade e políticos. O rol de direitos e garantias individuais vem enunciado no artigo 122, com evidente redução do seu alcance e amplitude, com a supressão inclusive do mandado de segurança. Não obstante, nesse período houve avanços inegáveis no campo trabalhista, com o aumento de direitos aos trabalhadores (artigos 136 a 139) ainda que em uma atuação governamental de caráter paternalista e do atrelamento dos sindicatos ao poder público.

Nessa Carta, o trabalho passa a ser considerado um dever social e são acrescidos direitos como o repouso em feriados civis e religiosos, de acordo com a tradição local; a indenização proporcional aos anos de serviço nas empresas em que não haja lei prevendo estabilidade; modalidade de salário apropriada às exigências do operário e da empresa; a 
garantia de manutenção do emprego e dos direitos no caso de sucessão de empregadores; remuneração de trabalho noturno maior que o diurno, com exceção dos casos em que é exercido periodicamente em turnos; assistência médica e higiênica ao trabalhador e à gestante, assegurado a esta, sem prejuízo do salário, um período de repouso antes e depois do parto; a instituição de seguros de velhice, de invalidez, de vida e para os casos de acidentes do trabalho.

A CF/37 impõe a obrigação das convenções coletivas (na época denominadas contratos coletivos de trabalho), criadas por associações legalmente reconhecidas de empregadores, trabalhadores, artistas e especialistas, de estipular a duração do trabalho, o valor e as modalidades de salário, a disciplina na empresa e o horário de trabalho, sendo aplicadas a todos os que as associações que os representem. Essas associações tem o dever, ademais, de prestar auxílio ou assistência aos seus trabalhadores representados no que tange aos litígios administrativos ou judiciais relativos aos seguros de acidentes de trabalho e aos seguros sociais. Embora preveja a livre associação profissional ou sindical, apenas aos sindicatos reconhecidos regularmente pelo Estado reconhece o direito de representação legal dos participantes da categoria, de defesa de direitos dos representados, de estipulação de instrumentos coletivos obrigatórios para os associados, de imposição de contribuição sindical e de exercer funções estipuladas pelo poder público, o que demonstra a intervenção do poder público de forma direta ou indireta na formação e atuação dos sindicatos. Nessa Constituição, outrossim, a greve e o lock-out são declarados, expressamente, recursos antisociais nocivos ao trabalho e ao capital e incompatíveis com os superiores interesses da produção nacional. Não é previsto, também, como na $\mathrm{CF} / 34$, a proibição de diferença de salários por motivo de sexo, idade, nacionalidade ou estado civil.

A Constituição de 1946 estabelece nos artigos 129 a 140 (Capítulo I do Título IV) os direitos relativos à nacionalidade e os direitos políticos, nos artigos 141 a 144 (Capítulo II do mesmo Título) os direitos e garantias individuais, e no Título V ("Da Ordem Social e Econômica"), mais especificamente nos artigos 145 e 157 a 159, os direitos mínimos trabalhistas. O trabalho é visto como obrigação social, sendo assegurado a todos para possibilitar uma existência digna. Retorna a previsão de proibição de diferença de salários por motivo de sexo, idade, nacionalidade ou estado civil e prevê jornada diária não excedente de oito horas diárias, exceto nos casos que a lei prever. Amplia o direito ao salário do trabalho noturno superior ao diurno para qualquer situação, sem exceções. A proibição do trabalho noturno é estendida para os menores de 18 e não mais apenas menores de 16. Estipula novos direitos como a participação obrigatória e direta do 
trabalhador nos lucros da empresa, nos termos e pela forma que a lei determinar; a assistência aos desempregados; a assistência sanitária, inclusive hospital e médica, à gestante e ao trabalhador; a previdência, mediante contribuição da União, do empregador e do empregado, em favor da maternidade e contra as conseqüências da doença, da velhice, da invalidez e da morte; a obrigatoriedade da instituição do seguro pelo empregador contra acidentes do trabalho. Prevê, ainda, expressamente a higiene e segurança no trabalho, a estabilidade, na empresa ou na exploração rural, com indenização ao trabalhador despedido nos casos e nas condições que a lei estatuir. A greve é reconhecida expressamente e seu exercício será regulado em lei, refletindo o período de abertura democrática do período pós-Estado Novo. Porém, a forma de constituição dos sindicatos, a sua representação legal nas convenções coletivas e o exercício de funções delegadas pelo Poder Público continuam vinculadas fortemente ao Estado.

A Constituição de 1967, novamente sob um regime ditatorial, mantém a declaração de direitos precedente, incluindo os direitos de nacionalidade nos artigos 140 e 141 (Título II, Capítulo I), os direitos políticos nos artigos 142 a 149 (Título II, Capítulo II e III) e os direitos e garantias individuais nos artigos 150 e 151 (Título II, Capítulo IV). Nos artigos 158 e 159 (Título III), mantém os direitos trabalhistas da Constituição anterior, com as seguintes novidades: salário-família aos dependentes do trabalhador; integração do trabalhador na vida e no desenvolvimento da empresa, não somente na participação nos lucros como já previsto, mas, também, excepcionalmente, na gestão, nos casos e condições que forem estabelecidos; previsão de intervalo para descanso, no curso da jornada diária, salvo os casos dispostos em lei; a proibição de trabalho diminui para 12 anos de idade e não 14, como previsto anteriormente; fundo de garantia equivalente como opção à estabilidade com indenização; seguro-desemprego e proteção à maternidade, pagos pela Previdência Social, com contribuições de empregados e empregadores; colônias de férias e clínicas de repouso, recuperação e convalescença, mantidas pela União, conforme dispuser a lei; e aposentadoria para a mulher, aos trinta anos de trabalho, com salário integral. Estipula, ainda, dentre as funções delegadas aos sindicatos, a de arrecadar contribuições para o custeio de suas atividades e para a execução de programas de interesse das categorias representadas; e o voto obrigatório nas eleições sindicais, demonstrando a intervenção estatal nas associações profissionais e sindicais.

A Emenda Constitucional n. 1, de 17 de outubro de 1969, que alterou parte considerável da Constituição de 1967, admitindo regime de exceção constitucional permanente, acarreta ou possibilita significativas alterações no campo dos direitos 
individuais. O Título II estabelece os direitos de nacionalidade (Capítulo I, artigos 145 e 146), os direitos políticos (Capítulo II, artigos 147 a 152) e os direitos e garantias individuais (Capítulo IV, artigos 153 e 154), como a previsão de restrições no Capítulo V, em virtude de medidas de emergência, Estado de Sítio e Estado de Emergência. Sem embargo, no Título III ("Da Ordem Econômica e Social”), são mantidos, em regra, os direitos sociais previstos, inclusive no que se refere aos direitos trabalhistas, estipulados no artigo 165. Como novidades, aparecem apenas a aposentadoria para o professor após 30 anos e, para a professora, após 25 anos de efetivo exercício em funções de magistério, com salário integral.

É importante ressaltar que desde 1934, as Constituições passaram a incorporar os direitos econômicos, sociais e culturais, mas somente em 1988 a Constituição afirma que os direitos sociais são direitos fundamentais.

\subsubsection{A Constituição Cidadã de 1988 como marco dos direitos fundamentais trabalhistas}

A Constituição Federal de 1988, denominada também de Constituição "cidadã", é apresenta um verdadeiro sistema de direitos fundamentais, com diretrizes acerca da aplicabilidade, eficácia jurídica e efetividade desses direitos, sendo considerada, ademais, um marco na garantia dos direitos sociais, inclusive dos direitos mínimos trabalhistas.

\subsubsection{A sistemática dos direitos fundamentais na Constituição vigente}

A Constituição vigente é o resultado das lutas pela instauração do Estado Democrático de Direito no Brasil, tendo como meta específica garantir, proteger e assegurar o exercício dos direitos fundamentais. Ademais, é a primeira a integrar ao elenco dos direitos fundamentais os direitos sociais, que nas Cartas anteriores, desde 1934, estavam pulverizados no capítulo pertinente à ordem econômica e social.

Logo após o Título I, que estabelece os princípios fundamentais do Estado brasileiro, a Constituição enumera no Título II ("Dos Direitos e Garantias Fundamentais") os direitos e garantias fundamentais, antes mesmo de tratar da estruturação do Estado, 
dividindo-os em "Direitos e Deveres Individuais e Coletivos", "Direitos Sociais", direitos relativos à "Nacionalidade", "Direitos Políticos" e direitos concernentes aos "Partidos Políticos".

Essa disposição inaugurada pela Constituição vigente teve o claro intuito de que a Organização do Estado, a Organização do Poder, a Defesa do Estado, a Tributação e o Orçamento, a Ordem Econômica e Financeira e a Ordem Social e todas as demais disposições articuladas nos Títulos seguintes ao Título II estejam vinculadas obrigatoriamente aos direitos fundamentais, ou seja, a Estado deve se organizar de modo eficaz para proteger e concretizar os direitos fundamentais.

Não obstante, a Lei Maior vigente não se restringe ao Título II, enunciando em outros Títulos posteriores direitos fundamentais, como na "Ordem Econômica", na "Ordem Social", no "Meio Ambiente", entre outros.

É necessário salientar que para diversos doutrinadores, como Rui Barbosa, os direitos fundamentais diferenciam-se das garantias, de modo que os primeiros seriam enunciados por meio de disposições meramente declaratórias que imprimem existência legal aos direitos reconhecidos e as garantias seriam transmitidas por meio de disposições assecuratórias que, em defesa dos direitos, limitam o poder ${ }^{130}$. Não obstante, uma mesma disposição constitucional pode configurar um direito e uma garantia.

Canotilho entende que as garantias são também direitos, porém de caráter instrumental, e traduzem-se no direito dos cidadãos de exigir dos poderes públicos a proteção dos seus direitos e no reconhecimento de meios processuais adequados a essa finalidade. $^{131}$

Jorge Miranda, com a clareza de redação que lhe é peculiar, apresenta as diferenças entre os direitos fundamentais propriamente ditos e as garantias:

\footnotetext{
Os direitos representam só por si certos bens, as garantias destinam-se a assegurar a fruição desses bens; os direitos são principais, as garantias acessórias e, muitas delas, adjectivas [...]; os direitos permitem a realização das pessoas e inserem-se directa e imediatamente, por isso, as respectivas esferas jurídicas, as garantias só nelas se projectam pelo nexo que possuem com os direitos; na acepção jusracionalista inicial, os direitos declaram-se, as garantias estabelecemse. $^{132}$
}

\footnotetext{
${ }^{130}$ MORAES, Alexandre de. Direito constitucional. Op. cit., p. 59.

${ }^{131}$ CANOTILHO, J. J. Gomes. Direito constitucional. Op. cit., p. 520.

${ }^{132}$ MIRANDA, Jorge. Op. cit., p. 88-89.
} 
$\mathrm{O}$ art. $5^{\circ}$, parágrafo $2^{\circ}$, que estabelece o princípio de abertura das normas definidoras de direitos, deixa claro que a enumeração de direitos fundamentais previstos na Constituição Federal não é exaustiva, mas apenas exemplificativa, sendo possível a afirmação de outros direitos decorrentes do regime e dos princípios por ela adotados e dos tratados internacionais que o Estado brasileiro faça parte.

Os direitos infraconstitucionais, por exemplo, podem ser considerados fundamentais, caso em que são denominados de materialmente fundamentais ${ }^{133}$, pois, embora formalmente não estejam na Constituição, a eles deve ser aplicado todo o regime de direitos fundamentais constante da Constituição Federal de 1988.

No caso dos instrumentos internacionais ratificados, as normas de direitos fundamentais ingressam no ordenamento jurídico nacional, como regra geral, com o status de lei ordinária, segundo entendimento do STF, não sendo, considerados e tratados como verdadeiros direitos fundamentais, na realidade. Com a Emenda 45 de 2004, é possível que as normas de tratados sobre direitos humanos entrem como Emenda Constitucional, desde que, para isso, sejam seguidas as mesmas formalidades de aprovação relativas às Emendas, ou seja, votação em dois turnos em cada casa do Congresso Nacional, tendo a maioria absoluta dos votos em cada votação. ${ }^{134}$ Porém, segundo entendimento do STF, apenas no caso de tratados sobre direitos humanos, ratificados pelo Brasil após a Emenda Constitucional em relevo, é possível o ingresso das normas, insertas nesses instrumentos internacionais, com o status de normas constitucionais.

$\mathrm{O}$ art. $5^{\circ}$, parágrafo $1^{\circ}$, por seu turno, estabelece a aplicabilidade imediata das normas definidoras de direitos e garantias fundamentais, que visa garantir a máxima eficácia jurídica a ser extraída dessas normas.

Deve-se salientar que, em sentido avesso ao estabelecimento de um sistema de direitos fundamentais que promova a eficácia máxima das normas relativas a direitos fundamentais individuais e sociais, existe corrente que prega que pelo fato do art. $5^{\circ}$, parágrafo $1^{\circ}$ estar contido no capítulo dos direitos individuais e coletivos, apenas a eles se referiria. Não obstante tal entendimento, a própria expressão "direitos e garantias fundamentais", contida no dispositivo, revela que mesmo se procedendo a uma

\footnotetext{
${ }^{133}$ Segundo Hermano Queiroz Júnior, alguns direitos trabalhistas considerados fundamentais são o direito à estabilidade acidentária, previsto no artigo 118 da Lei n. 8.213/91, e o direito à duração da hora noturna inferior à diurna, disposto no artigo 73, parágrafo $1^{\circ}$, da CLT. Cf. QUEIROZ JÚNIOR, Hermano. Os direitos fundamentais dos trabalhadores e a Constituição de 1988. São Paulo: LTr, 1996, p. 164.

${ }^{134}$ Cf. TAVARES, André Ramos (Coord.). Reforma do Judiciário analisada e comentada. São Paulo: Método, 2005, p. 103-105; e MAZZUOLI, Valério de Oliveira. O novo $\S 3^{\circ}$ do art. $5^{\circ}$ da Constituição e sua eficácia. Revista da AJURIS, Porto Alegre, v. 32, p. 303-332, jan. 2005.
} 
interpretação meramente literal, não há como sustentar a aplicação dessa norma a nenhuma categoria específica de direitos fundamentais.

Também se argumentou em prol de uma interpretação restritiva ao dispositivo, como se o legislador constituinte tivesse dito mais do que era realmente a sua intenção, o que de igual forma não procede segundo entendimento hoje majoritário, visto que uma interpretação sistemática e teleológica leva a compreender que os direitos políticos e de nacionalidade, bem como os sociais, integram o conjunto dos direitos fundamentais da Constituição brasileira, além do que não há, na Lei Maior, nenhuma distinção quanto à aplicabilidade dos direitos individuais e dos sociais, como ocorre com a Constituição Portuguesa. ${ }^{135}$ Assim, todos os direitos fundamentais constantes do Título II da Constituição, englobando direitos individuais e sociais, políticos e de nacionalidade, bem como os localizados em outras partes do texto constitucional e nos tratados internacionais se balizam pela aplicabilidade imediata.

A aplicabilidade imediata que, na verdade, visa extrair a máxima eficácia jurídica das normas de direitos fundamentais significa que, ainda que algumas normas não possam ser efetivadas plenamente, ou seja, alguns direitos não possam ser usufruídos, no sentido positivo, por não serem auto-executáveis, necessitando de regulamentação pelo legislador infraconstitucional, não podem ser essas normas fundamentais violadas pelo Estado ou por entes privados, no sentido negativo, nem podem ser objeto de inobservância ou violação por outras leis infraconstitucionais aprovadas pelo Congresso Nacional ou por medidas provisórias adotadas pelo Presidente da República.

O grau de aplicabilidade imediata, portanto, está diretamente atrelado à autoexecutoriedade ou não da norma constitucional. A aplicabilidade imediata alcança integralmente as normas autoexequíveis, de maneira que a legislação infraconstitucional pode ser útil ou necessária para a perfeita aplicação do direito, mas não essencial para o exercício dos direitos contidos nessas normas. Em relação às normas não autoexequíveis, o Estado, incluindo o Legislativo, os entes públicos e privados devem agir de forma a não violar os direitos fundamentais previstos nessas normas. Ademais, se a norma possuir densidade suficiente, pode o intérprete buscar suprir a lacuna constitucional, no caso concreto, com recurso aos instrumentos de interpretação jurídico-constitucional, desde que não se crie a norma inexistente exigida do legislador infraconstitucional.

${ }^{135}$ SARLET, Ingo Wolfgang. Os direitos fundamentais sociais e os vinte anos da Constituição Federal de 1988: resistências e desafios à sua eficácia e efetividade. Op. cit., p. 174. 
Obviamente para uma aplicabilidade plena, alguns direitos fundamentais, sobretudo os direitos sociais que demandam a criação de um programa governamental para a sua efetivação $^{136}$ ou o estabelecimento de regras específicas de instituição do dispositivo constitucional, caso não venha a norma infraconstitucional regulamentadora, estarão fadados à sua aplicabilidade apenas no sentido de não violação pelos entes públicos, privados e pelo legislador.

As garantias do mandado de injunção e da ação de inconstitucionalidade por omissão, que visavam originariamente resolver esse problema, propiciando o exercício de direitos fundamentais por meio de uma decisão proferida pelo Supremo Tribunal Federal, têm o alcance um tanto limitado, embora, desde 2006, o entendimento da Corte acerca dos efeitos do mandado de injunção se modificou de modo a propiciar diretamente ao autor da ação ou a todos a efetivação do direito sem regulamentação.

O remédio do mandado de injunção, previsto no art. 5, LXXI, da Constituição Federal, é uma ação constitucional que visa suprir a falta de norma regulamentadora que torne inviável o exercício de direitos e liberdades constitucionais e das prerrogativas inerentes à nacionalidade, soberania e cidadania, podendo ser ajuizado por qualquer pessoa cujo exercício de um direito, liberdade ou prerrogativa constitucional esteja sendo inviabilizado em virtude de falta de norma reguladora, em face dos entes estatais responsáveis pela emanação de provimentos normativos.

Em relação aos efeitos do mandado de injunção, duas posições se formaram: a concretista - que entende que o Poder Judiciário, por meio de uma decisão constitutiva, declara a existência da omissão administrativa ou legislativa e implementa o exercício do direito, da liberdade ou da prerrogativa constitucional, até que venha regulamentação do poder competente - podendo ser concretista geral, se gerados erga omnes da decisão (posição pouca aceita na doutrina, em virtude da violação da competência do poder legislativo pelo judiciário), ou concretista individual, só produzindo efeitos para o autor da ação, diretamente (julgado procedente a ação, o Judiciário implementa a eficácia da norma constitucional do autor) ou de forma intermediária (após julgado a ação, é fixado prazo para que o Congresso elabore a norma regulamentadora, sob pena do Judiciário fixar as condições de exercício do direito pelo autor). Tem-se, ainda, a posição não concretista,

\footnotetext{
${ }^{136} \mathrm{Em}$ virtude do conjunto de diretrizes, programas e fins que enuncia a ser realizados pelo Estado e pela sociedade, a Constituição de 1988 é considerada uma Constituição dirigente, ou seja, uma Constituição, insculpida em um modelo socializante, mas não necessariamente vinculado a um Estado socialista, que já traz em seu bojo programas sociais, e em que os planos plurianuais e o planejamento social detalhado são constantes ideológicas. Cf. GRAU, Eros Roberto. Op. cit., p. 153.
} 
adotada pela jurisprudência dominante do STF até 2005, que atribui ao mandado de injunção a finalidade específica de reconhecer a inércia do Poder Público em dar concretude à norma constitucional e dar ciência ao poder competente para que edite a norma faltante. O STF, desde 2006, tem adotado as correntes concretista individual e geral, dependendo do caso.

Em relação à inconstitucionalidade por omissão, é possível o ajuizamento da ação pelo Presidente da República, pela Mesa do Senado Federal, pela Mesa da Câmara dos Deputados, pelas Mesas das Assembléias Legislativas e da Câmara Legislativa, pelos Governadores dos Estados e do Distrito Federal, pelo Procurador-Geral da República, pelos partidos políticos com representação no Congresso, pelo Conselho Federal da Ordem dos Advogados do Brasil e por confederações sindicais ou entidades de classe de âmbito nacional. Verificada a omissão pelo Supremo, dela dar-se-á ciência à Administração Pública para resolver a questão em 30 dias, mas no caso da omissão do legislador, o STF pode apenas dar ciência do problema ao Congresso. Porém, se não houver vontade política, não há nenhuma punição ao Poder Legislativo pela sua mora ou desinteresse em tomar providências para regulamentar as normas programáticas.

Outro ponto que merece destaque é a questão da inserção dos direitos fundamentais sociais como cláusulas pétreas na Constituição Federal de 1988. O art. 60, § 4º inc. IV, da CF/88 estabelece como cláusula pétrea "os direitos fundamentais individuais", dispositivo cuja redação causou e até hoje causa controvérsias acerca da sua interpretação.

Inicialmente, deve-se ressaltar que quando uma matéria consta como cláusula pétrea significa que ela não pode ser objeto de reforma constitucional, inclusive por meio de emenda constitucional que venha a aboli-la ou que seja tendente a aboli-la, e também por meio de redução do alcance da norma constitucional. As cláusulas pétreas constituem limites materiais, portanto, ao poder de reforma constitucional que pode, sem embargo, ampliar o alcance da norma para lhe dar maior eficácia e efetividade.

Ingo Wolfgang Sarlet explana que a previsão de possibilidade de alteração da Constituição, por meio de emendas constitucionais no Brasil, é indispensável para o contínuo ajuste da Constituição formal à realidade constitucional, juntamente com a previsão de mecanismos que garantam a proteção de seu conteúdo contra ataques externos ou internos como são os limites à reforma. ${ }^{137}$

${ }^{137}$ SARLET, Ingo Wolfgang. Os direitos fundamentais sociais como cláusulas pétreas. Interesse Público. Sapucaia do Sul : Notadez, v.5, n.17, jan./fev. 2003, p.57. 
Diante da previsão do artigo 60 , parágrafo $4^{\circ}$, inciso IV, da Lei Maior, existe corrente doutrinária que defende que apenas os direitos e garantias individuais, situados no art. $5^{\circ}$ se encontram incluídos no rol de cláusulas pétreas.

A crítica mais contundente que se faz a essa exegese literal é que, conforme essa compreensão, os direitos sociais (art. $6^{\circ}$ ao 11), os direitos de nacionalidade (art. 12 e 13), e os direitos políticos (art. 14 a 17), com exceção do sufrágio universal e secreto assegurado no artigo 60, parágrafo $4^{\circ}$, inciso II, estariam excluídos da proteção contida no artigo 60, parágrafo $4^{\mathrm{o}}$, inciso IV, assim como os direitos coletivos dispostos no art. $5^{\mathrm{o}}{ }^{138}$ Outra crítica é que a expressão "direitos e garantias individuais" não se encontra reproduzida em nenhum outro dispositivo constitucional, motivo pelo qual ainda que com base em uma interpretação literal não se pode confundir com os direitos individuais e coletivos do art. $5^{\circ}$.

Uma segunda interpretação que costuma ser dada ao artigo 60, parágrafo $4^{\circ}$, inciso IV é a de que apenas os direitos fundamentais equiparáveis aos direitos individuais do art. $5^{\circ}$ podem ser considerados cláusulas pétreas. Sem embargo, depara-se com a difícil tarefa de distinguir os direitos individuais e os não individuais, ainda que se considere os direitos individuais como direitos de defesa, buscando nos outros capítulos do Título II da Carta os direitos e garantias passíveis de ser equiparados como direitos de defesa, como, por exemplo, as liberdades sociais, isto é, os direitos sociais não-prestacionais.

Sarlet critica essa interpretação, pois ao contrário da Constituição portuguesa não há um regime jurídico diferenciado previsto expressamente na Constituição brasileira entre direitos de defesa e direitos prestacionais, não havendo sentindo em criar distinção no tocante à fundamentalidade dos direitos sociais.

Argumenta-se, ainda, que caso o legislador tivesse a intenção de inserir os direitos fundamentais sociais como cláusulas pétreas, ele teria o feito expressamente ou ainda escolhido a expressão “direitos e garantias fundamentais". Sarlet contra-argumenta essa concepção, nos seguintes termos:

[...] Os partidários de uma exegese conservadora e restritiva partem da premissa de que todos os direitos sociais podem ser conceituados como direitos a prestações materiais estatais, quando, em verdade, já se demonstrou que boa parte dos direitos sociais é equiparável, no que diz com sua função precípua e estrutura jurídica, aos direitos de defesa; [...] relembramos que uma interpretação

\footnotetext{
${ }^{138}$ Sarlet entende que esse posicionamento é facilmente contestável, pois assim estariam excluídos direitos de participação política, liberdade sindical, direito de greve e até mesmo o mandado de segurança coletivo, mas não o individual. Cf. SARLET, Ingo Wolfgang. Os direitos fundamentais sociais como cláusulas pétreas. $O p$. cit., p.67.
} 
que limita o alcance das "cláusulas pétreas" aos direitos fundamentais elencados no art. $5^{\circ}$ da $\mathrm{CF}$ acaba por excluir (caso levada às últimas conseqüências) também os direitos de nacionalidade e os direitos políticos, que igualmente não foram expressamente previstos no art. 60, $§ 4^{\circ}$, inc. IV, da Lei Fundamental. ${ }^{139}$

A última corrente defende uma interpretação teleológica e sistemática em torno do artigo 60 , parágrafo $4^{\circ}$, inciso IV, incluindo como cláusulas pétreas os direitos sociais, os de nacionalidade, os políticos e outros direitos fundamentais situados em outros pontos tópicos do texto constitucional. Esse tem sido o posicionamento prevalente no Supremo Tribunal Federal.

Invoca essa corrente doutrinária o artigo $1^{\circ}$, incisos I a III e artigo $3^{\circ}$, incisos I, III e IV, que consagram a ideia de um Estado Democrático e Social de Direito, de maneira que os direitos sociais constituem elemento essencial da Constituição, pois compõem a identidade da ordem constitucional brasileira, sendo considerados, no mínimo, como limites materiais implícitos à reforma constitucional. ${ }^{140}$ Os direitos sociais, estando dispostos no Título II, juntamente com os direitos individuais, submetem o poder constituinte derivado às mesmas restrições, não havendo diferença de hierarquia entre os direitos fundamentais elencados na Constituição. ${ }^{141}$

Explicita, ademais, que não há sentido em prever extenso leque de direitos sociais, se eles fossem destituídos de fundamentalidade necessária para evitar que o legislador ordinário pudesse, apenas com base em um quórum qualificado e um procedimento mais meticuloso, suprimi-los da Constituição. Até mesmo porque os direitos humanos, como já ressaltado, são indivisíveis e universais.

Argumenta-se, ainda, que, na realidade, todos os direitos fundamentais consagrados em nossa Constituição apresentam a faceta da titularidade individual, ainda que alguns sejam de expressão coletiva, como o direito do indivíduo à saúde, à assistência social, e mesmo ao meio ambiente equilibrado e sadio, pois ainda que um dano ambiente possa

\footnotetext{
${ }^{139}$ SARLET, Ingo Wolfgang. Os direitos fundamentais sociais como cláusulas pétreas. Op. cit., p. 68.

${ }^{140}$ Ibidem, p. 69. Paulo Bonavides também coaduna desse entendimento. Cf. BONAVIDES, Paulo. Curso de direito constitucional. Op. cit., p. 598.

${ }^{141}$ O STF não admite a existência de hierarquia entre os direitos fundamentais dispostos na Constituição Federal. Ademais, no julgamento da ADI n. 939, de relatoria do Ministro Sidney Sanches, o Supremo entendeu que os direitos individuais a serem preservados como cláusulas pétreas não são apenas os elencados no art. $5^{\circ}$, mas outros espalhados pela Constituição que lhe garantam efetividade. Marcus Orione Gonçalves Correia defende que esse entendimento deve ser estendido aos direitos sociais, de maneira que não apenas os direitos dispostos nos arts. $6^{\circ}$ a 11 da Constituição seriam protegidos do poder reformador, mas todos aqueles que permeiam a Constituição, como, por exemplo, os arts. 194, 201 e 202. Cf. CORREIA, Marcus Orione Gonçalves. Os direitos sociais enquanto direitos fundamentais. CORREIA, Marcus Orione Gonçalves; CORREIA, Érica Paula Bacha (Coords.). Op. cit., p. 31.
} 
atingir um grupo dificilmente identificável de pessoas, gera um direito à reparação para cada prejudicado.

Outrossim, adotando-se o posicionamento segundo o qual todos os direitos concebidos como fundamentais pela Constituição Federal são tanto formalmente, quanto materialmente fundamentais, não há como perfilhar do entendimento de que existam posições jurídicas no Título II da Carta que não são merecedoras do status de verdadeiros direitos fundamentais e, por isso, estariam sujeitas à supressão por meio de emenda. Até porque, se assim fosse, várias posições jurídicas elencadas no art. $5^{\circ}$ seriam revestidas de inquestionável fundamentalidade.

Adota-se, nessa tese, a última corrente mencionada, entendendo-se que os direitos fundamentais sociais, inclusive os trabalhistas, fazem parte do rol implícito de limites materiais de reforma constitucional, por meio da interpretação sistemática do art. $60, \S 4^{\circ}$, inc. IV, da CF/88, sendo, portanto, cláusulas pétreas que não podem estar ao alvedrio do legislador infraconstitucional, merecendo proteção que vede qualquer retrocesso social, seja na implementação, seja na interpretação desses direitos.

Antes de adentrar na configuração dos direitos trabalhistas na Constituição vigente, é importante salientar que os direitos fundamentais não formam um sistema separado e fechado no contexto da Constituição, mas, sim, "um sistema aberto e flexível, receptivo a novos conteúdos e desenvolvimentos, integrado ao restante da ordem constitucional, além de sujeito aos influxos do mundo circundante". ${ }^{142}$ Assim, embora direitos fundamentais apresentem características próprias e tratamento específico dado pela Constituição Federal, estão eles diretamente conectados a todas as outras normas constitucionais, gerando e sofrendo influências de todo o texto constitucional e do ordenamento jurídico brasileiro, inclusive no que tange ao desenvolvimento do tratamento dos próprios direitos fundamentais.

\subsubsection{Os direitos fundamentais trabalhistas na Constituição Federal de 1988}

Estudada a sistemática da Constituição acerca desses direitos, passar-se-á agora à análise dos direitos fundamentais trabalhistas, direitos sociais por natureza.

${ }^{142}$ SARLET, Ingo Wolfgang. Eficácia dos direitos fundamentais. Op. cit., p. 80. 
Pode-se dizer que, na Constituição Federal de 1988, o qualitativo de social dado a um direito não está exclusivamente vinculado a uma atuação positiva no Estado na promoção e na garantia de proteção e segurança social, como "instrumento de compensação de desigualdades fáticas manifestas e modo de assegurar um patamar pelo menos mínimo de condições para uma vida digna”. Também são sociais direitos que asseguram e protegem um espaço de liberdade ou um bem jurídico para determinados segmentos da sociedade, "em virtude de sua maior vulnerabilidade" em face do poder estatal ou mesmo social ou econômico, como "demonstram justamente os direitos dos trabalhadores". 143

Os direitos fundamentais sociais genéricos estão sediados no art. $6^{\circ}$ da Constituição, englobando o direito ao trabalho, à educação, à saúde, à moradia, à alimentação, à segurança, à previdência social, à assistência aos desamparados e de proteção à maternidade e à infância; e no Título VIII, "Da Ordem Social”), abrangendo, além de alguns já citados, o direito à seguridade social, à cultura, à proteção à família, ao adolescente, ao idoso e aos índios.

Os direitos fundamentais trabalhistas estão basicamente esculpidos nos arts. $6^{\circ}$ ao 11 da Constituição Federal e no art. 10 do Ato das Disposições Constitucionais Transitórias. Ademais, aplicam-se, indubitavelmente, às relações trabalhistas e a outras relações jurídicas estabelecidas pelo Estado e pelos empregadores públicos e privados que tenham influência sobre as relações de trabalho, os princípios fundamentais da dignidade da pessoa humana, da cidadania e dos valores sociais do trabalho (art. $1^{\circ}$, incisos II, III e IV), o princípio da valorização do trabalho humano no qual se funda a ordem econômica (art. 170, caput) e do meio ambiente saudável e ecologicamente equilibrado, no que tange ao meio ambiente de trabalho (art. 170, inciso VI, também instituído como direito fundamental no art. 225, caput), e os princípios do primado do trabalho e da justiça social em que se baseia a ordem social (art. 193). Outrossim, os direitos fundamentais de índole coletiva e individual, inclusive os direitos de personalidade, estipulados implícita e explicitamente no art. $5^{\circ}$ da Lei Maior, como os direitos à associação profissional, à vida, à integridade física, à honra, à intimidade e à privacidade, entre outros, incidem na relação de emprego, pois o trabalhador, antes de ser empregado, é ser humano e não deixa de ter personalidade por laborar.

${ }^{143}$ SARLET, Ingo Wolfgang. Os direitos fundamentais sociais e os vinte anos da Constituição Federal de 1988. Op. cit., p. 169. 
Observa-se que o art. $7^{\circ}$ da Constituição Federal elencou como direitos fundamentais diversos direitos que já estavam estabelecidos infraconstitucionalmente, como uma forma de preservá-los das alterações advindas do legislador infraconstitucional derivadas da flutuação de interesses políticos e econômicos e das seqüelas de um poder executivo cuja base anterior a 1988 era o autoritarismo.

André Jobim de Azevedo e Guilherme Luiz Thofehrn Osório esclarecem a vantagem da constitucionalização dos direitos já estabelecidos em patamar infraconstitucional:

O que se percebe é que, frente aos distintos focos políticos dos governos pósconstituição (sic), o Direito do Trabalho teria sido alvo de irrefletidas alterações dos "governantes de plantão" de acordo com suas tendências políticas. Teríamos, por leis ordinárias, alterado e re-alterado o Direito do Trabalho, em insuportável hesitação e [...] de insegurança. A sua inclusão no texto constitucional teve efeito de estabilidade e que exige maior esforço e adequação, nas pretendidas e necessárias mudanças, pelo simples fato de somente poderem realizar-se por reforma constitucional. ${ }^{144}$

Não obstante, a Lei Fundamental ampliou qualitativamente e quantitativamente o rol de direitos fundamentais trabalhistas já existentes constitucional e infraconstitucionalmente e positivou novos direitos fundamentais do trabalhador.

Foram mantidos na CF/88 o seguro-desemprego; a participação nos lucros, ou resultados, agora expressamente desvinculada da remuneração, e, excepcionalmente, a participação na gestão da empresa, conforme definido em lei; o salário-família, que não obstante agora é pago ao trabalhador com dependentes em razão da baixa renda; o repouso semanal remunerado, preferencialmente aos domingos; a licença-gestante (agora, sem embargo, com a duração prevista de cento e vinte dias); o reconhecimento das convenções e acordos coletivos de trabalho; seguros contra acidentes de trabalho, a cargo do empregador; a proibição de diferença de salários, de exercício de funções e de critério de admissão, por motivo de sexo, idade, cor ou estado civil; a proibição de distinção entre trabalho manual, técnico e intelectual ou entre os profissionais respectivos; a proibição de qualquer trabalho a menores, agora a partir de 16 anos, salvo na condição de aprendiz a partir dos 14 anos; a proibição de trabalho insalubre ou perigoso a menores de 18 anos;

O FGTS, já previsto anteriormente, foi estendido aos trabalhadores rurais e se tornou o sistema vigente em substituição ao sistema da estabilidade decenal. O salário

144 AZEVEDO, Antônio Jobim de; OSÓRIO, Guilherme Luiz Thofehrn. Direito do trabalho, constituição e efetividade. In: VILLATORE, Marco Antônio César; HASSON, Roland (coord.); ALMEIDA, Ronald Silka de (Org.). Direito constitucional do trabalho vinte anos depois: Constituição federal de 1988. 1 ed. 1 reimpr. Curitiba: Juruá, 2009, p. 21. 
mínimo, anteriormente fixado regionalmente, passou a ser unificado nacionalmente, com ampliação das necessidades do trabalhador e de sua família que o valor do salário deve atender.

O $13^{\circ}$ salário, a remuneração do serviço extraordinário superior, no mínimo, em cinqüienta por cento à do normal, a licença-paternidade (agora, porém com previsão mínima de cinco dias), o aviso prévio (agora, não obstante, proporcional ao tempo de serviço, sendo, no mínimo de 30 dias); e o adicional por atividades insalubres ou perigosas, foram elevados a patamar constitucional.

Foram estabelecidos: o direito à relação de emprego protegida contra dispensa arbitrária ou sem justa causa, que deverá ser regulada por lei complementar até hoje não editada, fixando indenização compensatória, entre outros direitos; o piso salarial proporcional à extensão e à complexidade do trabalho; irredutibilidade do salário, salvo o disposto em convenção ou acordo coletivo; a garantia de salário, nunca inferior ao mínimo, para os que percebem remuneração variável; proteção do salário na forma da lei, constituindo crime sua retenção dolosa; salário-família pago em razão do dependente do trabalhador de baixa renda nos termos da lei; a previsão de jornada máxima semanal de quarenta e quatro horas, além da manutenção da jornada diária de oito horas já prevista, bem como a compensação de horários e a redução da jornada, mediante acordo ou convenção coletiva de trabalho; a jornada de seis horas para o trabalho realizado em turnos ininterruptos de revezamento, salvo negociação coletiva; as férias anuais remuneradas ganharam o adicional de um terço a mais; a proteção do mercado de trabalho da mulher, mediante incentivos específicos, nos termos da lei; o adicional por atividades penosas, na forma da lei; a aposentadoria, agora prevista genericamente; assistência gratuita aos filhos e dependentes desde o nascimento até 5 (cinco) anos de idade em creches e pré-escolas; proteção em face da automação, na forma da lei; redução dos riscos inerentes ao trabalho, por meio de normas de saúde, higiene e segurança; indenização no caso de acidente de trabalho, por culpa ou dolo do empregador; ação, quanto aos créditos resultantes das relações de trabalho, com prazo prescricional de cinco anos para os trabalhadores urbanos e rurais, até o limite de dois anos após a extinção do contrato de trabalho (anteriormente à $\mathrm{CF} / 88$, o prazo prescricional dos urbanos para pleitear verbas era de dois anos, prevista infraconstitucionalmente; para os rurais até a Emenda Constitucional n. 28, de 25/05/2000, era previsto apenas o prazo prescricional de dois anos após a extinção do contrato de trabalho, sem prazo prescricional em relação às verbas a serem pleiteadas); proibição de qualquer discriminação no tocante a salário e critérios de admissão do trabalhador portador 
de deficiência; igualdade de direitos entre o trabalhador com vínculo empregatício permanente e o trabalhador avulso; a previsão constitucional de vários direitos aos domésticos, incluindo salário mínimo, irredutibilidade de salário, licença-maternidade e paternidade, direito à aposentadoria, $13^{\circ}$ salário, aviso prévio, férias com um terço a mais, repouso semanal remunerado e integração à previdência social; proibição de trabalho perigoso a menor de dezoito anos; estabilidade da gestante da confirmação da gravidez até cinco meses após o parto; a estabilidade do membro empregado da Comissão Interna de Prevenção de Acidentes; a participação assegurada dos trabalhadores e empregadores nos colegiados dos órgãos públicos em que seus interesses profissionais ou previdenciários sejam objeto de discussão e deliberação; a eleição assegurada, nas empresas de mais de duzentos empregados, de um representante destes com a finalidade exclusiva de promoverlhes o entendimento direto com os empregadores.

Em relação aos sindicatos, a liberdade sindical é assegurada de forma mais ampla, no que tange à filiação sindical e à fundação e organização sindical, não mais se exigindo autorização estatal para criação de sindicatos; é estabelecida, também, a atribuição expressa aos sindicatos de defender os interesses coletivos ou individuais da categoria, inclusive em questões judiciais ou administrativas.

Porém, a CF/88 mantém, ainda, alguns resquícios do sistema autoritário corporativista, implantado na Consolidação das Leis Trabalhistas, como o princípio da unicidade sindical (vedação de criação de mais de uma organização sindical, em qualquer grau, representativa de categoria profissional ou econômica, na mesma base territorial, que será definida pelos trabalhadores ou empregadores interessados, não podendo ser inferior à área de um Município) e o registro dos sindicatos em órgão competente (justamente para assegurar a unicidade sindical). Prevê, ademais, a fixação, por assembléia geral, de uma contribuição que, em se tratando de categoria profissional, será descontada em folha, para custeio do sistema confederativo da representação sindical respectiva, independentemente da contribuição prevista em lei, o que configura em reforço ao sistema sindical corporativo e fragilizado.

A estabilidade provisória do dirigente sindical (a partir do registro da candidatura a cargo de direção ou representação sindical e, se eleito, ainda que suplente, até um ano após o final do mandato, salvo se cometer falta grave nos termos da lei) é elevada a patamar constitucional. $\mathrm{O}$ direito de greve é mantido, agora expressamente com a liberdade dos trabalhadores decidirem sobre a oportunidade de exercê-lo e sobre os interesses que devam por meio dele defender, devendo a lei ordinária definir os serviços ou atividades essenciais 
e o atendimento das necessidades inadiáveis da comunidade, bem como os abusos a serem punidos.

É prevista, ainda, a necessidade da participação obrigatória dos sindicatos nas negociações coletivas de trabalho; o direito de voto e de ser votado do aposentado filiado; a extensão dos direitos sindicais dos sindicatos urbanos para os sindicatos rurais.

No intuito de sistematizar os direitos fundamentais trabalhistas estabelecidos na Constituição Federal de 1988, com base no que foi analisado nesse capítulo, o quadro, situado no Anexo I dessa tese, apresenta o histórico constitucional, o comando constitucional, os sujeitos titulares e os destinatários de cada um desses direitos. Também consta desse quadro, a aplicabilidade e a eficácia jurídica das normas constitucionais que embasam os direitos fundamentais trabalhistas, bem como a função principal, de defesa e/ou prestacional, externada por cada uma dessas normas.

O presente capítulo buscou esmiuçar o processo de surgimento e desenvolvimento dos direitos sociais, especialmente dos direitos fundamentais trabalhistas, e sua sedimentação constitucional e internacional; apresentar a caracterização desses direitos e das normas jurídicas que os embasam; estudar os direitos trabalhistas enquanto direitos sociais, abordando tópicos como a questão da eficácia jurídica, da aplicabilidade e da efetividade ou eficácia social das normas que estabelecem esses direitos, da eficácia no que tange aos destinatários dessas normas e de como se deu a organização dos direitos do trabalhador nas Constituições brasileiras até 1988, dando-se especial atenção à Constituição vigente.

O capítulo que se segue apresentará a matriz teórica que embasa a presente tese, qual seja, a interpretação constitucional evolutiva (ou mutação constitucional pela via judicial), mecanismo da hermenêutica jurisdicional que tem como objetivo interpretar as normas constitucionais, inclusive as que estabelecem os direitos fundamentais trabalhistas, em consonância com a realidade fática, levando-se em conta as mudanças ocorridas no meio social. 


\section{A INTERPRETAÇÃO CONSTITUCIONAL EVOLUTIVA COMO MECANISMO DA HERMENÊUTICA JURISDICIONAL}

O presente capítulo tem como objetivo apresentar o mecanismo da interpretação constitucional evolutiva, técnica da hermenêutica jurisdicional que busca interpretar as normas constitucionais, alterando o seu sentido ou o alcance, em virtude das transformações sociais ao longo do tempo, sem a necessidade da alteração do texto normativo.

Nesse sentido, inicialmente apresentar-se-á a diferença entre hermenêutica e interpretação jurídica e estudar-se-ão os princípios da interpretação constitucional, bem como os métodos tradicionais (método histórico, gramatical, sistemático e teleológico) e os métodos modernos (método cintífico-espiritual, método tópico, método normativoestruturante e método hermenêutico-concretizante) de interpretação das normas constitucionais.

\subsection{A hermenêutica e a interpretação jurídica: diferenciação}

A interpretação jurídica não se confunde com a hermenêutica jurídica, pois essa seria a ciência auxiliar do Direito que estabelece as regras, os princípios e os institutos relativos à interpretação das normas jurídicas. Os autores têm ao longo do tempo traçado o diferencial entre hermenêutica e interpretação.

Emilio Betti entendia que a hermenêutica englobava o estudo da atividade humana de interpretar e que a interpretação jurídica estaria dentro de uma Hermenêutica Geral. ${ }^{1}$ Ainda que tal assertiva não esteja incorreta, ela não se revela de grande efeito prático para a interpretação jurídica especificamente, visto que existe uma Hermenêutica do Direito, com princípios e institutos próprios.

Carlos Maximiliano acredita que a Hermenêutica Jurídica tem por objeto o estudo e a sistematização dos processos aplicáveis para determinar o alcance das expressões do Direito. Hermenêutica e interpretação não são sinônimas, visto que interpretação é

\footnotetext{
${ }^{1}$ BETTI, Emilio. Interpretazione della legge e degli atti giuridici. Teoria generale e dogmática. Milano: Giuffrè, 1971, p. 62 apud BASTOS, Celso Ribeiro. Hermenêutica e interpretação constitucional. 2 ed. rev. e ampl. São Paulo: Celso Bastos Editor, Instituto Brasileiro de Direito Constitucional, 1999, p. 18.
} 
aplicação da Hermenêutica. A primeira descobre e fixa os princípios que regem a segunda. Em síntese, hermenêutica é a teoria científica da arte de interpretar e interpretar é determinar o sentido e o alcance das expressões de direito. ${ }^{2}$

Nas palavras de Celso Ribeiro Bastos

\begin{abstract}
A hermenêutica (jurídica) seria o ramo da ciência dedicado ao estudo e determinação das regras que devem presidir o processo interpretativo de busca do significado da lei, e não da sua aplicação, a busca efetiva desse significado em cada caso. Distinguir-se-ia, pois, da interpretação, na medida em que a hermenêutica seria mais ampla, situando-se num momento lógico anterior. ${ }^{3}$
\end{abstract}

A hermenêutica trabalha com regras sobre regras jurídicas, seu alcance, sua validade, investigando sua origem, seu desenvolvimento. Essas regras, ou enunciados (para diferenciá-las das regras jurídicas propriamente ditas) preordenam-se a uma atividade ulterior de aplicação, mas existem de forma autônoma do uso que se pode fazer delas. Por seu turno, a interpretação tem um caráter sempre pragmático, concreto, consistente em trazer para o campo do estudo o caso ao qual vai se aplicar a norma.

O vocábulo interpretar, do latim interpres, quer dizer atribuir significado a coisas, sinais, fatos e acontecimentos, explicar ou aclarar o sentido de uma expressão e reproduzir, por outras palavras, um pensamento interiorizado. ${ }^{4}$

Segundo Norberto Bobbio, a interpretação pode ser precisamente definida como a tarefa de "remontar do signo (signum) à coisa significada (designatum), isto é, compreender o significado do signo, individualizando a coisa por este indicada". 5

Canotilho, por seu turno, acredita que interpretação importa na atribuição de "um significado a um ou vários símbolos lingüísticos escritos (na Constituição) com o fim de se obter uma decisão de problemas práticos, normativo-constitucionalmente fundadas". 6

A interpretação jurídica consiste na "atividade prática de revelar o conteúdo, o significado e o alcance de uma norma, tendo por finalidade fazê-la incidir em um caso

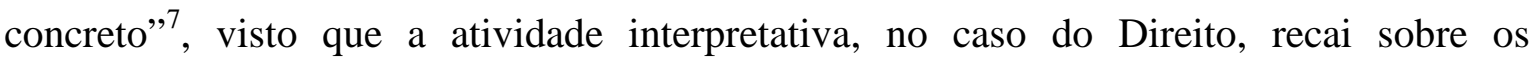
enunciados normativos que podem ser genéricos, abstratos e até polissêmicos.

\footnotetext{
${ }^{2}$ MAXIMILIANO, Carlos. Hermenêutica e aplicação do direito. Rio de Janeiro: Forense, 1988, p. 1.

${ }^{3}$ BASTOS, Celso Ribeiro. Op. cit., p. 19-20.

${ }^{4}$ FERRAZ, Anna Cândida da Cunha. Processos informais de mudança da Constituição. São Paulo: Max Limonad, 1986, p. 19.

${ }^{5}$ BOBBIO, Norberto. O positivismo jurídico. São Paulo: Ícone, 1995, p. 212.

${ }^{6}$ CANOTILHO, Joaquim Jaques Gomes. Direito constitucional. Coimbra: Almedina, 1991, p. 208.

${ }^{7}$ BARROSO, Luís Roberto. Interpretação e aplicação da constituição. 5 ed. São Paulo: Saraiva, 2003, p. 103.
} 
Deve-se ressaltar que a interpretação no campo jurídico é indispensável e será tanto mais necessária quanto maior for o grau de abstratividade da norma ou em se tratando de norma, seja ela constitucional ou infraconstitucional, que necessita de regulamentação.

Feita a distinção, em linhas gerais, da interpretação e da hermenêutica jurídica, é importante salientar que o objeto da presente tese não é a apresentação pormenorizada do tema interpretação jurídica, embora a análise da interpretação constitucional especificamente, em suas bases principais, seja importante naquilo em que for útil para o estudo das mudanças informais da Constituição, visto que uma das formas de realização da mutação constitucional é a interpretação constitucional evolutiva das normas constitucionais realizada pelos juízes, inclusive pelos que compõem a Justiça do trabalho.

\title{
3.2 Peculiaridades das normas constitucionais que influem na interpretação constitucional
}

A Constituição é um documento composto por enunciados normativos - sistema aberto de princípios e regras - e se diferencia das demais espécies normativas, por apresentar várias particularidades, motivo pelo qual foram desenvolvidos técnicas, métodos e princípios próprios para a interpretação das normas constitucionais.

Anna Cândida da Cunha Ferraz afirma que

\begin{abstract}
A interpretação constitucional é uma espécie do gênero interpretação jurídica, porém revestida de características e critérios peculiares, derivados, especialmente, da natureza e das notas distintivas das disposições constitucionais: supremacia e rigidez constitucional, diferentes conteúdos das normas constitucionais, caráter sintético, esquemático e genérico da Constituição, etc. ${ }^{8}$
\end{abstract}

A moderna concepção de interpretação constitucional não enseja um processo abstrato de descoberta do sentido da norma, mas engloba o ato de atribuir significado aos enunciados lingüísticos do texto constitucional, e os atos de densificar e aplicar esse conteúdo a um caso concreto, levando-se em consideração as suas particularidades e as condições de realidade que o envolvem. A atribuição de significado aos enunciados lingüísticos importa na definição do programa normativo e a delimitação do âmbito normativo ocorre pela identificação dos elementos fáticos influenciados pela disposição

\footnotetext{
${ }^{8}$ FERRAZ, Anna Cândida da Cunha. Processos informais de mudança da Constituição. Op. cit. , p. 19.
} 
normativa. A concretização das normas constitucionais ocorre por meio da junção desses dois procedimentos parciais ${ }^{9}$.

Por esse conceito moderno, os fatos concretos e os enunciados normativos são vistos como elementos concatenados e inseparáveis de um mesmo processo de criação da norma constitucional, e não como elementos estanques e distintos, como na época do Estado Liberal. Os fatos concretos, a realidade, deixam de ser enxergados como um simples objeto sobre o qual se reporta uma disposição normativa e assumem a condição de elementos integrantes das normas constitucionais, aptos, inclusive, se variarem, a modificá-las em seu conteúdo, mesmo sem a alteração do texto. Ou seja, a mutação constitucional pode ocorrer inclusive por meio da interpretação constitucional, no sentido moderno em que o conceito é adotado nessa tese.

A interpretação da norma se apresenta como pressuposto indispensável para a aplicação, visto que "por interpretação se entende o processo lógico mediante o qual se assinala e se põe em evidência o conteúdo da disposição legal ou constitucional". ${ }^{10}$

A interpretação constitucional se diferencia da interpretação jurídica em função do seu objeto, as normas constitucionais, que apresentam como peculiaridades a superioridade hierárquica, a peculiaridade semântica e o caráter político.

A superioridade hierárquica confere à Lei Fundamental "o caráter paradigmático e subordinante de todo o ordenamento, de forma tal que nenhum ato jurídico possa subsistir validamente ao âmbito do Estado se contravier seu sentido". ${ }^{11}$

Sendo a Constituição o fundamento de validade de todas as leis, a determinação do significado de suas normas importará no afastamento de uma regra infraconstitucional até então vigente, mas que se torna incompatível com a norma constitucional da forma pela qual passa a ser compreendida. ${ }^{12}$

Em adição, o postulado da supremacia da Constituição repele todo o tipo de interpretação que parta das normas infraconstitucionais, pois o que deve ser feito é sempre o contrário, ou seja, procede-se à interpretação do ordenamento jurídico a partir da Constituição.

O caráter semântico próprio das normas constitucionais também deve ser destacado, pois são elas predominantemente principiológicas e esquemáticas, apresentando

\footnotetext{
${ }^{9}$ CANOTILHO, J. J. Gomes. Direito constitucional. Op. cit. , p. 1179-1184.

${ }^{10}$ FERRAZ, Anna Cândida da Cunha. Processos informais de mudança da Constituição. Op. cit. , p. 22/23.

${ }^{11}$ BARROSO, Luís Roberto. Interpretação e aplicação da Constituição. Op. cit. , p. 107.

${ }^{12}$ BASTOS, Celso Ribeiro. Hermenêutica e interpretação constitucional. Op. cit. , p. 53. Segundo o autor, nesse sentido é importante uma Corte Constitucional que imponha erga omnes o sentido de determinada norma constitucional.
} 
maior grau de abertura, abstração e generalidade e, portanto, menor grau de densidade jurídicas em relação às normas infraconstitucionais, propiciando, assim, a mediação concretizadora dos aplicadores do Direito.

Segundo Konrad Hesse, a Constituição regula apenas o que é fundamental, remetendo o que assim não considera às normas infraconstitucionais, seja porque existem questões insuscetíveis de regulamentação minuciosa e exaustiva, seja porque deixa algumas questões intencionalmente em aberto. Afinal, a "Constituição deve permanecer incompleta e inacabada por ser a vida que pretende normar vida histórica e, como tal, submetida a modificações históricas". ${ }^{13}$

As normas constitucionais, ademais, são políticas tanto no que tange à sua origem, quanto em relação aos resultados de sua aplicação. Nas palavras de Paulo Bonavides,

\begin{abstract}
A norma constitucional é de natureza política, porquanto rege a estrutura fundamental do Estado, atribui competências, poderes, dispõe sobre os direitos humanos básicos, fixa o comportamento dos órgãos estatais e serve, enfim, de pauta à ação dos governos, visto que no exercício de suas atribuições não podem eles evidentemente ignorá-la.

$[\ldots]$

As relações que a norma constitucional, pela sua natureza mesma, costuma disciplinar são de preponderantemente conteúdo político e social e, por isso mesmo sujeito a um influxo político considerável, senão essencial, o qual se reflete diretamente sobre a norma, bem como sobre o método interpretativo aplicável. $^{14}$
\end{abstract}

Anna Cândida da Cunha Ferraz, citando o constitucionalista italiano Carbone, afirma que o elemento política atua na interpretação constitucional, de várias maneiras: para definir o conteúdo dos princípios constitucionais que realizam os princípios políticos correspondentes; para determinar a atualidade do regime político à base do qual é analisada a norma no último estágio da interpretação; e para concretizar o fim público, que dá a medida da discricionariedade atribuída pelas normas constitucionais aos órgãos constitucionais. ${ }^{15}$

Apesar de a interpretação constitucional ser influenciada pelo caráter político das normas constitucionais, ela é uma tarefa jurídica, de modo que o aplicador do Direito deve motivar as suas decisões, zelando pela racionalidade e objetividade.

\footnotetext{
${ }^{13}$ HESSE, Konrad. Escritos de derecho constitucional. Madrid: Centro de Estudios Constitucionales, 1983, p. 19.

${ }^{14}$ BONAVIDES, Paulo. Curso de direito constitucional. Op. cit., p. 461.

${ }^{15}$ CARMELO, Carbone. La consuetudine nel dirrito constituzionale. Padova: Cedam, 1948, p. 29-30 apud FERRAZ, Anna Cândida da Cunha. Op. cit. , p. 26.
} 


\subsection{Princípios da interpretação constitucional}

Tendo em vista que as normas constitucionais apresentam características próprias em relação às demais normas do ordenamento jurídico, a interpretação constitucional também apresentará princípios específicos em comparação à interpretação jurídica em geral.

O princípio da unidade da Constituição significa que a Lei Maior deve ser interpretada na sua globalidade, evitando-se contradição em suas normas por meio da harmonização dos "espaços de tensão existentes entre as normas constitucionais a concretizar". 16

Celso Ribeiro Bastos explica que, como consequência desse princípio, as normas constitucionais "devem sempre ser consideradas como coesas e mutuamente imbricadas. Não se poderá jamais tomar determinada norma isoladamente, como suficiente em si mesma" ${ }^{17}$, pois a interpretação constitucional deve evitar antinomias entre duas normas ou entre a norma analisada e o sistema como um todo.

É importante ressaltar que o princípio da unidade da Constituição não significa que os preceitos constitucionais são todos harmônicos, coerentes e desprovidos de ambiguidades semânticas e contradições. Na realidade, as situações de tensão existem, visto que a Constituição é fruto da tentativa de harmonização de diversos interesses que se contradizem, consubstanciados nas regras e nos princípios. O princípio da unidade visa, portanto, harmonizar as relações de conflito, limitando e equilibrando as divergências que possam surgir na aplicação das normas constitucionais.

O princípio da concordância prática ou da harmonização é diretamente decorrente do princípio da unidade e tem como objetivo conformar os diversos bens jurídicos em conflito, de forma que se evite o sacrifício total de uns em relação aos outros. Deve-se sempre preferir que prevaleçam todas as normas, com a efetividade particular de cada uma delas em face das demais. ${ }^{18}$

Outro princípio peculiar à interpretação constitucional, mencionado por Canotilho, é o da força normativa da Constituição, segundo o qual o intérprete, diante dos casos

\footnotetext{
${ }^{16}$ CANOTILHO, J. J. Gomes. Direito constitucional. Op. cit. , p. 1187.

${ }^{17}$ BASTOS, Celso Ribeiro. Op. cit. , p. 103.

${ }^{18}$ Para atingir esse fim, o intérprete constitucional deve se valer da ponderação de interesses entre os bens jurídicos tutelados, pautando-se pelo princípio da proporcionalidade e das máximas da adequação, da necessidade e da proporcionalidade stricto sensu.
} 
concretos trazidos à sua análise, deve "dar prevalência aos pontos de vista que, tendo em conta os pressupostos da constituição (normativa) contribuem para uma eficácia óptima da lei fundamental". ${ }^{19}$

O princípio da máxima efetividade (ou máxima eficiência, para Canotilho) significa que, sempre que possível, deverá ser o dispositivo constitucional interpretado num sentido que lhe atribua maior eficácia, banindo, assim, "a ideia de que um artigo ou parte dele possa ser considerado sem efeito algum, o que equivaleria a desconsiderá-lo mesmo" ${ }^{\text {, }}$, pois a Constituição não deve ser dotada de dispositivos dotados de mero valor moral.

O princípio do efeito integrador impõe que o aplicador do direito, na busca de soluções para os problemas jurídico-constitucionais deve dar primazia aos critérios e pontos de vista que favoreçam a integração política e social e o reforço da unidade política. $^{21}$ Esse critério, segundo David Diniz Dantas, mostra-se particularmente importante na interpretação de preceitos constitucionais em relação a casos que envolvam as atribuições dos poderes, órgãos, agentes e instituições públicas. ${ }^{22}$

\subsection{Métodos de interpretação constitucional}

O intérprete da Constituição, além de se valer dos métodos tradicionais utilizados para a interpretação das demais normas do ordenamento jurídico, conta com métodos próprios, específicos para a tarefa de atribuir o significado e o alcance das normas constitucionais.

\subsubsection{Métodos clássicos ou tradicionais}

Os métodos tradicionais de interpretação foram consolidados durante o Estado Liberal, período no qual o Estado tinha atuação mínima e a interpretação era concebida

\footnotetext{
${ }^{19}$ CANOTILHO, J. J. Gomes. Direito constitucional. Op. cit. , p. 1189.

${ }^{20}$ BASTOS, Celso Ribeiro. Op. cit. , p. 105.

${ }^{21}$ CANOTILHO, J. J. Gomes. Direito constitucional. Op. cit. , p. 1097.

22 DANTAS, David Diniz. Interpretação constitucional no pós-positivismo: teoria e casos práticos. São Paulo: Madras, 2004, p. 263.
} 
com base no princípio da legalidade e visava revelar a vontade da norma em si (mens legis) e a vontade do legislador (mens legislatoris).

O método gramatical, também denominado de método literal, consiste em interpretar o texto constitucional de acordo com o sentido próprio de suas palavras, analisadas isoladamente ou no contexto da oração, sendo que somente o que consta das palavras do enunciado normativo é que serão objeto de consideração.

Esse método constituiu-se no ideal iluminista de uma aplicação mecanicista da lei, em que a significação das expressões lingüísticas é tão evidente que o intérprete resolveria sua missão se lesse atentamente o dispositivo a ser interpretado. ${ }^{23}$

Mas, na realidade, apreender o significado das palavras não é tarefa tão simples, visto que a linguagem jurídica muitas vezes é técnica e sofisticada, exigindo do intérprete a apreensão do significado jurídico e não o usual das palavras por meio das quais a norma é instrumentalizada.

As Constituições contêm tanto palavras técnicas, quanto vocábulos não-técnicos, cujo conteúdo não é claro, sendo que por meio da atividade interpretativa, nesse último caso, é que se irá atribuir o sentido de uso cotidiano mais pertinente ao termo ou expressão em foco.

Ademais, para sobreviver, a Constituição deve ser escrita em termos vagos, possibilitando a apreensão das mudanças da realidade ocorridas ao longo do tempo. Nos dizeres do Mr. Olliver Wendel Holmes, juiz da Suprema Corte dos Estados Unidos entre os anos de 1902 e 1932, uma palavra não é "um cristal, transparente e imutável, é a pele de um pensamento vivo e pode variar bastante em conteúdo e cores de acordo com as circunstâncias e o tempo em que são usadas". ${ }^{24}$

É importante ressaltar que o elemento literal demarca o espaço onde o intérprete irá trabalhar, pois cada significante pode possuir certa variedade de significados, embora não infinitos, sob pena de invalidar a função da língua como instrumento de particularização.

Apesar das suas limitações, a interpretação literal constitui sempre o ponto de referência obrigatório para o intérprete e, a partir daí, até mesmo em virtude da busca de variantes lingüísticas de sentido que o texto da norma indica com referência ao caso, o aplicador do direito irá recorrer aos outros métodos existentes.

${ }^{23}$ CASTRO, Flávia de Almeida Viveiros de. Interpretação constitucional e prestação jurisdicional. Rio de Janeiro: Lumen Juris, 2000, p. 41.

${ }^{24}$ Tradução livre do texto "A word is not a crystal, transparent and unchanged, it is the skin of a living thought and may very greatly in color and content according to the circunstances and the time in wich it is used". Holmes, J. apud FISHER, Louis. Constitucional dialogues: interpretation as political process. New Jersey: Princeton University Press, 1988, p. 67-68. 
O método lógico, na divisão de métodos apresentada por parte da doutrina, engloba os métodos da interpretação lógico-histórica, lógico-teleológica e lógico-sistemática. ${ }^{25}$ Por meio da interpretação lógica, o intérprete busca "reconstruir o pensamento ou a intenção do constituinte de modo a alcançar, depois, a precisa vontade do texto constitucional". ${ }^{26}$

A interpretação lógico-sistemática consiste na descoberta do significado do enunciado normativo em relação ao contexto sistêmico no qual ele está inserido, de acordo com a estrutura e o posicionamento do preceito jurídico no sistema. Como a Constituição é um sistema aberto de regras e princípios jurídicos, que se interrelacionam e formam um todo, em virtude do princípio da unidade constitucional, é deveras importante que o exegeta analise o preceito normativo levando em conta as suas relações com as demais normas constitucionais.

A sistematicidade também se refere aos demais elementos que formam a totalidade hermenêutica, pois os resultados parciais obtidos por cada um dos métodos interpretativos empregados devem ser relacionados precisamente por intermédio dessa metodologia. Ou seja, ela opera por fora e por dentro do objeto a ser interpretado. ${ }^{27}$

O método lógico-histórico consiste em uma análise do processo de criação do texto que é objeto da interpretação, por meio da investigação dos trabalhos prévios, dos projetos, das motivações, etc.

É importante salientar que o intuito desse método não é necessariamente procurar descobrir a vontade primeira e original do constituinte e intuir seu ponto de vista no contexto do caso em análise, ou seja, não é a busca da mens legislatoris, pois essa vontade não poder ser apreendida com a clareza desejada na interpretação do texto. Na realidade, os preceitos normativos são o resultado de diversas vontades particulares das diferentes forças políticas presentes na elaboração da Constituição.

Assim, como a interpretação deve ser consonante com o momento histórico presente, esse método pode ser utilizado para efeito comparativo entre os dados políticos e sociais contemporâneos da promulgação da uma Constituição e a evolução histórica desses elementos e sua influência sobre o texto normativo.

O método teleológico importa na aplicação das normas tendo em conta o seu espírito e a sua finalidade, ou seja, busca-se apreender qual o motivo prático, a ratio legis

\footnotetext{
${ }^{25}$ Os métodos lógico-histórico e lógico-teleológico também são denominados simplesmente como métodos histórico e teleológico.

${ }^{26}$ Anna Cândida da Cunha. Processos informais de mudança da Constituição. Op. cit. , 1986, p. 40.

${ }^{27}$ CASTRO, Flávia de Almeida Viveiros de. Interpretação constitucional e prestação jurisdicional. $O p$. cit. , p. 47.
} 
da norma constitucional. A busca da finalidade deve ser realizada na própria Lei Fundamental, pois o argumento teleológico deve estar conectado ao contexto jurídico no qual o texto normativo se insere.

Os métodos tradicionais de interpretação constitucional mostraram-se, com o tempo, insuficientes e inadequados, em virtude das mudanças ocorridas no papel desempenhado pelo Estado e nas interações entre atividade estatal e sociedade, com a integração de elementos extrajurídicos ao processo constitucional.

Nessa esteira, Paulo Bonavides explica que

\begin{abstract}
a moderna interpretação da Constituição deriva de um estado de inconformismo de alguns juristas com o positivismo lógico-formal, que tanto prosperou na época do Estado Liberal.

Redundou assim na busca do sentido mais profundo das Constituições como instrumentos destinados a estabelecer a adequação rigorosa do Direito com a Sociedade; do Estado com a legitimidade que lhe serve de fundamento; [...].

Ao se exaurirem porém as potencialidades sociais, políticas e econômicas contidas naquele rígido quadro de separação entre o Estado e a Sociedade, típico da idade do liberalismo, o constitucionalismo ingressou numa fase de todo distinta, em que Estado e Sociedade se interpenetram numa conciliação de conceitos e realidades, com alta dose de politização ou estatização (essa ocorre em casos mais extremos) das relações sociais básicas, cujo eixo de gravitação já não se contém como dantes em esfera inteiramente privatística. ${ }^{28}$
\end{abstract}

Assim, foram desenvolvidos os denominados métodos modernos de interpretação constitucional, mais adequados à nova concepção de Estado, na medida em que possibilitam uma maior abertura da Constituição às condições sócio-políticas da realidade. Diante dessa nova realidade, a tarefa do intérprete passa a ser o principal foco da interpretação constitucional e não mais a vontade da lei ou do legislador abstratamente considerados. A atividade interpretativa não se resume mais a realizar uma correta subsunção do fato à norma, mas assume um papel muito mais complexo, de apreender as normas conforme a confirmação política dos fatos.

\title{
3.4.2 Métodos modernos
}

Os métodos modernos de interpretação constitucional que serão sinteticamente abordados são o método científico-espiritual, o tópico-problemático, o normativoestruturante e o hermenêutico-concretizador.

${ }^{28}$ BONAVIDES, Paulo. Curso de direito constitucional. Op. cit. , p. 476. 
O método científico-espiritual ou integrativo é defendido por Rudolf Smend em seu livro Verfassung und Verfassungsrecht (Constituição e Direito Constitucional) e tem como linha mestra a premissa de que a interpretação constitucional não tem como objetivo extrair o sentido do texto constitucional, mas, sim, compreender o sentido e a realidade da Constituição como um todo.

A Constituição consubstancia todos os momentos de integração, todos os valores primários e superiores do ordenamento estatal (direitos humanos, preâmbulo, território do Estado, forma de Estado), enfim, a totalidade espiritual de que tudo mais deriva, inclusive a sua força integrativa. ${ }^{29}$ Portanto, o intérprete deve buscar, pela análise integrativa, o "espírito da Constituição", ou seja, os mais distintos sentidos, conforme o tempo, a época, as circunstâncias.

A ideia de Constituição não pode se separar de uma ordem de valores, cujo sentido só poderá ser captado levando em conta os conteúdos axiológicos últimos da ordem constitucional.

O método tópico-problemático foi trabalhado por Theodor Viehweg e exposto em seu livro Topik und Jurisprudenz (Tópica e jurisprudência). A tópica é um processo especial de tratamento de problemas que se caracteriza pelo emprego de certos pontos de vista considerados pertinentes (tópicos ou “topoi”). Esses pontos de vista servirão para a ponderação dos prós e dos contras das opiniões, podendo conduzir o aplicador do Direito ao que é verdadeiro ${ }^{30}$, ou seja, à interpretação mais conveniente para o problema dentro das várias possibilidades derivadas da polissemia de sentido do texto constitucional.

O método tópico se centraliza no problema concreto e não no contexto sistemático, afastando, assim, a aplicação da dedução da norma ao fato, do sistema normativo para o caso concreto. Ademais, pode ser articulado com os outros métodos interpretativos e é aberto à participação dos vários intérpretes da Constituição.

Sem embargo, em virtude do perigo da arbitrariedade das decisões judiciais baseada no casuísmo, Canotilho pondera que

\footnotetext{
a concretização do texto constitucional a partir do topoi merece sérias reticências. Além de poder conduzir a um casuísmo sem limites, a interpretação não deve partir do problema para a norma, mas desta para os problemas. A interpretação é uma actividade normativamente vinculada, constituindo a "constitutio scripta" um limite ineliminável (Hesse) que não admite o sacrifício da primazia da norma em prol da prioridade do problema. ${ }^{31}$
}

\footnotetext{
${ }^{29}$ BONAVIDES, Paulo. Curso de direito constitucional. Op. cit. , p. 478.

${ }^{30}$ DANTAS, David Diniz. Op. cit. , p. 241.

${ }^{31}$ CANOTILHO, J. J. Gomes. Direito constitucional. Op. cit. , p. 1175.
} 
O método normativo-estruturante foi desenvolvido principalmente pelo jurista alemão Friedrich Müller em sua obra Juristiche Methodik (Metódica Jurídica), que partiu da distinção entre "norma" e "texto da norma", visto que a "norma" seria o resultado de um trabalho de construção a partir do texto, ou seja, a norma é o resultado da concretização na medida em que não está contido no texto, nem preexiste ao trabalho do operador do direito.

Canotilho buscou sintetizar os postulados básicos do método científicoestruturante:

(1) a metódica jurídica tem como tarefa investigar as várias funções de realização do direito constitucional (legislação, administração e jurisdição); (2) e captar a transformação das normas a concretizar numa "decisão prática"; (3) a metódica deve preocupar-se com a estrutura da norma e do texto normativo, com o sentido de normatividade e de processo de concretização, com a conexão da concretização normativa e com as funções jurídico-práticas; (4) elemento decisivo para a compreensão da estrutura normativa é uma teoria hermenêutica da norma jurídica que arranca da não-identidade entre norma e texto normativo; (5) o texto de um preceito jurídico positivo é apenas a parte descoberta do iceberg normativo (F. Müller); (6) mas a norma não compreende apenas o texto, antes abrange um "domínio normativo", isto é, um "pedaço de realidade social" que o programa normativo só parcialmente completa; (7) conseqüentemente, a concretização normativa deve considerar e trabalhar com dois tipos de elementos de concretização: um formado pelos elementos resultantes da interpretação do texto da norma (=elemento literal na doutrina clássica); outro, o elemento de concretização resultante da investigação do referente normativo (domínio ou região normativa). ${ }^{32}$

Müller desenvolveu uma metodologia jurídica relativa ao processo de interpretação das normas constitucionais a ser adotado pelo aplicador do direito. Inicialmente, o intérprete deve escolher os textos de norma que lhe pareçam apropriados para o caso; depois, deve delimitar o "campo factual", por meio da soma das hipóteses de textos de normas incidentes sobre os fatos, e do "campo de espécie", incidentes especificamente sobre o caso concreto; em seguida, far-se-á a interpretação do conjunto de dados lingüísticos, obtendo-se, assim, o "programa normativo"; à continuação, delimitar-se-á, a partir do "campo factual/" e do "programa normativo", o "âmbito normativo", ou seja, os fatos co-normativos para a solução do caso concreto ou, em outras palavras, o recorte da realidade social abrangida no âmbito de regulamentação; após, far-se-á o reconhecimento da norma jurídica, abstratamente considerada, por meio da junção entre "programa

\footnotetext{
${ }^{32}$ CANOTILHO, J. J. Gomes. Direito constitucional. Op. cit. , p. 1177.
} 
normativo" e "âmbito normativo"; e, finalmente, realizar-se-á a individualização da norma jurídica em uma "norma-decisão". 33

O método hermenêutico-concretizador foi desenvolvido por Konrad Hesse, em seu livro Grundzuge des Verfassungsrechts (Elementos de Direito Constitucional). De acordo com o jurista, o operador do Direito cumpre a tarefa da interpretação mediante um procedimento racional que tem por objetivo a tomada de decisões em um problema concreto. Por isso, a interpretação constitucional não é um procedimento de subsunção, mas de concretização.

O procedimento de concretização da norma vincula-se a três elementos: a précompreensão do intérprete, o problema concreto a ser resolvido e a norma a ser concretizada. E tem como objetivos descobrir o resultando constitucionalmente correto, por meio de um procedimento racional e controlável, e fundamentar, também de forma racional, esse resultado, dotando-se o método jurídico de certeza e previsibilidade. ${ }^{34}$

Canotilho sintetiza as principais características do método de Hesse:

\begin{abstract}
O método hermenêutico-concretizador arranca da idéia que a leitura de um texto normativo se inicia pela pré-compreensão do seu sentido através do intérprete. A interpretação da Constituição também não foge a esse processo: é uma compreensão de sentido, um preenchimento de sentido juridicamente criador, em que o intérprete efectua uma actividade prático-administrativa, concretizando a norma para e a partir de uma situação jurídica concreta. No fundo, esse método vem realçar e iluminar vários pressupostos da tarefa interpretativa: (1) os pressupostos subjectivos, dado que o intérprete desempenha um papel criador (pré-compreensão) na tarefa de obtenção do sentido do texto constitucional; (2) os pressupostos objectivos, isto é, o contexto actuando o intérprete como operador de mediações entre o texto e a situação em que se aplica; (3) relação entre o texto e o contexto com a mediação criadora do intérprete, transformando a interpretação em movimento de ir e vir (círculo hermenêutico). ${ }^{35}$
\end{abstract}

Analisados os principais métodos de interpretação constitucional, é importante salientar que nenhum deles deve ser absolutizado, pois todos, inclusive os métodos tradicionais, podem contribuir para a tarefa de interpretar e concretizar a Constituição.

Nesse sentido, Canotilho afirma que a interpretação das normas constitucionais é um conjunto de "métodos, desenvolvidos pela doutrina e pela jurisprudência com base em critérios ou premissas (filosóficas, metodológicas, epistemológicas) diferentes, mas, em geral, reciprocamente complementares." 36

\footnotetext{
${ }^{33}$ DANTAS, David Diniz. Op. cit. , p. 253-255.

${ }^{34}$ DANTAS, David Diniz. Op. cit. , p. 247.

${ }^{35}$ CANOTILHO, J. J. Gomes. Direito constitucional. Op. cit. , p. 1176.

${ }^{36}$ Ibidem, p. 1085.
} 


\subsection{As mutações constitucionais}

A partir de agora, será analisado o fenômeno de mudança constitucional denominado mutação constitucional, as suas características, o seu fundamento jurídicopolítico e as suas modalidades, incluindo a interpretação constitucional evolutiva. Abordarse-á, também, os sujeitos que realizam as mutações constitucionais, sejam eles os entes estatais (Poderes Judiciários, Legislativo e Executivo), sejam eles os entes não-estatais (povo, opinião pública), dando ênfase à interpretação jurisdicional, em virtude do objeto da presente tese ser a implementação dos direitos fundamentais trabalhistas pela Justiça do Trabalho, por meio da interpretação evolutiva das normas constitucionais. Por fim, serão trabalhados os limites jurídicos à interpretação evolutiva e como essa modalidade de mutação vem sendo utilizada no Brasil pelo Poder Judiciário para interpretar as normas constitucionais.

\subsubsection{A rigidez e as mudanças na Constituição}

O Direito convive com a permanente tensão entre a pretensão de permanência, visto que uma de suas funções é a de conferir certa dose de previsibilidade às relações sociais, e a necessidade de mudança, uma vez que as normas jurídicas que estão em descompasso com a realidade fática perdem, em muitos casos, a sua eficácia.

O estudo mais pormenorizado dado pela doutrina em relação às mudanças normativas no âmbito do Direito Constitucional decorre da superioridade formal e da supremacia material das normas constitucionais dentro do sistema jurídico.

A noção de Constituição como regulamentação da estrutura do Estado, dos seus órgãos e das suas atividades, bem como da organização social politicamente relevante e da consagração dos direitos e garantias individuas é derivada do movimento denominado Constitucionalismo $^{37}$, ocorrido no século XVIII, que deu forma material ao conceito de

\footnotetext{
${ }^{37}$ Esse movimento tinha o objetivo de consolidar as conquistas da Revolução Francesa, em especial as ideias de liberdade e igualdade, e pregava a necessidade da separação dos Poderes e da enunciação dos direitos individuais como forma de garantia dos cidadãos e limitação do poder do Estado. Ademais, exaltava o princípio da legalidade, com a tripla função de limitar o poder estatal, garantir a segurança jurídica e assegurar a igualdade formal entre os indivíduos.
} 
Constituição e acabou por conduzir à ideia de superioridade hierárquica, identificando-a como fundamento de validade das demais leis editadas em um Estado.

As normas constitucionais precisam apresentar maior permanência em comparação com as demais normas do ordenamento jurídico, pois estabelecem a organização políticojurídica e as bases fundamentais do Estado. Esse intuito de permanência tem como objetivos garantir a segurança jurídica e a estabilidade institucional, bem como a eficácia e eficiência do texto constitucional, por meio do chamado "sentimento constitucional", favorecendo a "força normativa" da Constituição.

Como as bases do Estado são fixadas pela Constituição, existe uma pretensão, pela comunidade, de segurança e certeza em relação à atuação dos poderes constituídos os quais deverão adaptar os seus objetivos e o seu agir às previsões constitucionais.

A permanência das normas constitucionais é fator decisivo para a eficácia e para a efetividade da Constituição, na medida em que possibilita a consolidação do "sentimento constitucional", que é uma espécie de adesão espontânea da sociedade à Constituição, gerada pelo maior conhecimento e compreensão de seus termos pela população em geral. Nesse sentido, Karl Loewenstein explica que

[...] com a expressão "sentimento constitucional" (Vergassungsgefühl) é feita menção a um dos fenômenos psico-sociais e sociológicos do existencialismo político mais difíceis de se captar. Este pode ser descrito como aquela consciência da comunidade que, transcendendo a todos os antagonismos e tensões político-partidárias, econômico-sociais, religiosas ou de qualquer outro tipo, promove a integração entre os detentores e os destinatários do poder no marco de uma ordem comunitária obrigatória, submetendo o processo político aos interesses da comunidade. ${ }^{38}$

O fortalecimento do "sentimento constitucional" enseja a afirmação da força normativa da Constituição, a qual "está condicionada à vontade atual dos participantes da vida constitucional de realizar o conteúdo" do texto constitucional. ${ }^{39}$

Por outro lado, a superioridade da Constituição encontra fundamento no exercício soberano do poder constituinte e na rigidez constitucional, definida, segundo Adriana Zandonade, “como a positivação de um processo complexo e solene para a realização de

${ }^{38}$ LOEWENSTEIN, Karl. Teoría de la constitución. Barcelona: Ariel, 1965, p. 200. Trad. Alfredo G. Anabitarte.

${ }^{39}$ HESSE, Konrad. Elementos de direito constitucional da República Federativa da Alemanha. Porto Alegre: Sérgio Antônio Fabris, 1998, p. 49. Trad. Luís Afonso Heck. 
modificações formais na Constituição, movida pelos valores da estabilidade e da segurança jurídicas". 40

Em outras palavras, a rigidez ${ }^{41}$ da Constituição importa em ser estabelecido um procedimento mais difícil para a modificação das normas constitucionais em relação ao procedimento adotado para a alteração das leis ordinárias e das demais normas infraconstitucionais, justamente para evitar que as normas da Lei Fundamental fiquem sujeitas a atos temerários do legislador.

É importante salientar que a rigidez nos processos de alterações formais da Constituição difere da imutabilidade absoluta, que abala forçosamente os valores da estabilidade e da segurança jurídicas, visto que não se podendo introduzir na Lei Fundamental, por mecanismos constitucionalmente fixados, as modificações sociais, essas se realizarão de qualquer modo, provocando uma ruptura radical e trazendo prejuízos para a própria sociedade, com a desvalorização da Constituição e a destruição da consciência constitucional.

Da mesma forma, mudanças frequentes no texto constitucional também podem gerar insegurança jurídica e um estado de indiferença popular em relação à Lei Fundamental. Nesse sentido, esclarece Pablo Lucas Verdú que "la apertura constitucional y la reforma del texto fundamental han de hacerse cautelosamente de modo que no se hiera su fórmula política, su esencia"42.

Existe, portanto, no Direito um constante estado de tensão entre a pretensão de permanência, visto que uma das funções das normas jurídicas é a de conferir certa dose de previsibilidade às relações sociais e, por outro lado, a necessidade de mudança, uma vez que as normas que ficam em descompasso com a realidade fática perdem, em muitos casos, sua autoridade e sua eficácia.

Assim, se, por um lado, a rigidez é necessária para manter a estabilidade constitucional $^{43}$, por outro lado, deve aquela permitir que a evolução da sociedade seja acompanhada pela evolução da Constituição. Com esta finalidade, existem mecanismos

\footnotetext{
${ }^{40}$ ZANDONADE, Adriana. Mutação constitucional. Revista de direito constitucional e internacional. São Paulo, v. 9, n. 35, abr./jun. 2001, p. 196.

${ }^{41}$ Além da rigidez constitucional, os outros mecanismos ou técnicas de defesa da Constituição são as cláusulas pétreas, ou seja, limites materiais ao poder de reforma constitucional, e a instituição e exercício de uma jurisdição constitucional.

${ }^{42}$ VERDÚ, Pablo Lucas. La constitución abieta y sus “enemigos”. Madrid: Beiramar, 1993, p. 60.

${ }^{43}$ Porém, não é a excessiva rigidez constitucional que fomenta as mutações, mas, sim, a necessidade de manter a eficácia dos mandamentos constitucionais quando da ocorrência de mudanças na realidade fática ou na percepção do direito.
} 
formais e informais de mudanças na Constituição para adequá-la às transformações sociais e interagir com elas.

De um ponto de vista mais amplo, existem mudanças que interferem de uma forma global ou parcial na Constituição de um Estado, as quais Jorge Miranda ${ }^{44}$ denomina de "vicissitudes constitucionais", ou seja, quaisquer eventos que projetem sobre a subsistência da Constituição ou de algumas das suas normas.

Nesse sentido, o que interessa para o desenvolvimento da presente tese é o estudo específico da mutação constitucional que se enquadra dentre as mudanças parciais da Constituição, que não rompem com a noção de Estado, nem com a de Poder Constituinte, assim como também ocorre com a reforma constitucional, que abrange as revisões e as emendas constitucionais.

A Constituição pode, portanto, ser parcialmente modificada por meio de procedimentos formais e informais. Os primeiros recebem a denominação genérica de reforma constitucional (Verfassungsänderung, em alemão), abrangendo a revisão (poder de reforma extraordinário) e a emenda (poder de reforma extraordinário), e se caracterizam pela alteração da Constituição rígida, por meio da atuação de certo órgão, mediante certas formalidades estabelecidas nas próprias Constituições para o exercício do poder reformador, acompanhada da alteração da sua letra escrita.

Já o processo informal é denominado mutação constitucional, (Verfassungswandlung) e consiste na alteração do significado, do sentido e do alcance das disposições constitucionais, por meio da interpretação ou das práticas constitucionais, sem atingir a letra do texto constitucional.

As mudanças constitucionais são necessárias como meio de preservação e de conservação da própria Constituição, visando o seu aperfeiçoamento e buscando, por meio de um processo dialético, alcançar a harmonia com a sociedade.

Assim, as normas constitucionais não podem ser consideradas perfeitas e acabadas se estão constantemente em situação de interação com a realidade.

\footnotetext{
${ }^{44}$ MIRANDA, Jorge. Op. cit., p. 132. De acordo com o autor, essas vicissitudes constitucionais são de uma gama muito variada e podem ser divididas por cinco critérios: a) quanto ao modo: expressas (revisão constitucional stricto sensu, derrogação constitucional, transição constitucional, revolução, ruptura não revolucionária, e suspensão parcial da Constituição) e tácitas (costume constitucional, interpretação evolutiva da Constituição, revisão indireta); b) quanto ao objeto: parciais (todas as modificações constitucionais, exceto a revolução e a transição constitucional) e totais (revolução e transição constitucional); c) quanto ao alcance (geral e abstrato (todas, exceto a derrogação constitucional), e individual e concreto ou excepcional (derrogação constitucional); d) quanto às conseqüências sobre a ordem constitucional: evolução constitucional (todas, exceto a revolução e a ruptura não revolucionária) e ruptura (revolução e ruptura não revolucionária); e) e quanto à duração dos efeitos: definitivos (todas, exceto a suspensão parcial da Constituição) e temporários (suspensão parcial da Constituição).
} 
Realmente, as Constituições são o resultado de um compromisso estabelecido entre as tendências sócio-econômicas, políticas e culturais predominantes no momento de sua criação. Contudo, as circunstâncias que deram origem à criação do texto estão em permanente modificação, fomentando as modificações constitucionais.

Nas palavras de Karl Loewenstein

Cada constitución es un organismo vivo, siempre en movimiento como la vida misma, y está sometido a la dinámica de la realidad que jamás puede ser captada a través de fórmulas fijas. Una constitución no es jamás idéntica consigo misma, y está sometida constantemente al panta rhei heraclitiano de todo o vivente. ${ }^{45}$

Em síntese, a Constituição, ao mesmo tempo em que objetiva, por meio da estabilidade das suas normas, a segurança jurídica, a estabilidade institucional e a efetividade normativa, também deve estar aberta às modificações inerentes às exigências do progresso, da evolução e do bem estar social.

Nos próximos subitens, será realizado um estudo específico das modificações informais da Constituição, com ênfase para a mutação constitucional realizada por meio da interpretação constitucional evolutiva pelos órgãos do Poder Judiciário, visto que o objetivo da presente tese é analisar como esse mecanismo pode ser utilizado pelos órgãos da Justiça do Trabalho para fins de implementação e ampliação da concretização dos direitos fundamentais trabalhistas esculpidos na Constituição Federal de 1988.

\subsubsection{Evolução do conceito de mutação constitucional}

A noção de mutação constitucional não é algo recente, pois remonta à Constituição do Império Alemão de 1871, quando surgem os primeiros trabalhos sobre o tema. Segundo Ana Victoria Urrutia, os pressupostos necessários para o desenvolvimento desse tema na Europa foram um determinado grau de rigidez das Constituições e a compreensão delas como instrumento normativo. ${ }^{46}$

A existência de mutações constitucionais foi constatada pela doutrina publicista alemã do final do século XIX e início do século XX ao observar que havia uma

\footnotetext{
${ }^{45}$ LOEWENSTEIN, Karl. Teoría de la constitución. Op. cit., p. 164.

${ }^{46}$ URRUTIA, Ana Victoria Sánchez. Mutación constitucional y fuerza normativa de la Constitución. Una aproximación al origen del concepto. Revista Española de Derecho Constitucional. Madri, v. 20, n. 58, jan./abr. 2000, p. 107.
} 
discrepância entre a "realidade constitucional" e a Constituição formal. A existência de mecanismos rígidos para a reforma da Constituição não se apresentava como uma garantia suficiente para prevenir a sua modificação informal.

Os juristas da Escola Alemã de Direito Público ${ }^{47}$ foram os primeiros a tratar diretamente desse fenômeno, destacando-se Georg Jellinek e Paul Laband.

Paul Laband (1838-1918) constatou que a Constituição pode se transformar além dos mecanismos formais de reforma, descrevendo, em sua obra Wandlungen der Deutschen Reichverffassung (Mutação da Constituição Alemã), publicada em 1895, como a Constituição do Reich foi transformada sem que fossem acionados tais mecanismos e propondo, pela primeira vez, a diferenciação entre reforma constitucional e mutação constitucional.

Segundo Laband, enquanto as Constituições são normas jurídicas em sentido estrito, a ação do Estado pode transformá-las, sem necessidade de modificação formal. Assim, o autor observa que na Constituição, além de muitos dispositivos de significado subordinado e passageiro, de escasso interesse para a maioria do povo, existe uma essência real do direito do Estado plasmada na Constituição que pode experimentar uma modificação radical e significativa, sem que o texto constitucional seja alterado na sua expressão escrita. $^{48}$

A ausência de regulação constitucional de instituições centrais do Estado ${ }^{49}$ propiciou que o aperfeiçoamento e a transformação da situação constitucional do Reich pudessem ser produzidos à margem da modificação formal da Constituição.

Georg Jellinek (1851-1911), por seu turno, utiliza o critério da intencionalidade da mudança para fazer a distinção entre reforma e mutação constitucional, de maneira que a reforma comporia uma modificação voluntária do texto constitucional, enquanto a mutação constitucional seria uma alteração não necessariamente consciente da Constituição que não

\footnotetext{
${ }^{47}$ A Escola Alemã de Direito Público propugnava como ponto de partida metodológico a separação entre direito e política, de modo que o direito público deveria ser estudado sem levar em conta os fenômenos políticos cambiantes. Desse ponto de vista, parece paradoxal que dois autores desta tradição iniciem o estudo do contraste entre os descrito nas normas constitucionais e o funcionamento real do Estado constitucional.

${ }^{48}$ URRUTIA, Ana Victoria Sánchez. Mutación constitucional y fuerza normativa de la Constitución. Op. cit., p. 106.

${ }^{49}$ Como, por exemplo, a inexistência de definição da posição política dos ministros do Reich, a não previsão de um procedimento de incorporação de novos territórios à união alemã, a regulação constitucional imperfeita e escassa das finanças do Reich e a vaga e incompleta previsão constitucional de distribuição de competências entre os Länder e o Reich supunham que sua situação real somente pudesse ser deduzida do conteúdo das leis do Reich, ou seja, as leis permitiam, na prática, uma mudança da situação constitucional da época.
} 
modifica o seu texto. Em seu livro Verfassungänderung und Verfassungwandlung

(Reforma e mutação constitucional), o autor assim se manifesta:

Por reforma de la Constitución entiendo la modificación de los textos constitucionales producida por acciones voluntarias e intencionadas. Y por mutación de la constitución, entiendo la modificación que deja indemne su texto sin cambiarlo formalmente que se produce por hechos que no tienen que ir acompañados por la intención, o consciencia, de tal mutación. No es menester advertir que la doctrina de las mutaciones es mucho más interesante que la de las reformas constitucionales. ${ }^{50}$

$\mathrm{O}$ autor se refere à possibilidade de a Constituição se transformar por meio da jurisprudência, levando em conta que o juiz, no sistema de controle de constitucionalidade na América ${ }^{51}$, ocupa efetivamente o lugar do legislador constitucional. Sem embargo, como não existia em regra, naquela época, controle de constitucionalidade de leis, a lei do Parlamento constituía, na grande maioria dos casos, um fator constante de mudança constitucional.

Jellinek se preocupava com a realidade histórica concebida como fato social indissoluvelmente unido à evolução estatal e constitucional. $\mathrm{O}$ autor entende que o Direito é um compromisso entre interesses diferentes e até mesmo opostos, resultante não apenas das forças desses interesses, mas também do poder social dos interessados neles. A modificação das forças reais das relações entre os órgãos superiores do Estado se infiltra nas próprias instituições, até mesmo quando não houver sido alterada uma letra da Constituição.

Nessa esteira, Pablo Lucas Verdú explica que

Seguiendo a Lasalle relacionándolo con la fuerza normativa de lo fáctico, y apoyándose en numerosos datos de Derecho comparado, Jellinek encuentra fases suficientes para enfrentarse con el problema de las mutaciones constitucionales, considerándolas como resultado de la dialéctica normatividad escrita y realidad constitucional, causa fundamental de dichas transformaciones constitucionales indirectas, tácitas, silentes, que configuran el cuadro de la dinámica constitucional. $^{52}$

\footnotetext{
${ }^{50}$ JELLINEK, Georg. Reforma y mutación de la constitución. Madrid: Centro de Estudios Constitucionales, 1991, p. 7. Trad. Christian Förster. A versão em espanhol do trabalho de Jellinek, originalmente intitulada Verfassungsänderung und Verfassungswandlung. Eine staatsrechtlich-politische Abhandlung, foi fruto de uma conferência sobre reforma da Constituição e mutação constitucional proferida, em 18 de março de 1906, na Academia Jurídica de Viena.

${ }^{51}$ Segundo Ana Victoria Sánchez Urrutia, naquela época o único sistema de controle de constitucionalidade era o dos Estados Unidos da América, não se esquecendo do sistema suíço de controle parcial. Cf. URRUTIA, Ana Victoria Sánchez. Mutación constitucional y fuerza normativa de la Constitución. Op. cit. , p. 112.

52 VERDÚ, Pablo Lucas. Estudo preliminar da obra de JELLINEK, Georg. Reforma y mutación de la constitución. Madrid: Centro de Estudios Constitucionales, 1991, p. LXIV. Trad. Christian Förster.
} 
Jellinek acredita que a força normativa dos fatos faz com que junto das constituições escritas rígidas e contra elas se desenvolva um direito constitucional não escrito.

Apesar das contribuições do autor no que tange à constatação da existência de tensão entre realidade e norma e da ocorrência de mudanças normativas que se produzem, deixando intacto o teor literal da norma, observa-se que o jurista alemão apresenta apenas uma explicação fática do fenômeno da mutação. Ele buscou suplementar o positivismo legalista com uma análise empírica ou descritiva dos processos político-sociais, considerando a mutação constitucional como um fenômeno empírico não resolvido normativamente.

Portanto, o conceito de mutação constitucional, adotado por Jellinek, fundado na força normativa dos fatos, não pode ser adotado em um Estado Democrático de Direito que se pauta na força normativa da Constituição.

Após analisar sinteticamente as contribuições de Laband e Jellinek, pode-se dizer que a inexistência de um mecanismo de controle de constitucionalidade das leis e o caráter extremamente sucinto da Constituição Alemã de 1871 impediram que os conceitos de reforma e de mutação constitucional fossem delimitados claramente, cingindo-se os autores dessa Escola a mostrar sua perplexidade frente às contradições entre a realidade, 0 fático e o estabelecido pela letra da Constituição.

Já na época da Constituição de Weimar, em consequência da instabilidade, os teóricos da Constituição centraram boa parte de seus esforços para refletir acerca das mudanças constitucionais e procuraram compreender a relação existente entre a dinâmica política e a Constituição escrita. Autores, como Hermann Heller e Rudolf Smend, procuraram descrever a Constituição como ente dinâmico, em constante movimento, que se alimenta continuamente da realidade política que a circunda. Eles apreendem o conceito de Constituição elaborado por Georg Jellinek e o convertem em um elemento da teoria da Constituição.

Herman Heller (1891-1933) parte de uma concepção de que a Constituição, no sentido de ciência da realidade, se equipara com a organização material do Estado, pois representa a cooperação entre indivíduos e grupos, mediante relações graças às quais o Estado alcança existência e unidade de ação.

Nesse sentido, o seu raciocínio é parecido com o de Ferdinand Lassalle, ao assinalar que a Constituição material está determinada pelas relações de poder que se encontram 
em constante movimento e mudam a cada momento, apesar de que não dão lugar a um caos, mas geram, como organização e constituição, a unidade e a ordenação do Estado. Toda organização humana perdura enquanto constantemente renasce. ${ }^{53}$

Para Heller, é necessário distinguir "a Constituição não normada [normalidade] e a normada [normatividade], e dentro desta, a normada extrajuridicamente e a que o é juridicamente" ${ }^{, 54}$. A relação entre o ser e o dever ser da Constituição é recíproca, pois, de um lado, a normalidade cria normatividade, mas, por outro lado, a normatividade cria normalidade.

\footnotetext{
Sobre a infra-estrutura da Constituição não normada, e influída essencialmente por esta infra-estrutura, ergue-se a Constituição formada por normas na qual, ao lado da tradição e do uso, desempenham o seu papel peculiar, a função diretora e preceptiva, que têm caráter autônomo e que, com frequência, decidem contra o tradicional. ${ }^{55}$
}

A norma constitucional pode se transformar pela mudança de conteúdo dos elementos normados não jurídicos (princípios constitucionais e princípios gerais de direito), pois a ausência de conteúdo preciso seria a característica que torna possível que os princípios evoluam e desempenhem uma função transformadora da Constituição.

Hermann Heller acredita que a normatividade do sistema constitucional está sempre procurando adequar-se à normalidade. Quando essa operação tem sucesso, preserva-se a continuidade do ordenamento. Porém, pode ocorrer que a normalidade não seja incorporada nem pelas normas não jurídicas (princípios) nem pelo normado juridicamente, e que se mantenha em oposição a eles. Em outras palavras, a normatividade pode perder sua capacidade normalizadora e a realidade não normada pode revelar-se mais forte que a norma estatal ${ }^{56}$. A mudança informal, para o autor, estaria dentro da concepção dinâmica da Constituição por meio de elementos não normados que contribuiriam para transformála, sem que sejam operados mecanismos formais de reforma constitucional.

O questionamento que se faz à teoria de Heller é que a mutação, para ele, poderia ocorrer ainda quando a realidade social fosse contrária aos ditames da norma constitucional, gerando as denominadas "mutações inconstitucionais".

\footnotetext{
${ }^{53}$ HELLER, Hermann. Teoria do Estado. São Paulo: Mestre Jou, 1968, p. 295. Trad. Lycurgo Gomes da Motta.

${ }^{54}$ Ibidem, p. 296.

${ }^{55}$ Ibidem, p. 296.

${ }^{56}$ URRUTIA, Ana Victoria Sánchez. Mutación constitucional y fuerza normativa de la Constitución. Op. cit., p. 118 . Nota 431.
} 
Sem embargo, esse problema pode ser resolvido por um sistema de controle de constitucionalidade - que viria a ser desenvolvido, posteriormente, nos países da Europa ocidental - pois, ainda que a mutação constitucional tenha os seus limites, devendo o aplicador da norma observá-los, não será o fenômeno descaracterizado desde que suas características essenciais estejam presentes, podendo, se necessário, ser detectada a sua inconstitucionalidade em momento posterior, assim como ocorre com as leis infraconstitucionais.

Rudolf Smend (1882-1975), por seu turno, entende que o Estado é integração e a Constituição é o ordenamento jurídico dessa integração; que a norma constitucional não pode abarcar tudo, mas é um elemento controlador das forças sociais que estão em constante mudança; que ao contrário da interpretação jurídica das normas infraconstitucionais, a interpretação constitucional deve ser flexível, devido à natureza expansiva e elástica das normas constitucionais; que a própria Constituição contém os elementos para sua transformação por meio de mutação constitucional. ${ }^{57}$

$\mathrm{Na}$ visão do autor, como as forças políticas reais são capazes de modificar a Constituição, são elas também forças criadoras do Direito. Explica Smend que

\begin{abstract}
cualquier ciencia del espíritu que atienda únicamente al elemento vitalista y organicista siguiendo la metodología monista propia de las ciencias de la naturaleza o que, por el contrario, se ocupe exclusivamente del contenido atemporal o ideal, como hace la lógica de normas de la Escuela de Viena, no llega a captar la verdadera naturaleza del objeto; es necesario considerar al objeto, por el contrario, en toda su ambivalencia, como estructura orgánica ideal, desde la perspectiva de un pensamiento que abarque ambas dimensiones. ${ }^{58}$
\end{abstract}

A Constituição não pode prever nem regular todos os aspectos da vida estatal, pois a dinâmica da vida gera constantemente situações não previstas no texto constitucional. Por isso, é característica própria das fórmulas constitucionais sua elasticidade e enorme capacidade autotransformadora e supletiva de suas próprias lacunas:

Por su própia naturaleza la Constitución no tiende, así pués, a regular supuestos concretos, sino a abarcar la totalidad del Estado y la totalidad del proceso integrador. Y es esta misma finalidad la que no sólo permite, sino que incluso exige del intérprete constitucional una interpretación extensiva y flexible, que difiere en gran medida de cualquier otra forma de interpretación jurídica. ${ }^{59}$

\footnotetext{
${ }^{57}$ URRUTIA, Ana Victoria Sánchez. Mutación constitucional y fuerza normativa de la Constitución. Op. cit. , p. 123.

${ }_{58}$ SMEND, Rudolf. Constitución y derecho constitucional. Madrid: Centro de Estudios Constitucionales, 1985, p. 130. Trad. José Maria Beneyto Pérez.

${ }^{59}$ Ibidem, p. 134.
} 
Rudolf Smend apresenta a mutação constitucional como um elemento central do seu conceito de Constituição e não como um problema, visto que ela é considerada movimento, processo de integração da qual a mudança informal é inerente.

Hsü Dau-Lin (1906-1973) foi discípulo de Smend e teve como mérito sintetizar e sistematizar os trabalhos sobre mutação constitucional conhecidos até então. A grande contribuição do autor foi ter se preocupado em estudar especificamente o fenômeno, ao invés de proceder como aqueles que somente se referiram ao conceito de maneira genérica como parte do conceito de Constituição, como fez Smend, ou como aqueles que descobriram sua existência e mostraram sua perplexidade diante delas, como Laband e Jellinek.

Para Dau-Lin, a mutação decorre da separação entre o preceito constitucional e a realidade, sendo esta última mais ampla que a normatividade constitucional. Segundo o jurista,

\begin{abstract}
hay mutaciones constitucionales permitidas y exigidas por la Constitución. Son, precisamente, complemento y ampliaciones del sistema significativo propuesto por ella de manera ideal, y hay mutaciones, que por cierto no son intencionadas o deseadas por la Constitución, pero que no pueden impedirse ni suprimirse: son mutaciones del sistema de sentido propuesto por ella o de algunas instituciones normativizadas de intenciones manifestadas en el sistema. ${ }^{60}$
\end{abstract}

Hsü Dau-Lin sintetiza as distintas relações que podem existir entre as normas constitucionais e a realidade. Uma possibilidade consiste na congruência entre a norma e a realidade, correspondente a duas dinâmicas distintas: quando a realidade segue a norma, o que supõe a plena vigência do direito constitucional, e quando a norma segue a realidade, como ocorre em uma reforma constitucional. A outra possibilidade consiste na incongruência entre norma e realidade, onde reside a mutação constitucional.

A mutação é o resultado da incompletude e da elasticidade das normas constitucionais, das peculiaridades do Estado como objeto da regulação jurídica e da falta de uma instância superior que garanta a existência da Constituição. Essa forma de modificação constitucional pode ocorrer mediante prática que não vulnera formalmente a Constituição escrita; por impossibilidade do exercício de determinada atribuição descrita

${ }^{60}$ DAU-LIN, Hsü. Mutación de la constitución. Bilbao: Instituto Vasco de Administración Pública, 1998, p. 36. Trad. Pablo Lucas Verdú e Christian Förster. 
na Constituição; em razão de prática que contraria a Constituição; e mediante interpretação da Constituição.

No primeiro caso, contradiz-se uma prescrição constitucional ou um princípio da Constituição resultante do sistema geral de normas constitucionais, pois se tratam de relações jurídicas que não se regulam por um preceito constitucional.

Dau-Lin acredita que não existem lacunas constitucionais para quem concebe a Constituição como uma unidade espiritual de sentido. Os casos de mutação constitucional por meio de prática que não viola a Constituição não são supostos de lacunas constitucionais, mas surgem pela existência de uma nova situação jurídica que não corresponde ao sentido da Constituição. ${ }^{61}$

Na segunda hipótese, a mutação decorre da eventual impossibilidade de exercer competências de poder que correspondam ao conteúdo de certas prescrições constitucionais. O direito que atribui os artigos constitucionais a certos sujeitos se perde ante a impossibilidade de exercê-los, de modo que estes artigos da Constituição já não correspondem atualmente à realidade jurídica.

Nas palavras de Hsü Dau-Lin

La comprabación de que una proposición constitucional experimenta una
mutación por la imposibilidad de ejercer los derechos que estatuye, o por su
aplicación, plantea la cuestión de cómo una proposición jurídica pierde validez
porque no se aplica, de modo que se convierte en proposición jurídica
"obsoleta". ${ }^{2}$

Nessa situação, do ponto de vista da realidade jurídico material, a norma perde a vigência e poder ser considerada, inclusive, inconstitucional.

A terceira possibilidade de mutação decorre de prática que contraria claramente os preceitos da Constituição,

\begin{abstract}
sea por la llamada reforma material de la Constitución, sea por la legislación ordinaria, sea por todos reglamentos de los órganos estables superiores o por su práctica efectiva. La situación de tensión es clara aquí, porque la contradicción entre el Sein (ser) y el deber ser (Sollen) es inequívoca. ${ }^{63}$
\end{abstract}

E o último caso é quando a mutação constitucional se dá meio de interpretação. Ocorre quando os preceitos constitucionais são interpretados segundo considerações e

61 URRUTIA, Ana Victoria Sánchez. Mutaciones constitucionales. Tese (Doutorado). Universidad de Barcelona, 1998, p. 10.

${ }^{62}$ DAU-LIN, Hsü. Op. cit., p. 36.

${ }^{63}$ Ibidem, p. 39. 
necessidades que mudam com o tempo, sem atender particularmente ao texto fixo da Constituição, ou sem que se considere o sentido originário que o constituinte deu às normas em questão. $\mathrm{O}$ texto constitucional permanece intacto, mas a prática constitucional que pretende segui-la é distinta. ${ }^{64}$

Todos esses autores até então mencionados adotavam um conceito amplo e genérico de mutação constitucional, compreendendo-a como uma situação de discrepância entre a Constituição e a realidade constitucional.

Esse conceito foi alvo de críticas, visto que "não permite estabelecer diferenças entre o desenvolvimento constitucional, a mudança informal da Constituição e a transgressão e negação da Constituição". 65

Com o desenvolvimento e fortalecimento dos sistemas de controle de constitucionalidade e a afirmação do entendimento de que as Constituições são normas jurídicas, a doutrina passou a adotar um conceito mais restrito de mutação constitucional, com especial relevo para Konrad Hesse e Friedrich Müller.

Nesse sentido, a mutação constitucional tem sido compreendida como um fenômeno por meio do qual se produzem alterações de significado, alcance ou sentido das normas constitucionais desde que dentro dos limites estabelecidos pela própria Constituição. Essa limitação imposta pela ordem constitucional é o que torna a mutação um processo absolutamente legítimo de evolução constitucional.

Utilizando-se da terminologia adotada por Friedrich Müller, as normas constitucionais seriam o resultado da combinação entre o programa normativo (Normaprogram) e o "âmbito normativo" (Normbereich) e as mutações seriam alterações ocorridas no âmbito normativo (recorte da realidade que se pretende normatizar), em virtude de evoluções da sociedade, comportadas pelo "programa normativo" (texto da norma, norma escrita com caráter abstrato), as quais devem ser aferidas no processo de densificação e concretização das normas. Portanto, as mudanças informais somente seriam válidas se abrangidas pelo "programa normativo", não podendo violar a letra e nem o espírito da Constituição.

Nessa direção, Konrad Hesse esclarece que

a concretização de conteúdo de uma norma constitucional, assim como a sua realização, somente resulta possível incorporando as circunstâncias da "realidade" que essa norma é chamada a regular. As particularidades, muitas

\footnotetext{
${ }^{64}$ DAU-LIN, Hsü. Op. cit., p. 45.

${ }^{65}$ URRUTIA, Ana Victoria Sánchez. Mutaciones constitucionales. Tese (Doutorado). Op. cit., p. 10.
} 
vezes, já moldadas juridicamente, dessas condições formam o "âmbito da norma" que, da totalidade das realidades, afetadas por uma prescrição, do mundo social, é destacado pela ordem, sobretudo expressada no texto da norma, o "programa da norma", como parte integrante do tipo normativo. Como essas particularidades, e com elas o "âmbito da norma", estão sujeitas às alterações históricas, podem os resultados da concretização da norma modificar-se, embora o texto da norma (e, com isso, no essencial, o "programa da norma") fique idêntico. Disso resulta uma "mutação constitucional" permanente, mais ou menos considerável, que não se deixa compreender facilmente e, por causa disso, raramente fica clara. ${ }^{66}$

O autor sustenta que o limite da mutação é a própria Constituição, ou seja, a mudança informal não pode estar em contradição expressa com o texto constitucional, nem como o seu espírito finalístico.

No Brasil, em obra pioneira sobre o assunto, Anna Cândida da Cunha Ferraz expressou o seu entendimento de que o fenômeno da mutação constitucional consiste

[...] na alteração, não da letra ou do texto expresso, mas do significado, do sentido e do alcance das disposições constitucionais, por meio ora da interpretação judicial, ora dos costumes, ora das leis, alterações essas que, em geral, se processam lentamente, e só se tornam claramente perceptíveis quando se compara o entendimento atribuído às cláusulas constitucionais em momentos diferentes [...] ou em épocas distintas e diante de circunstâncias diversas. [...] Trata-se pois de uma mudança constitucional que não contraria a Constituição, ou seja, que indireta ou implicitamente é acolhida pela Lei Maior. [...] a alteração da Constituição se processa por modo ou meio diferentes das formas organizadas de Poder Constituinte instituído ou derivado. ${ }^{67}$

Uadi Lammêgo Bulos define a mutação constitucional como sendo

o processo informal de mudanças da Constituição, por meio do qual são atribuídos novos sentidos, conteúdos até então não ressaltados à letra da Lex Legum, quer através da interpretação, em suas diversas modalidades e métodos, que por intermédio da construção (construction), bem como dos usos e costumes constitucionais. $^{68}$

De acordo com Adriana Zandonade, a mutação constitucional consiste na alteração da Constituição segundo um processo informal, na medida em que não se encontra prevista no próprio conjunto das normas constitucionais, em contraposição aos processos formais, porque estão naquele expressamente regulados, como, por exemplo, as emendas

\footnotetext{
${ }^{66}$ HESSE, Konrad. Elementos de direito constitucional da República Federativa da Alemanha. Op. cit., p. 48.

${ }^{67}$ FERRAZ, Anna Cândida da Cunha. Processos informais de mudança da Constituição. Op. cit., p. 9-11.

${ }^{68}$ BULOS, Uadi Lammêgo. Mutação constitucional. São Paulo: Saraiva, 1997, p. 57.
} 
constitucionais. Conforme a autora, "na sua acepção formal, mutação é o processo de alteração, e na acepção material, o resultado desse mesmo processo". ${ }^{69}$

É importante salientar que se não existisse o procedimento de mutação constitucional, a Lei Fundamental ou se manteria estática ou dependeria de contínuas alterações formais, por meio das emendas e das revisões constitucionais, para se adaptar às mudanças inerentes à evolução das sociedades.

Nas palavras de Zandonade, a mutação, como mecanismo informal de reforma, é a ponte que mantém a Constituição aberta ao tempo e que conduz à “valorização do próprio sentimento constitucional, alimentando a consciência constitucional na medida em que favorece a sua estabilidade, a sua permanência, mas como um texto vivo e atento às modificações sociais". ${ }^{70}$

Para Konrad Hesse, a concretização do conteúdo de uma norma constitucional somente resulta possível por meio da incorporação das circunstâncias da realidade que essa norma é chamada a regular. Essas circunstâncias se modificam porque são conformadas pela dinâmica das relações sociais, num processo histórico que, essencialmente mutante, determina modificações também no resultado da aplicação da Constituição, ainda que se mantenha inalterado o seu texto. ${ }^{71} \mathrm{Na}$ verdade, a mutação é um processo informal porque ela é conseqüência da informalidade das alterações que se verificam na realidade cotidiana, regida pela Constituição.

A mutação constitucional (Verfassungswanderlung, em alemão) não apresenta designação uniforme, sendo denominada de diferentes formas, como transição constitucional ou revisão informal $\left(\right.$ Canotilho $^{72}$ ), vicissitude constitucional tácita (Jorge Miranda ${ }^{73}$ ), processos não formais (Biscaretti Di Ruffia ${ }^{74}$ ), processos oblíquos ou processos não formais ou informais (Anna Cândida da Cunha Ferraz ${ }^{75}$ ); mudança material (Pinto Ferreira ${ }^{76}$ ).

Na França, onde o fenômeno não alcançou desenvolvimento significativo, foi denominado de coutume constitucionnelle (costume constitucional). Na Espanha, país que

\footnotetext{
${ }^{69}$ ZANDONADE, Adriana. Op. cit., p. 200.

${ }^{70}$ Ibidem, p. 195.

${ }^{71}$ HESSE, Konrad. Elementos de direito constitucional da República Federativa da Alemanha. Op. cit., p. 48.

${ }^{72}$ CANOTILHO, J. J. Gomes. Direito constitucional. Op. cit..

${ }^{73}$ MIRANDA, Jorge. Manual de direito constitucional. Op. cit.

74 BISCARETTI DI RUFFIA, Paolo. Diritto constituzionale: istuzioni di diritto pubblico. 10 ed. Napoli: Jovene, 1974.

${ }^{75}$ FERRAZ, Anna Cândida da Cunha. Processos informais de mudança da Constituição. Op. cit., 1986.

${ }^{76}$ FERREIRA, Luís Pinto. Curso de direito constitucional. São Paulo: Saraiva, 1984.
} 
sofreu forte influência da doutrina alemã sobre o tema, é chamado de mutaciones constitucionales. Na Itália, predomina o termo "processos de fato".

$\mathrm{Na}$ presente tese, embora não haja o objetivo de um rigorismo técnico-jurídico, as expressões ora mencionadas serão utilizadas como sinônimas, dando-se preferência para o termo "mutação constitucional", em virtude de ser a denominação utilizada pelas doutrinas originárias do instituto e ser a mais adotada nos estudos atuais sobre o tema.

\subsubsection{Fundamento jurídico-político das mutações constitucionais}

Demonstrada a existência das mutações constitucionais, por meio do estudo da sua evolução histórica, e fixado o seu conceito, surge a necessidade de se analisar o fundamento jurídico dessas alterações de sentido das normas constitucionais.

Inicialmente, deve-se salientar que as mutações constitucionais não são a manifestação do Poder Constituinte originário, visto que não têm o condão de criar uma nova Constituição, e nem encontram fundamento no Poder Constituinte derivado, pois não tem o intuito de modificar o texto constitucional, nem de estabelecer uma Constituição estadual.

Anna Cândida da Cunha Ferraz ${ }^{77}$ entende que a justificação e fundamento jurídico das alterações constitucionais havidas mediante processos informais é o poder constituinte difuso.

O jurista francês Georges Burdeau, citado por Anna Cândida, explica que

se o poder constituinte é uma força que faz ou transforma as constituições, é necessário admitir que sua ação não é limitada às modalidades juridicamente organizadas de seu exercício. Na verdade, ele não cessa jamais de agir. Percebese geralmente esta ação permanente quando se qualifica o costume constitucional [...]. Há um exercício cotidiano do poder constituinte que, por não estar registrado pelos mecanismos constitucionais, não é menos real [...]. Mais que sobre a elegância ou lógica dos textos, a solidez de um regime político se apóia no plebiscito jornalístico pelo qual a opinião faz a Constituição se transformar viva, ou seja, aplicável em certas de suas disposições, em desuso ou inoportuna em outras. Sem dúvida alguma, convém não exagerar a cargar dessas observações e de concluir apressadamente a validade da Constituição no sentido formal do termo, e sem dúvida também não é possível analisar as formas de exercício desse poder constitucional discreto e não denominado, uma vez que não saberíamos isolá-los de todo o contexto da vida política que os envolve. Todavia, me parece que a ciência política deve mencionar a existência deste

\footnotetext{
${ }^{77}$ FERRAZ, Anna Cândida da Cunha. Processos informais de mudança da Constituição. Op. cit., p. 10.
} 
"poder constituinte difuso", que nenhum procedimento consagra, mas, se não fosse por ele, a Constituição oficial e visível não teria outro conhecimento que aquele dos registros de arquivo. Fiel aos métodos tradicionais, nós analisaremos o exercício do Poder Constituinte segundo suas formas codificadas, mas sem esquecer que, mesmo sendo mais visíveis, talvez não sejam os métodos mais perfeitos nem as mais eficazes. ${ }^{78}$

Para José Alfredo de Oliveira Baracho, a mutação constitucional "é uma das formas da manifestação do Poder Constituinte em sentido amplo, considerado como um processo permanente e não temporariamente delimitado". 79 Já Carmen Lúcia Antunes Rocha se refere ao Poder Constituinte "espontâneo e informal, que brota na sociedade e se realiza ao Estado pelo movimento de depuração social" 80 .

As alterações que resultam de mutação constitucional são, portanto, uma derivação do Poder Constituinte originário, exercido de modo difuso e informal, não para estabelecer uma Constituição, mas para atender à exigência de um exercício contínuo da tarefa de possibilitar a efetiva aplicação da Constituição já estabelecida.

Esse poder constituinte é inorganizado e exercido de modo difuso, tanto pelos poderes instituídos (convenções, práticas constitucionais e atos normativos emanados dos Poderes Legislativo e Executivo e construções jurisprudenciais operadas pelo Poder Judiciário), quanto por figuras não estatais (como a doutrina, os grupos de pressão, etc.).

Por seu turno, o fundamento lógico das mutações constitucionais seria a necessidade de se ter mecanismos que visam assegurar a máxima efetividade da Constituição. Nas palavras de Anna Cândida da Cunha Ferraz

\begin{abstract}
A Constituição é obra que nasce para ser efetivamente aplicada, sobretudo naquilo que tem de essencial, e o essencial, por vezes incompleto, exigindo atuação ulterior capaz de defini-lo, precisá-lo, resolver-lhe obscuridades, dar-lhe continuidade e aplicação, sem vulnerar a obra constitucional escrita. ${ }^{81}$
\end{abstract}

Portanto, pode-se dizer que as mutações constitucionais encontram fundamento em um Poder Constituinte difuso, que decorre implicitamente do Poder Constituinte originário e se caracteriza por ser informal, espontâneo e permanente, podendo ser exercido por todos

78 BURDEAU, Georges. Traité de science politique. 2 ed. Paris: Librarie Générale de droit et de jurisprudence, 1969, v. 4, p. 246-247 apud FERRAZ, Anna Candida da Cunha. Processos informais de mudança da Constituição. Op. cit., p. 10.

79 BARACHO, José Alfredo de Oliveira. Teoria geral da revisão constitucional e teoria da constituição originária. Revista de direito administrativo. Rio de Janeiro, Renovar, v. 39, n. 198, [s.d.], p. 51.

${ }^{80}$ ROCHA, Carmen Lúcia Antunes. Constituição e constitucionalidade. Belo Horizonte: Editora Lê, 1991, p. 58.

${ }^{81}$ FERRAZ, Anna Candida da Cunha. Processos informais de mudança da Constituição. Op. cit., p. 10. 
que interpretam a Constituição para adaptar o texto constitucional às transformações sociais, dentro de certos limites, possibilitando a aplicação e a efetividade máxima das normas constitucionais.

\subsubsection{Características e pressupostos das mutações constitucionais}

O objetivo da mudança informal da Constituição é acompanhar as transformações sociais que não importam na modificação substancial do texto constitucional, mas que exigem adaptação do sentido ou alcance da norma, aplicável a um caso concreto, em virtude das alterações ocorridas na realidade.

O que diferencia a mutação constitucional do assim chamado poder formal de revisão é o fato daquele mecanismo não se encontrar previsto no próprio texto constitucional, ao contrário desse, que deve se processar nos exatos limites em que regulado na Constituição. As mutações constitucionais são caracterizadas, portanto, pela informalidade, visto que ocorrem por meio da interpretação das normas constitucionais, da prática e dos costumes constitucionais, entre outros procedimentos.

Outra característica da mutação constitucional é a alteração no significado, no alcance ou no sentido da norma constitucional, sem qualquer modificação do texto constitucional escrito.

As mutações constitucionais podem ocorrer pela atividade de inúmeros agentes, englobando tanto os órgãos dos Poderes Executivo, Legislativo e Judiciário responsáveis por interpretar e concretizar a Constituição, quanto os membros da sociedade em geral.

Essas modificações informais da Constituição também estão sujeitas a limites mínimos, ou seja, não podem ofender nem o texto nem o espírito constitucional.

Anna Cândida da Cunha Ferraz ${ }^{82}$ propõe que seja denominada de mutação constitucional apenas a alteração cujo resultado não fere a Constituição e de mutação inconstitucional aquela que produz uma inconstitucionalidade. Para a autora, seriam nitidamente inconstitucionais aqueles processos informais que mudam a Constituição contra a sua letra ou o seu espírito, e anômalos os que, sem provocar modificações na letra, produzem uma alteração sobre a qual não se pode facilmente determinar se ferem, e até que ponto, o espírito da Constituição.

\footnotetext{
${ }^{82}$ FERRAZ, Anna Candida da Cunha. Processos informais de mudança da Constituição. Op. cit., p. 213.
} 
Adriana Zandonade entende que são essenciais ao fenômeno da mutação constitucional apenas as características de apresentar-se como um meio de alteração informal e a mudança gerada não atingir o texto da norma, mas tão somente o seu significado, o seu sentido ou o seu alcance, sendo que o resultado a que essas modificações conduzem no que tange à constitucionalidade ou não produzida, localizar-se-iam no âmbito do controle de constitucionalidade, assim como ocorre com as emendas constitucionais, que são produto de um processo formal de alteração. ${ }^{83}$ Assim, uma emenda não-conforme à Constituição não deixa de se constituir no resultado de um processo formal de modificação, embora, após um controle de constitucionalidade eficaz, deva ser declarada inconstitucional.

De qualquer forma, a mutação constitucional não deve ferir o espírito da Constituição, nem violar o conjunto sistemático das normas constitucionais, gerando uma deformidade de conteúdo ou de sentido do texto constitucional. Ainda que existam mutações com resultado inconstitucional, o aplicador do Direito deve tentar realizar uma interpretação constitucional se atendo aos limites do próprio texto da norma, aos princípios constitucionais e à ideia de sistema, ou seja, o norte da atuação do intérprete deve ser a conformidade com a Constituição, tal como ocorre com o processo legislativo e o processo de alteração constitucional formal.

Conforme Konrad Hesse, a existência de mutações inconstitucionais não deve ser considerada irrelevante, mas deve ser tomada em consideração, pois deve ser feito o possível para "evitar que se produza uma realidade inconstitucional ou para situar de novo a realidade de acordo com a Constituição". ${ }^{84}$

As mutações constitucionais "inconstitucionais" podem ocorrer por meio de decisões judiciais consideradas ilegais ou inconstitucionais, de leis ditas inconstitucionais ou por meio de práticas que denotam descumprimento de preceitos constitucionais.

Segundo Anna Cândida da Cunha Ferraz ${ }^{85}$ e Javier Perez-Royo ${ }^{86}$, a mutação constitucional processa-se lentamente e não pode ser percebida facilmente, mas apenas quando se examina o entendimento atribuído ao mesmo texto constitucional em épocas diferentes, em momentos cronologicamente afastados entre si. Em virtude da segurança

\footnotetext{
${ }^{83}$ ZANDONADE, Adriana. Op. cit., p. 207.

${ }^{84}$ HESSE, Konrad. Escritos de derecho constitucional. Op. cit., p. 31.

${ }^{85}$ FERRAZ, Anna Candida da Cunha. Processos informais de mudança da Constituição. Op. cit., p. 9.

86 PEREZ-ROYO, Javier. La reforma de la Constitución. Madrid: Publicaciones del Congreso de los Disputados, 1987, p. 113-114.
} 
jurídica, toda mudança abrupta na Constituição deve ser introduzida por meio da reforma constitucional e não pela mutação.

Konrad Hesse, no entanto, pondera que o fato de um grande número de mutações constitucionais ocorrerem em momentos distanciados no tempo não pode ser considerado como regra. $^{87}$

Uadi Lammêgo Bulos acredita que normalmente as mutações ocorrem lentamente e em momentos afastados no tempo, mas podem acontecer, também, mutações em momentos próximos temporalmente ${ }^{88}$, posicionamento o qual se adota na presente tese.

Realmente, percebe-se que o ritmo das alterações informais varia em cada época e lugar, na proporção em que modifica o ritmo das transformações sociais e políticas de cada comunidade, citando-se, como exemplo, a alta frequência das transformações espontâneas e informais constatadas na Suprema Corte norte-americana no período que se estende do final do século XIX até a primeira década do século XX, acompanhando o vertiginoso desenvolvimento da técnica e da economia capitalistas.

Ao lado das características específicas das mutações constitucionais, deve-se apresentar, de forma sintética, alguns pressupostos ${ }^{89}$ que possibilitam a ocorrência desse fenômeno.

Um dos pressupostos mais importantes para a realização e proliferação das mutações em um dado país é o grau de abertura da Constituição.

As Constituições se situam no vértice da pirâmide normativa e apresentam um maior grau de abertura, o que torna indispensável a atuação dos aplicadores do Direito no sentido de concretizar os preceitos normativos.

A Constituição, enquanto um sistema aberto de normas, apresenta uma abertura vertical, em virtude do caráter geral e indeterminado de muitas normas constitucionais, e horizontal, em razão da incompletude e do caráter fragmentário do texto constitucional.

A abertura de uma Constituição pode ser observada no caráter mais ou menos principiológico de suas normas; na maior ou menos frequência em que há necessidade de harmonização das normas constitucionais; na existência de normas que necessitam de regulamentação posterior; e na existência de lacunas constitucionais.

\footnotetext{
${ }^{87}$ HESSE, Konrad. Escritos de derecho constitucional. Op. cit., p. 86-87.

${ }^{88}$ BULOS, Uadi Lammêgo. Op. cit., p. 63.

89 Anna Cândida da Cunha Ferraz menciona os fatores que influenciam na existência das mutações constitucionais: o caráter sintético, genérico e esquemático das normas constitucionais; a linguagem do texto constitucional; a existência de lacunas e obscuridades; a existência de diferentes categorias de normas constitucionais; os diferentes métodos interpretativos; e o conteúdo político das normas constitucionais. Cf. FERRAZ, Anna Candida da Cunha. Processos informais de mudança da Constituição. Op. cit., p. 62-63.
} 
Os princípios constitucionais são normas jurídicas que apresentam uma maior abertura, um maior grau de abstração e, consequentemente, uma menor densidade jurídica em comparação com as demais normas do ordenamento jurídico, conferindo ao intérprete um significativo espaço de discricionariedade na sua aplicação. ${ }^{90}$

Os direitos fundamentais estão dispostos na Constituição em normas constitucionais com estrutura principiológica, possibilitando, portanto, a atuação do aplicador do Direito no sentido de concretizá-los, em um significativo espaço de discricionariedade, favorecendo a ocorrência de mutações constitucionais.

As normas plasmadas na Constituição representam os anseios e interesses das sociedades democráticas e, por isso, é inevitável o surgimento de tensões entre os bens jurídicos tutelados por meio dessas normas, sobretudo no que tange às normas que embasam os direitos fundamentais.

Assim, para manter o caráter unitário da Constituição foram desenvolvidos mecanismos que visam promover, por meio de um juízo de ponderação, a harmonização ou a concordância prática dos interesses em conflito em cada caso concreto, evitando-se, assim, a exclusão absoluta de qualquer um dos bens jurídicos envolvidos.

As normas constitucionais, consoante tradicional distinção desenvolvida por José Afonso da Silva ${ }^{91}$ e já apresentada no capítulo 2 dessa tese, são classificadas em normas de eficácia plena, normas de eficácia contida e normas de eficácia limitada.

As primeiras, desde a entrada em vigor da Constituição, já têm a possibilidade de produzir todos os efeitos essenciais que o legislador constituinte quis regular. As de eficácia contida são as que o legislador constituinte regulou suficientemente os efeitos, mas deixou margem a uma atuação restritiva por parte do legislador infraconstitucional, nos termos em que a lei estabelecer ou nos termos dos conceitos gerais nela enunciados. E as normas de eficácia limitada apresentam aplicabilidade mediata ou reduzida, porquanto para surtir todos os efeitos para os quais foi criada é necessária a atuação do Poder Público, seja o legislador infraconstitucional ou o administrador público.

Nos casos das normas de eficácia contida e das normas de eficácia limitada, a atuação do Poder Público na concretização normativa pode variar ao longo do tempo, alterando o sentido, o significado e o alcance dessas normas, sem que o texto constitucional seja modificado. As normas de eficácia plena não dependem de legislação posterior para sua inteira operatividade, motivo pelo qual não exigem a elaboração de

\footnotetext{
${ }^{90}$ BARROSO, Luís Roberto. Interpretação e aplicação da Constituição. Op. cit., p. 107.

${ }^{91}$ SILVA, José Afonso. Op. cit., p. 101.
} 
normas legislativas que lhes complete o sentido ou o alcance, embora, esporadicamente, possa ser criada legislação que venha aclarar o sentido do preceito normativo e, com isso, ocorrer mutação constitucional.

É importante ressaltar, finalmente, que a Constituição inegavelmente possui omissões e lacunas conscientes (aqueles que o legislador constituinte conscientemente, por alguma razão, deixou de regular a matéria) e inconscientes (aquelas produzidas porque era impossível prever, no momento da promulgação da Constituição, o advento de determinada necessidade).

A existência de lacunas constitucionais influi na ocorrência e na intensidade das mutações, pois, por meio da interpretação ou dos costumas, abre espaço para o desenvolvimento, a complementação e a alteração do significado, alcance ou sentido das normas constitucionais.

Além da abertura das normas constitucionais, outro pressuposto que influencia na maior ou menor incidência das mutações constitucionais em um país é o grau de rigidez da Constituição.

Quanto maiores forem as dificuldades impostas para a alteração formal de um texto constitucional, em comparação com o procedimento previsto para as demais normas do ordenamento jurídico, ou seja, quanto maior a rigidez constitucional, maior a tendência em se alterar a Constituição por meio das vias informais. ${ }^{92}$

Segundo Adriana Zandonade ${ }^{93}$, esse meio de alteração constitucional encontra ambiente mais propício no sistema de constituições rígidas, que representam uma excelente via alternativa de adaptação da Constituição à realidade, quando a via formal, oferecida pelo próprio sistema, estabelece freio às mudanças, pela complexidade do processo que propõe.

Ademais, quanto maior o número de reformas constitucionais, menor o número de mudanças informais da Constituição, embora Anna Cândida da Cunha Ferraz ressalte que mesmo nos países que aprovam emendas constitucionais com frequência, a via da mutação por meio da interpretação constitucional é necessária e inegável. ${ }^{94}$

Outro fator que influi na ocorrência e intensidade das mutações constitucionais é a existência de um mecanismo de controle de constitucionalidade dos atos normativos. Normalmente, é atribuído ao Poder Judiciário o dever de rever os atos emanados pelos

\footnotetext{
${ }^{92}$ URRUTIA, Ana Victória Sanchez. Mutaciones constitucionales. Tese (Doutorado). Op. cit., p. 12.

${ }^{93}$ ZANDONADE, Adriana. Op. cit., p. 206.

${ }^{94}$ FERRAZ, Anna Candida da Cunha. Processos informais de mudança da Constituição. Op. cit., p. 59.
} 
Poderes Executivo e Legislativo a fim de adequar o seu sentido à norma constitucional (judicial review) e, quando isso não for possível, esses atos deverão ser extirpados do ordenamento jurídico.

Nos EUA, primeiro país onde foi criado um sistema de constitucionalidade das leis (em 1803), o procedimento de reforma constitucional é bastante complexo, de modo que o Poder Judiciário, em especial a Supre Corte, adquiriu um importante papel como atualizadora das normas constitucionais.

Sem embargo, apenas na segunda metade de século XX é que foram criados Tribunais Constitucionais, em diversos países europeus, encarregados de exercer o controle concentrado de constitucionalidade das leis.

Assim, até antes da metade do século XX, as mutações constitucionais ocorriam, em grande parte, por meio de leis, atos normativos e práticas constitucionais e, após a metade daquele século, a maioria das mutações passou a ocorrer por meio da atuação do Poder Judiciário, em especial no âmbito do controle de constitucionalidade.

Finalmente, pode-se traçar uma relação entre a maior frequência na ocorrência das mutações constitucionais e o fato de o país adotar uma Constituição sintética. Dessa forma, quanto mais detalhista for o texto constitucional, maior a possibilidade dele se inviabilizar, em virtude de ideologias e imperativos econômicos distintos daqueles que o estabeleceram, e, quanto mais sintético e processual, maior a possibilidade de adaptação das normas genéricas aos anseios da sociedade, sem a necessidade de alterações em seu texto.

No Brasil, apesar da adoção de uma Constituição mais analítica, ocorrem as mutações constitucionais com certa frequência, em especial em matéria de direitos fundamentais.

\subsubsection{Modalidades de mutação constitucional}

Não há consenso na doutrina no que tange à sistematização dos tipos de processos informais de mutação constitucional.

Anna Cândida da Cunha Ferraz, adotando a classificação de Biscaretti Di Ruffia ${ }^{95}$, agrupa as mutações constitucionais em dois grupos, quais sejam, modificações operadas

${ }^{95}$ BISCARETTI DI RUFFIA, Paolo. Diritto constituzionale: istuzioni di diritto pubblico. 10 ed. Napoli: Jovene, 1974, p.60-68 apud FERRAZ, Anna Candida da Cunha. Processos informais de mudança da Constituição. Op. cit., p. 213. 
em virtude de atos elaborados por órgãos estatais (de caráter normativo e de natureza jurisdicional) e modificações produzidas em virtude de fatos (de caráter jurídico, como os costumes, ou de natureza político-social, como as normas convencionais, as regras de conduta correta frente à Constituição e as práticas constitucionais).

Para Carmen Lúcia Antunes Rocha ${ }^{96}$, as vias pelas quais se realizam as mutações constitucionais são a interpretação, que pode sofrer alterações segundo se modifiquem o significado, a extensão ou a forma de aplicação das normas constitucionais, os costumes e até mesmo as leis.

$\mathrm{Na}$ presente tese, defende-se a existência de mutações constitucionais realizadas pela via da interpretação constitucional pelos órgãos do Estado, ou seja, pelo legislador, pelo Poder Judiciário e pela Administração Pública, e por agentes não pertencentes ao Poder Público - a chamada interpretação inorgânica, bem como as mutações que ocorrem por meio do costume constitucional.

As normas constitucionais têm um maior grau de abertura e abstração, sendo que muitas delas apresentam estrutura principiológica, que implica a polissemia e a indeterminação de significados. Essas normas são elaboradas, em regra, em meio a conflitos ideológicos, em virtude dos inúmeros valores embutidos nas sociedades democráticas, de modo que o consenso é obtido por meio de enunciados redigidos em termos pouco precisos e até mesmo colidentes entre si. ${ }^{97}$

Justamente em virtude da sua estrutura, as normas constitucionais exigem uma interpretação que as densifique, precise ou as complemente, interpretação que assume, muitas vezes, uma função criadora na medida em que o intérprete se vê obrigado a preencher, com pautas valorativas e opções ideológicas próprias, o espaço aberto que o constituinte conscientemente ou não deixou.

Na realidade, a interpretação implica um juízo decisório, pois atribui sentido à norma, dentro de uma esfera de várias decisões viáveis. Essa escolha discricionária por parte do intérprete implica inevitavelmente na criação de regras jurídicas. ${ }^{98}$ Não busca o

\footnotetext{
${ }^{96}$ ROCHA, Carmen Lúcia Antunes. Op. cit., p. 59.

97 A redação de normas constitucionais em termos pouco precisos pelo legislador constituinte pode ocorrer em duas situações. Existem determinadas questões que, por motivo de ordem pública ou técnica, o constituinte não tem condições de decidir no momento da elaboração da norma constitucional. Com isso, introduz tais questões na Constituição, mas deixa sua solução em aberto para a complementação ou harmonização posterior (pela legislação infraconstitucional, pelos Tribunais Constitucionais, etc.). Em outros casos, o constituinte introduz determinadas normas da Constituição apenas e tão somente para satisfazer os anseios momentâneos de determinados grupos de pressão, mesmo sabendo que a norma resultante terá baixo grau de eficácia.

${ }_{98}$ BARROSO, Luís Roberto. Interpretação e aplicação da Constituição Op. cit., p. 163.
} 
aplicador do Direito, portanto, investigar o significado "verdadeiro" da norma, até porque muitas vezes o intérprete não conseguirá aferir qual a mens legis ou a volunta legis da época em que o preceito normativo foi elaborado. Ademais, o sentido a ser atribuído à norma é o que melhor se coaduna com o sistema de valores e com a realidade do momento da interpretação.

Nesse sentido, Cappelletti explicita que

[...] com ou sem a consciência do intérprete, certo grau de discricionariedade, e pois de criatividade, mostra-se inerente a toda interpretação [...]. Por mais que o intérprete se esforce por permanecer fiel ao "texto", ele será sempre, por assim dizer, forçado a ser livre - porque não há texto musical ou poético, nem tampouco legislativo, que não deixe espaço para variações e nuances para a criatividade interpretativa. ${ }^{99}$

Nesse contexto é que a interpretação atua como mecanismo de mutação constitucional, visto que o intérprete, ao aclarar, complementar ou aperfeiçoar as regras e os princípios constitucionais, pode promover uma alteração no sentido, significado e alcance das normas constitucionais sem qualquer alteração do seu texto. Em outras palavras, por meio da atividade interpretativa, o aplicador apresenta novas possibilidades de incidência da norma aos casos concretos ou extrai dela consequências e princípios até então não vislumbrados, ensejando assim mudanças informais na Constituição.

A realização da mutação constitucional por intermédio da interpretação é favorecida primordialmente porque a norma constitucional é expressa em linguagem, que já é, em si, dinâmica, apresentando características como a riqueza de conceitos nãojurídicos que não apresentam uma e única significação definida, sofrendo alterações com a evolução dos tempos, como, por exemplo, os conceitos de ordem pública, interesse público, bons costumes, segurança pública, interesse social, utilidade pública, dentre outros.

A interpretação constitucional pode ser realizada por vários sujeitos. Ela pode ser promovida pelos órgãos do Poder Público, incumbidos pela Constituição, de concretizar e aplicar as normas constitucionais, desdobrando-as quanto à sua amplitude, ao seu sentido e ao seu conteúdo, imprimindo-lhes atuação efetiva, caso em que é denominada de interpretação orgânica. ${ }^{100}$

${ }^{99}$ CAPPELLETTI, Mauro. Juízes legisladores. Porto Alegre: Sérgi Antônio Fabris Editor, 1993, p. 21-22. Trad. Carlos Alberto A. de Oliveira.

${ }^{100}$ BULOS, Uadi Lammêgo. Op. cit., p. 131-132. 
A interpretação constitucional legislativa é realizada pelo legislador constitucional, por atuação do poder constituinte derivado, ou pelo legislador ordinário e tem como objetivo buscar o significado, o sentido e o alcance da norma constitucional para o fim de fixar-lhe o conteúdo concreto, completá-la e criar condições para a sua efetiva aplicação. ${ }^{101}$

Cronologicamente, a primeira interpretação é a do próprio legislador, como condição para o exercício da sua atividade legislativa. Essa interpretação não visa à solução de um caso concreto, mas, sim, a extração do verdadeiro sentido da norma para compreender o seu âmbito de atuação.

O órgão legislativo, ao promulgar uma lei, ordinária ou complementar, que tenha por objetivo disciplinar a aplicação de alguma norma constitucional, atribui um sentido concreto à referida norma, influenciando e condicionando a sua aplicação futura. ${ }^{102}$

O legislador, seja ele constitucional ou ordinário, não pode ignorar as normas constitucionais, sob pena de produzir resultados em desacordo com a Constituição que passarão pelo crivo do sistema de controle de constitucionalidade exercido pelo Poder Judiciário.

As Constituições mais sintéticas normalmente se limitam a traçar diretrizes de atuação ao intérprete nas matérias por elas redigidas, deixando ao legislador um grande espaço de atuação, enquanto as Constituições analíticas, como, por exemplo, a Constituição de 1988, cerceiam a atividade do legislador, reduzindo suas possibilidades de atuação.

Sem embargo, como os preceitos normativos da Constituição, sendo ela sintética ou analítica, são dotados de grande abertura e abstração, haverá sempre espaço para a atuação do legislador na interpretação e complementação da Lei Fundamental.

As mutações constitucionais podem ocorrer por meio da atividade legislativa, ou seja, pela edição de um ato normativo legislativo - lei complementar, lei ordinária, lei delegada, lei federal, lei especial, ou qualquer outra espécie legislativa que a Constituição definir de forma expressa como via de sua complementação - voltado para a aplicação direta de uma prescrição constitucional.

O órgão legislativo, em geral, edita normas que têm por objetivo completar a Constituição, favorecendo a sua efetiva aplicação. Contudo, o ato legislativo assim editado pode fixar o conteúdo concreto de uma norma constitucional, alterando-lhe o alcance, o sentido ou o significado, sem violar o seu texto.

\footnotetext{
${ }^{101}$ FERRAZ, Anna Candida da Cunha. Processos informais de mudança da Constituição. Op. cit., p. 65.

${ }^{102}$ Ibidem, p. 81.
} 
Nas palavras de Anna Cândida da Cunha Ferraz

\begin{abstract}
A mutação constitucional legislativa ocorre quando, por essa via, se transmuda o sentido atribuído aos conceitos fixados pela norma constitucional, para adaptá-la a realidades novas, a situações distintas, a momentos e circunstâncias sociais, políticas ou econômicas diferentes; ocorre, também, quando se altera, se amplia ou se restringe o programa apenas esboçado pela norma constitucional; ocorre, ainda, quando se preenchem vazios constitucionais, se suprem omissões, se esclarecem obscuridades, dando-se, por via legislativa, novo alcance ao texto constitucional, que irá abranger situações novas ou disciplinar, de modo atual e definido, comportamentos imprecisamente previstos na Constituição. ${ }^{103}$
\end{abstract}

Normalmente, a ocorrência da mutação constitucional pode ser observada mais frequentemente quanto às normas constitucionais de eficácia contida (que admitem uma limitação de seu alcance por meio de uma complementação legislativa) e as de eficácia limitada de princípios institutivos ou programáticos (que dependem da edição de lei para desenvolver a sua eficácia), sem, com isso, excluir a sua possibilidade de incidência nos casos de normas de eficácia plena.

É necessário salientar que as mutações constitucionais, pela via legislativa, decresceram em importância com a consolidação em diversos países do sistema de controle de constitucionalidade de leis. Antes, não existia a possibilidade jurídica de se controlar a modificação da Constituição pela ação parlamentar, uma via privilegiada de mutação constitucional. Mas, com a inserção desse controle, a lei vai se tornando mecanismo residual de modificação informal da Constituição, nos casos em que os mecanismos do sistema de controle de constitucionalidade não são acionados. ${ }^{104}$

A interpretação administrativa geralmente é realizada pelos órgãos e entidades do Poder Executivo, quando aplica diretamente a norma constitucional ou no momento de edição dos atos administrativos (decretos, regulamentos, portarias, entre outros), que servem para concretizar preceitos constitucionais relacionados à atuação da Administração Pública.

A interpretação constitucional administrativa é a mais restrita das modalidades de interpretação, tendo em vista que está limitada tanto pela Constituição, quanto pela lei, submetendo-se ao controle judicial de constitucionalidade e de legalidade, mas não deixa de ser importante, visto que objetiva aperfeiçoar as atividades desenvolvidas pela Administração Pública.

\footnotetext{
${ }^{103}$ FERRAZ, Anna Candida da Cunha. Processos informais de mudança da Constituição. Op. cit., p. 92.

${ }^{104}$ URRUTIA, Ana Victoria Sánchez. Mutaciones constitucionales. Tese de Doutorado. Op. cit., p. 381-382.
} 
Os atos administrativos também são veículos de mutação constitucional, pois, antes de editá-los, é necessária uma interpretação prévia da norma constitucional, o que pode gerar alteração do seu sentido, do seu alcance ou do seu significado. Esses atos são editados com a finalidade de complementar o conteúdo de uma norma constitucional, seja quando a atuação do administrador é determinada diretamente pela Constituição, seja quando o administrador atua para integrar ou complementar uma norma infraconstitucional, editada em razão de comando constitucional. ${ }^{105}$

A interpretação judicial ou jurisdicional é realizada pelos órgãos do Poder Judiciário, ou seja, pelos juízes, desembargadores e ministros dos Tribunais comuns e pelos ministros do Tribunal Constitucional, no caso do Brasil. ${ }^{106}$ Essa modalidade de interpretação pode ocorrer pela aplicação direta de um preceito constitucional ou pela verificação de incompatibilidade de uma norma em face da Constituição, por meio do controle de constitucionalidade.

A interpretação constitucional jurisdicional será tanto mais ampla, profunda e extensa, quanto mais concisa, sintética e genérica a Constituição, e ocorrerá com mais frequência, quanto maiores forem as limitações impostas aos poderes constituídos. ${ }^{107}$

A interpretação judicial é a via de excelência das mutações constitucionais, em virtude da frequência maior em que ocorrem em relação às mutações realizadas por meio dos órgãos e entidades da Administração Pública, do Poder Legislativo ou mesmo dos costumes. Conforme Anna Cândida da Cunha Ferraz,

mais frequentemente do que qualquer outro intérprete constitucional o juiz deve desentranhar o sentido da disposição constitucional com um fim mediato e imediato e aplicá-la, de forma adequada e razoável, no caso concreto ${ }^{108}$.

\footnotetext{
${ }^{105}$ Uadi Lammêgo Bulos menciona como exemplo de mutação constitucional, pela via administrativa, o exercício dos denominados "poderes de crise ou de emergência" pelo presidente da França, contexto em que, sem revisões ou emendas constitucionais, houve uma alteração do art. 16 da Constituição francesa de 1958. Cf. BULOS, Uadi Lammêgo. Op. cit., p. 134.

${ }^{106} \mathrm{O}$ Brasil adota o sistema de controle de constitucionalidade misto, que engloba o controle concentrado realizado pelo Supremo Tribunal Federal, cujo objeto das ações específicas é a análise da constitucionalidade da lei ou do ato normativo, e o sistema difuso, realizado por todos os Tribunais, caso em que o juiz ou desembargador dispõe de liberdade para analisar a compatibilidade da norma a ser aplicada com os preceitos da Constituição Federal de 1988.

${ }^{107}$ De qualquer forma, em virtude da consolidação dos Tribunais Constitucionais após a Segunda Guerra mundial, houve um fortalecimento da interpretação judicial constitucional em diversos países do mundo, incluindo os países da Europa continental e os Estados Unidos, onde já havia uma tradição forte nesse sentido. No Brasil, esse fenômeno se verificou mais tardiamente, após a Constituição Federal de 1988, que incrementou o sistema de controle de constitucionalidade das leis, sobretudo o sistema concentrado, e ampliou a competência do Supremo Tribunal Federal.

${ }^{108}$ FERRAZ, Anna Candida da Cunha. Processos informais de mudança da Constituição. Op. cit., p. 128.
} 
Normalmente, a doutrina menciona como formas de mutação constitucional, pela via judicial, a interpretação constitucional evolutiva e a construção judicial. Como essa modalidade de mutação constitui parte substancial do embasamento teórico da presente tese, será ela desenvolvida, especificamente, no próximo subitem desse capítulo, em virtude de sua importância vital para o processo de implementação, pelos Tribunais trabalhistas, dos direitos fundamentais do trabalhador.

De qualquer forma, por ora é importante salientar que a mutação constitucional que se verifica por intermédio de decisão judicial importa, de um lado, em uma evolução no sentido do conteúdo, do significado ou do alcance de normas constitucionais e, de outro, uma verdadeira construção jurisprudencial, com aplicação da norma "a situações não previstas expressamente no texto constitucional, mas que dele decorrem ou emanam por imperativos lógicos ou do próprio sistema constitucional"109.

A interpretação constitucional também poderá ser realizada por outros sujeitos, não componentes dos Poderes estatais, caso em que é denominada de interpretação inorgânica.

De acordo com Peter Häberle, a atividade de interpretar a Constituição é um atividade aberta, pois "todas as potências públicas, participantes materiais do processo social, estão nela envolvidas, sendo ela, a um só tempo, elemento resultante da sociedade aberta e um elemento formador ou constituinte dessa sociedade". ${ }^{110}$ Assim, são intérpretes constitucionais não apenas os órgãos estatais, mas, também, os grupos de pressão, a opinião pública e os cidadãos em geral que poderão se manifestar por meio de audiências públicas, consultas públicas e por meio da figura do amicus curiae, terceiro interessado que pode prestar informações e trazer elementos de convencimento à Corte Constitucional acerca de uma determinada controvérsia, no julgamento de uma ação no sistema de controle de constitucionalidade das leis.

É necessário ressaltar que a interpretação inorgânica não terá por meta imediata a aplicação concreta da Constituição, visando apenas dar significação ao texto constitucional. ${ }^{111}$ Todavia, em uma sociedade democrática, essa modalidade de interpretação possibilita que a sociedade participe, por meio da influência exercida sobre a atuação dos intérpretes orgânicos, da interpretação constitucional, levando a mutações constitucionais, ainda que forma indireta.

\footnotetext{
${ }^{109}$ Ibidem, p. 129.

${ }^{110}$ HÄBERLE, Peter. Hermenêutica constitucional. A sociedade aberta dos intérpretes da Constituição: contribuição para a interpretação pluralista e "procedimental" da Constituição. Porto Alegre: Sérgio Antônio Fabris, 1997, p. 14. Trad. Gilmar Ferreira Mendes.

${ }^{111}$ FERRAZ, Anna Candida da Cunha. Processos informais de mudança da Constituição. Op. cit., p. 54.
} 
Além da interpretação constitucional orgânica e inorgânica, outra modalidade de mutação constitucional é o costume constitucional.

Os costumes jurídicos, no qual se incluem os costumes constitucionais, são fatos normativos, pois, apesar de seu procedimento de elaboração e a sua forma de expressão não serem totalmente delimitados, podem ensejar o surgimento de normas consuetudinárias.

Na definição de Anna Cândida da Cunha Ferraz

[...] o costume constitucional é a expressão do Poder Constituinte difuso, atuado pelos órgãos constituídos competentes enquanto preenchem lacunas na obra constitucional originária ou interpretam-lhe disposições obscuras. Tal costume consistirá na prática constitucional, reiterada ou não, porém consentida e desejada, de determinados atos ou comportamentos, pelos poderes competentes e pelo povo, sem forma prevista ou consagrada na Constituição. Cede, todavia, diante da norma constitucional escrita. ${ }^{112}$

A autora entende possível a existência do costume constitucional mesmo nos países onde a Constituição é escrita rígida, desde que exercido dentro de certos limites pelos poderes constitucionais que o criaram. Não se admite, portanto, a formação de costume constitucional por órgão incompetente para atualizar a norma, nem de costume contra constitutionem. $^{113}$

O costume constitucional, em geral, é identificado pela reiteração de determinado comportamento ou prática ${ }^{114}$ (elemento objetivo), cuja obrigatoriedade de observância é derivada de uma convicção generalizada (elemento subjetivo). São fundados no poder constituinte difuso e são materialmente constitucionais, ou seja, normalmente não são escritos.

Ademais, os costumes podem ser de três tipos: secundum constitutionem, praeter constitutionem e contra constitutionem. No primeiro caso, o costume se forma para embasar a interpretação de uma norma constitucional escrita, desenvolvendo-a e corrigindo eventuais imperfeições e obscuridades.

\footnotetext{
${ }^{112}$ Ibidem, p. 185.

${ }^{113}$ Ibidem, p. 184.

${ }^{114}$ Embora presente na maioria dos casos, não é sempre necessária repetição para a formação de um costume constitucional, pois o que importa mais é o significado político-constitucional da prática.
} 
Na segunda hipótese, o costume intervém primordialmente no preenchimento de lacunas constitucionais, complementando as disposições da Lei Fundamental, corrigindo as omissões, intencionais ou não, do legislador constituinte. ${ }^{115}$

O costume, seja ele praeter ou secundum constitutionem, não pode substituir norma expressa da Constituição, ou seja, não pode derrogá-la, pois não possui a mesma força impositiva das normas constitucionais escritas. ${ }^{116}$

E, finalmente, o costume contra constitutionem é o que se forma mediante práticas e comportamentos nitidamente contrários às normas constitucionais escritas, ou por prática expressa em contrariedade ao texto constitucional ou pelo desuso, pela inobservância uniforme, constante e prolongada do texto escrito. Esse tipo de costume não é admitido pela doutrina em geral, sendo considerado inconstitucional. Como exemplos, pode-se dar a persistência de omissões legislativas e o desrespeito reiterado das normas orçamentárias que fixam limites de despesa com pessoal e tetos remuneratórios.

Os costumes constitucionais também se apresentam como mecanismos de mutação constitucional, pois são aptos a produzir alterações no sentido, significado e alcance das disposições constitucionais. Por meio do costume, interpretam-se as normas constitucionais, dando-lhes novos sentido e alcance; complementa-se suas disposições; preenchem-se lacunas constitucionais, criando-se normas para situações não previstas no texto, sem todavia feri-lo; suprem-se omissões, propositais ou consentidas, introduzindo-se mudanças difusas e silenciosas na Constituição.

Apresentadas as modalidades de mutação constitucional, passa-se para uma análise mais detida da interpretação constitucional realizada por meio da atividade jurisdicional, mais especificamente denominada de interpretação constitucional evolutiva.

\footnotetext{
${ }^{115}$ No Brasil, um exemplo tradicional de costume praeter constitutionem é o descumprimento, pelo Poder Executivo, de leis que repute inconstitucionais, comportamento que se consagrou pelo uso. Cf. BARROSO, Luís Roberto. Interpretação e aplicação da Constituição. Op. cit., p. 145.

${ }^{116}$ BULOS, Uadi Lammêgo. Op. cit., p. 186-187.
} 


\subsubsection{A interpretação constitucional evolutiva como modalidade de mutação constitucional via judicial}

Nesse tópico, será esmiuçado em que consiste o mecanismo de mutação constitucional denominado interpretação evolutiva, quais os seus limites de utilização no que tange à interpretação das normas constitucionais e quais são os motivos pelos quais esse fenômeno vem se desenvolvendo no Brasil, após a promulgação da Constituição Federal de 1988.

\subsubsection{Configuração}

A mutação constitucional por via judicial se revela por meio da interpretação judicial evolutiva e da construção judicial.

Existe uma corrente que sustenta que a interpretação constitucional é completamente diferente da construção constitucional, com métodos, procedimentos e resultados próprios.

Sem embargo, no Brasil, predomina a corrente que entende que a construção é uma espécie de interpretação constitucional, pois na verdade toda interpretação é uma construção, já que o intérprete não deve se ater exclusivamente ao texto, isolando-o dos princípios e valores da justiça e da moral, das contingências históricas, da evolução e das necessidades sociais. ${ }^{117}$

A construção constitucional deriva do fato de que o caráter sintético e genérico das normas exige do intérprete, em muitos casos, mais do que apenas descobrir e revelar o sentido da norma; exige que, ao aplicá-la, adapte-a à multiplicidade, à complexidade dos casos concretos e da situação histórica presente. Assim, ao buscar ajustar as normas da Constituição às modificações da sociedade em evolução, à realidade, a uma situação ou comportamento não expressamente disciplinados pelo texto constitucional, a construção constitucional enseja a introdução de modificações informais na Constituição.

Nos dizeres de Uadi Lammêgo Bulos, apesar de a construção e da interpretação serem fases de um mesmo processo, são estágio que não se confundem, pois a

\footnotetext{
${ }^{117}$ BULOS, Uâdi Lammêgo. Op. cit., p. 146.
} 
[...] interpretação stricto sensu é aquela em que o intérprete não sai do Texto Constitucional para buscar outros elementos interpretativos, diversamente da interpretação lato sensu (é o mesmo que construção), pois o intérprete extrapola os limites prescritos pelo legislador constituinte, buscando recursos através de outras fontes, totalmente alheias do articulado na Carta Maior. ${ }^{118}$

A interpretação constitucional evolutiva consubstancia-se em um processo informal de reforma do texto constitucional, sem a necessidade do exercício do poder constituinte derivado. Segundo Barroso, "consiste ela na atribuição de novos conteúdos à norma constitucional, sem modificação do seu teor literal, em razão de mudanças históricas ou fatores políticos e sociais que não estavam presentes na mente dos constituintes". 119

Ainda que haja a necessidade de acomodação dos valores inicialmente dispostos à realidade, não há como desejar que a Constituição seja revista sempre, no ato de interpretação e mesmo de atuação do Poder Constituinte derivado para modificá-lo às contingências dos fatos sociais, políticos e econômicos.

Os valores acordados pelo constituinte originário devem ser detectados, mas amoldados à atual condição social, sob pena de a Constituição não refletir o que é acordado pela sociedade em se que insere.

Essa modalidade de mutação constitucional se concretiza, muitas vezes, por meio de conceitos jurídicos indeterminados, de natureza aberta, como, por exemplo, a função social da propriedade, a redução das desigualdades, a autonomia, que podem assumir vários significados ao longo do tempo. ${ }^{120}$ Por meio da interpretação evolutiva, permite-se que o intérprete, a fim de adaptar o conteúdo do texto normativo às exigências práticas surgidas depois da sua elaboração, tenha uma atuação mais criativa e inovadora.

Anna Cândida da Cunha Ferraz ressalta a importância da interpretação evolutiva para a atualização da Constituição, citando Ramón Real ${ }^{121}$ e Linares Quintana ${ }^{122}$ :

[...] mantida dentro de seus legítimos limites, enquanto não contraria os textos e nem o sistema da Constituição, é indispensável para mantê-la viva e adaptada às necessidades do povo e do governo.

$[\ldots]$

A Constituição, enquanto instrumento de governo permanente cuja flexibilidade e generalidade permite adaptar-se a todos os tempos e circunstâncias, deve ser

\footnotetext{
${ }^{118}$ Ibidem, p. 146.

${ }^{119}$ BARROSO, Luís Roberto. Interpretação e aplicação da Constituição. Op. cit., 137.

120 Ibidem, 137.

${ }^{121}$ RAMÓN REAL, Alberto. Los métodos de interpretación constitucional. Revista de Direito Público, São Paulo, n. 53-54, 1980, p. 54 apud FERRAZ, Anna Candida da Cunha. Processos informais de mudança da Constituição. Op. cit., p. 46.

${ }^{122}$ LINARES QUINTANA, Segundo V. La constitución interpretada. Buenos Aires: Depalma, 1960, p. 17 apud FERRAZ, Anna Candida da Cunha. Processos informais de mudança da Constituição. Op. cit., p. 46.
} 
interpretada tendo-se em conta não apenas as condições e necessidades existentes no momento de sua elaboração, mas, também, as condições sociais, econômicas e políticas que existam ao tempo de sua interpretação e aplicação, de maneira que seja sempre possível o cabal cumprimento dos fins e propósitos que informam e orientam a lei fundamental do país.

A interpretação evolutiva jurisdicional pode ocorrer quando se exige simples aplicação de norma constitucional para a solução de uma lide qualquer, seja no caso em que a questão reside na própria constitucionalidade ou não de lei ou ato normativo, desde que haja a transformação do alcance, do sentido ou do significado da Constituição.

No primeiro caso, a mutação constitucional é veiculada por intermédio de decisões proferidas pelos órgãos competentes do Poder Judiciário em litígios fundados em matéria constitucional, incluindo os órgãos da Justiça do Trabalho que processam e julgam questões envolvendo os direitos fundamentais trabalhistas dispostos nos artigos $6^{\circ}$ a 11 , da Constituição Federal, e, no segundo caso, a mutação se dá por meio de decisões proferidas pelos órgãos do Poder Judiciário aos quais a Constituição defere a atribuição especial de exercer o controle de constitucionalidade de leis.

Nos EUA, a interpretação evolutiva desempenha um papel de destaque no direito e é apontada como uma das causas da longevidade e da estabilidade da Constituição do país.

Meirelles Teixeira demonstra a decisiva importância que a jurisprudência da Suprema Corte dos Estados Unidos teve na modificação das constituições rígidas, ao atribuir conteúdo concreto às cláusulas e conceitos vagos e indeterminados da Constituição.

\begin{abstract}
Há menos de cinquenta anos, leis estaduais e federais, que fixavam salários mínimos, horas de trabalho de certas indústrias, condições de trabalho das mulheres e menores, etc., foram consideradas pela Corte "interferência arbitrária na liberdade contratual". Essa jurisprudência, reflexo de um individualismo exacerbado, foi corrigida e alterada graças a trabalhos e estudos de juízes tais como Stone, Holmes, Brandeis e Cardozo e a Corte Suprema, com o tempo, acabou adotando pontos de vista mais condizentes com a realidade políticosocial e novas idéias de justiça social e solidariedade humana. Assim, frente aos mesmos conceitos e preceitos, modifica-se o sentido da Constituição, evidenciando o papel verdadeiramente criador da jurisprudência. ${ }^{123}$
\end{abstract}

No Brasil, onde a história do país é estigmatizada pela hipertrofia do Poder Executivo e por uma interpretação constitucional involutiva que convalida os abusos por ele cometidos, a longa tradição autoritária tem mantido a interpretação constitucional

123 MEIRELLES TEIXEIRA, José Horácio. Curso de direito constitucional. Rio de Janeiro: Forense Universitária, 1991, p. 29. 
evolutiva por meio do Poder Judiciário em limites bem mais contidos ${ }^{124}$, embora existam exemplos ao longo da história, como a ampliação da função do habeas corpus e o reconhecimento de direitos decorrentes da união estável, sobretudo quando ainda não havia lei regulando a matéria.

A interpretação evolutiva está intimamente ligada à efetividade das normas constitucionais e assume especial relevância na aplicação dos direitos sociais inscritos no texto constitucional. Considerada como um quarto plano de apreciação das normas jurídicas, além dos planos da existência, da validade e da eficácia, a efetividade significa a realização do Direito, a atuação prática da norma no mundo dos fatos, conforme os valores e interesses por ela tutelados, realizando a maior aproximação possível entre o dever-ser normativo e o ser da realidade social. Assim, havendo mais de uma opção possível, devese optar pela exegese conduzente à concretização endereçada à plenitude da norma. Barroso esclarece tal assertiva, afirmando que

"O intérprete constitucional deve ter compromisso com a efetividade da
Constituição: entre interpretações alternativas e plausíveis, deverá prestigiar
aquela que permita a atuação da vontade constitucional, evitando, no limite do
possível, soluções que se refugiem no argumento da não-auto-aplicabilidade da
norma ou na ocorrência de omissão do legislador". ${ }^{125}$

No exercício da interpretação constitucional evolutiva, o aplicador do Direito poderá se valer dos vários métodos de interpretação constitucional estudados, os tradicionais e os modernos, para extrair o sentido da norma que mais se coaduna à realidade político-social do momento da interpretação que, em razão de mudanças históricas, não é mais a mesma do momento da elaboração da Constituição.

A interpretação constitucional evolutiva, entretanto, não pode ser realizada de forma ilimitada, sob pena de conduzir a um desprezo dos valores da certeza e da segurança jurídicas e de retroceder em relação ao processo histórico de formação da Constituição, visto que o Constitucionalismo não é senão uma reação ao poder exercido de modo absoluto e ilimitado, "facilmente favorecido pela mutabilidade sem limites, quer materiais, quer formais, que assim poderia realizar-se ao sabor de conveniências pessoais dos que pretendem perpetuar-se no poder." ${ }^{126}$ Dessa forma, no próximo subitem serão apresentados os limites, de ordem objetiva e subjetiva, às mutações constitucionais.

${ }^{124}$ FERRAZ, Anna Cândida da Cunha. Processos informais de mudança da Constituição. Op. cit., p. 133134.

${ }^{125}$ BARROSO, Luís Roberto; BARCELLOS, Ana Paula. Op. cit., p.72.

${ }^{126}$ ZANDONADE, Adriana. Op. cit., p. 199. 


\subsubsection{Limites jurídicos à interpretação constitucional evolutiva}

Se a mutação constitucional é, de um lado, expressão do Poder Constituinte, definido como poder incondicionado, ilimitado, por outro lado é resultado de um exercício difuso, formalmente não organizado desse Poder, que não tem o objetivo de criar uma Constituição, mas tão somente de atualizar uma Constituição já existente, possibilitando a aplicação de suas normas.

Dessa forma, as mutações constitucionais apresentam limites subjetivos e objetivos à sua ocorrência.

Uadi Lammêgo Bulos acredita que a única limitação para as mudanças informais da Constituição, mas, ainda assim, de natureza subjetiva, é a consciência do intérprete em não estar desrespeitando a norma constitucional. ${ }^{127}$

Também de cunho subjetivo seria o respeito à consciência jurídica geral (ciência jurídica, bibliografia especializada, opinião pública, etc.), visto que o aplicador do direito está em situação de permanente troca com os demais atores sociais, recebendo influência direta da sociedade que o circunda. A mutação que não observa essa consciência jurídica dificilmente será reconhecida como autêntica, pois não será aceita pela comunidade como norma jurídica vinculante.

Como limite objetivo, tem-se, inicialmente, o texto da norma constitucional a ser interpretada que não pode ser alterado. A atuação do Poder Constituinte difuso se circunscreve à modificação do sentido, do alcance ou do significado do texto constitucional, sendo-lhe defeso alterar a estrutura desse mesmo texto e, consequentemente, a própria Constituição, produzindo normas inconstitucionais.

De acordo com Konrad Hesse

[...] (o) direito não-escrito não deve entrar em contradição com a "constitutio scripta", é esta um limite insuperável da interpretação constitucional. Esse limite é pressuposto da função racionalizadora, estabilizadora e limitadora do poder da Constituição. Ele inclui a possibilidade de uma mutação constitucional por interpretação; ele exclui um rompimento constitucional - o desvio do texto em cada caso particular - e uma modificação constitucional por interpretação. Onde o intérprete passa por cima da Constituição, ele não mais interpreta, senão ele modifica ou rompe a Constituição. Ambos estão proibidos a ele pelo direito vigente. Mesmo que um problema, por conseguinte, não se deixe resolver adequadamente por concretização, o juiz, que está vinculado à Constituição, não tem livre escolha dos topoi [...] Para a interpretação constitucional, que parte do primado do texto, é o texto limite insuperável de sua atividade. A amplitude das

${ }^{127}$ BULOS, Uadi Lammêgo. Op. cit., p. 91. 
possibilidades de compreensão do texto delimita o campo de suas possibilidades tópicas. ${ }^{128}$

As mutações constitucionais são, na realidade, produzidas dentro da norma constitucional, visto que decorrem de modificações no "âmbito normativo", que é um dos componentes da norma constitucional. Assim, as modificações encontram limite nas possibilidades de compreensão da norma constitucional que não entram em contradição explícita com o texto constitucional. Nesse sentido, o intérprete não pode inserir, no programa normativo, significados que ele evidentemente não comporta, bem como não pode dar interpretações ao texto que sejam forçadas ou antinaturais da linguagem constitucional.

Se a alteração não for comportada pelo "programa normativo", viola-se o limite da mutação, surgindo, então, duas soluções: ou a necessidade de reforma constitucional ou a rejeição da mutação por uma atitude firme do aplicador do Direito.

Dessa forma, pode-se dizer que não são admitidas mutações contra a Constituição, embora esse tipo de mutação possa ocorrer e somente depois de algum tempo seja constatado que a modificação é inconstitucional.

Ademais, devem ser respeitados os princípios fundamentais e as normas constitucionais, em seu conjunto e em seu espírito, no que diz respeito à matéria do dispositivo constitucional a ser interpretado, em observância ao princípio da unidade da Constituição, enquanto sistema normativo.

No que tange à mutação pela via interpretativa, os direitos fundamentais devem ser especialmente observados, não se podendo realizar alterações informais que atentem contra o conteúdo essencial desses direitos.

As mutações constitucionais devem ser devidamente motivadas, sobretudo em se tratando da mudança informal realizada por meio da interpretação jurisdicional, pois é necessário que a leitura do significado da norma constitucional seja compreensível e razoavelmente sustentada, evitando-se, assim, arbitrariedades.

Também constituem limites específicos da mutação constitucional a verificação da mudança dos fatos práticos e da consciência ideológica coletiva, bem como a idoneidade e

\footnotetext{
${ }^{128}$ HESSE, Konrad. Elementos de direito constitucional da República Federativa da Alemanha. Op. cit., p.
} 69-70. 
a justificação da mudança do critério jurisprudencial, nos dizeres de Lucas Gonçalves da Silva $^{129}$.

Para o autor, existe uma realidade constitucional originária, que foi abarcada pelo constituinte originário e se converteu em direito positivo, e uma realidade constitucional que se espera, ou seja, que pode ser acolhida juridicamente no futuro por estar de acordo com os mandamentos constitucionais. A realidade constitucional se compõe dos fatos práticos e de fundamentos ideológicos, sendo que os primeiros se referem a acontecimentos físicos que ocorrem empírica ou materialmente na sociedade, enquanto que os segundos remetem à ideia que tem a sociedade sobre o significado das normas ${ }^{130}$.

O juiz afere o sentido de uma disposição constitucional aberta por meio dos efeitos práticos ou da visão ideológica da sociedade ${ }^{131}$, produzindo, mediante interpretação, uma mutação no conteúdo da norma com base na realidade social que passará a ser, também, realidade constitucional. Esses fatos ou visões de mundo, ainda que majoritários, podem não ser acolhidos pelo juiz, se houver clara oposição entre a norma e o consenso, pois é necessário que a realidade constitucional opere dentro do programa normativo da Constituição.

Para evitar que o juiz, em nome de uma fictícia transformação da realidade constitucional, introduza modificações intensas no conteúdo de uma norma, pretendendo impor sua opção moral, é necessário que a sua decisão seja justificada, demonstrando a conexão direta e a concordância precisa com a efetiva realidade que se transformou, ou seja, os parâmetros que fundamentam a decisão devem ser reais, existentes e comprovados. $^{132}$

Para verificar uma modificação nos fatos práticos, o juiz deve observar fisicamente os acontecimentos, por meio de diversos recursos no intuito de auferir fenômenos materiais e reais que acontecem no âmbito geográfico brasileiro. Assim, por meio da argumentação jurídica, o aplicador do direito terá condições de justificar as modificações normativas que pretender produzir no conteúdo das normas, valendo-se da interpretação.

As alterações na consciência ideológica da sociedade, por seu turno, são aferidas por meio da transposição do debate sobre as normas do âmbito estritamente jurídico e

\footnotetext{
129 SILVA, Lucas Gonçalves da. Mutação constitucional: tipologia e limites. 2009. Tese (doutorado). Pontifícia Universidade Católica de São Paulo, Faculdade de Direito, São Paulo, p. 120/121.

${ }^{130}$ Ibidem, p. 122.

${ }^{131}$ A dinâmica da vida social faz com que os valores de hoje possam ser divergentes ou inovadores em relação aos que vigoraram outrora. As modificações ideológicas, relativas à valoração dos fatos (análises morais), são acolhidas pelas normas abstratas e abertas, como os princípios, que possibilitam as mutações.

${ }^{132}$ SILVA, Lucas Gonçalves da. Op. cit., p. 122.
} 
técnico das decisões da Corte para o debate realizado pelos diversos intérpretes da Constituição (associações, autoridades religiosas, doutrinadores, grupos econômicos, instituições do Estado), que é próprio de uma "sociedade aberta de intérpretes", denominação e concepção desenvolvida por Peter Härbele. Nos dizeres do constitucionalista alemão

[...] en los procesos de interpretación constitucional están incluidos potencialmente todos los órganos del estado, todos los poderes públicos, todos los ciudadanos y los grupos. No hay un númerus clausus de intérpretes de la Constitución. Hasta ahora, la interpretación constitucional ha sido en exceso, de manera consciente y menos realiter, un asunto de una "sociedad cerrada": la de los intérpretes constitucionales jurídicos y de quienes participan formalmente en el proceso constitucional; pero en la realidad es más un asunto de una sociedad abierta, es decir, la de todos los poderes públicos en tanto participen materialmente, porque la interpretación constitucional participa una y otra vez en la constitución de esta sociedad abierta y es constituida por ésta. Sus criterios serán tan abiertos como pluralista sea la sociedad. ${ }^{134}$

A Justiça Constitucional, por exemplo, conta com a possibilidade de realizar audiências públicas com o objetivo de conhecer a opinião pública, isto é, de colher o significado da Constituição na perspectiva dos atores sociais, evitando que a mutação por via interpretativa colida com a consciência ideológica da coletividade, de sorte a quebrar com o sistema constitucional.

Ademais, a mutação pode ocorrer pela via da mudança do critério jurisprudencial, ou seja, por meio da ação do juiz que modifica a jurisprudência por razões que não se amparam na alteração da realidade constitucional, na qual o processo hermenêutico é a fonte jurídica que produz a modificação no conteúdo normativo da norma constitucional. O novo critério deve ser mais idôneo para dar eficácia à norma constitucional em uma realidade existente, pois seu fundamento se encontra na obrigação de o juiz constitucional realizar a Constituição, encontrando os critérios mais capazes para alcançar tal finalidade. $^{135}$

O Tribunal Constitucional, por meio da atividade interpretativa, realiza o controle de constitucionalidade das leis e edita súmulas vinculantes que possuem força obrigatória sobre os demais operadores jurídicos, de modo que os demais órgãos devem interpretar a norma constitucional nos mesmos termos delineados pelos juízes constitucionais.

\footnotetext{
${ }^{133}$ SILVA, Lucas Gonçalves da. Op. cit., p. 129.

${ }^{134}$ HÄBERLE, Peter. El estado constitucional. Buenos Aires: Astra, 2007, p. 264.

${ }^{135}$ SILVA, Lucas Gonçalves da. Op. cit., p. 130/131.
} 
Para ser válida, a mudança do critério jurisprudencial deve respeitar os limites de idoneidade e da justificação das mudanças, sob pena de corresponderem à arbitrariedade da jurisdição constitucional. Assim, a decisão, por meio da mudança de critério jurisprudencial, deve alcançar o fim almejado, qual seja, a eficácia das normas constitucionais, em maior medida do que com a utilização do critério anterior. Para aferir a idoneidade da alteração do critério, é necessário avaliar a justificação da mutação constitucional, pela motivação e argumentação das decisões.

Apresentados os limites objetivos e subjetivos que devem pautar a atuação do intérprete no campo das mutações constitucionais, aspecto de suma importância para garantir a razoabilidade das decisões judiciais que interpretam evolutivamente o Direito, resta imprescindível, para concluir esse capítulo, a análise da conjuntura jurídicoconstitucional do Brasil a partir da promulgação da Constituição Federal de 1988, que abriu espaço para a ocorrência, em escala crescente, do fenômeno da mutação constitucional.

\subsubsection{A interpretação constitucional evolutiva no Brasil pós-1988}

A Constituição Federal de 1988 foi elaborada em um contexto de mudanças no cenário internacional, que influenciaram sobremaneira na forma como o texto normativo foi promulgado. No plano político, vivia-se o fim da Guerra Fria, com a consolidação da hegemonia do capitalismo financeiro. Ademais, o movimento de internacionalização da política relativizou conceitos tradicionais como soberania e Estado-Nação, juntamente com o fortalecimento dos blocos políticos e econômicos, como União Europeia e Mercosul. Concomitantemente a isso, difunde-se a ideologia do neoliberalismo, com a redução do Estado como empresário por meio dos procedimentos de privatizações. No plano econômico, a circulação internacional do capital financeiro se fortalece, com a transnacionalização dos mercados de produção e de consumo e, consequentemente, com a luta pela eliminação de barreiras à atuação das empresas estrangeiras e da proteção à indústria nacional. No plano social, observa-se um aumento das desigualdades sociais e de concentração de rendas entre os países. Observa-se, ainda, um super desenvolvimento científico-tecnológico, caracterizado, principalmente, pela utilização dos recursos de informática, fator que fomentou a internacionalização das comunicações. 
Ademais, evidencia-se na Constituição Federal de 1988 uma ruptura com o período ditatorial vivido pelo país desde 1964, por meio de uma transição consensual, com a instalação do Estado Democrático de Direito, que tenta abranger as demandas de uma sociedade extremamente plural como a brasileira. A sobreposição de concepções ideológicas, apesar de dar um caráter democrático à Constituição, gerou a proliferação de focos de tensão em seu texto.

Por outro lado, os trabalhos da Assembleia Nacional Constituinte foram marcados por uma enorme descentralização, caracterizada não por um projeto-base inicial, mas pelo procedimento de junção de projetos parciais elaborados por oito comissões e vinte e quatro subcomissões, que analisaram milhares de emendas, as quais, depois de uma seleção, foram incorporadas pelo voto da maioria simples dos parlamentares. Esses fatores contribuíram para a introdução no texto dos mais variados dispositivos, bastando para isso que contassem com o apoio substancial de algum grupo de pressão ou bancada parlamentar e não ferissem os interesses da maioria do Congresso.

Assim, a Constituição é composta de dispositivos que contemplam interesses específicos de determinadas categorias econômicas e sociais, além de políticas governamentais, os quais, quando alterado o equilíbrio das forças presente no momento da Constituição, criam focos de tensão que, se intensificados, geram a necessidade de alteração do texto ou do sentido ou alcance desse texto. Com isso, se justifica a incidência prática dos mecanismos de modificação na Constituição brasileira de 1988.

A Constituição Federal vigente está submetida aos seguintes mecanismos de alteração: a reforma constitucional, que engloba as modalidades formais da revisão constitucional e das emendas constitucionais, e a mutação constitucional, que abrange o conjunto de modificações constitucionais informais representadas pela interpretação (administrativa, legislativa e judicial) e pelos costumes constitucionais.

A Constituição de 1988 apresenta uma estrutura aberta, ou seja, é um "sistema aberto de princípios e regras", caracterizado pelo grande número de normas com estrutura principiológica e de normas que demandam complementação (normas de eficácia contida e de eficácia limitada), além de inúmeros dispositivos antagônicos que dependem de um esforço de harmonização por parte do aplicador do Direito. Essa estrutura possibilita a ocorrência de alterações em um ritmo constante e intenso ${ }^{136}$.

\footnotetext{
${ }^{136}$ Pode-se dizer que os dispositivos abertos e flexíveis são suscetíveis à incidência do fenômeno da mutação constitucional para a adequação das normas à realidade cambiante. Já os dispositivos redigidos de modo
} 
As normas de estrutura principiológica ensejam, por parte do aplicador, uma interpretação evolutiva como forma de atualização do texto constitucional à realidade sócio-econômico-política. As normas de eficácia contida e as de eficácia limitada demandam a atuação do legislador ordinário ou do administrador público para a sua restrição ou complementação, o que favorece a ocorrência de alterações informais. E, finalmente, a existência de conceitos jurídicos indeterminados, lacunas normativas descobertas e ocultas e de dispositivos antagônicos que precisam ser harmonizados gera um campo para o intérprete, de modo criativo e inovador, integrar as lacunas, complementar ou desenvolver o sentido e solucionar as colisões entre as normas constitucionais.

Constata-se que, nos últimos anos, inúmeros dispositivos da Constituição Federal de 1988 têm sofrido alterações, no sentido de adequar o texto constitucional à realidade social no momento de sua aplicação, o que resulta na ocorrência do fenômeno da mutação constitucional.

Sem embargo, esse cenário se apresentava bem diferente antes da promulgação da Constituição vigente. A mutação constitucional no Brasil e, também na América Latina, até então não tinha maior expressão ${ }^{137}$, em virtude da predominância do Poder Executivo sobre a Corte Suprema, da ocorrência de frequentes reformas constitucionais e de uma constante instabilidade institucional, sobretudo decorrente da instalação e permanência por décadas, de regimes totalitários em vários países.

A ocorrência mais intensa de mutações constitucionais, a partir da promulgação da Constituição Federal de 1988, é decorrente das próprias características do texto constitucional derivadas de sua inserção no contexto do neoconstitucionalismo, notadamente o seu caráter altamente principiológico, associado à valorização dos direitos fundamentais, e o fortalecimento da atuação do Supremo Tribunal Federal, sobretudo por meio do controle concentrado de constitucionalidade dos atos normativos.

hermético, que não dão margem à atuação criativa do intérprete, são modificados apenas por meio dos procedimentos de alteração formal da Constituição.

${ }^{137}$ Apesar da constatação mencionada, um dos primeiros exemplos de mutação constitucional, por meio de interpretação construtiva jurisprudencial do Supremo Tribunal Federal, ocorreu no início do século XX, com a importante ampliação do instituto do habeas corpus, fortemente influenciada pelas figuras de Ruy Barbosa, na tribuna de defesa, e de Pedro Lessa, na magistratura. O Supremo, em 1909, deu ampla interpretação ao conceito genérico contido no art. 72, parágrafo 22 , da Constituição de 1891 , e estendeu o remédio do habeas corpus, originalmente utilizado como instrumento de proteção apenas da liberdade de locomoção, à proteção de quaisquer direitos pessoais, praticadas por abuso de autoridade pública. Cf. FERRAZ, Anna Cândida da Cunha. Processos informais de mudança da Constituição. Op. cit., p. 138. 
O movimento do constitucionalismo, que antecedeu o constitucionalismo, exaltava o princípio da legalidade, visto que a lei era considerada a forma da expressão do Direito por excelência. O Direito era entendido como um sistema de regras, na qual os princípios ocupavam uma posição secundária de integração das lacunas no ordenamento jurídico. Os juízes, por seu turno, deveriam se ater aos termos da lei, não se admitindo qualquer tipo de criatividade judicial.

A ocorrência de atrocidades praticadas pelos países que adotaram os regimes totalitários, com especial relevo para os movimentos fascista e nazista, com o respaldo da lei, demonstraram a inconveniência do modelo até então dominante, atrelado aos paradigmas da legalidade formal, da rígida separação de poderes e da regra da maioria como fundamento da democracia.

A partir da segunda metade do século XX começa a ganhar força, especialmente nos países que saíam dos regimes totalitários, um movimento que ficou conhecido como neoconstitucionalismo, bem explicitado por Luís Roberto Barroso:

\begin{abstract}
O neoconstitucionalismo ou o novo direito constitucional [...] identifica um conjunto amplo de transformações ocorridas no Estado e no direito constitucional, em meio às quais podem ser assinalados, (i) como marco histórico, a formação do Estado Constitucional de Direito, cuja consolidação se deu ao longo das décadas finais do século XX; (ii) como marco filosófico, o póspositivismo, com a centralidade dos direitos fundamentais e a reaproximação entre Direito e ética; e (iii) como marco teórico, o conjunto de mudanças que incluem a força normativa da Constituição, a expansão da jurisdição constitucional e o desenvolvimento de uma nova dogmática da interpretação constitucional. Desse conjunto de fenômenos resultou um processo extenso e profundo de constitucionalização do Direito. ${ }^{138}$
\end{abstract}

O neoconstitucionalismo apresenta algumas características que devem ser ressaltadas. A substituição do Estado legalista pelo Estado Constitucional de Direito coloca a Constituição em um lugar central no ordenamento jurídico, pois devido ao seu maior grau de abstração passou a ser vista como o instrumento mais adequado para harmonizar valores e aspirações muitas vezes conflitantes entre si, no cenário atual de sociedades pluralistas e complexas.

Como conseqüência do papel central ocupado pela Constituição, inicia-se um movimento de alargamento do âmbito de incidência da Constituição sobre todos os ramos do Direito, inclusive sobre o Direito Civil e o Direito do Trabalho. Dessa forma, temas até então tradicionalmente tratados como matéria infraconstitucional passam a constar do texto

\footnotetext{
${ }^{138}$ BARROSO, Luís Roberto. Neoconstitucionalismo e constitucionalização do Direito: o triunfo tardio do
} direito constitucional no Brasil. Op. cit., p.11-12. 
constitucional. Ademais, os princípios previstos na Constituição começam a irradiar os seus valores e influenciar na interpretação e aplicação das normas infraconstitucionais.

A expressão jurídico-filosófica do neoconstitucionalismo é o denominado póspositivismo, movimento que se desenvolveu posteriormente à superação histórica do jusnaturalismo (séc. XVI e XVII) e o fracasso do positivismo jurídico (séc. XIX e XX) e que buscava um fundamento para explicar o Direito dentro de uma perspectiva apta a conciliar a legalidade com um sistema pautado por valores, já que restou reconhecido que o sistema jurídico é inevitavelmente permeado por valores.

A principal característica do movimento pós-positivista foi tentar reaproximar o Direito e a moral, para possibilitar a entronização dos parâmetros da justiça no âmbito do Direito, valendo-se, para isso, da valorização dos princípios constitucionais e dos direitos fundamentais.

$\mathrm{Na}$ fase pós-positivista, os princípios não funcionam mais como meros axiomas jurídicos, sem qualquer normatividade, como no jusnaturalismo, nem como apenas fontes subsidiárias, como no positivismo, mas passam a se apresentar como normas jurídicas aptas a incidir diretamente nos casos concretos e servirem de apoio à interpretação jurídica de outras normas e à atuação dos poderes públicos e dos entes privados.

As Constituições atuais, incluindo a Constituição brasileira de 1988, são em grande parte Constituições abertas ou pluralistas, pois possuem grande quantidade de normas de estrutura principiológica, que têm abertura suficiente para abranger os diversos valores existentes. $^{139}$

Por seu turno, os direitos fundamentais se fortalecem, assumindo um papel especial dentro do sistema constitucional, pois passaram a ser considerados materialmente superiores às demais normas constitucionais e dotados de força suficiente para pautar a forma de sua interpretação e aplicação.

\footnotetext{
${ }^{139}$ Além dos princípios constitucionais e dos direitos fundamentais, a Constituição Federal de 1988 também contém os chamados conceitos jurídicos indeterminados ou cláusulas gerais, que são dispositivos constitucionais dotados de textura abertura, fornecendo apenas um indício de significação a ser complementado pelo intérprete, levando em conta as circunstâncias do caso concreto. Como exemplos, têmse as expressões "razoável duração do processo", "ordem pública", "relevante interesse coletivo", entre outras. Ademais, não se nega que a Constituição vigente apresenta lacunas constitucionais, mencionando-se, por exemplo, o artigo $5^{\circ}$, caput, que estabelece que "todos são iguais perante a lei, sem distinção de qualquer natureza, garantindo-se aos brasileiros e aos estrangeiros residentes no País a inviolabilidade do direito à vida, à liberdade, à igualdade, à segurança e à propriedade", visto que o referido dispositivo não previu a proteção aos direitos fundamentais dos estrangeiros em trânsito no Brasil, o que gerou dificuldades práticas na sua aplicação. A lacuna foi preenchida pelo Supremo Tribunal Federal que, nos autos do HC n. 74.0513/SC, ampliou a proteção dos direitos fundamentais inclusive aos estrangeiros em trânsito, realizando uma típica mutação constitucional.
} 
A natureza aberta dos princípios e dos direitos fundamentais, visto que também são normas de estrutura principiológica, demanda uma atividade criativa por parte dos intérpretes, sobretudo por parte dos Tribunais Constitucionais, o que leva ao surgimento de uma nova hermenêutica constitucional, dotada de princípios e métodos próprios, e ao fortalecimento e expansão da jurisdição constitucional.

Ao final da Segunda Guerra Mundial, há um deslocamento do centro das decisões dos Poderes Legislativo e Executivo para o Poder Judiciário ${ }^{140}$, considerado o mais imparcial e independente dos três poderes em relação ao jogo político e, por isso mesmo, o mais adequado para assegurar a realização dos princípios e direitos fundamentais inscritos no texto constitucional.

A Constituição de 1988 foi, portanto, editada no contexto do neoconstitucionalismo, atribuindo importância ímpar aos princípios constitucionais e aos direitos e garantias fundamentais e, também, aos mecanismos de fortalecimento da jurisdição constitucional, com especial relevo para a atuação do Supremo Tribunal Federal.

A consagração e a multiplicação dos direitos e garantias fundamentais na Constituição Federal de 1988 também favoreceu o aumento da incidência prática do fenômeno da mutação constitucional, na medida em que os dispositivos que embasam tais direitos e garantias são dotados de alta carga axiológica e, dessa forma, demandam de seus intérpretes uma atuação constante no sentido de adequar os seus termos às aspirações atuais da sociedade. Os valores contidos na norma podem variar ao longo do tempo e ensejar uma leitura adequada do conteúdo do direito, mesmo sem qualquer alteração da letra do texto constitucional, incidindo aí o fenômeno da mutação constitucional.

Por outro lado, o Supremo Tribunal Federal, instituído formalmente em 1890 com o objetivo de ser o "guardião da Constituição", teve as suas competências ampliadas ao longo de mais de um século. Todavia, a Constituição Federal de 1988 teve um papel crucial no fortalecimento do jurisdição constitucional e do STF, pois manteve o sistema misto de controle de constitucionalidade, mas valorizou substancialmente o sistema concentrado, com a previsão original de quatro instrumentos de controle: ação direta de inconstitucionalidade genérica (ADI genérica); ação direta de inconstitucionalidade por omissão (ADI por omissão); argüição de descumprimento de preceito fundamental (ADPF); e ação direta de inconstitucionalidade interventiva (ADI interventiva).

\footnotetext{
${ }^{140}$ Vários países europeus passaram no período pós-1945 por um processo de fortalecimento da jurisdição constitucional, representado pelo enrijecimento dos mecanismos de controle de constitucionalidade e pela criação de tribunais constitucionais, que assumiram a função de "guardiões" da Constituição. Entre esses países, pode-se citar Alemanha (1951), Itália (1956), Espanha (1978) e Portugal (1982).
} 
Em relação à $\mathrm{ADI}$ genérica, a novidade trazida pela $\mathrm{CF} / 88$ foi a ampliação do rol dos legitimados ${ }^{141}$ a manejar a ação, que antes só podia ser ajuizada pelo Procurador-Geral da República. Com isso, elevou-se o número de ADI's ajuizadas no STF e ampliou-se a natureza dos temas julgados pela Corte, incluindo questões de cunho eminentemente político, que ensejaram, por seu turno, uma atuação mais discricionária e política do Supremo.

A ADPF foi criada pela Constituição Federal de 1988 como um instrumento por meio do qual, mediante a provocação de um dos colegitimados do artigo 103 (os mesmos da ADI genérica), o STF pode conhecer e julgar causas fundadas na ocorrência de desrespeito a normas basilares da ordem jurídica pelo Poder Público ou na existência de controvérsia sobre lei ou ato normativo federal, estadual ou municipal, inclusive os anteriores à Constituição.

Outra novidade da constituição foi a previsão da ADI por omissão, que atribui ao STF a competência para, diante de uma norma de eficácia limitada carente de regulamentação, dar ciência ao Poder competente para a adoção das providências necessárias para torná-la efetiva.

Ademais, a Emenda Constitucional n. 03/93 estabeleceu a denominada ação declaratória de constitucionalidade (ADC), por meio da qual o STF pode ser acionado por um dos colegitimados do artigo 103 da CF/88, na hipótese de existência de comprovada controvérsia judicial, a se manifestar in abstrato acerca da constitucionalidade de determinada lei ou ato normativo federal, transformando a presunção relativa de constitucionalidade, que estes atos naturalmente possuem em presunção absoluta.

Além dos instrumentos do controle concentrado, com a Emenda Constitucional $\mathrm{n}$. 45/04 foi introduzido o instituto da súmula vinculante, por meio do qual o STF poderá, de ofício ou por provocação, mediante decisão de $2 / 3$ dos seus membros e depois de reiteradas decisões sobre matéria constitucional, aprovar súmula que terá efeito vinculante em relação aos demais órgãos do Poder Judiciário e da Administração Pública direta e indireta, nas esferas federal, estadual e municipal.

Finalmente, a Constituição vigente ampliou o papel do STF no exercício da jurisdição constitucional voltada à proteção dos direitos fundamentais, na medida em que manteve inúmeros instrumentos de tutela jurisdicional dos direitos fundamentais, como o direito de petição, o direito de certidão, o habeas corpus, o mandado de segurança e a ação

\footnotetext{
${ }^{141} \mathrm{O}$ rol dos legitimados consta do artigo 103 da CF/88.
} 
popular, e criou outros instrumentos como o mandado de segurança coletivo, o mandado de injunção e o habeas data.

Esses instrumentos têm o condão de fortalecer os direitos fundamentais, visto que dotam o cidadão de ferramentas efetivas para exigir do Poder Público o respeito e a concretização dos direitos e garantias dispostos na Constituição, e o próprio Poder Judiciário, na medida em que este detém competência, desde que previamente provocado, para exigir dos demais Poderes ou adotar diretamente ações voltadas para a concretização dos direitos fundamentais.

Dessa forma, o fortalecimento do papel institucional do Supremo decorrente das amplas atribuições que lhe foram conferidas pela $\mathrm{CF} / 88$, é que o torna o principal agente das mutações constitucionais no Brasil.

Essa importante atuação do STF como responsável pela atualização e complementação da Constituição foi explicitada pelo Ministro Celso de Mello, nos seguintes termos:

\begin{abstract}
A Suprema Corte passa (com a Constituição Federal de 1988) a exercer, então, verdadeira função constituinte com o papel de permanente elaboração do texto constitucional. Essa prerrogativa se exerce, legitimamente, mediante processos hermenêuticos. Exerce uma função política e, pela interpretação das cláusulas constitucionais, reelabora seu significado, para permitir que a Constituição se ajuste às novas circunstâncias históricas e exigências sociais, dando-lhe, com isso, um sentimento permanente e de necessária atualidade. Essa função é plenamente compatível com o exercício da jurisdição constitucional. O desempenho desse importante encargo permite que o STF seja co-partícipe do processo de modernização do Estado Brasileiro. ${ }^{142}$
\end{abstract}

Com o fortalecimento do Supremo Tribunal Federal, após a promulgação da Constituição Federal de 1988, constata-se que o fenômeno da mutação constitucional no Brasil passou a ocorrer com muito mais frequência.

Como exemplo, pode-se citar a decisão proferida pelo STF no julgamento do HC n. $82.424 / \mathrm{RS}$, em que se discutiu o conceito do termo "raça", visto que o paciente, um escritor e editor de livros com conteúdo anti-semita que havia sido acusado da prática do crime de racismo, sustentou perante a Corte a tese de que não havia cometido tal crime, considerado imprescritível pelo artigo $5^{\circ}$, inciso XLII, da CF/88, na medida em que o povo judeu não é uma raça e sim um povo. O Supremo, no julgamento realizado, entendeu que o

${ }^{142}$ MELLO, Celso de. Retrospectiva 2006: a Constituição e o Supremo na visão dos seus guardiões. Disponível em:

http://www.academus.pro.br/implementos/entrevistas/impressao_entrevista.asp?titulo=Entrevistas\&codigo=3 9>. Acesso: 18 set. 2011. 
termo "raça" originalmente tutelava basicamente os indivíduos de "raça nega", em virtude do histórico da escravidão no Brasil, e de outras "raças", mas, em decorrência de descobertas do projeto Genoma Humano de que não existem raças no sentido biológico, a interpretação foi alterada para tutelar qualquer grupo humano passível de discriminação. Ou seja, o Supremo alargou o conceito indeterminado de "racismo" originalmente previsto na Constituição, em decorrência de alterações ocorridas no contexto social, mas sem contrariar a letra ou o espírito constitucional.

Outro exemplo muito comentado se refere à interpretação dada pelo STF ao artigo $5^{\circ}$, inciso XLVI, da CF/88, que prevê o princípio da individualização da pena. A Lei Federal n. 8.072/90, que regula os crimes hediondos, estabelece, em seu artigo $2^{\circ}$, parágrafo $1^{\circ}$, que o cumprimento da pena decorrente da condenação pela prática de crime hediondo, prática de tortura, tráfico ilícito de entorpecentes ou terrorismo, deve ser feita integralmente em regime fechado. Ao se manifestar sobre a constitucionalidade do dispositivo, o Supremo inicialmente havia firmado entendimento, no julgamento do HC n. 67.657-1/SP, de que a vedação à progressão de pena nos crimes hediondos não fere o mencionado artigo $5^{\circ}$, inciso XLVI. Sem embargo, posteriormente, nos autos do HC n. 82.959-7/SP, reviu o seu posicionamento anterior e entendeu ser inconstitucional o artigo $2^{\circ}$, parágrafo $1^{\circ}$, da Lei de Crimes Hediondos, sob o argumento de que a vedação à progressão de regime afronta o direito fundamental à individualização da pena, visto que, ao não permitir que se considerem as peculiaridades de cada pessoa, a sua capacidade de reintegração social e os esforços aplicados com vistas à ressocialização, acaba-se por afetar o núcleo essencial desse direito.

Apesar da importância do Supremo Tribunal Federal como "guardião da Constituição" e da sua atuação no sentido de complementar e concretizar dispositivos constitucionais, não se pode perder de vista que os outros órgãos do Poder Judiciário também podem realizar, no julgamento de casos concretos, interpretação evolutiva das normas constitucionais aplicáveis. Dessa forma, os órgãos do ramo judiciário trabalhista, quais sejam, Tribunal Superior do Trabalho, Tribunais Regionais do Trabalho e Juízes do Trabalho, no julgamento de casos que envolvem a interpretação dos direitos fundamentais trabalhistas estabelecidos na Constituição Federal de 1988, poderão realizar mutações constitucionais.

Antes de passar para o estudo específico da atuação da Justiça do Trabalho no que tange à implementação ampliativa dos direitos fundamentais trabalhistas, por meio da interpretação constitucional evolutiva, objeto do último capítulo dessa tese, é necessário 
apresentar outro elemento essencial legitimador de uma interpretação jurisdicional, por parte dos juízes do trabalho, de implementação efetiva dos direitos fundamentais do trabalhador, qual seja, a concepção de cidadania social adotada pela Constituição Federal de 1988. 


\section{A CIDADANIA SOCIAL COMO FUNDAMENTO DA HERMENÊUTICA JURIDISCIONAL DE IMPLEMENTAÇÃO DOS DIREITOS FUNDAMENTAIS}

A proposta desse capítulo é, inicialmente, traçar um paralelo entre a evolução da concepção de cidadania e as teorias restritivas e ampliativas do exercício dos direitos fundamentais, para se averiguar qual a concepção de cidadania adotada pela Constituição Federal de 1988. Em seguida, analisar-se-á o papel do Judiciário, partindo do estudo da evolução da teoria da separação dos poderes, desenvolvida por Montesquieu, até se chegar a uma releitura dessa teoria diante do paradigma do Estado Democrático de Direito. À continuação, realizar-se-á um estudo das concepções da atuação do Poder Judiciário em relação à implementação dos direitos fundamentais sociais e a questão da concretização do princípio de acesso à Justiça, pelo prisma tanto do acesso aos Tribunais, quanto da implementação dos direitos materiais pleiteados por meio do processo judicial, ainda que em face de complexas questões como a omissão do legislador em regulamentar direitos fundamentais sociais e a linguagem aberta dos direitos fundamentais. Por fim, o presente capítulo ainda pretende abordar a questão dos fenômenos da judicialização da política e do ativismo judicial, diante de uma visão atualizada da teoria dos três poderes, analisando-se quais são os limites existentes a uma postura mais ativa, embora legítima, do Poder Judiciário.

\subsection{Cidadania social e direitos fundamentais}

A interpretação evolutiva das normas constitucionais de direitos fundamentais, realizada pelo Poder Judiciário, visando implementá-los efetivamente, está intrinsecamente relacionada com a cidadania social, enquanto vetor disposto no texto constitucional que tem como, dentre outros, o objetivo de propiciar ao cidadão que recorre à Justiça o acesso a uma ordem jurídica realmente justa, englobando, nesse aspecto, não apenas a oportunidade de apresentar uma demanda ao Judiciário, mas, também, que o julgamento realizado possibilite o exercício dos direitos fundamentais pleiteados.

As possibilidades de exercício desses direitos é tema que deve ser estudado tendo como base a evolução da concepção de cidadania, visto que a forma como o Estado 
considera o indivíduo e as prerrogativas que lhe confere enquanto cidadão são diretamente vinculadas à maior ou menor amplitude dos direitos fundamentais do indivíduo.

\subsubsection{A relação entre a concepção de cidadania e as teorias restritivas e ampliativas do exercício dos direitos fundamentais}

A concepção de cidadania tem se alterado ao longo dos tempos, desde o prisma de que o cidadão era apenas o indivíduo detentor das liberdades clássicas, passando pelo indivíduo que podia votar, ou votar e ser votado, até o conceito amplo de cidadania, que confere à pessoa humana um feixe de situações jurídicas subjetivas que englobam não somente o papel político tradicional de direito ao sufrágio universal, mas também a possibilidade de participação direta na elaboração de políticas públicas, pelos meios que estão disponíveis no ordenamento jurídico, e, outrossim, conferem ao indivíduo formas reguladas de efetivar os direitos fundamentais dispostos na Constituição, com especial relevo os direitos sociais, inclusive por meio da atuação do Judiciário.

Thomas Humphrey Marshall, em sua clássica obra "Cidadania, Classe Social e Status", desenvolveu um estudo sobre o alcance e o desenvolvimento da cidadania na sociedade inglesa, desde o século XVIII até o século XX. O autor define a existência de três elementos essenciais do conceito de cidadania, o civil, o político e o social, que, sendo confundidos na Idade Média, passam a se distanciar a partir da formação do Estado Liberal, obedecendo a uma evolução de acordo com a importância dos direitos em cada período histórico. Assim, os direitos civis surgem no século XVIII, os políticos se formam no século XIX e os sociais se sedimentam no século XX. ${ }^{1}$

A cidadania inicialmente é declarada como o resultado da aquisição dos direitos civis, que são próprios do indivíduo. Apesar de esses direitos terem sido identificados no século XVIII, foi no século XIX que eles foram reconhecidos e consolidados na maioria dos países. Por sua vez, os direitos políticos, embora inicialmente arraigados aos direitos civis, adquirem independência no século XX. E, os direitos sociais se universalizam durante o decorrer do século XX, ganhando posição de destaque após a Segunda Guerra Mundial, com o surgimento do Estado de Bem-Estar Social. ${ }^{2}$

\footnotetext{
${ }^{1}$ MARHALL, T. H. Cidadania, classe social e status. Rio de Janeiro: Zahar Editores, 1967, p. 63.

${ }^{2}$ Ibidem, p. 66.
} 
Marshall, ao analisar a trajetória do desenvolvimento da categoria cidadania, procura identificar a existência de antagonismos e de congruências com a categoria classe social.

O conceito de classe social, surgido a partir dos estudos de Marx, revela a existência da propriedade dos meios de produção pertencentes a uma elite que, aproveitando-se da mão-de-obra dos não proprietários, apropria-se também do resultado do trabalho por eles realizado. Na sociedade capitalista, a elite proprietária ou burguesia, formada a partir do surgimento do próprio sistema, confronta-se com os reais produtores da mercadoria, o proletariado, que, despojado do fruto do seu trabalho, passa a realizar reivindicações por meio de organizações associativas, criadas a partir do século XIX. ${ }^{3}$

Em decorrência dessas lutas políticas e econômicas do proletariado é que os direitos sociais passam a ser positivados, inicialmente em leis esparsas e, posteriormente, consolidados nas Constituições. A partir desse processo de contestação do Estado Liberal capitalista, surgiram duas outras concepções de Estado, o Estado Socialista, que tinha como objetivo realmente suplantar o modelo de Estado Liberal, e o Estado de Bem-Estar Social, que não deixou de se pautar no capitalismo, mas passou da postura liberal para uma atitude intervencionista nas relações sociais e econômicas, de modo a garantir os direitos sociais.

Os direitos sociais são, portanto, resultado das lutas decorrentes dos antagonismos de classe, sendo necessário saber, então, como é construída a formulação teórica que os absorve na categoria de cidadania, a qual está, a princípio, ligada a uma noção jurídicopolítica norteada pelo arcabouço ideológico capitalista e liberal.

Marshall explica que a cidadania, a qual traz implícita a ideia de igualdade, tem sido uma instituição em desenvolvimento desde o século XVII, e que o seu crescimento se acelerou com o desenvolvimento do capitalismo, que é um sistema de desigualdade. As relações sociais na sociedade capitalista são pautadas pela desigualdade, o que gera a existência de classes sociais. ${ }^{4}$ Então, a tendência seria de incompatibilidade natural entre a categorias cidadania e classes sociais. Entretanto, na prática o princípio da cidadania acabou por justificar a desigualdade social do sistema capitalista.

Marshall explica esse processo, afirmando que o desenvolvimento simultâneo das duas categorias, classe social e cidadania, não se estabelece em virtude do que traduzem,

\footnotetext{
${ }^{3}$ ESTEVES, João Luiz Martins. Cidadania e judicialização de conflitos sociais. Revista Jurídica da Unifil, v. 1, n. 1, 2004, p. 122.

${ }^{4}$ MARHALL, T. H. Op. cit., p. 76.
} 
ou seja, igualdade ou desigualdade, mas fundamentalmente por serem entendidas como instituições de origens distintas. As diferenças de classe, no sistema capitalista, não se estabelecem em virtude de leis e costumes da sociedade, mas emergem da combinação de uma variedade de fatores relacionados, como as instituições da propriedade, da educação e da estrutura econômica. A cidadania, por sua vez, é estabelecida por uma determinação vinculada ao direito, é concedida aos que são membros integrais de uma comunidade, que são iguais em direitos e obrigações. ${ }^{5}$

$\mathrm{Na}$ verdade, a diferença da natureza de ambas as categorias é que permitiu a convivência entre elas, de modo que a cidadania passou a legitimar a desigualdade por meio do argumento de que todos os homens, sendo livres, têm o igual direito de exercer a liberdade para gozá-la plenamente. Marshall explicita essa compatibilização entre cidadania e desigualdade:

\begin{abstract}
Começando do ponto no qual todos os homens eram livres, em teoria, capazes de gozar de direitos, a cidadania se desenvolveu pelo enriquecimento do conjunto de direitos de que eram capazes de gozar. Mas esses direitos não estavam em conflito com as desigualdades da sociedade capitalista; eram, ao contrário, necessários para a manutenção daquela determinada forma de desigualdade. A explicação reside no fato de que o núcleo da cidadania, nesta fase, se compunha de direitos civis. E os direitos civis eram indispensáveis a uma economia de mercado competitivo. Davam a cada homem, como parte de seu status individual, o poder de participar, como uma unidade independente, na concorrência econômica, e tornaram possível negar-lhes a proteção social com base na suposição de que o homem estava capacitado a proteger a si mesmo. ${ }^{6}$
\end{abstract}

Posteriormente, mesmo com a consolidação da cidadania política, não mais atrelada à noção de cidadania civil, não se modificou o quadro de desigualdade social existente nos dois últimos séculos. Todavia, conforme observa João Lima Esteves, a possibilidade aberta a partir da sedimentação desse tipo de cidadania no século XX e a ampliação do sufrágio, antes censitário e masculino e, posteriormente, universal, fez com que as reivindicações sociais passassem a ser positivadas nas Constituições, sendo a de Weimar um exemplo clássico. ${ }^{7}$ Mas, em termos mundiais, tal positivação, pelo menos na primeira metade do século XX, não fora suficiente para dar garantia e efetividade a esses direitos”, servindo para fomentar o reconhecimento dos direitos sociais, que acabaram por consolidar a "cidadania social".

\footnotetext{
${ }^{5}$ Ibidem, p. 77-79.

${ }^{6}$ Ibidem, p. 79.

${ }^{7}$ ESTEVES, João Luiz Martins. Cidadania e judicialização de conflitos sociais. Op. cit., p. 124.
} 
Marshall prossegue o seu raciocínio, afirmando que a cidadania social, concebida a partir da incorporação dos direitos sociais ao instituto de cidadania, fato ocorrido durante o século XX, fez com que surgisse um antagonismo entre cidadania e o sistema de classes sociais do capitalismo, e acredita que as duas categorias passam a um estado de guerra, causando um forte impacto nas relações econômicas e sociais. ${ }^{8}$

João Lima Esteves pondera que Marshall, em sua obra, não demonstra preocupação com a efetividade dos direitos sociais:

\begin{abstract}
Sua exposição faz a análise do desenvolvimento da cidadania tendo como pressuposto um conjunto de atos legislativos que identificam, em cada momento histórico, a afirmação dos direitos civis, políticos e sociais. Talvez essa falta de preocupação seja simplesmente decorrente do fato de que na Inglaterra as determinações legislativas são cumpridas, e de que o estado de bem estar social desenvolveu-se na Inglaterra através de uma participação ativa do parlamento em conjunto com a sociedade, cujas vontades talvez sejam as únicas na garantia desses direitos. ${ }^{9}$
\end{abstract}

Sem embargo, constata-se que a evolução do conceito de cidadania está diretamente ligada à passagem das teorias mais restritivas para as teorias mais ampliativas no que tange ao exercício dos direitos fundamentais sociais, ou seja, a cidadania social está conectada com a posição subjetiva do indivíduo de poder exercitar os direitos sociais que o ordenamento lhe confere, seja exercendo-os diretamente, seja cobrando a implementação de programas de governo que ponham em prática os direitos sociais, seja ajuizando ações para implementar esses direitos que, por vezes, não podem ser usufruídos pela omissão do poder legislativo em regulamentá-los ou pela postura omissiva da Administração Pública de estatuir normatização pertinente, e, seja, ainda, pela interposição de ações que visam a implementação dos direitos fundamentais sociais por meio de uma interpretação não restritiva do Poder Judiciário acerca das normas que os estatuem.

Duas teorias restritivas dos direitos fundamentais sociais podem ser apresentadas, ambas vinculadas a uma matriz inspirada nas ideias sedimentadas no Estado Liberal.

A primeira teoria defende uma concepção de cidadania como mero exercício dos direitos políticos, de modo que apenas os direitos individuais poderão ser exercidos subjetivamente, enquanto os direitos sociais não seriam considerados fundamentais, podendo ser, portanto, suprimidos por Emenda Constitucional.

\footnotetext{
${ }^{8}$ MARHALL, T. H. Op. cit, p. 103.

${ }^{9}$ ESTEVES, João Luiz Martins. Cidadania e judicialização de conflitos sociais. Op. cit, p. 125.
} 
Manoel Gonçalves Ferreira Filho, por exemplo, identifica a cidadania como um status ligado ao regime político-representativo. Assim, o analfabeto, por poder votar, é considerado cidadão ativo, mas não cidadão passivo já que é considerado inelegível. ${ }^{10}$

Essa visão, comum entre os constitucionalistas brasileiros, reduz a cidadania a um caráter político-representativo como modelo de positivação da ordem capitalista vigente.

José Afonso da Silva apresenta uma visão um pouco menos restritiva, pois entende que há direito subjetivo em relação a direitos fundamentais sociais, mas somente em sua vertente negativa, isto é, quando o legislador ou a administração tomam qualquer atitude que viole esses direitos, ${ }^{11}$ o que não possibilita que o indivíduo pleiteie juridicamente qualquer condição material de vida digna.

João Luiz Esteves critica essa concepção, pois ela enquadra a cidadania em uma definição reduzida e hermética, retirando-lhe o conteúdo e amoldando-a simplesmente a uma concepção de Estado liberal, em que o indivíduo teria a possibilidade apenas do exercício das suas liberdades individuais. ${ }^{12}$

A segunda teoria, embora amplie a concepção de cidadania, não a limitando a questões políticas, restringe a subjetividade dos direitos fundamentais sociais ao mínimo possível a ser pleiteado ao Poder Judiciário ${ }^{13}$, ou seja, ao mínimo existencial necessário para o exercício das liberdades públicas ou ao mínimo existencial extraído diretamente do princípio da dignidade da pessoa humana.

Ricardo Lobo Torres valendo-se da doutrina do status de Jellinek, que busca a delimitação da atividade do Estado perante o indivíduo ${ }^{14}$, dividindo o status em quatro categorias (subiectiones, libertatis, civitatis e activae civitatis) e dos estudos de Peter Habërle, que ampliou o quadro do status na realidade do Estado Social, agregando a categoria do status ativus processualis, termina por afirmar a existência de status negativus, status positivus libertatis, status positivus socialis e de status ativus processualis. Segundo Torres, os direitos da liberdade exigem não somente um status negativus, mas também um

\footnotetext{
${ }^{10}$ FERREIRA FILHO, Manoel Gonçalves. Curso de direito constitucional. 22 ed. São Paulo: Saraiva, 1995, p. 99.

${ }^{11}$ SILVA, José Afonso. Op. cit.

${ }^{12}$ ESTEVES, João Luiz M. Direitos fundamentais sociais no Supremo Tribunal Federal. Op. cit, p. 27-28.

${ }^{13}$ Ibidem, p. 39.

${ }^{14}$ De acordo com essa doutrina, existem quatro categorias de status: o status subiectiones, que exclui a autodeterminação dos sujeitos no que tange ao exercício dos direitos políticos; o status libertatis, que é o exercício das liberdades; o status civitatis, que se apresenta como fundamento do complexo de prestações estatais no interesse individual; e o status activae civitatis, na qual o indivíduo é autorizado a exercer os seus direitos políticos. Cf. TORRES, Ricardo Lobo. A cidadania multidimensional na era dos direitos. In: MELlO, Celso de Albuquerque et al (Coords.). Teoria dos direitos fundamentais. 2 ed. Rio de Janeiro: Renovar, 2001, p. 255.
} 
status positivus, de modo que o Estado, além de abster-se de intervir na vida do indivíduo, deve também assegurar o exercício da sua liberdade, impedindo que haja o constrangimento do direito de outro particular. O indivíduo também teria um status ativus processualis, para garantir o exercício da efetivação dos direitos e um status positivus socialis, que não garante o exercício dos direitos fundamentais sociais, mas apenas de um mínimo existencial, visto que o restante seria dependente de políticas públicas reivindicatórias. ${ }^{15}$

Para o autor, como a igualdade só existe como uma condição da liberdade, ou seja, como uma igualdade de oportunidades e não como uma igualdade de resultados para diminuir as desigualdades sociais, os direitos sociais somente existem como condição para o cidadão exercer os seus direitos de liberdade, justificando, por parte do Estado, a garantia das condições materiais mínimas de vida, que é denominado "mínimo existencial". ${ }^{16}$ Ou seja, a liberdade de expressão só se consolidaria se o cidadão soubesse ler e escrever, donde se conclui que o ensino da leitura e da escrita é o mínimo existencial. Segundo Torres,

sem o mínimo necessário à existência cessa a possibilidade de sobrevivência do homem e desaparecem as condições iniciais da liberdade. A dignidade humana e as condições materiais da existência não podem retroceder aquém de um mínimo, do qual nem os prisioneiros, os doentes mentais e os indigentes podem ser privados. ${ }^{17}$

Andreas Krell critica a tentativa de Torres em relacionar o "mínimo existencial" ao status positivus libertatis, ou seja, o mínimo social como condição para o exercício das liberdades, pois acredita que a tipologia do exercício dos direitos fundamentais como status negativos e positivos do indivíduo em relação ao Estado, é marca de um individualismo consagrador das teses liberais dos séculos XVII e XIX, que regularam o Estado Liberal, estando, portanto, ultrapassada. Não é possível a transformação na esfera socioeconômica estatal se a interpretação jurídica fica amarrada ao modelo jurídicoideológico do Estado Liberal. ${ }^{18}$

Nesse sentido, não há como afirmar que os direitos sociais exigem sempre prestações positivas do Estado e que os direitos individuais impõem uma agir negativo

\footnotetext{
${ }^{15}$ TORRES, Ricardo Lobo. A cidadania multidimensional na era dos direitos. Op. cit, p. 256.

${ }^{16}$ Ibidem, p. 273.

${ }^{17}$ Ibidem, p. 267.

${ }^{18}$ KRELL, Andreas Joachim. Realização dos direitos fundamentais sociais mediante controle judicial da prestação de serviços públicos básicos (uma visão comparativa). Revista de Informação Legislativa/Senado Federal. Brasília: Subsecretaria de Edições Técnicas, n. 36, out./dez. 1999, p. 246-247.
} 
estatal, pois, como já ressaltado no capítulo 2, existem direitos sociais que, para serem exercidos, reclamam preponderantemente um não-agir estatal, como o direito de greve e o direito à livre organização sindical. Da mesma forma, alguns direitos individuais exigem do Estado prestações materiais para o seu pleno exercício, como se dá com o direito ao voto que demanda que o Estado desenvolva todo um aparato necessário para a realização das eleições.

$\mathrm{Na}$ verdade, essa visão restritiva, apresentada por Torres, pretende apenas que o indivíduo seja mantido vivo a fim de exercer a liberdade, mas não se preocupa com as suas condições de vida, ou seja, o cidadão não teria a prerrogativa de reivindicar os seus direitos fundamentais de natureza prestacional a fim garantir a igualdade material com outros indivíduos.

Anna Paula de Barcelos, embora concorde com a restrição ao exercício dos direitos sociais, entende que o "mínimo existencial" se vincula a uma "reserva do possível", ou seja, o Estado deverá garantir o mínimo para os cidadãos baseado nos limites do orçamento financeiro estatal. ${ }^{19}$ Por seu turno, Daniel Sarmento acredita que os direitos sociais e o mínimo existencial são extraídos diretamente do princípio da dignidade humana. ${ }^{20}$

De qualquer forma, ainda que vinculando o exercício dos direitos sociais a um mínimo existencial derivado do princípio da dignidade da pessoa humana, essa concepção reduz os direitos sociais apenas à garantia de condições materiais mínimas de vida.

A terceira teoria, já pautada nos valores nos quais se fundam o Estado Social e o Estado Democrático de Direito, se vale da concepção de cidadania social em seu conteúdo máximo, incluindo, dentre os direitos exercitáveis, os direitos fundamentais sociais ${ }^{21}$, que não podem simplesmente ser estabelecidos na Constituição como simples promessas, sem força normativa alguma, devendo o Estado instituir os meios regulares para propiciar-lhes eficácia e aplicabilidade máximas.

Ser cidadão, portanto, não é apenas votar e ser votado, mas participar das decisões políticas direta e indiretamente, pelas formas que a Constituição disponibiliza, exercer substancialmente os direitos civis e sociais, pleitear a defesa de direitos e garantias fundamentais, por meio dos remédios constitucionais e da ação popular, e ter acesso a uma ordem jurídica justa, em que o Judiciário atue em prol do cumprimento dos direitos

\footnotetext{
${ }^{19}$ BARCELOS, Ana Paula. A eficácia jurídica dos princípios constitucionais: o princípio da dignidade da pessoa humana. Rio de Janeiro: Renovar, 2002, p. 246.

${ }^{20}$ SARMENTO, Daniel. Interpretação dos direitos fundamentais e os conflitos entre poderes. In: MELLO, Celso de Albuquerque et al. Teoria dos direitos fundamentais. 2 ed. Rio de Janeiro: Renovar, 2001.

${ }^{21}$ ESTEVES, João Luiz M. Direitos fundamentais sociais no Supremo Tribunal Federal. Op. cit, p. 39.
} 
fundamentais violados e, em determinados casos, implemente esses direitos, caso o seu exercício seja obstaculizado devido a uma interpretação involutiva da norma jusfundamental ou em virtude de ausência de lei infraconstitucional.

O termo "cidadania social", embora dê ênfase para as questões sociais, exaltando a noção de que o indivíduo deve poder exercer os direitos sociais estabelecidos constitucionalmente, não exclui a prerrogativa de que o cidadão continua sendo detentor dos direitos civis e políticos fundamentais. A cidadania social, portanto, não exclui os direitos individuais, pois o cidadão é aquele que faz jus ao exercício das liberdades e da igualdade, só que agora não mais em sentido apenas formal, mas também em sua vertente material.

Os direitos fundamentais são indissociáveis e indivisíveis, como já ressaltado no capítulo 2, de maneira que não é possível que o indivíduo seja considerado cidadão, em seu sentido pleno, se puder votar e exercer sua liberdade de expressão, mas não tiver onde morar ou o que comer, ou, ao contrário, se tiver garantidas todas as condições mínimas para uma vida digna, mas não tiver liberdade de expressão e direito à informação. Portanto, na presente tese, a "cidadania social" será utilizada no sentido pleno aqui mencionado.

Após o estudo das várias concepções de cidadania, importa saber qual delas foi a adotada pela Constituição brasileira de 1988.

\subsubsection{Cidadania social e Constituição Federal de 1988}

A cidadania está expressa no Título I (“Dos Princípios Fundamentais”), artigo 1, inciso II, da Constituição de 1988 como um dos fundamentos do Estado Democrático de Direito brasileiro. Estabelecida em uma norma com estrutura de princípio, a cidadania apresenta uma dimensão subjetiva, visto que deve ser exercida por meio de um complexo de direitos subjetivos, e uma dimensão objetiva, visto que a cidadania permeia a Constituição como um feixe de valores fundantes do Estado brasileiro, interferindo na interpretação das normas constitucionais, inclusive as normas princípio que estabelecem os direitos fundamentais sociais.

A Constituição de 1988 estabelece no Título II, Capítulo I, que dispõe sobre os direitos e garantias fundamentais "individuais e coletivos", várias garantias do exercício de outros direitos, como a garantia do direito de receber informações dos órgãos públicos (artigo $5^{\circ}$, inciso XXXIII); o direito de petição aos Poderes Públicos e de obter certidões de 
repartições públicas (artigo 5, inciso XXXIV); a apreciação pelo Poder Judiciário de lesão ou ameaça a direitos, ou seja, o acesso à justiça (artigo $5^{\circ}$, inciso XXXV); a assistência jurídica integral e gratuita aos que comprovarem insuficiência de recursos (artigo $5^{\circ}$, inciso LXXIV); e a gratuidade do registro civil de nascimento e do óbito aos reconhecidamente pobres (artigo $5^{\circ}, \mathrm{LXXVI)}$.

Dentre essas garantias, encontram-se os remédios constitucionais, ou seja, ações que podem ser impetradas pelos cidadãos, individual ou coletivamente, para garantir o exercício de outros direitos fundamentais como o habeas corpus (artigo $5^{\circ}$, LXVIII), habeas data (artigo 5 $5^{\circ}$ LXXII), mandado de segurança individual (artigo $5^{\circ}$, LXIX), mandado de segurança coletivo (artigo $5^{\circ}$, LXX), mandado de injunção (artigo $5^{\circ}$, LXXI) e a ação popular ${ }^{22}$ (artigo $5^{\circ}$, LXXIII). São gratuitas as ações de habeas corpus e habeas data e, na forma da lei, os demais atos necessários ao exercício da cidadania (artigo $5^{\circ}$, LXXVII).

Nos artigos 12 e 13 (Capítulo III, Título II) e 14 (Capítulo IV, Título II) da Constituição Federal constam os direitos de cidadania civil e política. São eles o direito à nacionalidade e os diversos direitos políticos, respectivamente. Entre esses últimos, encontramos as disposições sobre o direito de votar e ser votado e o de participação em plebiscitos e referendos.

Diferentemente da Lei Fundamental alemã que não estabelece os direitos sociais, a Constituição brasileira não somente apresenta forte presença de direitos sociais, a qual se encontra disseminada em seu texto, mas também traz um título específico que trata da Ordem Social, de forma a sistematizá-los, e os inclui entre os direitos fundamentais no Título II, Capítulo II ("Dos Direitos Sociais”).

No caput do artigo $6^{\circ}$, ficam assegurados parte dos direitos sociais: a educação, a saúde, o trabalho, a moradia, o lazer, a segurança, a previdência social, a proteção à maternidade e à infância, a assistência aos desamparados. Todos estes figuram reconhecidamente como direitos de cidadania. Com relação aos direitos à educação, saúde, previdência social e proteção à maternidade, infância e assistência aos desamparados, a Constituição destinou, no Título VIII, denominado "Da Ordem Social”, normas protetoras, fixadas exatamente para assegurar esses direitos.

\footnotetext{
${ }^{22}$ A ação popular tem existência anterior à da Constituição, pois foi prevista na Lei n. 4.717/65. O instrumento visa proteger os interesses difusos e coletivos, pois meio da anulação de atos lesivos aos bens e direitos de valor econômico, artístico, estético, histórico ou turístico. A Lei da Ação Civil Pública (Lei n. 7.347/85) ampliou essa proteção, estendendo-a ao meio ambiente e aos bens de valores paisagísticos.
} 
Os direitos fundamentais trabalhistas estão dispostos nos artigos $6^{\circ}$ a 11 da Lei Fundamental, também no Capítulo II, visto que são direitos sociais por excelência. Nesses dispositivos estão listados todos os direitos considerados mínimos para que o cidadão trabalhador possa exercer o seu labor em condições dignas.

A Constituição Federal de 1988 estabelece, em seu artigo $5^{\circ}$, parágrafo $1^{\circ}$, a aplicabilidade imediata dos direitos individuais e sociais implícitos ou explícitos, demonstrando a intenção do constituinte de lhes imprimir a máxima efetivação, posição compatível com o tipo ideológico de Estado consubstanciado na Constituição ${ }^{23}$.

Nessa esteira, é importante ressaltar que a doutrina que pretende restringir a aplicabilidade imediata dos direitos fundamentais sociais vem perdendo força argumentativa, pois o caráter aberto dessas normas e o seu caráter principiológico não são impeditivos ao reconhecimento, pelos órgãos estatais, da maior eficácia possível às normas definidoras desses direitos, mesmo nas hipóteses de omissão do legislador infraconstitucional de regular as normas de eficácia limitada. Nesses casos, o legislador não poderá legislar e o administrador não poderá expedir atos normativos que visem violar os direitos sociais instituídos nas normas programáticas. Ademais, essas normas principiológicas servem de eixo condutor para a interpretação das demais normas constitucionais.

Por outro lado, os direitos fundamentais sociais nem sempre demandam gastos por parte do Estado, pois muitos são os direitos sociais cuja natureza predominante é a de direito de defesa e não direito de cunho prestacional, como, por exemplo, o direito dos empregados à livre organização sindical e à greve, previsto nos artigos $8^{\circ}$, caput e inciso I, e $9^{\circ}$ da $\mathrm{CF} / 88$.

Obviamente que vários direitos sociais exigem predominantemente prestações fáticas do aparelho estatal como, por exemplo, os direitos fundamentais à saúde e à educação. Sem embargo, como já ressaltado no capítulo 2, vários direitos individuais apresentam também natureza prestacional, como, por exemplo, o direito de propriedade (artigo $5^{\circ}, \mathrm{XXII}$ ), pois para que uma propriedade urbana não seja ocupada por cidadão que não têm onde morar, é necessário a manutenção de um aparato policial em mobilização constante, o que demanda prestação positiva por parte do poder público.

A concretização plena desses direitos se encontra sujeita à "reserva do possível", não no sentido de garantir apenas o "mínimo existencial” dos indivíduos após dar

\footnotetext{
${ }^{23}$ ESTEVES, João Luiz M. Direitos fundamentais sociais no Supremo Tribunal Federal. Op. cit., p. 46.
} 
prioridade aos direitos não-prestacionais, mas com o objetivo dar máxima aplicabilidade ao exercício de todos os direitos fundamentais, inclusive dos direitos sociais, de modo a garantir a dignidade do cidadão. Para isso, a previsão orçamentária do Estado deve contemplar todas as diretrizes traçadas na Constituição, não podendo o administrador público simplesmente privilegiar alguns direitos em detrimento de outros.

Nesse sentido, João Luiz Esteves explica como o Legislativo deve se pautar para aprovar o orçamento público e como o Executivo deve agir para executar o gerenciamento dos recursos públicos no intuito de concretizar os direitos fundamentais:

[...] não há como desprezar o fato da existência de limites financeiros para realização das despesas com o exercício dos direitos fundamentais. É uma realidade concreta que os Estados podem dispor de recursos para custear a sua atividade à medida que haja o ingresso suficiente de receita. Os gastos ficam, portanto, adstritos a um orçamento público, o qual faz a previsão de receita e indica a fonte de arrecadação ao tempo em que limita a execução da despesa e contempla, excluindo ou restringindo gastos com certos direitos, as prioridades definidas pelo Executivo e pelo Legislativo mediante o devido processo. Ao mesmo tempo, tem sido tarefa do Executivo decidir as prioridades no momento da execução do orçamento, ou seja, quais tarefas se realização prioritariamente e, caso o ingresso de recursos seja inferior ao previsto, quais deixarão de se realizar. Mas a não-efetivação de direitos fundamentais sociais não pode ter por obstáculo a explicação de que existe "não-previsão orçamentária" ou que, tendo sido prevista, ocorreu "exaurimento de recursos orçamentários". Acontece que a elaboração do orçamento deve contemplar todas as diretrizes estabelecidas na Constituição, e não há de ser privilegiados certos direitos em detrimento de outros. E o mesmo se diga quando ocorre a execução do orçamento por parte do administrador público, que deve ter sua discricionariedade limitada à vista dos direitos consagrados na Constituição. $\mathrm{O}$ estabelecimento de prioridades orçamentárias no estabelecimento das políticas públicas deve ser retirado da própria Constituição, conforme as diretrizes dela emanadas, sob pena de ser tido como inconstitucional. Já o gerenciamento de recursos orçamentário, por sua vez, deve ter por motivação e limite o mesmo comando constitucional, sem o qual também estaria exorbitando a competência delegada constitucionalmente. ${ }^{24}$

Muitas vezes a definição sobre qual direito deverá ser privilegiado, quando não há receita suficiente para arcar com a despesa necessária para o exercício de todos os direitos fundamentais, é o Poder Judiciário.

Uma das formas de exercício da cidadania ativa, prevista constitucionalmente, é justamente a garantia do indivíduo de acesso ao Poder Judiciário, como meio para a solução dos conflitos sociais e para a implementação dos direitos fundamentais individuais e sociais, inclusive os que demandam, para o seu exercício, despesas por parte dos entes públicos.

\footnotetext{
${ }^{24}$ ESTEVES, João Luiz M. Direitos fundamentais sociais no Supremo Tribunal Federal. Op. cit., p. 57.
} 
Entretanto, a atuação do Judiciário no sentido de implementar e concretizar direitos fundamentais sociais, sobretudo os de cunho prestacional, exige um estudo, que será feito no tópico seguinte, da teoria da separação dos poderes, originalmente apresentada por Montesquieu e posteriormente desenvolvida e adaptada às transformações inerentes ao paradigma do Estado Democrático de Direito, visto que essa teoria tem sido utilizada, muitas vezes, com o intuito de fulminar as prerrogativas constitucionais do Poder Judiciário no que tange à concretização de direitos sociais.

Após traçar a sistemática adotada pelo legislador constituinte no que tange ao tratamento dado aos direitos individuais e sociais e às garantias que visam assegurar o exercício desses direitos, conclui-se que a Constituição se vincula a uma concepção ampla de cidadania, a denominada "cidadania social", que enseja o exercício pleno dos direitos fundamentais, sejam eles de índole individual ou coletiva (liberdades públicas, direitos civis e políticos e garantias), sejam eles de índole social, pela sua origem ou natureza.

Paulo Bonavides afirma que a Constituição de 1988 inaugurou um novo paradigma de cidadania a partir do Estado Democrático de direito, pois

(...) não é apenas forma de governo, senão princípio constitucional da mais
sabida juridicidade na hierarquia dos ordenamentos; é, como já se disse, direito
de quarta geração que agrega todas as dimensões antecedentes na escala de
direitos humanos. É também síntese de valores que o País sacraliza na
obediência do cidadão e lhe rende o mais inviolável dos cultos. É, de último,
direito objetivo e subjetivo, com titularidade respectiva e concomitante no povo
e no cidadão; o povo, ente universal, expressão da humanidade, e o cidadão, ente
particular, expressão de personalidade.

Ou seja, a Constituição Federal, ao proclamar direitos e garantias com forte conteúdo social, adquire forma que a coloca na condição de reguladora e garantidora da cidadania social, estabelecida como pilar fundamental do Estado Democrático de Direito brasileiro.

\subsection{A atuação do Poder Judiciário para a concretização da cidadania social}

Tendo em vista que a Constituição Federal de 1988 adotou a cidadania social como uma das bases fundamentais do Estado Democrático de Direito brasileiro, ou seja, garantiu

25 BONAVIDES, Paulo. Os direitos humanos e a democracia. In: SILVA, Reinaldo Pereira e. Direitos humanos como educação para a justiça. São Paulo: LTr, p. 11. 
ao cidadão um rol amplo de direitos fundamentais, imprimindo-lhes aplicabilidade máxima, constata-se que o indivíduo poderá exercitar os direitos sociais que o ordenamento lhe confere, seja diretamente, quando esses direitos não implicarem a realização de políticas públicas ou demandarem a criação de leis infraconstitucional para regulamentá-los, seja ajuizando ações para efetivar esses direitos que, por vezes, não podem ser usufruídos pela omissão do poder legislativo em regulamentá-los ou pela postura omissiva da Administração Pública de estatuir normatização pertinente.

Entretanto, quando se trata da interposição de ações judiciais que visam a concretização dos direitos fundamentais sociais, observa-se que, muitas vezes, o Poder Judiciário tem restringido a sua atuação, em virtude de uma suposta falta de legitimação e de competência para a implementação desses direitos. Em outras palavras, a postura de atuação restritiva do Judiciário geralmente se respalda no respeito ao princípio da separação dos poderes, porém sob uma leitura desatualizada, que não leva em conta as alterações do contexto sócio-político-econômico sofridas pelo Brasil, que hoje se estabelece sob o paradigma do Estado Democrático de Direito.

Sem embargo, posturas restritivas de atuação do Judiciário não se coadunam com a concepção de cidadania adotada pela Lei Fundamental, pois o Estado brasileiro elegeu a pessoa humana como o seu eixo central, de modo que todas as instâncias estatais deverão trabalhar em prol da implementação efetiva dos direitos fundamentais garantidos ao indivíduo e à coletividade. Não basta que o cidadão possa apresentar uma demanda perante o Judiciário, ou seja, que tenha direito de ação e acesso aos tribunais. É necessário que os juízes possam exercer a sua função jurisdicional de maneira a concretizar os direitos materiais violados ou não implementados, respeitando a garantia constitucional de acesso à justiça. Porém, no momento do Judiciário efetivar direitos fundamentais dispostos em normas principiológicas que, por vezes, exigem ainda regulamentação infraconstitucional, não há como se esquivar da análise da controvertida questão da judicialização da política e do ativismo judicial e até onde o juiz poderia agir "ativamente", sem violar a própria Constituição.

Nos próximos subitens será analisada toda essa problemática que envolve a atuação do Judiciário no sentido de concretizar direitos fundamentais em geral, incluindo os direitos sociais, possibilitando o exercício desses direitos pelo indivíduo e materializando o princípio e valor da cidadania social. 


\subsubsection{A teoria da tripartição dos poderes de Montesquieu e sua evolução no tempo}

De certa forma, pode-se dizer que o princípio da separação dos poderes surgiu com Aristóteles, que distinguiu a assembléia-geral, o corpo de magistrados e o corpo do judiciário na Política. Sem embargo, foi com Montesquieu, em "O Espírito das Leis", que houve uma divulgação e melhor definição da denominada separação dos poderes ou tripartição dos poderes.

O princípio da separação dos poderes de Montesquieu tem como objetivo a limitação do poder exercido pelos monarcas dos Estados absolutistas, em virtude do exercício da liberdade individual pelos súditos.

O pensador francês aplicou o princípio como forma de garantia da liberdade, expondo que "a liberdade política em um cidadão é aquela tranqüilidade de espírito que provém da convicção que cada um tem da sua segurança. Para ter-se essa liberdade, precisa que o Governo seja tal que cada cidadão não possa temer outro". ${ }^{26}$ Depois de mencionar a liberdade política, afirma o autor que todo homem que se encontra no poder está propenso a abusar do mesmo.

Montesquieu explica que cada um dos poderes (Executivo, Legislativo e Judiciário) desenvolve determinadas funções. Os órgãos que legislam não podem ser os mesmos que executam, assim como nenhum deles pode ser destinado a dirimir as controvérsias. Um poder não deve interferir no outro, pois assim não haveria liberdade. ${ }^{27}$

Em relação à função judicial, Montesquieu acredita que "os juízes da nação [...] são apenas a boca que pronuncia as palavras da lei; seres inanimados que não lhe podem moderar nem a força, nem o rigor". ${ }^{28}$

Assim, sob influência da teoria da separação dos poderes, no constitucionalismo clássico constrói-se a dogmática segundo a qual cabe ao legislador a criação do direito e ao juiz a aplicação do direito. ${ }^{29}$

Sem embargo, esse esquema formalista de que o Legislativo cria o direito e o Executivo e o Judiciário o aplica não se vislumbrou perfeito na prática. Em muitos momentos, ocorreu uma interferência explícita entre os poderes ou, pelo menos, uma

\footnotetext{
${ }^{26}$ MONTESQUIEU. O espírito das leis. Trad. Pedro Vieira Mota. São Paulo: Saraiva, 1987, p. 165.

${ }^{27}$ Ibidem. Na realidade, o poder estatal é uno; o que são divididas são as funções do poder.

${ }^{28}$ Ibidem, p. 176.

${ }^{29}$ BÖCKENFÖRDE, Ernest-Wolfgang. Escritos sobre derechos fundamentales. Trad. Juan Requejo Pagés e Ignácio Villaverde Menéndez. Baden-Baden: Nomos Ver.-Ges, 1993, p. 131.
} 
interpenetração, segundo a qual as três esferas praticam funções atípicas, administrativas, legislativas e judiciárias.

Com efeito, durante as revoluções burguesas dos séculos XVIII e XIX, declarava-se a supremacia do parlamento como poder do qual emanava a "vontade geral da nação, que não poderia ser suplantada por nenhuma outra, ideia que permanece no constitucionalismo francês até pelo menos o primeiro terço do século XX.

De acordo com o jurista Carré de Malberg, o sistema francês de organização dos poderes estabelecido na Constituição de 1791 estabeleceu entre o corpo legislativo e as outras autoridades uma espécie de desigualdade que excluía qualquer possibilidade de uma separação verdadeira entre o poder legislativo e o poder constituinte.

\footnotetext{
Enquanto o executivo e a autoridade judiciária exerciam suas atribuições na forma e com os poderes de funcionários que agem a serviço da nação, a assembléia de deputados, concebida como órgão que 'quer pela nação', se tornava a 'representação' mesma desta última e adquiria, a esse título, a posse da soberania nacional com os poderes daí decorrentes. ${ }^{30}$
}

O sistema austríaco, ao se basear na ideia de supremacia da Constituição no conceito de ordenamento jurídico, acabou por romper com os sistemas de controle de constitucionalidade existentes na Europa, como o modelo francês, que privilegiava o parlamento, como os modelos das monarquias constitucionais que se pautavam pela supremacia do Executivo, transformando o monarca no "guardião da Constituição".

Assim, a Constituição da Áustria, de 1920, estabeleceu para um único órgão o exercício de verificar, em abstrato, a constitucionalidade das leis, adotando o sistema concentrado (Verfassungsgerichtbarkeit) e não permitindo que fosse analisada a constitucionalidade na aplicação aos casos concretos, como ocorre no modelo difuso (judicial review of legislation).

Segundo Kelsen, a ideia de separação de poderes deve ser entendida como de “divisão de poderes", ou seja, o poder deve ser repartido entre os diferentes órgãos, "não tanto para isolá-los reciprocamente quanto para permitir um controle recíproco de uns sobre os outros". ${ }^{31}$ Assim, justifica-se que o Judiciário possa anular leis do parlamento consideradas inconstitucionais, atuando por meio da função do legislador negativo, já que a anulação teria o mesmo caráter de generalidade que a elaboração da norma. Apesar do

\footnotetext{
${ }^{30}$ MALBERG, Carré de. In: KELSEN, Hans. Jurisdição Constitucional. São Paulo: Martins Fontes, 2003, p. 71.

${ }^{31}$ KELSEN, Hans. Jurisdição Constitucional. São Paulo: Martins Fontes, 2003, p. 152.
} 
avanço das ideias do jurista austríaco, ainda não se vislumbrava o Judiciário como Poder que objetivamente tem a tarefa dar efetividade à Constituição.

Karl Loewenstein discorda expressamente do conceito clássico de separação de poderes ao atribuí-lo a um modelo ideológico que teve como objetivo específico estabelecer e proteger a liberdade individual:

\begin{abstract}
Es necesario tener bien claro que el principio de la necesaria separación de las funciones estatales según sus diversos elementos substanciales y su distribución entre diferentes detentores, ni es esencial para el ejercicio del poder político, ni presenta una verdad evidente y válida para todo tiempo. El descubrimiento o invención de la teoría de la separación de funciones estuvo determinado por el tiempo y las circunstancias como una protesta ideológica del liberalismo político [...]. Este proceso recibió su cuño específico ante la necesidad ideológica de establecer y proteger la libertad individual. ${ }^{32}$
\end{abstract}

Com o tempo, a maior extensão das atividades do Estado contemporâneo repercutiu em uma remodelação da teoria da tripartição dos poderes, com novas formas de relacionamento entre os órgãos do Legislativo e Executivo e destes com os do Judiciário, buscando-se uma convivência harmônica entre os poderes.

Cada um dos três poderes (o Legislativo, ao criar normas, o Executivo, ao administrar a máquina burocrática estatal e o Judiciário, ao promover a aplicação das leis no caso concreto) tem a sua devida importância para o bom funcionamento do Estado simplesmente ao desempenhar as suas chamadas funções próprias. Contudo, para que seja preservada uma autonomia eficiente entre esses Poderes, não deve existir uma independência absoluta, pois esta viria apenas a servir como elemento desagregador e criador de inoperância.

Assim sendo, entende-se que é necessária uma individualidade harmônica, de maneira que cada Poder deverá possuir sua devida autonomia para exercitar sadiamente as suas funções, mas desde que de forma conjugada e compatibilizada com os demais no sentido de manter uma interação equilibrada entre os Poderes, a fim de que não entrem em choque. Eis o ideário do sistema de freios e contrapesos (checks and balances).

Segundo essa teoria, os atos que o Estado pratica podem ser de duas espécies: ou são gerais ou são especiais. Os atos gerais, que só podem ser praticados pelo poder legislativo, constituem-se na emissão de regras gerais e abstratas, não se sabendo, no momento de serem emitidas, a quem elas irão atingir. Dessa forma, o poder legislativo, que só pratica atos gerais, não atua concretamente na vida social, não tendo meios para cometer

${ }^{32}$ LOEWENSTEIN, Karl. Teoría de la Constitución. Op. cit., p. 56. 
abusos de poder, nem para beneficiar ou prejudicar a uma pessoa ou a um grupo em particular. Só depois de emitida a norma geral é que se abre a possibilidade de atuação do poder executivo, por meio de atos especiais. O Executivo dispõe de meios concretos para agir, mas está igualmente impossibilitado de atuar discricionariamente, porque todos os seus atos estão limitados pelos atos gerais praticados pelo legislativo. E se houver exorbitância de qualquer dos poderes surge a ação fiscalizadora do Poder Judiciário, obrigando cada um a permanecer nos limites de sua respectiva esfera de competências. ${ }^{33}$

As crises da função legislativa, os novos formatos de controle de constitucionalidade e a emergente necessidade de soluções prestacionais ofertadas pelo Estado têm impulsionado uma perspectiva funcional mais flexível da teoria da divisão de poderes.

As decisões decorrentes das experiências do judicial review, incluindo as cortes constitucionais europeias e o Supremo Tribunal Federal, no Brasil, têm apresentado essa tendência, sobretudo porque, nesses lugares, a nova preocupação para o debate da divisão de poderes é o tema da concretização de direitos.

A elaboração da teoria da separação de poderes se deu em meio à necessidade de limitação da atuação do Estado e para evitar a formação de Estados centralizadores e ditatoriais. Diversamente, nos dias de hoje, prevalece a cobrança, pela sociedade, dos deveres prestacionais do Estado. Este se encontra imerso em uma complexa teia social, de modo que necessita da interação de todos os poderes para o efetivo cumprimento de suas ações, em virtude da evolução contínua das sociedades. Com isso, a sociedade moderna busca meios que aumentem a eficácia do Estado:

[...] a evolução da sociedade criou exigências novas, que atingiram profundamente o Estado. Este passou a ser cada vez mais solicitado a agir, ampliando sua esfera de ação e intensificando sua participação nas áreas tradicionais. Tudo isso impôs a necessidade de uma legislação muito mais numerosa e mais técnica, incompatíveis com os modelos da separação de poderes. O legislativo não tem condições para fixar regras gerais sem ter o conhecimento do que já foi ou está sendo feito pelo executivo e sem saber de que meios este dispõe para atuar. O executivo, por seu lado, não pode ficar à mercê de um lento processo de elaboração legislativa, nem sempre adequadamente concluído, para só então responder às exigências sócias, muitas vezes graves e urgentes. $^{34}$

\footnotetext{
${ }^{33}$ DALLARI, Dalmo de Abreu. Elementos de teoria geral do Estado. 19. ed. atual. São Paulo: Saraiva, 1995, p. 183-185.

${ }^{34}$ Ibidem, p. 186.
} 
Nessa seara, é tema relevante a polêmica em torno da violação ao princípio constitucional da separação dos poderes, quando o Judiciário, face à omissão dos poderes legislativo e executivo, adentra na seara de competência destes na tentativa de corrigir iniqüidades, implementando aquilo que deveria ser feito por intermédio de ações positivas de cunho social.

Na realidade, nos dias de hoje, a teoria da divisão dos poderes passa por uma releitura, pois os direitos sociais não podem ser fustigados simplesmente pela omissão de qualquer um dos poderes, visto que as Constituições atuais não apenas elencam esses direitos, mas exigem a sua máxima implementação e efetivação por parte do Estado.

Pode-se dizer que há uma relativização da teoria da separação dos poderes, uma vez que os papéis exercidos por cada um deles passam por uma remodelação, de acordo com as exigências sociais. Dessa forma, o Judiciário, uma vez provocado, em virtude da omissão de deveres do Legislativo e do Executivo no que tange à efetivação de direitos fundamentais, não pode ficar omisso face à questão que lhe foi posta, arraigando-se ao princípio da separação dos poderes conforme uma leitura tradicionalista dessa teoria, baseada na concepção original apresentada por Montesquieu.

Werneck Viana realça que o movimento de judicialização da política exprime mudanças nos campos jurídico e político-institucional, observando-se o esvaziamento do cânone doutrinário da separação entre os poderes, tal como compreendido pela cultura jurídico-política dos países de civil law, passando o tema da limitação a prevalecer sobre o da divisão dos poderes. ${ }^{35}$

A análise acerca da releitura da teoria da divisão dos poderes no Brasil, sobretudo diante do sistema de direitos fundamentais adotado pela Constituição Federal de 1988, será objeto do próximo subitem.

\subsubsection{A releitura da teoria dos três poderes no Estado Democrático brasileiro}

Nas Constituições brasileiras a partir da proclamação da República, com exceção da Constituição de 1937, tem sido adotada teoricamente a tripartição de poderes, estruturados

\footnotetext{
35 VIANNA, Luiz Werneck; REZENDE DE CARVALHO, Maria Alice; CUNHA MELO, Marcelo P. e BURGOS, Marcelo Baumann. Corpo e alma da magistratura brasileira. Rio de Janeiro: Revan, 1997, p. 32.
} 
como Poder Legislativo, Poder Executivo e Poder Judiciário, resguardadas entre eles a independência e a harmonia.

Sem embargo, a organização dos poderes no país sempre refletiu as circunstâncias políticas do Estado, revelando as expectativas de correlação das forças dominantes, nem sempre expressivas dos anseios da sociedade.

A identidade do Poder Judiciário no Brasil, ao longo dos anos, foi sendo diluída, ora por meio de emendas ou atos institucionais que restringiam as suas prerrogativas e competências, ora por intermédio da elaboração de nova Constituição, que lhe transmudava a organização ou procurava resgatar os momentos de refluxo da Constituição imediatamente anterior.

A Constituição de 1988 adotou modelo que visa articular com equilíbrio as três órbitas de poder. O princípio da separação autônoma e da convivência harmônica entre os poderes encontra previsão expressa ${ }^{36}$ no artigo $2^{\circ}$ e recebeu o status de cláusula pétrea (artigo 60, parágrafo $4^{\circ}$ ).

Na realidade, nos últimos anos, percebe-se, no Brasil, uma relativização do dogma da separação dos poderes, pois o Judiciário vem apresentando uma postura mais ativa no sentido de garantir o exercício dos direitos fundamentais sociais, diante da impossibilidade de se esquivar das necessidades da sociedade brasileira.

Lima Esteves critica o fato de, no Brasil, a invocação do dogma da separação dos poderes ser feita, geralmente, com o sentido de obstaculizar a possibilidade do papel ativo do Poder Judiciário, o que não ocorre em se tratando da crítica à edição de medidas provisórias com força de lei pelo Presidente da República ou diante das interferências do Executivo nas votações do Legislativo, com o visível e não parcimonioso favorecimento de cargos no Executivo em troca de $\operatorname{votos}^{37}$, ou acrescenta-se, com o oferecimento de dinheiro em espécie ou outros favores.

No país, vislumbra-se certa submissão do Legislativo ao Executivo, o que evidencia uma abdicação do Poder Legislativo a expressar a vontade da maioria pelo qual os seus representantes foram eleitos. Sem embargo, muitas vezes o Legislativo também se vale de uma postura ameaçadora de não votar as leis urgentes e necessárias, com o intuito de mostrar a força do grupo de oposição às políticas governamentais, ou se omite no sentido de criar e votar as leis imprescindíveis à regulação, por exemplo, das normas

\footnotetext{
${ }^{36}$ Artigo $2^{\circ}$. São Poderes da União, independentes e harmônicos entre si, o Legislativo, o Executivo e o Judiciário.

${ }^{37}$ ESTEVES, João Luiz M. Direitos fundamentos sociais no Supremo Tribunal Federal. Op. cit., p. 74.
} 
constitucionais de eficácia limitada, por pressão de grupos de poder que exercem lobby sobre os deputados e senadores.

É fato que todos os órgãos estatais, incluindo o Judiciário, têm função política. João Luiz Lima Esteves esclarece que a visão de que o Judiciário é um órgão estatal incumbido apenas de uma função meramente jurisdicional - incompatível com a atividade política atribuída ao Legislativo e ao Executivo e, que por esse motivo, deve-se manter estritamente "submetido a uma interpretação que 'revele' o direito contido nos pressupostos legais, doutrinários e jurisprudenciais, dando-lhe uma característica de neutralidade diante das posições políticas que envolvem o conjunto da sociedade" somente encontra fundamento em uma construção ideológica que tenta esconder a existência de discricionariedade na jurisdição. ${ }^{38}$

E a própria tarefa de interpretação das normas constitucionais envolve um exercício de criatividade por parte do juiz, como visto no capítulo 3, já que, em muitos casos, o intérprete é chamado a complementar ou determinar o sentido e o alcance dos preceitos constitucionais de natureza aberta ou de preencher as denominadas "lacunas constitucionais". Ao tomar uma determinação decisão, o juiz, ainda que inconscientemente, está se pautando por um posicionamento ideológico definido, assim como ocorre com o legislador, ao formular uma lei.

$\mathrm{Na}$ verdade, não existe uma separação estanque entre os órgãos estatais que justifique a invocação de uma dogmática superada, sob o pretexto de manutenção de um modelo de organização estatal que não condiz com as necessidades enfrentadas pelo Poder Judiciário, que vem sendo chamado a desempenhar funções que garantam e dêem eficácia e aplicabilidade à Constituição em questões como o direito de minorias, a justiça distributiva, a ausência de normas infraconstitucionais que regulem normas constitucionais de modo a possibilitar o exercício de direitos fundamentais e a dissonância entre a realidade fática existente nos momentos de criação da norma constitucional e de interpretação dessa norma.

João Luiz Esteves explica que o Judiciário não deve substituir os Poderes Executivo e Legislativo, quanto à decisão sobre a característica a ser dada ao Estado, a qual é encontrada na Constituição Federal, nem deve ser o órgão que define as políticas públicas a serem desenvolvidas para concretizar os mandados constitucionais, mas deve atuar objetivamente com os demais órgãos na efetivação dos direitos sociais, anulando regras

\footnotetext{
${ }^{38}$ Ibidem, p. 74.
} 
inconstitucionais, dando aplicação à norma infraconstitucional no caso concreto de forma que o resultado seja adequado aos objetivos constitucionais e suprindo omissões legislativas e administrativas, e redefinindo políticas públicas quando ocorrer inoperância de outros poderes. ${ }^{39}$

Para o autor, havendo reconhecimento de omissão constitucional, o Poder Judiciário deveria se manifestar sobre a matéria até que a omissão legislativa fosse suprida e fixar prazo para que o órgão inadimplente cumprisse um mandado constitucional, realizando a expedição de comandos normativos que vigorassem até o pronunciamento objetivo do poder inoperante no cumprimento da Constituição. ${ }^{40}$

Segundo Andreas Krell, o cumprimento das tarefas sociais e respectivas políticas do Estado social de direito têm fundamento nas normas constitucionais e deve ser controlado pelo Judiciário, que não pode ficar inerte porque essas normas também são dirigidas a ele. Nesse sentido, o autor explica que o princípio da separação de poderes, idealizado por Montesquieu,

está produzindo, com sua grande força simbólica, um efeito paralisante às reivindicações de cunho social e precisa ser submetido a uma nova leitura para poder continuar a servir ao seu escopo originar de garantir direitos fundamentais contra o arbítrio e, hoje também, omissão estatal. ${ }^{41}$

Lenio Luiz Streck acredita que o Poder Judiciário, quando no controle de constitucionalidade, deve assumir uma postura intervencionista, longe da postura absenteísta do modelo liberal-individualista-normativista que permeia a dogmática jurídica brasileira.

\begin{abstract}
Quando falo em "intervencionismo substancialista”, refiro-me ao cumprimento dos preceitos e princípios ínsitos aos Direitos Fundamentais Sociais e ao núcleo político do Estado Social previsto na Constituição de 1988, donde é possível afirmar que, na inércia dos poderes encarregados precipuamente de implementar políticas públicas, é obrigação constitucional do Judiciário, através da jurisdição constitucional, propiciar as condições necessárias para a concretização dos direitos sociais fundamentais. ${ }^{42}$
\end{abstract}

Vieira de Andrade apresenta uma visão mais restritiva da atuação do Poder Judiciário, entendendo que as tarefas constitucionais não vinculam de modo imediato os

\footnotetext{
${ }^{39}$ Ibidem, p. 76.

${ }^{40}$ Ibidem, p. 80.

${ }^{41}$ KRELL, Andreas Joachim. Op. cit., p. 252.

42 STRECK, Lênio Luiz. Quinze anos de Constituição - análise crítica da jurisdição constitucional e das possibilidades hermenêuticas de concretização dos direitos fundamentais sociais. Revista da Ajuris Associação dos Juízes do Rio Grande do Sul, Porto Alegre, v. 30, n. 92, dez. 2003, p. 224.
} 
poderes públicos e que a divisão de poderes impede que os juízes as determinem quanto à sua extensão, a não ser em caráter excepcional, quando houver uma violação evidente e arbitrária, pelo legislador, da incumbência constitucional. ${ }^{43}$

Outros autores como Luís Roberto Barroso ${ }^{44}$ e Daniel Sarmento ${ }^{45}$, embora não se filiem à atuação do Judiciário como exceção ao princípio da separação dos poderes como Vieira de Andrade, acreditam que o Judiciário deve se limitar à definição de políticas públicas para garantir conteúdos mínimos dos direitos sociais, ou seja, o "mínimo existencial”. O princípio da dignidade humana prepondera sobre o princípio da separação dos poderes, de modo que esse último princípio não pode ser utilizado para inibir a atuação do Judiciário na tarefa que lhe incumbe, de garantidor da Constituição, pelo menos quando o que se está buscando garantir, mediante procedimento judicial, é a dignidade da pessoa humana no seu aspecto máximo. A regra contida no artigo $2^{\circ}$ da Constituição Federal de 1988, que define os poderes da República e proclama a independência harmônica entre eles é meio e não fim do Estado, devendo ser utilizada para dar concretização à Constituição, com fundamento nos princípios contidos no artigo $3^{\circ}{ }^{46}$

De qualquer forma, independentemente da adoção de um ou outro posicionamento doutrinário acerca da amplitude de atuação do Poder Judiciário no Brasil atual e a sua congruência com a releitura da teoria da divisão dos poderes, vislumbra-se uma modificação da postura do Supremo Tribunal Federal em relação aos julgamentos realizados em vários campos de atuação, o que inevitavelmente está remodelando, na prática, o princípio da separação de poderes no país, ainda que sujeito a críticas.

No que tange à interferência nos demais poderes, o Supremo era legatário da teoria constitucional americana no sentido de não interferir nas questões políticas dos demais poderes. Sem embargo, antes mesma da EC n. 45/04, a jurisdição constitucional brasileira vem flexibilizando esse entendimento, como se pode ver nas decisões que ampliaram o poder de investigação das Comissões Parlamentares de Inquérito (CPI’s). ${ }^{47}$

\footnotetext{
${ }^{43}$ ANDRADE, José Carlos Vieira de. Op. cit., p. 374.

${ }^{44}$ BARROSO, Luís Roberto. O direito constitucional e a efetividade de suas normas. Op. cit., p. 155.

45 SARMENTO, Daniel. Interpretação dos direitos fundamentais e o conflito entre poderes. In: MELLO, Celso de Albuquerque et al (coords.). Op. cit., 2001,

${ }^{46}$ Artigo $3^{\circ}$. Constituem objetivos fundamentais da República Federativa do Brasil:

I - construir uma sociedade livre, justa e solidária;

II - garantir o desenvolvimento nacional;

III - erradicar a pobreza e a marginalização e reduzir as desigualdades sociais e regionais;

IV - promover o bem de todos, sem preconceitos de origem, raça, sexo, cor, idade e quaisquer outras formas de discriminação.

47 VALLE, Vanice Regina Lírio do (Org.). Ativismo jurisdicional e o Supremo Tribunal Federal: laboratório de análise jurisprudencial do STF. Curitiba: Juruá, 2009, p. 96.
} 
Ademais, o Supremo vem quebrando a orientação antes adotada em relação à função de legislador negativo, como se verifica em vários casos, como na ADI n. 3.105, sobre a contribuição previdenciária dos inativos, na ADPF n. 45, com o voto do Ministro Celso de Mello sustentando a competência da corte para o controle e mesmo a formulação de políticas públicas e na discussão da admissibilidade da ADPF n. 45, que versa sobre a descriminalização do aborto em gravidez que dê origem a feto anencefálico, mesmo com o parecer contrário do então Procurador-Geral da República Cláudio Fonteles. ${ }^{48}$

Por fim e diretamente relacionada ao objeto da presente tese, merece atenção a atuação do STF na concretização de direitos fundamentais. Se no início do século passado, a intenção, por meio do alargamento do instituto do habeas corpus, foi garantir determinados direitos individuais, atualmente a Corte se vê diante de situação muito mais complexa, em virtude do amplo rol de direitos fundamentais, inclusive de natureza prestacional, estabelecidos na Constituição Federal de 1988 e que exigem implementação, ainda que diante da omissão dos outros poderes que, primordialmente, deveriam fazê-lo, de modo que remédios constitucionais, como o mandado de injunção, têm recebido um novo tratamento pelo Supremo. Nesse sentido, fica patente que nos julgados dos MI n. 670/ES, MI n. 708/DF e MI n. 712/PA relativos ao exercício do direito fundamental dos servidores públicos à greve, entravado pela ausência de lei ordinária específica regulamentadora, o Supremo atuou de forma pró-ativa, decidindo que, enquanto não for criada, pelo Legislativo, a referida lei, os servidores poderão exercer o seu direito fundamental à greve, constitucionalmente garantindo, observando, no que couber em relação a esse exercício, a lei n. 7.738/89 que regula o direito de greve dos empregados regidos pela CLT.

Sem embargo, essa postura ativa do Supremo Tribunal Federal e de outros órgãos do Poder Judiciário no sentido de implementar direitos fundamentais é ainda recente e bem restrita em relação aos direitos sociais, sobretudo os que exigem do Estado, para a sua efetivação, políticas que envolvam gastos públicos, consequência direta das concepções acerca do papel do Poder Judiciário predominantes no Brasil, que defendem uma postura restritiva no que diz respeito à efetivação dos direitos sociais, destituída de fundamentação jurídico-constitucional e que influencia diretamente na formação e na atuação dos magistrados.

${ }^{48}$ Ibidem, p. 97. 


\subsubsection{A postura do Poder Judiciário no tocante à efetivação dos direitos sociais: concepções possíveis e suas críticas}

No Estado Liberal, o papel do juiz se resumia basicamente a aplicar a lei ao caso concreto para resolver os problemas que lhe eram postos, visto que, nessa época, a atuação estatal se pautava pela observância estrita do princípio da legalidade e da submissão do Direito à lei.

Luigi Ferrajoli, citado por Maria Cecília M. Teodoro, afirma que o juízo, nesse período histórico, torna-se um verificador do que foi estabelecido pela lei e essa, por sua vez, serve para dar fundamento às garantias, incluindo a certeza do direito à igualdade perante a lei e a liberdade frente à arbitrariedade, a independência do juiz à carga de prova para acusação e os direitos de defesa. ${ }^{49}$

No campo da hermenêutica jurídica surge a denominada Escola da Exegese que defendia a perfeita identidade entre o texto legal e a norma, tomando a disposição legislativa como um dogma e devendo o intérprete limitar-se a pesquisar a "vontade do legislador. "Assim, quando clara a lei, o intérprete e aplicador deveria fixar-se no sentido das palavras usadas pelo legislador (método gramatical ou literal) e, se obscura, deveria pesquisar e descobrir o exato pensamento do legislador nela contido". ${ }^{50}$ Ou seja, o magistrado deveria restringir-se a ser "a boca da lei" (la bouche de la loi).

O juiz deveria exercer as suas funções com neutralidade, ou seja, desvinculado dos valores sociais de um determinado tempo e lugar, consagrados na Constituição de um país, e indiferente em relação às circunstâncias particulares do caso concreto trazido ao seu conhecimento e julgamento.

Sem embargo, com a superação do dogma liberal, constatou-se que a exigência de neutralidade do juiz, além de ser impossível, é "prejudicial aos princípios do paradigma do Estado Democrático de Direito hoje vigente, por contrariar os ideais de efetividade e justiça da tutela jurisdicional". ${ }^{51} \mathrm{Na}$ verdade, imprescindível é imparcialidade do juiz, ou seja, a proibição de favorecimento indevido de uma das partes do processo.

49 FERRAJOLI, Luigi. Pasado e futuro del Estado de derecho. In: CARBONNEL, Miguel (ed.). Neconstitucionalismo(s). Madrid: Trotta, 2005, p. 16 apud TEODORO, Maria Cecília Máximo. O juiz ativo e os direitos trabalhistas. São Paulo: LTr, 2011, p. 45.

50 PIMENTA, José Roberto Freire; PORTO, Lorena Vasconcelos. Instrumentalismo substancial e tutela jurisdicional civil e trabalhista: uma abordagem histórico-jurídica. Revista do Tribunal Regional da $3^{\mathrm{a}}$ Região. Belo Horizonte, v. 43, n. 73, jan./jun. 2006, p. 94-95.

51 Ibidem, p. 95. 
O princípio da igualdade jurídica de todos perante a lei, ou seja, a igualdade apenas formal não enseja a efetivação dos direitos. Ademais, não se observava o respeito à dignidade da pessoa humana, pois o magistrado não poderia oferecer tratamento diverso a situações concretas e indivíduos de diferentes posições sociais. ${ }^{52}$

Após o fim da Segunda Guerra Mundial, sedimenta-se, na maioria dos países da Europa Ocidental, o Estado de Bem-Estar Social, com o objetivo de tentar implementar as políticas sociais necessárias à promoção da igualdade material, o que passa a exigir outra forma de atuação por parte dos magistrados.

Ao contrário do período anterior em que do intérprete exigia-se simplesmente uma leitura gramatical e literal das normas jurídicas e do juiz uma aplicação "neutra" da lei, no paradigma do Estado Social os intérpretes e aplicadores do direito devem desenvolver uma atividade construtiva do sentido das normas, atentando para os valores emanados pelos princípios dispostos na Constituição.

Segundo Ferrajoli, o juiz passa a aplicar a lei somente se ela for constitucionalmente válida. Assim, desenvolve um juízo de valor sobre a lei, pois tem o dever de definir acerca de sua validade ou invalidade, mediante a denúncia de sua inconstitucionalidade, quando não seja possível interpretá-la no sentido constitucional. ${ }^{53}$ Assim, o Judiciário desenvolve a função do controle de legitimidade da legislação infraconstitucional, com base nos princípios e garantias constitucionais.

Nessa nova forma de jurisdição, diante de antinomias e lacunas do ordenamento jurídico, o juiz deverá buscar sua superação por meio dos princípios constitucionais existentes ${ }^{54}$ que passam a ser compreendidos como normas jurídicas e não mais como postulados sem mero valor jurídico ou apenas vetores direcionadores da interpretação jurisdicional.

Ademais, como o Estado Social tem como característica a intervenção nas searas econômica e social, uma das formas de sua atuação é o desenvolvimento de uma legislação composta de direitos mínimos que deverão incidir nas relações jurídicas privadas para tentar minorar o desequilíbrio entre as partes. Dessa forma, o Direito do Trabalho torna-se uma forma de proteção do trabalhador, parte hipossuficiente na relação contratual mantida com o empregador, que passa a ter a sua autonomia da vontade mitigada sobretudo no que tange às cláusulas contratuais relativas às condições de trabalho.

\footnotetext{
52 TEODORO, Maria Cecília Máximo. Op. cit., p. 46.

${ }^{53}$ FERRAJOLI, Luigi. Op. cit., p. 18 apud TEODORO, Maria Cecília Máximo. Op. cit., p. 77.

54 TEODORO, Maria Cecília Máximo. Op. cit., p. 78.
} 
O juiz, portanto, deverá prestar a sua atividade jurisdicional atentando para a observância dos direitos pleiteados pelas partes da relação jurídica material, seja o respeito às normas mitigadoras do desequilíbrio contratual, seja a observância ao princípio da autonomia da vontade.

Com a crise do Estado Social e a alteração paulatina para o paradigma do Estado Democrático de Direito, o papel do juiz, no sentido de aplicar os direitos sociais, se fortalece, pois não é mais possível efetivar apenas aqueles direitos estabelecidos em lei. É necessário implementar os direitos fundamentais dispostos na Constituição, incluindo os direitos fundamentais de natureza prestacional, sejam eles direitos individuais ou sociais. E, como esses direitos estão estabelecidos em normas com estrutura principiológica, aberta, a concretização e densificação delas dependerá da atividade interpretativa do juiz, que deverá ser pautada por técnicas específicas desenvolvidas para tentar apreender o sentido e o alcance da norma constitucional em consonância com a realidade vivenciada pelos cidadãos.

Sem embargo, apesar da alteração do paradigma de Estado e dos clamores de uma sociedade plúrima e complexa que não mais se contenta em ter apenas assegurados os direitos e garantias fundamentais, pleiteando a sua concretização, a atuação mais ativa do Judiciário ainda tem sido podada pela adoção de uma postura autorestritiva em relação à efetivação dos direitos fundamentais sociais, oferecendo uma prestação jurisdicional baseada em valores e em técnicas interpretativas atinentes a uma realidade jurídico-social ultrapassada. Ademais, o papel de concretizador efetivo de direitos fundamentais sociais também tem sido alvo de teorias restritivas desenvolvidas pela doutrina.

O juiz de Direito Antonio Celso Aguillar Cortez acredita que a atuação dos magistrados tem se manifestado por meio de uma postura formalista e restritiva no que diz respeito à concretização dos direitos fundamentais sociais:

\footnotetext{
O processo de civilização da humanidade tem sido marcado pelo reconhecimento formal dos direitos inerentes à condição humana, mas sua efetiva aplicação tem sido ainda negada para a grande maioria das pessoas e o Juiz tem tido um papel importante na permanência desta situação, enquanto conformado com as limitações formalistas tradicionais e com a banalização dos conflitos de interesses para os quais o enfoque normal tem sido o da fragmentação e da aplicação de soluções técnicas que ignoram muitas vezes o justo para fazer o legal, o instrumental: que evitam a dimensão social das causas para fazer prevalecer o interesse meramente individual. ${ }^{55}$
}

${ }^{55}$ CORTEZ, Antonio Celso Aguillar. Acesso à justiça. Revista dos Tribunais, ano 82, v. 692, jun. 1993, p. 198. 
Com efeito, o Poder Judiciário é o meio pelo qual muitos cidadãos buscam a solução dos conflitos sociais, inclusive os que envolvem a concretização de direitos fundamentais sociais. Sem embargo, a atuação dos magistrados tem sido alvo de objeções quanto à sua amplitude, alicerçadas em diferentes matrizes ideológicas.

A primeira, de caráter jurídico-sociológico, defende que o Judiciário é incapaz de resolver questões ligadas ao exercício da cidadania social, em virtude de problemas relativos à eficácia de suas decisões, eficiência e acessibilidade ao sistema judicial. Assim, o indivíduo deverá buscar exercer sua cidadania apenas na comunidade em sentido micrológico. Segundo João Lima Esteves, essa concepção revela o descompromisso social relativo à consolidação dos direitos sociais e coloca "os setores mais fracos da relação social em condições de subjugação aos setores comunitários mais organizados ou violentos". 56

O segundo entendimento que, de acordo com o autor se encontra disseminada na cultura jurídica brasileira, é calcada em postulados jurídico-ideológicos e acredita que a resolução de conflitos sociais não é tarefa do Judiciário. Ou seja, a atuação desse Poder estatal é limitada, de modo que o juiz só deveria agir por meio da clássica fórmula da subsunção do fato à norma, em conflitos particularizados, com a prevalência da garantia dos direitos individuais. Os magistrados que se formaram com base nessa concepção jurídica mostram-se avessos ou perplexos diante das novas exigências, "negando a tutela do Judiciário aos reclamos da sociedade para o efetivo exercício da cidadania em toda a sua plenitude, particularmente no tocante à garantia dos direitos sociais". ${ }^{57}$

A terceira concepção, de cunho político-ideológico, defende que a judicialização dos conflitos sociais frustra a possibilidade de desenvolvimento das lutas populares pela reivindicação de direitos. Segundo Esteves, essa linha de pensamento não se preocupa com a postura que deve ser adotada pelo Estado em face das demandas apresentadas, somente propondo o deslocamento do campo onde ocorre o embate em torno da concretização dos direitos fundamentais. ${ }^{58}$

Esteves desconsidera a última concepção, pois seus seguidores sequer procuram entender os motivos que tornam as salas dos Tribunais o local eleito para a disputa pelos direitos sociais, e critica a primeira e segunda posições, visto que sempre foram utilizadas em proveito de interesses que pretendem a manutenção da ordem atual das coisas. Dessa

\footnotetext{
${ }^{56}$ ESTEVES, João Luiz M. Direitos fundamentos sociais no Supremo Tribunal Federal. Op. cit., p. 59.

${ }^{57}$ Ibidem, p. 59.

${ }^{58}$ Ibidem, p. 59-60.
} 
forma, "a partir do momento em que o Estado e, particularmente, o Judiciário dão as costas aos conflitos sociais e se escudam em uma teoria que nega a possibilidade de atuação concreto do último, frustra-se a possibilidade de consolidação da cidadania social."

Sem embargo, nas últimas décadas vêm se desenvolvendo uma concepção teórica acerca da atuação do Judiciário brasileiro mais consentânea com a efetivação dos direitos sociais. Clèmerson Clève afirma que, ao lado de uma corrente denominada de "dogmática da razão do Estado" que pretende a manutenção do status quo, apresenta-se outra nomeada de "dogmática constitucional emancipatória" que tem como objetivo estudar o texto constitucional à luz da dignidade da pessoa humana.

\begin{abstract}
Consiste em formação discursiva que procura demonstrar a radicalidade do constituinte de 1988, tendo em vista que o tecido constitucional passou a ser costurado a partir de uma hermenêutica prospectiva que não procura apenas conhecer o direito como ele é operado, mas que, conhecendo suas entranhas e processos concretizadores, ao mesmo tempo fomente uma mudança teorética capaz de contribuir para a mudança da triste condição que acomete a formação social brasileira. ${ }^{60}$
\end{abstract}

Levando em consideração que os direitos de defesa e os direitos prestacionais podem ser direitos individuais ou sociais, deve ser analisada qual a postura do Judiciário quando é levada a processar e julgar demandas em que se apresentam pretensões de efetivação de um ou outro tipo de direito fundamental.

Ocorrendo violação dos direitos de defesa, ao Judiciário caberá uma atuação declaratória e mandamental do direito para exigir da Administração Pública, do Legislativo ou mesmo de particulares uma abstenção ou a cessação de uma atitude arbitrária e inconstitucional contrária a um direito já materializado que esteja sendo violado.

Em relação aos direitos prestacionais, sejam eles direitos individuais ou sociais, os órgãos jurisdicionais deverão expedir um mandado que tenha por objeto a materialização do direito, mediante atuação da Administração Pública, do Legislativo e de particulares. Sem embargo, a falta ou omissão de manifestação acerca do mandado judicial é que tem se apresentado como barreira diante de direitos que demandam prestações objetivas e servido de argumento para combater a judicialização dos direitos fundamentais sociais e a possibilidade de atuação concreta do Judiciário, frustrando a consolidação da cidadania social. $^{61}$

\footnotetext{
${ }^{59}$ Ibidem, p. 60.

${ }^{60}$ CLÈVE, Clèmerson Merlin. A eficácia dos direitos fundamentais sociais. Boletim Científico - Escola Superior do Ministério Público da União. Brasília: ESMPU, n. 8, jul./set., 2003, p. 151.

${ }^{61}$ ESTEVES, João Luiz M. Direitos fundamentos sociais no Supremo Tribunal Federal. Op. cit., p. 62.
} 
Parte da doutrina brasileira se funda em concepções estrangeiras, como a de Bockenförde, para quem os direitos fundamentais são custosos, não podem ser interpretados e que, em um ordenamento jurídico pautado pelo princípio da separação dos poderes, a garantia deles é tarefa do legislador e do administrador. ${ }^{62}$ Sem embargo, o jurista alemão relativiza o seu entendimento quando, em condições extremas de inatividade abusiva, os direitos fundamentais sociais puderem fundamentar diretamente uma pretensão judicial, extraindo das normas constitucionais um componente jurídico-subjetivo sem que se ponha em risco o sistema jurídico-constitucional. ${ }^{63}$

Essa visão também é adotada por Vieira de Andrade que, excepcionalmente, entende viável que se retire diretamente da Constituição a aplicabilidade de um direito social, desde que para atender a um conteúdo mínimo, servindo essa possibilidade como meio para regular "crises do sistema" a partir de um serviço que já esteja sendo prestado pelo Estado.

\begin{abstract}
No caso de inexistência de legislação sobre a matéria, ou na parte em que esta se revelar insuficiente para permitir o cumprimento das normas constitucionais, estas não poderão, em regra, ser actualizadas e aplicadas pelo juiz ou pela Administração. É aqui indispensável o juízo autônomo do legislador e ele não pode ser substituído por outra entidade. No entanto, em casos excepcionais, pode pensar-se em retirar directamente da Constituição um direito a determinada prestação social: julgamos que isso será admissível quando esteja em causa "o conteúdo mínimo" dos preceitos constitucionais, nomeadamente em situações de necessidade ou de injustiça extremas, de tal modo que, a verificarem-se, permitam configurar esse recurso como uma "válvula de segurança" da ordem jurídico-constitucional $[\ldots] .{ }^{64}$
\end{abstract}

No Brasil, essa tese não totalmente restritiva da atuação do Judiciário para efetivar direitos sociais sofre algumas mutações. Anna Paula de Barcelos, por exemplo, entende exigível perante os órgãos jurisdicionais o atendimento a um "mínimo existencial", embora não vincule essa possibilidade à existência de um serviço já prestado e também a condicione a regulação de crises do sistema. Segundo a autora, o "mínimo existencial" guarda correspondência direta com o principio da dignidade da pessoa humana e, por isso, o cidadão tem a condição subjetiva necessária para pleitear juridicamente direitos sociais não efetivados pelo legislador ou pelo administrador.

Na linha do que se identificou no exame sistemático da própria Carta de 1988, o "mínimo existencial" que ora se concebe é composto de quatro elementos, três

\footnotetext{
${ }^{62}$ BÖCKENFÖRDE, Ernest-Wolfgang. Escritos sobre derechos fundamentales. Op. cit., p. 77.

${ }^{63}$ Ibidem, 65-66.

${ }^{64}$ ANDRADE, Carlos Vieira de. Op. cit., p. 384.
} 
materiais e um instrumental, a saber: a educação fundamental, a saúde básica, a assistência aos desamparados e o acesso à Justiça. Repita-se, ainda uma vez, que esses quatro pontos correspondem ao núcleo da dignidade da pessoa humana a que se reconhece eficácia jurídica positiva e, a fortiori, o status de direito subjetivo exigível diante do Poder Judiciário. ${ }^{65}$

Ingo Wolfgang Sarlet defende que as condições mínimas de dignidade devem ser atendidas, não sendo pertinentes os argumentos comuns da falta de verbas e da nãocompetência do Judiciário para decidir sobre a questão dos recursos públicos. Para isso, o juiz poderá se valer da técnica de ponderação de bens de forma a possibilitar o reconhecimento de um direito subjetivo a um "mínimo existencial", que engloba, além dos direitos já citados por Ana Paula de Barcelos, o direito à moradia e à formação profissional. ${ }^{66}$

Na realidade, a possibilidade de efetivação dos direitos fundamentais sociais não depende apenas da aceitação do Judiciário como poder estatal que deve conhecer e solucionar os conflitos sociais, mas que os juízes, quando exerçam a jurisdição constitucional, se valham de instrumentos processuais e de técnicas de interpretação constitucional voltadas para a máxima aplicabilidade e eficácia das normas de direitos fundamentais.

Além das resistências externas a uma atuação mais ativa do Judiciário no que tange à concretização de direitos fundamentais sociais, a postura autorestritiva dos próprios juízes que acreditam que a decisão sobre as prioridades é dos órgãos políticos do sistema, ${ }^{67}$ tem sido um dos grandes obstáculos para superar o dogma da separação dos poderes, na sua vertente tradicionalista.

Nos dizeres de João Luiz Esteves, o comportamento autorestritivo do Judiciário, quando chamado a desempenhar, com o Executivo e o Legislativo, a tarefa de concretizador dos direitos fundamentais, demonstra a existência de uma concepção "político-ideológica que afirma não existir legitimidade democrática do Judiciário que lhe dê incumbência objetiva na efetividade dos direitos fundamentais sociais". ${ }^{6}$

No Brasil, a discussão sobre a legitimidade do Judiciário, para o exercício de uma postura concretizadora de direitos, somente ganha força com a Constituição de 1988, quando fica clara a opção pelo estabelecimento de um controle misto de constitucionalidade.

\footnotetext{
${ }^{65}$ BARCELOS, Ana Paula de. Op. cit., p. 258.

${ }^{66}$ SARLET, Ingo Wolfgang. A eficácia dos direitos fundamentais. Op. cit., p. 300-319.

${ }^{67}$ ABRAMOVICH, Vitor; COURTS, Christian. Op. cit., p. 127.

${ }^{68}$ ESTEVES, João Luiz M. Direitos fundamentos sociais no Supremo Tribunal Federal. Op. cit., p. 82.
} 
Historicamente, vislumbra-se o Legislativo claramente submetido ao Executivo que, muitas vezes sob a pecha de favores políticos, consegue as maiorias favoráveis à aprovação dos projetos de leis sobre os seus programas e as suas políticas governamentais. Nos últimos anos, entretanto, o Legislativo também tem atuado no sentido de dificultar a ação do Executivo, emperrando a aprovação de leis essenciais para a criação de políticas públicas ou para a regulamentação de direitos fundamentais.

Dessa forma, para João Luiz Esteves, não procedem as argumentações tendentes a defender a existência de uma "separação de poderes" que confira legitimidade absoluta ao Parlamento na conformação discricionária de dar efetividade aos direitos fundamentais sociais, pois se o sistema não funciona para o Legislativo, não se poderia exigir que o dogma da separação permaneça como discurso para o Judiciário. É necessário, então, buscar reequilibrar o sistema.

\begin{abstract}
Na existência de um Parlamento submisso ao Executivo, criam-se distorções na sua atividade, as quais podem impedir a efetividade da Constituição, pois toda a atividade estatal corre o risco de ficar submetida a um tipo de projeto governamental; nestas condições somente um Judiciário ativo e comprometido com sua tarefa de guardião da Constituição pode dar possibilidade à tarefa constitucional. ${ }^{69}$
\end{abstract}

Pode-se dizer que, no Brasil, não existe oposição presente no modelo constitucional adotado ou na sociedade quanto à legitimação do Judiciário na tarefa de dar efetividade à Constituição. A doutrina se preocupa mais em discutir o aspecto teórico-jurídico da atuação do Judiciário do que colocar a questão da sua legitimidade política como eixo central do problema. Dessa forma, percebe-se que a existência de dificuldades na efetivação da Constituição pode estar partindo do próprio Poder Judiciário, o que se denomina de autorestrição do Judiciário na tarefa de efetivar a Constituição.

De acordo com João Luiz Esteves, a história do Estado brasileiro revela que durante a vigência de todas as Constituições, ${ }^{70}$ pelo menos até 1988 , o Judiciário não assumiu papel ativo na garantia das normas constitucionais e sempre se moldou ao poder estabelecido. Esse fenômeno tem como característica principal "o entendimento, de membros do Judiciário, de que as decisões sobre questões fundamentais do Estado cabem

\footnotetext{
${ }^{69}$ Ibidem, p. 85.

70 As Constituições de 1824, 1937, 1967 e 1969 foram impostas por poderes centralizadores antidemocráticos. A Constituição de 1891 não contou com real participação popular. E as Constituições de 1934 e 1946, embora tenham sido promulgadas por governos mais democráticos, foram dissolvidas por golpes de Estado.
} 
aos chamados poderes políticos",71 negando o Judiciário, a si próprio, a tarefa política de intérprete e aplicador da Constituição.

Com a Constituição Federal de 1988, quando se estabeleceu um conjunto ampliativo de direitos sociais, também foi efetivamente estipulado o controle misto de constitucionalidade, o que deu à República Federativa do Brasil características de Estado Democrático de Direito, com amplas possibilidades de concretização dos direitos fundamentais sociais com o auxílio da via jurisdicional.

Dessa forma, para a efetivação dos direitos sociais não basta a adoção de um amplo leque de opções processuais de controle de constitucionalidade, nem é necessária apenas a positivação desses direitos. É necessário, também, que exista jurisdição construída sob a concepção de que efetivamente cabe ao Judiciário a guarda da Constituição, pois os juízes devem agir como órgãos estatais vinculados aos objetivos constitucionais, não podendo se esconder atrás de uma concepção doutrinária que leve à sua autorestrição. ${ }^{72}$

É necessário salientar que embora os estudos doutrinários acerca da efetivação e concretização de direitos fundamentais sociais geralmente sejam mais voltados para a atuação do Supremo Tribunal Federal, em virtude da importância da sua função relativa ao controle concentrado de constitucionalidade, não se pode esquecer que os outros órgãos do Poder Judiciário, inclusive os órgãos que compõem a Justiça do Trabalho, também exercem a jurisdição constitucional, por meio do controle difuso de constitucionalidade dos atos normativos do Legislativo e da Administração Pública, além de interpretar e aplicar diretamente preceitos constitucionais que estabelecem direitos fundamentais.

Assim, quando se fala de atuação mais ativa do Poder Judiciário, deve-se entender que todos os órgãos jurisdicionais brasileiros, incluindo os da Justiça do Trabalho, têm legitimidade para agir de modo a concretizar direitos fundamentais sociais, sob o manto de uma concepção não autorestritiva.

\subsubsection{O Judiciário e a cidadania social: a observância do princípio de acesso à justiça}

É importante ressaltar que a adoção, pelo Judiciário, de uma postura mais restritiva de atuação, no que tange à interpretação e aplicação dos direitos fundamentais sociais

\footnotetext{
${ }^{71}$ ESTEVES, João Luiz M. Direitos fundamentos sociais no Supremo Tribunal Federal. Op. cit., p. 86.

${ }^{72}$ Ibidem, p. 89.
} 
esculpidos na Constituição, pode comprometer seriamente a efetivação desses direitos e impedir a concretizado do princípio de acesso à justiça, tão bem delineado por Mauro Cappelletti e Bryant Garth $^{73}$, pelo prisma tanto do acesso aos órgãos jurisdicionais, quanto da efetivação dos direitos materiais pleiteados por meio do processo judicial, ainda que em face de complexas questões como a omissão do legislador em regulamentar direitos fundamentais sociais e a linguagem aberta dos direitos fundamentais que dificulta a sua aplicação.

\subsubsection{O acesso a uma ordem jurídica justa}

Do mesmo modo que a forma de atuação dos juízes na interpretação e aplicação do direito se modificou ao longo do tempo, a concepção do que seria o "acesso à Justiça" também vem passando por alterações decorrentes das discussões sobre qual deve ser o papel do Estado no tocante ao aperfeiçoamento das instituições responsáveis por garantir e proporcionar a efetiva realização da proteção jurídica de que cada ser humano é titular.

A ideia de que o acesso à justiça se restringe ao direito de ingressar com uma demanda no Poder Judiciário, com a possibilidade de ver os problemas resolvidos pela esfera judicial, não mais se coaduna com o papel a ser desempenhado pelo Poder Judiciário no paradigma do Estado Democrático de Direito.

Realmente, em tempos de Estado Liberal, a mera garantia ao cidadão do direito formal de apresentar a sua pretensão em juízo, sem obstáculos por parte do Estado, era considerada suficiente para a proteção dos interesses do indivíduo, não importado se esse teria condições socioeconômicas de exercer efetivamente o direito de ação. ${ }^{74}$

$\mathrm{Na}$ atualidade, além do direito de provocar o Judiciário por meio da propositura de uma demanda, o verdadeiro acesso à justiça exige que o resultado jurídico e prático do processo seja favorável a quem tem razão. Ou seja, deve-se sempre garantir que o titular de

\footnotetext{
${ }^{73} \mathrm{Na}$ obra "Acesso à justiça", os dois autores apresentam as três ondas renovatórias do processo, passando pela primeira, calcada na prestação de assistência jurídica gratuita às pessoas necessitadas, pela segunda onda, relativa à tutela adequada aos interesses metaindividuais e chegando-se à terceira, relacionada à criação e modernização de instrumentos processuais que visam dar maior efetividade ao processo, adaptando o tipo de procedimento ao tipo de litígio, e estabelecendo mecanismos informais ou privados de solução de litígios, além dos judiciais já existentes. Essa última onda renovatória tem como base a ideia de que o direito de ação, para ser realmente efetivo, deve tutelar eficazmente o direito material pleiteado. Cf. CAPPELLETTI, Mauro; GARTH, Bryant. Acesso à justiça. Porto Alegre: Sérgio Antônio Fabris, 1988.

${ }^{74}$ PIMENTA, José Roberto Freire; PORTO, Lorena Vasconcelos. Op. cit., p. 97.
} 
uma pretensão que venha a ser em definitivo julgada procedente possa vê-la concretizada por intermédio de uma prestação jurisdicional dotada de efetividade.

Mauro Cappelletti e Bryan Garth ${ }^{75}$ apresentam as três ondas renovatórias do processo contemporâneo que tem por fim último assegurar o direito fundamental ao pleno acesso à justiça. O primeiro movimento de modificações processuais visava garantir às pessoas necessitadas o patrocínio gratuito por uma advogado e a isenção do pagamento das despesas e custas processuais, correspondendo, no Brasil, à garantia da assistência judiciária gratuita e da justiça gratuita, respectivamente.

A segunda onda renovatória diz respeito à criação e ampliação de instrumentos adequados de tutela dos direitos metaindividuais, pois não é possível que um ente defenda direitos de terceiros se não estiver efetivamente legitimado para tal. No Brasil, anteriormente a regra do artigo $6^{\circ}$ do $\mathrm{CPC}$, que estabelece a possibilidade de defesa, em juízo, apenas dos interesses próprios, foi relativizada por meio da criação de ações próprias para a defesa dos direitos metaindividuais, como a ação popular, a ação civil coletiva e ação civil pública. ${ }^{76}$

A terceira onda se caracteriza pela adoção de vários meios processuais e de inovações no sistema judiciário, com o fim de propiciar um significativo aumento na satisfação dos direitos materiais reconhecidos em juízo, por meio de uma tutela jurisdicional eficaz. No país, esse terceiro aspecto do acesso à justiça é caracterizado pelas sucessivas reformas do processo e do Poder Judiciário, no sentido de torná-los aptos a prestar a função jurisdicional de acordo com exigências de um Estado Democrático de Direito. Essas reformas primam pela eliminação dos exageros de formalidade que emperram o verdadeiro acesso à justiça, como se observa nos artigos 154 e 244 do CC, que consideram válidos os atos processuais realizados de forma diversa da prescrita em lei, desde que alcancem a sua finalidade essencial.

Para Maria Cristina de Souza Alvim, o fenômeno do acesso à justiça na sua versão atualizada

deve ser compreendido como a possibilidade material do ser humano conviver em uma sociedade onde o direito é realizado de forma concreta, seja em decorrência da manifestação da atuação judiciária, seja como atuação das grandes políticas públicas engendradas e decorrentes das respectivas e pontuais ações executivas. Essa efetivação é de suma importância, pois teremos a certeza de uma atuação garantidora que prestigie a vida, a dignidade e o respeito

\footnotetext{
75 CAPPELLETTI, Mauro; GARTH, Bryant. Op. cit., 1988.

${ }^{76}$ PIMENTA, José Roberto Freire; PORTO, Lorena Vasconcelos. Op. cit., p. 106.
} 
incorruptível aos direitos fundamentais do homem. Enfim, o enaltecimento do valor e do papel da justiça como referência a ser seguida.

O Poder Judiciário, para dar sentido à sua existência como Poder do Estado, deve enfrentar os desafios que o momento histórico apresenta.

E cada juiz, representando o Poder Judiciário, deve pensar o exercício de sua função como algo capaz de garantir ao conjunto da população acesso real à verdadeira justiça, bem como aos direitos constitucionais uma existência efetiva, concreta, material, e nunca apenas simbólica. ${ }^{77}$

O Estado brasileiro assumiu, como dever fundamental, garantir o acesso à prestação jurisdicional. Esse acesso compreende, em primeiro plano, não só o direito de estar em juízo, de produzir provas e alegações, mas também o direito de ser ouvido, em condições de igualdade entre as partes, e a garantia de serem observados os procedimentos regulares de tramitação dos feitos previstos em lei. Ou seja, os direitos à ampla defesa, ao contraditório e ao devido processo legal devem ser regularmente observados, para se garantir a todos o acesso aos meios processuais e recursais conducentes à decisão justa (artigo $5^{\circ}$, incisos LV e LIV).

$\mathrm{O}$ acesso à ordem jurídica justa engloba, também, a capacidade de o Judiciário, ao apreciar e julgar a demanda, concretizar, em tempo razoável, o direito material pleiteado, caso se conclua que o cidadão que ingressou com a ação realmente faz jus àquele direito.

O artigo $5^{\circ}$, inciso XXXV, da Constituição Federal de 1988, que estabelece a apreciação obrigatória, pelo Judiciário, de lesão ou ameaça a direito trazida ao seu conhecimento, em virtude do disposto no artigo $1^{\circ}$, inciso III e artigo $3^{\circ}$, incisos I, III e IV do mesmo Texto Fundamental, não pode ser visto como expressão de mera garantia do exercício do direito de ação, devendo hoje ser interpretado e aplicado como a consagração do direito fundamental a uma tutela jurisdicional efetiva, que deve ser concretizada.

A Lei Fundamental, ainda, redimensionou as relações jurídicas, ampliando o seu conceito, de forma a alcançar as demandas repetidas e massificadas oriundas da sociedade moderna, como aquelas referentes aos interesses coletivos e difusos, e apresentou os instrumentos processuais e políticos próprios para a proteção desses direitos, como a ação popular, a ação civil pública e o mandado de segurança coletivo.

Constata-se que vários são os dispositivos constitucionais que garantem e viabilizam o "acesso à justiça" e, em consequiência, auxiliam no exercício da cidadania. A Constituição de 1988, juntamente com as reformas do Código de Processo Civil e de outras leis infraconstitucionais, criaram e ampliaram instrumentos e garantias processuais que

\footnotetext{
77 ALVIM, Maria Cristina de Souza. Educação, cidadania e acesso à justiça. Revista Mestrado em Direito. Osasco, v. 6, n. 2, 2006, p. 103-104.
} 
permitem o acesso à justiça para assegurar a tutela aos direitos de cidadania, nos planos individual, coletivo e difuso.

José Alfredo de Oliveira Baracho afirma que o acesso à justiça é primordial para a efetividade dos direitos humanos, tanto na ordem jurídica interna quanto na internacional. O cidadão tem a necessidade de mecanismos próprios e adequados para que possa efetivar seus direitos, não podendo as diferenças entre os litigantes e, acrescenta-se, entre os direitos substanciais pleiteados serem deixados de lado pela processualística contemporânea. $^{78}$

Sem embargo, é importante salientar que, como o acesso a uma ordem jurídica justa encampa a efetivação dos direitos materiais reconhecidos em juízo, por meio de uma tutela jurisdicional adequada, o papel do juiz se torna ainda mais relevante, pois, não basta o magistrado utilizar corretamente as tutelas jurisdicionais aptas a satisfazer os direitos materiais do postulante. Muitas vezes, para concretizar os direitos fundamentais materiais, o juiz terá de se valer de uma interpretação jurídica condizente com as normas constitucionais que estabelecem esses direitos.

A tutela jurisdicional engloba, portanto, não apenas a aplicação dos mecanismos processuais existentes para tentar concretizar os direitos substanciais pleiteados, pois, em se tratando de direitos fundamentais sociais, o juiz, muitas vezes, terá que fazer um esforço interpretativo, valendo-se dos mecanismos de interpretação constitucional para extrair o sentido e o alcance das normas que, dentro dos limites traçados pelo texto e pelo espírito constitucional, sejam aptos a implementar os direitos materiais lesados ou ameaçados do cidadão que busca o Judiciário.

$\mathrm{O}$ direito de acesso à justiça, portanto, não se compraz apenas com resultados corretos do ponto de vista formal e decisões apenas legalmente adequadas. $\mathrm{O}$ verdadeiro sentido desse direito supõe a produção de resultados materialmente concretos do ponto de vista social, político, econômico e cultural, isto é, resultados que possam produzir consequências efetivas, realizando a distribuição democrática dos bens e direitos essenciais à vida humana. Aliás, a distribuição igualitária desses bens e direitos, que no fundo são “direitos necessários”, é providência indispensável à consolidação de qualquer padrão de sociabilidade que se pretenda ético, sustentável.

Flávia de Almeida Viveiros de Castro relaciona a cidadania com a atuação do Judiciário, argumentando que o cidadão é reconhecido como titular originário da Justiça e,

\footnotetext{
${ }^{78}$ BARACHO, José Alfredo de Oliveira. Teoria geral da cidadania: a plenitude da cidadania e as garantias constitucionais e processuais. São Paulo: Saraiva, 1995, p. 25-30.
} 
enquanto tal, seu direito de acesso aos Tribunais não é um benefício proporcionado pelo Estado, mas um direito subjetivo público garantido constitucionalmente. Ademais, o indivíduo deve participar do aperfeiçoamento do sistema judicial, reflexo da própria cidadania ativa. E, finalmente, há o direito de eficiência do Poder Judiciário, pois, não basta que o sistema judicial seja independente, devendo ele estar a serviço do homem. ${ }^{79}$

Nos dizeres de Mauro Cappelletti, o direito ao acesso jurisdicional efetivo

tem sido progressivamente reconhecido como sendo de importância capital entre os novos direitos individuais e sociais, uma vez que a titularidade de direitos é destituída de sentido, na ausência de mecanismos para a sua efetiva reivindicação. $\mathrm{O}$ acesso à justiça pode, portanto, ser encarado como requisito fundamental - o mais básico dos direitos humanos - de um sistema jurídico moderno e igualitário que pretenda garantir, e não apenas proclamar os direitos de todos. 80

Portanto, o novo papel que o Judiciário assume, no Estado Democrático de Direito, de poder estatal legítimo para materializar os direitos fundamentais sociais pleiteados por meio do ajuizamento de uma ação, é essencial para viabilizar a implementação desses direitos, de modo a concretizar a garantia do acesso a uma ordem jurídica realmente justa.

\subsubsection{A implementação dos direitos fundamentais sociais pelo Poder Judiciário em face da omissão do legislador e da linguagem aberta dos direitos fundamentais}

A simples existência de normas constitucionais que consagrem direitos sociais de cidadania não garante a sua conseqüente implementação concreta no mundo dos fatos, pois direitos não são auto-realizáveis e demandam mobilização política e social para serem concretizados em níveis democraticamente satisfatórios.

Todavia, em inúmeros casos o Poder Legislativo se torna inerte, seja por descaso dos parlamentares em apresentar e aprovar projetos de lei que venham regulamentar direitos fundamentais estabelecidos em normas constitucionais de eficácia limitada, seja pela conveniência em atender e manter interesses político-econômicos, do governo ou de grupos sociais, que possam ser ameaçados pela existência de lei ou pela inclusão de verba orçamentária que possibilite o exercício de determinados direitos sociais

\footnotetext{
${ }^{79}$ CASTRO, Flávia de Almeida Viveiros de. O poder judiciário na virada do século: paradigmas de atuação. Rio de Janeiro: Lumen Juris, 1998, p. 33-34.

${ }^{80}$ CAPPELLETTI, Mauro; GARTH, Bryant. Op. cit., p. 9.
} 
Outras vezes, quem é omissa é a Administração Pública que não inclui na proposta de orçamento, a ser aprovada pelo Legislativo, nenhuma verba ou verba suficiente à implementação de ações governamentais que viabilizem o exercício de direitos sociais ou não executa materialmente as políticas públicas ou, ainda, não edita os atos administrativos necessários à efetivação de direitos fundamentais sociais, seja por descaso ou para manutenção de interesses político-econômicos de determinados grupos de poder, tal como ocorre com o Legislativo.

A omissão do Poder Legislativo, na elaboração e na aprovação de leis regulamentadoras de normas constitucionais que estabelecem direitos fundamentais, e do Poder Executivo, na criação de atos normativos necessários para a concretização de direitos, são apenas um dos problemas que emperram a efetivação de direitos fundamentais pelos órgãos originariamente competentes. Assim, os titulares desses direitos acabam, muitas vezes, recorrendo ao Judiciário no intuito de tentar, ao menos no caso concreto julgado, a materialização do direito social pleiteado.

O Poder Judiciário com o objetivo de promover a garantia do acesso a uma ordem jurídica justa, não pode se quedar inerte diante dos clamores sociais que chegam ao seu conhecimento. Os órgãos do Judiciário devem não apenas deixar de aplicar leis inconstitucionais em casos específicos, como também concretizar direitos fundamentais, no caso de omissão dos demais poderes.

Sobre a tarefa de colmatar as lacunas deixadas pelo Executivo e pelo Legislativo no desempenho de sua tarefa constitucional relativa aos direitos fundamentais, Andreas Krell explana que

em princípio, o Poder Judiciário não deve intervir em esfera reservada a outro
poder, para substituí-lo em juízos de conveniência e oportunidade, querendo
controlar as opções legislativas de organização e prestação, a não ser,
excepcionalmente, quando haja uma violação evidente e arbitrária, pelo
legislador, da incumbência constitucional. No entanto, parece necessária a
revisão do vetusto dogma da "separação dos poderes' em relação ao controle de
gastos públicos e da prestação dos serviços públicos básicos do Estado Social,
visto que os Poderes Legislativo e Executivo no Brasil se mostraram incapazes
de garantir um cumprimento racional dos respectivos preceitos constitucionais.

João Luiz Esteves acredita que é possível que o Judiciário atue na redefinição de políticas públicas, quando, mediante decisão que reconhece omissão constitucional, o

${ }^{81}$ KRELL, Andreas Joachim. Op. cit., p. 241. 
órgão judicial já disponha sobre a matéria, notificando o poder inoperante até que ele se pronuncie objetivamente para o cumprimento da Constituição. ${ }^{82}$

Ao lado da omissão do Legislativo na regulamentação de normas de eficácia limitada que estabeleçam direitos sociais e da inércia do Executivo na execução de políticas que efetivem esses direitos, outra questão importante que também demanda um papel legitimamente ativo e criador dos juízes diz respeito à densificação e concretização das normas constitucionais de direitos fundamentais sociais, visto que essas normas têm natureza principiológica e estrutura aberta e precisam da atuação do intérprete e aplicador para materializá-las em conformidade com as mudanças sociais que ocorrem na realidade fática.

As relações sociais, com suas múltiplas facetas, são derivadas de uma sociedade complexa que vive mudanças em ritmo acelerado, de modo que o legislador constituinte não pode trancar as possibilidades de aplicação das normas constitucionais que estabelecem direitos fundamentais por meio de uma formatação fechada, impedindo a sua evolução interpretativa no tempo.

Tendo em vista a própria impossibilidade de prever e regrar constitucionalmente todos os conflitos e necessidades sociais, o constituinte cria aberturas para que a norma seja construída pelo juiz, observando as circunstâncias do caso concreto.

Portanto, seja em virtude da omissão do Legislativo e Executivo, seja pelo fato de as próprias normas de estrutura aberta que estabelecem os direitos fundamentais sociais exigirem a densificação e concretização por parte do juiz, constata-se que a postura de atuação do Judiciário tornou-se legitimamente ativa e criadora, pois não é possível materializar direitos fundamentais sem realizar necessariamente uma atividade interpretativa condizente com as peculiaridades das normas constitucionais.

Embora no caso da omissão do Legislativo e do Executivo, a doutrina crie uma série de entraves para legitimar a atuação pró-ativa do Judiciário, valendo-se sobretudo do dogma da separação dos poderes em sua vertente tradicionalista, não existe nenhum questionamento de ordem democrática ou suscitado pela sociedade no sentido de deslegitimar os juízes de cumprir os comandos constitucionais que também lhe são dirigidos, quando os direitos fundamentais sociais não podem ser exercidos pelos cidadãos por longo tempo.

\footnotetext{
${ }^{82}$ ESTEVES, João Luiz M. Direitos fundamentos sociais no Supremo Tribunal Federal. Op. cit., p. 80.
} 
Em se tratando da atividade densificadora e concretizadora das normas principiológicas de direitos fundamentais que não exigem regulamentação infraconstitucional, a atuação mais "ativa" do Judiciário tem sido naturalmente aceita, pois, sem interpretar os preceitos constitucionais, valendo-se das técnicas da hermenêutica jurisdicional, não há como apreender o sentido e o alcance das normas constitucionais.

De qualquer forma, em ambas as situações, o cidadão que ajuíza uma ação visando o exercício de um direito fundamental social deve receber uma resposta congruente do Judiciário, no sentido de tentar, tanto quanto possível, materializar o direito pleiteado, pois, como já ressaltado no subitem anterior, o acesso a uma ordem jurídica justa não diz respeito apenas à possibilidade de o cidadão ter acesso aos tribunais, mas, também, de receber uma tutela jurisdicional adequada, que engloba mecanismos processuais e técnicas de interpretação jurídico-constitucionais, com vistas a satisfazer os direitos materiais do postulante.

Na realidade, o magistrado dos dias atuais deve avaliar e interpretar as necessidades do caso concreto, assim como aplicar a técnica processual, em conformidade com o direito substancial e os valores positivados na Constituição, sobretudo o direito fundamental a uma tutela jurisdicional efetiva.

A discussão sobre a legitimação do Judiciário em atuar de forma ativa e "criativa" implica no estudo dos movimentos judiciários denominado de "judicialização da política e “ativismo judicial”, matérias do próximo subitem.

\subsubsection{A controvertida questão do ativismo judicial e a visão atualizada da teoria da separação dos poderes}

Falar de uma concepção mais ampliativa da atuação do Poder Judiciário esbarra inevitavelmente na abordagem dos movimentos denominados “judicialização da política” e “ativismo judicial”, pois é tênue o limite que separa uma atuação política ativa do Judiciário, decorrente dos próprios assuntos que os magistrados atualmente devem conhecer e julgar, e uma postura ativa derivada de arbitrariedades e opções pessoais, sem qualquer embasamento nas técnicas de interpretação constitucional. Nos próximos subitens, procurar-se-á esclarecer quais são as diferenças entre "judicialização da política" e "ativismo judicial" e se esses movimentos podem ser exercidos legitimamente pelo 
Judiciário, sem adentrar no terreno das arbitrariedades. Ademais, buscar-se-á apresentar quais são os possíveis limites a uma atuação ativista, que não vulnere o princípio da separação dos poderes, em sua concepção atualizada.

\subsubsection{A judicialização dos conflitos que demandam decisões de natureza política e o ativismo judicial: necessidade ou arbitrariedade}

O termo judicialização da política ficou conhecido na obra The global expansion of judicial power $^{83}$, de Tate e Vallinder, publicada nos Estados Unidos, em 1997.

De acordo com Vallinder, a judicialização da política é um processo complexo composto por dois movimentos distintos:

(1) a expansão da jurisdição dos tribunais ou dos juízes a expensas dos políticos e/ou dos administradores, isto é, a transferência da tomada de decisões sobre direitos da legislatura, do gabinete ou da administração pública para os tribunais, ou, pelo menos, (2) a propagação dos métodos de decisões judiciais fora da competência jurisdicional propriamente dita. Em resumo, podemos dizer que a judicialização envolve essencialmente transformar algo em processo judicial. ${ }^{84}$

José Eisenberg acredita que os dois fenômenos mencionados por Tate e Vallinder podem ser diferenciados em "judicialização" e "tribunalização", pois o primeiro movimento "refere-se a um processo de expansão dos poderes de legislar e executar leis do sistema judiciário, representando uma transferência do poder decisório do Poder Executivo e do Poder Legislativo para os juízes e tribunais - isto é, uma politização do Judiciário", e o segundo importa na "disseminação de métodos de tomada de decisão típicos do Poder Judiciário nos outros Poderes". ${ }^{85}$ A judicialização diz respeito a uma transformação das normas e das formas de atuação dos membros do Poder Judiciário,

\footnotetext{
${ }^{83}$ TATE, C. Neal; VALLINDER, Tobjörn (Orgs.). The global expansion of judicial power. New York Univesity, 1995.

${ }^{84}$ Tradução livre do trecho: "should normally mean either: (1) the expansion of the province of the courts or the judges at the expense of the politicians and/or the administrators, that is, the transfer of decision-making rights form the legislature, the cabinet, or the civil service to the court or, at least, (2) the spread of judicialmaking methods outside the judicial province proper. In summing up we might say that judicialization essencially involves turning something into a form of judicial process. Cf. TATE, C. Neal; VALLINDER, Tobjörn (orgs.). Op. cit., p. 13.

85 EISENBERG, José. Pragmatismo, direito reflexivo e judicialização da política. In: VIANNA, Luiz Werneck (Org.). A democracia e os três poderes no Brasil. Belo Horizonte: UFMG; Rio de Janeiro: IUPERJ/FAPERJ, 2003, p. 47.
} 
enquanto a tribunalização se refere a transformações no âmbito dos outros dois Poderes e seus membros.

No caso da presente tese, interessa apenas o primeiro fenômeno, ou seja, a judicialização da política, visto que o que se normalmente questiona é o fato de o Judiciário se apropriar de prerrogativas constitucionais que não lhe são próprias para julgar casos relativos à concretização de direitos fundamentais sociais, envolvendo decisões de cunho político.

A judicialização da política ocorre no momento em que certas situações, de grande repercussão política ou social, são levadas não para as instâncias políticas tradicionais como o Congresso Nacional e o Poder Executivo, mas para os órgãos do Poder Judiciário. Ou seja, a juristocracia (juristocracy) representa a progressiva transferência de poderes decisórios das instituições representativas para o Judiciário. ${ }^{86}$

De acordo com Ran Hirschl, em estudo comparativo dos sistemas judiciários do Canadá, Nova Zelândia, Israel e África do Sul, ${ }^{87}$ a conjugação de modelos constitucionais estáveis com o judicial review, como instrumento de autopreservação, proporcionou a judicialização do que denomina mega-politcs (o jogo da política competitiva), como decorrência da constitucionalização dessa mesma dimensão de política (polity), no sentido de estruturação e conformação do Estado que se tenha organizado pela Constituição.

Para o autor, o fenômeno seria acompanhado e alimentado por uma mudança na ideologia jurídica, consistente em uma crítica crescentemente realizada pelas elites políticas, jurídicas e econômicas à premissa majoritária que define a democracia em sua dimensão popular. Desse modo, ocorreria uma convergência entre distintos interesses políticos, econômicos e jurídicos na defesa da "democracia constitucional" e no ataque à "democracia" ou "premissa majoritária". 88

Hirschl utiliza uma metodologia que procura afastar esse tema dos debates normativos usuais nesse campo de investigação, privilegiando o estudo das origens e consequências das revoluções constitucionais, ou seja, a consolidação histórica do neoconstitucionalismo em diferentes sociedades contemporâneas. ${ }^{89}$

\footnotetext{
${ }^{86}$ HIRSCHL, Ran. Towards juristocracy: the origins and consequences of the new constitucionalism. Harvard University Press, 2004, p. 1. A expansão da potilização dos tribunais nas democracias contemporâneas ocidentais constitui um fenômeno que caracteriza o início do século XXI, chegando até os sistemas políticos da África do Sul, Canadá, Israel e Nova Zelândia.

${ }^{87}$ HIRSCHL, Ran. The new constitutionalism and the judicialization of pure politics worldwide. Fordham Law Review, v. 75, n. 2, 2006-2007.

${ }^{88}$ Ibidem.

${ }^{89}$ HIRSCHL, Ran. Towards juristocracy: the origins and consequences of the new constitucionalism. $O p$. cit., p. 3.
} 
Nesse sentido, o autor indica três postulados responsáveis pela sua orientação metodológica. $\mathrm{O}$ primeiro diz respeito à transferência progressiva de poderes do Legislativo para o Judiciário, assim como para outras instâncias administrativas de decisão cujos representantes não são eleitos administrativamente, tópico que não pode ser estudado separadamente das lutas políticas, econômicas e sociais que modelam o sistema jurídicopolítico de uma sociedade. O segundo implica na promoção de efeitos distributivos diferenciados pelas instituições políticas e jurídicas e suas reformas, inclinando-se, inevitavelmente, para alguns grupos e indivíduos em detrimento de outros. E o terceiro indica que os diferentes atores políticos, econômicos e jurídicos tendem a agir estrategicamente no sentido de apoiar a consolidação de estruturas institucionais que beneficiarão, na maior medida possível, os seus próprios interesses particulares ou corporativos. $^{90}$

A hipótese explicativa apresentada por Hirschl para o fenômeno da judicialização da política é a tese da "preservação hegemônica" (hegemonic preservation thesis), segundo a qual o poder judicial é politicamente construído. A constitucionalização de direitos e o fortalecimento do controle de constitucionalidade das leis resultam de um pacto estratégico liderado por elites políticas hegemônicas continuamente ameaçadas, que buscam isolar suas preferências políticas contra mudanças em razão da política democrática, em associação com elites econômicas e jurídicas que possuem interesses compatíveis. ${ }^{91}$

Essa abordagem do fenômeno da judicialização da política permite afirmar que a progressiva transferência de poderes para o Judiciário nas democracias contemporâneas "serve aos interesses" de uma Suprema Corte que procura ressaltar sua influência política. $^{92}$

Ademais, segundo Hirschl, a judicialização promove o entrincheiramento constitucional de direitos, isto é, tanto o Executivo quanto o Legislativo podem, mediante apoio deliberado à estratégia de transferência de poderes, retirar temas controvertidos do debate político, os quais dificilmente seriam decididos em sentido favorável, seja porque não há consenso, seja porque não foram suficientemente debatidos. ${ }^{93} \mathrm{Na}$ verdade, a judicialização de questões sociais polêmicas pode acabar reduzindo os custos eleitorais ou de apoio político de uma decisão controvertida, ou, ainda, obstaculizar a abertura de um

\footnotetext{
${ }^{90}$ Ibidem, p. 38.

${ }^{91}$ Ibidem, p. 49.

92 Ibidem, p. 49.

${ }^{93}$ Ibidem, p. 67.
} 
debate sobre políticas públicas ou reformas políticas à participação da sociedade, por exemplo.

Marcus Faro de Castro explica que a judicialização da política ocorre

\begin{abstract}
porque os tribunais são chamados a se pronunciar onde o funcionamento do Legislativo e do Executivo se mostra falho, insuficiente ou insatisfatório. Sob tais condições, ocorre uma certa aproximação entre Direito e Política e, em vários casos, torna-se mais difícil distinguir entre um "direito" e um "interesse público", sendo possível se caracterizar o desenvolvimento de uma "política de direitos". ${ }^{4}$
\end{abstract}

No Brasil, o processo de judicialização da política iniciou-se mais especificamente com o advento da Constituição de 1988, que além de prever um extenso rol de direitos e garantias fundamentais, trouxe medidas inovadoras e democráticas, ampliando os remédios constitucionais até então existentes que reforçam uma ampla participação popular, seja individualmente, seja por meio de entidades de classe. A Constituição também redefiniu as relações entre os três Poderes, dando maior importância ao sistema da judicial review, principalmente quando se admite um rol de legitimados para participar do controle de constitucionalidade das leis.

Luís Roberto Barroso apresenta os motivos pelos quais o fenômeno da judicialização da política teve grande impulso nas últimas décadas no Brasil. A primeira causa diz respeito ao processo de redemocratização do país, que teve ponto culminante com a promulgação da Constituição de 1988. Com a recuperação das garantias da magistratura, o "Judiciário deixou de ser um departamento técnico-especializado e transformou-se em um verdadeiro poder político, capaz de fazer valer a Constituição e as leis, inclusive em confronto com os outros poderes". Ademais, a população passou a ter um maior nível de informação e maior consciência de seus direitos, pleiteando, em escala crescente, a proteção de seus interesses perante juízes e tribunais, inclusive por meio do fortalecimento e expansão das Defensorias Públicas. Ou seja, "a redemocratização fortaleceu e expandiu o Poder Judiciário, bem como aumento a demanda por justiça na sociedade brasileira". 95

A segunda causa foi a constitucionalização abrangente, que trouxe para a Constituição inúmeras matérias que antes eram deixadas para o processo político

\footnotetext{
${ }^{94}$ CASTRO, Marcus Faro de. O Supremo Tribunal Federal e a judicialização da política. Revista Brasileira de Ciências Sociais. São Paulo, 1997, n. 34, v. 12, p. 196.

95 BARROSO, Luís Roberto. Judicialização, ativismo judicial e legitimidade democrática. Revista da EMARF, Cadernos Temáticos, Rio de Janeiro, dez. 2010, p. 391.
} 
majoritário e para a legislação ordinária, tendência também verificada nas Constituições de Portugal, de 1976, e da Espanha, de 1978.

Barroso explica a relevância da constitucionalização de uma determinada matéria jurídica.

\begin{abstract}
Na medida "em que uma questão - seja direito individual, uma prestação estatal ou um fim público - é disciplinada em uma norma constitucional, ela se transforma, potencialmente, em uma pretensão jurídica, que pode ser formulada sob a forma de ação judicial. Por exemplo: se a Constituição assegura o direito de acesso ao ensino fundamental ou ao meio-ambiente equilibrado, é possível judicializar a exigência desses dois direitos, levando ao Judiciário o debate sobre ações concretas ou políticas públicas praticadas nessas duas áreas. ${ }^{96}$
\end{abstract}

A terceira e última causa da judicialização da política foi o fortalecimento do sistema de controle de constitucionalidade das leis, com a Constituição de 1988, como estudado no capítulo 3. O Brasil adota um sistema misto de controle que engloba o controle difuso e incidental e o controle concentrado. O primeiro advém do sistema americano e existe desde o início da República. Por meio dele, qualquer juiz ou tribunal pode deixar de aplicar uma lei, em um caso concreto que lhe tenha sido submetido, se a considerar inconstitucional. O segundo sistema, de origem européia, possibilita a propositura de ação própria ${ }^{97}$ a ser ajuizada diretamente no Supremo Tribunal Federal, pelo rol de legitimados estabelecido no artigo 103 da Lei Fundamental. Dessa forma, qualquer questão política ou moralmente relevante que envolva inconstitucionalidade ou interpretação constitucional pode ser alçada ao STF. $^{98}$

Gisele Citadino explica a influência que a Constituição de 1988 teve no desenvolvimento da judicialização da política no Brasil.

Se hoje nos permitimos discutir o processo de "judicialização da política" é
porque fomos capazes de superar o autoritarismo e reconstruir o Estado de
Direito, promulgando uma Constituição que, nesse processo, representa um
consenso, ainda que formal, em torno dos princípios jurídicos universais [...].
Para isso, o processo de "judicialização da política" não precisa invocar o
domínio dos tribunais, nem defender uma ação paternalista por parte do Poder
Judiciário. A própria Constituição de 1988 instituiu diversos mecanismos
processuais que buscam dar eficácia aos seus princípios, e essa tarefa é de
responsabilidade de uma cidadania juridicamente participativa que depende, é

${ }^{96}$ Ibidem, p. 391-392.

97 As ações constitucionais existentes no ordenamento jurídico brasileiro são ADI (Ação Direta de Inconstitucionalidade) genérica, ADI por omissão, ADI interventiva, ADPF (Arguição de Descumprimento de Preceito Fundamental) e ADECON (Ação Declaratória de Constitucionalidade), sendo que as três últimas foram estabelecidas na Constituição Federal de 1988. As duas primeiras já existiam, mas o rol de legitimados da ADIN genérica foi consideravelmente aumentado, pois antes apenas o procurador geral da república é que poderia ajuizar essa ação perante o STF.

98 BARROSO, Luís Roberto. Judicialização, ativismo judicial e legitimidade democrática. Op. cit., p. 391392. 
verdade, da atuação dos tribunais, mas sobretudo do nível de pressão e mobilização política que, sobre eles, se fizer. ${ }^{99}$

No país, a atividade política é exercida pelos membros do Poder Judiciário, e predominantemente pelos membros do Supremo Tribunal Federal, por serem integrantes do aparato do poder do Estado, que é uma sociedade política, e por aplicaram normas de direito, que são necessariamente políticas. Ademais, quando o STF declara a constitucionalidade de uma lei perante a Constituição, existirá uma conotação política, "pois em qualquer caso haverá efeitos sociais e alguém será beneficiado ou prejudicado". ${ }^{100}$ E, além disso, em várias situações o Supremo será levado a se manifestar sobre questões de natureza eminentemente política, sendo que a sua orientação dependerá da convicção ideológica dos Ministros no momento do julgamento.

Barroso ressalta os vários temas que vêm sendo analisados pelo Supremo Tribunal Federal nos últimos anos e que demonstram a sua atuação política:

\begin{abstract}
a) políticas governamentais, envolvendo a constitucionalidade de aspectos centrais da Reforma da Previdência (contribuição de inativos) e da Reforma do Judiciário (criação do Conselho Nacional de Justiça); b) relações entre poderes, com a determinação dos limites legítimos de atuação das comissões parlamentares de inquérito (como quebras de sigilos e decretação de prisão) e do papel do Ministério Público na investigação criminal; c) direitos fundamentais, incluindo limites à liberdade de expressão no caso de racismo (Caso Elwanger) e a possibilidade de progressão de regime para os condenados pela prática de crimes hediondos. Deve-se mencionar, ainda, a importante virada da jurisprudência no tocante ao mandado de injunção, em caso no qual se determinou a aplicação do regime jurídico das greves no setor privado àquelas que ocorram no serviço público. ${ }^{101}$
\end{abstract}

Para Canotilho ${ }^{102}$, o "Poder Judiciário faz política quando se proclama o poder de defesa dos direitos dos cidadãos contra as orientações das instituições políticorepresentativas e quando se assume como o poder de revelação dos valores fundamentais" da comunidade. O juiz que é o guardião dos direitos e que realiza os objetivos moralmente justos representa hoje uma ruptura com o modelo do "juiz executor".

No Estado Democrático de Direito, a função do juiz não é apenas aplicativa, ou seja, não consiste apenas em aplicar o disposto na lei, mas, sim, interpretativa. O processo

\footnotetext{
${ }^{99}$ CITADINO, Gisele. Judicialização da política, constitucionalismo democrático e separação dos poderes. In: VIANNA, Luiz Werneck (Org.). A Democracia e os Três Poderes no Brasil. 1 ed. Belo Horizonte,v. 1: Editora da UFMG/IUPERJ/FAPERJ, 2002, p. 39.

${ }^{100}$ DALLARI, Dalmo de Abreu. O poder dos juízes. 3 ed. São Paulo: Saraiva, 2008, p. 89-97.

${ }^{101}$ BARROSO, Luís Roberto. Judicialização, ativismo judicial e legitimidade democrática. Op. cit., p. 393.

102 CANOTILHO, J. J. Gomes. Um olhar jurídico-constitucional sobre a judiciarização da política. In: RIBEIRO, Lauro Luiz Gomes e BERARDI, Luciana Andrea Accorsi (Orgs.). Estudos de direito constitucional: em homenagem à professora Maria Garcia. São Paulo: IOB-Thomson, 2007, p. 230-241.
} 
de decisão exige que o juiz interpreta a norma para, posteriormente, aplicá-la ao caso concreto.

É importante ressaltar que a "judicialização da política" não se confunde com o "ativismo judicial", desde que essa última expressão seja compreendida como um fenômeno com definição e características próprias.

No contexto brasileiro, a judicialização, nos dizeres de Barroso, "é um fato, uma circunstância que decorre do modelo constitucional que se adotou, e não um exercício deliberado de vontade política". ${ }^{103}$ Já o ativismo judicial ocorre por meio de uma atitude do julgador, uma opção de interpretar pró-ativamente a Constituição, difundindo seu alcance e propósito.

De acordo com o Black's Law Dictionary, o ativismo encontra base em um elemento comportamental, ou seja, surge um espaço aberto à prevalência das visões pessoais de cada magistrado quanto à compreensão das normas constitucionais. ${ }^{104}$

A primeira vez que se tem notícia da utilização da expressão "ativismo judicial” foi nos Estados Unidos, em 1947, no artigo The Supreme Court: 1947, publicado na Revista Fortune, quando o jornalista Arthur Schlesinger Junior delineou o perfil dos nove juízes da Suprema Corte norte-americana ${ }^{105}$.

A partir de então, a expressão passou a ser empregada por constitucionalistas ${ }^{106} \mathrm{dos}$ EUA, com um direcionamento crítico geralmente de cunho negativo, para caracterizar um

${ }^{103}$ BARROSO, Luís Roberto. Judicialização, ativismo judicial e legitimidade democrática. Op. cit., p. 393394.

${ }^{104}$ O Black's Law Dictionary define o judicial activism como “[...] a philosophy of judicial-making whereby judges allow their personal views about public policy, among other factors, to guide their decisions, usu. with the suggestion that adherents of this philosophy tend do find constitutional violations and are willing to ignore precedent”. Cf. BLACK's Law Dictionary. Eighth edition. Bryan A. Garner: Books, 2004. Sem embargo, a expressão "ativismo judicial" encontra outras definições possíveis, como a presente no Dictionary of Law, que dá ênfase ao compromisso do Judiciário com a expansão dos direitos individuais: "[...] the practice in the judiciary of protecting or expanding individual rights through decisions that depart from established precedent or are independent o for in opposition to supposed constitutional or legislative intent [...]". Cf. MARTIN, Elizabeth A.; LAW, Jonathan. Dictionary of law. Oxford Paperback Reference, 2009.

${ }^{105}$ Schlesinger classificou como ativistas judiciais os juízes Black, Douglas, Murphy e Rutlege; como campeões de autolimitação os juízes Frankfurter, Jackson e Burton; e os juízes Reed e Vinson, como integrantes de um grupo de centro. $\mathrm{O}$ autor do artigo, responsável por uma obra dedicada à crítica social americana, com ênfase na exploração do liberalismo exercitado por importantes políticos da história dos EUA, tinha no ativismo judicial "um elemento condicionante de sua análise, ao reconhecer, em uma linha divisória entre juízes ativistas e os de uma autolimitação, um reflexo de uma tendência liberal ou conservadora na atividade judicante de cada magistrado". Cf. VALLE, Vanice Regina Lírio do (Org.). $O p$. cit., p. 20.

${ }^{106}$ Kermit Roosevelt III, em sua obra Myth of judicial activism, afirma que o termo, como tipicamente usado, é vazio de conteúdo, apresentando-se apenas como uma maneira inflamada de registrar a desaprovação frente a uma decisão. Cf. ROOSEVELT III, Kermit. Myth of judicial activism: making sense of Supreme Court decisions. New Haven: Yale University, 2006. Embora tradicionalmente associado à atuação das Cortes de viés político liberal (como, por exemplo, a Suprema Corte no período em que o juiz Earl Warren foi o seu 
comportamento não condizente com a opinião jurisprudencial até então dominante que ultrapasse os ditames constitucionais.

O ativismo judicial tem sido associado a uma participação mais ampla e intensa do Judiciário na concretização de valores e fins constitucionais, com maior interferência no espaço de atuação dos outros dois poderes. A postura ativista manifesta-se por meio de vários tipos de condutas, que incluem

\begin{abstract}
a) a aplicação direta da Constituição a situações não expressamente contempladas em seu texto e independentemente de manifestação do legislador ordinário; b) a declaração de inconstitucionalidade de atos normativos emanados do legislador, com base em critérios menos rígidos que os de patente e ostensiva violação da Constituição; c) a imposição de condutas ou de abstenções ao Poder Público, notadamente em matéria de políticas públicas. ${ }^{107}$
\end{abstract}

Keenan Kmiec, citado por William P. Marshall, sistematiza as cinco principais conceituações do ativismo judicial, de uso corrente na atualidade: 1) a prática dedicada a desafiar atos de constitucionalidade defensável emanados de outros poderes; 2) estratégia de não-aplicação dos precedentes; 3) conduta que permite aos juízes legislar "da sala de sessões"; 4) afastamento dos cânones metodológicos de interpretação; 5) julgamento para alcançar resultado pré-determinado. ${ }^{108}$

No caso do primeiro sentido dado ao ativismo, o problema que se vislumbra na atuação do Judiciário, que não dá deferência à atividade desenvolvida pelos outros poderes, é a potencialidade lesiva do princípio da separação dos poderes. Isso porque o Judiciário, ao invés de adotar uma postura autolimitativa (self-restraint) e privilegiar a escolha política do Legislativo em face das questões controversas, pode dizer o direito aplicável às questões politicamente sensíveis, o que caracterizaria o ativismo judicial, ao invalidar por inconstitucionalidade escolhas políticas dos outros órgãos.

Nessa situação, o problema para identificar o ativismo judicial se encontra nas dificuldades inerentes ao processo de interpretação constitucional, pois o parâmetro para caracterizar uma decisão como ativismo ou não reside na controvertida questão de saber qual é a correta leitura de um determinado dispositivo constitucional. A identificação do

presidente, de 1953 a 1969, atuando em diversos julgados que expandiram o espectro das liberdades civis nos EUA, a expressão "ativismo judicial" também tem sido utilizada para denominar a atuação de cortes consideradas conservadoras, como a época em que o juiz Rhenquist presidiu a Suprema Corte. Cf. MARSHALL, William P. Conservatives and the seven sins of judicial activism. University of Colorado Law Review, v. 73, sept. 2002.

${ }^{107}$ BARROSO, Luís Roberto. Judicialização, ativismo judicial e legitimidade democrática. Op. cit., p. 393394.

${ }^{108}$ MARSHALL, William P. Op. cit., p. 1463-1476. 
ativismo judicial se encontra na reiteração dessa mesma conduta de desafio aos atos do outro poder, perante casos difíceis, pois nem sempre é fácil delimitar o que é um caso difícil. $^{109}$

A segunda manifestação do ativismo diz respeito ao afastamento, pelo julgador, dos precedentes judiciais. No sistema do commom law, as decisões proferidas por órgãos de julgamento superiores devem ser seguidas pelas entidades judicantes inferiores toda vez que estas estiverem diante de fatos idênticos (verticalização dos precedentes). Ademais, um tribunal não deve ignorar suas próprias decisões anteriores (horizontalização dos precedentes), a menos que haja espaço para a desconstituição fundamentada do precedente, que perde o caráter vinculante (overruling). $\mathrm{O}$ ativismo judicial, nesse caso, se constituiria no desrespeito às decisões com força vinculante (vertical ou horizontal) sobre o respectivo órgão judicante.

O problema, nessa hipótese, circunscreve-se à complexidade do sistema de precedentes, porquanto enquanto se pode qualificar como ativista a Corte inferior que não respeita os precedentes emanados por uma superior, dificilmente se poderá chamar de ativista uma corte que supera seus próprios precedentes, à medida que o overruling constitui-se em uma técnica própria do sistema. Nos dizeres de Vanice Lírio do Valle, “a superação de interpretação ou ajuste em face de novas circunstâncias históricas, ainda que determinem o overruling, não são vistas pela doutrina como sinais de ativismo". ${ }^{110}$

O terceiro sentido emprestado à expressão "ativismo judicial", que leva em consideração a atuação legislativa dos juízes, envolve a própria concepção de direito, visto que, para alguns, o papel dos tribunais não é criar, mas revelar o sentido implícito do texto normativo, de modo que o ativismo seria aquela atuação que ultrapassasse os limites dados pelo texto normativo. Diante das inúmeras concepções de direito, questiona-se sobre qual seria o comportamento adotado por uma Corte que se caracterizaria por criar o direito sem autorização para fazê-lo. ${ }^{111}$

A definição de ativismo relativa à prática que envolve o afastamento, pela Corte, dos cânones aceitos de interpretação, apresenta os mesmos problemas associados ao ativismo por meio do juiz legislador, pois uma Corte ativista pode ser considerada como tal pelo afastamento dos cânones da hermenêutica constitucional partilhados pela comunidade de intérpretes, mas resta definir quais seriam esses parâmetros minimamente

\footnotetext{
${ }^{109}$ VALLE, Vanice Regina Lírio do. Op. cit., p. 21-22.

${ }^{110}$ Ibidem, p. 22.

${ }^{111}$ Ibidem, p. 23.
} 
compartidos. ${ }^{112}$ Ou seja, na verdade é difícil vislumbrar um consenso sobre os métodos de interpretação constitucional que justifiquem a configuração razoável do ativismo judicial.

Por último, a definição que identifica o ativismo como a prática jurisdicional cuja finalidade seria alcançar objetivos predeterminados apresenta como dificuldade específica a verificação empírica, "pois dificilmente será possível descortinar os motivos subjacentes à decisão judicial, ainda mais de forma a evidenciar que a vontade do julgador tenha sido o principal elemento". ${ }^{113}$

Nos EUA, um dos primeiros exemplos de ativismo da Suprema Corte para frear o Congresso e o Executivo ocorreu no caso Marbury v. Madison, ${ }^{114} \mathrm{em} \mathrm{1803.} \mathrm{Entretanto,} \mathrm{foi}$ no período entre 1890 e 1937 que a Corte se mostrou bem ativista, em um contexto econômico em que o liberalismo reinava sem limites. A Corte Suprema se preocupava em defender os interesses das grandes empresas americanas, criando uma jurisprudência que defendia o livre mercado e limitava os demais poderes do Estado.

No período de 1937 a 1953, a Suprema Corte americana passou a atuar de forma mais passiva, preocupando-se com as liberdades civis.

Um caso julgado pela Suprema Corte americana que é muito citado para caracterizar a sua postura ativista é a decisão proferida em Brown versus Board of

\footnotetext{
${ }^{112}$ VALLE, Vanice Regina Lírio do. Op. cit., p. 23. A autora exemplifica a questão citando o posicionamento de dois juízes da Suprema Corte norte-americana. Stephen Bryer entende que a Constituição dos EUA é um ente vivo, de modo que os juízes devem ir além da estrita interpretação literal das leis, sobretudo quando as palavras são ambíguas ou incorporam um valor somente aplicado às circunstâncias atuais. Antonin Scala, por seu turno, defende o "originalismo", ou seja, a leitura precisa das palavras da Constituição, considerando os significados na época em que foram escritos.

${ }_{113}$ VALLE, Vanice Regina Lírio do. Op. cit., p. 24.

114 O Caso Marbury contra Madison, ocorreu no ano de 1803 nos Estados Unidos, sendo considerado a fonte do controle de constitucionalidade difuso no direito, já que consagrou a Constituição como lei fundamental e suprema da nação e também a idéia de que o Judiciário possui a maior força na interpretação constitucional.

Thomas Jefferson, após derrotar John Adams que tentava a reeleição, determinou a seu secretário de Estado, James Madison, que não entregasse o título de Juiz de Paz a William Marbury, que fora assim nomeado no testamento político de Adams. Marbury não tomou posse do cargo, e, por isso, requereu ao Tribunal a notificação de James Madison para que apresentasse suas razões, pelas quais não lhe entregava o título de nomeação para possibilitar-lhe a posse.

O mérito da causa só foi decidido dois anos mais tarde, quando o juiz John Marshall declarou o direito de Marbury à posse do cargo de Juiz, e conseqüentemente consolidando uma jurisprudência do "Judicial Review" desconfortável para o Governo Republicano de Jefferson e cômoda para os Federalistas, que eram absoluta maioria no Poder Judiciário. A originalidade lógica de Marshall teve inspiração na doutrina, como as lições de Hamilton, no clássico "O Federalista" ("The Federalist"),escrito quinze anos antes do caso (Marbury v. Madison), onde sustentava-se a competência do Poder Judiciário no controle das leis, e a supremacia da Constituição sobre as leis ordinárias.

Em seu voto, o juiz Marshall defende que é competência somente do Judiciário interpretar as leis em casos conflitantes e definir se determinada lei é ou não inconstitucional para que seja então anulada ("The rule must be discharged"), tendo tudo isso como base a Constituição, definida por ele como a lei máxima do ordenamento jurídico.

O caso foi um marco na história por ser a primeira vez em que foi discutida a constitucionalidade das leis e a palavra final das decisões judiciais foi designada à Suprema Corte.
} 
Education of Topeka, em 1954. Nessa situação, o objetivo da ação era a incorporação das crianças negras ao sistema público de educação de Topeka, provando que uma socialização segregada resultava em conseqüências negativas ao desenvolvimento da pessoa. Ao final, a Corte declarou inconstitucional a segregação racial nas escolas públicas, dissolvendo-se, assim, a doutrina dos "iguais, mas separados". 115

Um juiz da Suprema Corte norte-americana que se caracteriza pela sua atuação ativista e que ficou famoso nesse período foi Earl Warren, nomeado, em 1953, por Ensenhower para a função de Chief of Justice.

Após Warren, a função passa a ser exercida por William H. Rehnquist, nomeado, em 1972, por Richard Nixon. Rehnquist assume uma postura menos ativista e mais restritiva, iniciando o período do chamado self-restraint.

A teoria do self-restraint defende uma atuação do Judiciário limitada à interpretação da Constituição, uma "ética de autocontrole do órgão que tem a prerrogativa de exercer a jurisdição constitucional, para que ele não se transforme em tutor dos demais poderes". Os juízes estariam impedidos de transformar a prerrogativa de interpretar a Constituição "em um monopólio de dizer o direito de acordo com as suas conveniências, sem respaldo da Lei Maior, ferindo a atuação dos poderes estabelecidos”. 116

$\mathrm{O}$ ativismo judicial encontrou expressivo desenvolvimento nos Estados Unidos, em virtude das características próprias do constitucionalismo e do common law, e do papel que, ao longo da história, tem se reconhecido à Suprema Corte, sugerindo que, nos tempos de positivismo jurídico, o ativismo jurisdicional ocorreu com mais frequência nesse sistema do que nos sistemas de civil law.

Sem embargo, essa diferenciação foi perdendo a importância com o surgimento do movimento neoconstitucionalista, que combina Constituições dotadas de forte conteúdo valorativo com novas práticas jurisprudenciais que se valham de técnicas interpretativas próprias aos princípios constitucionais como a ponderação de bens jurídicos e a maximização dos efeitos normativos dos direitos fundamentais, entre outras. Ademais, as modificações do Estado, enquanto unidade de poder - do modelo Liberal, passando pelo Bem-Estar Social até a priorização das funções intervencionistas e impulsionadoras - e do Direito, como uma das linguagens de trabalho da política, ocorrem insuficiências no

\footnotetext{
${ }^{115}$ Essa doutrina ganhou força a partir do julgamento do caso Plessy v. Ferguson, em 1896, em que restou estabelecido que a companhias ferroviárias deveriam providenciar acomodações iguais, mas separadas para as raças brancas e de cor. Em consequência disso, o serviço de educação e dos demais transportes eram prestados de forma separada também.

${ }_{116}$ AGRA, Walber de Moura. A reconstrução da legitimidade do Supremo Tribunal Federal: densificação da jurisdição constitucional brasileira. Rio de Janeiro: Forense, 2005, p. 136-137.
} 
modelo vigente, em relação às crises de produção e de aplicação das leis e da interação entre elas e a sociedade as quais se destina. O Poder Judiciário, destinatário final dos conflitos sociais e institucionais, deverá buscar novas respostas a esse novo Direito. Assim, o fenômeno do ativismo judicial passa a alcançar, em maior ou menor intensidade, quase todos os países que tenham optado pelo constitucionalismo no modelo ocidental. ${ }^{117}$

Ahumado Ruiz acrescenta que os catálogos de direitos fundamentais associados a uma jurisdição constitucional cujo exercício se outorgue a uma magistratura revestida de das garantias institucionais adequadas, a judicialização mais intensa de questões da vida e da política e, ainda, a consolidação dos regimes democráticos possibilitaram a intensificação do ativismo judicial em vários países, com o intuito de garantir os enunciados do texto constitucional, buscando-lhes dar eficácia. ${ }^{118}$

No Brasil, após a Constituição Federal de 1988, o Supremo Tribunal Federal passou a adotar uma postura mais ativa, sobretudo em virtude do fortalecimento do sistema de controle concentrado de constitucionalidade, que fizeram com que inúmeras questões de cunho político chegassem para a sua análise e julgamento. Com as alterações introduzidas pela Emenda Constitucional n. 45/04 e em virtude da mudança da composição do STF a partir de 2003, essa atuação ativa se intensificou, sobretudo em relação à redefinição dos limites de sua própria competência, "alcançando áreas e temas que talvez não estivessem no traçado original da Constituição, alterando, assim, seu próprio peso no concerto político da relação entre os poderes". ${ }^{119}$

Em virtude dos termos vagos, ambíguos, abre-se espaço para o aplicador do direito exercer a sua tarefa de concretizador, densificador das normas constitucionais, de modo que nessa tarefa de criação jurídica, o intérprete poderá tomar decisões de cunho pessoal, com base apenas na política, na economia ou em valores morais. Nos dizeres de Streck, “acabamos por confundir a era dos princípios e a abertura semântica, que sempre existe, com autorização para uma livre atribuição de sentido, como se existisse um grau zero de sentido". 120

\footnotetext{
${ }^{117}$ VALLE, Vanice Regina Lírio do. Op. cit., p. 24. Em sua obra "Juízes legisladores”, Mauro Cappelletti já advertia para a convergência dos sistemas Common Law e Civil Law, em relação à intensificação da criatividade jurisprudencial. Cf. CAPPELLETTI, Mauro. Op. cit.

${ }_{118}$ AHUMADA RUIZ, Marian. Alternativas a la judicial review y variedades de judicial review. Themis, a. IV, n. 10, 2005, p. 52.

${ }^{119}$ VALLE, Vanice Regina Lírio do. Op. cit., p. 40.

${ }^{120}$ STRECK, Lênio. Entrevista com Lênio Streck para o site Consultor Jurídico. Ativismo judicial não é bom para a democracia. Disponível em: <http://www.conjur.com.br/2009-mar-15/entrevista-lenio-streckprocurador-justica-rio-grande-sul>. Acesso em: 28 out. 2011.
} 
Diante dessa constatação, em alguns casos o Supremo vem sendo alvo de críticas, sob o argumento de que a Corte estaria ultrapassando os limites que lhe foram outorgados constitucionalmente $^{121}$, inclusive os limites em que poderia atuar politicamente no julgamento dos casos, comprometendo a segurança jurídica.

De acordo com Canotilho, o homem necessita de segurança para conduzir, planificar e conformar sua vida de forma autônoma e responsável. Por isso, os princípios da segurança jurídica e da proteção da confiança são considerados elementos constitutivos do Estado de Direito.

\begin{abstract}
Em geral, considera-se que a segurança jurídica está conexionada com elementos objectivos da ordem jurídica - garantia de estabilidade jurídica, segurança de orientação e realização do direito - enquanto a protecção da confiança se prende mais com os componentes subjectivos da segurança, designadamente a calculabilidade e previsibilidade dos indivíduos em relação aos efeitos jurídicos dos actos dos poderes públicos. A segurança e a proteç̧ão da confiança exigem, no fundo (1) fiabilidade, clareza, racionalidade e transparência dos atos do poder; (2) de forma que em relação a eles o cidadão veja garantida a segurança nas suas disposições pessoais e nos efeitos jurídicos dos seus próprios actos. ${ }^{122}$
\end{abstract}

O princípio da segurança jurídica abrange a proteção dos atos normativos, como a precisão das normas jurídicas, a proibição de pré-efeitos de atos normativos e a proibição de normas retroativas aos atos jurisdicionais e administrativos, tendo em vista que o indivíduo precisa de uma garantia para confiar na administração do Estado. ${ }^{123}$

Na Constituição brasileira de 1988, a expressão "segurança", em sentido amplo está presente no caput do artigo $5^{\circ}$, incluindo a segurança jurídica, a segurança à educação, à saúde, ao lazer, ao desenvolvimento econômico, à liberdade, à dignidade humana, entre outros direitos e garantias individuais e sociais. Já o princípio da segurança jurídica pode ser extraído dos incisos das garantias estabelecidas nos XXXVI a LXXIII do artigo $5^{\circ}$ e importa na função, do Estado, de garantir e tutelar os direitos garantidos aos indivíduos, inclusive por meio da atuação do Poder Judiciário visando conhecer e julgar casos que envolvam lesão ou ameaça a direito.

\footnotetext{
${ }^{121}$ Esse movimento ativista do Supremo Tribunal Federal, com o objetivo inclusive de ampliar as suas competências, que, em outros países estão distribuídos a outros órgãos, já foi denominado de "supremocracia” (cf. VIEIRA, Oscar Vilhena. Entrevista à Revista Época. Vivemos em uma supremocracia. Disponível em: <http://revistaepoca.globo.com/Revista/Epoca/1,_EMI19313-15295,00.html>. Acesso em 29 out. 2011) e poderia conduzir a um "governo de juízes". A expressão foi utilizada por Yves Lemoine, em sua obra Le complot des juges, editada pelo Editora Du Félin de Paris, em 1993, para afirmar que, na realidade, a magistratura continua exercendo a função de servir aos interesses do Estado, determinados pelo governo, não sendo o "governo de juízes" algo novo ou recente no contexto político-jurídico dos Estados.

${ }^{122}$ CANOTILHO, J. J. Gomes. Direito constitucional e teoria da constituição. Op. cit., p. 257.

${ }^{123}$ Ibidem, p. 257.
} 
Assim, em respeito ao princípio da segurança jurídica, o julgador, mesmo com suas convicções próprias, (pré)juízos e (pré)compreensões, naturais a qualquer ser humano, não pode pautar as suas decisões por subjetivismos, por arbitrariedades, devendo sempre fundamentar a interpretação das normas constitucionais a serem aplicadas em um caso concreto com base nos princípios jurídicos e nos métodos hermenêuticos utilizados.

Embora o Supremo Tribunal Federal seja considerado o principal "guardião da constituição", em virtude de suas funções ligadas precipuamente à interpretação das normas constitucionais, sobretudo em virtude da competência para processar e julgar as ações do sistema de controle concentrado de constitucionalidade das leis, todos os demais tribunais e juízes do país têm a prerrogativa de aplicar diretamente as normas constitucionais aos casos concretos que são trazidos ao seu conhecimento e de, inclusive, argüir a inconstitucionalidade de algum ato normativo em uma situação concreta.

Diante da constatação de que os magistrados (ministros, desembargadores e juízes), por meio da jurisdição constitucional, podem atuar, no julgamento dos casos concretos ou abstratos (em se tratando do STF, nesse último caso), de forma arbitrária, ultrapassando o que seria considerado um "ativismo judicial" aceitável ou necessário e atentando contra os princípios da segurança jurídica e da separação dos poderes, na sua versão atualizada e consentânea com o Estado Democrático de Direito, surge a necessidade de apresentar os possíveis limites, que a doutrina elenca, para o exercício da função jurisdicional relativa à concretização das normas constitucionais.

\subsubsection{Possíveis limitações ao ativismo judicial}

Todos os órgãos do Poder Judiciário estão sujeitos a limites no que tange à implementação dos direitos fundamentais estabelecidos na Constituição Federal de 1988, pois existe uma diferença entre o juiz trabalhar com situações que demandam uma atuação mais política, pela própria essência do ato de concretizar determinadas matérias que estão dispostas nas normas constitucionais, ou de apresentar uma postura mais pró-ativa, em virtude de situações que exigem uma interpretação mais consentânea com a realidade social, e uma atuação jurisdicional arbitrária, eivada de opiniões pessoais, sem qualquer fundamentação jurídica, destituída de razoabilidade e proporcionalidade e que viole os princípios da segurança jurídica e da separação harmônica dos poderes. 
No caso do Supremo Tribunal Federal, é compreensível a preocupação dos juristas em traçar limites ao exercício das suas funções constitucionais, no que tange à atuação em questões políticas, pois o STF detém a prerrogativa de interpretar os limites de sua própria jurisdição, ao passo que as demais funções do Estado - Executivo e Legislativo - possuem suas respectivas competências interpretadas pelo Supremo, por meio do controle de constitucionalidade.

Ademais, o STF é um órgão inevitavelmente político, uma vez que suas decisões, principalmente as proferidas no julgamento das ações do sistema do controle concentrado de constitucionalidade, repercutem nos demais poderes e na sociedade em geral.

Sem embargo, tanto o Supremo, ao exercer a função de "guardião da Constituição", em um Estado Democrático de Direito, quanto os demais órgãos do Poder Judiciário, em suas respectivas atuações enquanto concretizadores das normas constitucionais, precisam se submeter aos ditames da Lei Fundamental no que tange às competências estipuladas, em respeito ao princípio da separação harmônica dos poderes, em sua versão atualizada.

Em outras palavras, o Poder Judiciário é destinatário das normas de direitos fundamentais e deve dar a maior aplicabilidade possível a elas, inclusive por meio de uma interpretação constitucional em consonância com as transformações sócio-políticoeconômicas, ainda quando os Poderes Legislativo e Executivo se mantêm inertes em sua tarefa de materializadores desses direitos. Todavia, os juízes não podem simplesmente estabelecer políticas públicas para implementar direitos fundamentais ou criar leis que venham regulamentar normas constitucionais, se imiscuindo as funções precípuas dos demais Poderes, a não ser, nesse último caso, que o Legislativo esteja impedindo, de forma flagrante e abusiva, ou seja, por longo período, o exercício de um direito fundamental cuja implementação não causará maiores repercussões sócio-econômicas no país e o Supremo Tribunal Federal possa, por meio de algum instrumento normativo já existente, possibilitar o exercício do referido direito enquanto não for criada a lei regulamentadora.

Ademais, o Judiciário, ao aplicar uma norma constitucional a um caso trazido à análise e julgamento, deve se pautar pelos princípios da interpretação constitucional, sobretudo aos da unidade da Constituição, da harmonização e do efeito integrador.

Nesse sentido, Canotilho explicita que

mesmo quando os juízes se podem assumir tendencialmente como "legisladores negativos" (ao declararem a inconstitucionalidade de normas) ou criadores de direito (ao elaborarem "normas" para a decisão do caso), [eles] estão vinculados à constituição e à lei, à distribuição funcional de competências constitucionais, à separação de poderes e ao princípio democrático. É certo que estes limites 
jurídico-constitucionais não têm sido suficientes para evitar aquilo que os autores chamam de "activismo judicial" à sombra do desenvolvimento e complementação jurisprudencial do direito. O desenvolvimento tem passado sobretudo a nível dos tribunais constitucionais e dos tribunais ordinários com funções constitucionais - pela descoberta de novas funções e novas dimensões do direito. ${ }^{124}$

Na verdade, os limites da atuação do Supremo Tribunal Federal e dos demais órgãos que exercem a jurisdição constitucional estão na própria Constituição. Nas palavras de Walber de Moura Agra, esses limites

são os princípios dispositivos da Lei Maior, que não poderão ser desrespeitados, principalmente por um órgão que tem a função de defendê-los e assegurar sua eficácia. O tribunal ou corte constitucional incumbido de velar pela supremacia da Carta Magna não pode declarar a inconstitucionalidade das normas produzidas pelo Poder-Constituinte, nem pode deixar sem concretização nenhum de seus mandamentos. ${ }^{125}$

Oscar Vilhena Vieira acrescenta que a atuação do Supremo Tribunal Federal deve se pautar em alguns critérios, a fim de cumprir o seu papel estabelecido na Constituição, quais sejam:

\begin{abstract}
1) tomar decisões com base em decisões anteriores que lhes foram préordenadas pelos Poderes representativos, portanto, seguir a normatividade (que é composta por regras e princípios) e não outros critérios extraconstitucionais ou legais, como a comumente invocada comoção popular ou a pretensa eficiência econômica, pois não tem legitimidade democrática para fazer este tipo de escolha; 2) plena obediência ao princípio do devido processo legal, que permita um procedimento justo [...] onde as partes possam, com igual peso e espaço, apresentar seus argumentos; 3) o imperativo da imparcialidade do juiz, que decorre do princípio da igualdade, segundo o qual todos devem ser tratado com respeito e consideração; 4) a decisão deve ser a decorrência mais correta, mais bem justificada, desse procedimento que busca a realização da justiça. ${ }^{126}$
\end{abstract}

Esses critérios podem ser estendidos à atuação dos demais órgãos do Judiciário, incluindo os da Justiça do Trabalho, pois, ainda que na importante tarefa de concretizador dos direitos fundamentais, o juiz, desembargador ou Ministro jamais poderá se esquecer do texto do dispositivo constitucional a ser interpretado e do contexto em que ele está inserido e do respeito ao princípio do devido processo legal; deverá agir com imparcialidade, com respeito ao contraditório e à ampla defesa; e terá como obrigação fundamentar fática e

${ }^{124}$ CANOTILHO, J. J. Gomes. Um olhar jurídico-constitucional sobre a judiciarização da política. In: RIBEIRO, Lauro Luiz Gomes; BERARDI, Luciana Andrea Accorsi (Orgs.). Estudos de direito constitucional: em homenagem à professora Maria García. São Paulo: IOB - Thomson, 2007, p. $230-241$.

125 AGRA, Walber de Moura. Op. cit., p. 136.

${ }^{126}$ VIEIRA, Oscar Vilhena. Supremo Tribunal Federal: jurisprudência e política. 2 ed. São Paulo: Malheiros, 2002, p. 229. 
juridicamente as decisões proferidas, apresentando argumentos lógicos e razoáveis que assegurem aos jurisdicionados a segurança jurídica e a confiabilidade no Judiciário.

Constata-se que os limites da jurisdição constitucional são, em grande parte, os limites da interpretação jurisdicional, porquanto antes de aplicar uma norma constitucional a uma situação abstrata ou a um caso concreto o juiz terá necessariamente de fazer uso da interpretação dessa norma ${ }^{127}$, apreendendo-lhe o sentido e o alcance.

E a interpretação constitucional, inclusive a interpretação constitucional evolutiva exercida pelos órgãos do Judiciário, encontra limites no próprio texto normativo e nos princípios e nas regras constitucionais consideradas em seu conjunto, ou seja, no espírito da Constituição.

Quando o Tribunal Constitucional interpreta a Constituição com efeito vinculativo para os cidadãos e para os demais órgãos do Estado, somente haverá legitimidade nessa vinculação se as decisões expressarem o conteúdo constitucional. "Ainda que o tribunal esteja autorizado para determinar com obrigatoriedade esse conteúdo, ele, contudo, não é superior à Constituição, à qual [ele] deve sua existência". ${ }^{128}$ Esse mesmo raciocínio pode ser utilizado para a interpretação constitucional realizada pelos demais órgãos do Poder Judiciário.

A atividade interpretativa, como já salientado no capítulo 3, envolve necessariamente um esforço por parte do aplicador do direito no sentido de demonstrar as razões fáticas e jurídicas que o levaram a adotar um determinado sentido ou alcance para a norma constitucional aplicável ao caso concreto. Ou seja, a decisão jurisdicional deve ser fundamentada racionalmente, demonstrando o juiz o raciocínio lógico-jurídico desenvolvido para chegar à conclusão adotada, tornando transparente ao jurisdicionado o motivo pelo qual a norma constitucional foi interpretada em um determinado sentido, e não em outro, em respeito ao princípio da segurança jurídica.

De acordo com Mauro Cappelletti, o juiz, vinculado a precedentes ou à lei (ou a ambos), "tem como dever mínimo apoiar sua própria argumentação em tal direito judiciário ou legislativo, e não (apenas) na "equidade" ou em análogos e vazios critérios de valoração". ${ }^{129}$

\footnotetext{
${ }^{127}$ Nos dizeres de Konrad Hesse, não existe norma jurídica, senão norma jurídica interpretada. Cf. HESSE, Konrad. A força normativa da Constituição. Op. cit., p. 22.

${ }^{128}$ HESSE, Konrad. Elementos de direito constitucional na República Federal da Alemanha. Op. cit., p. 5455.

${ }^{129}$ CAPPELLETTI, Mauro. Op. cit., p. 25.
} 
Pontuados os limites de uma postura mais pró-ativa do Judiciário, em conformidade com uma leitura atualizada da teoria da separação dos poderes, passar-se-á, no próximo capítulo, para a análise da atuação jurisdicional da Justiça do Trabalho no que tange à implementação dos direitos fundamentais trabalhistas, com base nas teorias estudadas nos capítulos anteriores, que embasam a construção de uma hermenêutica jurisdicional comprometida efetivamente com a concretização desses direitos sociais, e em exemplos extraídos da jurisprudência dos Tribunais Regionais do Trabalho e do Tribunal Superior do Trabalho. 


\section{A INTERPRETAÇÃO CONSTITUCIONAL EVOLUTIVA E A CIDADANIA SOCIAL: ELEMENTOS PARA A IMPLEMENTAÇÃO EFETIVA DOS DIREITOS FUNDAMENTAIS TRABALHISTAS PELA JUSTIÇA DO TRABALHO NO BRASIL}

Esse capítulo tem por objetivo demonstrar que o princípio da cidadania social e o mecanismo da interpretação constitucional evolutiva são elementos que fundamentam uma atuação jurisdicional da Justiça do Trabalho comprometida com a implementação dos direitos fundamentais trabalhistas. Nesse sentido, será realizado, primordialmente, um breve estudo acerca da criação e desenvolvimento desse ramo especializado do Judiciário e da formação dos magistrados que a compõem. Em seguida, demonstrar-se-á que os juízes e desembargadores do trabalho e Ministros do Tribunal Superior do Trabalho têm não apenas o poder, mas o dever de atuar de forma comprometida com a implementação dos direitos fundamentais trabalhistas, pois a concepção de cidadania albergada pela Constituição Federal de 1988 confere ao cidadão trabalhador o direito de buscar o Judiciário sabendo que, ao final, o provimento jurisdicional estará comprometido em dar a maior aplicabilidade jurídica a esses direitos, possibilitando o seu efetivo exercício. À continuação, serão apresentados alguns casos concretos em que a Justiça do Trabalho implementou direitos fundamentais trabalhistas, por meio da interpretação constitucional evolutiva das normas que os estabelecem, e serão exemplificadas algumas situações em que os magistrados do trabalho ainda atuam de forma "involutiva", interpretando normas constitucionais de maneira desvinculada da realidade social, e como os direitos fundamentais poderão ser efetivamente implementados nessas hipóteses.

\subsection{A Justiça do Trabalho no Brasil e a formação jurídica e humanista dos juízes trabalhistas}

Antes de adentrar no tema da atuação da Justiça do Trabalho no que tange à implementação dos direitos fundamentais trabalhistas, é importante apresentar a origem e a evolução histórica desse ramo especializado do Judiciário e a formação jurídica dos membros que o compõe, visto que esses aspectos estão diretamente relacionados a uma postura mais ou menos restritiva na concretização dos direitos sociais. 
No Brasil, a história da Justiça do Trabalho se confunde com a história do Direito Processual do Trabalho. Inicialmente, a resolução de questões trabalhistas no Brasil era de atribuição da Justiça comum. As leis de 13 de setembro de 1830 e de 11 de outubro de 1837 estabeleceram rito sumaríssimo e o Regulamento n. 737, de 15 de setembro de 1850, determinou o rito sumário para as causas que envolviam o trabalho subordinado, à época reguladas pelo contrato de locação de serviços. Portanto, até então não existia nenhum órgão destinado a cuidar dos conflitos trabalhistas nem regras processuais específicas para esse tipo de demanda.

A primeira fase histórica da Justiça do Trabalho, propriamente dita, engloba três períodos de institucionalização. No primeiro, destacam-se os Conselhos Permanentes de Conciliação e Arbitragem, que foram criados pela Lei n. 1.637 de 05/11/1907, sendo que os processos de conciliação seriam regulados pelo regimento interno do próprio Conselho, enquanto a arbitragem observaria as disposições do Direito Comum. No segundo período surgem os Tribunais Rurais ${ }^{1}$, instituídos pela Lei n. 1869 de 10/10/1922, destinados à decidir litígios decorrentes da interpretação e execução dos contratos de serviços agrícolas, no valor de até quinhentos mil réis. Esses Tribunais eram compostos pelo Juiz de Direito da Comarca, um representante dos trabalhadores e outro, dos fazendeiros. No terceiro período, surgiram as Juntas de Conciliação e Julgamento (1932), responsáveis por dirimir os conflitos individuais, e as Comissões Mistas de Conciliação, restritas aos conflitos coletivos de trabalho, sendo que ambas eram órgãos administrativos vinculados ao Poder Executivo. ${ }^{2}$ Somente os empregados sindicalizados tinham direito de ação e as decisões das Juntas, com instância única de julgamento, valiam como título da dívida líquida e certa para a execução judicial.

A constitucionalização da Justiça do Trabalho caracteriza a segunda fase histórica, porquanto as Constituições brasileiras de 1934 a 1937 passaram a dispor expressamente sobre ela, embora não como órgão integrante do Poder Judiciário.

De acordo com Carlos Henrique Bezerra Leite, nessa fase ocorreu o debate crucial entre Waldemar Ferreira e Oliveira Viana acerca do Poder Normativo da Justiça do Trabalho. De acordo com o primeiro, a atribuição dos juízes do trabalho para criar normas nos dissídios coletivos contrariava os princípios constitucionais, mormente o princípio da separação dos poderes, já que somente ao Legislativo competia criar normas gerais e

1 Os Tribunais Rurais se justificavam pois, à época, a economia do Estado de São Paulo era predominantemente rural.

${ }^{2}$ NASCIMENTO, Amauri Mascaro. Curso de direito processual do trabalho. 22 ed. São Paulo: Saraiva, 2007, p. 33-34. 
abstratas destinadas a pessoas não identificadas. Por seu turno, Oliveira Viana sustentava a competência normativa da Justiça do Trabalho, fundando-se, sobretudo, na escola sociológica do direito e nos jusrealismo estadunidense, "no sentido de que o juiz teria função criativa e de colaborador na construção de normas jurídicas, não se limitando a ser mero intérprete gramatical dos textos legais". 3

O artigo 122 da Constituição Federal de 1934 estabelecia a Justiça do Trabalho, mas não como um ramo jurisdicional autônomo, pois estava vinculada ao Poder Executivo. A Constituição de 1937, em seu artigo 130, imprimiu maior autonomia à Justiça laboral, mas se quedou silente em relação à sua inserção ou não no Poder Judiciário.

Todavia, o Supremo Tribunal Federal, em acórdão de 30/09/1943, relativa ao Recurso Extraordinário n. 6.310, reconheceu o caráter jurisdicional das cortes trabalhistas:

\begin{abstract}
A natureza da atividade dos Tribunais do Trabalho não é administrativa, mas sim, e essencialmente jurisdicional. O juiz do trabalho, embora sem as prerrogativas do magistrado comum, é juiz, proferindo verdadeiros julgamentos na solução de determinados litígios. ${ }^{4}$
\end{abstract}

A terceira fase histórica se inicia com o reconhecimento da Justiça do Trabalho como órgão integrante do Poder Judiciário, pelo Decreto-lei n. 9.777 de 09/09/1946, que regulava sobre sua organização. Logo em seguida, a Constituição Federal de 1946 dispôs expressamente que o Poder Judiciário é exercido pelos juízes e tribunais do trabalho (artigo 94, inciso V), estabelecendo, ainda, que a Justiça do Trabalho era composta dos seguintes órgãos: Tribunal Superior do Trabalho, Tribunais Regionais do Trabalho e Juntas ou Juízes de Conciliação e Julgamento (artigo 122).

Amauri Mascaro descreve a importância da integração, pelo Judiciário, da Justiça do Trabalho.

\begin{abstract}
$\mathrm{Na}$ sociedade empresarial, as controvérsias entre trabalhadores e empresários assumem especial significado. O Estado, intervindo na ordem econômica e social, não pode limitar-se a dispor sobre matéria trabalhista. Necessita, também, de aparelhamento adequado para a solução dos conflitos de interesse, tanto no plano individual como no coletivo. Assim, a existência de um órgão jurisdicional do Estado para questões trabalhistas é o resultado da própria transformação da ideia de autodefesa privada em processo judicial estatal, meio característico de decisão dos litígios na civilização contemporânea. ${ }^{5}$
\end{abstract}

\footnotetext{
${ }^{3}$ LEITE, Carlos Henrique Bezerra. Curso de direito processual do trabalho. 4 ed. São Paulo: LTr, 2006, p. 104.

${ }^{4}$ MARTINS FILHO, Yves Gandra da Silva; NASCIMENTO, Amauri Mascaro do. História do trabalho, do direito do trabalho e da justiça do trabalho. 2 ed. São Paulo: LTr, 2002, p. 204.

${ }^{5}$ NASCIMENTO, Amauri Mascaro. Op. cit., p. 50.
} 
A fase contemporânea se caracteriza pela multiplicação e massificação dos conflitos trabalhistas, seja pelo descumprimento reiterado dos direitos dos trabalhadores pelos empregadores, seja pela ampliação da competência da Justiça do Trabalho, o que gera problemas como a morosidade da prestação jurisdicional e a incapacidade dos institutos tradicionais do processo de se adaptaram às tutelas jurisdicionais necessárias.

Nessa fase, verifica-se a necessidade de se instaurar uma nova cultura humanística entre os operadores do Direito, visto que o processo deve propiciar a concretização dos direitos humanos de segunda dimensão, que são os direitos sociais dos trabalhadores. Assim, dá-se cada vez mais ênfase à jurisdição trabalhista metaindividual, como meio de ampliar o acesso coletivo dos trabalhadores a uma ordem jurídica justa, e à utilização, no processo do trabalho, de novos institutos estabelecidos pelas reformas do processo civil que sejam compatíveis com a gênese principiológica do processo laboral. Ao lado dessas modificações do processo do trabalho, verifica-se, também, a necessidade de uma leitura hermenêutica adequada dos preceitos fundamentais trabalhistas com vistas à implementação dos direitos dos trabalhadores esculpidos na Constituição Federal.

A Constituição Federal de 1988 imprimiu ao Poder Judiciário a tarefa de ser o guardião da Constituição, ou seja, os órgãos jurisdicionais devem preservar os valores e princípios que fundamentam o novo Estado Democrático de Direito, como a cidadania, a dignidade da pessoa humana, os valores sociais do trabalho e da livre iniciativa e o pluralismo políticos.

No que tange especificamente à Justiça do Trabalho, a Constituição, em seu artigo 111, elencou os seus órgãos: o Tribunal Superior do Trabalho, os Tribunais Regionais do Trabalho e os Juízes do Trabalho.

A Justiça do Trabalho integra o Poder Judiciário da União, apresentando estrutura federalizada. Os órgãos de primeiro grau são os Juízes do Trabalho, que atuam nas Varas do Trabalho ${ }^{6}$; os de segundo grau são os Tribunais Regionais do Trabalho ${ }^{7}$, compostos pelos Desembargadores federais do Trabalho; e o órgão da instância superior é o Tribunal Superior do Trabalho $^{8}$, composto pelos Ministros do TST. ${ }^{9}$

\footnotetext{
${ }^{6}$ Artigo 116. Nas Varas do Trabalho, a jurisdição será exercida por um juiz singular.

${ }^{7}$ Os TRT's são compostos por desembargadores do Trabalho, englobando Juízes do Trabalho de carreira, promovidos por antiguidade e merecimento, e membros do Ministério Público do Trabalho e por advogados, com mais de dez anos de exercício profissional, notório conhecimento jurídico e reputação ilibada, nomeados alternadamente. Os membros do MPT e advogados nomeados formam o chamado quinto constitucional.

${ }^{88}$ Junto ao TST funcionam a Escola Nacional da Magistratura do Trabalho, encarregada do aperfeiçoamento dos magistrados trabalhistas, e o Conselho Superior da Justiça do Trabalho, cabendo-lhe exercer, na forma da
} 
A Justiça do Trabalho, inspirada no modelo da Itália fascista, desde o seu nascimento contava com a representação paritária em todos os seus órgãos, com juízes classistas, também denominados "vogais", recrutados nos Sindicatos da categoria profissional e da categoria econômica, ao lado de um juiz togado, ou seja, com formação jurídica. Os juízes classistas atuavam majoritariamente na fase de conciliação e votavam nos julgamentos, uma vez que conheciam a fundo a realidade das categorias que representavam.

Com o tempo, em virtude do crescimento dos conflitos de trabalho e do aumento da complexidade das questões analisadas pela Justiça do Trabalho, exigindo mais conhecimento técnico do juiz formado em Direito do que o senso prático dos classistas, a manutenção desses juízes leigos passou a ser bastante questionada, até que a Emenda Constitucional n. 24/99 extinguiu a representação classista tanto nas Juntas de Conciliação e Julgamento, que passaram a ser denominadas Varas do Trabalho, quanto nos Tribunais Regionais do Trabalho e no Tribunal Superior do Trabalho.

Apesar de perder a representação classista, a Justiça do Trabalho é, ainda, inconfundível pela matéria específica de sua competência ${ }^{10}$, pela singularidade de seus ritos processuais e pela peculiaridade de suas decisões.

Os juízes são os membros do Judiciário que têm a função precípua de julgar, ou seja, de decidir os conflitos que lhe são submetidos pelos jurisdicionados.

Para exercer bem a sua função, com imparcialidade e independência a Constituição Federal estabelece, em seu artigo 95, algumas garantias aos juízes, em virtude do exercício do cargo. Essas garantias são, também, do próprio cidadão, que terá a sua causa examinada por um Juiz imparcial e independente. Assim, o juiz tem vitaliceidade (após dois anos de efetivo exercício, o juiz adquire a vitaliceidade, somente perdendo o cargo mediante

lei, a supervisão administrativa, orçamentária, financeira e patrimonial da Justiça do Trabalho de primeiro e segundo graus, como órgão central do sistema, cujas decisões terão efeito vinculante.

${ }^{9}$ O TST tem jurisdição em todo o território nacional e é composto por 27 Ministros, sendo que quatro quintos são juízes de carreira nomeados pelo Presidente da República, após figurarem em lista tríplice elaborada pelo próprio Tribunal, e um quinto é formado por advogados e membros do Ministério Público do Trabalho, com mais de dez anos de exercício profissional, nomeados, de maneira alternada.

${ }^{10} \mathrm{O}$ art. 114 da Constituição Federal de 1988, que estabelece a competência da Justiça do Trabalho, antes da Emenda Constitucional n. 45/04 apresentava a seguinte redação: “Compete à Justiça do Trabalho conciliar e julgar os dissídios individuais e coletivos entre trabalhadores e empregadores, abrangidos os entes de direito público externo e da administração pública direta e indireta dos Municípios, do Distrito Federal, dos Estados e da União e, na forma da lei, outras controvérsias decorrentes da relação de trabalho, bem como os litígios que tenham origem no cumprimento de suas próprias sentenças, inclusive as coletivas." A Emenda Constitucional n. 45/04 ampliou a competência da Justiça do Trabalho para apreciar, além das controvérsias entre empregados e empregadores, as demandas decorrentes das relações de trabalho lato sensu e outras questões relativas à relação de emprego, como as ações relativas à representação sindical, à fiscalização do trabalho, entre outras. 
sentença judicial transitada em julgado), irredutibilidade de vencimentos (a remuneração do juiz, na forma de subsídio, é irredutível nominalmente) e inamovibilidade (o juiz não pode ser removido da jurisdição em que é titular, salvo a requerimento ou por motivo de interesse público, mediante voto da maioria absoluta do Tribunal ou do Conselho Nacional de Justiça, assegurada a ampla defesa).

Os juízes do trabalho, como os demais juízes em geral, ingressam na carreira por meio de concurso público de provas e títulos, após se formarem em uma faculdade de Direito e terem, pelo menos, três anos de prática jurídica.

A faculdade, além de preparar tecnicamente o aluno que se tornará bacharel em Direito, "tem a missão de desenvolver-lhe a sua consciência social a respeito de suas funções enquanto operadores do direito" "11, pois os candidatos a juiz, no processo de seleção, devem não somente possuir conhecimentos técnico-jurídicos suficientes, como também apresentar uma postura ética e de compromisso com a função de julgador apto a solucionar as controvérsias que envolvem os seres humanos.

Nesse sentido, os cursos de Direito, embora muitos não o façam, deveriam efetivamente integrar ensino, pesquisa e extensão, de modo a propiciar ao discente uma formação abrangente, que desenvolvesse o sentido ético e a sensibilidade dos alunos para as questões práticas que lhe serão apresentadas na vida profissional.

No campo do ensino, é relevante que o currículo contenha disciplinas que trabalhem com a filosofia, sociologia, psicologia e ética, essenciais para o conhecimento da realidade das sociedades humanas e, portanto, da formação humanística do estudante, sendo que as questões filosófico-jurídicas apresentadas aos alunos em sala devem ser inseridas nas aulas das disciplinas tradicionais de formação básica do estudante, promovendo um conhecimento interdisciplinar.

Segundo Dalmo de Abreu Dallari, independentemente do conflito jurídico a ser analisado, temas que envolvem conhecimentos profundos dessas disciplinas humanísticas, "sempre estará presentes e é importante que o profissional do direito saiba reconhecê-los"12 e, indo mais além, que tenha capacidade para analisá-los com propriedade.

Ademais, de extrema relevância é o estudo mais aprofundado da hermenêutica jurídica, levando-se em consideração que o objeto do trabalho de futuros advogados, privados ou públicos, procuradores e juízes envolve necessariamente o ato de interpretar e aplicar normas jurídicas e, especialmente, normas constitucionais.

\footnotetext{
${ }^{11}$ TEODORO, Maria Cecília Máximo. Op. cit., p. 139.

${ }^{12}$ DALLARI, Dalmo de Abreu. O poder dos juízes. Op. cit., p. 30.
} 
$\mathrm{Na}$ área da pesquisa, os discentes devem ser incentivados a realizar trabalhos que vinculem o conhecimento adquirido nas aulas à sua aplicação prática, de forma a promover a interação teórico-prática, e a desenvolver pesquisas sobre temas controvertidos que apresentem repercussão prática, propondo soluções concretas.

Finalmente, na seara da extensão, a Universidade deve estimular o estudante a trabalhar diretamente com a população ${ }^{13}$, inclusive a de baixa renda, em órgãos públicos que atendam a esse perfil, como as defensorias públicas e juizados, em ONG's que desenvolvam projetos sociais, nos setores de assistência judiciária das próprias faculdades, e nos projetos de extensão desenvolvidos pela faculdade, que trabalhem com parcelas específicas da população, tendo em vista que parte considerável desse público é que apresentará demandas a serem julgadas pelos juízes, sobretudo os da área trabalhista. É necessário, portanto, que os discentes sejam efetivamente estimulados a conhecer a realidade social com que, muitos deles, trabalharão cotidianamente em sua vida profissional.

Maria Cecília Máximo Teodoro ressalta a importância da formação intelectual e ética dos candidatos ao ingresso na magistratura:

\begin{abstract}
A formação [...] do magistrado deve ter como premissa básica o fato de que o conhecimento do direito não ocorre por simples repetição de textos normativos. Pelo contrário, é preciso o profundo e paciente estudo da história humana, da realidade para a qual trabalha e dos dados filosóficos e culturais de cada comunidade, que são minuciosamente diferentes e relevantes. ${ }^{14}$
\end{abstract}

Em virtude da baixa qualidade de muitos dos cursos de graduação em Direito e do alto nível de conhecimento exigido nos concursos, com especial relevo para os de ingresso na carreira da magistratura, na última década o número de cursos preparatórios aumentou substancialmente, inclusive na modalidade telepresencial, por ser um negócio lucrativo em virtude do preço das mensalidades e da grande demanda, de modo que é raro o candidato aprovado que não tenha passado por pelo menos um desses cursos.

Voltados especificamente para as matérias dos editais dos concursos, tais cursos preparatórios costumam completar a formação técnico-jurídica que não foi bem ministrada nos cursos de graduação, suprindo carências de conteúdo, mas, da mesma forma a maioria

\footnotetext{
${ }^{13}$ Muitos alunos de cursos de Direito se limitam a realizar apenas os estágios obrigatórios, cumprindo os créditos necessários para a conclusão do curso, ou fazem apenas um estágio específico e pouco abrangente, durante boa parte do curso, o que pode reduzir a possibilidade de aquisição de conhecimento prático desses discentes. Ademais, não raramente, os estágios oferecidos colocam o estudante para desempenhar tarefas de secretário ou meramente burocráticas que muito pouco acrescentarão à sua formação.

14 TEODORO, Maria Cecília Máximo. Op. cit., p. 142.
} 
das faculdades, não preparam o candidato do ponto de vista ético-humanístico, ou seja, o candidato, após a aprovação, quando iniciar o exercício na carreira, se defrontará com uma realidade que, muitas vezes, era então desconhecida, e que exige uma postura crítica e sensível que nem sempre aqueles profissionais estão habituados a apresentar.

Na realidade, a formação e o aperfeiçoamento dos juízes do trabalho em temas mais aprofundados e humanísticos, essenciais à sua atuação profissional, acabam ficando para os cursos oferecidos pelas Escolas de Formação e Aperfeiçoamento dos Tribunais Regionais do Trabalho e a Escola Nacional de Magistrados Trabalhistas que funciona junto ao Tribunal Superior do Trabalho. Ademais, os juízes que se interessarem poderão realizar cursos de pós-graduação, em nível de especialização, mestrado ou doutorado, conveniados ou não às referidas Escolas, para ampliarem o seu conhecimento teórico e prático.

Portanto, é necessário ressaltar a imprescindibilidade, para os magistrados, de uma formação humana e ética somada a um conhecimento mais detido da hermenêutica jurídica, adquiridos desde os bancos das universidades até os cursos realizados nas Escolas de Formação e Aperfeiçoamento dos Magistrados, pois os candidatos que ingressam na carreira da magistratura do trabalho precisam ter um olhar ainda mais apurado para as questões sociais sensíveis, tendo em vista que a matéria bruta com a qual lidarão cotidianamente diz respeito à interpretação e aplicação dos direitos trabalhistas, inclusive os direitos de índole fundamental, de cidadãos trabalhadores que buscam a Justiça do Trabalho justamente para obterem o reconhecimento desses direitos violados ou não implementados pelos empregadores.

\subsection{A cidadania social como elemento legitimador de uma Justiça Especializada comprometida com os direitos fundamentais trabalhistas}

A Justiça do Trabalho tem como competência processar e julgar os casos envolvendo os sujeitos da relação de trabalho e da relação de emprego, além de outras controvérsias listadas no artigo $114^{15}$ da Constituição Federal, conforme a redação

\footnotetext{
${ }^{15}$ Art. 114 - Compete à Justiça do Trabalho processar e julgar:

I - as ações oriundas da relação de trabalho, abrangidos os entes de direito público externo e da administração pública direta e indireta da União, dos Estados, do Distrito Federal e dos Municípios;

II - as ações que envolvam exercício do direito de greve;

III - as ações sobre representação sindical, entre sindicatos, entre sindicatos e trabalhadores, e entre sindicatos e empregadores;
} 
apresentada pela Emenda Constitucional n. 45/2004, que ampliou a competência desse ramo especializado do Poder Judiciário.

Em se tratando da relação de emprego, os juízes do trabalho aplicam o Direito do Trabalho como direito material pertinente para a solução dos casos jurídicos e se valem do Processo do Trabalho como meio instrumental para a realização do fim maior que é a reparação ou afirmação dos direitos trabalhistas violados ou não implementados.

O Direito do Trabalho levando em conta, como regra geral, a hipossuficiência do empregado, como sujeito da relação de emprego, confere a este uma superioridade jurídica que tem como objetivo a redução das desigualdades fáticas e socioeconômicas, a melhoria da qualidade de vida dos trabalhadores e de seus dependentes e uma distribuição mais equânime da riqueza e do poder na sociedade, essenciais ao regime democrático. ${ }^{16}$

Os direitos trabalhistas são direitos sociais, fruto das lutas operárias, nos séculos XVIII e XIX, por melhores condições de trabalho e de vida, em virtude do quadro de extrema desigualdade econômica que se estabeleceu entre o proletariado e a burguesia, detentora dos meios de produção e que super explorava os trabalhadores com o objetivo de obter altos lucros.

Os Estados, com receio de que as revoltas populares e os movimentos organizados abalassem as instituições liberais, passaram a ter interesse em contornar a situação de crise, mediante a adesão às teorias do socialismo utópico e do socialismo cristão para manter a lógica do sistema capitalista. Assim, por meio da atuação estatal, começa-se o processo de elaboração de leis que visavam proteger minimamente o trabalhador, criando os primeiros direitos trabalhistas. Ao longo do tempo, esses direitos foram sendo ampliados e os considerados mínimos foram estabelecidos nas Constituições de vários países e em instrumentos internacionais, como Declarações e Convenções Internacionais.

No Brasil, embora já existisse alguma legislação esparsa desde o final do século XIX, a partir da década de 30 se acelera o processo de produção de leis que regulam diversos direitos trabalhistas e que culminou, em 1943, com a publicação da Consolidação

IV - os mandados de segurança, habeas corpus e habeas data, quando o ato questionado envolver matéria sujeita à sua jurisdição;

V - os conflitos de competência entre órgãos com jurisdição trabalhista, ressalvado o disposto no art. 102, I, "o";

VI - as ações de indenização por dano moral ou patrimonial, decorrentes da relação de trabalho;

VII - as ações relativas às penalidades administrativas impostas aos empregadores pelos órgãos de fiscalização das relações de trabalho;

VIII - a execução, de ofício, das contribuições sociais previstas no art. 195, I, "a", e II, e seus acréscimos legais, decorrentes das sentenças que proferir;

IX - outras controvérsias decorrentes da relação de trabalho, na forma da lei.

${ }^{16}$ PIMENTA, José Roberto Freire; PORTO, Lorena Vasconcelos. Op. cit., v. 43, n. 73, p. 
das Leis do Trabalho, que consolidou e ampliou a legislação já existente, assumindo, desse modo, a natureza ao menos próxima a um código do trabalho. Outras leis infraconstitucionais foram estabelecidas após 1943, regulando aspectos específicos da relação de trabalho.

No âmbito constitucional, a partir de 1934 foram estabelecidos os primeiros direitos constitucionais trabalhistas que foram sendo ampliados paulatinamente até a Constituição de 1988, nomeada de "cidadã", que inaugurou um marco na constitucionalização desses direitos sociais, integrando-os efetivamente ao rol dos direitos fundamentais e conferindolhes aplicabilidade imediata e natureza de cláusulas pétreas.

Os direitos fundamentais trabalhistas, estabelecidos nos artigos $7^{\circ}$ ao 11 da Constituição Federal de 1988 e no artigo 10 do Ato das Disposições Constitucionais Transitórias, visam harmonizar o desequilíbrio entre os sujeitos da relação empregatícia e assegurar ao trabalhador um mínimo de condições para que viva e trabalhe com dignidade.

A relação de emprego nada mais é do que uma relação jurídica privada em que incidem normas de ordem pública, incluindo os direitos fundamentais do trabalhador, para tentar reduzir a desigualdade dos contratantes. Por isso, esses direitos sociais têm, naturalmente, incidência direta na relação de emprego, ou seja, eficácia horizontal direta e imediata, pois são direcionados a reger especialmente essa relação jurídica privada, mitigada por normas de ordem pública, além da relação de trabalho do trabalhador avulso, por expressa disposição legal (artigo $7^{\circ}$, inciso XXXIV).

Esses direitos, pertencentes à segunda dimensão dos direitos fundamentais, apresentam algumas características específicas, como o fato de o destinatário das normas que os estabelecem ser, como regra geral, os empregadores, privados - incluindo as sociedades civis e empresárias e o particular, individualmente considerado, ou públicos em se tratando de empregados públicos, que trabalham em empresas públicas e sociedades de economia mista, e servidores públicos detentores de emprego público, que laboram na Administração Direta, autarquias e fundações. Em alguns casos, esses direitos sociais terão como destinatários o Poder Público ou o Poder Público e os empregadores, e, em outras situações, os sindicatos.

Ademais, muitos direitos fundamentais trabalhistas apresentam natureza precípua de defesa, exigindo dos destinatários apenas a não violação do direito que poderá ser exercido livremente. Outros são direitos de defesa e prestacionais, pois são necessárias prestações fáticas do empregador para a realização do direito. E há, ainda, os direitos de 
índole predominantemente prestacional, que necessitam da atuação estatal, por meio da criação de políticas públicas e de programas de governo para serem plenamente exercidos.

Os direitos fundamentais do trabalhador e, também os direitos trabalhistas infraconstitucionais, estão sujeitos a um alto grau de ineficácia social ou inefetividade, ou seja, de descumprimento reiterado pelos destinatários das normas que os estatuem, em virtude da cultura de que é mais barato descumprir direitos do que ser um empregador exemplar.

Por outro lado, vários direitos fundamentais trabalhistas não chegam sequer a ser implementados, em sua plenitude, em virtude da ausência de leis infraconstitucionais regulamentadoras necessárias para dar eficácia às normas de aplicabilidade limitada, ou, então, são implementados restritivamente, devido a uma interpretação involutiva e não consentânea com a realidade social por parte da Justiça do Trabalho, ramo do Poder Judiciário especializado em processar e julgar demandas que envolvam conflitos entre os sujeitos da relação de emprego, da relação de trabalho e outras questões listadas no artigo 114 da Constituição Federal.

A postura do Judiciário em geral, incluindo a Justiça do Trabalho, no que tange à concretização de direitos fundamentais sociais, tem base em uma concepção autorestritiva que entende que o Judiciário não tem legitimidade para implementar esses direitos, pois as decisões sobre que questões fundamentais do Estado seriam de competência dos denominadores poderes políticos, ou seja, o Judiciário, muitas vezes de forma não intencional, mas por valores arraigados, se nega à tarefa política de interpretar e aplicar a Constituição.

Sem embargo, as normas de direitos fundamentais sociais não estão dirigidas apenas aos Poderes Executivo e Legislativo, mas também ao Judiciário, visto que todo o aparato estatal deve fazer um esforço para materializar as conquistas sociais estabelecidas constitucionalmente. Dessa forma, ao Poder Judiciário como um todo cabe a guarda da Constituição, pois os juízes, inclusive os da Justiça laboral, são órgãos estatais vinculados intrinsecamente aos objetivos constitucionais, exercendo o controle difuso de constitucionalidade dos atos normativos do Legislativo e da Administração Pública, e interpretando e aplicando diretamente preceitos normativos que estabelecem direitos fundamentais.

Não há oposição no modelo constitucional adotado no Brasil ou mesmo da sociedade quanto à legitimação do Judiciário na tarefa de implementação dos direitos sociais estabelecidos na Constituição, incluindo os direitos fundamentais trabalhistas. 
É importante salientar que os setores mais fragilizados da sociedade, com menos capacidade de organização e luta pela garantia de seus direitos, vêem no Poder Judiciário, cada vez mais, uma instituição para afirmação desses direitos, não demonstrando a menor disposição para livrar o Estado das obrigações decorrentes da cidadania social. ${ }^{17} \mathrm{O}$ acesso aos juízes continua sendo um dos mais recursos mais frequentes dos grupos interessados em materializar direitos já positivados, mas ainda não implementados.

Outro obstáculo, de natureza externa, para a não implementação ou a implementação restritiva dos direitos fundamentais sociais pelo Judiciário é o argumento da incompetência baseado no princípio da separação dos poderes. Esse tipo de argumentação é resultado de uma leitura desatualizada da teoria da separação dos poderes de Montesquieu, que entende que cada um dos poderes tem as suas determinadas funções, que um poder não poder interferir no outro e que os juízes são apenas a boca que pronuncia as palavras da lei.

Na verdade, a maior extensão e complexidade das atividades desenvolvidas pelo Estado, ao longo do tempo, repercutiu em uma remodelação dessa teoria, implicando em novas formas de relacionamento entre os três poderes. Assim, desenvolveu-se a ideia dos freios e contrapesos (checks and balances), segundo a qual cada poder deve possuir sua autonomia para exercer as suas funções, mas de forma conjugada e compatibilizada com os demais no sentido de manter uma interação equilibrada entre eles, de modo a não entrarem em choque. Ademais, a evolução da teoria da tripartição dos poderes demonstrou que, embora os poderes Legislativo, Executivo e Judiciário exerçam, predominantemente e respectivamente, a função de legislar, executar as leis e políticas públicas e dirimir as controvérsias entre os sujeitos, cada um deles também exerce algumas funções atípicas dos outros dois poderes. Finalmente, as crises da função legislativa, os novos formatos de controle de constitucionalidade e a necessidade de soluções prestacionais ofertadas pelo Estado têm gerado uma perspectiva mais flexível da teoria da divisão de poderes, visto que hoje prevalece não mais o temor de Estados centralizadores e ditatoriais que devem ter sua atuação limitada, mas a cobrança, pela sociedade, do cumprimento dos deveres prestacionais estatais.

Dessa forma, os direitos sociais, inclusive os trabalhistas, não podem mais ser desconsiderados em virtude da omissão de qualquer dos poderes, pois as Constituições

\footnotetext{
${ }^{17}$ CAMPILONGO, Celso Fernando. Os desafios do Judiciário: um enquadramento. In: FARIA, José Eduardo de (Org.). Direitos humanos, direitos sociais e justiça. São Paulo: Malheiros Editores, 2005, p. 33.
} 
atuais não apenas estabelecem esses direitos, sejam eles de defesa ou prestacionais, mas também exigem a sua máxima aplicabilidade e implementação.

No caso do Brasil, a Constituição de 1988 traz, explicitamente, o princípio da separação autônoma e da convivência harmônica dos poderes, em seu artigo $2^{\circ}$, com o intuito de articular as três órbitas de poder com equilíbrio e, ao mesmo tempo estabelece o princípio e valor da cidadania, no artigo $1^{\circ}$, inciso II, como um dos fundamentos da República Federativa. Ademais, a Constituição vigente alarga as prerrogativas do Poder Judiciário, de uma forma geral, e amplia os instrumentos de controle de constitucionalidade do Supremo Tribunal Federal.

Em virtude das conquistas sociais estabelecidas na Lei Fundamental de 1988 que vinculam os três poderes, todo o aparato estatal, inclusive o Judiciário, deve se pautar no sentido de implementar os direitos fundamentais que visam garantir o mínimo para que os seres humanos vivam com dignidade.

Portanto, a dogmática que estabelece uma separação dos poderes com base em uma visão desatualizada, pautada na teoria original de Montesquieu, ou na sua evolução para os poderes harmônicos no sistema de freios e contrapesos, se refere a um modelo de organização estatal superado no atual estágio do Estado Democrático de Direito brasileiro, pois não mais se coaduna com as necessidades enfrentadas pelo Judiciário, que vem sendo chamada a desempenhar funções que garantam e dêem eficácia e aplicada à Constituição, inclusive em questões como a dissonância entre a realidade social existente nos momentos de criação da norma constitucional e o da interpretação posterior dessa norma e a ausência de leis infraconstitucionais que regulam normas constitucionais, quando ocorrer inoperância abusiva dos demais poderes, impossibilitando o exercício de direitos fundamentais por longos períodos, em seus conteúdos mínimos.

No Brasil, já se percebe uma relativização do dogma da separação dos poderes no que tange à efetivação de direitos fundamentais, pois paulatinamente o Judiciário vem apresentando uma postura um pouco mais ativa no sentido de implementar alguns direitos sociais, justamente porque a sociedade brasileira clama pelo exercício efetivo desses direitos e não há como os juízes se esquivarem de apresentar um resposta, ainda que não seja a mais satisfatória, para os pedidos apresentados pelos cidadãos que buscam a Justiça.

Em síntese, o princípio da separação dos poderes deve ser lido em uma perspectiva atualizada, que o compreenda como um meio para dar concretização à Constituição, visando garantir a dignidade da pessoa humana no seu aspecto máximo. Nessa esteira, o papel do juiz se revela de crucial importância, pois os direitos fundamentais, de defesa ou 
de natureza prestacional, individuais ou sociais, deverão ser implementados, inclusive por meio da atuação do Judiciário, ao exercer a sua função jurisdicional.

Essa perspectiva atualizada da teoria da tripartição dos poderes se relaciona diretamente à concepção de cidadania adotada pela Constituição Federal de 1988. Na verdade, a concepção de cidadania se ampliou ao longo do tempo, desde o momento em que o cidadão era detentor apenas dos direitos civis, passando pelo exercício dos direitos políticos, incluindo o direito ao sufrágio universal e de participar direta ou indiretamente da elaboração de políticas públicas e do controle da Administração Pública, pelos meios previstos no ordenamento jurídico de cada Estado, até chegar ao estágio atual, em que o cidadão tem direito ao exercício não apenas dos direitos políticos e civis, mas, também, dos direitos sociais, podendo se valer, nesse sentido, de todos os instrumentos que lhe são conferidos pela Constituição para a concretização desses direitos, inclusive por meio da busca do Poder Judiciário que dever atuar para implementá-los efetivamente.

É importante salientar que, no Brasil, a ampliação do conceito de cidadania não ocorreu exatamente na ordem referida, ou seja, do direito do indivíduo ao exercício dos direitos civis, passando pelos direitos políticos até chegar aos direitos sociais, como no caso da Inglaterra, objeto de estudo de Thomas Humphrey Marshall. ${ }^{18}$ Existiram momentos em que um setor da sociedade, como os trabalhadores urbanos e depois os rurais, tiveram reconhecidos os direitos sociais, mas não podiam exercer os seus direitos civis e políticos.

De acordo com o historiador Jorge Luiz Ferreira, na Primeira República, até 1930, o Estado não reconhecia os trabalhadores, não existindo relação entre cidadania (que num conceito amplo envolve direitos civis, políticos e sociais) e trabalho. Era trabalhador exatamente quem não tinha direitos, pois os que trabalhavam o faziam não para melhorar de vida, mas porque eram pobres. Em virtude da quase ausência de leis sociais, a relação era direta entre o trabalhador e o patrão. ${ }^{19}$

Com a Revolução de 1930, um novo grupo político assume o poder no Brasil, e adota uma postura reformista, afinado com os intelectuais, ou seja, com o pensamento moderno da época. Defendia o aumento da capacidade do Estado (Estatismo), a intervenção do Estado como regulador das relações sociais e o reconhecimento político e social dos trabalhadores. Jorge Ferreira esclarece que esse reformismo era uma tendência

${ }^{18}$ Cf. MARSHALL, T. H. Op. cit., 1967.

19 Palestra proferida pelo historiador Jorge Luiz Ferreira, intitulada "A Era dos Direitos: Estado, Trabalhadores e Cidadania Social no Brasil (1930-1945)", no Tribunal Regional do Trabalho da $3^{\text {a }}$ Região. Belo Horizonte, 15 maio 2011. 
mundial, já que não se concebia a construção de uma nação forte, desenvolvida, sem nenhuma espécie de proteção social, super explorando os trabalhadores. Reconhecendo isso, os Estados Nacionais começam a assegurar direitos aos trabalhadores. A Alemanha edita as primeiras leis sociais; no México (1911-1917), houve profunda e verdadeira reforma agrária, os camponeses passam a ter acesso à terra e os trabalhadores urbanos a direitos sociais; na Turquia (1922), o poder do Estado é aumentado, cria-se a Justiça Civil, os direitos das mulheres são equiparados aos dos homens; na União Soviética, foi instituída a previdência social de base e construídas habitações populares; nos Estados Unidos, foram garantidos direitos sociais e criadas empresas estatais; e, na Argentina, os direitos sociais chegaram na era Perón. ${ }^{20}$

No Brasil, o primeiro ato de Getúlio Vargas foi criar o Ministério do Trabalho, da Indústria e do Comércio. A promulgação da maioria das leis que garantiram direitos sociais ainda hoje existentes, entre os anos de 1931 e 1934, causou grande impacto na vida dos trabalhadores. Foram criados, ainda, o Ministério da Educação e Saúde e o sistema de saúde pública, numa rede que chegava ao interior. Nas capitais, foram erguidos grandes hospitais e criado um sistema de educação primário, com acesso a todos.

Ainda conforme Jorge Luiz Ferreira, os empresários reagiram às mudanças de forma extremamente negativa, afirmando que não iam cumprir as leis. Nesse contexto foi que surgiu a Justiça do Trabalho, nitidamente para "enquadrar" o empresariado, pois se não fosse assim, as leis não teriam sido cumpridas. Os trabalhadores, por seu turno, começaram a descobrir que tinham direitos e a saber a quem deveriam recorrer para que fossem cumpridos. ${ }^{21}$ A Justiça do Trabalho foi, sem dúvidas, uma das invenções democráticas, imprescindível na defesa dos direitos sociais dos trabalhadores.

Apesar dos avanços da era Vargas, com a inclusão dos direitos sociais e a criação da Justiça Especializada, paralelamente foram suspensos os direitos civis e políticos. Ademais, os direitos sociais somente se estendiam aos trabalhadores urbanos com carteira assinada, a quem o Estado reconhecia oficialmente.

Os trabalhadores receberam bem os direitos sociais estabelecidos pelo Estado no período entre 1931 e 1934. Esse fato foi usado com o intuito de dar legitimidade à ditadura implantada em 1937, mediante a pregação de que a cidadania não é a política, mas sim a

${ }^{20}$ Ibidem.
${ }^{21}$ Ibidem. 
social ${ }^{22}$, de nada adiantando o cidadão votar, sem ter direito a um salário mínimo, às férias ou ao descanso semanal remunerado, entre outros direitos sociais. ${ }^{23}$ Ou seja, a cidadania social era sinônimo de garantia de alguns direitos sociais estabelecidos pelo Estado, mas da ausência dos direitos políticos e de alguns direitos civis.

Esse processo de reconhecimento dos direitos sociais vindo do Estado, direcionado a um determinado setor da sociedade, em uma situação de ausência de direitos civis e políticos repete-se da ditadura de Médici, quando os direitos sociais foram estendidos aos trabalhadores rurais. ${ }^{24}$

De qualquer maneira, com a Constituição de 1988 e a redemocratização do Brasil, o Estado brasileiro passa a adotar uma concepção ampla de cidadania, estabelecida como um dos fundamentos da República Federativa brasileira (artigo $1^{\circ}$, inciso II), que nessa tese denomina-se de "cidadania social". Isso porque, além de estabelecer diversas garantias para o exercício de outros direitos - como, por exemplo, o direito de receber informações de órgãos públicos e a apreciação pelo Poder Judiciário de lesão ou ameaça a direitos alguns remédios constitucionais - como o habeas data, o mandado de segurança individual e coletivo, entre outros - e inúmeros direitos de cidadania civil e política, a Constituição vigente estabelece um amplo rol de direitos sociais, incluídos nos artigos $6^{\circ}$ a 11 (Título II, Capítulo II) e em diversos dispositivos do Título VIII (Da Ordem Social) e os concede aplicabilidade imediata (artigo $5^{\circ}$, parágrafo $1^{\circ}$ ). Isso significa que os direitos sociais de defesa poderão serão automaticamente exercidos pelos cidadãos e os direitos prestacionais, estabelecidos em normas de eficácia limitada, exigirão do Executivo a criação de políticas públicas para implementá-los e do Legislativo a aprovação de leis infraconstitucionais para regulamentá-los ou do orçamento público para colocá-los em prática. Todavia, por meio do exercício de suas funções, o Executivo e o Legislativo não poderão violar os direitos sociais instituídos nessas normas, devendo, antes pelo contrário, atuar no sentido de aplicálos em seu grau máximo, respeitando todas as diretrizes estabelecidas na Constituição, ou

\footnotetext{
22 Deve-se salientar que a cidadania social defendida por Getúlio Vargas não se confunde com a concepção de cidadania social utilizada nessa tese, tendo em vista que o termo "social" é inserido apenas para enfatizar que o cidadão tem garantido, constitucionalmente, não somente os direitos civis e políticos, mas, também, os direitos sociais, que devem ser implementados pelo Estado, inclusive por meio da atuação do Poder Judiciário, garantindo o exercício integral de direitos pelos indivíduos. Portanto, em nenhum momento, a expressão "cidadania social", usada nessa tese, tem como intuito excluir o exercício, pelo cidadão, dos direitos civis e políticos, mas apenas acrescentar o exercício efetivo dos direitos sociais ao conceito de cidadão.

${ }_{23}$ Palestra proferida pelo historiador Jorge Luiz Ferreira, intitulada "A Era dos Direitos: Estado, Trabalhadores e Cidadania Social no Brasil (1930-1945)", no Tribunal Regional do Trabalho da $3^{\text {a }}$ Região. Belo Horizonte, 15 maio 2011.

${ }^{24}$ SOUKI, Lea Guimarães. A atualidade de T. H. Marshall no estudo da cidadania no Brasil. Revista de Ciências Sociais. Porto Alegre, v. 6, n. 1, jan./jun. 2006, p. 55.
} 
seja, não privilegiando certos direitos em detrimento de outros. O Judiciário, por seu turno, deverá se valer das normas programáticas para interpretar as demais normas constitucionais, tentando extrair delas a maior aplicabilidade possível.

Ademais, a concepção de cidadania adotada pela Constituição de 1988 enseja o acesso do cidadão, incluindo o trabalhador, ao Judiciário para não somente requerer a cessação de lesões aos direitos fundamentais civis, políticos e sociais, como também para pleitear a sua implementação, no maior grau possível. Ou seja, todo o aparato estatal, inclusive os juízes e tribunais do trabalho, por meio dos mecanismos processos e da hermenêutica constitucional pertinentes, deverão trabalhar em prol da efetivação e materialização dos direitos fundamentais garantidos aos trabalhadores.

O acesso a uma ordem jurídica justa, extraído de diversos dispositivos constitucionais e também denominado de acesso à Justiça, engloba um leque de direitos e garantias dos cidadãos: o direito de acesso aos tribunais ${ }^{25}$, inclusive garantindo aos necessitados os direitos à assistência judiciária gratuita e à justiça gratuita e, em alguns casos, propiciando o ingresso em juízo sem a necessidade de estar acompanhado de advogado; o direito de estar em juízo, com o respeito às garantias do devido processo legal, do contraditório e da ampla defesa; e o direito de recebimento de uma tutela jurisdicional efetiva e célere que materialize os direitos reconhecidos em juízo, inclusive os direitos fundamentais sociais e especificamente os trabalhistas, seja por meio de mecanismos processuais adequados (tutelas antecipada, coletiva, específica, inibitória, entre outras) para satisfazer os direitos substanciais do reclamante, seja por intermédio de uma interpretação jurídica condizente com as normas constitucionais que estabelecem os direitos fundamentais dos trabalhadores.

O papel assumido pelo Judiciário no Estado Democrático de Direito, de poder estatal legítimo para materializar os direitos fundamentais sociais, incluindo os direitos fundamentais trabalhistas, pleiteados pelo trabalhador por meio do ajuizamento de uma

\footnotetext{
${ }^{25}$ Podem ser citadas, como exemplos de normas processuais trabalhistas que visam claramente proteger $\mathrm{o}$ litigante hipossuficiente, a gratuidade do processo (a isenção do pagamento de custas e despesas aplica-se ao empregado, não ao empregador) e a assistência judiciária gratuita ao obreiro, por meio do sindicato. Ademais, é importante salientar que nos casos de impetrações de habeas corpus, ações interpostas perante os Juizados Especiais, com valor da causa de até 40 (quarenta) salários mínimos, e ações ajuizadas por empregados, ex-empregados e empregadores na Justiça do Trabalho (artigo 791, da CLT), em relação à primeira e segunda instâncias, existe a possibilidade de o litigante se valer da figura do jus postulandi, ou seja, de ajuizar uma ação e postular pessoalmente em juízo, sem a necessidade de representação por advogado. Independentemente das discussões a respeito da inconstitucionalidade dessa figura, em virtude do artigo 133 da Constituição Federal de 1988, que estabelece que o advogado é indispensável à administração da justiça, pode-se dizer que o jus postulandi visa ampliar o acesso aos tribunais, facilitando o exercício do direito de ação, sem a necessidade de contratar obrigatoriamente um advogado.
} 
reclamação, é essencial para concretizar a garantia de acesso a uma ordem jurídica justa. Quanto mais amplas forem as possibilidades de acesso ao Judiciário, maior a contribuição do Judiciário para a produção do direito e a expansão da cidadania social.

O juiz trabalhista, no atual contexto democrático, é tutor e garantidor dos cidadãos trabalhadores contra os poderes, públicos ou privados, e vinculado à soberania popular, pois tem o poder-dever de implementar os direitos fundamentais trabalhistas formalmente enunciados na Constituição.

Afinal, o cidadão vai ao Judiciário na esperança de ver reconhecido, garantido e materializado um direito constitucionalmente positivado. A decisão proferida pelo juiz do trabalho, portanto, não deve frustrar a sua pretensão, pois pode comprometer a confiança na Justiça do Trabalho e nas bases do Estado Democrático de Direito.

\subsection{A interpretação evolutiva como mecanismo para a implementação dos direitos fundamentais trabalhistas pela Justiça do Trabalho}

A Justiça do Trabalho tem como uma de suas funções cruciais a concretização dos direitos fundamentais trabalhistas, pois é o ramo especializado do Poder Judiciário competente para apreciar e julgar as demandas que envolvem as relações de trabalho lato sensu e a relação de emprego, sendo essa última relação jurídica objeto de incidência das normas fundamentais estabelecidos nos artigos $7^{\circ}$ a 11 da Constituição Federal de 1988.

Embora a Justiça do Trabalho seja um ramo do Judiciário que lida cotidianamente com controvérsias sociais, não existe uma cultura jurídica sedimentada no sentido de tratar os direitos estabelecidos na Constituição Federal como verdadeiros direitos fundamentais, no que tange, inclusive, à sua aplicabilidade e interpretação jurídica. Ou seja, os direitos mínimos trabalhistas estão dispostos na Constituição Federal de 1988 no rol dos direitos fundamentais sociais, pertencendo, portanto, ao sistema de direitos fundamentais brasileiro. Isso significa que todo o tratamento relativo à caracterização desses direitos, estrutura das normas que os estabelecem, vinculação jurídica dos destinatários dessas normas, eficácia jurídica, efetividade e aplicabilidade delas é o mesmo que é conferido aos outros direitos fundamentais estabelecidos na Constituição vigente, ainda que os direitos fundamentais trabalhistas apresentem algumas características próprias em relação aos seus destinatários e à sua efetividade ou eficácia social. 
Essa cultura de pouca atenção aos direitos fundamentais do trabalhador se vislumbra em vários aspectos da atuação jurisdicional da Justiça laboral.

Como alguns direitos trabalhistas já eram previstos infraconstitucionalmente, sendo posteriormente alçados à esfera constitucional, os aplicadores do Direito reiteradamente se esquecem que esses direitos, a partir de 1988, passaram a ser fundamentais, transformando-se na fonte primordial de consulta do intérprete. Não são os direitos infraconstitucionais, previstos na CLT ou em outras leis, que devem ser, à primeira vista, interpretados e aplicados. Antes, é necessário que os juízes analisem a matriz constitucional para compreender como aqueles direitos estão estabelecidos na Lei Fundamental, inclusive realizando uma interpretação jurídica com base nos princípios constitucionais aplicáveis à relação de emprego. O hábito de sequer citar os dispositivos constitucionais de direitos fundamentais e os instrumentos internacionais, que estabelecem diretrizes de interpretação jurídica dos direitos trabalhistas, como se a Constituição não tivesse nenhuma força normativa, parece ser algo arraigado aos aplicadores do Direito de uma maneira geral e essa situação não é muito diferente quando se faz uma consulta aos acórdãos e ementas publicados nos sites dos Tribunais do Trabalho.

Existem situações, também, em que os magistrados dos TRT's e do TST dão mais importância para as normas heterônomas (normas estatais) ou autônomas (normas oriundas da negociação coletiva) infraconstitucionais do que para os dispositivos constitucionais que esculpem os direitos fundamentais laborais, ainda que aqueles sejam menos favoráveis aos trabalhadores.

Em outros casos, os juízes do trabalho citam os direitos fundamentais trabalhistas, compreendendo-os como direitos a serem efetivamente considerados, mas o problema se centra na ausência de um tratamento do direito enquanto direito fundamental. Em outras palavras, trabalha-se com os direitos fundamentais como se eles fossem meros direitos infraconstitucionais e não exigissem uma leitura e uma interpretação próprias, pautadas pelos princípios, métodos e mecanismos da interpretação constitucional a ser analisadas e aplicadas pelos juízes do trabalho.

A tarefa do intérprete não mais se resume à mera aplicação do fato à norma como ocorria no Estado Liberal, exigindo a Constituição brasileira, que legitima o Estado Democrático de Direito, uma atuação do juiz muito mais complexa e árdua que inclui o estudo e a escolha dos métodos, dentre os tradicionais e os modernos, mais adequados para interpretar determinado dispositivo constitucional, a observância dos princípios da interpretação constitucional a serem eternamente perseguidos pelos aplicadores da 
Constituição e a utilização, sempre que pertinente, do mecanismo da interpretação constitucional evolutiva, ou seja, da interpretação das normas de direitos fundamentais pautada pelas mudanças sociais e econômicas que alterem o sentido ou o alcance do conteúdo dessas normas, sem a alteração formal do seu texto. Raramente se observa algum acórdão que menciona os princípios e métodos de interpretação utilizados pelo aplicador das normas constitucionais, ainda quando o juiz realize essa atividade interpretativa, em maior ou menos profundidade, o que dificulta a análise da argumentação do magistrado no que diz respeito à fundamentação fático-jurídica da decisão proferida.

Em último lugar, constata-se que, em algumas situações, a jurisprudência dos Tribunais Regionais e Superior do Trabalho, embora se valha da interpretação constitucional das normas jusfundamentais, imprime a elas uma leitura involutiva ou restritiva no que tange à possibilidade de exercício dos direitos fundamentais pelos cidadãos trabalhadores, dificultando a implementação efetiva e ampla desses direitos.

Obviamente, por se tratar do ramo do Poder Judiciário que mais trabalha cotidianamente com a interpretação e aplicação de direitos sociais, incluindo os previstos constitucionalmente, não é de se estranhar que a Justiça do Trabalho tenha uma atuação relativamente avançada no que tange à implementação dos direitos sociais, em comparação com os demais ramos do Judiciário.

Com efeito, ao realizar pesquisa na jurisprudência dos Tribunais Regionais do Trabalho e do Tribunal Superior do Trabalho, pode-se encontrar exemplos de interpretação vanguardista de normas constitucionais que tiveram o mérito de implementar, na maior medida possível, alguns direitos fundamentais trabalhistas. Essas decisões, em algumas situações, tornaram-se entendimento majoritário ou de parte tribunais e, em outros casos, são entendimentos individualizados minoritários de juízes ou desembargadores do trabalho.

Sem embargo, essa atuação mais vanguardista da Justiça do Trabalho ainda é insuficiente para a implementação ampliativa e máxima dos direitos fundamentais trabalhistas e não responde totalmente aos anseios dos cidadãos trabalhadores que buscam o Judiciário com o objetivo de poder exercitar, de forma plena, os direitos sociais mínimos que lhe são garantidos pela Constituição.

As razões para essa cultura sedimentada de tratamento não adequado dos direitos fundamentais trabalhistas encontra raízes em alguns aspectos já mencionados no capítulo anterior, como uma postura de auto-restrição dos juízes trabalhistas no que se refere à legitimação para implementar direitos fundamentais sociais, nos argumentos externos que 
pregam o princípio da separação dos poderes como fator impeditivo de uma postura mais proativa do Poder Judiciário na concretização de direitos sociais e que adotam uma concepção reduzida de cidadania diretamente relacionada ao exercício restrito dos direitos fundamentais sociais. Como já reiteradamente explicado, todos esses fatores não encontram respaldo jurídico no atual estágio do Estado Democrático brasileiro, na Constituição Federal de 1988 e na consciência dos jurisdicionados.

Outra razão que poderia ser utilizada para justificar a postura da Justiça do Trabalho é a sua origem a partir de órgãos estatais administrativos e não jurisdicionais, que visavam de forma célere, simplificada e prática solucionar os conflitos entre trabalhadores e empregadores. Com o passar do tempo, embora os procedimentos trabalhistas tenham se tornado mais diversificados e os temas objeto dos julgamentos tenham crescido em quantidade e complexidade, a Justiça do Trabalho ainda tem como objetivo o julgamento célere das demandas, pois a maioria delas envolvem créditos trabalhistas de natureza alimentar, e a tentativa de redução das formalidades procedimentais justamente para imprimir essa celeridade ao trâmite das causas trabalhistas.

Sem embargo, esse tipo de argumentação não encontra qualquer respaldo jurídico, pois, em primeiro lugar, a Constituição de 1934 estabeleceu a Justiça do Trabalho, ainda como órgão do Poder Executivo, e a Constituição de 1937 previa a Justiça do Trabalho, não falando a qual Poder ela pertencia, mas, ao mesmo tempo, ambas as Constituições já traziam em seu bojo direitos trabalhistas mínimos, que deveriam ser observados pelos destinatários das normas e concretizados pelos aplicadores do Direito, fossem os órgãos de natureza administrativa ou jurisdicional.

Em segundo lugar, ainda que esse argumento fosse plausível para justificar a pouca atenção dada às normas constitucionais pelos intérpretes, desde a decisão proferida no Recurso Extraordinário n. 6.310, o Supremo Tribunal Federal reconheceu o caráter jurisdicional às cortes trabalhistas, decisão corroborada pelo Decreto-lei n. 9.777 de 09/09/1946 que estabeleceu a Justiça do Trabalho como órgão integrante do Poder Judiciário e definitivamente sepultada com a previsão expressa contida na Constituição Federal de 1946 que afirmou que o Poder Judiciário era exercido, entre outros, pelos juízes e tribunais do trabalho. Dessa forma, há mais de sessenta e cinco anos a Justiça do Trabalho é considerada, indubitavelmente, como pertencente ao Poder Judiciário, tempo mais que suficiente para adaptação dos seus juízes ao exercício da sua função jurisdicional, que implica, entre outras atribuições, a interpretação e aplicação das normas jurídicas, inclusive as constitucionais. 
Em último lugar, a Justiça do Trabalho é o ramo do Poder Judiciário que mais se destaca pela aplicação de direitos sociais, pois o objeto da maior parte das demandas apreciadas diz respeito a conflitos entre empregados e empregadores acerca de direitos trabalhistas, ou seja, direitos sociais historicamente criados e positivados em normas constitucionais e infraconstitucionais. Se a base primordial da maior parte dos principais direitos trabalhistas está na Constituição, não há como os juízes se esquivarem da interpretação e aplicação das normas fundamentais, até mesmo porque se anteriormente havia discussão quanto à fundamentalidade e força normativa dos preceitos que estabelecem os direitos fundamentais sociais, com o movimento neoconstitucionalista e pós-positivista que exerceram influência incontestável na Constituição de 1988, não há mais qualquer dúvida de que os direitos constitucionais sociais, incluindo os trabalhistas, são fundamentais, até porque expressamente assim consignado, nem de que eles estão estabelecidos em normas constitucionais, detendo, portanto, força normativa.

Constata-se, assim, que não existe qualquer razão jurídica ou fática plausível no ordenamento jurídico brasileiro para que os juízes e tribunais do trabalho não confiram tratamento adequado aos direitos trabalhistas previstos constitucionalmente, esquecendo que se tratam de direitos fundamentais sociais e que devem ser interpretados e aplicados com todo o cuidado e rigor que exige a tarefa do intérprete das normas constitucionais que estatuem direitos fundamentais.

A ausência de implementação ou implementação restritiva, pela Justiça do Trabalho, de vários direitos trabalhistas dispostos na Constituição não é apenas um dado fático, mas uma constatação inconcebível no atual estágio do Estado Democrático brasileiro que tem o ser humano como eixo central no qual deve se convergir toda a atividade estatal, inclusive do Poder Judiciário. A Justiça laboral tem o poder e dever de garantir aos trabalhadores o mínimo necessário à sua condição de ser humano digno, princípio e valor fundamental esculpido na Constituição de 1988.

Na era pós-positivista, o papel dos juízes sublinha-se com real importância, já que não mais atrelados unicamente à atividade de enquadrar as regras jurídicas aos fatos, devendo concretizar as normas constitucionais de estrutura principiológica, inclusive as normas que prevêem os direitos fundamentais. Para o exercício de tão importante função, o Poder Judiciário deve se valer dos métodos clássicos e modernos de interpretação, além da observância dos princípios de interpretação especificamente constitucionais. 
Os direitos constitucionais trabalhistas são direitos fundamentais sociais e, portanto, estão estabelecidos em normas principiológicas, de caráter aberto, ensejando a utilização, pelo aplicador do Direito, dos métodos e mecanismos de interpretação constitucional.

O juiz, por meio dos instrumentos que a hermenêutica lhe oferece, completa o teor das normas constitucionais que por sua própria natureza são abertas e multidimensionais, dando-lhes, assim, o significado pertinente em cada caso concreto. Sem embargo, a atuação da Justiça do Trabalho só será eficaz, se os magistrados interpretarem os direitos fundamentais trabalhistas a partir dos valores estabelecidos pelas normas constitucionais que traduzem tais direitos e de acordo com uma pré-compreensão das questões sociais voltada para a realidade, ou seja, para o que ocorre efetivamente no espaço externo aos tribunais.

A tarefa do Judiciário é muito mais complexa do que se possa imaginar, pois os juízes não estão lidando apenas com normas e fatos abstratos, no sentido meticuloso e calculista, mas com seres humanos que realizam suas atividades, apresentam os seus anseios e frustrações diante das relações jurídicas que travam no cotidiano, e que compõem assim, um movimento contínuo de mudança social que pode ser percebido de tempos em tempos. E é essa realidade social que o jurista, sobretudo o juiz, não pode se descuidar, nem se esquecer em nenhum momento, pois ela é a matéria prima com a qual ele está a lidar para proferir decisões com repercussões que envolvem vidas humanas.

Com base no estudo da interação entre as mudanças sociais e a interpretação das normas constitucionais, constata-se que o mecanismo da hermenêutica jurisdicional capaz de solucionar a distância reinante entre a realidade social vivenciada pelos trabalhadores e a implementação restritiva ou a ausência de implementação dos direitos fundamentais trabalhistas, em virtude de uma interpretação restritiva desses direitos, inclusive em casos de falta de regulação infraconstitucional, é a interpretação constitucional evolutiva. Essa mecanismo permite ao aplicador da norma realizar a interpretação mais adequada da norma constitucional, por meio da comparação entre os valores originariamente dispostos na Constituição e os fatos sociais contemporâneos, possibilitando uma implementação mais ampla do rol de direitos fundamentais trabalhistas.

A interpretação da Constituição é de extrema relevância para a constante adequação do direito à realidade social. Por isso, para que as normas constitucionais tenham força normativa não basta uma interpretação meramente literal. O próprio Konrad Hesse já diria que a força normativa da Constituição decorre da confluência dos dois fatores (realidade e norma) que a informam. 
Para Hesse, a concretização do conteúdo da norma constitucional torna-se possível se forem incorporadas as circunstâncias da realidade histórica no âmbito normativo. ${ }^{26}$ Para Saldanha, "a Constituição não é um mero dado, é uma obra, uma realização, uma tentativa permanente de ajuste recíproco das intenções textualizadas e das circunstâncias existenciais da sociedade política." 27

A interpretação constitucional das normas constitucionais que encerram direitos fundamentais sociais é essencialmente uma interpretação de princípios, posto que aqueles se estabelecem por meio de normas de estrutura aberta. Por isso, para dar força normativa à Constituição, o juiz, especialmente em matéria de direito social, deve fazer um esforço interpretativo "a que nossos juízes estão poucos habituados - deve, portanto, haver uma verdadeira revisão de conceitos e um reposicionamento do status conferido à interpretação dentro deste sistema". ${ }^{28}$

A interpretação, no plano constitucional, sobretudo em matéria de direitos fundamentais, deve ser evolutiva e tem como perspectiva a adequação dos desideratos acordados constitucionalmente a uma visão histórica e política contemporânea. "Assim, diríamos que houve um pacto em 1988, mas este pacto tem que ser constantemente renovado e, para tanto, os valores ali expostos devem ser adequados à realidade do dia-adia". 29

Assim, o juiz do trabalho, enquanto representante do poder estatal que tem por objeto a resolução dos conflitos sociais que lhe são apresentados, por meio da aplicação de direitos sociais, inclusive de natureza fundamental, deve atentar para a realidade vivenciada pelos trabalhadores com a qual ele se depara em seu cotidiano profissional, buscando aferir as mudanças sociais e as necessidades desses cidadãos, fatos que interferirão diretamente na interpretação das normas de direitos fundamentais trabalhistas.

Esse exercício interpretativo demanda um papel legitimamente ativo e criador dos juízes do trabalho, pois as normas que estabelecem os direitos fundamentais apresentam estrutura principiológica, aberta, e precisam da atuação do intérprete e aplicador do direito para densificá-las e colmatá-las em conformidade com as mudanças que ocorrem na realidade social. Assim, ainda que inconscientemente, os juízes, ao interpretarem normas constitucionais que estatuem direitos fundamentais, assumem um posicionamento

\footnotetext{
${ }^{26}$ HESSE, Konrad. A força normativa da Constituição. Op. cit., p. 18.

${ }^{27}$ SALDANHA, Nélson. O poder constituinte. São Paulo: RT, 1986, p. 88.

${ }^{28}$ CORREIA, Marcus Orione Gonçalves. Os direitos sociais enquanto direitos fundamentais. Op. cit., p. 161.

29 Ibidem, p. 161.
} 
ideológico específico, assim como ocorre com o legislador, ao formular a lei, ou o administrador, ao definir as melhores formas de executar uma política pública.

É importante salientar que a atuação mais ativa e "criativa" dos juízes em geral, incluindo os juízes do trabalho, é legitimada pela própria Constituição, que elencou um amplo rol de direitos fundamentais, estabelecidos em normas de estrutura principiológica, permeadas de valores, e fortaleceu o Poder Judiciário. Para concretizar esses direitos, exige-se dos juízes uma atividade interpretativa intensa que envolve decisões sobre questões políticas. A judicialização da política, portanto, é uma circunstância que decorre do modelo constitucional adotado pelo Brasil e não um exercício arbitrário da vontade política dos juízes e implica em uma atuação mais pró-ativa desses no que tange à tarefa interpretativa de normas constitucionais.

\subsubsection{A interpretação constitucional evolutiva aplicada aos direitos fundamentais trabalhistas: exemplos da doutrina e da jurisprudência dos TRT's e TST e apresentação de propostas}

Sublinhando a importância da utilização no plano fático das teorias apresentadas no âmbito jurídico, sobretudo em se tratando de estudo voltado à interpretação de normas constitucionais pela Justiça do Trabalho, a presente tese tem como intuito elencar, a seguir, exemplos de aplicação prática da interpretação evolutiva pesquisados na doutrina e na jurisprudência dos Tribunais Regionais do Trabalho e do Tribunal Superior do Trabalho, incluindo posicionamentos majoritários dos Tribunais e, também, entendimentos minoritários. Ademais, serão apresentadas algumas propostas de interpretação evolutiva das normas constitucionais que estabelecem direitos fundamentais trabalhistas no sentido de implementá-los efetivamente, em situações que a jurisprudência tem interpretado restritivamente as normas constitucionais que os estabelecem.

Para sistematizar o estudo da interpretação dos direitos fundamentais trabalhistas, esses direitos serão divididos por grupos relativos direitos à relação de trabalho lato sensu, à proteção contra a dispensa e à estabilidade provisória, à não-discriminação do trabalhador, à remuneração e ao salário, à jornada de trabalho, à saúde e segurança no trabalho, à proteção à maternidade e paternidade, e à liberdade atuação sindical e à participação coletiva dos trabalhadores. 


\subsubsection{Direitos relativos à relação de trabalho lato sensu}

A questão dos direitos mínimos do trabalhador parassubordinado(artigo $7^{\circ}$, caput, da $\underline{C F / 88)}$

$\mathrm{O}$ art. $7^{\circ}$ da Constituição Federal traz em seu texto normativo os direitos fundamentais mínimos, além de outros que lhe venham a ser conferidos, que são garantidos aos trabalhadores urbanos e rurais, não explicitando, entretanto, a abrangência do termo "trabalhadores", ou em outras, palavras, não esmiuçando os destinatários do dispositivo constitucional.

Dessa forma, qualquer tentativa de apreciação dos direitos trabalhistas a que fará jus o trabalhador brasileiro, que se subsuma na definição parassubordinado, recai, necessariamente, na interpretação do art. $7^{\circ}$, caput, da Lei Maior. Analisar qual o tipo de interpretação adequada a essa norma constitucional, diante das peculiaridades do ordenamento jurídico nacional, e, ainda, se o trabalhador parassubordinado encaixa-se na noção de trabalhador que a Constituição traduz são as questões que, a partir de agora, pretende-se analisar.

A relação de emprego, ou relação de trabalho stricto sensu, base do sistema capitalista, é uma das espécies do gênero relação de trabalho e se caracteriza pela concomitância dos seguintes elementos: trabalho prestado por pessoa física, com pessoalidade, onerosidade, não-eventualidade e sob subordinação jurídica ${ }^{30}$ em face do empregador.

\footnotetext{
${ }^{30}$ É importante salientar que, no Brasil, existe uma tendência de alargamento e de releitura da figura da subordinação, visto que o entendimento da jurisprudência tem sido no sentido de compreender como trabalhador subordinado não apenas aquele que se submete, por meio do contrato de trabalho, a uma subordinação jurídica direta e subjetiva do empregador, mas, também, os trabalhadores que estão vinculados à dinâmica e organização estrutural empresarial, caso em que é denominada de subordinação estrutural, expressão cunhada pelo Ministro Mauricio Godinho Delgado. Cf. DELGADO, Mauricio Godinho. Direitos fundamentais na relação de trabalho. Revista de Direito do Trabalho, São Paulo, v. 32, n. 123, jul./set. 2003, p. 143-165. Marcus Menezes Barberino Mendes e José Eduardo de Resende Chaves Júnior entendem que há subordinação econômica entre a empresa prestadora de serviços e a empresa tomadora, de modo que esta seria responsável pelos empregados daquela, configurando a subordinação estrutural reticular. Cf.MANDES, Marcus Menezes Barberino; CHAVES JÚNIOR, José Eduardo de Resende. Subordinação estrutural: reticular e alienidade. Revista do Tribunal Regional do Trabalho da $15^{\text {a }}$ Região, Campinas, n. 32, jan./jun. 2008, p. 127-146. A subordinação jurídica quando mitigada, apresentando poucos traços de subjetivismo da figura do empregador em relação ao trabalhador, também tem sido denominada de subordinação objetiva, pois os serviços prestados pelo trabalhador estão diretamente vinculados aos objetivos, fins empresariais. Lorena Vasconcelos Porto defende a ampliação do conceito de subordinação do trabalhador, que não mais deve-se ater à tradicional subordinação jurídica inscrita na CLT, em virtude das alterações no contexto sócio-
} 
Com na dificuldade de caracterização de certos trabalhadores em autônomos ou subordinados que a doutrina italiana desenvolveu a definição de trabalhado parassubordinado, como aquele decorrente de um contrato de colaboração no qual o trabalhador se compromete a desempenhar uma atividade mediante a coordenação, e não subordinação, da empresa tomadora.

Para Mauro Sferrazza ${ }^{31}$, o parassubordinado é aquele trabalhador que não é subordinado nem autônomo ou, ao menos, não bastante autônomo para poder ser colocado na área do trabalho autônomo tradicional, encontrando-se regulado pela lei 533, de 11 de agosto de 1973 e pelo art. 409, n. 3 do Código de Processo Civil.

A noção de parassubordinação foi criada para as relações de trabalho que se inserem na organização da empresa, embora se desenvolvam com independência e sem a direção do tomador de serviços. O trabalho parassubordinado, basicamente, caracteriza-se pela preponderância da natureza pessoal da prestação de serviços, onerosidade, continuidade, a relação de coordenação e, para uma parte da doutrina, pela dependência econômica. Dessa forma, diferentemente do trabalhador subordinado que está submetido às ordens e à fiscalização do empregador, no trabalho parassubordinado prevalece a dependência econômica e o intuito de colaboração entre as partes, inserindo-se, portanto, o prestador de serviços no processo produtivo empresarial.

No Brasil, embora o trabalho parassubordinado seja uma realidade, a legislação ainda não se ocupou dela, sendo o tema objeto de estudos doutrinários ainda esparsos. Com base na definição de relação de trabalho parassubordinado e observando-se a sistemática do Direito do Trabalho pátrio, o ponto de partida para qualquer definição de direitos desse

econômico que propiciaram o surgimento de figuras cuja subordinação ao empregador se encontra mitigada, havendo, entretanto, uma subordinação objetiva em relação aos fins do empreendimento. O objetivo de alargamento do conceito de subordinação, denominada pela autora de subordinação integrativa, é manter caracterizada a relação de emprego, com todos os direitos trabalhistas a ela aplicáveis. De acordo com essa leitura da subordinação, os trabalhadores parassubordinados brasileiros deveriam ser considerados empregados, não havendo necessidade de discussões acerca dos direitos trabalhistas incidentes para essa categoria de empregados. Para uma melhor compreensão sobre o tema, vide PORTO, Lorena Vasconcelos. A subordinação no contrato de trabalho: uma releitura necessária. São Paulo: LTr, 2009.

Sem embargo, como não há necessariamente uma definição acerca da concepção atual da subordinação, enquanto elemento da relação de emprego, a proteção de um trabalhador cuja subordinação esteja mitigada, por meio do reconhecimento do vínculo empregatício, dependerá da posição adotada pelo juiz que julgar o caso concreto trazido à sua análise. Nesse sentido, no intuito de proteger esses trabalhadores, inclusive por meio da garantia dos direitos trabalhistas mínimos, mesmo nos casos em que a configuração do vínculo não esteja clara ou não seja reconhecida pela Justiça do Trabalho, é que apresentamos a proposta de interpretação evolutiva do artigo $7^{\circ}$, caput, da CF/88, para ampliar o conceito de "trabalhadores" que hoje é entendido, majoritariamente, apenas como os empregados.

${ }^{31}$ SFERRAZZA, Mauro. Il contratto di lavoro a progetto. Milão: Giuffrè, 2004, p. 206. 
tipo de trabalhador recai no art. $7^{\circ}$ da Constituição Federal, que elenca os direitos mínimos a serem garantidos "aos trabalhadores urbanos e rurais".

Dentre as interpretações mais comuns que a doutrina e a jurisprudência faz do art. $7^{\circ}$, caput, da CF/88 ("São direitos dos trabalhadores urbanos e rurais, além de outros que visem à melhoria de sua condição social"), a predominante entende que a expressão "trabalhadores urbanos e rurais" se refere apenas aos empregados urbanos e rurais, ou seja, aos trabalhadores que prestam serviços pessoalmente, sob subordinação jurídica, de forma não-eventual e onerosa. Para essa vertente, o legislador constituinte não utilizou a palavra "trabalhadores" de forma técnica, ou seja, referindo-se às relações de trabalho lato sensu, mas, sim, valendo-se da linguagem corriqueira e popular que se remete a trabalhadores como empregados. Por tradição, direitos como férias, décimo terceiro salário, adicional noturno, por exemplo, somente teriam sentido em relação ao empregado.

Outro argumento dessa corrente seria o de que se o constituinte quisesse se referir a todos os tipos de trabalhadores teria feito essa ressalva expressamente, assim como fez em relação aos direitos relativos aos trabalhadores avulsos (art. $7^{\circ}$, inciso XVII), e aos empregados domésticos (art. $7^{\circ}$, parágrafo único) - que é um tipo de relação de emprego especial.

Em face desse entendimento, percebe-se que o trabalhador parassubordinado não estaria inserido nos "trabalhadores" do art. $7^{\circ}$, caput, por não prestar serviços com subordinação jurídica, elemento caracterizador principal da relação de emprego.

A interpretação minoritária entende que a expressão "trabalhadores urbanos e rurais" se refere a todos os tipos de trabalhadores, ou seja, todos os direitos elencados no art. $7^{\circ}$ da Lei Maior incidiriam em todos os tipos de relação de trabalho, seja o trabalho subordinado, o autônomo e o eventual.

Para os defensores dessa vertente, se o constituinte quisesse excepcionar os trabalhadores em geral teria feito expressamente, como ocorreu com os empregados domésticos, que mais do que sujeitos de uma relação de trabalho compõem uma relação de emprego com características especiais, e com os servidores públicos cujos direitos do art. $7^{\circ}$ a eles aplicáveis estão dispostos no art. $39, \S 3^{\circ}$. Diante dessa posição, observa-se que os trabalhadores parassubordinados estariam englobados nos "trabalhadores" do art. $7^{\circ} \mathrm{e}$ todos os direitos previstos nos dispositivos incidiriam na relação de trabalho parassubordinada.

A terceira interpretação que, na realidade, se constitui em uma variante da segunda, compreende que os "trabalhadores" do caput do art. $7^{\circ}$ da Constituição englobam todos 
trabalhadores que laboram no Brasil, sejam eles empregados, eventuais, domésticos, autônomos. Entretanto, não necessariamente todos os direitos dispostos nos incisos do art. $7^{\circ}$ incidiriam em todas as relações de trabalho, dependendo, sempre, da compatibilidade de cada um dos direitos com o tipo de relação de trabalho existente entre prestador e tomador de serviços. Assim, diante das peculiaridades da relação de trabalho seria compatível a incidência de todos os direitos, de alguns deles, ou mesmo dos direitos mitigados. A própria relação de emprego, por exemplo, possui peculiaridades em certas situações. No que tange aos domésticos, os incisos do art. $7^{\circ}$ aplicáveis estão elencados no parágrafo único do mesmo dispositivo constitucional. Aos empregados que laboram em atividade externa ou que são ocupantes de cargo de confiança não se aplicariam os dispositivos relativos à jornada, fazendo a CLT expressa ressalva a esse respeito em seu art. $62 .{ }^{32}$

Aliás, alguns incisos do art. $7^{\circ}$ da Constituição apresentam logicamente aplicação a determinados destinatários, não se devendo dizer que são aplicáveis a todos os empregados indiscriminadamente. Dessa forma, somente à mulher grávida se aplica o direito à licençamaternidade; apenas ao trabalhador que labora em horário noturno ou em atividades perigosos ou insalubres faz sentido falar em adicional noturno, de periculosidade ou insalubridade; aos empregados que estão sob contrato por prazo determinado não cabe aviso prévio, pela própria lógica do contrato ${ }^{33}$; e assim por diante.

Seria, assim, possível que determinados direitos fossem aplicáveis aos autônomos, aos eventuais e aos parassubordinados, de acordo com o grau de proteção necessário a cada um desses tipos de trabalhadores e conforme as peculiaridades inerentes a cada forma de prestação de serviços. Esses trabalhadores podem, apenas para exemplificar, receber férias e décimo terceiro proporcionais ao tempo de serviço prestado ao tomador e ter direito ao recolhimento do FGTS durante o prazo do contrato com cada tomador de serviços.

Tereza Aparecida Asta Gemignani acredita que alguns direitos possam ser estendidos aos trabalhadores sem vínculo empregatício, de uma forma geral - e não somente aos parassubordinados, frise-se - tais como o salário (respeitado o valor do salário

\footnotetext{
${ }^{32} \mathrm{Na}$ realidade, existe uma discussão a respeito da constitucionalidade do art. 62 , tendo em vista que diante da sistemática da Constituição de 1988 não haveria sentido em excepcionar os ocupantes de cargo de confiança do controle de jornada, tendo em vista a própria Norma Fundamental traz a jornada máxima diária e semanal de trabalho que seriam 8 e 44 horas, respectivamente. Em relação aos trabalhadores em atividade externa, entende-se que se possível o controle da jornada, por meio dos modernos mecanismos de comunicação ou mesmo da passagem do trabalhador na empresa no início e no final da jornada, não há que se falar em aplicação dos artigos celetistas relativas à jornada de trabalho.

33 A não ser que empregado e empregado estabeleçam a possibilidade de a qualquer momento poder rescindir o contrato de trabalho, caso em que se aplicam todas as regras do contrato por prazo indeterminado.
} 
mínimo, assegurada a proteção e a irredutibilidade salarial, observado o piso profissional), o pagamento de adicional noturno superior ao diurno, ou ao menos, salário maior para trabalho no horário noturno, o limite diário e semanal de duração da jornada contratada e a observância das normas referentes à segurança e à saúde na prestação do trabalho. ${ }^{34}$

Percebe-se que a primeira corrente está comprometida com uma visão ultrapassada em que a praticamente toda a massa de trabalhadores se regia pelo contrato de emprego e que entendia que apenas os empregados eram sujeitos hipossuficientes os quais deveriam ser protegidos pelo Estado por intermédio do Direito do Trabalho. Nesse sentido, já argumentou Arion Sayão Romita ${ }^{35}$ que o papel do Direito do Trabalho não é o de proteger o trabalhador, mas de apenas regular as relações entre empregado e empregador. Segundo esse autor, como se trata de relação desigual, cabe ao Direito do Trabalho introduzir desigualdades no interior do contrato de trabalho com o intuito de favorecer o empregado, que não detém poder econômico.

A crítica que se faz a esse posicionamento adentra justamente em uma análise da dinâmica social que se vislumbra desde a entrada em vigor da CLT e, sobretudo, após a promulgação da Constituição de 1988. O fato é que a divisão trabalho autônomo versus trabalho subordinado acabou protegendo quem não precisava ser protegido com a mesma intensidade, como ocorre em relação aos altos-empregados. Além disso, deixou de proteger quem não deveria, ao excluir determinados tipos de trabalhadores autônomos, em situação de debilidade contratual ou de dependência econômica.

Nessa esteira, está Nelson Manrich, para quem:

\begin{abstract}
Não tem lógica a legislação trabalhista regular igualmente as relações do operário, faxineiro ou de outro trabalhador braçal, e do diretor ou presidente da empresa. Seria de todo conveniente examinar a orientação de alguns ordenamentos estrangeiros, como o italiano ou francês, que trata de forma diferenciada tais trabalhadores. Por outro lado, o fato de determinados trabalhadores serem autônomos, por si, não exclui de todo a possibilidade de intervenção do legislador no sentido de corrigir certas distorções, em vista de sua dependência econômica em face do tomador dos serviços. ${ }^{36}$
\end{abstract}

\footnotetext{
${ }^{34}$ GEMIGNANI, Tereza Aparecida Asta. Direitos fundamentais e sua aplicação no mundo do trabalho: questões controversas. São Paulo: LTr, 2010, p. 94. A autora entende que para os trabalhadores em geral, sem vínculo de emprego, não caberiam os direitos a férias, $13^{\circ}$ salário, DSR e FGTS, pois estabelecidos como inerentes a relação de trabalho com vínculo empregatício. Não concordamos com a autora em relação a essa restrição no que tange aos trabalhadores parassubordinados, que estão em uma situação intermediária entre os autônomos e os subordinados, com certa dependência econômica do empregador e vinculados necessariamente aos fins empresariais.

35 ROMITA, Arion Sayão. O impacto das transformações econômicas no direito do trabalho: a crise da subordinação e o rearranjo de modalidades contratuais. Revista de Direito do Trabalho, v. 117, ano 31, jan./mar. 2005, p. 37.

36 MANRICH, Nelson. Autonomia, parassubordinação e subordinação: os diversos níveis de proteção do trabalhador e do teletrabalhador. Artigos de professores da Faculdade de Direito da Universidade
} 
Ademais, a realidade social demonstra a proliferação cada vez maior de novas formas de contratação de trabalhadores, que tem como escopo, na maior parte das vezes, precarizar direitos, ou seja, excluir o trabalhador da tradicional configuração de empregado, para que não faz jus aos direitos do art. $7^{\circ}$ da Constituição Federal e da CLT e das demais normas aplicáveis ao trabalhador subordinado. Essa situação vem gerando um paradoxo: protege-se uma pequena parcela de trabalhadores tipicamente subordinados, silenciando-se acerca um imenso contingente de trabalhadores hipossuficientes.

Além da questão da hipossuficiência, outro argumento que coaduna uma mudança de paradigma da compreensão acerca da proteção dos trabalhadores em geral é o grau de inserção do trabalhador na atividade produtiva do tomador de serviços. Nesse sentido, Amauri Mascaro cita Giancarlo Perone em Lineamenti di diritto Del lavoro, de 1999, obra na qual o jurista italiano sustenta a transformação do "trabalho subordinado para o trabalho centralizado não só na subordinação, mas sobre a conexão funcional, continuativa e pessoal para uma organização como contraparte". ${ }^{37}$ Nesta proposta, o grau de tutela haveria de ser proporcional ao grau de inserção na atividade produtiva, apesar de ser patente a dificuldade na extensão dos direitos ou mesmo da definição da proporcionalidade desta tutela.

Interpretar evolutivamente um dispositivo constitucional significa fazer uma leitura do texto enfocando a realidade social, os acontecimentos advindos do mundo dos fatos, os novos valores insertos na sociedade. Não tem sentido, portanto, entender o termo "trabalhadores" presente no caput do art. $7^{\circ}$ da Constituição Federal como se referindo apenas aos empregados urbanos e rurais, pois essa não é única relação de trabalho existente e muito menos a única em que o prestador de serviços está em uma situação vulnerável e necessita de proteção jurídica, por meio da incidência de normas cogentes na relação de trabalho em que é sujeito.

É necessário salientar que essa interpretação do caput do art. $7^{\circ}$ representa uma mutação constitucional do dispositivo, visto que modifica o entendimento que normalmente é dado ao texto normativo em apreço, porém respeitando os limites dessa modalidade de modificação da Constituição. Assim, a compreensão do termo

Plesbiteriana. 2011.

37 NASCIMENTO, Amauri Mascaro do. Op. cit., p. 413. 
"trabalhadores" como prestadores de serviços em geral é muito mais lógica e se coaduna com uma interpretação sistemática da Constituição que traz como um de seus princípios o valor social do trabalho (e não o valor social do emprego) e que prevê o direito ao trabalho (e não apenas o direito ao emprego).

De qualquer maneira, deve-se ter em mente que o fato do caput do art. $7^{\circ}$ da Constituição Federal abranger os trabalhadores em sentido amplo e não apenas os empregadores não significa atribuir a todos eles indiscriminadamente todos os direitos elencados nos incisos do dispositivo, como de maneira equivocada prega a segunda corrente citada. A cada tipo trabalhador são aplicáveis determinados direitos, de acordo com as peculiaridades da relação de trabalho em que são partes, entre elas o grau de dependência econômica desses trabalhadores em relação ao tomador de serviços, o grau de inserção na atividade produtiva, a existência de subordinação jurídica do empregado ou de coordenação entre as partes, o local de prestação de serviços e as condições em que o trabalho é exercido.

Diante da evolução social, conclui-se que o trabalhador parassubordinado está, portanto, entre os "trabalhadores" a que o art. $7^{\circ}$, caput se refere. Sendo assim, nas relações de trabalho parassubordinado devem incidir os direitos elencados nesse dispositivo constitucional na exata medida da necessidade de proteção e das condições e peculiaridades do trabalho prestado, sobretudo no que tange à dependência econômica e ao grau de inserção do trabalhador na atividade produtiva empresarial. Defende-se, assim, uma disciplina mínima comum a todos os tipos de trabalho, sejam eles subordinados ou não, com uma extensão graduada de tutelas que respeite a dignidade da pessoa dos trabalhadores, inclusive do parassubordinado.

\subsubsection{Direitos relativos à proteção contra a dispensa e à estabilidade provisória}

\section{Proteção contra a dispensa individual arbitrária ou sem justa causa}

$\mathrm{O}$ artigo $7^{\circ}$, inciso I, da Constituição Federal de 1988 estabelece como direito fundamental do trabalhador a relação de emprego protegida contra despedida arbitrária ou sem justa causa, nos termos de lei complementar, que preverá indenização compensatória, dentre outros direitos. 
Por seu turno, o artigo 10, inciso I, do ADCT dispõe que, enquanto não for promulgada a lei complementar mencionada no artigo $7^{\circ}$, inciso $\mathrm{I}$, da $\mathrm{CF} / 88$, a proteção nele referida fica limitada ao pagamento, pelo empregador ao empregado, de uma indenização correspondente a 40\% dos depósitos do FGTS do trabalhador dispensado.

A dispensa arbitrária é aquela que, embora motivada, não se baseia em motivo relevante, podendo ser fundada em razão de origem disciplinar, técnica, econômica e financeira, consoante se depreende da redação do artigo 165 da CLT que trata da despedida arbitrária dos empregados membros da CIPA. Por seu turno, a dispensa sem justa causa é aquela desmotivada.

Em relação à aplicabilidade do artigo $7^{\circ}$, inciso I, o entendimento majoritário, que se sedimentou na doutrina e na jurisprudência acerca desses dispositivos constitucionais, é o de que a norma que estabelece a dispensa arbitrária ou sem justa causa é de aplicabilidade limitada, sendo necessária a sua regulamentação por meio de lei complementar. Em outras palavras, de acordo com essa compreensão da norma, a Constituição teria acabado com qualquer garantia de emprego, à exceção das provisórias estabelecidas no artigo 10 do ADCT e no artigo $8^{\circ}$, inciso VIII, do texto constitucional, sendo devida ao empregado, que não se enquadre nesses casos, apenas a indenização compensatória a ser regulamentada por lei complementar.

Sem embargo, existe parcela doutrinária que entende que a norma é de eficácia plena, encontra-se em pleno vigor e assegura a integração do trabalhador. Assim, a indenização somente caberia nos casos de impossibilidade de reintegração e a única parte do dispositivo constitucional que necessita de regulamentação, pois a lei complementar poderá prever, além outros direitos além da mera indenização.

Essa interpretação, a que essa tese se filia, é a que imprime maior aplicabilidade à norma constitucional em tela, pois não há sentido em prever uma proteção contra dispensa arbitrária ou sem justa causa se essa for compreendida apenas como a indenização e os outros direitos "compensatórios", visto que pelo menos a indenização já é paga na prática pelos empregadores, em virtude do disposto no artigo 10, inciso I, do ADCT.

Fábio Hiroshi Suzuki, citado por Luciana Terra Vidal, defende que, em não havendo motivo social ou juridicamente relevante para a dispensa, basta que o empregador se abstenha de dispensar o empregado. Assim, o juiz do trabalho poderia ordenar a reintegração do empregado tornando sem efeito o ato do empregador que pôs fim ao contrato, baseado seja no seu dever de proteção, seja na teoria do ato ilícito ou do abuso do direito. 
Os dispositivos constantes do ordenamento jurídico, tais como o art. 10, I e II, do ADCT e o art. 165 da CLT já formam um arcabouço normativo hábil a conter a dispensa desmotivada. E, ainda que assim não fosse, caberia ao intérprete determinar o conteúdo e o alcance da norma, definindo o que venha a ser dispensa arbitrária e fixando os seus efeitos. ${ }^{38}$

Outra celeuma jurídica acerca do artigo $7^{\circ}$, inciso I, da Constituição Federal de 1988 diz respeito à sua relação com a Convenção n. 158 da OIT, pois houve quem argumentasse que esse instrumento internacional teria aptidão para regulamentar o dispositivo constitucional, assumindo o papel da lei complementar mencionada.

A Convenção n. 158 passou a ter vigência no Brasil, por força do Decreto Legislativo n. 68/1992, que aprovou a Convenção n ${ }^{\circ} 158$, e do Decreto $n^{\circ} 1.855 / 1996$ que a promulgou.

Assim, tal Convenção se incorporou à ordem jurídica interna, pois foram cumpridos os requisitos de incorporação das Convenções Internacionais à legislação interna do Brasil, que não exige a edição de lei para tal, mas apenas a aprovação do Congresso Nacional e a promulgação por parte do Poder Executivo (artigos 49, inciso I e 84, inciso VIII, da Constituição Federal).

A Convenção Internacional, uma vez aprovada pelo Congresso Nacional e promulgada, tem aplicação imediata e irrestrita, tendo a mesma hierarquia que a lei ordinária. Ela entrou em vigor no Brasil, em 22 de outubro de 1996, com a republicação do Decreto n. 1855/96, em virtude de correções no texto.

Dessa forma, surgiu posicionamento contrário ao de que a Convenção n. 158 suprimiria a lei complementar exigida pelo artigo $7^{\circ}$, inciso I, da $\mathrm{CF} / 88$, pois, entrando no ordenamento como lei ordinária, ela não poderia ser considerada lei complementar.

Examinando o artigo $4^{\circ}$ da citada Convenção, percebe-se que esta veda o término da relação de trabalho, a menos que exista para isso uma causa justificada relacionada com sua capacidade ou seu comportamento ou baseada nas necessidades de funcionamento da empresa, estabelecimento ou serviço.

$\mathrm{O}$ artigo $8^{\circ}$ garante ao trabalhador o direito de recorrer contra o término da sua relação empregatícia perante um tribunal trabalhista, sendo que tais tribunais poderão se manifestar dizendo se o término da relação empregatícia é justificado ou não. Porém, o

\footnotetext{
${ }^{38}$ SUZUKI, Fábio Hiroshi. Proteção contra dispensa imotivada no direito do trabalho brasileiro. Revista de Direito do Trabalho: São Paulo, v. 32, n.123, p.7-52, jul./set.2006, p. 48-49 apud TERRA, Luciana Soares Vidal. Estabilidade no emprego: em busca da dignidade. Dissertação de Mestrado. Faculdade de Direito. Pontifícia Universidade Católica de Minas Gerais, p. 97.
} 
artigo 10 permite que os tribunais do trabalho anulem o término da relação empregatícia ou poderão ordenar o pagamento de uma indenização.

Ora, o texto da Convenção $\mathrm{n}^{\circ} 158$ da OIT se ajusta plenamente à primeira parte do inciso I do artigo $7^{\circ}$ da $\mathrm{CF}$, não se caracterizando propriamente inconstitucionalidade. Apenas seus ditames não poderiam ser aplicados de imediato, no que tange a esse dispositivo constitucional, porque a proteção contra a despedida arbitrária exige lei complementar e a Convenção Internacional tem hierarquia de lei ordinária e não complementar.

Sem embargo, repita-se, a lei complementar, no entendimento que ora se filia essa tese, serve apenas para regulamentar a indenização compensatória e os outros direitos relativos à dispensa, pois não é possível que o empregado esteja sujeito a dispensas arbitrárias ou sem justa causa, ainda mais levando-se em conta que, no caso de violação a direitos trabalhistas constitucionais ou infraconstitucionais, o trabalhador provavelmente só poderá ajuizar reclamação trabalhista pleiteando o cumprimento dos mesmos ou o pagamento das parcelas devidas após a extinção do contrato de trabalho, sob pena de ser dispensado. Esse problema social se agrava ainda mais quando se observa que o prazo prescricional para pleitear os direitos trabalhistas (artigo $7^{\circ}$, inciso XXIX, da CF/88) é bastante curto, limitando-se a dois anos após a extinção do contrato de trabalho em relação aos direitos referentes aos últimos cinco anos, para trás, contados do ajuizamento da ação.

Dessa forma, pode-se dizer que as matérias não auto-aplicáveis da Convenção n. 158 podem ser resolvidas por meio da integração com a legislação nacional brasileira, apenas sendo necessário a regulamentação dos dispositivos quando não houver norma jurídica interna sobre o assunto.

A referida Convenção, pelo menos para a maior parte da doutrina e jurisprudência, deixou de vigorar a partir de 20 de novembro de 1997, mediante a publicação do Decreto n. 2.100/96 que denunciou a Convenção, por considerá-la incompatível com a tradição brasileira. $^{39}$

\footnotetext{
${ }^{39}$ Sobre as interações mais aprofundadas entre a Convenção n. 158 da OIT e o artigo $7^{\circ}$, inciso I, da CF/88, do ponto de vista material e formal, vide TERRA, Luciana Soares Vidal. Estabilidade no emprego: em busca da dignidade. Dissertação de Mestrado. Faculdade de Direito. Pontifícia Universidade Católica de Minas Gerais. A autora também trabalha de forma detalhada a questão da constitucionalidade ou não da denúncia da Convenção n. 158 da OIT, tanto no que tange ao prazo para que essa denúncia fosse realizada, quanto no que se refere à competência ou não do chefe do executivo para efetuá-la, sem a ratificação da denúncia pelo Congresso Nacional, matérias objeto da ADI impetrada pela Confederação Nacional dos Trabalhadores na Indústria, em 19 de junho de 1997 e até hoje não julgada pelo STF.

No que tange ao tema do sistema de dispensa e estabilidade no Brasil, em estudo de Direito Comparado com outros países da Europa, com ênfase para o Direito italiano, vide PORTO, Lorena Vasconcelos. La disciplina dei licenziamenti in italia e nel diritto comparato: una proposta per il diritto del lavoro in Brasile. Tese de
} 
Embora não se adote o posicionamento segundo o qual a Convenção n. 158 regulou a matéria relativa à proteção contra a dispensa arbitrária ou sem justa causa, garantia prevista no artigo $7^{\circ}$, inciso I, da $\mathrm{CF} / 88$, por entender que essa proteção é auto-aplicável, o instrumento internacional traz diretrizes que se compatibilizam, sem maiores problemas, com esse dispositivo constitucional, até mesmo em virtude da legislação infraconstitucional sobre o tema. Essa interpretação, além estar em harmonia com os princípios constitucionais da unidade e da força normativa da Constituição, é mais consentânea com a realidade social vivenciada pelos trabalhadores brasileiros que ficam à mercê de seus empregadores, no que tange à dispensa sem justa causa, e ao mesmo tempo estão sujeitos a um prazo prescricional relativamente curto para a cobrança de seus direitos em juízo.

Dessa forma, acolhe-se o entendimento esposado por Jorge Luiz Souto Maior, no sentido de que a norma constitucional contida no artigo $7^{\circ}$, inciso I, da CF/88 é autoaplicável, embora não se compreenda que ela esteja regulamentada pela Convenção Internacional n. 158 da OIT. Assim, se manifestou o juiz da $15^{\text {a }}$ Região, no julgamento de recurso ordinário em que foi relator convocado:

DISPENSA IMOTIVADA. DIREITO POTESTATIVO UTILIZADO DE FORMA ABUSIVA E FORA DOS PARÂMETROS DA BOA FÉ. NULIDADE. APLICAÇÃO DO ARTIGO 7o. I, DA CF/88, DOS ARTS. 421, 422 E 472 DO NOVO CÓDIGO CIVIL, DA CONVENÇÃ̃ 158 DA OIT E DOS PRINCÍPIOS GERAIS DO DIREITO E DO DIREITO INTERNACIONAL DO TRABALHO. Todos os trâmites para validade da Convenção n. 158, da OIT, no ordenamento nacional foram cumpridos. Os termos da Convenção são, inegavelmente, constitucionais, pois a Constituição brasileira, no artigo $7 \mathrm{o}$, I, veda a dispensa arbitrária ou sem

justa causa, e o que faz a Convenção 158 é exatamente isto. O parágrafo 2o., do art. 5o., da $\mathrm{CF} / 88$, estabelece que os tratados internacionais - gênero do qual constituem espécies as Convenções da OIT - são regras complementares às garantias individuais e coletivas estabelecidas na Constituição. Assim, a Convenção 158, estando de acordo com o preceito constitucional estatuído no artigo 7o., inciso I, complementa-o. Além disso, a Constituição Federal de 1988 previu, em seu artigo 4o., que nas relações internacionais, a República Federativa do Brasil rege-se, dentre outros princípios, pela prevalência dos direitos humanos (inciso II) e não se pode negar ao direito do trabalho o status de regulação jurídica pertencente aos direitos humanos. Assim, um instrumento internacional, ratificado pelo Brasil, que traz questão pertinente ao direito do trabalho, há de ser aplicado como norma constitucional, ou até mesmo, supranacional. Mesmo que os preceitos da Convenção 158 precisassem de regulamentação (o que não se acredita seja o caso) já se encontrariam na legislação nacional os parâmetros dessa "regulamentação". A Convenção 158, da OIT, vem, de forma plenamente compatível com nosso ordenamento jurídico, impedir que um empregador dispense seu empregado por represálias ou simplesmente para contratar outro com salário menor. No caso de real necessidade, a dispensa está assegurada. Para

Doutorado. Università degli Studi di Roma "Tor Vergata". Roma, 2008. A autora apresenta, inclusive, propostas para uma maior proteção do empregado no Brasil, no que tange à dispensa sem justa causa. 
a dispensa coletiva necessária a fundamentação em "necessidade de funcionamento da empresa, estabelecimento ou serviço", "por motivos econômicos, tecnológicos, estruturais ou análogos". Quanto ao modo de apuração ou análise dos motivos alegados não há, igualmente, problemas de eficácia, valendo como parâmetro legal a regra e as interpretações doutrinárias e jurisprudenciais já dadas ao artigo 165 da CLT. A dispensa imotivada de trabalhadores, em um mundo marcado por altas taxas de desemprego, que favorece, portanto, o império da "lei da oferta e da procura", e que impõe, certamente, a aceitação dos trabalhadores a condições de trabalho subumanas, agride a consciência ética que se deve ter para com a dignidade do trabalhador e, por isso, deve ser, eficazmente, inibida pelo ordenamento jurídico. Não é possível acomodar-se com uma situação reconhecidamente injusta, argumentando que "infelizmente" o direito não a reprime. Ora, uma sociedade somente pode se constituir com base em uma normatividade jurídica se esta fornecer instrumentos eficazes para que as injustiças não se legitimem. Do contrário, não haveria do que se orgulhar ao dizer que vivemos em um "Estado democrático de direito". ${ }^{40}$

\section{Vedação de dispensa em massa de trabalhadores sem prévia negociação coletiva}

A Convenção n. 158, da OIT, também trata da dispensa coletiva ou em massa de trabalhadores, estipulando que o empregador deverá cientificar o órgão representante dos trabalhadores, informando o número de trabalhadores afetados, os motivos da dispensa, e data em que esta seria efetivada, assim como tem a obrigação de dar a este órgão a possibilidade de realizar consultas no sentido de minorar os efeitos da dispensa, seja fornecendo critérios de escolha dos empregados afetados, seja negociando a postergação das dispensas, com a adoção de outras medidas para atenuar a crise.

No Brasil, o caso que levou à repercussão das dispensas em massa e do posicionamento adotado pela Justiça do Trabalho - sem dúvida alguma evolutivo - foi a dispensa de quatro mil trabalhadores pela Empresa Brasileira de Aeronáutica (Embraer) e Eleb Embraer Ltda, sem que fosse realizada previamente negociação coletiva entre as partes a fim de buscar alternativas às dispensas ou amenizar os efeitos delas.

Diante desse fato, o Sindicato dos Metalúrgicos de São José dos Campos e Região, o Sindicato dos Metalúrgicos de Botucatu e a Federação de Metalúrgicos de São Paulo ajuizaram dissídio coletivo ${ }^{41}$ em face da Embraer e da Eleb Embraer Ltda, alegando a violação dos direitos à informação e à boa fé e do princípio da transparência nas negociações entre as partes, previstos na Convenção 98 e nas recomendações 94 e 163 da

\footnotetext{
${ }^{40}$ CAMPINAS. Tribunal Regional do trabalho da $15^{\text {a }}$ Região. RO 00935-2002-088-15-00-3. Relator: Juiz convocado Jorge Luiz Souto Maior. Publicação do acórdão no DJSP: 7 maio 2004.

${ }^{41}$ CAMPINAS. Tribunal Regional do Trabalho da $15^{\mathrm{a}}$ Região. DC 00309-2009-000-15-00-4, SDC, Relator: Desembargador José Antônio Pancotti. Publicação da Decisão no DJSP: 30 mar. 2009.
} 
OIT, e a agressão aos princípios constitucionais da dignidade da pessoa humana e dos valores sociais do trabalho e da livre iniciativa (CF, art. $1^{\circ}$, III e IV), do acesso à informação (CF, art. $5^{\circ}$, XIV), do reconhecimento das convenções e acordos coletivos de trabalho $\left(\mathrm{CF}\right.$, art. $\left.7^{\circ}, \mathrm{XXVI}\right)$, da representação sindical e da participação obrigatória dos sindicatos nas negociações (CF, art. $8^{\circ}$, III e VI). Todas essas violações de normas jurídicas seriam oriundas da não comunicação pelas reclamadas, de forma clara e transparente, da decisão de demitir, que permitiria a tentativa de negociação coletiva.

O desembargador presidente do Tribunal Regional da $15^{\mathrm{a}}$ Região, com o intuito de chamar as partes à tentativa de conciliação e de evitar o risco de ineficácia de eventual decisão final procedente, concedeu liminar para determinar a suspensão, a partir de 19/02/2009, das rescisões contratuais com ou sem justa causa até a data da audiência de conciliação.

Em defesa, as reclamadas argumentaram a necessidade das dispensas em face da redução de pelo menos $30 \%$ das encomendas de aviões em virtude da crise, já que a clientela da Embraer está basicamente em outros países, dependendo a situação da empresa, portanto, da dinâmica do mercado internacional. Outra alegação seria a de que a Justiça do Trabalho não teria competência para criar normas reguladoras da dispensa coletiva, visto que o tema deve ser objeto de lei, até mesmo porque a Convenção 158 da OIT foi denunciada no Brasil e a lei complementar que deve regulamentar o $\operatorname{art} .7^{\circ}$, I, da Constituição Federal ainda não foi elaborada. Ademais, as dispensas dos trabalhadoras foram feitas criteriosamente, dentro dos limites do poder diretivo empregatício e a lei no Brasil não condiciona a dispensa coletiva à prévia negociação coletiva.

Houve duas audiências de conciliação que restaram infrutíferas, mesmo diante da proposta apresentada pelo Presidente do Tribunal, sendo que na primeira ocasião a liminar concedida e na segunda, em 13/03/2009, foi decidido que seria mantida até o julgamento do dissídio.

O voto proferido pelo relator, Desembargador José Antônio Pancotti, teve a lucidez de ressaltar, inicialmente, que a Justiça do Trabalho não pode se furtar a analisar os fatos políticos, econômicos e sociais derivados da globalização que geram consequências nas relações de trabalho e que lhe são trazidos pelos cidadãos. Nesse sentido, o magistrado explica que o dissídio coletivo de natureza jurídica, como o caso em tela, é uma criação doutrinária e jurisprudencial, que além de não ter sido prevista na redação original do art. 114 da Constituição Federal, também não foi afetada pelas novas disposições 
constitucionais da Emenda n. 45/2004, que preservou, na nova redação do art. 114 o poder normativo da Justiça do Trabalho.

Especificamente no mérito, o relator argumenta que em face do ineditismo da matéria submetida a julgamento - a demissão coletiva em massa, sem a existência de aviso prévio, nem disposição para negociar uma demissão coletiva de menor impacto para a comunidade - é necessário que se faça um estudo da proteção do empregado em caso de demissão coletiva no direito comparado, e do ordenamento jurídico nacional com as suas lacunas sobre o tema, para que seja possível propor uma solução cabível para a questão concreta.

O julgador traz a baila a diferenciação entre dispensa individual e coletiva, ressaltando que a segunda se caracteriza pela rescisão simultânea de uma pluralidade de contratos de trabalho e que, de acordo com as disposições da Convenção n. 158 da OIT, nessa modalidade de dispensa, deve haver negociações entre o empregador e a representação de trabalhadores no sentido tanto de avisar acerca da dispensa, quanto também de buscar um programa que seja realizado em etapas sucessivas, visando minorar os efeitos maléficos da rescisão coletiva em massa.

No Brasil, como já mencionado, a referida Convenção foi ratificada pelo Decreto legislativo n. 68 de 17/11/1992, cuja publicação se deu em 11/04/1996, sendo denunciada, entretanto, em 20/11/1996, sob argumentos como o de que trazia uma proteção exagerada ao empregado em demissões individuais e coletivas incompatível com um país de economia frágil, além de criar barreiras ao desenvolvimento econômico, com elevação do custo de produção. Atualmente, o ato de denúncia é objeto de uma Ação Direta de Inconstitucionalidade perante o Supremo Tribunal Federal, que enquanto não for julgada enseja a permanência da denúncia.

O relator, astutamente, lembra que a Convenção 158 foi ratificada por várias países, entre eles Suécia, Iugoslávia, Venezuela, Zaire, Gabão, Iêmen, Uganda, Etiópia, França, Marrocos, Turquia, entre outros, sendo que a maioria deles possui economia muito menos desenvolvida que a do Brasil. A conclusão do magistrado é bastante lógica, visto que a denúncia ocorrida parece ser fruto muito mais de uma proteção ou lobby do empresariado nacional e internacional que atua no país.

Em seguida, o desembargador analisa diversas normatizações no direito comparado acerca da dispensa coletiva, entre elas a da União Européia e da Espanha, a de Portugal, a do México e a da Argentina que, em apertada síntese, apresentam como principais balizas a notificação da empresa acerca da dispensa dos trabalhadores aos sindicatos e/ou órgãos 
governamentais competentes e a negociação com esses entes de formas alternativas para a dispensa ou que gerem efeitos menos graves aos trabalhadores.

No que tange ao Brasil, o relator argumenta que só há previsão acerca da dispensa individual no art. $7^{\circ}, \mathrm{I}$, da $\mathrm{CF} / 88$, cujo efeito, no seu entendimento, resume-se à multa sobre o saldo do FGTS de 40\%, consoante estipulação do art. 10, I, alínea $a$, do ADCT da Constituição. Por outro lado, não há regramento algum acerca da despedida em massa coletiva, fato que tem sido contornado por meio de acordos e convenções coletivas de trabalho que estabelecem variados critérios de demissão coletiva, como os PDV's (planos ou programas de demissão voluntária), a suspensão de contratos, com ou sem o pagamento de salários e inclusive para cursos, férias coletivas, redução da jornada e de salários, etc.

Como no caso da Embraer não existem critérios para a dispensa coletiva em instrumentos coletivos das categorias envolvidas, o relator chegou ao ponto mais importante de seu voto: há, no ordenamento jurídico brasileiro, uma lacuna em relação à matéria. Dessa forma, como não é permitido aos juízes e tribunais se furtar de julgar os conflitos que lhes são trazidos, alegando a inexistência de disposição legal sobre a questão a ser decidida, o relator acertadamente, utiliza-se do instrumento da integração para o preenchimento das lacunas legais, por meio das alternativas fixadas no art. $8^{\mathbf{o}}$ da CLT. Nesse caso, o magistrado se serviu dos princípios do direito do trabalho nacional e comparado para tentar resolver o impasse jurídico.

Adentrando na matriz doutrinária que embasou a sua decisão, José Antônio Pancotti se vale de Robert Alexy e Ronald Dworkin, bem como das lições de Luís Roberto Barroso e Paulo Bonavides para explicitar que tanto as regras como os princípios são normas jurídicas, de modo que os princípios apresentam força normativa a reger determinadas situações, não

sendo apenas valores que servem para a compreensão e a interpretação de um ordenamento jurídico. Os princípios gerais de Direito se transformaram em princípios constitucionais ao serem inseridos na Constituição, formando a base do sistema jurídico e ensejando diversos estudos acerca de seu novo papel na hermenêutica constitucional.

O relator conclui que, pelo fato das normas constitucionais não terem mais apenas eficácia meramente programática, o juiz deve se valer das normas princípio para solucionar os casos que lhe são trazidos, tanto no que tange à aplicação direta dos princípios, quanto nos casos de integração de lacunas legais. Dessa forma, afirma que é possível reconhecer que o espectro constitucional de proteção ao trabalhador em caso de dispensa coletiva é mais amplo, mesmo no ordenamento jurídico nacional, tendo em vista os princípios 
constitucionais da dignidade da pessoa humana, dos valores sociais do trabalho e da livre iniciativa, da construção de uma sociedade livre justa e solidária, da garantia do desenvolvimento econômico, da erradicação da pobreza e da marginalização, da prevalência de direitos humanos e, também, da instituição de diretrizes da ordem econômica e social que visam garantir a livre iniciativa e livre concorrência, conter os abusos do poder econômico e instituir mecanismos de desenvolvimento social, inclusive através de ações que garantam ao cidadão o acesso ao trabalho, à previdência social, à saúde, entre outros direitos. Essa proteção aos trabalhadores em face de rescisão coletiva de contratos se diferenciaria daqueles que o Direito do Trabalho expressamente concede para as demissões individuais, insuficientes diante da gravidade das dispensas em massa.

Não se pode deixar de louvar essa parte do voto do relator, visto que o Direito Constitucional e a Teoria Geral do Direito, na maior parte das vezes, são olvidados ou deixados em último plano pelos julgadores, como se não fossem a base do ordenamento jurídico de onde se devem extrair os fundamentos primários de qualquer decisão, antes mesmo de se buscar soluções nas leis infraconstitucionais como é de praxe.

Nesse caso específico, a CLT e demais leis nada dizem sobre os efeitos e a forma da dispensa coletiva mas, ainda que dissessem, o texto constitucional deveria servir de parâmetro para a interpretação dos dispositivos infraconstitucionais ou mesmo prevalecer, se esses fossem contrários aos princípios da Lei Fundamental.

Outro ponto relevante do voto é a importância dada aos princípios constitucionais atinentes ao Direito do Trabalho que são elencados na decisão. A jurisprudência, em geral, infelizmente ainda leva mais em consideração a função meramente informativa desses princípios do que efetivamente a sua força normativa.

À continuação, o desembargador acrescenta que a Declaração da OIT sobre princípios e direitos fundamentais do trabalho declara que, independentemente da ratificação das convenções pelos membros da Organização, devem eles assumir o compromisso derivado do simples fato de pertencerem à OIT de respeitar, promover e tornar realidade de boa fé, e de conformidade com a Constituição, os princípios relativos aos direitos fundamentais que são objeto dessas convenções.

Deve-se ressaltar que o próprio Supremo Tribunal Federal reconheceu o conteúdo programático da Convenção n. 158, o que não impede que seus comandos sejam interpretados como princípios gerais de direito do trabalho, com força normativa, por dois motivos que ora se esclarece. Nem mesmo as normas programáticas, embora instituam programas a serem estabelecidos pelo administrador com fulcro em leis 
infraconstitucionais regulamentadoras, deixam de ter o mínimo de força normativa, visto que repelem leis e atos normativos que com elas se choquem ou são contrárias ao "espírito" que o legislador constituinte quis lhes imprimir. Outrossim, existe uma vertente que, parece ser, em certa medida, a qual o relator se filia e, ao meu entender, correta, de que, na falta de normas infraconstitucionais que possa reger uma determinada situação no ordenamento jurídico, os princípios podem ser utilizados para preencher essas lacunas. ${ }^{42}$

A importância dessa percepção do magistrado vai ao encontro dos seguintes enunciados $^{43}$ aprovados na $1^{\text {a }}$ Jornada de Direito Material e Processual do Trabalho, realizado pela ANAMATRA, em 2007, que transparecem a função integrativa e interpretativa que os princípios presentes nas Convenções da OIT devem ter, ainda que não ratificadas pelos países membros:

\begin{abstract}
FONTES DO DIREITO - NORMAS INTERNACIONAIS.
I - FONTES DO DIREITO DO TRABALHO. DIREITO COMPARADO. CONVENÇÕES DA OIT NÃO RATIFICADAS PELO BRASIL. O direito comparado, segundo o art. $8^{\circ}$ da Consolidação das Leis do Trabalho, é fonte subsidiária do Direito do Trabalho. Assim, as Convenções da Organização Internacional do Trabalho não ratificadas pelo Brasil podem ser aplicadas como fontes do direito do trabalho, caso não haja norma de direito interno pátrio regulando matéria.

II - FONTES DO DIREITO DO TRABALHO. DIREITO COMPARADO. CONVENÇÕES E RECOMENDAÇÕES DA OIT. O uso das normas internacionais, emanadas da Organização Internacional do Trabalho, constitui-se em importante ferramenta de efetivação do Direito Social e não se restringe à aplicação direta das Convenções ratificadas pelo país. As demais normas da OIT, como as Convenções não ratificadas e as Recomendações, assim como os relatórios dos seus peritos, devem servir como fonte de interpretação da lei nacional e como referência a reforçar decisões judiciais baseadas na legislação doméstica.
\end{abstract}

O relator, em seguida, expressa uma posição bastante coerente, já que admite que o número de postos ofertados pelas empresas está atrelado ao seu potencial produtivo, que dependem da estabilidade da economia do país e, em várias atividades empresariais, da

\footnotetext{
${ }^{42}$ Nesse sentido, está Marcus Orione, que entende, por exemplo, que o conceito de adicional de penosidade pode ser estabelecido a partir de uma noção que exclua as definições de direito à adicional de periculosidade e de insalubridade já estabelecidos em lei, buscando componentes, para a sua construção, do direito previdenciário, onde existe a noção de trabalho penoso, para fins de aproveitamento de tempo especial. Assim, ainda que não tenha sido estabelecido a lei que regulamenta o adicional de penosidade, é possível implementá-lo visto ser um direito constitucional social que, por falta de lei, não pode ser desprovido de força normativa. Cf. CORREIA, Marcus Orione Gonçalves. O postulado da razoabilidade e o Direito do Trabalho. In: CORREIA, Marcus Orione Gonçalves (Org.). Curso de Direito do Trabalho, v. 1 - Teoria geral do Direito do Trabalho. São Paulo: LTr, 2007, p. 136.

${ }^{43}$ ENUNCIADOS da $1^{\text {a }}$ Jornada de Direito Material e Processual na Justiça do Trabalho, realizado em 23 de novembro de 2007 pela ANAMATRA (Associação Nacional de Magistrados da Justiça do Trabalho). Disponível em: <http://www.amatra.org.br/jornada/enunciados/enunciados_aprovados.cfm>. Acesso: 25 out. 2011. Em relação a esses enunciados, é importante ressaltar, entretanto, que assim como outros que foram aprovados na $1^{\mathrm{a}}$ Jornada, eles não tem força vinculante, não se equiparando nem às Súmulas e Orientações Jurisprudenciais. Servem como balizas, entendimentos norteadores para o auxílio à compreensão e interpretação das normas do Direito do Trabalho e sua aplicação em casos concretos.
} 
estabilidade do mundo globalizado e, dessa forma, crises podem ser fatores inevitáveis de desemprego. Não obstante, para o magistrado, a forma como a demissão coletiva foi conduzida e efetivada, sem que se tenha dado anúncio prévio, nem se buscado a negociação para a amenização dos seus efeitos foi bastante condenável. $O$ poder empregatício para as dispensas não pode ser exercido de forma abusiva, com ausência de negociação coletiva prévia e espontânea ao ato demissional, sob pena de violar os princípios da dignidade da pessoa humana e dos valores sociais do trabalho e da livre iniciativa.

Diante dos argumentos apresentados, o relator votou pela abusividade da dispensa coletiva, por falta de boa fé objetiva, nos termos do art. 422 do Código Civil, "por ausência de negociação coletiva prévia, espontânea e direta entre as partes, que revela falta de lealdade da conduta, na medida em que houve tentativa de conciliação tão-somente com mediação judicial e, assim mesmo, por força de uma liminar de suspensão dos efeitos das demissões."

Ademais, deu provimento para declarar:

b) a inexistência de garantia de emprego ou de estabilidade que justifique a reintegração, ressalvados os casos de estabilidade provisória previstos em lei ou em normas coletivas, que poderão ser objeto dissídios individuais;

c) o direito de cada empregado demitido a uma compensação financeira de dois valores correspondentes a um mês de aviso prévio, até o limite de sete mil reais;

d) a eficácia da liminar concedida até o dia 13.03.2009, para manter vigente até esta data os contratos de trabalho em todos os seus efeitos;

e) a manutenção dos planos de assistência médica aos trabalhadores demitidos e seus familiares por doze meses a contar de 13.03.2009;

f) nos casos de reativação dos postos de trabalho, de acordo com as necessidades da empresa, preferência na seleção dos empregados despedidos que se apresentem e preencham as qualificações exigidas pelos cargos disponíveis, mantida durante dois anos.

A coerência e profundidade de argumentação do voto do Relator José Antônio Pancotti revela o cuidado e a perspicácia jurídica do magistrado em resolver uma espécie de caso ainda não julgado pela Justiça do Trabalho, sobretudo pelo viés que foi imprimido ao voto, com a importância alusiva aos princípios constitucionais e ao direito comparado do Trabalho, essenciais para a solução da lide apresentada.

Como era de se esperar, a Empresa Brasileira de Aeronáutica S. A - Embraer e outra, o Sindicato dos Metalúrgicos de São José dos Campos e Região e outros e o Sindicato dos Trabalhadores nas Indústrias de Construção de Aeronaves do Estado de São Paulo (Sindiaeroespacial), inconformados com a decisão do TRT da $15^{\text {a }}$ Região, 
interpuseram Recurso Ordinário ${ }^{44}$ que foi conhecido e julgado pela Seção de Dissídios Coletivos do Tribunal Superior do Trabalho, cujo relator foi o Ministro Maurício Godinho Delgado. A presidência do Tribunal concedeu efeito suspensivo ao Recurso Ordinário até julgamento final. O relator, por sua vez, apresentou proposta de conciliação, majorando para quatro vezes a quantia do aviso prévio indenizatório até o limite de $\mathrm{R} \$ 14.000,00$, o que não foi aceito pela Embraer.

A Embraer e outra alegam que a decisão do TRT da $15^{\mathrm{a}}$ Região utilizou princípios de forma supletiva, o que seria inadmissível ante a existência de regra própria, e que as empresas observaram a boa-fé objetiva nas dispensas.

Como um dos pontos iniciais, o ilustre Ministro relator destacou, em seu voto, coerentemente em relação ao voto do desembargador do TRT da $15^{\text {a }}$ Região, que a matéria tratada nesse dissídio é eminentemente jurídica, tendo em vista a interpretação no tocante à regência normativa das dispensas coletivas na ordem jurídica brasileira, não obstante apresente também dimensões econômicas. Tratando-se de conflito de extrema relevância, não pode o julgador se furtar da obrigação de julgar a ação, mesmo na ausência de normas específicas, devendo encontrar a melhor solução para o caso em apreço.

O relator argumenta que na atual sociedade de massas, em que os conflitos e danos também se massificaram, urge que o Direito se adéque enfrentando os problemas não sob um enfoque tradicional individualista, mas sob uma perspectiva coletiva. Dessa forma, após reafirmar argumentos do relator José Antônio Pancotti, acrescenta que a diferença entre os efeitos dos fatos individuais e coletivos pode ser observada em várias searas da vida social e do Direito e, especificamente no que se relaciona à dispensa, a ordem jurídica regula minuciosamente os efeitos da dispensa individual na CLT e na legislação trabalhista em geral, enquanto a dispensa coletiva possui estrutura, dimensão, efeitos e impactos diversos. Corresponde a rescisão coletiva a fato que se caracteriza pela acentuada lesão provocada e pelo alargamento dos efeitos que podem atingir além das pessoas diretamente envolvidas, toda a comunidade empresarial, trabalhista e da região do acontecimento, abalando, inclusive, o mercado econômico interno.

A seguir, o Ministro relator cita as diversas Convenções da OIT, ratificadas pelo Brasil (Convenções n. 11, 87, 98, 135, 141 e 151), que não permitem a dispensa coletiva puramente potestativa por parte do empregador, exigindo a participação do respectivo sindicato obreiro, como princípio constitucional do direito coletivo trabalhista (art. $8^{\circ}$, III e

${ }^{44}$ BRASIL. Tribunal Superior do Trabalho. RODC-309/2009-000-15-00.4. Seção de Dissídios Coletivos. Rel. Ministro Maurício Godinho Delgado. Publicação da decisão no DEJT em: 04 set. 2009. 
VI da CF/88), por ser matéria afeta a essa seara. Aqui, embora não tenha sido salientado pelo Ministro, vale o entendimento de que as normas principiológicas emanadas pela OIT, ainda que presentes em Convenções não ratificadas, devem ser observadas pelos países membros, como o Brasil. Em relação às normas de Convenções ratificadas, com mais razão ainda, o país não tem nem sequer a possibilidade de não as cumprir, sob pena de sofrer as sanções devidas da OIT.

À continuação, o relator argumenta que o art. $7^{\circ}, \mathrm{I}, \mathrm{CF} / 88$ enseja regulamentação por meio de lei complementar apenas no que tange às sanções das dispensas arbitrárias, estando já prevista a proteção contra dispensa sem justa causa, que seria norma de eficácia contida, em relação às dispensas coletivas, ensejando indenização.

Nesse ponto, essa tese não se coaduna com o entendimento do relator, pois defende-se que o art. $7^{\circ}$, inciso I, da CF/88, protege a relação de emprego em seu sentido genérico, tanto no que tange à dispensa individual, como no tocante à dispensa coletiva. Não obstante, como a legislação infraconstitucional atualmente estipula os direitos garantidos às dispensas individuais (pelo menos até a promulgação da lei complementar regulamentadora), e em relação à dispensa coletiva nada diz, compreendendo-se esta como uma modalidade de dispensa em massa que produz efeitos de amplitude diversa da dispensa individual, deve o julgador se socorrer dos princípios constitucionais do direito nacional e do direito comparado para integrar a lacuna jurídica presente no ordenamento jurídico pátrio. Deve-se frisar, contudo, que mesmo na dispensa coletiva, devem ser garantidos os direitos rescisórios individuais a que tem direito cada trabalhador, inclusive a indenização do art. 10, I, do ADCT.

Voltando ao voto analisado, o Ministro relator, de forma lógica, declarou a invalidade da dispensa coletiva enquanto não negociada com o sindicato de trabalhadores, seja espontaneamente, seja no plano judicial coletivo. O relator entendeu, tendo ficado vencido nesse aspecto, que até o surgimento de negociação trabalhista, o ato potestativo e unilateral empresarial seria inábil a produzir efeitos jurídicos. Entretanto, para a maioria dos Ministros que julgaram o caso essa premissa será válida sim, mas apenas para os casos futuros, por não ser ainda acolhida na Jurisprudência até então dominante, não se aplicando portanto no presente caso.

Nesse ponto, a crítica ao Colendo TST, salvo melhor juízo, deve-se sobretudo à aplicação, no caso concreto, de uma faculdade típica do Supremo Tribunal Federal no julgamento de mérito de Ação Direta de Inconstitucionalidade, de Ação Declaratória de Constitucionalidade e de Arguição de Descumprimento de Preceito Fundamental, qual 
seja, a aplicação da eficácia da decisão somente a partir do trânsito em julgado ou de outro momento que venha a ser fixado. Ocorre que a apreciação desse dissídio coletivo é de natureza concreta e não abstrata, o que torna a restrição de efeitos da decisão totalmente sem sentido para os cerca de quatro mil e duzentos trabalhadores dispensados da Embraer e não se coaduna com o papel do RO em dissídio coletivo, que está apreciando matéria fática e jurídica ao mesmo tempo, e não apenas tratando de interpretação constitucional em abstrato. Em adição, a lei n. 9.868/99, em seu art. 27, prevê essa possibilidade pela apreciação de um quórum qualificado de Ministros e não em toda e qualquer ação julgada pela totalidade de Ministros.

Para o relator, Maurício Godinho Delgado, a ausência de informação e de tentativa de negociação prévia com as entidades sindicais interessadas ou até mesmo com os próprios trabalhadores, que foram surpreendidos pela decisão da empresa, configura ofensa à boa-fé objetiva, ao princípio da confiança e ao dever de informação, além de constituir abuso de direito, já que a empresa excedeu aos limites impostos pelo seu fim social e econômico. O ilustre Ministro relator e a Ministra Kátia Arruda, infelizmente, ficaram vencidos também nesse ponto, sendo dado provimento ao recurso da empresa.

Os votos vencidos tiveram o mérito de apreciar o contrato de trabalho segundo a ótica dos princípios de viés constitucional que hoje se aplicam, por expressa determinação do Código Civil, para os contratos entre particulares em geral e, do Código de Defesa do Consumidor, para os contratos entre consumidores e fornecedores de bens e serviços. Ora, não há o menor sentido em se restringir a aplicação da boa fé e da função social do contrato aos contratos de trabalhos que constituem, em realidade, relações privadas limitadas por normas de ordem pública. Muito antes pelo contrário, nesses contratos há ainda mais razão de aplicação desses princípios, em face do desequilíbrio que, em regra, existe entre as partes da relação jurídica empregatícia.

Em relação à prorrogação dos contratos de trabalho até 13/03/2009, a SDC, por maioria, deu provimento ao recurso para excluir tal extensão, visto que não caberia invalidar o ato empresarial de ruptura, nem estender os contratos para dias ou semanas adicionais, ficando vencidos o relator e os Ministros Carlos Alberto Reis de Paula, Walmir Oliveira da Costa e Kátia Arruda. A posição aqui adotada pela maioria dos Ministros vai ao encontro da restrição de efeitos da decisão "para o futuro", sendo conseqüência dela. Valem, portanto, as mesmas críticas efetuadas anteriormente.

Na visão do Ministro relator, na falta de negociação, a dispensa massiva ensejaria inclusive indenização compensatória superior às simples verbas rescisórias individuais, 
além de outros efeitos, em conformidade com a situação concreta invocada. Nesse aspecto, também ficaram vencidos os Ministros Relator e Kátia Arruda, que haviam dado provimento parcial ao recurso dos Sindicatos obreiros, mantendo as demais vantagens, mas alterando:

\begin{abstract}
a compensação financeira aos empregados dispensados na seguinte proporção: o valor correspondente a dois meses de aviso prévio para os empregados com até dois anos de prestação de serviços para as empresas; o valor correspondente a três meses de aviso prévio para os empregados que possuam de dois a quatro anos de prestação de serviços para as empresas; o valor correspondente a quatro meses de aviso prévio para os empregados que possuam de quatro a oito anos de prestação de serviços para as empresas; o valor correspondente a cinco meses de aviso prévio para os empregados que possuam mais de oito anos de prestação de serviços para as empresas.
\end{abstract}

Para a maioria dos Ministros julgadores o valor fixado pela Corte Regional foi razoável, não havendo base jurídica na Constituição e na CLT para o alargamento da decisão recorrida. Mais uma vez, ousa-se discordar dos ilustres Ministros, acatando a posição adotada por Maurício Godinho Delgado e Kátia Arruda, por duas razões.

A primeira porque o art. $7^{\circ}, \mathrm{I}$, da $\mathrm{CF} / 88$ protege a relação de emprego contra dispensa arbitrária ou sem justa causa, tanto relativamente à dispensa coletiva, quanto no que se refere à dispensa individual. Como a lei complementar ainda não foi feita para regular essa proteção, e não havendo nenhum efeito da dispensa coletiva previsto em lei existente, ao contrário do que ocorre com a dispensa individual, deve o julgador se socorrer dos princípios constitucionais do direito do trabalho pátrio e princípios do direito comparado para regular a hipótese.

A segunda razão, que se relaciona com a primeira, está no fato incontestável de que a dispensa coletiva traz consequências muito mais pesadas e maléficas para a massa de trabalhadores, a comunidade em que eles estão inseridos e a economia da região onde vivem, devendo o julgador, justamente em virtude dos princípios elencados pelos ilustres relatores em seus votos e tomando por base que a indenização de $40 \%$ do FGTS se refere apenas a um efeito das dispensas individuais, previsto no ADCT enquanto não vier a lei complementar, aplicar aos trabalhadores uma majoração dos valores devidos em indenização e aplicar outras regras, como a manutenção de benefícios por certo tempo, a recontratação preferencial de trabalhadores dispensados, de forma a minorar os efeitos negativos da dispensa coletiva.

Finalmente, ao pedido de reintegração pleiteado pelos sindicatos obreiros não foi dado provimento pelo relator, que entendeu que o art. $7^{\circ}, \mathrm{I}$, da $\mathrm{CF} / 88$, previu indenização 
compensatória, entre outros direitos, mas não conferiu o direito à reintegração aos trabalhadores, não podendo o Poder Judiciário extrapolar a disposição constitucional. Agiu com razão o Ministro, embora por outros fundamentos. Como ainda não foi editada a lei complementar do art. $7^{\circ}$, inciso I, não há como se dizer que existe atualmente, para os empregados, direito à reintegração. A lei complementar poderá prever esse direito e outros mais, além da indenização já prevista, porém também não regulada. Como o caso está sendo analisado pela ótica dos princípios, entende-se que a reintegração seria a hipótese de maior proteção à relação de emprego, pois visa a estabilidade máxima do trabalhador, só excetuada por justa causa devidamente comprovada. O julgador agiria de forma arbitrária, não razoável, se deferisse a reintegração, justamente porque deve sopesar, no caso concreto, os princípios que se colidem: princípio da livre iniciativa (que garante a dispensa do trabalhador sem justa causa, no atual cenário do ordenamento brasileiro, sobretudo em caso da empresa estar sofrendo os efeitos de forte crise econômica mundial, não podendo entretanto o empregador agir com abuso de direito e má-fé) e princípio da proteção à relação de emprego (que engloba entre as várias proteções ao trabalhador, o direito ao trabalho e à proteção contra dispensa, que não pode ser absoluta por não haver previsão de estabilidade absoluta e reintegração ao emprego do trabalhador).

Após a análise efetuada, pode-se dizer que a posição adotada pelo Colendo Tribunal Superior do Trabalho mostra-se bem menos evolutiva que a acolhida pelo Tribunal Regional do Trabalho da $15^{\mathrm{a}}$ Região, visto que, além de nada contribuir para o caso da dispensa em massa da Embraer, regrediu em relação à decisão do Regional, em que pesem os avançados posicionamentos em contrário de alguns Ministros, sobretudo do ilustre relator e da Ministra Kátia Arruda.

Entender a negociação coletiva como condição prévia para a dispensa coletiva de trabalhadores não pode deixar de ser reconhecido como um avanço para os casos futuros, sem dúvida alguma. Porém, não há sentido em deixar de aplicar essa condição ao caso concreto da Embraer, visto que de nada serviu aos quatro mil e duzentos trabalhadores dispensados, que somente receberam as verbas rescisórias de praxe e tiveram direito à manutenção do plano de saúde por doze meses, como já decidido pelo TRT da $15^{\text {a }}$ Região. Os efeitos maléficos da dispensa não foram nem um pouco obstados, dando vazão à afirmação e manutenção das atitudes abusivas tomadas pela empresa em tela.

O caso Embraer, sem nenhuma dúvida, é de grande importância para a análise da dispensa coletiva, fenômeno típico da sociedade contemporânea e que tende a se tornar mais freqüente em virtude dos efeitos decorrentes de crises regionais ou mundiais que 
afetam o setor empresarial nacional cada vez mais integrado ao mercado globalizado. A constatação, pelo Tribunal Regional do Trabalho da $15^{\mathrm{a}}$ Região e pelo Tribunal Superior do Trabalho, da falta de dispositivos infraconstitucionais no ordenamento pátrio que regulem a dispensa em massa foi um grande avanço. O Regional em maior medida, mas também o TST, imprimiram a maior aplicabilidade possível ao artigo $7^{\circ}$, inciso $\mathrm{I}$, da Constituição Federal de 1988, ainda que compreendido como norma de aplicabilidade limitada, e à Convenção n. 158, da OIT, mesmo que considerada denunciada regularmente e não incorporada ao ordenamento jurídico brasileiro, o que demonstra a interpretação evolutiva daquele dispositivo constitucional, de acordo com as alterações sociais ocorridas na realidade vivenciada pelos trabalhadores.

Estabilidade provisória da gestante em caso de nascimento de filho morto ou de falecimento da criança após o parto

$\mathrm{O}$ artigo 10, inciso II, alínea $b$, do ADCT garante à empregada gestante a estabilidade provisória da confirmação da gravidez até cinco meses após o parto. Com base nesse dispositivo, chegou a ser argumentado que a empregada cujo filho nascesse morto ou falecesse logo após o parto não teria direito à estabilidade até cinco meses posteriormente ao parto, visto que o objeto de proteção do direito fundamental é a criança. Não obstante, essa interpretação involutiva e descabida desse dispositivo do ADCT felizmente não tem encontrado guarida nos Tribunais do Trabalho, pois o legislador constituinte não distinguiu entre a gestante cujo filho nasce vivo ou morto, ou seja, não condicionou a estabilidade provisória ao nascimento com vida da criança e, ademais, a proteção constitucional se dirige tanto à criança, quanto à mulher, gestante e trabalhadora, independentemente de exercer a maternidade após o parto. Assim, não se trata de dar interpretação evolutiva ao artigo 10, inciso II, alínea $b$, do ADCT, mas, sim, de não conferir ao dispositivo uma interpretação restritiva e involutiva que não se adéqua ao perfil da Justiça do Trabalho enquanto legítima implementadora de direitos fundamentais trabalhistas.

GESTANTE. MORTE DA CRIANÇA APÓS O PARTO. DIREITO À ESTABILIDADE. O legislador constituinte explicitou a tutela jurídica à gestante, desde a confirmação da gravidez até cinco meses após o parto, nada dispondo sobre a hipótese de a criança nascer ou não com vida. A Lei 8.213/91 também elegeu o parto como marco para a concessão do salário-maternidade, não excepcionando a hipótese de morte da criança, após o parto, pelo que, esta circunstância não pode ocasionar a cessação da licença-maternidade e tampouco 
compromete a garantia estabilitária assegurada pelo artigo $10^{\circ}$, II, $b$, do ADCT. Se o legislador não distinguiu, não pode o intérprete fazê-lo. A instituição de benefícios e garantias da gestante em nome da "utilidade social da função materna", no dizer de André Gorz, introduz "a idéia de que a mulher pode tornar-se o equivalente de um ventre de aluguel no interesse da sociedade", o que é de todo intolerável. A maternidade não pode ser dissociada da pessoa da mãe, sob pena de concretização da visão fantasmagórica de futuro referida na literatura e cinema (vide Matrix), em que a função materna, e portanto, a matriz da vida, acabará por ser retirada da mulher e terceirizada por meio de barrigas artificiais. Tampouco se pode aceitar a alocação da garantia constitucional à gestante condicionada à "maternidade útil", i. é, "bem sucedida", já que a proteção à mãe não pode deixar de existir pelo fato de a criança vir a falecer: a uma porque tal implicaria castigá-la como se tivesse falhado na missão de ser mãe, reduzindo-a assim, à humilhante condição de reprodutora fracassada; a duas, porque a trabalhadora gestante é a destinatária direta da proteção trabalhista conferida pelo artigo $10^{\circ}$, II, $b$, do ADCT da Constituição Federal, sem embargo de se reconhecer que o nascituro é beneficiário indireto desse amparo e goza do reconhecimento de direitos desde a concepção (Código Civil, art. $\left.2^{\circ}\right)$. Recurso provido para deferir a reintegração e conseqüentes. ${ }^{45}$

Vale reproduzir a exposição de Alice Monteiro de Barros sobre o tema: a melhor doutrina a respeito, da lavra da Alice Monteiro de barros:

[...] Cumpre salientar que o direito à licença-maternidade independe do estado civil da mulher (artigo $2^{\circ}$ da Convenção $n^{\circ} 103$, ratificada pelo Brasil), tampouco está condicionado ao nascimento com vida do filho. Anteriormente à ratificação da referida convenção pelo Brasil, havia os que admitiam o retorno da empregada ao trabalho antes do término da licença, caso o filho nascesse sem vida e desde que a saúde da mulher não o impedisse. Nesse caso, a empregada estaria onerada com a prova da necessidade de repouso após o parto; do contrário, seria facultado ao empregador exigir-lhe o retorno ao trabalho, antes do término da licença-maternidade.

Atualmente, o afastamento após o parto é obrigatório. É que a licença tem como fato gerador não só o nascimento do filho, mas também a gestação, que como é sabido ocasiona à mulher transtornos físicos naturais e até psíquicos. Aliás, o próprio diploma internacional citado, isto é, a Convenção $n^{\circ} 103$ da OIT (revista pela $n^{\circ} 183$ ) e ratificada pelo Brasil, em 1.966, previu no artigo $3^{\circ}$, item 6 , para a hipótese de doença decorrente do parto, uma prorrogação dessa licença, mas nunca substituição da licença-maternidade pela licença por doença, ainda que decorrente daquela.

O fato de a criança ter falecido não elide a pretensão. É que o dispositivo constitucional pertinente, o artigo 392 consolidado e a lei previdenciária não exigem que a criança nasça com vida para que a empregada tenha direito à licença-maternidade e à garantia de emprego. Logo, onde o legislador não distingue, não cabe ao intérprete fazê-lo.

Aliás, a totalidade dos doutrinadores, igualmente juízes e ministros aposentados do TST, que abordam o tema, especificamente, defendem o descanso, independentemente da criança nascer com vida, salvo a hipótese de aborto, dada a previsão legal específica. Se o legislador pretendesse reduzir a licença, nesta hipótese, deveria tê-lo feito expressamente, como ocorre com o Código do

${ }^{45}$ SÃO PAULO. Tribunal Regional de Trabalho da $2^{\mathrm{a}}$ Região. RO 01046200336102000. $4^{\mathrm{a}}$ Turma. Relator: Juiz Ricardo Antunes Costa Rodrigues. Publicado no DJSP: 22 out. 2007. 
Trabalho da Hungria, com a lei $\mathrm{n}^{\circ}$ 4, de 1.984, de Portugal, entre outras legislações. ${ }^{46}$

\section{Direito de estabilidade provisória ao suplente do cipeiro}

O caso em comento é um dos exemplos mais claros de interpretação evolutiva realizada pela Justiça do Trabalho. O artigo 10, inciso II, alínea $a$, do ADCT garante ao cipeiro, ou seja ao membro empregado eleito para a Comissão Interna de Prevenção de Acidentes da empresa, a estabilidade provisória no emprego desde o registro de sua candidatura até um ano após o término do seu mandato. Ou seja, o empregado somente poderá ser dispensado, nesse caso, se ocorrer uma das hipóteses listadas no artigo 165 , caput, da CLT. ${ }^{47}$

Entretanto, o legislador constituinte, por descuido ou falta de técnica, não incluiu o suplente do cipeiro como detentor da estabilidade provisória, motivo pelo qual durante certo tempo a jurisprudência oscilava em conferir esse direito fundamental a esse empregado.

Sem embargo, não havia nenhum motivo plausível para tratar o suplente do cipeiro de forma diferente do titular cipeiro, pois, enquanto membro eleito da CIPA e representante dos empregados, o suplente está sujeito à retaliações por parte do empregador, inclusive a ser dispensado de forma arbitrária ou sem justa causa.

Ademais, o artigo $8^{\circ}$, inciso VIII, da CF/88 prevê a estabilidade provisória do suplente do dirigente sindical, situação que muito se assemelha ao suplente do cipeiro, visto que também se trata de carga de representação da categoria ou de grupo de empregados.

Assim, hoje o entendimento majoritário da Justiça do Trabalho, inclusive esposado na Súmula n. 360, do C. TST ${ }^{48}$, é no sentido de conferir ao suplente do cipeiro a estabilidade provisória contra dispensa arbitrária ou sem justa causa, da candidatura até a

46 BARROS, Alice Monteiro de. O Trabalho da Mulher na Constituição de 1988. In: Constitucionalismo Social: estudos em Homenagem ao Ministro Marco Aurélio Mendes de Farias Mello. São Paulo: LTr, 2003, p.114.

47 Art. 165. Os titulares da representação dos empregados nas CIPAs não poderão sofrer despendida arbitrária, entendendo-se como tal a que não se fundar em motivo disciplinar, técnico, econômico ou financeiro.

48 O entendimento esposado foi sedimentado na Súmula n. 360, do C. TST:CIPA. SUPLENTE.

GARANTIA DE EMPREGO. CF/1988 (incorporadas as Orientações Jurisprudenciais nºs 25 e 329 da SBDI1) - Res. 129/2005, DJ 20, 22 e 25.04.2005I - O suplente da CIPA goza da garantia de emprego prevista no art. 10, II, "a", do ADCT a partir da promulgação da Constituição Federal de 1988. (ex-Súmula nº 339 - Res. 39/1994, DJ 22.12.1994 - e ex-OJ nº 25 da SBDI-1 - inserida em 29.03.1996). 
eleição e, se eleito, até um ano após o término do mandato, salvo nas hipóteses do artigo 165, como já ocorre com o titular cipeiro. A jurisprudência coletada no Tribunal Regional do Trabalho da $4^{\text {a }}$ Região ilustra o referido posicionamento:

EMENTA: SUPLENTE DA CIPA. ESTABILIDADE PROVISÓRIA. INDENIZAÇÃO SUBSTITUTIVA. Nos termos do entendimento consagrado na Súmula 339 do TST, a estabilidade provisória prevista para o cipeiro não se revela vantagem pessoal, mas sim garantia para as atividades da CIPA. A recusa do reclamante em aceitar a oferta de reintegração no emprego se apresenta como óbice à conversão do direito na indenização substitutiva, uma vez que o empregado tem direito ao emprego e não, necessariamente, à indenização, a qual só se justifica diante da impossibilidade concreta de efetivação de seu retorno, circunstância que não restou comprovada nos autos. Provimento negado. ${ }^{49}$

Estabilidade provisória do cipeiro que exerce suas funções mesmo após o término do $\underline{\text { mandato }}$

O caso a seguir, julgado pela $2^{\mathrm{a}}$ Turma do Tribunal Regional do Trabalho da $12^{\mathrm{a}}$ Região, apresenta exemplo de interpretação evolutiva, uma vez que foi dado novo alcance ao sentido originalmente conferido ao artigo 10, inciso II, alínea $a$, do Ato das Disposições Constitucionais Transitórias.

Com efeito, o mandato do cipeiro titular havia terminado, mas ele continuava a exercer a sua função de representante dos empregados junto à CIPA, pois nova eleição só foi convocada algum tempo depois. Assim, tendo em vista o caráter da função exercida, ou seja, representante dos trabalhadores, é nítida a necessidade de manter a estabilidade do cipeiro, visto que ele poderia sofrer represálias a qualquer momento, o que de fato ocorreu quando o empregador demitiu da comissão anterior todos os integrantes, com a intenção de reeleger apenas um deles.

CIPA. TITULAR QUE EXERCE INFORMALMENTE SUAS ATRIBUIÇÕES APÓS O TÉRMINO DO MANDATO. PRORROGAÇÃO E ESTABILIDADE. É dever do empregador constituir, manter e promover eleição para os membros da CIPA. Se demite todos os integrantes da comissão anterior e só convoca eleição posteriormente, fica nítida a intenção de obstar a reeleição de um dos titulares que continuou exercendo informalmente seu mandato após o seu término, o que lhe garante a prorrogação e estabilidade no emprego. $^{50}$

\footnotetext{
${ }^{49}$ RIO GRANDE DO SUL. Tribunal Regional do Trabalho da $4{ }^{\mathrm{a}}$ Região. RO 0001082-57.2010.5.04.0203. Desembargador Relator: Marçal Henri dos Santos Figueiredo. Publicação no DOE: 8 set. 2011.

${ }^{50}$ SANTA CATARINA. Tribunal Regional do Trabalho da 12a Região. RO 00499-2005-040-12-00-1. $2^{\mathrm{a}}$ Turma. Desembargadora Relatora: Sandra Márcia Wambier. Publicação no DOE/TRT 12a Região: 27 jul. 2007.
} 


\subsubsection{Direitos relativos à remuneração e ao salário}

Estipulação de piso salarial maior para empregado que exerce função mais complexa e com mais atribuições, com base nas funções estabelecidas em instrumento coletivo

$\mathrm{O}$ artigo $7^{\circ}$, inciso $\mathrm{V}$, estabelece como direito fundamental do trabalhador o piso salarial proporcional à extensão e à complexidade do trabalho. Normalmente, o piso salarial é negociado entre sindicatos dos trabalhadores e empresas ou sindicatos de empresas e fixado nos acordos ou convenções coletivas da categoria profissional.

Entretanto, é possível que o juiz, ao julgar um caso concreto em que se pleiteia o piso salarial de uma classe de trabalhadores, analise quais as atribuições exercidas e a complexidade das funções desempenhadas pelo reclamante e, independentemente da denominação da função do obreiro, estabeleça o piso salarial mais adequado ao trabalho desempenha, de acordo com os pisos definidos em instrumento coletivo.

Esse foi o entendimento do Relator Juiz convocado José Eduardo Ferri, ao julgar um recurso ordinário ${ }^{51}$ em que a autora era enquadrada na função de instrumentadora, que incluía as seguintes tarefas, quais sejam, marcação de consultas, preenchimentos de fichas clínicas, manutenção da ordem do arquivo e fichário, dentre outras, mais específicas, relacionadas à tarefa de esterilização e instrumentação. Foi comprovado que a reclamante exercia, nessa função, um número bem maior de atribuições do que aquelas conferidas ao cargo de "Recepcionista" ou "Atendente de Consultório". Assim, seria desprovido de razoabilidade garantir à profissional que exerce a função de instrumentadora e de atendente de consultório somente o piso salarial mínimo geral previsto nos instrumentos coletivos, ou seja, um valor inferior ao piso salarial percebido pelas empregadas que laboravam apenas como recepcionistas ou atendentes.

O próprio artigo $7^{\circ}, \mathrm{V}$, da Constituição Federal de 1988, estabelece como direito fundamental do trabalhador o piso salarial proporcional à extensão e à complexidade do trabalho, cabendo interpretar as normas dos instrumentos coletivos no sentido de dar a maior aplicabilidade possível aos dispositivos constitucionais, de acordo com as circunstâncias fáticas presentes na análise do caso concreto.

\footnotetext{
${ }^{51}$ MINAS GERAIS. Tribunal Regional do Trabalho da $3^{\mathrm{a}}$ Região. RO 00550-2011-014-03-00-6. $1^{\mathrm{a}}$ Turma. Relator: Juiz Convocado Eduardo Aurélio Pereira Ferri. Publicação no DEJT: 30 set. 2011
} 
Assim, se as atribuições exercidas pela autora se aproximam em parte, embora com mais complexidade, daquelas exercidas pelas recepcionistas e atendentes, tomando-se como base os instrumentos coletivos que lhes são aplicáveis, não se afigura razoável que a obreira perceba piso salarial inferior aos de empregados que exercem função com menos atividades ou atividades mais simples.

Nesse sentido, o juiz relator deu provimento ao recurso ordinário da reclamante, concedendo-lhe as diferenças salariais calculadas com base no piso salarial previsto para a categoria de recepcionista/atendente. Constata-se que o relator não criou simplesmente um piso salarial maior para a autora, por ela exercer funções mais extensas que as de recepcionista, mas, de forma proporcional e razoável, adequou o piso salarial previsto no instrumento coletivo da categoria profissional à realidade vivenciada pela obreira, imprimindo a maior aplicabilidade possível ao artigo $7^{\circ}$, inciso V, da Constituição Federal.

\section{Base de cálculo do adicional de insalubridade: salário-base do empregado}

$\mathrm{O}$ artigo $7^{\circ}$, inciso XXIII, da $\mathrm{CF} / 88$ garante o adicional de remuneração para atividades insalubres. O artigo 192, que regula o adicional de insalubridade desde a publicação da CLT, estabelece que a base de cálculo dessa parcela remuneratória é o salário mínimo.

Contudo, o inciso IV do mesmo dispositivo constitucional veda a vinculação do salário mínimo para qualquer fim. Dessa forma, a partir da promulgação da Constituição de 1998 iniciou-se uma discussão acerca de qual seria a base de cálculo do adicional de insalubridade, situação que perdura até os dias atuais.

Inicialmente, a posição adotada pelo Supremo Tribunal Federal era de que a base de cálculo do adicional de insalubridade poderia ser o salário mínimo, como já previsto no artigo 192 celetista, pois a vedação de vinculação para qualquer fim diria respeito a parcelas não trabalhistas que pudessem fomentar a inflação.

Assim, o Tribunal Superior do Trabalho se manifestou em inúmeros julgados no sentido de que, mesmo após a $\mathrm{CF} / 88$, não teria havido nenhuma alteração, o que restou sedimentado na Súmula n. 228 e na OJ n. 2, da SDI-1.

Ao longo dos anos, porém, o STF foi alterando o seu entendimento no sentido de que a vedação do salário mínimo para qualquer fim impedia que ele continuasse a ser a base de cálculo do adicional de insalubridade. 
Dessa forma, o Supremo acabou por editar a Súmula vinculante n. 4, afirmando expressamente que "o salário mínimo não pode ser usado como indexador de base de cálculo de qualquer vantagem de servidor público ou empregado", acrescentando que esse base de cálculo, entretanto, não pode ser substituída por decisão judicial, o que levou ao cancelamento da Súmula 17, do TST, que previa como parâmetro do adicional a utilização do "salário-profissional”, por construção judicial.

O TST revisou, então, a Súmula 228 que passou a ter a seguinte redação: "A partir de 9 de maio de 2008, data da publicação da Súmula Vinculante n. 4 do STF, o adicional de insalubridade será calculado sobre o salário básico, salvo critério mais vantajoso fixado em instrumento coletivo.

Essa alteração provocou acirrada celeuma, o que levou ao ajuizamento de três reclamações (n. 6.2666, pela Confederação Nacional da Indústria, n. 6.25e, pela Unimed Ribeirão Preto - Cooperativa de Trabalho Médico, e n. 6.277, pela Confederação Nacional da Saúde - Hospitais, Estabelecimentos e Serviços) junto ao STF, questionando a validade do novo texto da Súmula 228, do C. TST.

Ao apreciar o pedido, o presidente do E. STF deferiu liminar para "suspender a aplicação da Súmula 228 do C. TST na parte em que permite a utilização do salário básico para calcular o adicional de insalubridade".

A situação atual acerca da base de cálculo do adicional de insalubridade demonstra que embora o disposto no artigo 192, da CLT, deixou de ser exigível no que se refere à base de cálculo, pois "o salário mínimo não pode ser usado como indexador de base de cálculo de servidor público ou de empregado”, mas também não pode ser substituído por decisão judicial.

Dessa forma, indaga-se: do ponto de vista prático, nada mudou em relação à base de cálculo do adicional? Embora esse venha sendo a postura adotada pela Justiça do Trabalho $^{52}$, desde o deferimento da liminar que suspendeu a parte final da Súmula 228 , do

\footnotetext{
${ }^{52}$ ADICIONAL DE INSALUBRIDADE - BASE DE CÁLCULO - SALÁRIO MÍNIMO (CLT, ART. 192) DECLARAÇÃO DE INCONSTITUCIONALIDADE SEM PRONÚNCIA DE NULIDADE ("UNVEREINBARKEITSERKLARUNG") - SÚMULA 228 DO TST E SÚMULA VINCULANTE 4 DO STF.

1. O STF, ao apreciar o RE-565.714-SP, sob o pálio da repercussão geral da questão constitucional referente à base de cálculo do adicional de insalubridade, editou a Súmula Vinculante 4, reconhecendo a inconstitucionalidade da utilização do salário mínimo, mas vedando a substituição desse parâmetro por decisão judicial.

2. Assim decidindo, a Suprema Corte adotou técnica decisória conhecida no direito constitucional alemão como declaração de inconstitucionalidade sem pronúncia da nulidade ("Unvereinbarkeitserklarung"), ou seja, a norma, não obstante ser declarada inconstitucional, continua a reger as relações obrigacionais, em face da
} 
C. TST, esse entendimento é absurdo, visto que a atuação judicial deve poder suprir a lacuna da norma, sob pena de violar o direito fundamental referente à inafastabilidade da jurisdição, como um dos poderes da República.

Sem embargo, este não é um posicionamento único e uniforme, pois existem vozes no sentido imprimir ao artigo $7^{\circ}$, inciso XXIII, da Constituição uma interpretação atualizada e consentânea com os demais dispositivos que estabelecem parcelas de natureza salarial.

Tereza Aparecida Asta Gemignani acredita que o inciso XIII não determina que o adicional de insalubridade incida sobre a remuneração ${ }^{53}$ (não obstante a redação do dispositivo seja "adicional de remuneração [...] para atividades insalubres"), apenas se referindo a esse termo para fixar a natureza salarial da remuneração, pois, caso o legislador constituinte quisesse estabelecer como base de cálculo a remuneração teria dito "adicional sobre a remuneração". 54

Defende a autora como base de cálculo do adicional de insalubridade o saláriobase, argumentando que o termo é de fácil compreensão, extensão genérica e já é utilizada pela doutrina e jurisprudência, por longa data, como sendo a retribuição dos serviços prestados pelo empregado, por força do contrato de trabalho, sendo pago pelo empregador, que deles se utilizada para a realização dos fins colimados pela empresa. ${ }^{55}$

Assim, ao contrário de outros critérios como o salário profissional, piso normativo da categoria, remuneração e salário contratual, o salário-base seria o único que pode ser utilizado de forma genérica e servir de parâmetro para todo o universo de trabalhadores, urbanos e rurais, independentemente das especificidades de cada categoria, já que não existe trabalhador que não tenha um salário-base.

Ademais, o adicional de periculosidade, também previsto no mesmo artigo $7^{\circ}$, inciso XXIII, da Constituição Federal, a base de cálculo estipulada no parágrafo $1^{\circ}$ da CLT

impossibilidade de o Poder Judiciário se substituir ao legislador para definir critério diverso para a regulação da matéria.

3. Nesse contexto, ainda que reconhecida a inconstitucionalidade do art. 192 da CLT e, por conseguinte, da própria Súmula 228 do TST, tem-se que a parte final da Súmula Vinculante 4 do STF não permite criar critério novo por decisão judicial, razão pela qual, até que se edite norma legal ou convencional estabelecendo base de cálculo distinta do salário mínimo para o adicional de insalubridade, continuará a ser aplicado esse critério para o cálculo do referido adicional, salvo a hipótese da Súmula 17 do TST, que prevê o piso salarial da categoria, para aquelas categorias que o possuam (já que o piso salarial é o salário mínimo da categoria). Cf. BRASIL. Tribunal Superior do Trabalho. RR TST-RR-955/2006-099-15-00.1. 7ª Turma. Ministro Relator: Yves Gandra Martins Filho. Publicação no DJU: 16 maio de 2008.

${ }_{53}$ A remuneração engloba parcelas de natureza salarial e não salarial.

${ }^{54}$ GEMIGNANI, Tereza Aparecida Asta. Direitos fundamentais e sua aplicação no mundo do trabalho: questões controversas. São Paulo: LTr, p. 171.

${ }_{55}$ Ibidem, p. 173. 
foi o salário-base, o que serve de padrão para uma integração analógica por meio de lei já existente. Até mesmo porque é mais razoável sustentar que adicionais previstos no mesmo dispositivo constitucional tenham a mesma base de cálculo. E, em adição, a adoção do salário-base serve fator inibidor da conduta lesiva e estímulo à adoção de providências que tornem mais saudável o ambiente de trabalho.

Ademais, pode-se dizer que de acordo com a Súmula vinculante n. 4, do STF, a base de cálculo do adicional de insalubridade não pode ser substituído por decisão judicial, mas nada impede aplicação da analogia legal, sob pena de violar o princípio da inafastabilidade da jurisdição, pois o juiz não pode se eximir de sentenciar, devendo, para tanto, valer-se das demais normas legais, principalmente de direito do trabalho. ${ }^{56}$

\subsubsection{Direitos relativos à jornada de trabalho}

Trabalho em dois turnos alternados é considerado como trabalho em regime ininterrupto de revezamento

A alteração do sentido e alcance do texto normativo do artigo $7^{\circ}$, inciso XIV, da Constituição Federal, mais especificamente no que diz respeito à expressão "turnos ininterruptos de revezamento" é um dos exemplos mais claros em que a jurisprudência dos Tribunais Regionais do Trabalho e do Tribunal Superior do Trabalho se pautou por uma interpretação constitucional evolutiva.

Durante muitos anos, apenas aos trabalhadores que laboravam, revezadamente, em três ou mais turnos de trabalho, ou seja, de manhã, de tarde e de noite ou de madrugada, era aplicado o inciso XIV do artigo $7^{\circ}$, assegurando a esses empregados uma jornada limitada de 6 horas diárias, salvo no caso de haver ACT ou CCT prevendo jornada mais extensa até o limite de 8 horas.

Entretanto, inúmeros advogados começaram a pleitear a aplicação da jornada de 6 horas para os empregados que laboravam, também de forma revezada, porém em apenas dois turnos, englobando períodos diurnos e noturnos. Embora, inicialmente tenha havido uma certa resistência dos juízes em acatar o pleito formulado, sob o argumento de que os turnos ininterruptos exigiam o labor em pelo menos três turnos, visto que a empresa não poderia paralisar as suas atividades, o entendimento que se firmou nos últimos anos é de

\footnotetext{
${ }^{56}$ Ibidem, p. 188.
} 
que o empregado que labora em mais de um turno, periodicamente trabalhando nos horários diurno e noturno, de forma alternada, prejudica a sua saúde e a sua vida social, pois, além das alterações de metabolismo pelo fato de não dormir durante a noite, está de forma geral em descompasso com a vida de seus familiares e das pessoas em geral, o que dificulta a realização de outras atividades sociais e culturais. Essa releitura do inciso em comento está em consonância com a realidade social dos trabalhadores que laboram em turnos alternados e com o espírito da Constituição, pois a preservação da saúde e o descanso são direitos que devem ser respeitados e observados pelo empregador, ainda que ele adote apenas dois turnos de trabalho, para empresas que funcionem ou não ininterruptamente.

A ementa a seguir relativa ao julgamento de Recurso de Revista no Tribunal Superior do Trabalho demonstra o posicionamento atual e dominante da Justiça do Trabalho em relação à aplicação do artigo $7^{\circ}$, inciso $\mathrm{XIV}$, da $\mathrm{CF} / 88$, que inclusive se encontra sedimentado na Súmula n. $360^{57}$, do C. TST.

RECURSO DE REVISTA. TRABALHO EM REGIME DE ESCALA DE
REVEZAMENTO. TURNOS ININTERRUPTOS. TRABALHO EM DOIS
TURNOS ALTERNADOS. CARACTERIZAÇÃO. PROVIMENTO. O que
enseja a caracterização do trabalho em sistema ininterrupto de revezamento,
conforme previsão constitucional do artigo $7^{\circ}$, XIV, é o fato de o trabalhador
laborar em jornadas de trabalho que demandem, em alternância, o dia, a tarde e a
noite, o que lhe acaba causando males os mais variados pela própria alteração no
sistema biológico do sono, da alimentação, do descanso, isso sem falar no
aspecto social de convivência com a família e lazer regulares. No caso, o
delineamento fático foi traçado pelas instâncias ordinárias e consta,
expressamente, na decisão regional, que o obreiro se ativava das 11 às 22 horas,
alternando depois para o turno seguinte das $19 / 20$ horas às $5 / 6$ horas, fica
caracterizado o chamado trabalho ininterrupto em sistema de revezamento. E não
seria, frise-se, o fato de o reclamante deixar de fazer o turno de revezamento das
6 às 11 horas que lhe retiraria o direito à jornada especial, permanecendo indene
o desgaste físico e até psicológico na adoção dessa jornada, entendimento esse
em consonância com a jurisprudência da SBDI-1 que vem decidindo que, para a
configuração do sistema de trabalho em turnos ininterruptos, não é
imprescindível o trabalho do empregado nos três turnos, bastando o revezamento
entre o trabalho noturno e diurno. Recurso de revista de que se conhece para, no
mérito, reconhecendo o sistema de turnos ininterruptos de revezamento,
condenar a reclamada à paga de horas extraordinárias excedentes da sexta diária
e reflexos, restabelecendo a sentença de primeira instância. ${ }^{58}$

${ }^{57} \mathrm{~N}^{\mathrm{o}} 360$ TURNO ININTERRUPTO DE REVEZAMENTO. DOIS TURNOS. HORÁRIO DIURNO E NOTURNO. CARACTERIZAÇÃO. DJ 14.03.2008. Faz jus à jornada especial prevista no art. $7^{\circ}, \mathrm{XIV}$, da CF/1988 o trabalhador que exerce suas atividades em sistema de alternância de turnos, ainda que em dois turnos de trabalho, que compreendam, no todo ou em parte, o horário diurno e o noturno, pois submetido à alternância de horário prejudicial à saúde, sendo irrelevante que a atividade da empresa se desenvolva de forma ininterrupta.

${ }^{58}$ BRASIL. Tribunal Superior do Trabalho. RR 768358/2001.3. $1^{\text {a }}$ Turma. Ministra Relatora: Dora Maria da Costa. Publicação no DJU: 31 ago. 2007. 
No mesmo sentido, o Tribunal Regional da $1^{\text {a }}$ Região (Rio de Janeiro), interpretou o art. $7^{\circ}$, inciso XIV, da CF/88 (que prevê a jornada de 6 horas para o turno ininterrupto de revezamento) no sentido de que o trabalhador que exerce suas atividades em sistema de alternância de turnos, ainda que em dois turnos de trabalho, submete-se à alternância de horários prejudicial à saúde, sendo irrelevante que a atividade da empresa se desenvolva sem nenhuma pausa. Portanto, o termo ininterrupto foi compreendido no sentido de atividade constante e desenvolvida em mais de um turno que prejudica a saúde do trabalhador, sendo irrelevante que ela seja interrompida durante um dos três turnos diários. $^{59}$

\section{Direito do empregado doméstico a receber horas extraordinárias}

Os empregados domésticos sempre foram uma categoria mais explorada e que demorou a obter a garantia de alguns direitos trabalhistas. Apenas em 1973, a Lei n. 5.859/72 elencou os direitos aplicáveis ao trabalhador doméstico e o Decreto n. 71.885/73 definiu os pressupostos de configuração do vínculo empregatício desse tipo de trabalhador. A Lei n. 11.324/06 alterou a redação de alguns dispositivos da Lei n. 5.859/72, inclusive em relação ao período de férias que passou a ser de 30 (trinta) dias corridos, a inclusão do direito ao descanso remunerado em feriados e a proteção contra dispensa arbitrária ou sem justa causa da gestante desde a confirmação da gravidez até 5 (cinco) meses após o parto. A Lei n. 10.208/01, ademais, faculta ao empregador efetuar o depósito do FGTS para o trabalhador doméstico.

No âmbito constitucional, a Lei Fundamental estabeleceu no artigo $7^{\circ}$, parágrafo único, os direitos mínimos assegurados aos trabalhadores domésticos, quais sejam, salário mínimo, irredutibilidade salarial, décimo terceiro salário, repouso semanal remunerado, férias acrescidas de um terço; licença à gestante, licença-paternidade, aviso prévio proporcional ao tempo de serviço e aposentadoria.

Dessa forma, a Constituição diferenciou os direitos fundamentais trabalhistas garantidos ao empregado doméstico e ao empregado em geral, limitando substancialmente os direitos para a categoria dos domésticos.

Um dos dispositivos que mais gera polêmicas em relação à sua não aplicação ao trabalhador doméstico é o direito à limitação de jornada, previsto no inciso XIII do artigo ${ }^{59}$ RIO DE JANEIRO. Tribunal Regional da $1^{\mathrm{a}}$ Região. RO 00611.2007.005.05.00.7, $4^{\mathrm{a}}$ Turma, Rel.
Desembargador Valtércio de Oliveira. Publicação no DJ: 21 ago. 2008. 
$7^{\circ}$ da $\mathrm{CF} / 88$. Os argumentos contrários à extensão desse direito aos domésticos geralmente se atêm à dificuldade de controle de horário desse tipo de trabalhador, visto que as tarefas relacionadas ao trabalho se misturam, às vezes, com momentos de descanso e de afazeres pessoais e não profissionais. Assim, existe enorme resistência do legislador infraconstitucional em estender esse direito fundamental ao doméstico, o mesmo ocorrendo no âmbito jurisprudencial.

Contudo, o caso julgado pelo Tribunal do Trabalho da $2^{\mathrm{a}}$ Região, apresentado a seguir, demonstra que foi atribuído ao artigo $7^{\circ}$, parágrafo único, da $\mathrm{CF} / 88$, uma interpretação evolutiva no que tange à limitação de jornada do doméstico. Esse dispositivo não assegura ao doméstico a limitação de jornada do inciso XIII, nem a remuneração adicional em caso de labor extraordinário do inciso XVI do mesmo artigo constitucional, mas, ao mesmo tempo, não faz expressa referência à ausência de limitação de jornada de tal classe de trabalhadores ou de proibição de recebimento de adicional de horas extras. Como a dignidade da pessoa humana da Constituição, todos os seus dispositivos devem ser interpretados de forma teleológica. O propósito da especificação constitucional de garantia de alguns direitos ao empregado doméstico vem das particularidades de tal atividade. Garante o mínimo, sem prejuízo de lei própria que regularize a particular profissão. Ocorre que, até o momento, nenhuma lei especial cuidou de regulamentar a jornada do empregado doméstico, o que não pode deixá-lo à margem da lei, da proteção constitucional à dignidade humana.

EMPREGADO DOMÉSTICO. HORAS EXTRAORDINÁRIAS.
DEFERIMENTO. A Constituição da República Federativa do Brasil tem como
fundamento básico o princípio da dignidade humana. A negativa de limitação de
jornada ao trabalhador doméstico e de pagamento adicional por horas
extraordinariamente laboradas é retrocesso social, vez que o parágrafo único do
artigo sétimo do Texto Maior não pode ser interpretado como forma de
marginalização do empregado doméstico, mas sim como garantidor de direitos
mínimos. A ausência de lei especial que regulamente jornada e remuneração
adicional pelo trabalho extraordinário do trabalhador doméstico impõe ao
julgador o dever de aplicar norma geral ao trabalhador diferenciado, de forma
analógica, nos termos do artigo oitavo da CLT, a fim de cumprir com seu dever
de distribuir justiça. ${ }^{60}$

O desembargador relator Marcos Neves Fava ressalta a inércia do legislador infraconstitucional em regular a matéria de limitação de jornada dos domésticos e diz que a tarefa e dever do Judiciário é implementar esse direito social.

\footnotetext{
${ }^{60}$ SÃO PAULO. Tribunal Regional do Trabalho da $2^{\mathrm{a}}$ Região. RO 01403200905802009. 14 $4^{\mathrm{a}}$ Turma. Relator: Juiz Marcos Neves Fava. Publicação no DJSP: 05 jul 2011.
} 
Reconhecer que a Constituição Federal da República do Brasil marginalizou os empregados domésticos, deixando nas mãos do empregador, parte hipersuficiente da relação jurídica, o poder de exigir do trabalhador quantas horas de trabalho diário entender necessárias, é admitir que a permanência legal do regime de escravidão, flagelando parte dos trabalhadores. É negar seus fundamentos na dignidade da pessoa humana, no valor social do trabalho, previstos em seu primeiro artigo e seus objetivos de construção de uma sociedade igualitária sem discriminação.

No caso em tela, o Judiciário - instrumento de distribuição de justiça - não pode se mostrar inerte e decidir pela marginalização de toda uma classe de trabalhadores em face de lacuna legal. Não. Deve cumprir sua função, suprindo a inércia legislativa a fim de preservar os princípios nos quais se fundamenta a Carta Maior.

Agiu em exemplar cumprimento de seu dever legal, o Juízo de primeira instância, em não se calar diante da injustiça da omissão legal que se demonstra, em combate ao retrocesso social, aplicando, por analogia, conforme artigo oitavo da norma consolidada, os limites constitucionais de jornada e aplicar o adicional mínimo sobre as horas que a excedem. ${ }^{61}$

Marcus Orione Gonçalves Correia também acredita que o parágrafo único do art. $7^{\circ}$ da Constituição não só assegura aos trabalhadores domésticos os direitos ali assegurados, como não veda a utilização de outros que não os constantes no rol. "Tanto isto é verdade que ao trabalhador doméstico não é vedada a utilização da prescrição bienal prevista no inc. XXIX do art. $7^{\circ}$, não constante da relação". Assim, se é possível estender a restrição a um direito, como o prazo prescricional, com muito mais razão é possível a extensão de direitos, se as situações forem semelhantes ${ }^{62}$ entendimento o qual perfilha-se nessa tese.

\subsubsection{Direitos relativos à proteção à maternidade $\mathrm{e}$ à paternidade}

Direito de assistência gratuita aos filhos e dependentes em creches e pré-escolas até os 5 (cinco) anos de idade: norma de aplicabilidade direta

$\mathrm{O}$ artigo $7^{\circ}$, inciso XXV, da Constituição Federal de 1988, garante aos empregados, homens e mulheres, o direito à assistência gratuita aos filhos e dependentes em creches e pré-escolas até os cinco anos de idade. Esse dispositivo normativo se dirige aos empregadores e deve, necessariamente, ser por eles assegurado por é direito fundamental dos trabalhadores que tenham filhos ou dependentes até cinco anos de idade.

Todavia, na prática nem sempre esse direito fundamental é observado, pois, inúmeras vezes, o empregado tem que pagar uma creche ou escola para o filho ficar

\footnotetext{
${ }^{61}$ Ibidem.

62 CORREIA, Marcus Orione Gonçalves. O postulado da razoabilidade e o Direito do Trabalho. In: CORREIA, Marcus Orione Gonçalves (Org.). Curso de Direito do Trabalho. Op. cit., p. 136.
} 
enquanto trabalha, ou mesmo contar com a disposição e a boa vontade de parentes e amigos para tomar conta de seus filhos.

Não existe nenhum empecilho constitucional ou legal para entender que o referido dispositivo normativo não seja auto-aplicável, não sendo necessária a criação de lei específica para regular a matéria.

Defende-se, portanto, a aplicabilidade imediata do inciso XXV do artigo $7^{\circ}$, de modo que, uma vez comprovado que o empregado tenha filhos ou dependentes, o empregador deverá optar por qualquer das possibilidades seguintes para implementar esse direito fundamental: manutenção de creche na empresa onde labore a mãe, no período de amamentação dos filhos, nos termos do art. 389, parágrafo $1^{\circ}$, da CLT; a existência de convênio entre a empresa e estabelecimentos próximos para cuidado das crianças, nos termos do parágrafo $2^{\circ}$ do mesmo dispositivo legal; a existência de auxílio-creche, em que a empresa paga ou reembolsa o valor referente à creche dos filhos, nos termos da Portaria MTb/GM 3.296/86, se o benefício for estipulado via ACT ou CCT.

O empregador poderá optar, ainda, por manter creche ou escola pré-escolar para filhos ou dependentes dos seus empregados, mesmo fora do período de amamentação, ou fornecer o auxílio-creche, na forma de um valor mensal, independentemente de previsão em acordo ou convenção coletiva de trabalho.

A interpretação que entende que esse dispositivo constitucional tem aplicabilidade limitada, além de involutiva, pois não existe nenhum tipo de impedimento à concretização desse direito fundamental do trabalhador, ainda atenta contra os direitos de guarda e proteção das crianças pelos seus pais ou representantes legais, estabelecido no artigo 227, da $\mathrm{CF} / 88$.

No julgamento do caso concreto a seguir, a desembargadora Denise Alves Horta imprimiu interpretação evolutiva ao artigo $7^{\circ}$, inciso XXV, da Constituição Federal, embora não tenha sequer mencionado esse dispositivo constitucional. A relatora, ao observar que o empregador não cumpriu a regra do artigo 389 , parágrafo $1^{\circ}$, da CLT, que estabelece o direito da mãe estar perto do filho, durante o período de amamentação, por meio da manutenção, pelo empregador, de local apropriado para a guarda das crianças nessa fase, entendeu que esse fato enseja a rescisão indireta do contrato de trabalho por descumprimento de obrigação contratual por parte do empregador. Sem embargo, a relatora poderia ter ido até mais além, em sua argumentação, porque o descumprimento desse artigo celetista não é apenas uma obrigação contratual que deixou de ser observada, mas um direito fundamental da empregada que a empresa diretamente violou. 
RESCISÃO INDIRETA. MATERNIDADE. DESCUMPRIMENTO DO ART. 389, PARÁGRAFOS $1^{\circ}$. E $2^{\circ}$. DA CLT. O direito de exercer a maternidade não pode ser privado das condições mínimas necessárias à presença materna, na fase de amamentação. Logo, o descumprimento pela empregadora da obrigação de manter local apropriado onde seja permitido às empregadas guardar sob vigilância e assistência os seus filhos, no período da amamentação, na forma da lei e do instrumento normativo vigente para a categoria, constitui motivo justificador da rescisão indireta do contrato de trabalho, para a empregada, mãe, submetida a esse contexto. ${ }^{63}$

\section{Direito à licença-paternidade do pai adotivo}

$\mathrm{O}$ artigo $7^{\circ}$, inciso XIX, estabelece o direito à licença-paternidade, nos temos fixados em lei. Por seu turno, o artigo 10, parágrafo $1^{\circ}$, do ADCT garante, enquanto não vier a lei previsto no referido inciso do artigo $7^{\circ}$, o direito a 5 (cinco) dias de licençapaternidade.

Sem embargo, nada se fala a respeito da licença-paternidade para o pai que adota criança, ao contrário da licença-maternidade para a mãe-adotiva ${ }^{64}$ que foi disciplinada na Consolidação das Leis do Trabalho, no artigo392-A, com redação dada pela Lei n. 10.421/02 e posteriormente alterada pela Lei n. 12.010/09, e na Lei 8.213/91, que estabelece os benefícios previdenciários, no artigo 71-A .

Ora, da mesma forma que a licença-maternidade é um período necessário para a boa adaptação da criança adotada à mãe adotiva e para os estreitamentos do laço materno, também a presença e vínculo paternos são muito importantes para o desenvolvimento da criança adotada. Percebe-se, portanto, que a interpretação que mais se coaduna com a necessidade preeminente do estreitamento do contato entre criança e pai adotivo é que entende que a noção de paternidade é ampla e não se restringe apenas aos vínculos biológicos.

Essa interpretação evolutiva do termo "paternidade" é muito relevante, pois está em consonância com os dispositivos constitucionais que informam que a família é a base da sociedade e que a criança merece proteção da família, da sociedade e do Estado no sentido de assegurar-lhe, prioritariamente, vários direitos, inclusive o direito à convivência familiar (artigo 227, caput, CF/88).

\footnotetext{
${ }^{63}$ MINAS GERAIS. Tribunal Regional do Trabalho da $3^{\text {a }}$ Região. RO 00969-2006-091-03-00-0. Desembargadora Relatora: Denise Alves Horta. Publicação no DEJT: 28 fev. 2007.

${ }^{64}$ Atualmente, a licença-maternidade para a mãe adotiva é de 120 (cento e vinte) dias, independentemente da idade da criança.
} 
Dessa forma, deverá ser assegurado ao pai adotivo que adota criança 5 (cinco) dias de licença-paternidade, da mesma forma que já é assegurado ao pai biológico.

\subsubsection{Direitos relativos à não-discriminação}

Direito de reintegração ao trabalho ou de pagamento do período de afastamento em dobro do empregado dispensado por motivo de doença, condição física, opção sexual, mapa genético insatisfatório ou inclusão em listas negras, além de percepção dos danos morais sofridos

A República Federativa do Brasil tem como um de seus objetivos a erradicação de qualquer forma de discriminação (artigo $3^{\circ}$, inciso IV da $\mathrm{CF} / 88$ ), pois o texto do dispositivo constitucional deixa claro que não serão admitidas discriminações por motivo de origem, raça, sexo, cor, idade e "quaisquer outras formas de discriminação". O caput e o inciso LXI do artigo $5^{\circ}$ da $\mathrm{CF} / 88$ asseguram, respectivamente, que todos são iguais perante a lei, sem distinção de qualquer natureza e que a lei punirá qualquer discriminação atentatória dos direitos e liberdades fundamentais.

Especificamente no que tange à seara das relações de trabalho, o legislador constituinte estabeleceu preceitos específicos sobre isonomia e não-discriminação no artigo $7^{\circ}$, incisos XXX (proíbe diferença de salários, de exercício de funções e de critérios de admissão por motivo de sexo, idade, cor ou estado civil), XXXI (proíbe qualquer discriminação no tocante à salário e critério de admissão do portador de deficiência), XXXII (proíbe qualquer distinção entre o trabalho manual, técnico e intelectual e entre os profissionais respectivos).

A Lei n. 9.029, de 13 de abril de 1995, veio para corroborar os postulados da nãodiscriminação e da isonomia, proibindo, em seu artigo $1^{\circ}$, "a adoção de qualquer prática discriminatória e limitativa do acesso à relação de emprego, ou a sua manutenção, por motivo de sexo, origem, raça, cor, estado civil, situação familiar ou idade, ressalvadas, neste caso, as hipóteses de proteção ao menor previstas no inciso XXXIII do artigo $7^{\circ}$ da Constituição Federal" (grifos nossos).

Essa lei introduziu, no Brasil, de forma expressa e inequívoca, uma nova medida restritiva do direito de despedir, direcionada precisamente à vedação à despedida abusiva por motivo discriminatório. 
Observa-se que dentre as hipóteses de discriminação vedadas pelo artigo $7^{\circ}$, inciso XXX, da CF/88 estão os motivos de sexo, idade, cor ou estado civil. $\mathrm{O}$ artigo $1^{\circ}$ da Lei $\mathrm{n}$. 9.029/95 elencou, expressamente, mais alguns motivos discriminatórios que são vedados no âmbito da relação de emprego, tais como a origem, a raça, a cor e a situação familiar ${ }^{65}$.

É importante salientar que, na verdade, a lei infraconstitucional não ampliou as hipóteses de vedação à discriminação ao empregado, como se o legislador constituinte houvesse se esquecido de citar outros motivos discriminatórios e fosse necessário ao legislador infraconstitucional completá-los. O que a Lei n. 9.029/95 fez foi explicitar, para evitar qualquer sombra de dúvida, que a origem, a raça, a cor e a situação familiar também são motivos que não podem ser utilizados pelo empregador para realizar qualquer tipo de discriminação no que se refere à contratação ou manutenção do vínculo empregatício. Até mesmo porque o artigo $7^{\circ}$, inciso $\mathrm{XXX}$, da $\mathrm{CF} / 88$ apenas exemplifica alguns motivos discriminantes que são proibidos no que tange a salários, ao exercício de funções e a critério de admissão, não vedando a existência de outros motivos. Ou seja, a relação de motivos do artigo $7^{\circ}$, inciso $\mathrm{XXX}$ não é taxativa, até mesmo porque o legislador infraconstitucional ampliou o rol de motivos e incluiu a vedação à dispensa discriminatória, dando alguma aplicabilidade ao artigo $7^{\circ}$, inciso I da CF/88. Portanto, o rol de motivos de discriminação disposto no artigo $7^{\circ}$, inciso XXX e no artigo $1^{\circ}$ da Lei $n$. 9.029/99 e apenas exemplificativo, e não taxativo, como tem compreendido alguns juízes e doutrinadores que tentam imprimir à referida Lei e, ainda pior, a um dispositivo constitucional que estabelece um direito fundamental trabalhista uma interpretação restritiva e desatualizada, levando-se em consideração que, com as mudanças sociais e tecnológicas, constantemente podem surgir outras formas de discriminação utilizadas pelas empresas para simplesmente deixar de contratar um empregado, pagar-lhe salários diferenciados sem motivo plausível pertinente ou, sobretudo, para dispensá-los.

\footnotetext{
${ }^{65}$ Estévão Mallet menciona a situação familiar, que, além da Lei n. 9.029/95, está disposta no artigo 373 da CLT. "A filiação, como causa de discriminação, é completamente repudiada. Não se pode, por conta da filiação do trabalhador, negar-lhe certo direito. A Cour de Cassation francesa acertadamente considerou nula a dispensa do empregado decorrente do "le lien de filiation l'unissant à un autre salarié de l'entreprise". A recíproca é igualmente verdadeira. Tampouco se pode favorecer alguém em virtude de sua filiação. A conclusão a que chegou a Suprema Corte norte-americana em Kotch v. Board of River Port Pilot Com'rs for Port of New Orleans, ao validar a seleção de novos pilotos de navio feita de modo a favorecer sempre "relatives and friends", não é correta. Tinha toda razão o juiz Rutledge ao anotar, na sua dissenting opinion: "the result of the decision therefore is to approve as constitutional state regulation which makes admission to the ranks of pilots turn finally on consanguinity. Blood is, in effect, made the crux of selection. That, in my opinion, is forbidden by the fourteenth amendment's guaranty against denial of the equal protection of the laws". É muito pouco provável que hoje prevalecesse, na Suprema Corte, a decisão da maioria. Cf. MALLET, Estévão. Discriminação, igualdade e direito do trabalho. Revista do Tribunal Superior do Trabalho, Brasília, v. 76, n. 3, jul./set.2010, p. 29.
} 
Ana Lúcia Coelho de Lima reforça esse entendimento, no que se refere à Lei n. 9.029/95.

\begin{abstract}
A lei n. 9.029/1995 se destina a vedar toda e qualquer forma de discriminação patronal, independentemente do motivo da discriminação, não sendo exaustivo o elenco apresentado nas suas letras. Apesar de o dispositivo arrolar práticas discriminatórias por motivo de sexo, origem, raça, cor, estado civil, situação familiar ou idade, não significa que as demais formas de discriminação não estejam abrangidas pela norma, na medida em que o dispositivo também traz expresso que "[...] fica proibida a adoção de prática discriminatória [...]", sendo certo que a lei não contém palavras inúteis. Portanto, tal enumeração não pode ser compreendida como taxativa, pois, se assim fosse, o preceito legal não faria menção a "qualquer prática discriminatória". ${ }^{66}$
\end{abstract}

Estévão Mallet, por seu turno, compreende que as hipóteses estabelecidas no artigo $7^{\circ}$, inciso $\mathrm{XXX}$, da $\mathrm{CF} / 88$ são apenas exemplificativas, imprimindo uma interpretação atualizada, sistemática e de acordo com o espírito do legislador constituinte.

\begin{abstract}
Sem embargo das hipóteses mencionadas, o certo é que esse art. $7^{\circ}$, inciso XXX, da Constituição, traça apenas parâmetros exemplificativos. A Constituição pode-se claramente inferir isso do seu sistema e, especialmente, da parte final do seu art. $3^{\circ}$, inciso IV - proíbe genericamente qualquer forma de discriminação. Aliás, outras formas de discriminação acham-se mencionadas em dispositivos diversos, mas que têm toda a pertinência no campo do Direito do Trabalho. O art. $7^{\circ}$, inciso XXX, não se refere à discriminação por motivo de crença religiosa. Mas o art. $5^{\circ}$, inciso VIII, da mesma Constituição, alude à proibição de discriminação por esse motivo, solução que se estende, sem dúvida nenhuma, ao campo do Direito do Trabalho. ${ }^{67}$
\end{abstract}

A proposta que se apresenta nessa tese, e que já vem sendo observada por parte da jurisprudência trabalhista, é de ampliação das hipóteses do artigo $7^{\circ}$, inciso XXX da Constituição Federal de 1988, em virtude do espírito da Constituição, levando-se em consideração os aspectos sistemático e teleológico da norma.

Atento às alterações do mundo científico, o Supremo Tribunal Federal, no julgamento do Habeas Corpus n. 84.424/RS, também conhecido como "caso Ellwanger", atualizou o conceito de raça, inclusive para fins de tipificação do crime imprescritível de racismo, previsto no artigo $5^{\circ}$, inciso XLKK, da Constituição Federal, devido a alterações ocorridas no contexto social. Assim, a versão original provavelmente prevista pelo legislador constituinte era de que a tutela contra a não-discriminação se dirigia aos indivíduos de raça negra, em virtude do histórico da escravidão existente no Brasil, e a

\footnotetext{
${ }^{66}$ LIMA, Ana Lúcia Coelho. Dispensa discriminatória na perspectiva dos direitos fundamentais. São Paulo: LTr, 2009, p. 109.

${ }^{67}$ MALLET, Estévão. Op. cit., p. 29.
} 
outras "raças" normalmente conhecidas (amarelos, vermelhos, etc.). Sem embargo, em virtude das descobertas do projeta genoma humano de que não existem raças no sentido biológico, sua interpretação teve de ser alterada de modo a tutelar outros grupos humanos também passíveis de discriminação, incluindo os judeus. ${ }^{68}$

Pode-se dizer, então, que se o STF alterou a concepção de um motivo discriminante, qual seja, a "raça", com ainda mais motivo deve-se entender que o rol do artigo $7^{\circ}$, inciso XXX da CF/88 e do artigo $1^{\circ}$ da Lei n. 9.029/99 é exemplificativo, pois o legislador constitucional ou infraconstitucional não tem condições de elencar todos os motivos que podem ser utilizados pelo empregador como forma de discriminação, até mesmo em virtude das mudanças sócio-econômicas e tecnológicas. Essa interpretação, que pode ser compreendida como "evolutiva", está em consonância com toda a sistemática constitucional que veda qualquer tipo de discriminação entre os indivíduos de uma forma geral, como objetivo da República Federativa do Brasil a ser constantemente perseguido e como direito fundamental expressamente estabelecido na Lei Maior. Assim, não seria na relação de emprego que o constituinte reduziria as hipóteses de discriminação, justamente em uma relação jurídica que é caracterizada pelo desequilíbrio entre os seus sujeitos.

Dessa forma, qualquer motivo que não tenha por objetivo imprimir igualdade aos sujeitos da relação empregatícia - como as "discriminações positivas", incluindo as que dizem respeito ao mercado de trabalho da mulher, do menor e do deficiente - ou que não sirva para imprimir diferenças legítimas ${ }^{69}$ e justificadas entre os empregados, sobretudo em se tratando do tipo de atividade a ser exercida, não poderá ser utilizado para efeito de discriminação no âmbito das relações de trabalho, com ênfase para a relação de emprego. Dentre esses motivos se incluem questões relativas à saúde, ou seja, discriminações por motivo de qualquer doença ou síndrome (AIDS, câncer, hanseníase, hepatite C, por exemplo) física ou psíquica, atual ou futura (em se tratando de empresas que exigem a realização de exame genético ${ }^{70}$ para averiguação de possíveis problemas de saúde a serem

\footnotetext{
${ }^{68}$ Para maiores detalhes sobre o julgamento do "caso Ellwanger", vide LAFER, Celso. A internacionalização dos direitos humanos: Constituição, racismo e relações internacionais. Barueri, SP: Manole, 2005.

69 O art. 23, n. 1, do Código do Trabalho de Portugal, que trata da proibição da discriminação, apresenta amplo rol exemplificativo de motivos que não podem ensejar discriminação. Ademais, o art. 23, n. 2 faz uma distinção entre as discriminações e as diferenças que podem ser estabelecidas no âmbito da relação de emprego: "Não constitui discriminação o comportamento baseado num dos fatores indicados no número anterior, sempre que, em virtude da natureza das atividades profissionais em causa ou do contexto de sua execução, esse fator constitua um requisito justificável e determinante para o exercício da atividade profissional, devendo o objetivo ser legítimo e o requisito proporcional".

${ }^{70}$ Outro tipo de discriminação que pode ocorrer no mundo do trabalho advém dos avanços científicos no campo da biotecnologia. Assim, a discriminação genética, por meio da exigência ou do pedido de exame de
} 
desenvolvidos pelo candidatou ou empregado já contratado), de opção sexual, de religião, de convicção filosófica ou política, de nacionalidade, de condição física (incluindo obesos, pessoas de baixa estatura, anões, entre outros), de participação em sindicatos, associações ou cooperativas, de participação em movimentos grevistas, de ajuizamento de ações trabalhistas ou outros tipos de ações (quando o nome do empregado consta das chamadas "listas negras"), entre outras 71 .

A importância da compreensão ampla acerca dos motivos discriminatórios que podem gerar diferenças ilegítimas no âmbito da relação de trabalho repousa nas consequências previstas em lei, em se tratando de discriminação perpetrada pelo empregador em relação ao empregado.

Dessa forma, em caso de qualquer motivo utilizado pelo empregador para discriminar o empregado, esse terá direito à indenização por danos morais, em virtude do sofrimento psíquico causado ao obreiro. Ademais, havendo rompimento da relação de

DNA, pode ocorrer caso o empregador vislumbre a tendência do empregado de desenvolver algumas doenças. Conforme Estévão Mallet, o Código de Trabalho de Portugal, em seu artigo 22, n. 2, que "Nenhum trabalhador ou candidato a emprego pode ser privilegiado, beneficiado, prejudicado, privado de qualquer direito ou isento de qualquer dever, em razão, nomeadamente, de ... património genético...”. Ademais, o Genetic Information Nondiscrimination Act de 2008, estabelece ser ilegal um empregador "(1) to fail or refuse to hire, or to discharge, any employee, or otherwise to discriminate against any employee with respect to the compensation, terms, conditions, or privileges of employment of the employee, because of genetic information with respect to the employee; or (2) to limit, segregate, or classify the employees of the employer in any way that would deprive or tend to deprive any employee of employment opportunities or otherwise adversely affect the status of the employee as an employee, because of genetic information with respect to the employee". Cf. MALLET, Estévão. Op.cit., p. 32.

De acordo com Elaine Nassif, a genética poderá despertar a máxima de Taylor de que existe um homem certo para cada tipo de trabalho. "O papel do Direito é preservar a intimidade do indivíduo, sua identidade pessoal, inclusive biológica, genética, perante os avanços da tecnologia, evitando a utilização, a manipulação dessa intimidade para o alcance de um poder sem limites sobre outras pessoas e sobre o conhecimento." A autora narra o perigo da manipulação de dados genéticos para o futuro de um ser humano. "Quem assistiu o filme "Gattaca" lembra-se de que as chances de uma pessoa ser bem sucedida estavam na avaliação dos seus genes. Eram dois irmãos, um fruto do amor, concebido numa linda noite de lua numa praia e o outro foi encomendado com o que havia de melhor em genes. O resultado foi o que o primeiro era franzino, míope e tinha problema de coração, e nunca poderia seguir a carreira que desde pequeno desejou, que era de astronauta. O outro foi feito para dar certo e se adaptar à sociedade dos superdotados. Esse tipo de manipulação genética pode certamente levar a uma luta por dominação em vários campos, desde uma luta de família, raças ou países, ou sabese lá de indústrias, de conhecimento, ou do que quer que seja. Quem tiver as pessoas - o material humano mais apropriado para desenvolver tal tipo de tarefa que é necessária para manutenção do poder certamente terá esse poder. Que força terá a ética perante as forças seculares, milenares que conduzem o homem à competição?”. Cf. NASSIF, Elaine. Genética e discriminação no trabalho: uma cogitação. Revista do Tribunal do Trabalho da $3^{\text {a }}$ Região, Belo Horizonte, v. 30, n. 60, jul./dez. 1999, p. 109118.

${ }^{71}$ Estévão Mallet menciona a existência de outras formas de discriminação, como "as indicadas pela Lei belga de 10 de maio de 2007, a saber, fortuna, língua e origem social. A Carta dos direitos fundamentais da União Europeia também menciona a discriminação por motivo de 'riqueza'. O Código do Trabalho francês alude à discriminação fundada em hábitos ou costumes. Também a opção sexual da pessoa não pode ser causa de discriminação, como deixa expresso, aliás, a Lei belga há pouco referida. A Lei $n^{\circ} 9.029$ não abrange a hipótese, pois trata de discriminação por motivo de sexo, o que é diverso. Não importa. Nenhuma dessas formas de discriminação se admite, ainda que não exista previsão expressa no Direito brasileiro". Cf. MALLET, Estévão. Op. cit. p. 30. 
trabalho por ato discriminatório, o empregador poderá optar entre a readmissão (leia-se reintegração), com ressarcimento integral de todo o período de afastamento, mediante o pagamento das remunerações devidas, corrigidas monetariamente, acrescidas dos juros legais, ou a percepção, em dobro, da remuneração do período de afastamento, corrigida monetariamente e acrescida dos juros legais, consoante o disposto no artigo $4^{\circ}$ da Lei $n$. 9.029/95.

Em ementa esclarecedora sobre os efeitos da dispensa discriminatória pelo fato de o empregado ser portador do vírus HIV, o desembargador relator Luiz Otávio Linhares Renault, expôs o seu entendimento acerca da redação do artigo $7^{\circ}$, inciso XXX da Constituição Federal de 1988 e do artigo $1^{\circ}$ da Lei n. 9.029/95, interpretando evolutivamente esses dispositivos que vedam qualquer tipo de discriminação entre os trabalhadores, inclusive para fins de dispensa do empregado. Embora não tenha mencionado exatamente os referidos artigos, dando maior relevo aos efeitos do artigo $7^{\circ}$, inciso I da Constituição - no sentido de conferir-lhe alto grau de aplicabilidade, ainda que sem a referida lei complementar para regulamentá-lo, a partir do momento em que o trabalhador não poderia ser dispensado por motivos discriminatórios - o desembargador demonstra a importância de se fazer uma leitura atualizada da Constituição, a partir das modificações sociais, das alterações na realidade social, que impelem uma interpretação no sentido de implementar os direitos fundamentais trabalhistas. O fato de o empregado ser portador de alguma doença não pode ser, portanto, autorizador de qualquer tipo de discriminação no trabalho, inclusive para efeito de dispensa, ainda que o artigo $7^{\circ}$, inciso XXX da Constituição Federal de 1988 e o artigo $1^{\circ}$ da Lei n. 9.029/95 não tenham mencionado expressamente a saúde ou a falta dela como motivo discriminante.

PORTADOR DE HIV - PROTEÇÃO CONTRA A DESPEDIDA ARBITRÁRIA OU SEM JUSTA CAUSA - HIPÓTESES IMPLICITAMENTE ESCRITAS NO ART. 7o., INCISO I, E EM OUTROS DA CONSTITUIÇÃO FEDERAL, ASSIM COMO NA LEGISLAÇÃO ORDINÁRIA - PORTADORA DO VÍRUS HIV - A FACE OCULTA DA CONSTITUIÇÃO E O INTÉRPRETE - DISCRIMINAÇÃO E ABUSO DE DIREITO- O juiz deve caminhar dentro e fora da norma jurídica, isto é, em seu interior e em seu exterior, sem ultrapassar as barreiras do ordenamento jurídico fundamental, porque o tempo e a realidade social modelam e remodelam; desenham e redesenham a dimensão institucional de determinado direito. Essa afirmativa, talvez um pouco ousada, pode soar mal aos ouvidos de muitas pessoas, afeitas ou não ao Direito. Por isso uma breve explicação: quase nunca a norma jurídica diz tudo o que deveria dizer. Nem poderia, uma vez que, além da névoa que encobre certos aspectos da vida social por vir, quanto mais casuística ela for, tanto maior a possibilidade de injustiças. O Direito possui um fim belíssimo em favor do qual devemos lutar: a realização da Justiça. Mais do que um artista, o jurista pode talhar, sem retalhos, a solução - mãos justas e equânimes para determinada 
controvérsia. Todavia, sem os fatos, sem a realidade, o Direito não tem vida; sua soma é nula, seu fim são fragmentos sem colagem. Nunca, como na atual quadra da história, os juízes do trabalho tiveram tanta responsabilidade sócioeconômica. Nunca as decisões do Judiciário tiveram tamanha importância individual e coletiva, assim com tanta repercussão. Nunca os magistrados foram tão fiscalizados, tão cobrados em produção e qualidade. Julgar é um ato solitário, que requer ciência e consciência social. Recolhido em seu âmago, em seu interior, em seu íntimo, em seu debate unilateral, em seu monólogo inquietante, em seu ventríloquo diálogo, o juiz não pode desprezar o mundo que o cerca estar em si e fora de si, para realizar a justiça em quem e para quem a pede. No momento do julgamento, o seu pensar tem de estar povoado pela realidade social, da qual é parte, agente e ator. [...] Se os juízes não puderem estar maisalém do seu tempo, que pelo menos estejam no seu tempo; nunca aquém. Para julgar exigem-se os fatos, o conhecimento profundo da Ciência do Direito e a sensibilidade, isto é, o dom de estar no lugar do outro e perceber que a sua virtude, ser justo, dando a cada um o que é seu, se realiza fora de si. O juiz não perde nem ganha nenhuma demanda. Sente-se completamente realizado quando decide corretamente, com justiça. O mundo transforma-se cada vez mais rapidamente. As leis muito lentamente. Quem aviva e atualiza o Direito, são os intérpretes. Ler é reler. É apreender o sentido de cada palavra, de cada frase e do conjunto. Ler é, portanto e acima de tudo, interpretar, compreender e atribuir um sentido social e atual ao que foi dito pelo legislador, visando ao bem comum. A essência, vale dizer, o espírito da lei é também, de certa forma, a nossa essência, o nosso espírito, a nossa alma. Da mesma maneira que não existe vida sem luz, não existe linguagem sem metáfora, sem um dizer para além das palavras. Costumo afirmar que, em toda norma jurídica, faltam ou sobram palavras. Tudo depende mais do intérprete, do que do próprio texto, que sempre possui um contexto, um transtexto, um metatexto. Em suma, toda norma jurídica é, de certa forma, uma cópia de quem a cria: ela se esconde nela própria; possui um lado muito visível, muito claro, mas possui também um lado oculto, obscuro, aguardando para ser descoberto no momento exato; ser analisado, interpretado, compreendido e ser aplicado aos casos novos. Em certas situações pode ocorrer deficiência na interpretação; nunca na norma jurídica. Os conceitos de discriminação e preconceito podem ser extraídos de seus próprios significados. O verbo discriminar, segundo Aurélio Buarque de Holanda Ferreira, que vem "do latim discriminare, tem o significado de "diferençar, distinguir, discernir, estabelecer diferenças", ao passo que o vocábulo preconceito vem do latim praeconcetu e tem o sentido de conceito ou opinião formados antecipadamente, sem se levar em conta o fato que os conteste, e de intolerância, ódio irracional ou aversão a outras raças, credos, religiões, etc. (Ferreira, Aurélio Buarque de Holanda, "Novo Dicionário da Língua Portuguesa", 2a edição, 31a Impressão, Rio de Janeiro, Editora Nova Fronteira, 1986). Por sua vez, abuso de direito é o desvio de sua finalidade, cujos contornos são sociais. Definitivamente, não pode a empregadora discriminar a empregada aidética, nem abusar do exercício de determinado direito, como o potestativo de resilição contratual, que também se sujeita às regras da razoabilidade e da ponderação. Com efeito, a proteção à empregada portadora do vírus da AIDS está entranhada na C.F., nas leis ordinárias e nos princípios de Direito do Trabalho, caracterizando-se a despedida anti-social, discriminatória e arbitrária, quando a empregadora age desproporcionalmente, com o ímpeto de aniquilar o contrato de trabalho. Acaso não pode o juiz dar luz e efetividade à norma constitucional mais importante para a trabalhadora brasileira - garantia de emprego - enquanto por vinte anos se aguarda uma regulamentação? Hoje, mais do que nunca, quer-se atribuir à Constituição Federal o valor que ela desde sempre mereceu: holofote, intensíssimo facho de luz, direcionado a todo ordenamento jurídico, mas sobretudo à legislação inferior, de modo a iluminar e não a ser sombreada pelas leis a que dá vida, aquece e alimenta. A efetividade da Constituição Federal, composta de fundamentos, objetivos, princípios e regras, é, indubitavelmente, o passo mais firme que podemos dar em direção ao Estado Democrático de Direito e, por conseguinte, à justiça social. $\mathrm{O}$ resto são penhascos de ouro e de silêncio. 
Muita promessa, pouca realização, num país de muita desigualdade, muitos pobres, desempregados e excluídos. Passados quase vinte anos de vigência da Constituição Federal, os cidadãos reclamam mais efetividade, menos debate acadêmico a respeito dela. Aliás, quem realmente precisa da efetividade dos direitos sociais está, normalmente, excluído dos debates científicos e da apreensão técnica de seu sentido, não obstante sejam aqueles que menos necessitam dos seus resultados práticos as pessoas encarregadas da sua interpretação, assim como de sua aplicação. Durante anos, as discussões giraram em torno das funções dos princípios, assim como da efetividade das normas constitucionais. Esgotado esse debate, talvez outras controvérsias surjam e a concretude da Constituição, talvez, continue relegada para segundo plano. $\mathrm{O}$ cidadão comum, a empregada e a desempregada brasileira, a pessoa pobre, a excluída, mas também a rica, a empresária, a incluída, digital ou não, todos, sem exceção, todos querem uma Constituição mais prêt à porter; menos alta costura. Enfim, menos plumas e paetês, menos brilhos e mais luzes, mais cortes e menos recortes, menos promessas e mais realizações. Sabe-se que os princípios jurídicos são, simultaneamente, chave para a abertura do ordenamento jurídico, e chave para o fechamento dos casos difíceis. Portanto, em certa medida, são também, paradoxalmente, fim. Há infinitos pela estrada da Constituição, sem prévia significação de que uma esteja certa e outra equivocada. Compreender o sentido teleológico da norma, interpretá-la e aplicá-la é uma luta diária, constante, interminável e difícil de ser vencida. Logo, se, no âmago do ordenamento jurídico está a pessoa humana, núcleo de todos os núcleos, não me parece possível que possa prevalecer a dispensa, sem justa de causa, de empregada portadora do vírus HIV, apenas porque o direito de resilição é, em tese, livre, aberto, folgado, espaçoso. Para além das hipóteses de garantia de emprego expressamente previstas em lei, outras existem, reveladas pela realidade social, que foram implicitamente escritas pelo legislador e que precisam de cuidadoso desvelo, no caso concreto, para que a lei se ajuste à realidade e não a realidade à lei. ${ }^{72}$

Em outra ementa, também sobre o tema da reintegração de empregado dispensado por ser portador do vírus HIV, o desembargador Luiz Otávio Linhares Renault também ressalta a importância da leitura atualizada da lei e da Constituição, com base no método moderno de interpretação constitucional denominado normativo-estrutural, estudado no capítulo 2, que permite ao intérprete atualizar o texto normativo, em virtude das alterações da realidade social. O relator ressalta, também, a observância, pelo aplicador do Direito, das normas contidas na Convenção n. 111 da Organização Internacional do Trabalho, ratificada pelo Brasil, que vedam qualquer tipo de discriminação no âmbito das relações de trabalho $^{73}$. Ademais, o desembargador relator ainda acrescenta que, para provar a discriminação, o empregado poderá ser valer da prova indiciária ou por presunção ${ }^{74}$, em

\footnotetext{
${ }^{72}$ MINAS GERAIS. Tribunal Regional do Trabalho da $3^{\mathrm{a}}$ Região. $4^{\mathrm{a}}$ Turma. RO 00119-2008-091-03-00-3, Desembargador Relator: Luiz Otávio Linhares Renault. Publicação no DJMG: 17 dez. 2009.

${ }^{73}$ A preocupação em afastar práticas discriminatórias é uma tendência mundial, prevista nas Convenções 111 e 117 da OIT, ambas ratificadas pelo Brasil, que estabeleceram a supressão de todo tipo de discriminação que pudesse agredir ao empregado e às suas condições de trabalho, e também à sua remuneração.

${ }^{74}$ Nesse sentido, na $1^{\text {a }}$ Jornada de Direito Material e Processual na Justiça do Trabalho, realizada em Brasília/DF, em 23/11/2007, a Comissão de Direitos Fundamentais e das Relações de Trabalho aprovaram o Enunciado n. 2, inciso III:
} 
virtude das dificuldades inerentes à comprovação dos fatos alegados nesse tipo de situação.

\begin{abstract}
AIDS - EMPREGADO PORTADOR DO VIRUS HIV DISPENSA DISCRIMINACÃO- CONSTITUICAO FEDERAL E CONVENCÃO N. 111 DA OIT - PROVA INDICIÁRIA. REINTEGRACÃO O MAIS-ALÉM DO TEXTO DA LEI: O DIREITO E A JUSTIÇA - O contrato individual de trabalho caracteriza-se como importante instrumento de inclusão social apto a amalgamar princípios e direitos fundamentais, de que são exemplos os incisos II, III e IV do art. 1o, o caput e incisos X e XLI do art. 5o., o art. 6o., o caput do art. 170 e 193, da Constituição Federal. O nosso ordenamento jurídico, salvo raríssimas exceções expressamente previstas, refuta a estabilidade no emprego, apesar da trilha apontada, desde 1988, pelo art. 7o., inciso I, da Constituição. Dessa forma, a empregadora enfeixa em suas mãos o poder de resilição contratual, por intermédio do qual pode dispensar o empregado sem justa causa, pagando-lhe os direitos inerentes à rescisão sem justa causa. Não lhe é, contudo, outorgado o direito de abusar deste poder, desviando-o de sua finalidade. Uma coisa é despedir o empregado sem justa causa; outra é preencher este vazio falta de justa causa com um motivo subjacente lastreado em ato discriminatório. O princípio da igualdade, talhado ao longo dos séculos pelo homem e para o homem, é um autêntico direito fundamental delineador da personalidade humana e dirige-se tanto em face do Estado, quanto do particular, que não podem pautar-se por condutas discriminatórias, preconceituosas ou racistas. Não se desnatura o princípio da igualdade pela circunstância de a conduta ser proveniente de empregadora, empresa privada, ou de empregador, pessoa física, eis que, neste aspecto, adquire as características de um direito social, exercitável pela via da ação judicial, ainda que infiltrada no âmbito das relações privadas. A síndrome de imunodeficiência adquirida (SIDA ou AIDS) que, segundo Pedrotti, é "o conjunto de alterações provocadas pela perda de imunidade mediada por células, a partir da ação de um agente viral, provavelmente o HTLV 3 ou LAVE e que se manifestam pelo aparecimento de infecções oportunistas e/ou neoplasias,
\end{abstract}

\title{
2. DIREITOS FUNDAMENTAIS - FORÇA NORMATIVA:
}

$[\ldots]$

III - LESÃO A DIREITOS FUNDAMENTAIS. ÔNUS DA PROVA. Quando há alegação de que ato ou prática empresarial disfarça uma conduta lesiva a direitos fundamentais ou a princípios constitucionais, incumbe ao empregador o ônus de provar que agiu sob motivação ilícita.

Também no sentido de ressaltar a importância do princípio da disponibilidade da prova, Estévão Mallet afirma que "[...] condicionar a tutela do direito à apresentação de prova que, em decorrência de dificuldades materiais ou circunstancias, a parte não é concretamente capaz de produzir significa, em termos práticos, impedir ou dificultar excessivamente o acesso à justiça, privando de tutela o direito [...]. Assim, as regras relativas ao ônus da prova, para que não constituam obstáculo à tutela processual dos direitos, hão de levar em conta sempre as possibilidades, reais e concretas, que tem cada litigante de demonstrar suas alegações, de tal modo que recaia esse ônus não necessariamente sobre à parte que alega, mas sobre a parte que se encontra em melhores condições de produzir a prova necessária à solução do litígio. Cf. MALLET, Estévão. Discriminação e processo do trabalho. In: VIANA, Márcio Túlio; RENAULT, Luiz Otávio Linhares. Discriminação. São Paulo: LTr, 2000, p. 156-168.

Por fim, Márcio Túlio Viana defende a prova indiciária ou presunção para provar a discriminação, afirmando que a prova indiciária assume um peso maior, porquanto "[...] o juiz terá de valorizá-la bem mais do que nas situações comuns, sob pena de trair, por linhas tortas, o comando constitucional que garante o acesso à justiça”. Cf. VIANA, Márcio Túlio. A proteção trabalhista contra os atos discriminatórios: análise da Lei $\mathrm{n}$. 9.029/95. In: VIANA, Márcio Túlio; RENAULT, Luiz Otávio Linhares. Op. cit., p. 354-367.

O Tribunal Superior do Trabalho tem adotada o posicionamento da presunção de discriminação, no caso da dispensa imotivada do portador de HIV, conforme se observa na ementa a seguir:

AGRAVO DE INSTRUMENTO. RECURSO DE REVISTA DESCABIMENTO. 1. DESPEDIDA DISCRIMINATÓRIA. EMPREGADO PORTADOR DO HIV. REINTEGRAÇÃO. Esta Corte tem-se posicionado no sentido de que, quando da dispensa imotivada do portador do HIV, ciente o empregador da doença, resta presumida a ocorrência de discriminação. Cf. BRASIL. Tribunal Superior do Trabalho. AIRR -

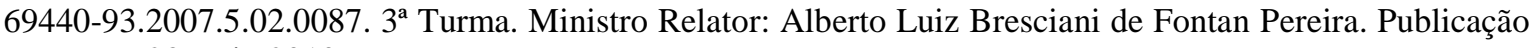
no DEJT: 28 maio 2010. 
particularmente o sarcoma de kaposi" (Pedrotti, Irineu Antônio, "Da AIDS e do Direito", Revista dos Tribunais, 1982, abril de 1993, vol. 690, pág. 295), nem sempre acarreta a impossibilidade da prestação de serviços, por parte dos infectados, permitindo-lhes, sem risco para os companheiros de trabalho e para a sociedade, a ocupação de um posto de trabalho, que muito lhe será proveitoso para fins de integração social. Muito embora a empregadora não tenha manifestado expressamente que a dispensa tivesse por fundamento o fato de o empregado ser portador do vírus HIV, a prova indiciária apontou para a prática de ato discriminatório, não podendo o julgador esperar que em casos desta natureza a prova seja exuberante. A prova indiciária, que a cada dia ganha maior importância, compreende todo e qualquer rastro, vestígio ou circunstância relacionada com um fato devidamente comprovado, suscetível de levar, por inferência, ao conhecimento de outro fato até então obscuro. A inferência indiciária é um raciocínio lógico-formal, apoiado em operação mental, que, em elos, nos permite encontrar vínculo, semelhança, diferença, causalidade, sucessão ou coexistência entre os fatos que circundam a lide. Se a dispensa sem justa causa está oxigenada pela discriminação, o empregado tem direito à reintegração, com base no princípio constitucional da igualdade. $\mathrm{Na}$ sociedade moderna, por essência livre, democrática e pluralista, predomina a interpretação contextual, transtextual, metatextual e intertextual, que permite uma visão atual e completa da realidade, que inúmeras vezes não se acomoda bem em textos genéricos, abstratos e concisos de dispositivos legais. Norma-texto e normaambiente (Muller) hão de encontrar-se, a fim de permitir uma adaptação do conteúdo normativo à realidade social, em constante avanço para além do tempo em que foi instituída. Essa aglutinação, normativa-estrutural, permite a constante atualização do texto legal, conduzindo o intérprete por horizontes para os quais a realidade o conduz. Essa é uma atribuição transferida pelo legislador ao intérprete e exigida pela sociedade, que não podem ficar parados no tempo, enquanto os fatos sociais avançam numa velocidade jamais imaginada. A questão do portador do vírus HIV é um problema que precisa ser também enfrentado pelas empresas, que têm importantíssima função social. No plano interno, o estado brasileiro tem tradicionalmente tomado medidas efetivas de inclusão social do aidético, seja através de programas educativos, de distribuição de medicamentos ou até mesmo mediante a possibilidade de movimentação da conta vinculada do FGTS, conforme art. 20, inciso XIII, da Lei 8036/90, regra esta desveladora da intenção do legislador quanto à manutenção do contrato de trabalho. No plano internacional, o Brasil ratificou a Convenção n. 111 da OIT, que trata da discriminação em matéria de emprego e ocupação, e que tem como principais preocupações a afirmação dos valores constantes da Declaração de Filadélfia, dentre os quais se inscrevem a igualdade de oportunidades, a dignidade e o progresso material, assim como a conscientização de que a discriminação constitui violação aos direitos enunciados na Declaração Universal dos Direitos do Homem. Assim, existe base jurídica para coibir-se a dispensa do empregado portador do vírus HIV, quando a distinção injustificada provoca a exclusão, que tem por efeito destruir ou alterar a igualdade de oportunidades ou tratamento em matéria de preservação do emprego, a mais importante forma de subsistência do ser humano. [...]. ${ }^{75}$

As ementas a seguir demonstram que os empregados discriminados ou dispensados por serem portadores, respectivamente, de hanseníase, obesidade mórbida, depressão hepatite "C"e neoplasia maligna, ou seja, por motivo de problemas de saúde, foram regularmente integrados e/ou receberam indenização por danos morais, conforme o caso.

\footnotetext{
${ }^{75}$ MINAS GERAIS. Tribunal Regional do Trabalho da $3^{\text {a }}$ Região. RO 00864-2007-072-03-00-3 . $4^{\text {a }}$ Turma. Desembargador Relator: Luiz Otávio Linhares Renault. Publicação no DJMG: 12 abr. 2008.
} 
Todos os julgamentos são exemplos de interpretação evolutiva do artigo $7^{\circ}$, inciso XXX e do artigo $1^{\circ}$ da Lei n. 9.029/95. Sem embargo, nem todos os juízes e todas as turmas dos tribunais têm seguido esse posicionamento, assim como parte da doutrina tem apresentado uma interpretação restritiva e desatualizada dos dispositivos supramencionados. ${ }^{76}$

\begin{abstract}
DANO MORAL. EMPREGADO PORTADOR DE HANSENIASE. AFASTAMENTO DO AUTOR SEM PREJUÍZO DE SALÁRIOS. O trabalho é a fonte da dignidade do ser humano. É trabalhando que a pessoa exercita a sua cidadania, gera o seu sustento e de sua família e se vê inserido na sociedade. Não basta apenas a fonte de renda. É necessário que haja a contraprestação, que o cidadão forneça a sua força de trabalho de tal sorte que não se sinta inútil e tampouco se veja como um peso para a sociedade. Ao afastar o obreiro e deixálo em sua casa, a reclamada praticou ato discriminatório. A atitude da reclamada em afastar o obreiro do trabalho, sem prejuízo dos salários, trata-se de um ato insensível, desaconselhável, diante das conseqüências danosas que a situação causa à auto-estima do trabalhador. Dessa forma, deve arcar com a reparação de danos morais provocados no obreiro, portador de hanseniase, a empresa que o afasta do trabalho após ele ter sido declarado apto pelo Órgão Previdenciário. ${ }^{77}$
\end{abstract}

RECURSO ORDINÁRIO - DANO MORAL. DISCRIMINAÇAO POR DOENÇA - Os elementos de prova demonstram que a reclamada provocou a ruptura unilateral do contrato de trabalho porque a empregada, portadora de obesidade mórbida, agendara cirurgia bariátrica. Apesar de a Lei ${ }^{\circ}$. 9.029/95 (que proíbe a adoção de qualquer prática discriminatória e limitativa para efeito de acesso à relação de emprego, ou sua manutenção) não cuidar explicitamente dessa modalidade de discriminação, a doutrina moderna e a melhor jurisprudência admitem sua aplicabilidade, na hipótese. Reforma-se, para se reconhecer o direito da autora à indenização pelo sofrimento moral que lhe foi imposto. Provimento parcial. ${ }^{78}$

ACIDENTE DO TRABALHO. REINTEGRAÇÃO NO EMPREGO. QUADRO DEPRESSIVO. DESPEDIDA SEM JUSTA CAUSA. Nexo causal caracterizado entre o quadro depressivo sofrido pela empregada com o acidente de trabalho ocorrido (acidente punctório que a levou ser submetida ao tratamento com coquetel de medicamentos, vulgarmente chamado de AZT). Situação que leva a concluir pelo exercício abusivo do direito potestativo, quando da despedida imotivada, tendo em vista que o empregador não tinha mais interesse em prosseguir o contrato de trabalho em face da condição psicológica da trabalhadora. Arbitrária a denúncia vazia do contrato, impondo a mantença da

\footnotetext{
${ }^{76}$ Sérgio Pinto Martins sustenta que a Lei n. 9.029/95 refere-se apenas a exames relativos à esterelização, a controle de gravidez ou a controle de natalidade, preceitos que dizem respeito à mulher e não à determinada doença, ou em relação ao sexo, origem, raça, cor, estado civil, situação familiar ou idade. Cf. MARTINS, Sérgio Pinto. Os efeitos do contrato de trabalho do empregado portador do vírus HIV. Revista IOB trabalhista e previdenciária, São Paulo, v. 19, n. 220, out. 2007, p. 29-37. Alice Monteiro de Barros também não entende possível a aplicação da Lei n. 9.029/95 para os casos de dispensa discriminatória de empregado soropositivo, pois entende que o legislador deveria ter incluído o estado de saúde, ao lado dos outros motivos que ensejam discriminação dispostos no artigo $1^{\circ}$, e não é viável a interpretação analógica ou extensiva da lei, uma vez que ela contém preceito de natureza penal. Cf. BARROS, Alice Monteiro de. Os efeitos do contrato de trabalho do empregado portador do vírus HIV. Revista IOB trabalhista e previdenciária, São Paulo, v. 19, n. 220, out. 2007, p. 7-28.

77 GOIÁS. Tribunal Regional do Trabalho da 18 ${ }^{\mathrm{a}}$ Região. RO 01241-2007-013-18-00-9. Relator: Desembargador Aldon do Vale Alves Taglialegna. Publicação no DJE: 16 out. 2008.

${ }^{78}$ SÃO PAULO. Tribunal Regional do Trabalho da $2^{\mathrm{a}}$ Região. RO 00404-2008-202-02-00-7. $4^{\mathrm{a}}$ Turma. Desembargador Relator: Wilma Nogueira de Araujo Vaz da Silva. Publicação no DOE: 23 abr. 2010.
} 
reintegração no emprego imposta pelo primeiro grau. Recurso interposto pelo reclamado a que se nega provimento no item. (...) ${ }^{79}$

ATO DISCRIMINATÓRIO DE DISPENSA DE EMPREGADO PORTADOR DO VIRUS DA HEPATITE “C”. ONUS DA PROVA: Tal qual jurisprudência consagrada no sentido de imputar ao empregador o ônus da prova de não haver promovido a dispensa discriminatória do portador do vírus HIV/AIDS, na hipótese do portador do vírus da "Hepatite C", estando incontroverso que , além de manter o empregado na quota dos portadores de necessidades especiais (deficiente visual), tinha conhecimento da enfermidade do trabalhador, deve a empresa se desincumbir do ônus da prova de que a dispensa não teve motivação dessa ordem, sob pena de haver de reintegrar o seu colaborador. ${ }^{80}$

PODER POTESTATIVO DO EMPREGADOR. LIMITAÇÃO NAS GARANTIAS DE EMPREGO E NO RESPEITO AOS PRINCÍPIOS QUE INFORMAM TODO NOSSO ORDENAMENTO JURÍDICO - ARTIGOS $1^{\circ}$, INCISO III, $5^{\circ}$,INCISO XXII, E 170, INCISO III, DA CARTA MAGNA, E ARTIGO 421, DO CÓDIGO CIVIL -. DISPENSA DE TRABALHADORA PORTADORA DE NEOPLASIA APÓS 30 (TRINTA) ANOS DE DEDICAÇÃO À EMPRESA. NEGAÇÃO DO DIREITO À VIDA E À SAÚDE. INEXISTÊNCIA DE NORMA LEGAL PREVENDO A ESTABILIDADE DO TRABALHADOR PORTADOR DE CÂNCER. OBSERVÂNCIA AOS PRINCÍPIOS DA DIGNIDADE DA PESSOA HUMANA DO TRABALHADOR E DA FUNÇÃO SOCIAL DO CONTRATO DE TRABALHO. ORDEM DE REINTEGRAÇÃO QUE ORA SE MANTÉM. ART. $1^{\circ}$, III, $5^{\circ}$, XXII E 170III DA CARTA MAGNA. ART. 421CÓDIGO CIVIL. 1. O poder de resilição do pacto laboral encontra limitações nas garantias de emprego, assim como no respeito aos princípios que informam todo o ordenamento jurídico, em especial o princípio da dignidade da pessoa humana, insculpido no artigo $1^{\circ}$, inciso III, da Carta Magna. Com a adoção do aludido princípio, a Constituição Federal de 1988 implantou no sistema jurídico brasileiro uma nova concepção acerca das relações contratuais, pela qual as partes devem pautar suas condutas dentro da legalidade, da confiança mútua e da boa fé. Tais premissas refletem o princípio da função social do contrato (artigos 421, Código Civil, e $8^{\circ}$, da CLT), o qual traduz genuína expressividade do princípio da função social da propriedade privada, consagrado nos artigos $5^{\circ}$, inciso XXIII, e 170, inciso III, da Constituição Federal, ou seja, o contorno é constitucional e se sobreleva à imediatidade da rescisão contratual decorrentes dos interesses meramente empresariais, conforme artigo $1^{\circ}$, III, Carta Magna Constituição Federal, artigo 421 do Código Civil, artigo $8^{\circ}$ da CLT, artigo $5^{\circ}$, XXIII e artigo 170, III da Constituição Federal. 2. A dispensa de trabalhadora portadora de neoplasia após trinta anos de dedicação à empresa a toda evidência importa verdadeira negação do direito à vida e à saúde, porquanto, dentro outros dissabores, conduz à depressão, ao distanciamento do convívio social e, consoante demonstram as regras de experiência,em sua maioria, ao desemprego. 3. A despeito da inexistência de norma legal prevendo a estabilidade do portador de câncer, até porque em determinadas fases da doença o paciente pode desenvolver normalmente suas atividades laborativas, imperiosa a solução controvérsia sob o prisma dos princípios da dignidade da pessoa humana do trabalhador e da função social do contrato. Ordem de reintegração ao emprego que ora se mantém. ${ }^{81}$

${ }^{79}$ RIO GRANDE DO SUL. Tribunal Regional da $4^{\mathrm{a}}$ Região. RO 0091900-04.2009.5.04.0005. $9^{\mathrm{a}}$ Turma. Desembargador Relator: João Alfredo Borges Antunes de Miranda. Publicação no DOE: 30 maio 2011.

${ }^{80}$ PARA E AMAPÁ. Tribunal Regional do Trabalho da $8^{\text {a }}$ Região. RO 00739-2008-005-08-00-5. $2^{\mathrm{a}}$ Turma. Desembargador Relator: Herbert Tadeu Pereira de Matos. Publicação no DOJT: 15 jan. 2009.

${ }^{81}$ SÃO PAULO. Tribunal Regional do Trabalho da $2^{\mathrm{a}}$ Região. RO 00947-2008-381-02-00-4. $9^{\text {a }}$ Turma. Desembargadora Relatora: Jane Granzoto Torres da Silva. Publicação no DJSP: 27 nov. 2009. 
A discriminação e a dispensa de empregado por motivo de condição física (excesso de peso, por exemplo) também vêm ensejando decisões dos Tribunais no sentido de reintegrá-lo ao trabalho e/ou da empresa ser condenada a pagar ao obreiro danos morais pelos abalos sofridos, consoante se observa da ementa de acórdão proferido pelo Ministro do TST Aloysio Corrêa da Veiga, in verbis:

\begin{abstract}
RECURSO DE REVISTA. INDENIZAÇÃO POR DANO MORAL E MATERIAL. ASSÉDIO MORAL. UTILIZAÇÃO DE EXPRESSÃO DEPRECIATIVA DA CONDIÇÃO FÍSICA DO EMPREGADO. REQUISITOS ENSEJADORES. MATÉRIA DE PROVA. SÚMULA 126 DO TST. A decisão recorrida está amparada na prova testemunhal, que reconheceu nexo de causalidade entre a conduta da empresa e o dano alegado pelo reclamante, em face de ofensa a sua condição física e a sua capacidade profissional. O empregador deve estabelecer um ambiente de trabalho com tratamento de dignidade e respeito ao trabalhador, não sendo razoável que se proceda a discriminação em razão de peso, ou qualquer outro, atribuindo incapacidade para o trabalho apenas em razão da condição física do empregado. Estando, assim, a decisão atrelada aos fatos e à prova produzida, aplicável o entendimento consagrado na Súmula 126 deste Tribunal Superior do Trabalho. Recurso de revista não conhecido. ${ }^{82}$
\end{abstract}

A Juíza convocada Lígia M. Teixeira Costa, do Tribunal Regional do Trabalho da $12^{\mathrm{a}}$ Região, entendeu que a opção sexual da empregada estaria contido no conceito de discriminação "por motivo de sexo", para aplicar à obreira as conseqüências jurídicas inerentes à dispensa discriminatória. Porém, ainda que assim não se entenda, defende-se, com base na interpretação evolutiva das normas, que qualquer motivo ensejador de discriminações no ambiente de trabalho, incluindo a opção sexual, está contido no teor normativo do artigo $7^{\circ}$, inciso XXX da CF/88 e no artigo $1^{\circ}$ da Lei n. 9.029/95.

\footnotetext{
DISPENSA DISCRIMINATÓRIA. OPÇÃO SEXUAL. CARACTERIZAÇÃO. Nas relações de emprego, a discriminação decorrente da orientação sexual do empregado enquadra-se no conceito de discriminação "por motivo de sexo", uma vez que este - o sexo - não está restrito ao seu aspecto biológico (feminino ou masculino), mas abrange também a sua manifestação nas relações interpessoais. Assim, uma vez demonstrada que a dispensa da obreira decorreu de relacionamento amoroso mantido com outra empregada da ré, há de ser reconhecido como discriminatório o ato praticado. ${ }^{83}$
}

\footnotetext{
${ }^{82}$ BRASIL. Tribunal Superior do Trabalho. RR 145/2006-872-09-00.4. $6^{\text {a }}$ Turma. Ministro Relator: Aloysio Corrêa da Veiga. Publicação no DEJT: 18 dez. 2007.

${ }^{83}$ SANTA CATARINA. Tribunal Regional do Trabalho da 12a Região. RO 07663-2006-034-12-00-0. $3^{\mathrm{a}}$

Turma. Relatora: Juíza convocada Ligia M. Teixeira Gouvêa. Publicação no DOE: 15 jan. 2008.
} 
No que diz respeito à inclusão do empregado em listas negras, o acórdão de relatoria do Ministro Barros Levenhagem não cita nenhum inciso do artigo $7^{\circ}$ da Constituição Federal, apenas se referendo ao artigo $5^{\circ}$, inciso $\mathrm{X}$, que trata do respeito à intimidade e à vida privada das pessoas em geral e se aplica à relação de emprego, em virtude da eficácia direta e imediata dos direitos fundamentais nas relações privadas. Sem embargo, a discriminação de empregado, cujo nome constava de "lista negra" elaborada por empresa, e que, por isso, não foi promovido para nova colocação, demonstra que o motivo ensejador da discriminação foi o empregado fazer parte de "lista negra" da empregadora. Ou seja, é mais uma razão discriminatória que pode ser inserida no amplo rol de formas de discriminação existentes que se extraem do artigo $7^{\circ}$, inciso XXX, da CF/88.

\begin{abstract}
DANO MORAL. CARACTERIZAÇÃO. DESNECESSIDADE DE DEMONSTRAÇÃO DA SUA OCORRÊNCIA. I - O dano moral prescinde de prova da sua ocorrência, em virtude de consistir em ofensa a valores humanos, os quais se identificam por sua imaterialidade, sendo imprescindível apenas a demonstração do ato ilícito do qual ele tenha sido resultado. II - É certo que o inciso $\mathrm{X}$ do artigo $5^{\circ}$ da Constituição elege como bens invioláveis, sujeitos à indenização reparatória, a intimidade, a vida privada, a honra e a imagem das pessoas. Encontra-se aí subentendida no entanto a preservação da dignidade da pessoa humana, em virtude de ela ter sido erigida em um dos fundamentos da República Federativa do Brasil, a teor do artigo $1^{\circ}$, inciso III, da Constituição. III - Comprovado que o nome do recorrente constara de "lista negra" elaborada pela recorrida, em que pese não ter havido sua divulgação, em razão da qual ele tivesse sido preterido em nova colocação, pois essa hipótese só teria relevância para a caracterização de dano material, por sinal, não pleiteado, acha-se caracterizado o ilícito patronal e por consequiência materializado o dano moral, consubstanciado na ofensa à sua intimidade profissional. IV - Vale registrar, de resto, não ter sido reiterada nas contra-razões do recurso de revista a impugnação veiculada, no recurso ordinário, ao valor arbitrado pelo Juízo de primeiro grau, de sorte que não há lugar para pronunciamento do TST. Recurso provido. ${ }^{84}$
\end{abstract}

\title{
5.3.1.7 Direitos relativos à saúde e segurança no trabalho
}

Direito ao adicional de penosidade no caso de trabalho exercido sob forte sol e calor, sujeito a intempéries

O direito ao adicional de remuneração pelo trabalho em atividades penosas está previsto no artigo $7^{\circ}$, inciso XXIII, da Constituição Federal de 1988. Sem embargo, a não ser nos casos em que as próprias categorias, por meio de negociação coletiva, estabelecem

\footnotetext{
${ }^{84}$ BRASIL. Tribunal Superior do Trabalho. RR -328/2004-091-09-00.0. $4^{\mathrm{a}}$ Turma. Ministro Relator: Barros Levenhagem. Publicação no DJU: 24 nov. 2006.
} 
em acordos ou convenções coletivas de trabalho o direito ao adicional de penosidade, mencionando as hipóteses em que o empregado fará jus a ele, o percentual do adicional e a base de cálculo, a jurisprudência nacional tem alegado a impossibilidade de aplicação desse dispositivo constitucional, sob o argumento de que a norma em tela é de eficácia indireta e mediata, dependendo de ser regulamentada por lei para que possa surtir efeitos plenos.

Entretanto, acredita-se que é possível conferir ao preceito constitucional em comento maior aplicabilidade, pois, como já reiterado no capítulo 3 dessa tese, não é possível que o legislador infraconstitucional se omita por mais de vinte anos ${ }^{85}$, desde a promulgação da Constituição e situações em que o empregado trabalha, sob condições penosas, permaneçam sem a devida proteção jurídica.

O empregado que labora em condições penosas está deteriorando a sua saúde, sem que haja nenhum tipo de contrapartida, inclusive a remuneratória prevista constitucionalmente. Embora seja obrigação dos empregadores zelar pelo ambiente de trabalho e pelos trabalhadores, por meio da observância de normas do Ministério do Trabalho e Emprego que regulem questões referentes à saúde, segurança e medicina do trabalho, sabe-se que, em algumas situações, não é possível eliminar o contato com os agentes insalubres - o que pode -se estender aos agentes penosos - mas apenas reduzi-los, de modo que o empregado passa a fazer jus a um adicional salarial.

Marcus Orione Gonçalves Correia defende a possibilidade da implementação do adicional de penosidade, ainda que a lei que o regulamenta ainda não tenha sido criada. $\mathrm{O}$ trabalho penoso atenta contra o direito ao trabalho em condições dignas e o direito à saúde e, também, contra direitos fundamentais individuais, como o direito à vida, de forma que a ausência de lei regulamentadora acaba por determinar a total ausência de sua força normativa. Para o autor, portanto, é necessário buscar no Direito elementos suficientes para a construção do conceito e das conseqüências de sua admissão, mesmo sem lei específica regulamentadora:

\footnotetext{
Veja-se, por exemplo, que, no direito do trabalho, já existem os adicionais de periculosidade e de insalubridade. Por exclusão, o conceito de trabalho penoso não coincidiria com essas noções. No entanto, poderia [...] extrair componentes, para a sua construção, de conceitos de direito previdenciário, onde existe a noção de trabalho penoso, para fins de aproveitamento de tempo especial. ${ }^{86}$
}

\footnotetext{
${ }^{85}$ Embora tenham sido apresentados projetos de lei para regulamentar o dispositivo constitucional, até hoje eles não foram votados.

${ }^{86}$ CORREIA, Marcus Orione Gonçalves. O postulado da razoabilidade e o Direito do Trabalho. In: CORREIA, Marcus Orione Gonçalves (Org.). Curso de Direito do Trabalho. Op. cit., p. 128.
} 
O adicional de penosidade era previsto na Lei n. 3.807, de 26 de agosto de 1960, ao instituir as aposentadorias especiais para os trabalhos penosos, insalubres e perigosos, assim com outros diplomas legais que tratavam da matéria, mas foram revogados.

Atualmente, o adicional de atividades penosas está restrito à Lei n. 8.112, de 11 de dezembro de 1990, que institui o Regime Jurídico dos Servidores Públicos Civis da União, mas a lei não traz maiores detalhes sobre o instituto.

Após a promulgação da Constituição Federal, tornou-se premente para os doutrinadores e estudiosos no assunto a busca pela caracterização ou conceituação das atividades penosas. Para isso, vem sendo adotados dois métodos: o da conceituação propriamente dita, tal qual prevista na CLT para as atividades insalubres ou perigosas, e o da enumeração das atividades.

Cretella Júnior, citado por Sebastião Geraldo de Oliveira, assim conceitua a atividade penosa:

Penoso é o trabalho acerbo, árduo, amargo, difícil, molesto, trabalhoso, incômodo, laborioso, doloroso, rude. [...] Penosas são, entre outras, as atividades de ajuste e reajuste de aparelhos de alta precisão (microscópios, rádios, relógios, televisores, computadores, vídeos, fornos de microondas, refrigeradores), pinturas artesanais de tecidos e vasos, em indústrias, bordados microscópios, restauração de quadros, de esculturas, danificadas pelo tempo, por pessoas ou pelo meio ambiente, lapidação, tipografia fina, gravações, revisão dejornais, revistas, tecidos, impressos. Todo esse tipo de atividade não é perigosa, nem insalubre, mas penosa, exigindo atenção constante e vigilância acima do comum. ${ }^{87}$

Oliveira também cita Leny Sato, psicóloga e estudiosa da saúde do trabalhador que assim enumera as atividades penosas:

- Esforço físico intenso no levantamento, transporte, movimentação, carga e descarga de objetos, materiais, produtos e peças;

- Posturas incômodas, viciosas e fatigantes;

- Esforços repetitivos;

- Alternância de horários de sono e vigília ou de alimentação;

- Utilização de equipamentos de proteção individual que impeçam o pleno exercício de funções fisiológicas, como tato, audição, respiração, visão, atenção, que leve à sobrecarga física e mental;

- Excessiva atenção ou concentração;

- Contato com o público que acarrete desgaste psíquico;

- Atendimento direto de pessoas em atividades de primeiros socorros, tratamento

e reabilitação que acarretem desgaste psíquico;

87 CRETELLA Júnior apud OLIVEIRA, Sebastião Geraldo de Oliveira. Proteção jurídica à saúde do trabalhador. 4 ed. São Paulo: LTr, 2002, p. 186. 
- Trabalho direto com pessoas em atividades de atenção, desenvolvimento e educação que acarretem desgaste psíquico e físico;

- Confinamento ou isolamento;

- Contanto direito com substâncias, objetos ou situações repugnantes e cadáveres humanos e animais,

- Trabalho direto na captura e sacrifício de animais. ${ }^{88}$

Segundo a estudiosa, essas condições de trabalho têm em comum o fato de exigirem esforço físico e/ou mental, provocarem incômodo, sofrimento ou desgaste da saúde. Elas podem provocar problemas de saúde que não são necessariamente doenças.

Algumas dessas atividades citadas por Leny Sato estão relacionadas na Norma Regulamentadora (NR) 17 - Ergonomia do MTE. Essa NR está em consonância com a mais moderna doutrina de prevenção dos riscos do trabalho que procura tornar o ambiente de trabalho o mais confortável possível em detrimento do pagamento de adicionais, que contribuem e muito para o surgimento de doenças ocupacionais, bem como de acidentes do trabalho.

Sem embargo, existem atividades que não são reguladas pela NR-17, pois não tem conexão com questões de ergonomia no trabalho e, dessa forma, sequer o desconforto ou doenças inerentes ao esforço ou desgaste podem ser atenuadas.

Um exemplo contundente acerca do tema da penosidade diz respeito ao trabalho em plantações a céu aberto, como os canaviais, ou seja, locais que estão constantemente sujeitos a intempéries, como sol forte e chuvas constantes.

$\mathrm{O}$ adicional de insalubridade em caso de exposição a raios solares tem sido negado por grande parte dos Tribunais Regionais e o Tribunal Superior do Trabalho chegou a editar a OJ n. 173 da SDI-1 nesse sentido. Sem embargo, embora possa ser considerada insalubre, como já entendeu o Tribunal Regional do Trabalho da $15^{\mathrm{a}}$ Região ${ }^{89}$, não parece ser esse o melhor enquadramento desse tipo de exposição.

Mais do que insalubre, a sujeição a raios solares, juntamente com a ocorrência de ventos e de chuvas, durante várias horas por dia, é penosa, pois, além de poder provar

\footnotetext{
${ }^{88}$ SATO, Leny apud OLIVEIRA, Sebastião Geraldo de Oliveira. Op. cit., p. 186-187.

${ }^{89}$ ADICIONAL DE INSALUBRIDADE. EXPOSIÇÃO AOS RAIOS SOLARES. DEVIDO. Não há como se filiar ao entendimento consubstanciado na Orientação Jurisprudencial 173 da SDI-1 do C. TST, tendo em vista o seu anacronismo, incoerência e ilegalidade, estando esta evidenciada pela afronta ao item 1 do Anexo 7, da NR-15, da Portaria 3.214/78 do MTb, e aos arts. 195 da CLT e 170 da CF, e, aquelas, pelo fato de ser público e notório os malefícios que podem causar à saúde humana a exposição excessiva ao sol, tais como, desidratação, insolação, danos na retina e na córnea, estresse térmico, queimaduras na pele, envelhecimento precoce e o aparecimento do melanoma, o mais temível dos cânceres de pele. Assim, não obstante a equivocada jurisprudência superior, impõe-se o enquadramento do trabalho em exposição contínua aos raios solares como atividade insalubre. CAMPINAS. Tribunal Regional do Trabalho da $15^{a}$ Região. RO 002242005-120-15-00-5. $11^{a}$ Turma. Relator: Desembargador Flávio Nunes Campos. Publicação no DJSP: 02 mar. 2007.
} 
problemas de saúde, como desde uma simples gripe até um câncer de pele, é incontestavelmente desgastante fisicamente e incômodo. Tanto isso é verdade que em ambientes abertos, como nas minas, algumas empresas costumam fornecer o protetor solar a ser usado obrigatoriamente com uma forma de Equipamento de Proteção Individual.

Dessa forma, com base na constatação de que o trabalho em lavouras a céu aberto, durante longos períodos, não está previsto como atividade nem insalubre e nem perigosa, pode-se concluir que - por eliminação, como sugere Marcos Orione - ele se encontra dentre as atividades penosas. Sendo assim, o empregado que labore nesse tipo de atividade fará jus a perceber o adicional de penosidade, pois há elementos fáticos concretos que demonstram que esse tipo de trabalho é desgastante e incômodo, além dos limites toleráveis pelo homem médio e não é possível que esse tipo de atividade continue sendo exercida, sem nenhuma contrapartida remuneratória, já que é praticamente impossível impedir o contato entre o empregado lavrador e os agentes penosos, mas apenas reduzi-los com uniforme próprio, impermeável e adequado às alterações climáticas e filtro solar.

O percentual do adicional de penosidade e a sua base de cálculo, como não existe lei infraconstitucional estipulando a respeito, poderão ser os já utilizados para os adicionais de insalubridade, por analogia, tendo em vista que esse tipo de atividade se aproxima mais do adicional de insalubridade, do que da concepção que enseja o direito ao adicional de periculosidade.

\subsubsection{Direitos relativos à atuação sindical e à participação coletiva dos trabalhadores}

Legitimidade do sindicato para a propositura de ação civil pública para defesa de direitos $\underline{\text { metaindividuais }}$

O posicionamento que predominava anteriormente nos Tribunais Regionais do Trabalho e no Tribunal Superior do Trabalho era de que a norma do artigo $8^{\circ}$, inciso III, da Constituição não era suficiente em si mesma para atribuir às entidades sindicais a possibilidade de atuarem, em juízo, para a defesa dos direitos metaindividuais dos integrantes da categoria a qual representam. Ou seja, o dispositivo constitucional em comento não era auto-aplicável, dependendo de legislação definindo as hipóteses em que o sindicato poderia agir em nome próprio defendendo direitos de terceiros (trabalhadores). 
Assim, o TST editou a Súmula 310, prevendo as poucas hipóteses em que os sindicatos poderiam atuar como substitutos processuais. Logo na época em que foi editada, haviam poucas situações previstas nesse sentido na legislação infraconstitucional, como, por exemplo, a Lei 8073/90, que autoriza o Sindicato demandar a satisfação da legislação de política salarial.

A Súmula 310 foi cancelada por meio da Resolução n. 119/03, quando os ministros da Seção Especializada iniciaram o exame de um recurso de embargos interposto pelo Sindicato dos Trabalhadores nas Indústrias Químicas e Petroquímicas do ABCD paulista. Sentiu-se a necessidade de reformular ou cancelar a súmula, optando-se pela segunda alternativa.

Em 2006, no julgamento do RE 210029/RS em sessão plenária, o STF se posicionou no sentido os sindicatos como entes legítimos para defender em juízo os direitos e interesses coletivos ou individuais dos integrantes da categoria que representam. $^{90}$

Dessa forma, a jurisprudência do TRT e dos TRT’s foi, paulatinamente, alterando o seu posicionamento anterior para "para admitir a ampla atuação das entidades sindicais em Juízo para pleitear, como substitutos processuais, os direitos e interesses individuais homogêneos dos integrantes das categorias por eles representadas". 91

SINDICATO. LEGITIMIDADE PARA ATUAR COMO SUBSTITUTO PROCESSUAL. ARTIGO $8^{\circ}$, III, DA CONSTITUIÇÃO FEDERAL. PAGAMENTO DE HORAS EXTRAS EM DECORRÊNCIA DA SUPRESS ÃO DO INTERVALO PARA LANCHE. O artigo $8^{\circ}$, III, da Carta Política de 1988 autoriza expressamente a atuação ampla das entidades sindicais na defesa inclusive judicial - dos interesses da categoria. Já não paira controvérsia na jurisprudência desta Corte uniformizadora quanto ao entendimento de que o sindicato tem legitimidade para atuar como substituto processual de toda a categoria, se fundado o pedido em direito individual homogêneo, havendo-se como tal o que tem origem comum. 2. O intervalo para lanche e as controvérsias a ele relacionadas constituem interesse dos integrantes da categoria, revelando-se

${ }^{90}$ PROCESSO CIVIL. SINDICATO. ART. $8^{\circ}$, III DA CONSTITUIÇÃO FEDERAL. LEGITIMIDADE SUBSTITUIÇÃO PROCESSUAL. DEFESA DE DIREITOS E INTERESSES COLETIVOS OU INDIVIDUAIS. RECURSO CONHECIDO E PROVIDO. O art. $8^{\circ}$, III da Constituição Federal estabelece a legitimidade extraordinária dos sindicatos para defender em juízo os direitos e interesses coletivos ou individuais dos integrantes da categoria que representam. Essa legitimidade extraordinária é ampla, abrangendo a liquidação e a execução dos créditos reconhecidos aos trabalhadores. Por se tratar de típica hipótese de substituição processual, é desnecessária qualquer autorização dos substituídos. Recurso conhecido e provido. Cf. BRASIL. Supremo Tribunal Federal. RE 210029/RS. Tribunal Pleno. Relator original: Ministro Carlos Velloso. Relator para o acórdão: Ministro Joaquim Barbosa. Publicação no DJU: 17 ago. 2007.

${ }_{91}$ PIMENTA, José Roberto Freire. A tutela metaindividual dos direitos trabalhistas: uma exigência constitucional. In: PIMENTA, José Roberto Freire; BARROS, Juliana Augusta Medeiros de; FERNANDES, Nádia Soraggi Fernandes. Tutela metaindividual trabalhista: a defesa coletiva dos direitos dos trabalhadores em juízo. São Paulo: LTr, 2009, p. 35. 
legítima a atuação do sindicato para, na qualidade de substituto processual, insurgir-se contra a sua supressão, bem como postular o pagamento das horas extras relativas aos 15 minutos diários que teriam extrapolado a jornada. 3. A decisão da Turma, calcada na Súmula no 310 desta Corte uniformizadora, não reflete a correta interpretação do artigo $8^{\circ}$, inciso III, da Constituição Federal, cuja violação exsurge manifesta. Embargos conhecidos e providos. ${ }^{92}$

Na realidade, a redação do artigo $8^{\circ}$, inciso III, da CF/88 ("ao sindicato cabe a defesa dos direitos e interesses coletivos ou individuais da categoria, inclusive em questões judiciais ou administrativas") já é bastante claro no sentido de outorgar aos sindicatos legitimidade para atuar em nome dos integrantes da categoria representada. Sem embargo, a jurisprudência trabalhista imprimia ao dispositivo uma interpretação bem restritiva, que não condizia com massificação cada vez mais intensa dos conflitos sociais trabalhistas e com a sistemática existente na Constituição que privilegia a participação das associações e sindicatos na defesa dos interesses e direitos coletivos.

Assim, com o objetivo de construir uma sociedade democrática, plural e participativa, o legislador constituinte fomentou a criação de associações, independentemente de autorização estatal (artigo $5^{\circ}$, inciso XXXIII), assegurou a liberdade de associação e de reunião (artigo $5^{\circ}$, incisos XVI, XVII e XX) e, no que tange aos sindicatos, garantiu a sua liberdade de fundação, funcionamento e filiação (artigo $8^{\circ}$, incisos I e V). ${ }^{93}$

A modificação do entendimento acerca da legitimidade sindical para ajuizar ações civis públicas ou coletivas, pleiteando direitos difusos, coletivos e individuais homogêneos dos membros da categoria representada, espelha nítido exemplo de interpretação constitucional evolutiva, pois houve uma alteração do alcance do preceito normativo em análise, em virtude de uma leitura mais atualizada da Constituição e mais consentânea com a realidade vivida pelos empregados que experimentam, muitas vezes, lesões em massa, sem ferir a sistemática constitucional.

\section{Estabilidade do militante sindical, em analogia ao dirigente sindical}

A estabilidade provisória do dirigente sindical da candidatura até a eleição e, se eleito, até um ano após o término do mandato, garantida constitucionalmente no artigo $8^{\circ}$,

\footnotetext{
92 BRASIL. Tribunal Superior do Trabalho. E-RR-449.723/1998.9. SDI-1. Ministro Relator: Lélio Bentes Corrêa. Publicação no DJU: 25 maio 2007.

93 FERNANDES, Nádia Soraggi. Ação civil pública trabalhista: forma célere e efetiva de proteção dos direitos fundamentais dos trabalhadores. São Paulo: LTr, p. 100.
} 
inciso VIII e visa dar ao trabalhador, que representa a sua categoria profissional, liberdade de atuação na defesa dos interesses dos membros representados, de modo a não sofrer retaliações e inclusive ser dispensado, por contrariar os interesses empresariais, por exemplo.

O caso julgado a seguir, colacionado da jurisprudência do Tribunal Regional do Paraná, embora mencione a garantia da livre associação sindical, prevista no artigo $8^{\circ}$, caput, da Constituição Federal, na realidade imprime uma interpretação mais extensiva ao inciso VIII do mesmo dispositivo constitucional ao conferir, também ao militante sindical, a estabilidade provisória no emprego a que o dirigente sindical tem direito. Essa interpretação da Constituição, mais do que simplesmente analógica, é evolutiva, tendo em vista que o militante sindical, ou seja, aquele trabalhador que constantemente está envolvido nas atividades sindicais, atuando de forma ativa em prol da categoria, visa defender os direitos dos representados, evitando a precarização das condições de trabalho. Por isso, também está sujeito a represálias por parte dos representantes da empresa, devendo, assim, ter assegura a estabilidade provisória no emprego.

O relator do caso, não obstante, entendeu necessária a prova de que o militante sindical sofreu retaliação, por meio de despedida discriminatório, para assegurar-lhe a reintegração ao trabalho.

DESPEDIDA DISCRIMINATÓRIA - MILITANTE SINDICAL
CONFIGURADA DESPEDIDA ABUSIVA - OFENSA Ã GARANTIA DA
LIVRE ASSOCIAÇÃO SINDICAL - ART. $8^{\circ}$, CAPUT, CF REINTEGRAÇÃO.
A despedida discriminatória de trabalhador por militância sindical enseja
disciplina análoga ao do dirigente sindical, porquanto ofende o princípio da livre
associação sindical (art. $8^{\circ}$, caput, CF), aplicando-se extensivamente as leis que
protegem o desempenho de atividades sindicais, bem como direitos e garantias
expressos nos tratados internacionais celebrados pelo Brasil (art. $5^{\circ}, \S \S 1^{\circ}, 2^{\circ} \mathrm{e}$
$3^{\circ}, \mathrm{CF} c / c$ art I", Convenção $\left.98, \mathrm{OIT}\right) . .^{94}$

De acordo com o relator do acórdão, para o "reconhecimento do alegado, no entanto, imprescindível prova de que a demissão foi forma de retaliação contra as atividades sindicais do autor, eis que, não se pode olvidar, o sistema jurídico-trabalhista pátrio reconhece como legítima a dispensa imotivada".

O doutrinador uruguaio Oscar Ermida Uriarte fundamenta a extensão da tutela contra atos de discriminação também ao militante sindical - e não apenas aos dirigentes:

\footnotetext{
${ }^{94}$ PARANÁ. Tribunal Regional do Trabalho da 9a Região. RO 00067-2005-654-09-00-9. $3^{\text {a }}$ Turma. Relator Desembargador Archimedes Castro Campos Júnior. Publicação no DJPR: 27 jun. 2008.
} 
esta extensão subjetiva do alcance da proteção vem imposta por sua própria função, que é, como já dito, a de garantir a atividade sindical, possibilitando seu desenvolvimento normal e eficaz. Com efeito, se somente se protegesse ao proporcionalmente pequeno número de dirigentes, representantes ou delegados, e se permitissem atos discriminatórios contra os "militantes" e simples trabalhadores que praticam atos sindicais, o sistema tutelar não alcançaria sua finalidade [...], uma vez que para que se possa praticar livre e efetivamente a liberdade sindical, não somente é necessário proteger aos que dirigem e tomam decisões, como também é necessário dar cobertura aos que executam. ${ }^{95}$

Dessa forma, com base na decisão pontual transcrita - visto que esse não é o entendimento, como regra geral, da jurisprudência trabalhista pátria ${ }^{96}$ - defende-se uma interpretação que dê maior alcance ao sentido originalmente conferido ao artigo $8^{\circ}$, inciso III, da CF/88 de que apenas o dirigente sindical teria direito à estabilidade sindical.

\section{$\underline{\text { Reconhecimento de sindicato único com base no princípio da maior representatividade }}$}

Um dos maiores problemas relativos ao sindicalismo no Brasil diz respeito à manutenção, pela Constituição Federal de 1988, da regra da unicidade sindical e da contribuição sindical compulsória, sendo ambas as previsões resquícios do sistema

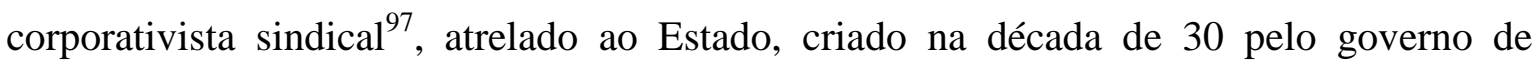
Getúlio Vargas e fortalecido com a Consolidação das Leis do Trabalho, de 1943.

\footnotetext{
95 URIARTE, Oscar Ermida. A proteção contra os atos sindicais. São Paulo: LTr, 1999, p. 21. Trad. Irany Ferrari.

${ }^{96}$ Nem todos os dirigentes sindicais têm direito à estabilidade provisória no emprego, visto que o Tribunal Superior do Trabalho, em entendimento consolidado na Súmula 369, item II, afirma que o artigo 522 da CLT, que limita para sete o número de dirigentes de um sindicato, foi recepcionado pela constituição Federal de 1988. Essa situação se alterou parcialmente com a alteração da referida Súmula, em 24 de maio de 2011, quando o TST passou a entender que além dos sete dirigentes sindicais, têm direito á estabilidade provisório mais sete suplementes.

${ }^{97}$ O Brasil se pautou pelo sistema corporativista italiano de Benito Mussolini, instaurado com a Lei Alfredo Roco, de 03 de abril de 1926, que traçou as diretrizes gerais do modelo intervencionista e se afastou do ideal de liberdade sindical contido no Tratado de Versailles. Essa ideologia corporativista foi abandonada pela Itália, bem como pela Alemanha como fim da Segunda Guerra Mundial, quando as entidades sindicais passaram a ter personalidade jurídica de direito privado. Após a guerra, com o movimento de internacionalização dos direitos humanos, a liberdade sindical, como corolário da livre reunião e associação pacíficas, acabou por se incluir dentre os institutos tutelados pela Declaração Universal dos Direitos Humanos e ganhou proteção específica com a aprovação da Convenção n. 87 da OIT - que tem como objetivo assegurar a plena liberdade sindical, sem a intromissão do Estado, ou seja, com independência em relação aos poderes públicos, com vistas à busca da autonomia sindical, em harmonia com os ideias pluralistas dos institutos internacionais de proteção aos direitos humanos. A referida Convenção consagra o direito de afiliação sindical, de constituir sindicatos sem necessidade de autorização prévia, de organizar livremente o sindicato, dos sindicatos obterem personalidade jurídica e de não ser dissolvidos administrativamente, direito a constituir federações e confederações, a afiliar-se a entidades internacionais e direito dos empregados de ter adequada proteção contra todo ato de discriminação tendente a menoscabar a liberdade sindical em relação ao seu emprego.
} 
No Brasil, de acordo com o artigo $8^{\circ}$, inciso II, da CF/88, somente pode ser constituído um sindicato, por categoria profissional ou econômica, no mesmo âmbito ou circunscrição territorial, ou seja, a regra da unicidade sindical é consagrada constitucionalmente.

Apesar da ampla aceitação do princípio da liberdade sindical na comunidade internacional, constatável pelo extenso número de países que ratificaram a Convenção n. 87 da OIT $^{98}$, o país insiste em manter legislação com características ligadas ao corporativismo, apesar das notáveis alterações experimentadas pela economia nacional ao longo das últimas décadas em relação aos meios de produção predominantes à época da Constituição de 1937 e da CLT.

A estrutura sindical pátria, portanto, se encontra obsoleta no que diz respeito ao enfrentamento dos desafios provenientes do crescente processo de globalização econômica, bem como do agravamento das questões sociais, justamente por se fundar em paradigmas referentes a ume estágio evolutivo do capitalismo pátrio já há muito ultrapassado.

Para garantir a unicidade sindical, o artigo 8º, inciso I, da Constituição de 1988 estabelece a necessidade de registro no órgão competente, embora estabeleça a liberdade de função de sindicato sem necessidade de autorização do Estado, vedando ao Poder Público a interferência e a intervenção na organização sindical.

Nesse sentido, o Supremo Tribunal Federal se manifestou no acórdão proferido no Mandado de Injunção n. 144-SP ${ }^{99}$, entendendo válido o registro dos entes sindicais junto ao Ministério do Trabalho, sendo este ato vinculado, sujeito apenas à observância de requisitos meramente objetivos. Ademais, o registro da constituição do sindicato se subordinaria à indagação acerca da inexistência, na base territorial, de outro entidade representativa da mesma categoria profissional.

Alguns anos depois, no julgamento do Recurso em Mandado de Segurança n. 21.080- $\mathrm{DF}^{100}$, em caso envolvendo a validade de ato do Ministro do Trabalho concedendo registro sindical à entidade intermunicipal quando já existente outro ente de abrangência estadual, o Ministro Marco Aurélio deixou implícito que a precedência de registro é o

\footnotetext{
${ }^{98}$ A maior parte dos países membros da OIT têm suas legislações sindicais pautadas pelos princípios constantes da Convenção n. 87, mas o Brasil não ratificou o instrumento internacional, pois o princípio da unicidade sindical, garantido no país por meio do registro dos sindicatos no Ministério do Trabalho e do Emprego, esbarra em alguns dispositivos da Convenção.

${ }_{99}$ BRASIL. Supremo Tribunal Federal. MI n. 144-SP. Relator: Ministro Sepúlveda Pertence. Plenário. Públicação no DJU: 28 maio 1993.

${ }^{100}$ BRASIL. Supremo Tribunal Federal. Recurso Ordinário em Mandando de Segurança n. 21.080-DF. Relator: Ministro Francisco Rezek. Plenário. Publicação em: $1^{\circ}$ out. 1993.
} 
critério-chave a ser verificado na concessão da personalidade sindical, independentemente de sua representatividade.

Dessa forma, o Ministério do Trabalho passou a editar normas internas regulamentando os procedimentos de registro sindical. E, havendo ente já cadastrado em seus arquivos, representando uma idêntica categoria na mesma base territorial, o Ministério deve se negar a conferir certidão ao segundo sindicato, federação ou confederação, salvo se as próprias partes chegarem a um acordo ou o Poder Judiciário assim deliberar. ${ }^{101}$

Portanto, em síntese, o atual sentido e alcance conferido à regra da unicidade sindical (artigo $8^{\circ}$, inciso II) pela jurisprudência do STF e pelo Ministério do Trabalho e Emprego é o de que serão outorgadas as prerrogativas sindicais à entidade que primeiro obteve seu registro sindical, independentemente da representatividade efetiva por ela exercida, ou seja, a outorga sindical é dada pelo critério da precedência.

Sem embargo, essa leitura do dispositivo constitucional, além de desatualizada, cria um problema, pois a entidade detentora do registro no Ministro do trabalho e Emprego permanecerá com as prerrogativas sindicais de modo incondicional e por tempo indeterminado, "bastando ter chegado primeiro àquele órgão, cumprido com os requisitos formais da Portaria n. 343/2000, não ter sofrido impugnação por ente do mesmo grau e, finalmente, ter sido contemplada com a respectiva certidão". ${ }^{102}$ A solicitação de registro sindical por outra entidade será barrada no âmbito do TEM e indeferida pelo Poder Judiciário, ainda que detenha número infinitamente maior de filiados, patrimônio mais robusto e maior presença junto aos respectivos trabalhadores ou empresários.

Para resolver esse problema, Paulo Roberto Lemgruber Ebert defende a superação do critério da precedência do registro para fins de conferir o título da entidade sindical a representar uma categoria. Nessa esteira, o autor propõe o critério da maior representatividade, prevista no artigo 519 da CLT, para preencher a lacuna existente no artigo $8^{\circ}$, inciso II, da CF/88 no que tange à comprovação da unicidade sindical.

Nos dizeres de Ebert, o critério de maior representatividade logra obter, pelo menos em certa medida,
uma correlação com a chamada "vontade geral" da categoria e o exercício das
prerrogativas sindicais. Nessa situação, pode-se afirmar que, pelo menos em tese,
o desenho da estrutura sindical é feito pelos próprios trabalhadores ou

${ }^{101}$ EBERT, Paulo Roberto Lemgruber. Sindicato mais representativo e mutação constitucional: uma proposta de releitura do art. $8^{\circ}$, II, da Constituição Federal. São Paulo: LTr, 2007, p. 161.

${ }^{102}$ Ibidem, p. 162. 
empresários diretamente interessados, do mesmo modo que as legislaturas são formadas pela manifestação popular nos processos eleitorais. ${ }^{103}$

Esse critério é mais consentâneo, também, com o princípio democráticorepublicano da transmissão do poder de acordo com os interesses gerais manifestados na lei que, com base no postulado da impessoalidade, estabelece a alternância das forças políticas na gestão da coisa pública. Essa lógica de transmissão do poder no Estado Democrático de Direito é plenamente aplicável às entidades sindicais, porque estas exercem inegável função pública, devendo pautar sua atuação pelo interesse das categorias representadas.

A Justiça do Trabalho, enquanto intérprete e aplicadora das normas constitucionais, poderá adotar em seus julgamentos sobre conflitos de representação sindical o critério da maior representatividade, valendo-se dos princípios constitucionais da unidade sindical e da máxima efetividade dos direitos fundamentais e a interpretação evolutiva das normas constitucionais, que não foram observados nas decisões proferidas pelo STF ao definir o critério da precedência do registro no órgão competente. Aliás, o Supremo sequer se manifestou sobre a recepção ou não do artigo 519 da CLT, na parte em que estabelece a outorga da investidura sindical à associação mais representativa.

A leitura do artigo $8^{\circ}$, inciso II, da $\mathrm{CF} / 88$, com base no critério da maior representatividade, realizada com base no mecanismo da interpretação constitucional evolutiva e nos princípios da interpretação constitucional, inclusive o da unidade da Constituição, demonstra que a nova interpretação do dispositivo é feita sistematicamente, observando-se outros princípios constitucionais como o pluralismo ideológico e a democracia (artigo $1^{\circ}$, caput e inciso $\mathrm{V}$, da CF/88).

Dessa forma, a regra do sindicato único continuará sendo respeitada, porém com um critério mais consentâneo com as necessidades das categorias representadas e com os valores constitucionais que imprimem a participação dos indivíduos diretamente interessados na condução de seus interesses de classe:

[...] além de possibilitar a coexistência de várias associações profissionais de ideologia diversa a postularem a personalidade sindical, estará reforçando o papel da categoria no estabelecimento da entidade que irá defender seus interesses, tal como exige o postulado democrático. ${ }^{104}$

${ }^{103}$ Ibidem, p. 163.

${ }^{104}$ Ibidem, p. 171. 
Assim, a Justiça do trabalho, ao resolver os casos envolvendo o conflito entre duas entidades, verificará o número de associados dos dois entes, os serviços sociais fundados e mantidos, bem como o valor do patrimônio dos litigantes, como determina o artigo 519, da CLT e, após ter uma definição, assegurará ao que é mais representativo o direito de representar a categoria em sua respectiva base territorial.

Essa leitura evolutiva do artigo $8^{\circ}$, inciso II, da $\mathrm{CF} / 88$ valoriza o princípio da liberdade sindical, enquanto direito fundamental que envolve a participação dos trabalhadores na vida do ente representativo de seus interesses perante os empregadores e o governo, bem como a atuação da referida entidade nesse sentido, aproximando-se mais da Convenção n. 87 da OIT, que embora não ratificada pelo Brasil, constitui um feixe de princípios e valores a ser observados no país, em virtude da inclusão desse instrumento internacional na Declaração sobre os Princípios e Direitos Fundamentais no Trabalho, de 1998.

Nessa tese, além de defender a proposta de Paulo Roberto Lemgruber Ebert, tendo em vista que o autor realiza uma interpretação evolutiva do artigo $8^{\circ}$, inciso II, da $\mathrm{CF} / 88$, acolhe-se o posicionamento de que, não havendo entidade sindical representativa de uma outra categoria, ou seja, não existindo conflito acerca de representatividade sindical, é possível uma associação profissional que efetivamente represente os interesses de sua categoria seja considerada sindicato, mesmo antes de seu registro no Ministério do Trabalho e Emprego. Nesse sentido, a ementa, a seguir, de julgamento de Recurso Ordinário pelo Tribunal Regional do Trabalho da $17^{\mathrm{a}}$ Região:

SINDICATO DE SERVIDORES PÚBLICOS - LIBERDADE SINDICAL -
RECONHECIMENTO DE EXISTÊNCIA MESMO SEM REGISTRO NO
MINISTÉRIO DO TRABALHO - IRREGULARIDADE ADMINISTRATIVA
- TEORIA DAS APARENNCIAS. A Constituição Federal de 1988 traz como
princípio a liberdade sindical, vedando que a lei possa exigir autorização estatal
para fundação de sindicato, interferência e intervenção do poder público na
organização sindical, ressalvando o registro no órgão competente, trazendo ainda
o princípio da unicidade sindical. A entidade sindical registrada no registro civil
de pessoas jurídicas, mesmo não estando registrado no MTb, deve ser
reconhecida como entidade sindical de primeiro grau representativa dos
servidores do município de Cachoeiro de Itapemirim e como destinatária das
contribuições sindicais, vez que suas ações no campo sindical são aquelas
desejadas por um sindicato, sendo reconhecida tacitamente tanto por esta
Especializada, pela administração municipal, pelo MPT, pelos servidores filiados
sendo inúmeras as evidências que a entidade vem cumprindo papel
constitucionalmente garantido aos sindicatos. Inteligência do art. $8^{\circ}$, caput e
incisos I, II, e III c/c art. 37 , VI, todos da CF/88. ${ }^{105}$

105 ESPÍRITO SANTO. Tribunal Regional do Trabalho da 17 ${ }^{\mathrm{a}}$ Região. RO - 01401.2005.132.17.00.0. Desembargadora Relatora: Wanda Lúcia Costa Leite França Decuzzi. Publicação no DOE: 20 fev. 2008. 
Se uma entidade representa efetivamente os interesses dos integrantes de uma categoria profissional, sendo reconhecida nesse sentido pelos representados e pela sociedade, de uma forma geral, e devidamente registrada no Cartório de Pessoas Jurídicas, não há motivos para impedir que essa entidade seja considerada como sindicato, com direito ao exercício de todas as prerrogativas dos entes sindicais, pois não é possível que a categoria fique sem qualquer tipo de defesa dos direitos individuais e coletivos dos seus integrantes quando há concretamente uma associação que já a representa na prática, apenas não sendo reconhecida como tal pelo Ministério do Trabalho e do Emprego.

Interpretação contrária a esse entendimento é involutiva, pois desprestigia os princípios da livre associação e da liberdade sindical, ao restringir apenas aos membros das categorias representadas pelos sindicatos registrados no MTE o direito de defesa dos seus interesses, judicialmente ou perante a Administração Pública. 


\section{CONCLUSÃO}

Os direitos trabalhistas são fruto das lutas operárias por melhores condições de vida e de trabalho, ao longo dos séculos XVIII e XIX. Os direitos sociais considerados mínimos foram inseridos nas Constituições e nos instrumentos internacionais ao decorrer do século XX.

No Brasil, embora já estabelecidos alguns direitos mínimos trabalhistas desde a Constituição de 1934, eles apenas foram denominados fundamentais com a Constituição Federal de 1988 que os ampliou e imprimiu-lhes aplicabilidade imediata e caráter de cláusulas pétreas. Esses direitos, consagrados nos artigos $6^{\circ}$ ao 11 da Constituição Federal de 1988 e no artigo 10 do Ato das Disposições Constitucionais Transitórias, fazem parte do chamado sistema de direitos fundamentais, devendo ser efetivamente tratados como direitos essenciais para assegurar a dignidade da pessoa humana. Em virtude de sua fundamentalidade, as normas que os embasam possuem estrutura principiológica aberta, pois os direitos fundamentais englobam um feixe de situações jurídicas subjetivas e objetivas que abrem ao intérprete um campo de atuação muito mais amplo do que em relação às regras constitucionais.

Os direitos fundamentais trabalhistas vêm sendo cotidianamente desrespeitados pelos empregadores, o que traz à torna o problema da efetividade ou eficácia desses direitos. Nesse sentido, têm sido utilizados alguns mecanismos processuais (tutela antecipada, inibitória, coletiva, específica, entre outros) para tentar assegurar os direitos materiais pleiteados em juízo.

Ao mesmo tempo, outro problema grave vem passando de certa forma despercebido. A ausência de implementação ou implementação restritiva de vários direitos fundamentais trabalhistas pela atuação da Justiça do Trabalho no que tange à interpretação das normas que os estabelecem, impedindo que eles sejam exercidos pelos trabalhadores. Ora esse ramo especializado do Judiciário não confere às normas de direitos trabalhistas aplicabilidade máxima e, em virtude da ausência de leis infraconstitucionais regulamentadoras necessárias para dar eficácia às normas de aplicabilidade limitada, resta impedido o exercício desses direitos sociais pelos cidadãos trabalhadores, ora os juízes e tribunais do trabalho dão aos direitos trabalhistas fundamentais uma interpretação involutiva e não consentânea com a realidade social. 
A postura do Judiciário em geral e, especificamente, da Justiça do Trabalho tem se embasado em uma concepção restritiva de cidadania e do exercício dos direitos fundamentais sociais. Ademais, os próprios juízes têm arraigado uma postura de autorestrição no que se refere à concretização dos direitos sociais, pautada não apenas em uma leitura desatualizada da teoria da separação dos poderes, originalmente desenvolvida por Montesquieu, como também na ideia de que o Poder Judiciário não seria legítimo para a tarefa de materializar os direitos fundamentais sociais. No caso da Justiça do Trabalho, esse problema tem se agravado, em virtude de uma cultura jurídica sedimentada no sentido de tratar os direitos estabelecidos na Constituição Federal como verdadeiros direitos fundamentais.

Não se descuida que esse ramo específico do Poder Judiciário tem uma atuação relativamente mais vanguardista no que tange à implementação dos direitos sociais, em comparação com os demais ramos do Judiciário. Sem embargo, essa postura um pouco mais pró-ativa não tem sido suficiente para implementar, de forma plena e efetiva, os direitos fundamentais trabalhistas.

Observa-se, ao longo dessa tese, que os argumentos utilizados para tirar a legitimidade do Judiciário no sentido de implementar direitos fundamentais não destituídos de fundamentos fáticos ou jurídicos plausíveis.

Após realizar um estudo detalhado acerca das concepções de cidadania e sua relação com o exercício dos direitos sociais em maior ou menor amplitude, constatou-se que a Constituição Federal de 1988 adotou a concepção de cidadania social, uma vez que elencou, além dos direitos fundamentais civis e políticos e dos remédios constitucionais, diversos direitos fundamentais sociais, imprimindo-lhes aplicabilidade máxima (artigo $5^{\circ}$, artigo $1^{\circ}$, da $\mathrm{CF} / 88$ ) e a garantia de acesso a uma ordem jurídica justa. É necessário salientar que o termo "social" não importa em excluir do âmbito de exercício do indivíduo os direitos civis e políticos, mas apenas ressaltar que a Lei Fundamental construiu uma sistemática em que os direitos sociais são colocados em posição de destaque, não servindo apenas como vetores axiológicos interpretativos, mas se constituindo como direitos fundamentais que devem ser exercidos pelos cidadãos em geral.

Ademais, as normas de direitos fundamentais sociais não estão dirigidas apenas aos Poderes Executivo e Legislativo, mas também ao Judiciário, visto que todo o aparato estatal deve fazer um esforço para materializar as conquistas sociais estabelecidas constitucionalmente. 
A cidadania social se constitui, portanto, em um elemento legitimador de uma atuação do Poder Judiciário, comprometida com a implementação efetiva dos direitos fundamentais, e consequentemente de uma hermenêutica jurisdicional que tem por objetivo interpretar e concretizar os direitos sociais na maior medida possível.

Não há oposição no modelo constitucional adotado no Brasil ou mesmo da sociedade quanto à legitimação do Judiciário na tarefa de implementação dos direitos sociais estabelecidos na Constituição, incluindo os direitos fundamentais trabalhistas.

Não se pode utilizar, também, como argumento para a atuação pouco vanguardista do Judiciário em relação à materialização de direitos sociais, a teoria dos três Poderes de Montesquieu, pois há muito essa teoria não se apresenta como originalmente desenvolvida. Com efeito, a ideia de que cada um dos poderes tem as suas determinadas funções, que um poder não poder interferir no outro e que os juízes são apenas a boca que pronuncia as palavras da lei são muito limitadas para a ideia de separação harmônica dos poderes estatais no paradigma do Estado Democrático de Direito que tem como fim último garantir ao ser humano as condições mínimas para uma vida com dignidade. Assim, o Judiciário vem sendo chamado a desempenhar funções que garantam e emprestem eficácia e aplicabilidade máxima aos dispositivos constitucionais que estabelecem direitos fundamentais.

No Brasil, o dogma da tradicional separação de poderes vem sendo relativizado, pois o Judiciário tem apresentado uma postura mais pró-ativa no sentido de implementar alguns direitos fundamentais sociais, de defesa ou de natureza prestacional. Sem embargo, essa atuação jurisdicional mais vanguardista ainda é insuficiente para implementar esses direitos, incluindo os direitos fundamentais trabalhistas.

Essa perspectiva atualizada da teoria da tripartição dos poderes se relaciona diretamente à concepção de cidadania social adotada pela Constituição Federal de 1988, que significa que o indivíduo não apenas tem os direitos fundamentais sociais garantidos, mas que deve poder efetivamente exercê-los. E, para isso, poderá inclusive buscar a Justiça do Trabalho para esse ramo especializado do Judiciário atue de forma a implementar os direitos estabelecidos constitucionalmente

A busca do cidadão pelo Poder Judiciário, com poder legítimo a implementar direitos fundamentais sociais, tem fulcro no princípio do acesso a uma ordem jurídica justa, que passa pelo acesso aos tribunais, pelo direito de estar em juízo e de direito de receber uma tutela jurisdicional efetiva e célere que materialize os direitos reconhecidos em juízo, inclusive os direitos fundamentais sociais e especificamente os trabalhistas, 
inclusive por meio de uma interpretação jurídica condizente com as normas constitucionais que estabelecem os direitos fundamentais dos trabalhadores.

Assim, juízes e tribunais do trabalho, por meio dos mecanismos processos e da hermenêutica constitucional pertinentes, deverão trabalhar em prol da efetivação e materialização dos direitos fundamentais garantidos aos trabalhadores, garantido ao cidadão o acesso a uma ordem jurídica justa, em sua concepção mais ampla.

Conclui-se, assim, que no atual contexto democrático, a Justiça do Trabalho tem o poder-dever de implementar os direitos fundamentais dos cidadãos trabalhadores, pois está legitimamente autorizada pela Constituição Federal de 1988.

Se o cidadão trabalhador vai ao Judiciário na esperança de ver reconhecido, garantido e materializado um direito constitucionalmente positivado, a decisão proferida pelo juiz do trabalho não deve frustrar a sua pretensão, sob pena de abalar a confiança do litigante no Poder Judiciário e na sua capacidade de implementação dos direitos sociais.

Os juízes do trabalho são, assim como todos os demais juízes, intérpretes da Constituição. No atual Estado Democrático, exige-se uma atuação muito mais complexa do juiz que é chamado a interpretar dispositivos constitucionais com estrutura principiológica, entre eles os direitos fundamentais trabalhistas. Para exercer tão importante função, o juiz deve se valer dos princípios e dos métodos (tradicionais e modernos) da interpretação constitucional e do mecanismo da mutação constitucional, que quando é efetuado por um órgão jurisdicional é denominado de interpretação evolutiva.

Esse mecanismo importa na interpretação das normas de direitos fundamentais pautada pelas mudanças sociais e econômicas que alterem o sentido ou o alcance do conteúdo dessas normas, sem a necessidade de alteração formal do seu texto.

Os direitos trabalhistas estabelecidos constitucionalmente devem ser constantemente relidos pelo aplicador do Direito, pois as alterações sociais e econômicas ao longo do tempo importam, muitas vezes, em uma alteração do sentido e do alcance das normas. Essa releitura deve ser feita com base nos valores estabelecidos pelas normas constitucionais que traduzem tais direitos e de acordo com uma pré-compreensão das questões sociais voltada para a realidade, ou seja, para o que ocorre efetivamente no espaço externo aos tribunais. Por isso, a importância da formação não apenas jurídica, mas, também, humanística dos magistrados, desde a graduação até os cursos de atualização e aperfeiçoamento de juízes. O Direito, encarado em uma perspectiva histórica, deve ser concebido como instrumento de direção e promoção social e valorizado como método para a correção das igualdades e consecução de padrões mínimos de equilíbrio socioeconômico, 
o que pressupõe um conhecimento multidisciplinar, por parte do aplicador do direito, sobre as dimensões política, sócio-econômica e ideológica da ordem legal.

Com o objetivo de solucionar a distância entre a realidade social vivenciada pelos trabalhadores e a implementação restritiva ou a ausência de implementação dos direitos fundamentais trabalhistas, em virtude de uma interpretação restritiva desses direitos, inclusive em casos de falta de regulação infraconstitucional, propõe-se a utilização, pelos juízes e tribunais do trabalho, do método da interpretação constitucional evolutiva.

Essa mecanismo possibilita ao aplicador da norma realizar a interpretação mais adequada da norma constitucional, por meio da comparação entre os valores originariamente dispostos na Constituição e os fatos sociais contemporâneos, possibilitando uma implementação mais ampla e efetiva dos direitos fundamentais trabalhistas.

A interpretação, no plano constitucional, em se tratando de matéria de direitos fundamentais, deve ser evolutiva e tem como perspectiva a adequação dos preceitos constitucionais originais a uma visão histórica e política contemporânea, sem a necessidade da realização de uma reforma constitucional.

Não se desconsidera que a tarefa interpretativa exige um papel legitimamente ativo e criador dos juízes do trabalho, pois inúmeras normas constitucionais, inclusive as que estatuem direitos fundamentais, apresentam estrutura principiológica, e é necessária a atuação do aplicador do direito para densificá-las, delimitando o alcance e o sentido em um determinado contexto histórico, em conformidade com as mudanças que ocorrem na realidade social.

Essa atuação mais ativa e "criativa" dos juízes em geral é legitimada na própria Constituição, que elencou um amplo rol de direitos fundamentais, estabelecidos em normas de estrutura principiológica, permeadas de valores, e fortaleceu o Poder Judiciário. Após os estudos acerca dos fenômenos da "judicialização da política" e do "ativismo judicial", constata-se que o primeiro decorre do modelo constitucional adotado pelo Brasil, não podendo ser considerado arbitrário a atuação política dos juízes acerca de determinados temas eminentemente políticos. O ativismo judicial também se coaduna as funções exigidas pelos juízes no contexto do Estado Democrático de Direito, desde que compreendido como uma atuação mais pró-ativa desses aplicadores do Direito em relação à tarefa interpretativa de normas constitucionais que trazem em seu bojo os direitos fundamentais. A interpretação evolutiva, como uma forma de interpretação mais pró-ativa da Constituição, deverá, contudo, observar alguns limites, como o espírito da Constituição, 
o texto da norma constitucional em análise e a sua contextualização na sistemática constitucional. A decisão judicial, ademais, terá que ser fundamentada com elementos fáticos e jurídicos razoáveis que demonstrem que houve mudanças econômico-políticosociais que implicam em uma leitura atualizada do dispositivo constitucional, evitando-se, assim, arbitrariedades e escolhas pessoais dos juízes sem qualquer argumentação plausível.

Com o objetivo de demonstrar a aplicação prática do mecanismo da interpretação constitucional evolutiva como forma de implementar, de forma mais ampla e efetiva, os direitos fundamentais trabalhistas, imprimindo-lhes uma interpretação não restritiva e conferindo-lhes a máxima aplicabilidade viável, foram trazidos exemplos colhidos na doutrina e na jurisprudência dos Tribunais Regionais do Trabalho e do Tribunal Superior do Trabalho. Em se tratando da atuação jurisdicional trabalhista, constatou-se que, em alguns casos, o posicionamento mais evolutivo é pontual e, em outras situações, já resta sedimentado na jurisprudência. Foram, também, apresentadas algumas propostas de interpretação constitucional evolutiva de direitos fundamentais trabalhistas, com o fim de implementá-los na maior medida possível, possibilitando o exercício desses direitos sociais mínimos pelo cidadão trabalhador.

Por fim, conclui-se que a cidadania social, diretamente vinculada a uma concepção ampliativa do exercício de direitos fundamentais sociais, é o elemento legitimador de uma postura mais ativa da Justiça do Trabalho no sentido de concretizar os direitos fundamentais trabalhistas. Para lograr êxito nessa complexa tarefa, os juízes e desembargadores dos Tribunais Regionais do Trabalho, assim como os Ministros do Tribunal Superior do Trabalho deverão se pautar por uma leitura atualizada dos preceitos constitucionais que estabelecem os direitos fundamentais trabalhistas dispostos nos artigos $7^{\circ}$ ao 11 da $\mathrm{CF} / 88$ e no artigo 10 do ADC, de modo a interpretá-los de forma mais consentânea com as modificações ocorridas na realidade social, sem a necessidade da alteração do texto da norma. Esse é um caminho verdadeiramente viável para que a Justiça do Trabalho implemente, na maior medida possível, os direitos fundamentais trabalhistas, possibilitando o seu exercício pleno e efetivo pelos cidadão trabalhadores, com vistas a assegurar-lhes condições para que trabalhem e vivam com dignidade. 


\section{REFERÊNCIAS BIBLIOGRÁFICAS}

ABRAMOVICH, Víctor; COURTIS, Christian. Los derechos sociales como derechos exigibles. Madrid: Trotta, 2002.

ABRANTES, José João Nunes. A vinculação das entidades privadas aos direitos fundamentais. Lisboa: Associação Acadêmica da Faculdade de Direito de Lisboa, 1990.

AGRA, Walber de Moura. A reconstrução da legitimidade do Supremo Tribunal Federal: densificação da jurisdição constitucional brasileira. Rio de Janeiro: Forense, 2005.

AHUMADA RUIZ, Marian. Alternativas a la judicial review y variedades de judicial review. Themis, a. IV, n. 10, 2005.

ALEXY, Robert. Teoría de los derechos fundamentales. Trad. Ernesto Garzón Valdés. Madri: Centro de Estúdios Constitucionales, 1993.

ALVIM, Maria Cristina de Souza. Educação, cidadania e acesso à justiça. Revista Mestrado em Direito. Osasco, v. 6, n. 2, p. 97-106, 2006.

ANDRADE, José Carlos Vieira de. Os direitos fundamentais na Constituição de 1976. 2 ed. Coimbra: Almedina, 2001.

BARACHO, José Alfredo de Oliveira. Teoria geral da cidadania: a plenitude da cidadania e as garantias constitucionais e processuais. São Paulo: Saraiva, 1995.

. Teoria geral da revisão constitucional e teoria da constituição originária. Revista de direito administrativo, Rio de Janeiro, Renovar, v. 39, n. 198 , p. 50-67, [s.d.].

BARCELOS, Ana Paula. A eficácia jurídica dos princípios constitucionais: o princípio da dignidade da pessoa humana. Rio de Janeiro: Renovar, 2002.

BARros, Alice Monteiro de. Curso de Direito do Trabalho. 3 ed. rev. e ampl. São Paulo: LTr, 2007.

Os efeitos do contrato de trabalho do empregado portador do vírus HIV. Revista IOB trabalhista e previdenciária, São Paulo, v. 19, n. 220, p. 728, out. 2007.

. O Trabalho da Mulher na Constituição de 1988. In: Constitucionalismo Social: estudos em Homenagem ao Ministro Marco Aurélio Mendes de Farias Mello. São Paulo: LTr, 2003, p. 100-138.

BARROSO, Luís Roberto. Interpretação e aplicação da constituição. 5 ed. São Paulo: Saraiva, 2003. 
Judicialização, ativismo judicial e legitimidade democrática.

Revista da EMARF, Cadernos Temáticos, Rio de Janeiro, p. 389-406, dez. 2010.

Neoconstitucionalismo e constitucionalização do Direito: o triunfo tardio do direito constitucional no Brasil. Revista de Direito Administrativo, Rio de Janeiro, n. 240, p. 1-42, abr./jun. 2005.

. O Direito Constitucional e a efetividade de suas normas limites e possibilidades da Constituição Brasileira. Rio de Janeiro: Renovar, 1996.

; BARCELlOS, Ana Paula. O começo da história. A nova interpretação constitucional e o papel dos princípios do Direito Brasileiro. Revista Interesse Público, Sapucaia do Sul: Notadez, v.5, n.19, p.51-80, maio/jun. 2003.

BASTOS, Celso Ribeiro. Hermenêutica e interpretação constitucional. 2 ed. rev. e ampl. São Paulo: Celso Bastos Editor, Instituto Brasileiro de Direito Constitucional, 1999.

BILBAO UBILLOS, Juan Maria. La eficacia de los derechos fundamentales frente a particulares. Madrid: Centro de Estudios Constitucionales, 1997.

BISCARETTI DI RUFFIA, Paolo. Diritto constituzionale: istuzioni di diritto pubblico. 10 ed. Napoli: Jovene, 1974.

BLACK's Law Dictionary. Eighth edition. Bryan A. Garner: Books, 2004.

BOBBIO, Norberto. A era dos direitos. Trad. Carlos Nelson Coutinho. Rio de Janeiro: Campus, 2000.

O positivismo jurídico. São Paulo: Ícone, 1995

BÖCKENFÖRDE, Ernest-Wolfgang. Escritos sobre derechos fundamentales. Trad. Juan Requejo Pagés e Ignácio Villaverde Menéndez. Baden-Baden: Nomos Ver.-Ges, 1993.

BONAVIDES, Paulo. Curso de direito constitucional. 20 ed. atual. São Paulo: Malheiros Editores, 2007.

BRASIL. Constituição da República Federativa do Brasil, promulgada em 05 de outubro de 1988.

BRASIL. Tribunal Superior do Trabalho. AIRR - 69440-93.2007.5.02.0087. $3^{\text {a }}$ Turma. Ministro Relator: Alberto Luiz Bresciani de Fontan Pereira. Publicação no DEJT: 28 maio 2010.

BRASIL. Tribunal Superior do Trabalho. E-RR-449.723/1998.9. SDI-1. Ministro Relator: Lélio Bentes Corrêa. Publicação no DJU: 25 maio 2007.

BRASIL. Supremo Tribunal Federal. MI n. 144-SP. Relator: Ministro Sepúlveda Pertence. Plenário. Públicação no DJU: 28 maio 1993.

BRASIL. Supremo Tribunal Federal. Recurso Ordinário em Mandando de Segurança n. 21.080-DF. Relator: Ministro Francisco Rezek. Plenário. Publicação em: $1^{\circ}$ out. 1993. 
BRASIL. Supremo Tribunal Federal. RE 210029/RS. Tribunal Pleno. Relator original: Ministro Carlos Velloso. Relator para o acórdão: Ministro Joaquim Barbosa. Publicação no DJU: 17 ago. 2007.

BRASIL. Tribunal Superior do Trabalho. RR -328/2004-091-09-00.0. $4^{\text {a }}$ Turma. Ministro Relator: Barros Levenhagem. Publicação no DJU: 24 nov. 2006.

BRASIL. Decreto-Lei 5.452, de $1^{\circ}$ de maio de 1943. Aprova a Consolidação das Leis do Trabalho. Diário Oficial da União, Brasília, 09 ago. 1943.

BRASIL. Tribunal Superior do Trabalho. RODC-309/2009-000-15-00.4. Seção de Dissídios Coletivos. Rel. Ministro Maurício Godinho Delgado. Publicação da decisão no DEJT em: 04 set. 2009.

BRASIL. Tribunal Superior do Trabalho. RR-955/2006-099-15-00.1. $7^{\text {a }}$ Turma. Ministro Relator: Yves Gandra Martins Filho. Publicação no DJU: 16 maio de 2011.

BRASIL. Tribunal Superior do Trabalho. RR 768358/2001.3. $1^{\text {a }}$ Turma. Ministra Relatora: Dora Maria da Costa. Publicação no DJU: 31 ago. 2007.

BRASIL. Tribunal Superior do Trabalho. RR 145/2006-872-09-00.4. 6a Turma. Ministro Relator: Aloysio Corrêa da Veiga. Publicação no DEJT: 18 dez. 2007.

BULOS, Uadi Lammêgo. Mutação constitucional. São Paulo: Saraiva, 1997.

CAMPILONGO, Celso Fernando. Os desafios do Judiciário: um enquadramento. In: FARIA, José Eduardo de (Org.). Direitos humanos, direitos sociais e justiça. São Paulo: Malheiros Editores, 2005, p. 30-51.

CAMPINAS. Tribunal Regional do trabalho da $15^{\text {a }}$ Região. RO 00935-2002-088-15-00-3. Relator: Juiz convocado Jorge Luiz Souto Maior. Publicação do acórdão no DJSP: 7 maio 2004.

CAMPINAS. Tribunal Regional do Trabalho da $15^{\text {a }}$ Região. RO 00224-2005-120-15-00-5. $11^{a}$ Turma. Relator: Desembargador Flávio Nunes Campos. Publicação no DJSP: 02 mar. 2007.

CAMPINAS. Tribunal Regional do Trabalho da $15^{\text {a }}$ Região. DC 00309-2009-000-15-00-4, SDC, Relator: Desembargador José Antônio Pancotti. Publicação da Decisão no DJSP: 30 mar. 2009.

CANARIS, Claus-Wihelm. Grundrechte und privatrecht. AcP 184, 1984.

CANOtilho, J. J. Gomes. Direito constitucional e teoria da constituição. 3 ed. Coimbra: Almedina, 1999.

. Direito constitucional. Coimbra: Almedina, 1991.

- Um olhar jurídico-constitucional sobre a judiciarização da política. In: RIBEIRO, Lauro Luiz Gomes e BERARDI, Luciana Andrea Accorsi (Orgs.). Estudos de direito constitucional: em homenagem à professora Maria Garcia. São Paulo: IOB-Thomson, 2007, p. 230-241. 
CAPPELLETTI, Mauro. Juízes legisladores. Porto Alegre: Sérgi Antônio Fabris Editor, 1993. Trad. Carlos Alberto A. de Oliveira.

Antônio Fabris, 1988.

; GARTH, Bryant. Acesso à justiça. Porto Alegre: Sérgio

CASTRO, Flávia de Almeida Viveiros de. Interpretação constitucional e prestação jurisdicional. Rio de Janeiro: Lumen Juris, 2000.

paradigmas de atuação. Rio de Janeiro: Lumen Juris, 1998.

O poder judiciário na virada do século:

CASTRO, Marcus Faro de. O Supremo Tribunal Federal e a judicialização da política. Revista Brasileira de Ciências Sociais. São Paulo, n. 34, v. 12, p. 149-156, jun. 1997.

CHAVES JÚNIOR, José Eduardo de Resende. Subordinação estrutural: reticular e alienidade. Revista do Tribunal Regional do Trabalho da $\mathbf{1 5}^{\mathbf{a}}$ Região, Campinas, n. 32, p. 127-146, jan./jun. 2008.

CITADINO, Gisele. Judicialização da política, constitucionalismo democrático e separação dos poderes. In: VIANNA, Luiz Werneck (Org.). A Democracia e os Três Poderes no Brasil. 1 ed. Belo Horizonte, v. 1: Editora da UFMG/IUPERJ/FAPERJ, 2002, p. 17-42.

CLÈVE, Clèmerson Merlin. A eficácia dos direitos fundamentais sociais. Boletim Científico - Escola Superior do Ministério Público da União. Brasília: ESMPU, n. 8, p. 151-161, jul./set., 2003.

COMPARATO, Fábio Konder. A afirmação histórica dos direitos humanos. São Paulo: Saraiva, 1999.

CORREIA, Marcus Orione Gonçalves. O postulado da razoabilidade e o Direito dTrabalho. In: CORREIA, Marcus Orione Gonçalves (Org.). Curso de Direito do Trabalho, v. 1 - Teoria geral do Direito do Trabalho. São Paulo: LTr, 2007.

CORTEZ, Antonio Celso Aguillar. Acesso à justiça. Revista dos Tribunais, ano 82, v. 692, p. 198-201, jun. 1993.

DALLARI, Dalmo de Abreu. Elementos de teoria geral do Estado. 19. ed. atual. São Paulo: Saraiva, 1995.

O poder dos juízes. 3 ed. São Paulo: Saraiva, 2008.

DANTAS, David Diniz. Interpretação constitucional no pós-positivismo: teoria e casos práticos. São Paulo: Madras, 2004.

DAU-LIN, Hsü. Mutación de la constitución. Bilbao: Instituto Vasco de Administración Pública, 1998. Trad. Pablo Lucas Verdú e Christian Förster.

DELGADO, Maurício Godinho. Curso de Direito do Trabalho. 5 ed. São Paulo: LTr, 2006. 
Direitos fundamentais na relação de trabalho. Revista de Direito do Trabalho, São Paulo, v. 32, n. 123, p. 143-165, jul./set. 2003.

DWORKIN, Ronald. Levando os direitos a sério. Tradução de Nelson Boeira. São Paulo: Martins Fontes, 2002.

EBERT, Paulo Roberto Lemgruber. Sindicato mais representativo e mutação constitucional: uma proposta de releitura do art. $8^{\circ}$, II, da Constituição Federal. São Paulo: LTr, 2007.

EISENBERG, José. Pragmatismo, direito reflexivo e judicialização da política. In: VIANNA, Luiz Werneck (org.). A democracia e os três poderes no Brasil. Belo Horizonte: UFMG; Rio de Janeiro: IUPERJ/FAPERJ, 2003, p. 43-62.

ENUNCIADOS da $1^{\text {a }}$ Jornada de Direito Material e Processual na Justiça do Trabalho, realizado em 23 de novembro de 2007 pela ANAMATRA (Associação Nacional de Magistrados da Justiça do Trabalho). Disponível em: <http://www.amatra.org.br/jornada/enunciados/enunciados_aprovados.cfm>. Acesso: 25 out. 2011.

ESPÍRITO SANTO. Tribunal Regional do Trabalho da $17^{\mathrm{a}}$ Região. RO 01401.2005.132.17.00.0. Desembargadora Relatora: Wanda Lúcia Costa Leite França Decuzzi. Publicação no DOE: 20 fev. 2008.

ESTEVES, João Luiz M. Direitos fundamentais sociais no Supremo Tribunal Federal. São Paulo: Método, 2007.

da Unifil, v. 1, n. 1, p. 118-131, 2004.

Cidadania e judicialização de conflitos sociais. Revista Jurídica

FERNANDES, Nádia Soraggi. Ação civil pública trabalhista: forma célere e efetiva de proteção dos direitos fundamentais dos trabalhadores. São Paulo: LTr

FERRAZ, Anna Cândida da Cunha. Processos informais de mudança da Constituição. São Paulo: Max Limonad, 1986.

FERREIRA FILHO, Manoel Gonçalves. Direitos humanos fundamentais. 5 ed. rev. São Paulo: Saraiva, 2002.

FERREIRA, Luís Pinto. Curso de direito constitucional. São Paulo: Saraiva, 1984.

FISHER, Louis. Constitucional dialogues: interpretation as political process. New Jersey: Princeton University Press, 1988.

GARCIA, Maria. Mas, quais são os direitos fundamentais? Revista de direito constitucional e internacional, São Paulo, v. 10, n. 39, p. 115, abr./jun. 2002.

GEMIGNANI, Tereza Aparecida Asta. Direitos fundamentais e sua aplicação no mundo do trabalho: questões controversas. São Paulo: LTr, 2010. 
GOIÁS. Tribunal Regional do Trabalho da $18^{\mathrm{a}}$ Região. RO 01241-2007-013-18-00-9. Relator: Desembargador Aldon do Vale Alves Taglialegna. Publicação no DJE: 16 out. 2008.

GOMES, Ana Virgínia Moreira; BERTOLIN, Patrícia Tuma Martins. O significado da Declaração de Princípios e Direitos Fundamentais dos Trabalhadores na posição da OIT como a organização internacional capaz de garantir um conteúdo laboral no processo de globalização. Revista de Direito do Trabalho. São Paulo: v.31, p. 15-30, n.119, jul./set.2005.

GOMES, Dinaura Godinho Pimentel. O processo de afirmação dos direitos fundamentais: evolução histórica, interação expansionista e perspectivas de efetivação. Revista de direito constitucional e internacional, São Paulo, v.11, n.45 , p.109-140, out./dez. 2003.

GONÇALVES, Rogério Magnus Varela. Os direitos fundamentais e sua validade no âmbito das relações privadas. Revista Prim@ Facie, João Pessoa, v. 3, n. 5, p. 73-100, 2004.

GRAU, Eros Roberto. A ordem econômica na Constituição de 1988. São Paulo: Malheiros, 2000.

GUERRA FILHO, Willis Santiago. Processo constitucional e direitos fundamentais. São Paulo: Celso Bastos, 1999.

HÄBERLE, Peter. El estado constitucional. Buenos Aires: Astra, 2007.

Hermenêutica constitucional. A sociedade aberta dos intérpretes da Constituição: contribuição para a interpretação pluralista e "procedimental" da Constituição. Porto Alegre: Sérgio Antônio Fabris, 1997. Trad. Gilmar Ferreira Mendes.

HABERMAS, Jürgen. Direito e democracia: entre faticidade e validade. Rio de Janeiro: Tempo brasileiro, 1997.

HELlER, Hermann. Teoria do Estado. São Paulo: Mestre Jou, 1968. Trad. Lycurgo Gomes da Motta.

HERRERA FLORES, Joaquín. Los derechos humanos como productos culturales: crítica del humanismo abstracto. Madri: Los Libros de la Catarata, 2005.

HESSE, Konrad. A força normativa da Constituição. Porto Alegre: Sérgio Antônio Fabris, 1991. Tradução: Gilmar Ferreira Mendes.

Elementos de direito constitucional da República Federativa da Alemanha. Porto Alegre: Sérgio Antônio Fabris, 1998. Trad. Luís Afonso Heck.

Constitucionales, 1983.

Escritos de derecho constitucional. Madrid: Centro de Estudios Grundzüge des verfassungsrechts der bundesrepublik deutschland. 20 ed. Heidelberg: CF Muller, 1995. 
HIRSCHL, Ran. The new constitutionalism and the judicialization of pure politics worldwide. Fordham Law Review, v. 75, n. 2, p. 721-754, 2006-2007.

Towards juristocracy: the origins and consequences of the new constitucionalism. Harvard University Press, 2004.

JELLINEK, Georg. Reforma y mutación de la constitución. Madrid: Centro de Estudios Constitucionales, 1991. Trad. Christian Förster.

Sistema dei diritti pubblici subbietivi. Milano, 1910.

KELSEN, Hans. Jurisdição Constitucional. São Paulo: Martins Fontes, 2003.

KRELL, Andreas Joachim. Direitos sociais e controle judicial no Brasil e na Alemanha. Porto Alegre: Sergio Antonio Fabris, 2002.

- Realização dos direitos fundamentais sociais mediante controle judicial da prestação de serviços públicos básicos (uma visão comparativa). Revista de Informação Legislativa/Senado Federal. Brasília: Subsecretaria de Edições Técnicas, n. 36, p. 2439-260, out./dez. 1999.

LAFER, Celso. A internacionalização dos direitos humanos: Constituição, racismo e relações internacionais. Barueri, SP: Manole, 2005.

LAFER, Celso. A reconstrução dos direitos humanos - Um diálogo com o pensamento de Hannad Arendt. São Paulo: Companhia das Letras, 1999.

LASSALE. Ferdinand. A essência da constituição. Tradução de Walter Stones. Rio de Janeiro: Liber Juris.

LEITE, Carlos Henrique Bezerra. Curso de direito processual do trabalho. 4 ed. São Paulo: LTr, 2006.

LIMA, Ana Lúcia Coelho. Dispensa discriminatória na perspectiva dos direitos fundamentais. São Paulo: LTr, 2009.

LOEWENSTEIN, Karl. Teoría de la constitución. Barcelona: Ariel, 1965. Trad. Alfredo G. Anabitarte.

MALLET, Estévão. Discriminação e processo do trabalho. In: VIANA, Márcio Túlio; RENAULT, Luiz Otávio Linhares. Discriminação. São Paulo: LTr, p. 156-168, 2000.

Discriminação, igualdade e direito do trabalho. Revista do Tribunal Superior do Trabalho, Brasília, v. 76, n. 3, p. 17-51, jul./set.2010.

MANRICH, Nelson. Autonomia, parassubordinação e subordinação: os diversos níveis de proteção do trabalhador e do teletrabalhador. Artigos de professores da Faculdade de Direito da Universidade Plesbiteriana. Disponível em: <http://www.mackenzie.br/fileadmin/Graduacao/FDir/Artigos/nelson_manrich.pdf $>$. Acesso em: 30 out. 2011. 
MARHALL, T. H. Cidadania, classe social e status. Rio de Janeiro: Zahar Editores, 1967.

MARSHALL, William P. Conservatives and the seven sins of judicial activism. University of Colorado Law Review, v. 73, set. 2002.

MARTIN, Elizabeth A.; LAW, Jonathan. Dictionary of law. Oxford Paperback Reference, 2009.

MARTINEZ, Luciano. Curso de direito do trabalho: relações individuais, sindicais e coletivas de trabalho. São Paulo: Saraiva, 2010.

MARTINS, Sérgio Pinto. Os efeitos do contrato de trabalho do empregado portador do vírus HIV. Revista IOB trabalhista e previdenciária, São Paulo, v. 19, n. 220, p. 29-37, out. 2007.

MARTINS FILHO, Yves Gandra da Silva; NASCIMENTO, Amauri Mascaro do. História do trabalho, do direito do trabalho e da justiça do trabalho. 2 ed. São Paulo: LTr, 2002 .

MAXIMILIANO, Carlos. Hermenêutica e aplicação do direito. Rio de Janeiro: Forense, 1994.

MAZZUOLI, Valério de Oliveira. O novo $\S 3^{\circ}$ do art. $5^{\circ}$ da Constituição e sua eficácia. Revista da AJURIS, Porto Alegre, v. 32, p. 303-332, jan. 2005.

MEIRELLES TEIXEIRA, José Horácio. Curso de direito constitucional. Rio de Janeiro: Forense Universitária, 1991.

MELLO, Celso de. Retrospectiva 2006: a Constituição e o Supremo na visão dos seus guardiões. Disponível em: < http://www.academus.pro.br/implementos/entrevistas/impressao_entrevista.asp?titulo=Entr evistas\&codigo=39> . Acesso: 18 set. 2011.

MINAS GERAIS. Tribunal Regional do Trabalho da $3^{\text {a }}$ Região. $4^{\text {a }}$ Turma. RO 001192008-091-03-00-3, Desembargador Relator: Luiz Otávio Linhares Renault. Publicação no DJMG: 17 dez. 2009.

MINAS GERAIS. Tribunal Regional do Trabalho da $3^{\text {a }}$ Região. RO 00864-2007-072-0300-3, $4^{\text {a }}$ Turma, Rel. Desembargador Luiz Otávio Linhares Renault. Publicação do DJMG: 12 abr. 2008.

MINAS GERAIS. Tribunal Regional do Trabalho da $3^{\text {a }}$ Região. RO 00550-2011-014-0300-6. $1^{\text {a }}$ Turma. Relator: Juiz Convocado Eduardo Aurélio Pereira Ferri. Publicação no DEJT: 30 set. 2011.

MIRANDA, Jorge. Manual de direito constitucional. T. IV. 2 ed. Coimbra: Coimbra Editora, 1993.

MONTESQUIEU. O espírito das leis. Trad. Pedro Vieira Mota. São Paulo: Saraiva, 1987. 
MORAES, Alexandre de. Direito constitucional. 7 ed. rev., ampl. e atual. São Paulo: Atlas, 2000.

NASSIF, Elaine. Genética e discriminação no trabalho: uma cogitação. Revista do Tribunal do Trabalho da $3^{\text {a }}$ Região, Belo Horizonte, v. 30, n. 60, jul./dez. 1999, p. 109118.

NARANJO DE LA CRUZ, Rafael. Los límites de los derechos fundamentales en las relaciones entre particulares: la buena fe. Madrid: Centro de Estudios Políticos e Constitucionales, 2000.

NASCIMENTO, Amauri Mascaro. Curso de direito processual do trabalho. 22 ed. São Paulo: Saraiva, 2007.

NIPPERDEY, Hans Carl. Grundrechte und privatrecht. In: NIPPERDEY, Hans Carl (Hrsg.) Festschrift für Erich Molitor zum 75. Geburtstag. München: C.H. Beck, 1962.

OLIVEIRA, Sebastião Geraldo de Oliveira. Proteção jurídica à saúde do trabalhador. 4 ed. São Paulo: LTr, 2002.

ORGANIZAÇÃO INTERNACIONAL DO TRABALHO. La libertad sindical. 4 ed, p. 13 (n. 35) e p. 15 (n. 46).

PARA E AMAPÁ. Tribunal Regional do Trabalho da $8^{a}$ Região. RO 00739-2008-005-0800-5. $2^{\text {a }}$ Turma. Desembargador Relator: Herbert Tadeu Pereira de Matos. Publicação no DOJT: 15 jan. 2009.

PARANÁ. Tribunal Regional do Trabalho da $9^{\mathrm{a}}$ Região. RO 00067-2005-654-09-00-9. $3^{\mathrm{a}}$ Turma. Relator Desembargador Archimedes Castro Campos Júnior. Publicação no DJPR: 27 jun. 2008.

PEREZ LUÑO, Antoine-Enrique. Los derechos fundamentales. 6 ed. Madrid: Ed. Tecnos, 1995.

PEREZ-ROYO, Javier. La reforma de la Constitución. Madrid: Publicaciones del Congreso de los Disputados, 1987.

PIMENTA, José Roberto Freire. A tutela metaindividual dos direitos trabalhistas: uma exigência constitucional. In: PIMENTA, José Roberto Freire; BARROS, Juliana Augusta Medeiros de; FERNANDES, Nádia Soraggi (Coords.). Tutela metaindividual trabalhista: a defesa coletiva dos direitos dos trabalhadores em juízo. São Paulo: LTr, 2009, p. 9-50.

; PORTO, Lorena Vasconcelos. Instrumentalismo substancial e tutela jurisdicional civil e trabalhista: uma abordagem histórico-jurídica. Revista do Tribunal Regional da $3^{\text {a }}$ Região. Belo Horizonte, v. 43, n. 73, p. 85-122, jan./jun. 2006.

PIOVESAN, Flávia. A proteção dos direitos sociais nos planos interno e internacional. In: GONÇALVES, Marcus Orione; CORREIA, Érica Paula Bacha (Coords.). Direito previdenciário e constituição. São Paulo: LTr, 2004. 
. Carta africana dos direitos humanos e dos povos. Disponível em: http://www.esmpu.gov.br/dicionario/tikiindex.php?page $=$ Carta + africana + dos + direitos + humanos + e + dos + povos. Acesso: 30 set. 2010.

Introdução ao sistema interamericano de proteção dos direitos humanos. In: GOMES, Luiz Flávio; PIOVESAN, Flávia. (Coords.). O sistema interamericano de proteção dos direitos humanos o e o direito brasileiro. São Paulo: RT, 2000, p. 18-45.

PORTO, Lorena Vasconcelos. A subordinação no contrato de trabalho: uma releitura necessária. São Paulo: LTr, 2009.

La disciplina dei licenziamenti in italia e nel diritto comparato: una proposta per il diritto del lavoro in Brasile. Tese de Doutorado. Università degli Studi di Roma “Tor Vergata”. Roma, 2008.

PRATA, Ana. A tutela constitucional da autonomia privada. Coimbra: Almedina, 1982.

QUADRA-SALCEDO, Tomás. El recurso de amparo y los derechos fundamentales en las relaciones entre particulares. Madrid: Civitas, 1981.

QUEIROZ JÚNIOR, Hermano. Os direitos fundamentais dos trabalhadores e a Constituição de 1988. São Paulo: LTr, 1996.

RAMOS, André de Carvalho. Direitos humanos na integração econômica: análise comparativa da proteção de direitos humanos e conflitos jurisdicionais na União Européia e no Mercosul. Rio de Janeiro: Renovar, 2008.

REALE, Miguel. Filosofia do Direito. 19 ed. São Paulo: Saraiva, 2000.

RIO DE JANEIRO. Tribunal Regional da $1^{\mathrm{a}}$ Região. RO 00611.2007.005.05.00.7, $4^{\mathrm{a}}$ Turma, Rel. Desembargador Valtércio de Oliveira. Publicação no DJRJ: 28 fev.. 2007.

RIO GRANDE DO SUL. Tribunal Regional da $4^{\mathrm{a}}$ Região. RO 009190004.2009.5.04.0005. $9^{\text {a }}$ Turma. Desembargador Relator: João Alfredo Borges Antunes de Miranda. Publicação no DOE: 30 maio 2011.

RIO GRANDE DO SUL. Tribunal Regional do Trabalho da $4^{\mathrm{a}}$ Região. RO 000108257.2010.5.04.0203. Desembargador Relator: Marçal Henri dos Santos Figueiredo. Publicação no DOE: 8 set. 2011.

ROCHA, Carmen Lúcia Antunes. Constituição e constitucionalidade. Belo Horizonte: Editora Lê, 1991.

ROMITA, Arion Sayão. Direitos fundamentais nas relações de trabalho. 2 ed. rev. e aum. São Paulo: LTr, 2007.

ROMITA, Arion Sayão. O impacto das transformações econômicas no direito do trabalho: a crise da subordinação e o rearranjo de modalidades contratuais. Revista de Direito do Trabalho, v. 117, ano 31, p. 37- jan./mar. 2005. 
ROOSEVELT III, Kermit. Myth of judicial activism: making sense of Supreme Court decisions. New Haven: Yale University, 2006.

SALDANHA, Nélson. O poder constituinte. São Paulo: RT, 1986.

SANTA CATARINA. Tribunal Regional do Trabalho da $12^{\text {a }}$ Região. RO 00499-2005040-12-00-1. $2^{\text {a }}$ Turma. Desembargadora Relatora: Sandra Márcia Wambier. Publicação no DOE/TRT 12 $2^{\mathrm{a}}$ Região: 27 jul. 2007.

SANTA CATARINA. Tribunal Regional do Trabalho da $12^{\mathrm{a}}$ Região. RO 07663-2006034-12-00-0. $3^{\text {a }}$ Turma. Relatora: Juíza convocada Ligia M. Teixeira Gouvêa. Publicação no DOE: 15 jan. 2008.

SANTOS, Boaventura de Souza. Pela mão de Alice. São Paulo: Cortez Editora, 1995.

SARLET, Ingo Wolfgang. A eficácia dos direitos fundamentais. 7 ed. rev., atual. e ampl. Porto Alegre: Livraria do Advogado Ed., 2007.

- Os direitos fundamentais sociais como cláusulas pétreas. Interesse Público. Sapucaia do Sul: Notadez, v.5, n.17, p. 56-74, jan./fev. 2003.

Os direitos fundamentais sociais e os vinte anos da Constituição Federal de 1988: resistências e desafios à sua eficácia e efetividade. Revista do Instituto de Hermenêutica Jurídica, v. 1, n. 6, p. 163-2006, 2008.

SARMENTO, Daniel. Direitos Fundamentais e Relações Privadas. 2 ed. Rio de Janeiro: Lumen Juris Editora, 2006.

- Interpretação dos direitos fundamentais e o conflito entre poderes.

In: MELLO, Celso de Albuquerque et al (Coords.). Teoria dos direitos fundamentais. Rio de Janeiro: Renovar, 2001.

SÃO PAULO. Tribunal Regional de Trabalho da $2^{\mathrm{a}}$ Região. RO 01046200336102000. $4^{\mathrm{a}}$ Turma. Relator: Juiz Ricardo Antunes Costa Rodrigues. Publicado no DJSP: 22 out. 2007.

SÃO PAULO. Tribunal Regional do Trabalho da $2^{a}$ Região. RO 00947-2008-381-02-00-4. $9^{a}$ Turma. Desembargadora Relatora: Jane Granzoto Torres da Silva. Publicação no DJSP: 27 nov. 2009.

SÃO PAULO. Tribunal Regional do Trabalho da $2^{\mathrm{a}}$ Região. RO 00404-2008-202-02-00-7. $4^{\text {a }}$ Turma. Desembargador Relator: Wilma Nogueira de Araujo Vaz da Silva. Publicação no DOE: 23 abr. 2010.

SÃO PAULO. Tribunal Regional do Trabalho da $2^{\mathrm{a}}$ Região. RO 01403200905802009. $14^{\mathrm{a}}$ Turma. Relator: Juiz Marcos Neves Fava. Publicação no DJSP: 05 out. 2011.

SFERRAZZA, Mauro. Il contratto di lavoro a progetto. Milano: Giuffrè, 2004.

SILVA, José Afonso. Aplicabilidade das normas constitucionais. 4 ed. São Paulo: Malheiros, 2000. 
SILVA, Lucas Gonçalves da. Mutação constitucional: tipologia e limites. Tese (doutorado). Pontifícia Universidade Católica de São Paulo, Faculdade de Direito, São Paulo, 2009.

SILVA, Virgílio Afonso da. A constitucionalização do direito: os direitos fundamentais nas relações entre particulares. São Paulo: Malheiros, 2005.

SITE DA Organização Internacional do trabalho. Disponível em: http://www.ilo.org/global/What_we_do/InternationalLabourStandards/Applyingandpromot ingInternationalLabourStandards/lang--fr/index.htm. Acesso em: 29 set. 2010.

SMEND, Rudolf. Constitución y derecho constitucional. Madrid: Centro de Estudios Constitucionales, 1985. Trad. José Maria Beneyto Pérez.

SOARES, José Ronald Cavalcante (Coord.). Estudos de direito constitucional: homenagem a Paulo Bonavides. São Paulo: LTr, 2001.

SOUKI, Lea Guimarães. A atualidade de T. H. Marshall no estudo da cidadania no Brasil. Revista de Ciências Sociais. Porto Alegre, v. 6, n. 1, p. 39-58, jan./jun. 2006.

SOUTO MAIOR, Jorge Luiz; CORREIA, Marcus Orione. O que é direito social? In: CORREIA, Marcus Orione Gonçalves (Org.). Curso de Direito do Trabalho, v. 1 Teoria geral do Direito do Trabalho. São Paulo: LTr, 2007, p.

. A desconstitucionalização do Direito do Trabalho. Justiça

do Trabalho: Doutrina, Jurisprudência, Legislação, Sentenças e Tabelas, Porto Alegre, v.18, n.213, p. 44-47, set. 2001.

STRECK, Lênio Luiz. As constituições sociais e a dignidade da pessoa humana com princípio fundamental. In: CAMARGO, Margarida Maria Lacombe (Coord.). 1988-1998: uma década de Constituição. Rio de Janeiro: Renovar, 1999.

Quinze anos de Constituição - análise crítica da jurisdição constitucional e das possibilidades hermenêuticas de concretização dos direitos fundamentais sociais. Revista da Ajuris - Associação dos Juízes do Rio Grande do Sul, Porto Alegre, v. 30, n. 92, p. 212-229, dez. 2003.

. Entrevista com Lênio Streck para o site Consultor Jurídico. Ativismo judicial não é bom para a democracia. Disponível em: $<$ http://www.conjur.com.br/2009-mar-15/entrevista-lenio-streck-procurador-justica-riogrande-sul>. Acesso em: 28 out. 2011.

SUSSEKIND, Arnaldo. Direito constitucional do trabalho. Rio de Janeiro: Renovar, 1999.

TARTUCE, Flávio. Direito Civil e Constituição. Disponível em: <www.flaviotartuce.adv.br>. Seção artigos do professor. Acesso em: 10 out. 2010.

TATE, C. Neal; VALLINDER, Tobjörn (Orgs.). The global expansion of judicial power. New York Univesity, 1995. 
TAVARES, André Ramos (Coord.). Reforma do Judiciário analisada e comentada. São Paulo: Método, 2005.

TEODORO, Maria Cecília Máximo. O juiz ativo e os direitos trabalhistas. São Paulo: LTr, 2011.

TERRA, Luciana Soares Vidal. Estabilidade no emprego: em busca da dignidade. Dissertação de Mestrado. Faculdade de Direito. Pontifícia Universidade Católica de Minas Gerais.

TORRES, Ricardo Lobo. A cidadania multidimensional na era dos direitos. In: MELLO, Celso de Albuquerque et al (Coords.). Teoria dos direitos fundamentais. 2 ed. Rio de Janeiro: Renovar, 2001.

URIARTE, Oscar Ermida. A proteção contra os atos sindicais. São Paulo: LTr, 1999. Trad. Irany Ferrari.

URRUTIA, Ana Victoria Sánchez. Mutación constitucional y fuerza normativa de la Constitución. Una aproximación al origen del concepto. Revista Española de Derecho Constitucional. Madri, v. 20, n. 58, p. 105-138, jan./abr. 2000.

Universidad de Barcelona, 1998.

Mutaciones constitucionales. Tese (Doutorado).

VALLE, Vanice Regina Lírio do (Org.). Ativismo jurisdicional e o Supremo Tribunal Federal: laboratório de análise jurisprudencial do STF. Curitiba: Juruá, 2009.

VERDÚ, Pablo Lucas. La constitución abierta y sus “enemigos”. Madrid: Beiramar, 1993.

VIANA, Márcio Túlio. A proteção trabalhista contra os atos discriminatórios: análise da Lei n. 9.029/95. In: VIANA, Márcio Túlio; RENAULT, Luiz Otávio Linhares. Discriminação. São Paulo: LTr, 2000, p. 354-367.

VIANNA, Luiz Werneck; REZENDE DE CARVALHO, Maria Alice; CUNHA MELO, Marcelo P. e BURGOS, Marcelo Baumann. Corpo e alma da magistratura brasileira. Rio de Janeiro: Revan, 1997.

VIEIRA, Oscar Vilhena. Entrevista à Revista Época. Vivemos em uma supremocracia. Disponível em: $\quad$ http://revistaepoca.globo.com/Revista/Epoca/1,EMI19313$\underline{15295,00 . h t m l}>$. Acesso em 29 out. 2011

Paulo: Malheiros, 2002.

Supremo Tribunal Federal: jurisprudência e política. 2 ed. São

VILLATORE, Marco Antônio César; HASSON, Roland (coord.); ALMEIDA, Ronald Silka de (Org.). Direito constitucional do trabalho vinte anos depois: Constituição Federal de 1988. 1 ed. 1 reimpr. Curitiba: Juruá, 2009.

ZANDONADE, Adriana. Mutação constitucional. Revista de direito constitucional e internacional. São Paulo, v. 9, n. 35, p. 195-227, abr./jun. 2001. 


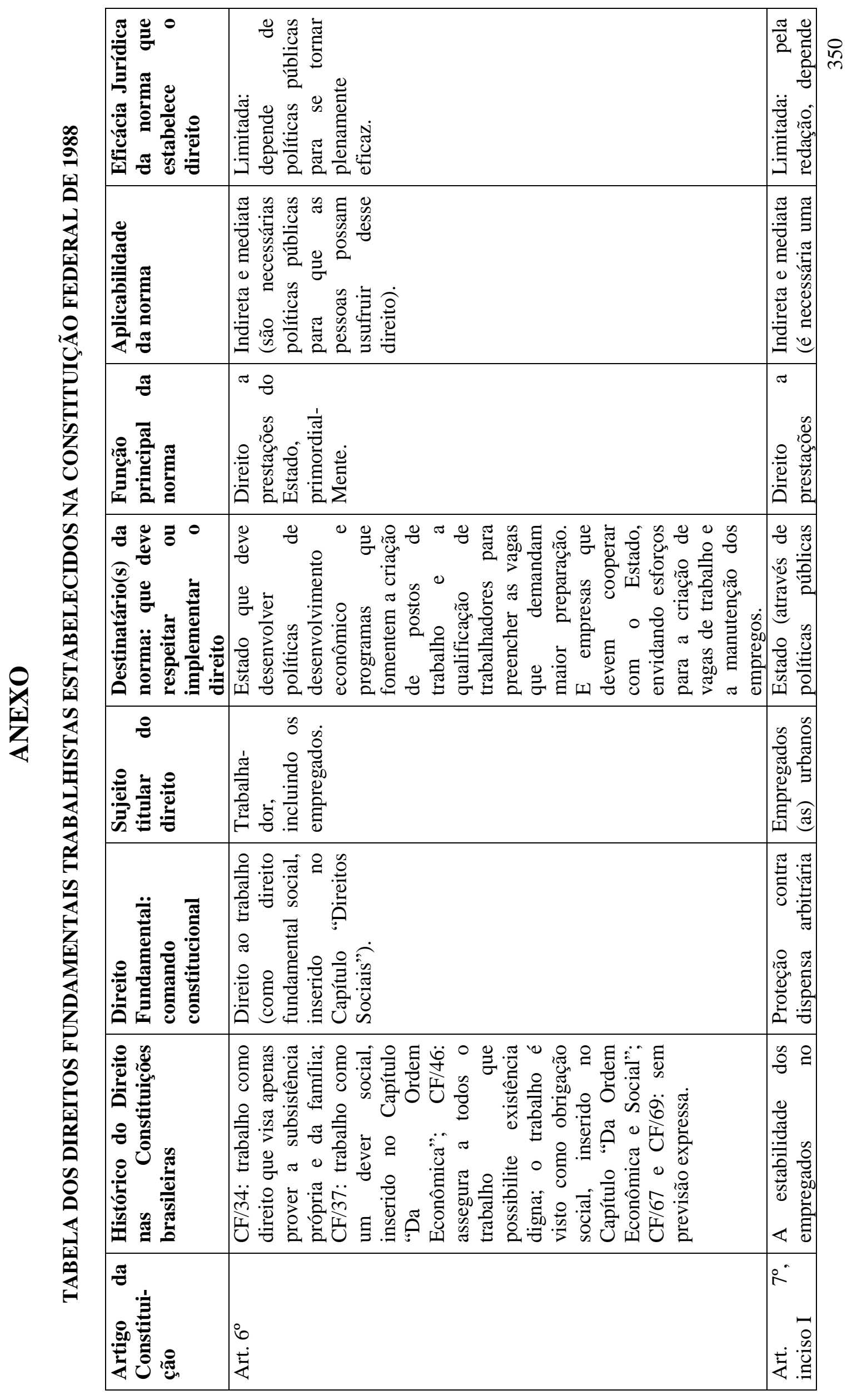




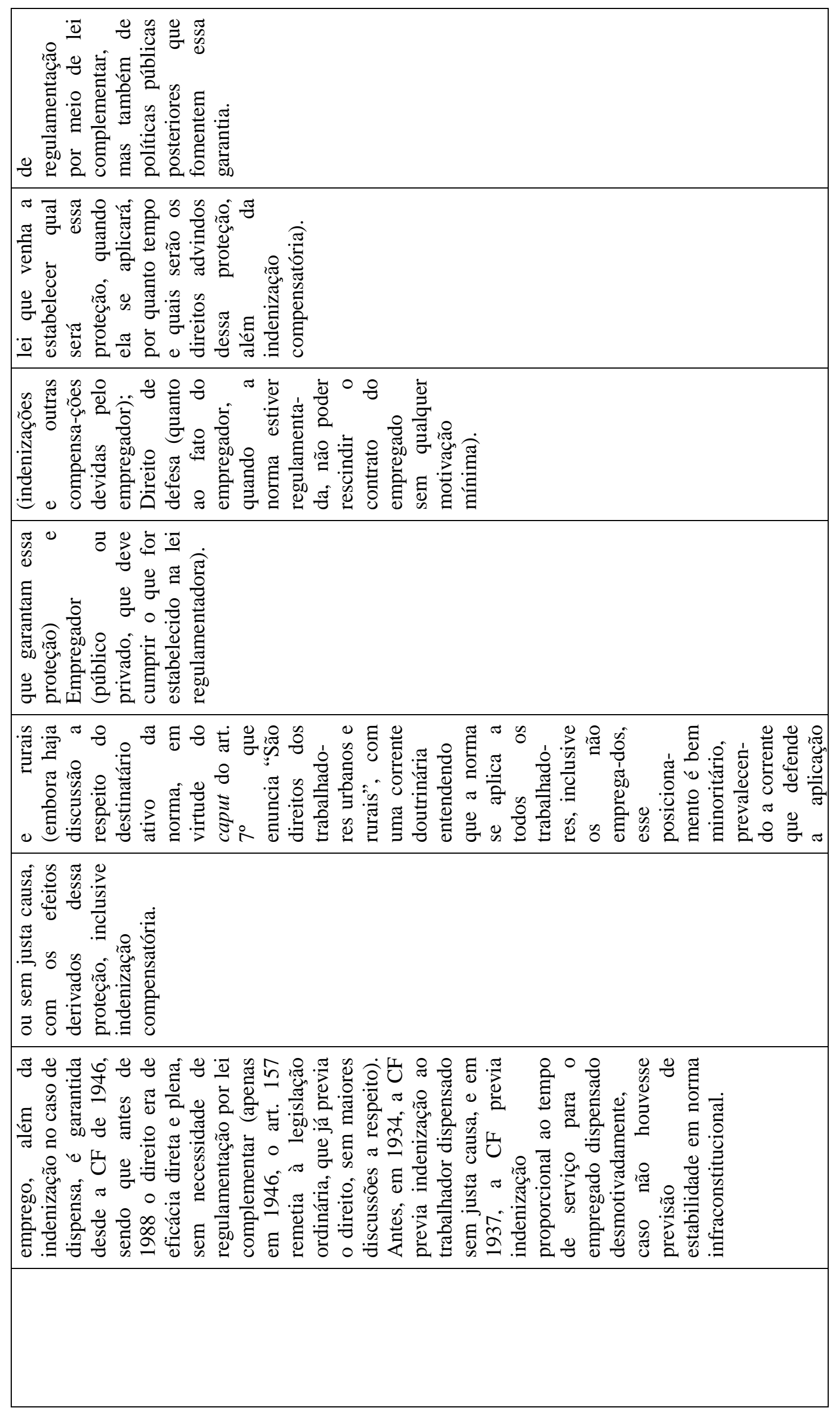




\begin{tabular}{|c|c|}
\hline & 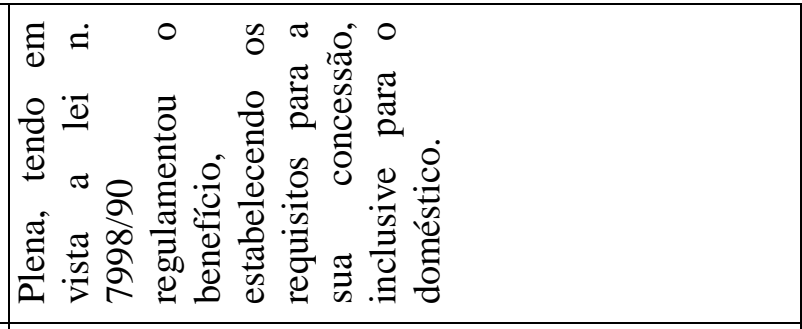 \\
\hline & 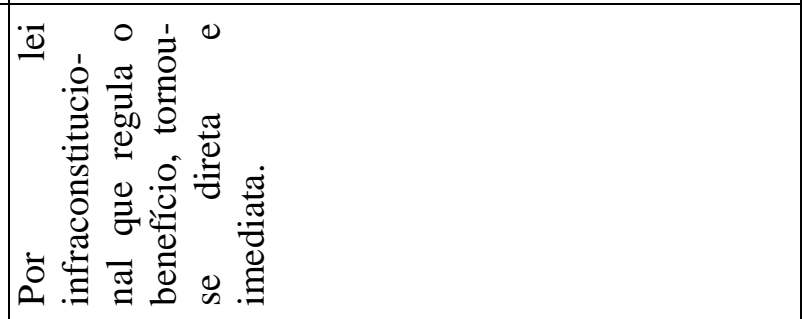 \\
\hline & 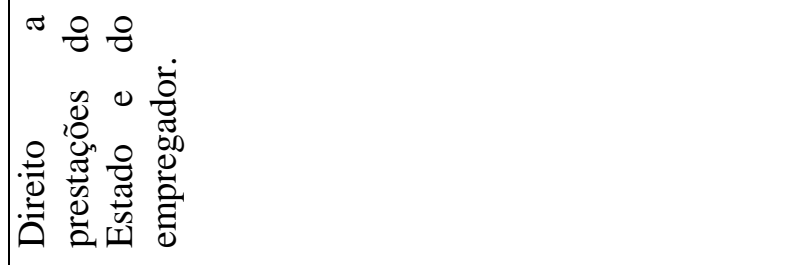 \\
\hline & 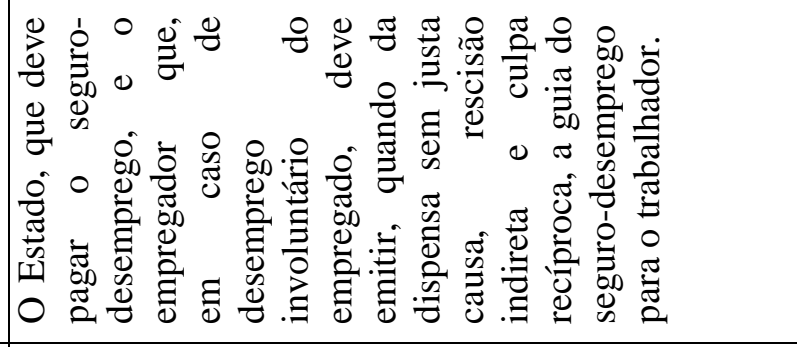 \\
\hline \multirow[t]{4}{*}{ 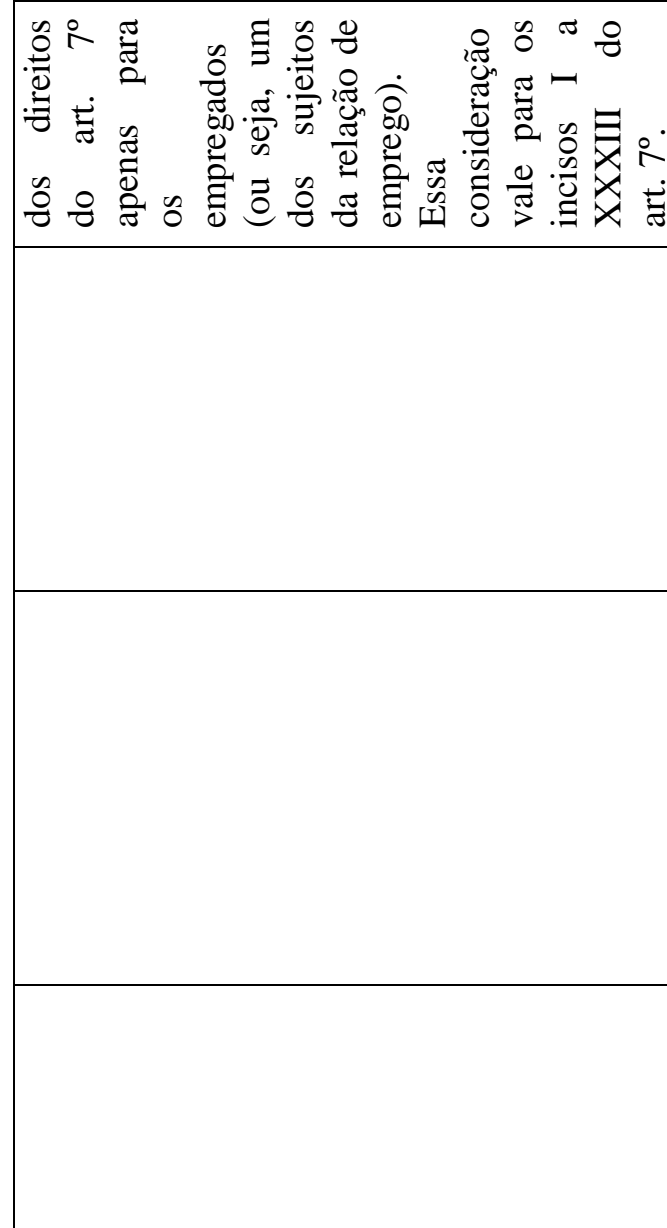 } & 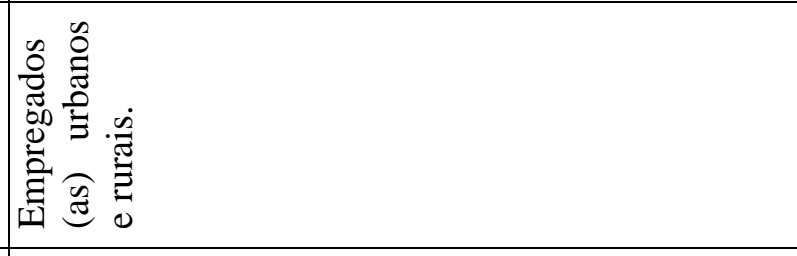 \\
\hline & 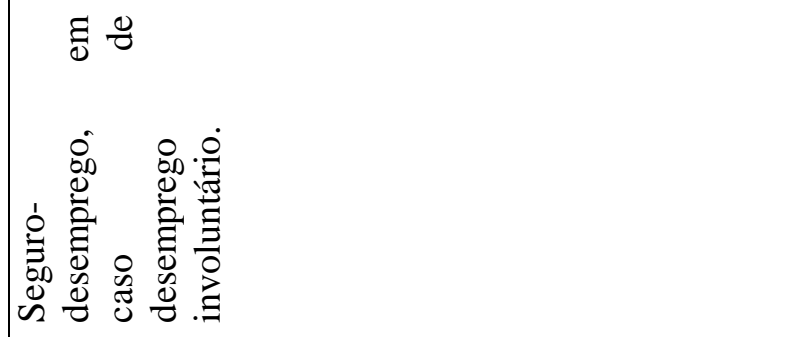 \\
\hline & 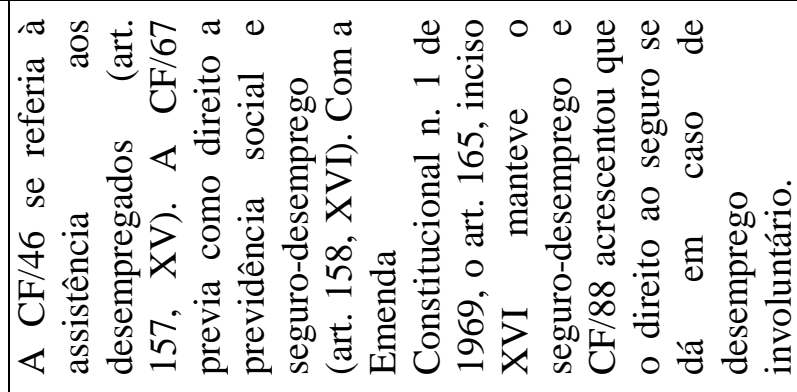 \\
\hline & 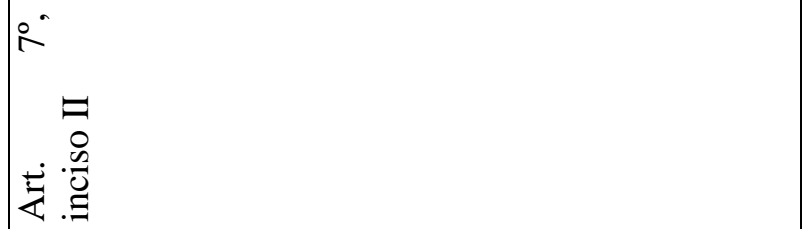 \\
\hline
\end{tabular}




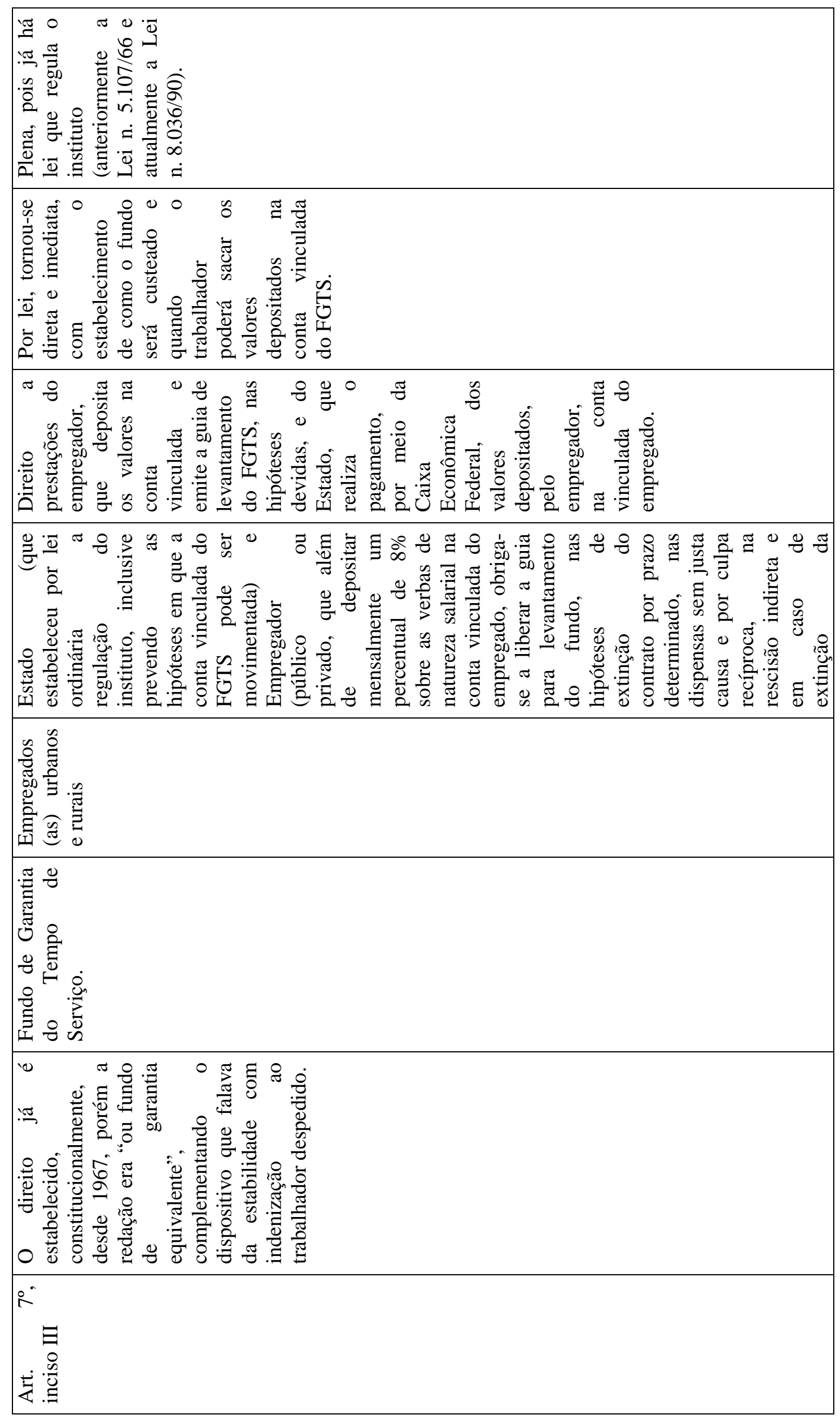




\begin{tabular}{|c|c|c|}
\hline & 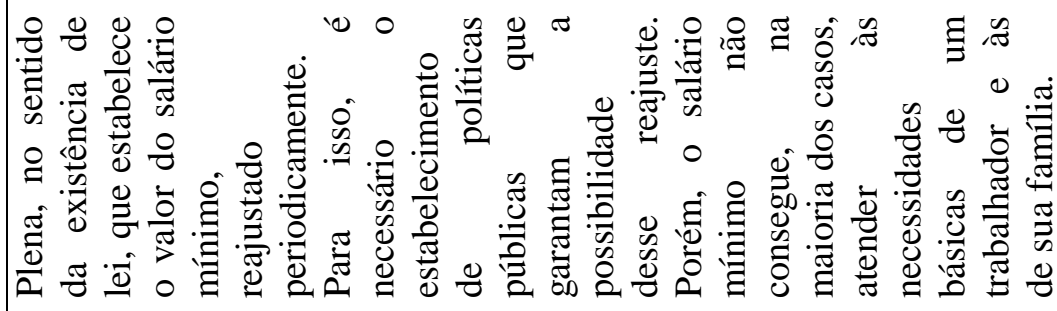 & 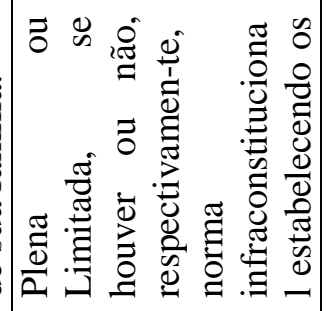 \\
\hline & 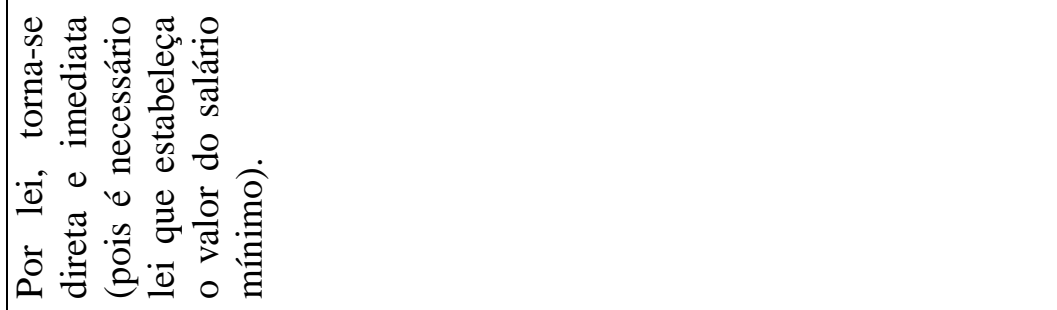 & 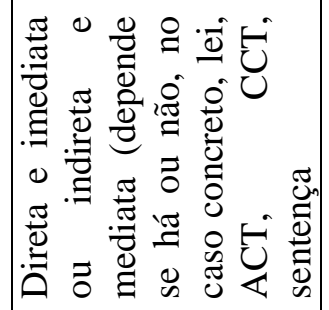 \\
\hline & 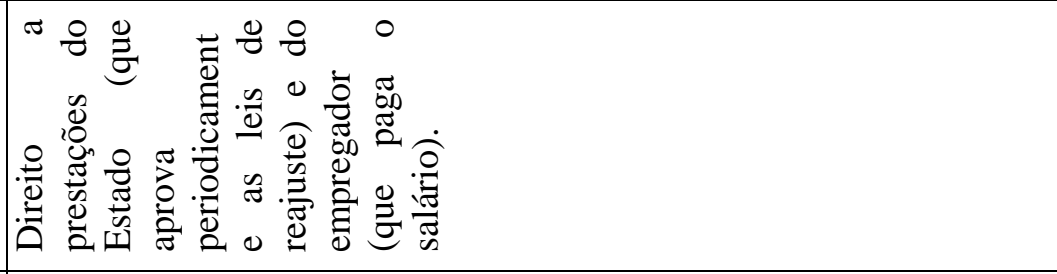 & 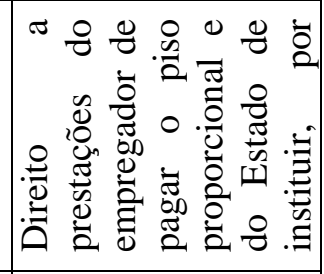 \\
\hline 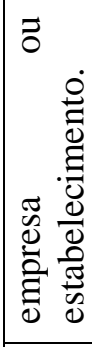 & 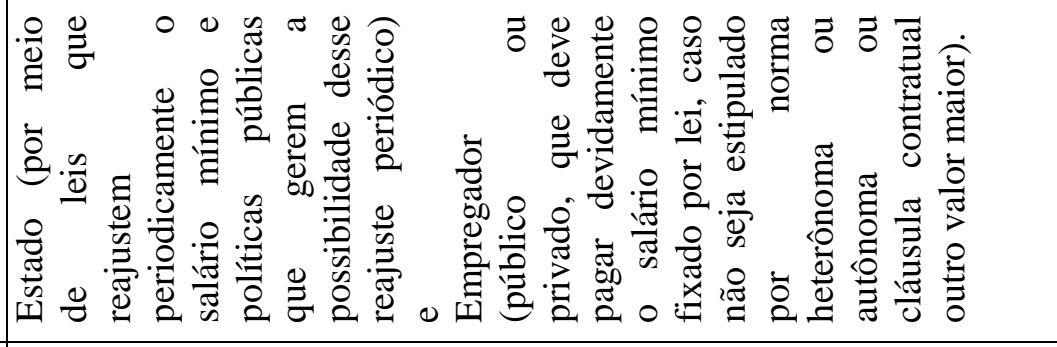 & 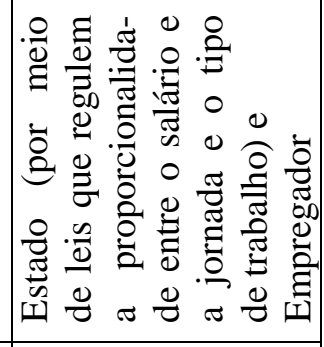 \\
\hline & 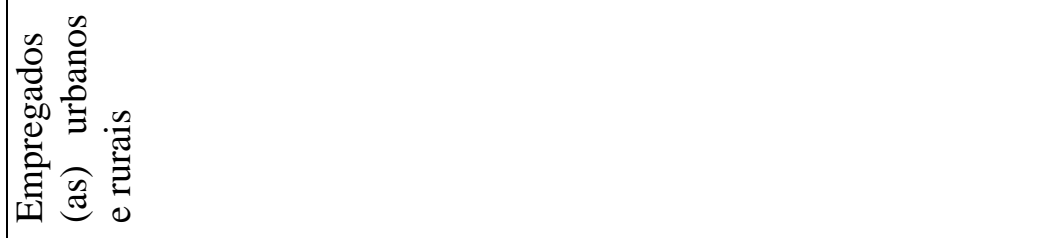 & 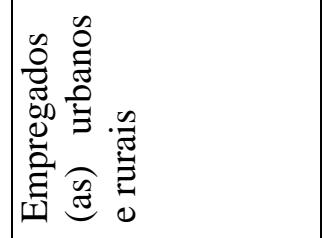 \\
\hline & 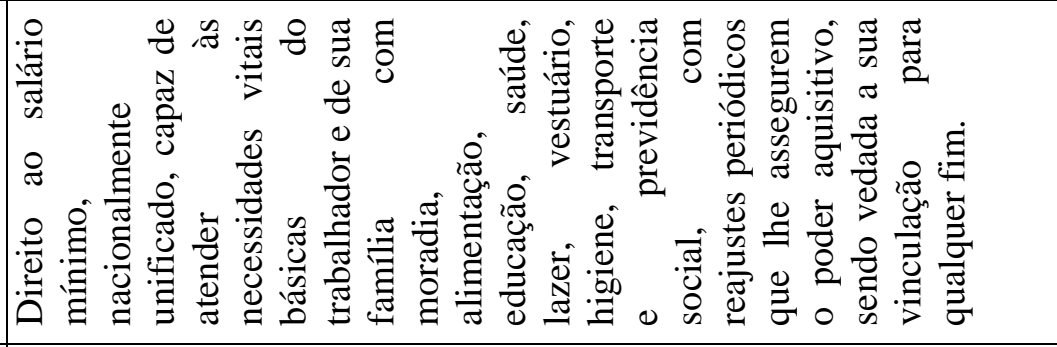 & 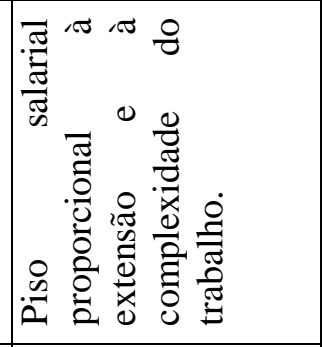 \\
\hline & 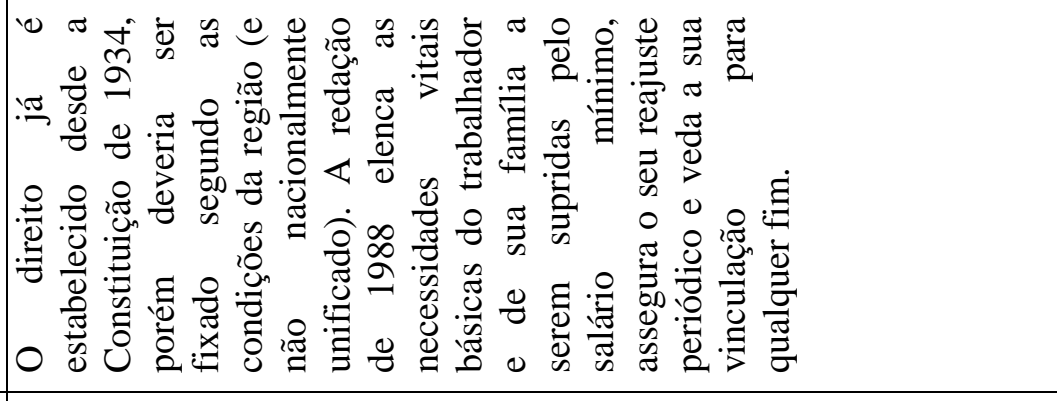 & 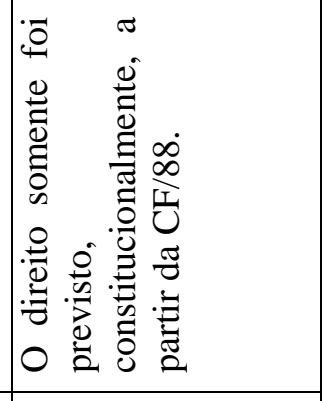 \\
\hline & 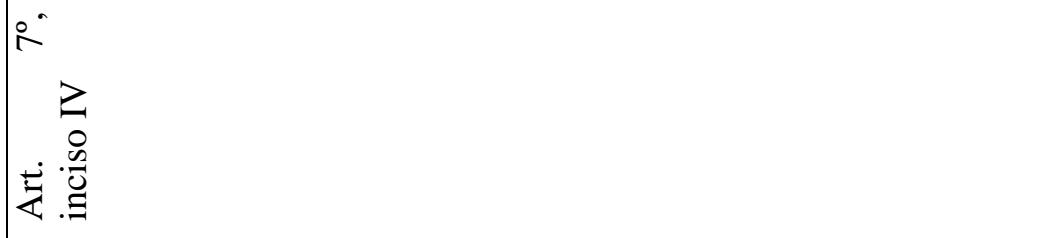 & 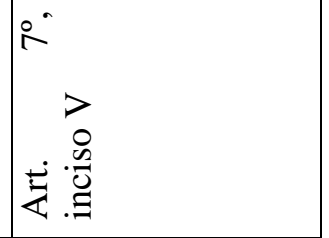 \\
\hline
\end{tabular}




\begin{tabular}{|c|c|}
\hline $\begin{array}{l}\dot{0} \\
.0 \\
.2 \\
\end{array}$ & 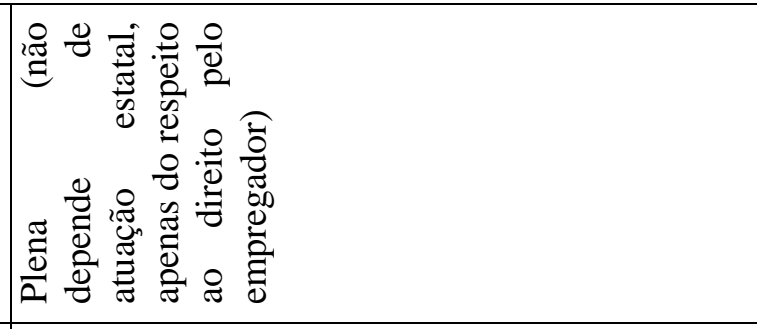 \\
\hline 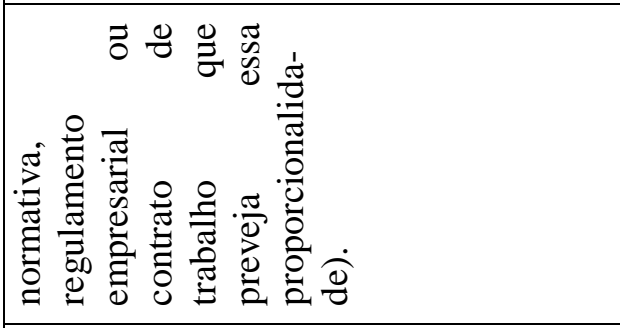 & 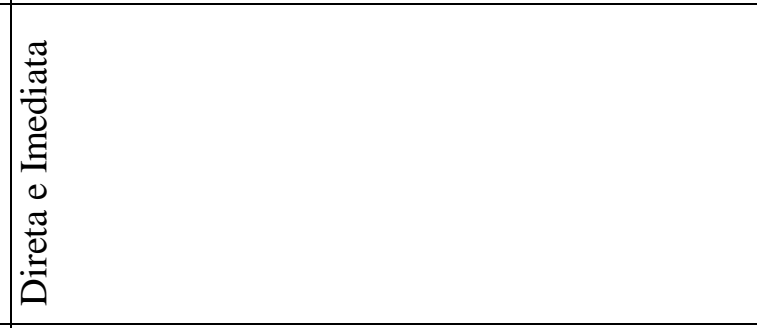 \\
\hline 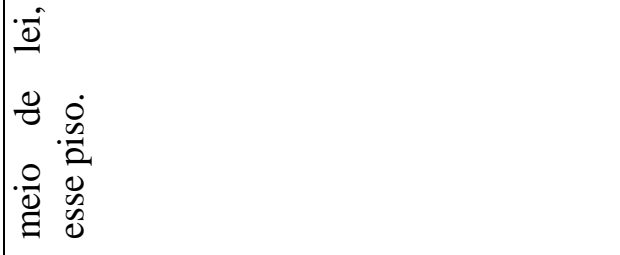 & 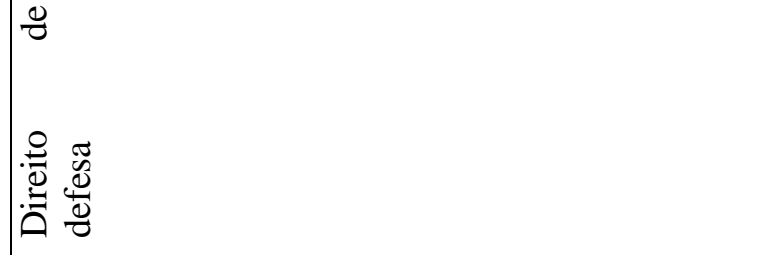 \\
\hline \multirow[t]{5}{*}{ 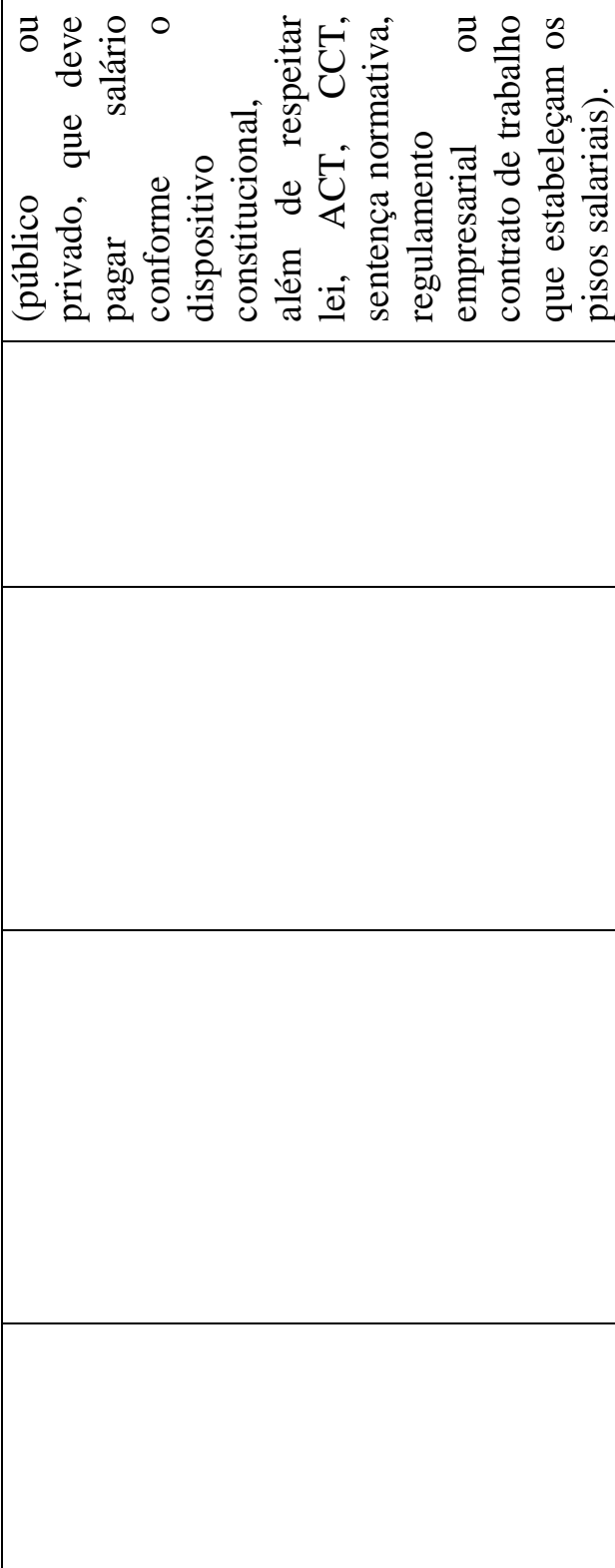 } & 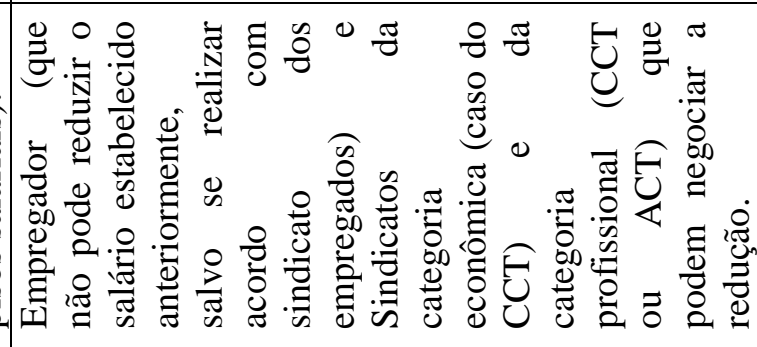 \\
\hline & 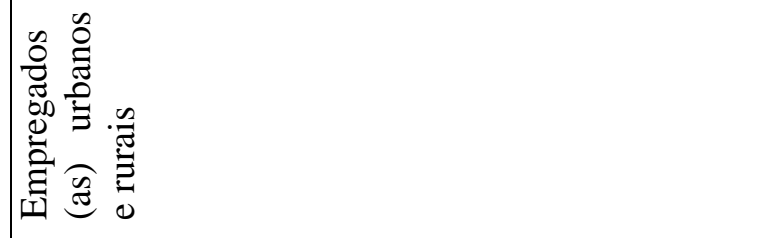 \\
\hline & 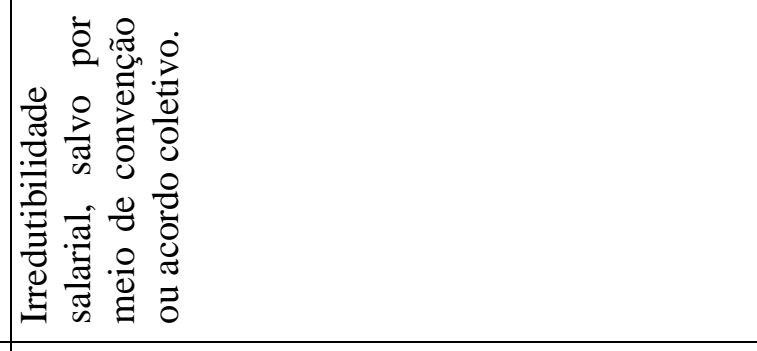 \\
\hline & 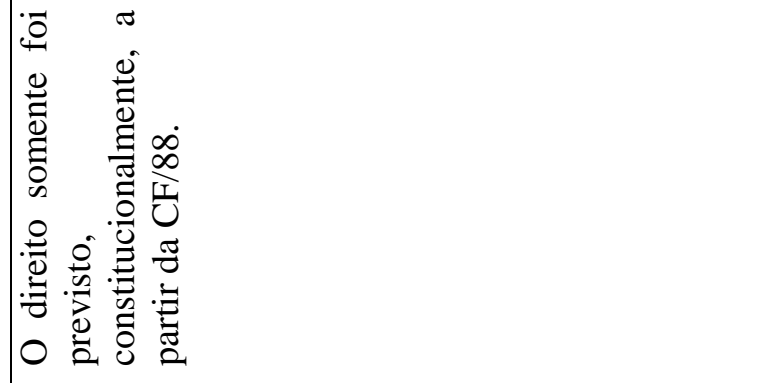 \\
\hline & 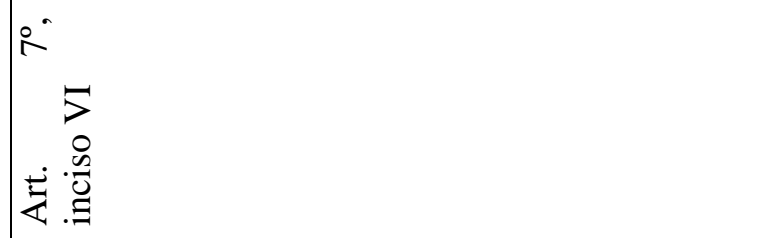 \\
\hline
\end{tabular}




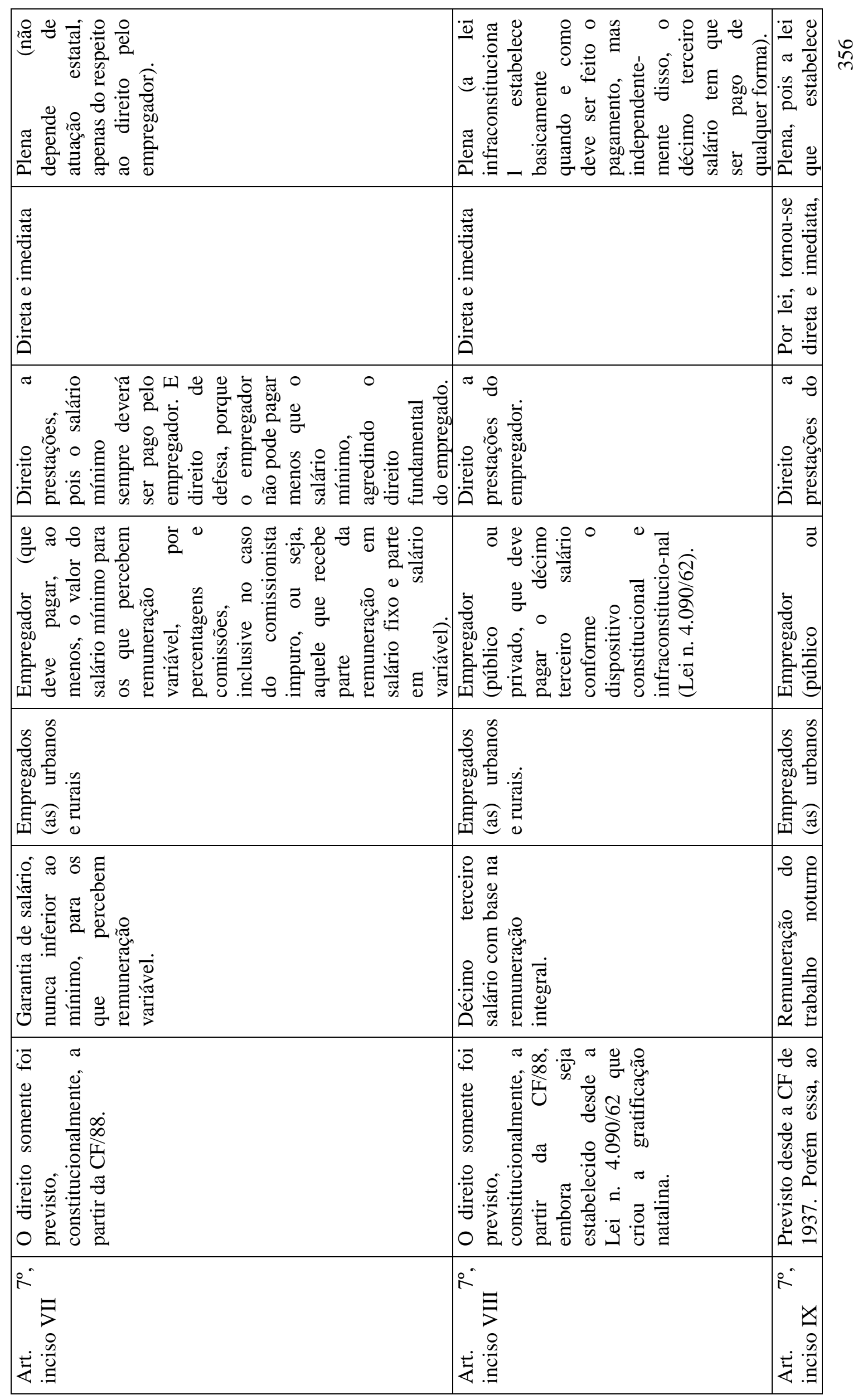




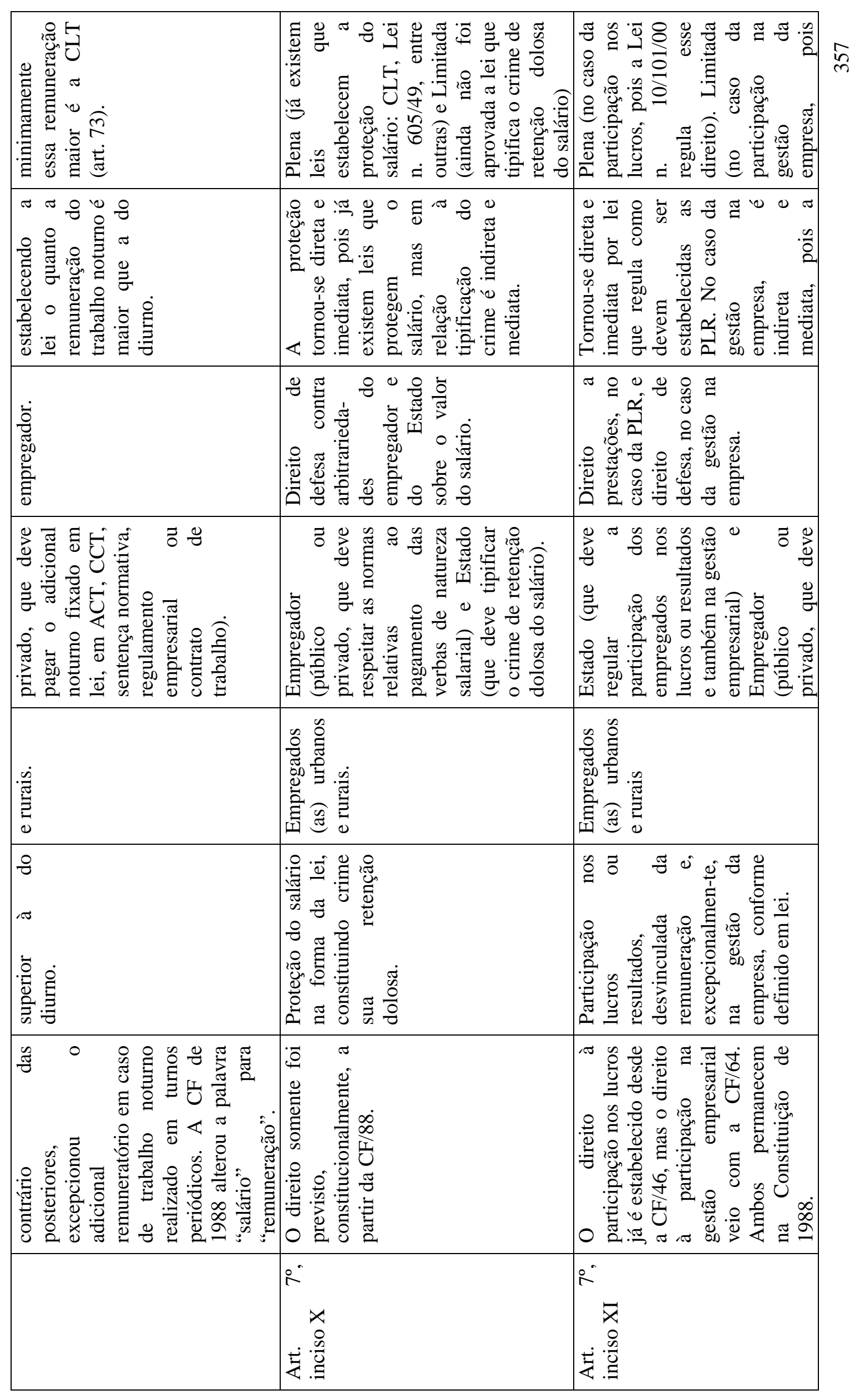




\begin{tabular}{|c|c|c|}
\hline 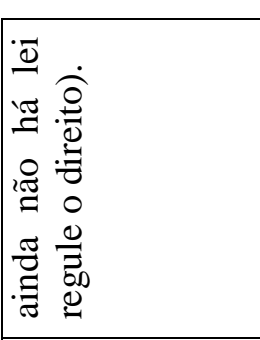 & 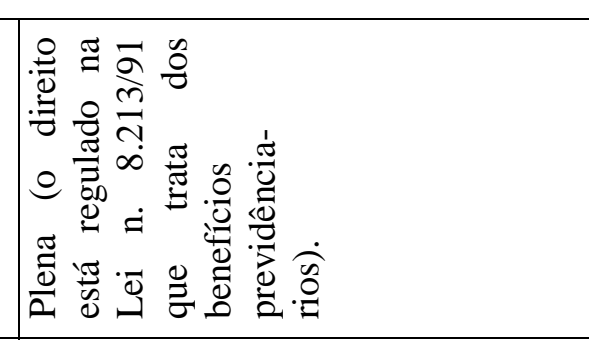 & 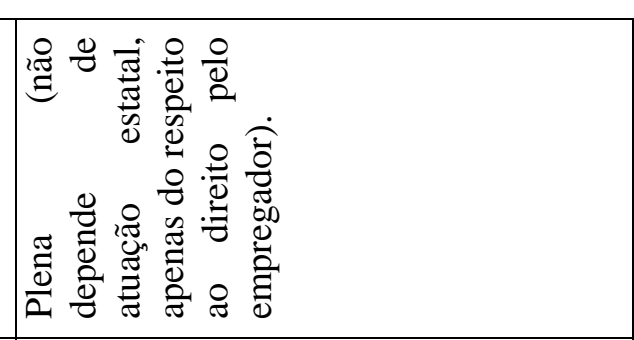 \\
\hline \multirow[t]{2}{*}{ 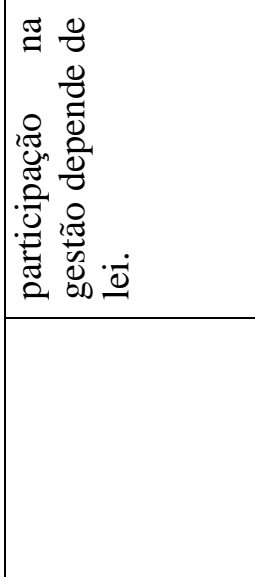 } & 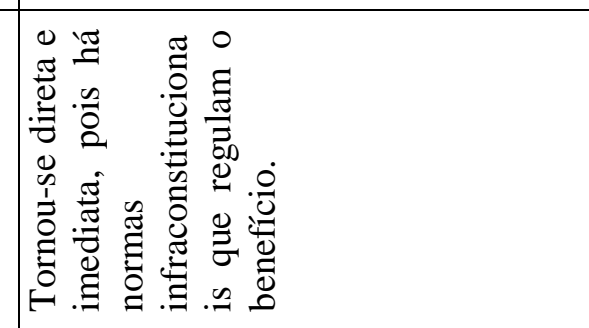 & 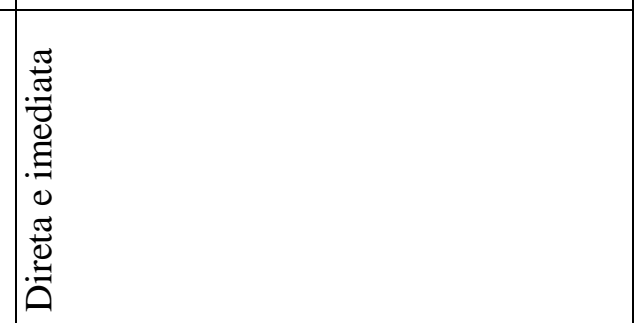 \\
\hline & 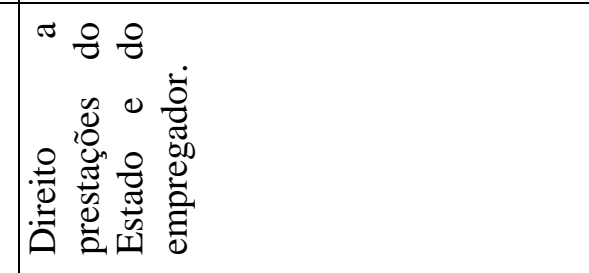 & 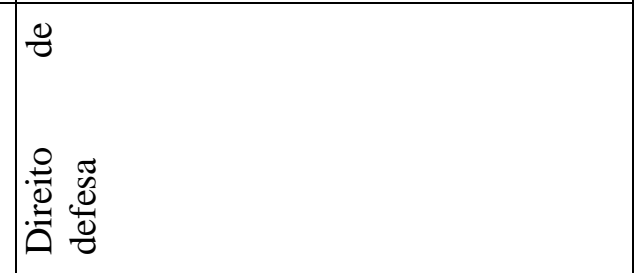 \\
\hline \multirow[t]{5}{*}{ 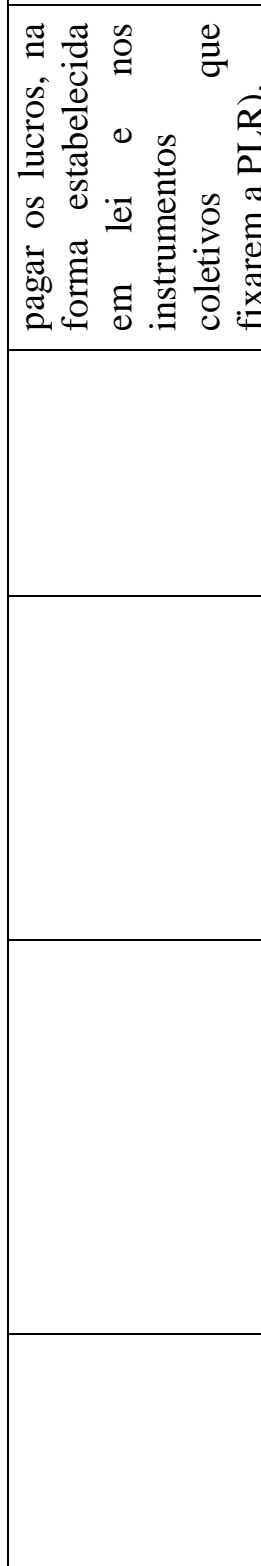 } & 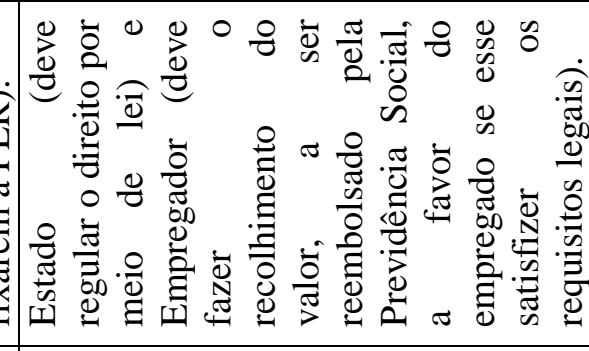 & 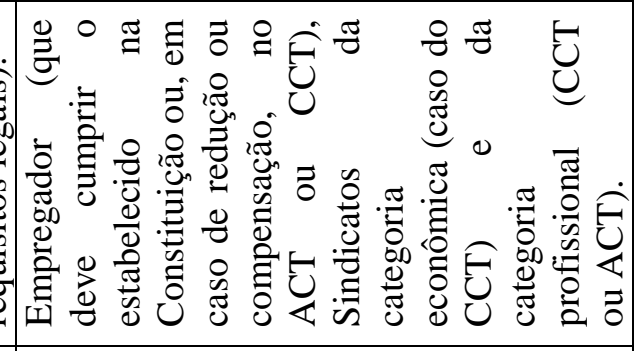 \\
\hline & 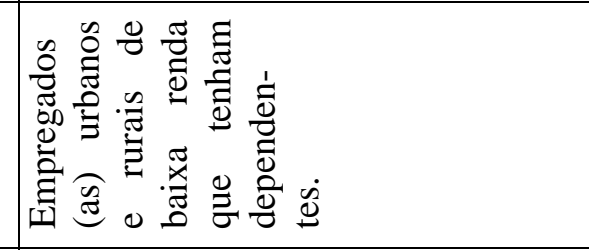 & 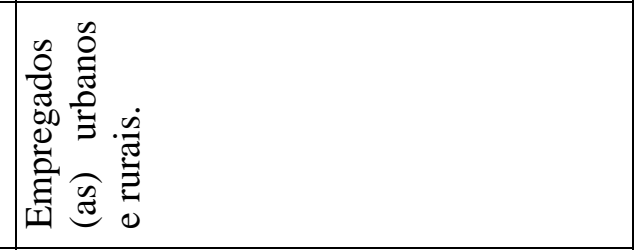 \\
\hline & 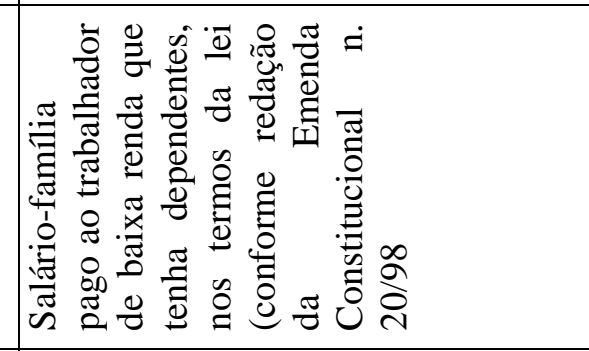 & 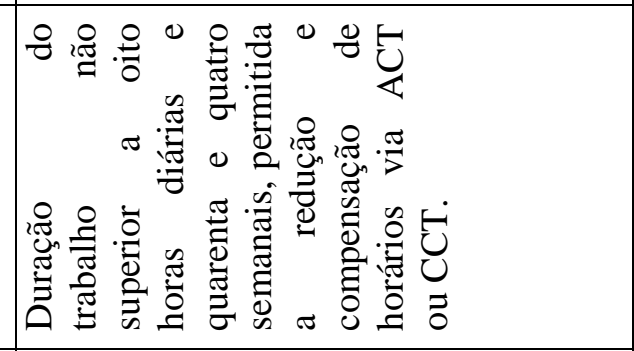 \\
\hline & 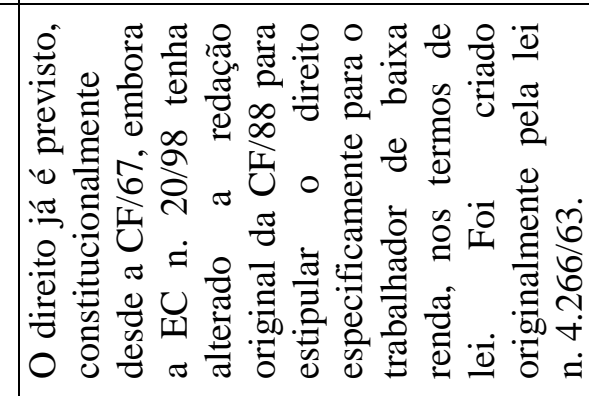 & 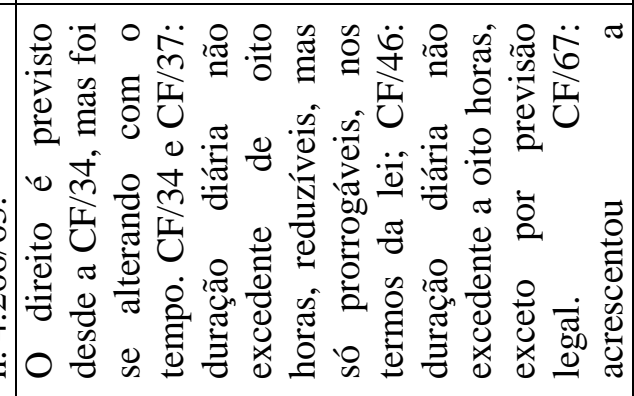 \\
\hline & 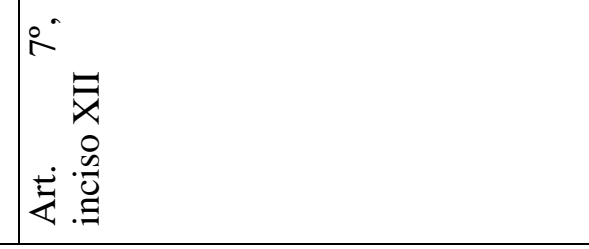 & 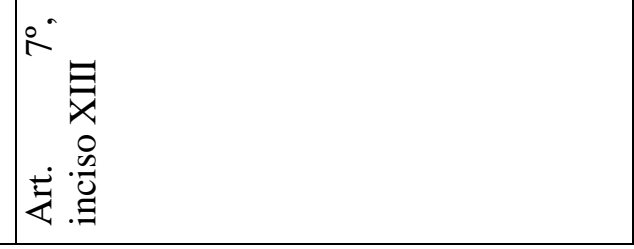 \\
\hline
\end{tabular}




\begin{tabular}{|c|c|}
\hline & 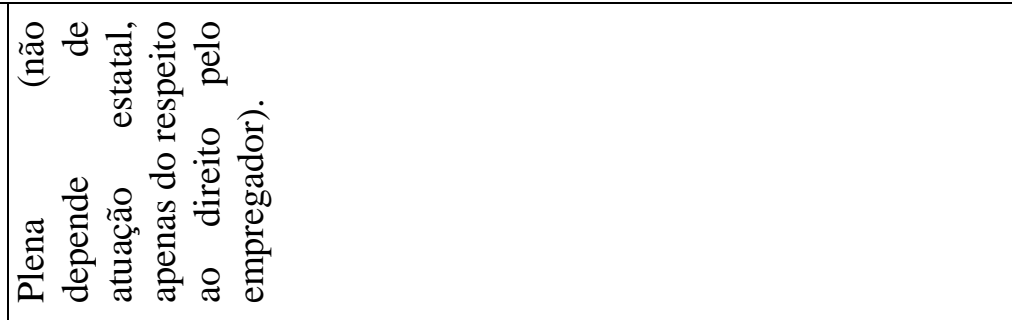 \\
\hline & 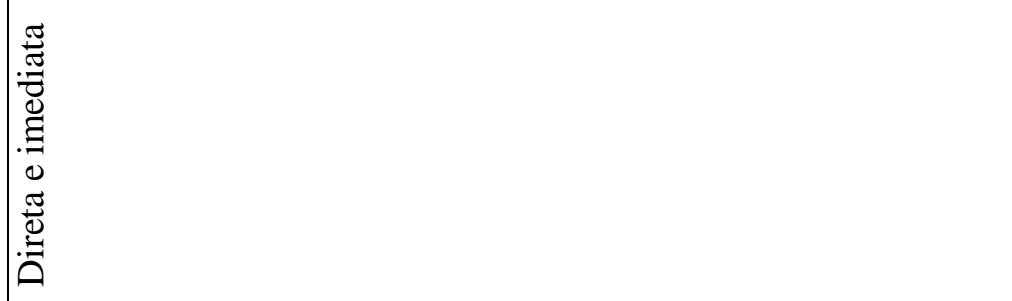 \\
\hline & 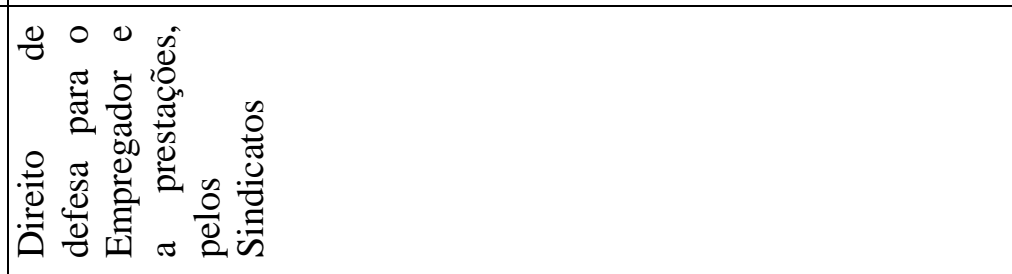 \\
\hline & 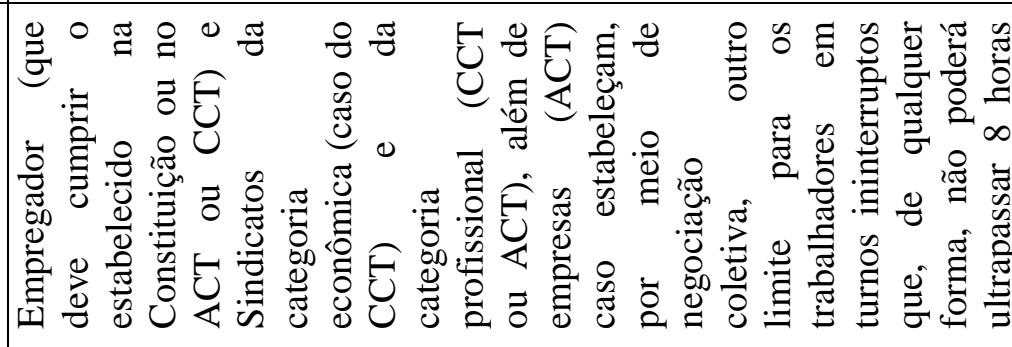 \\
\hline & 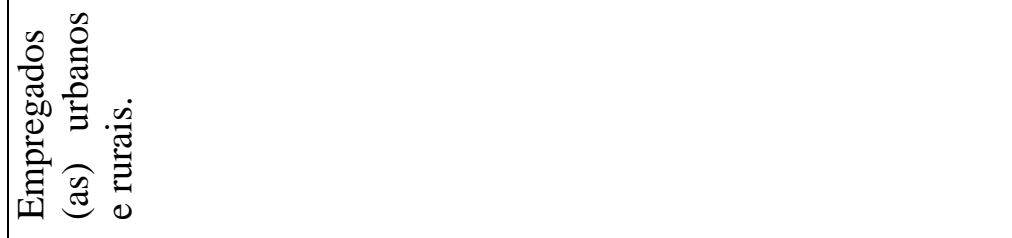 \\
\hline & 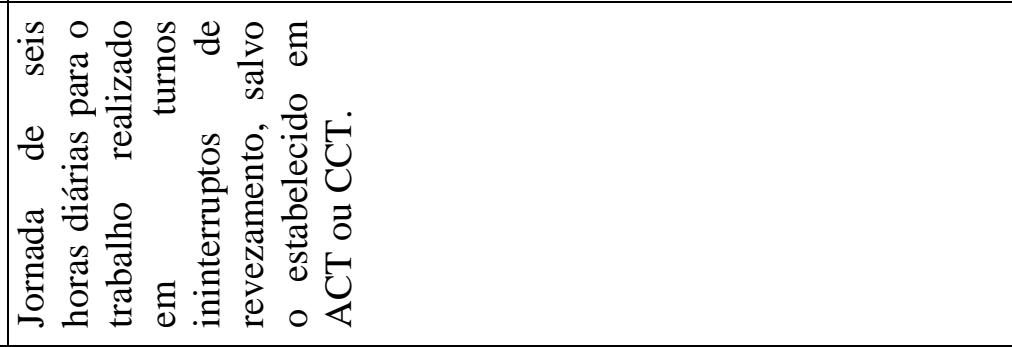 \\
\hline 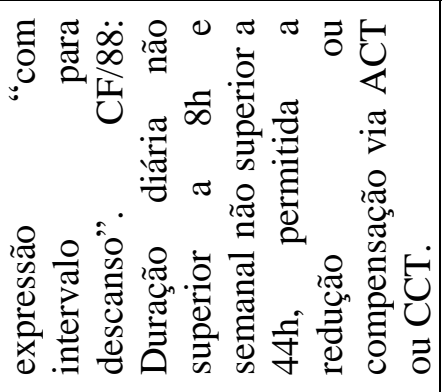 & 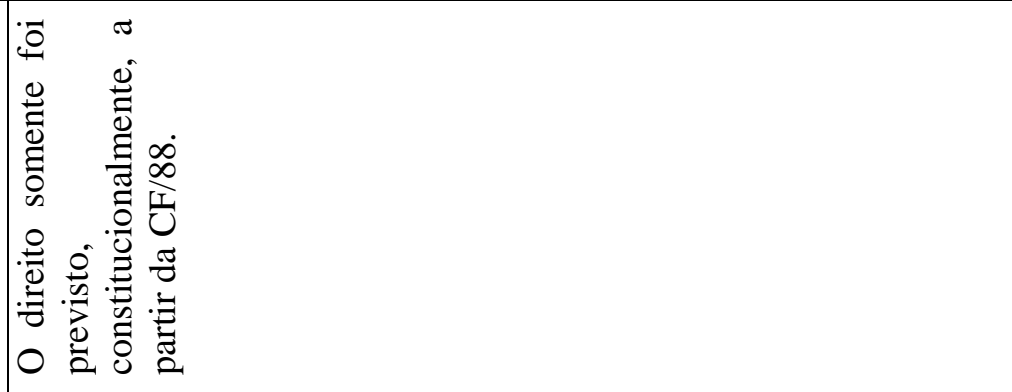 \\
\hline & 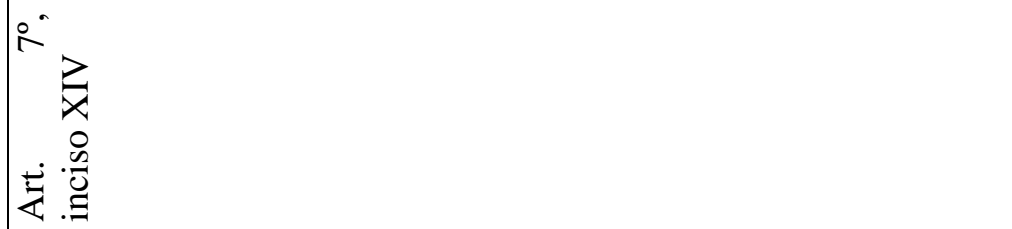 \\
\hline
\end{tabular}




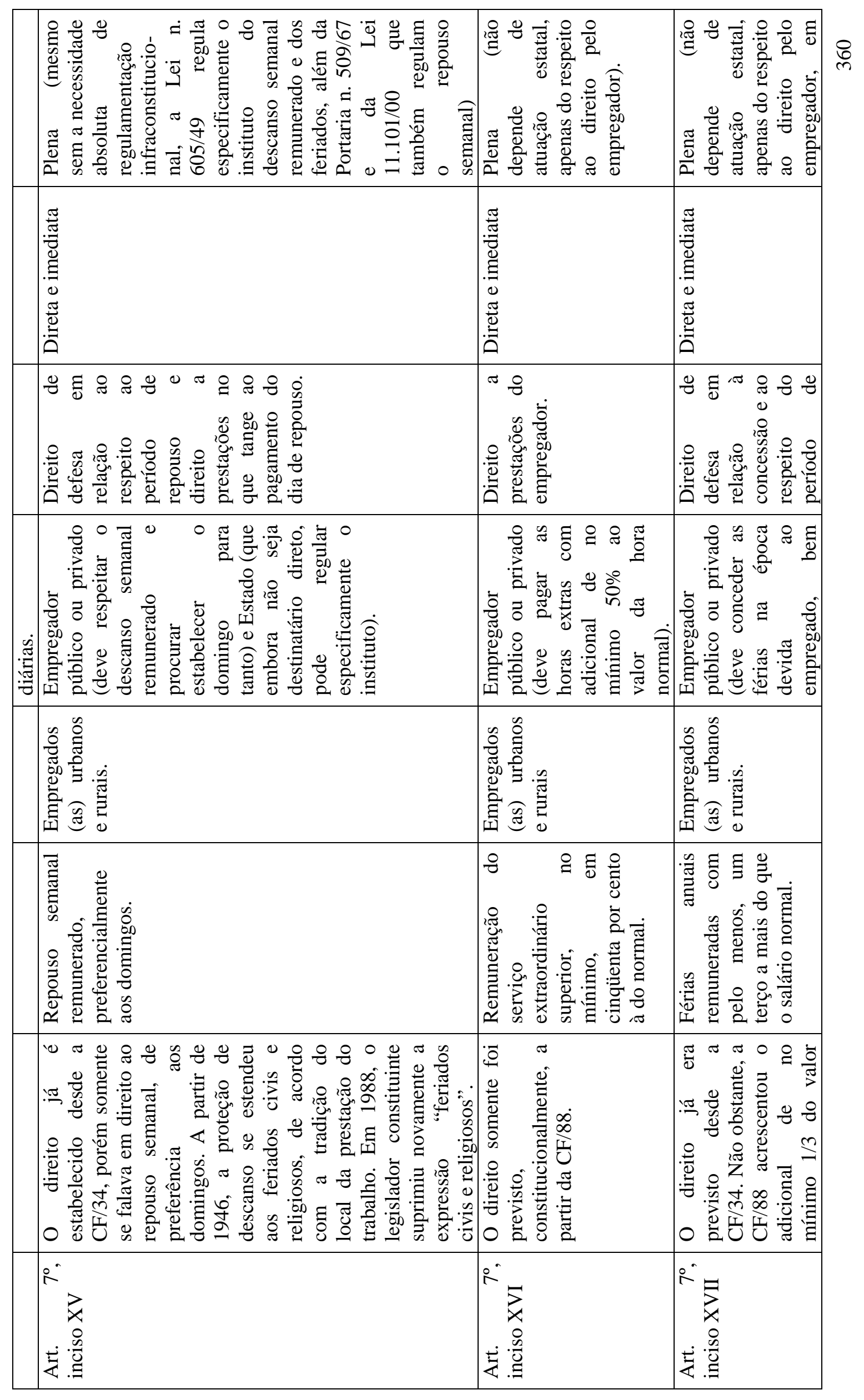




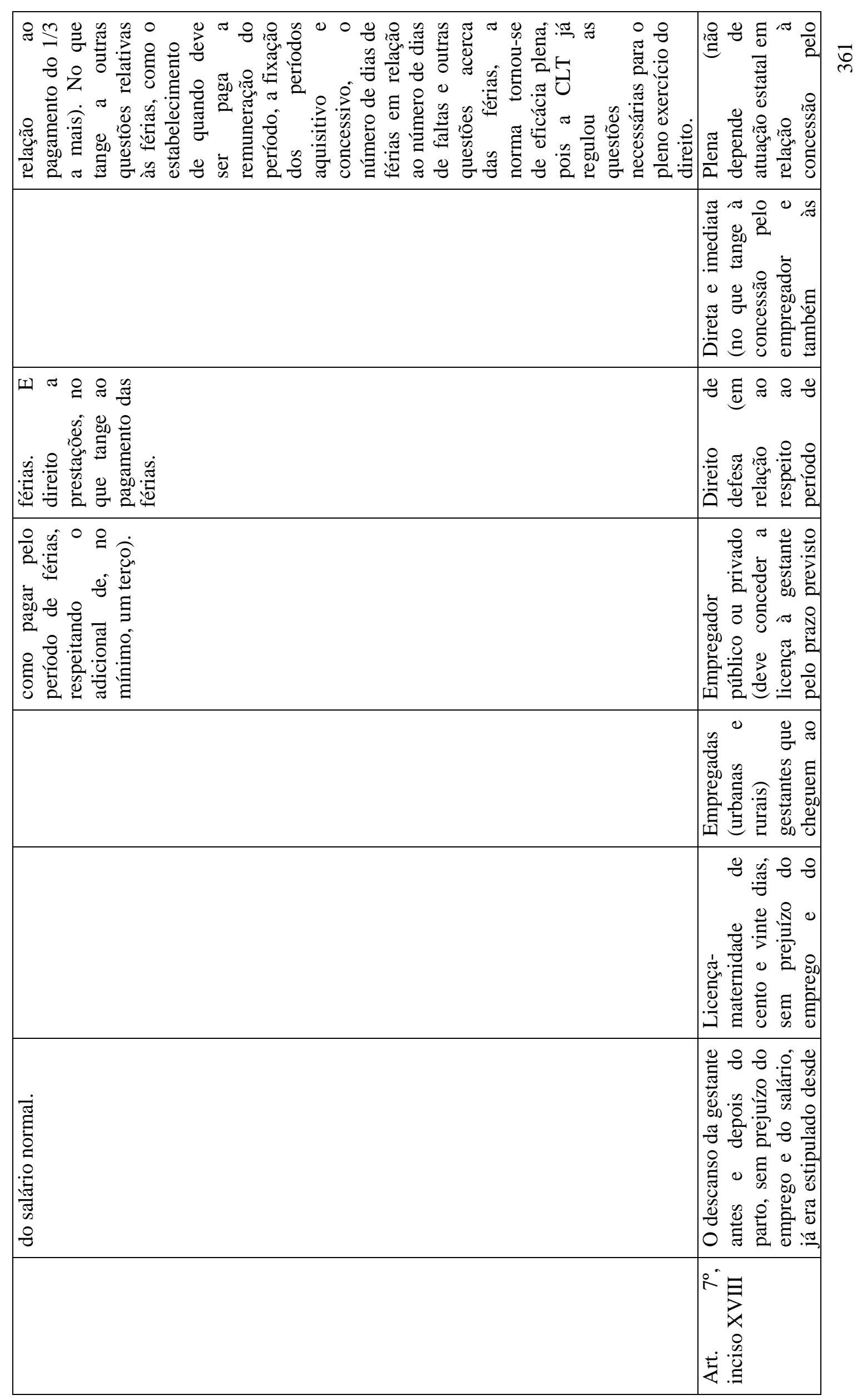




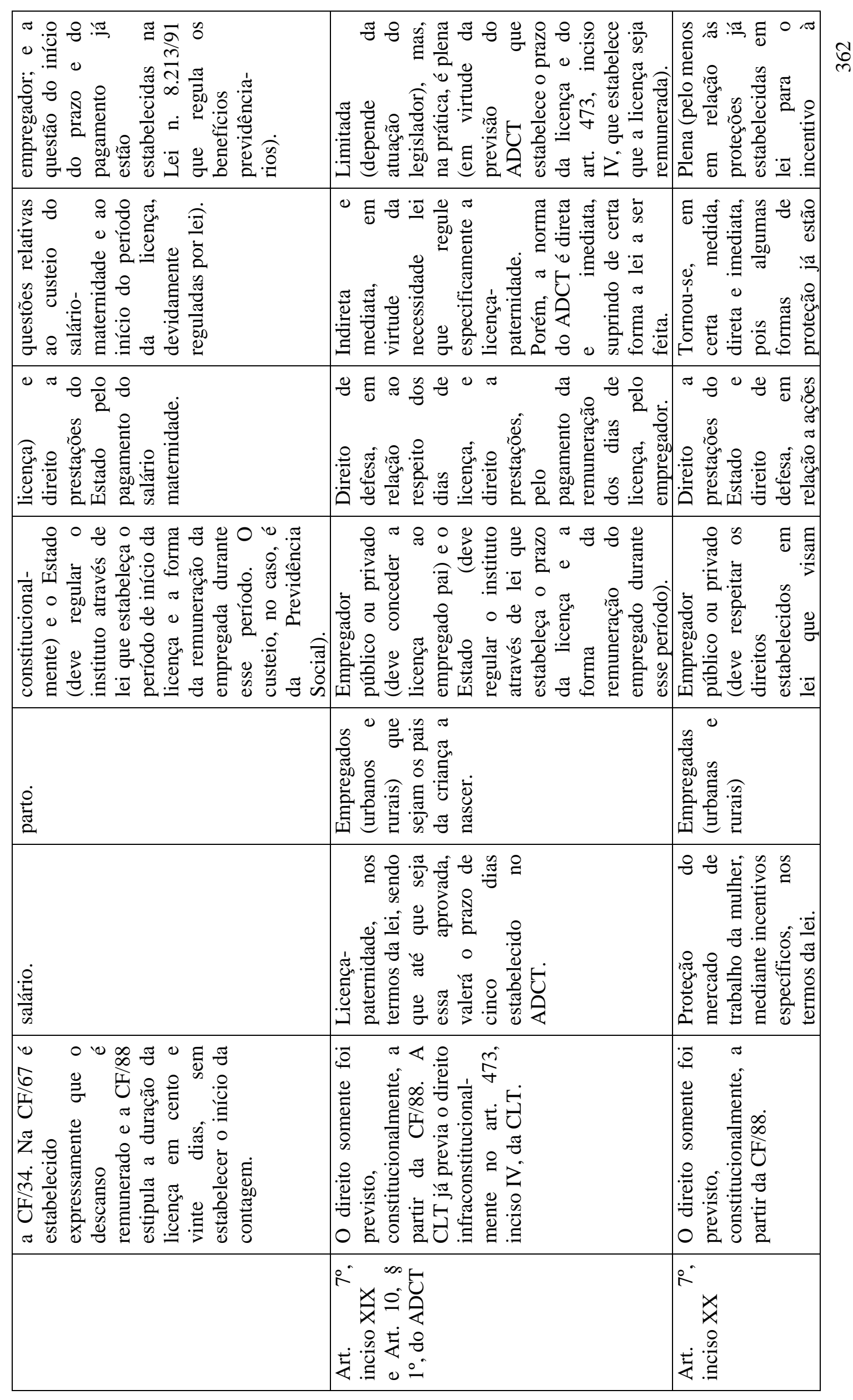




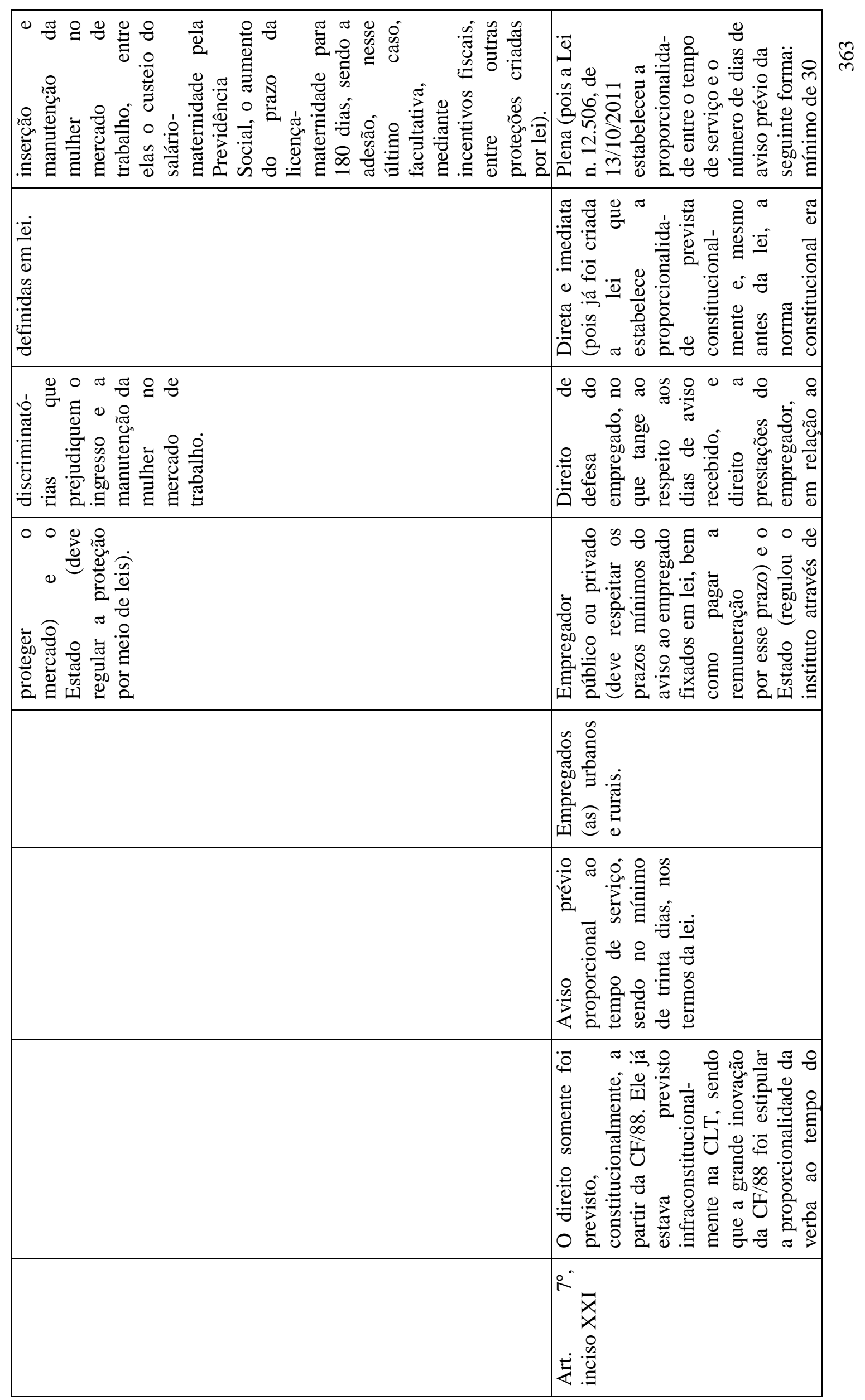




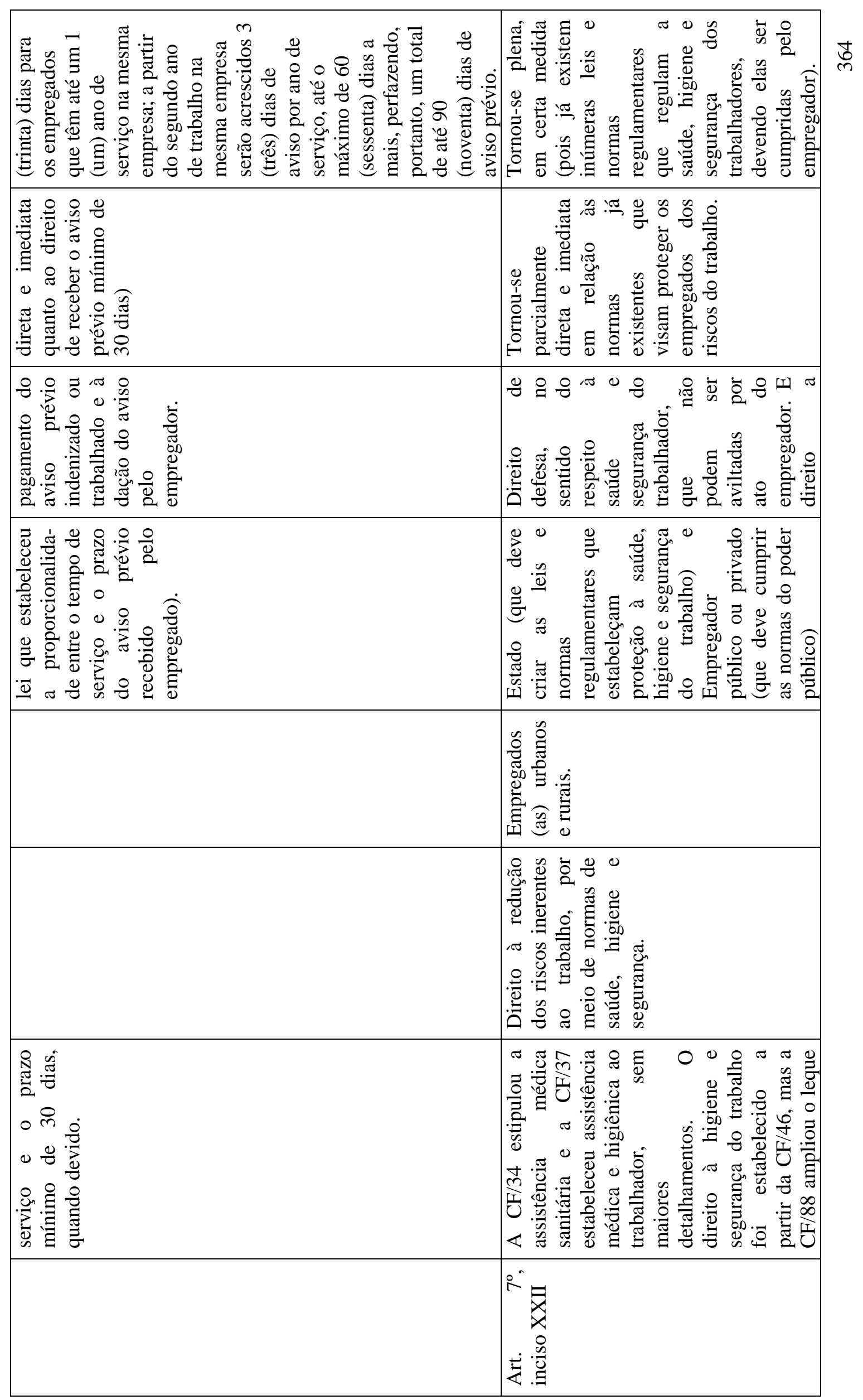




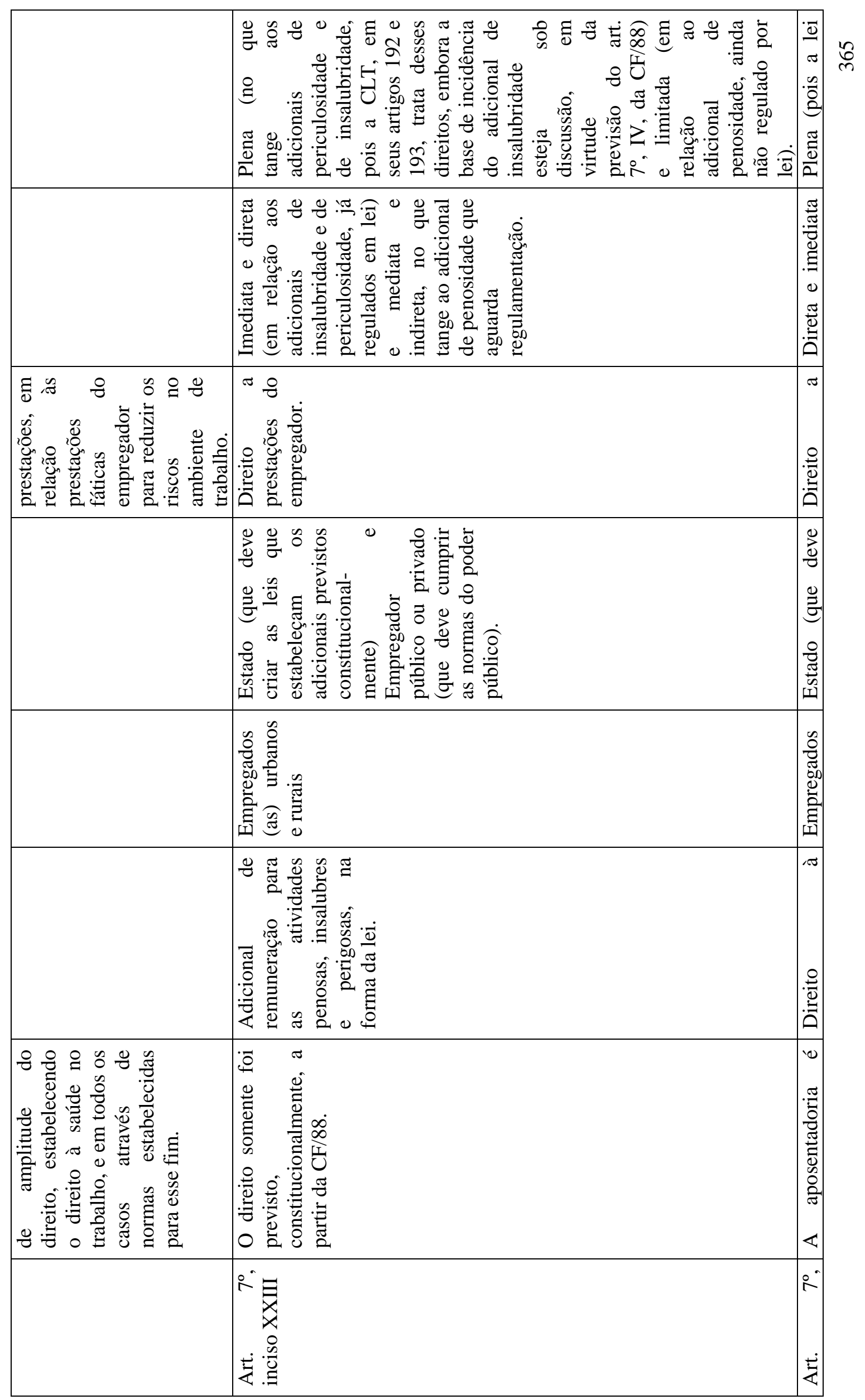




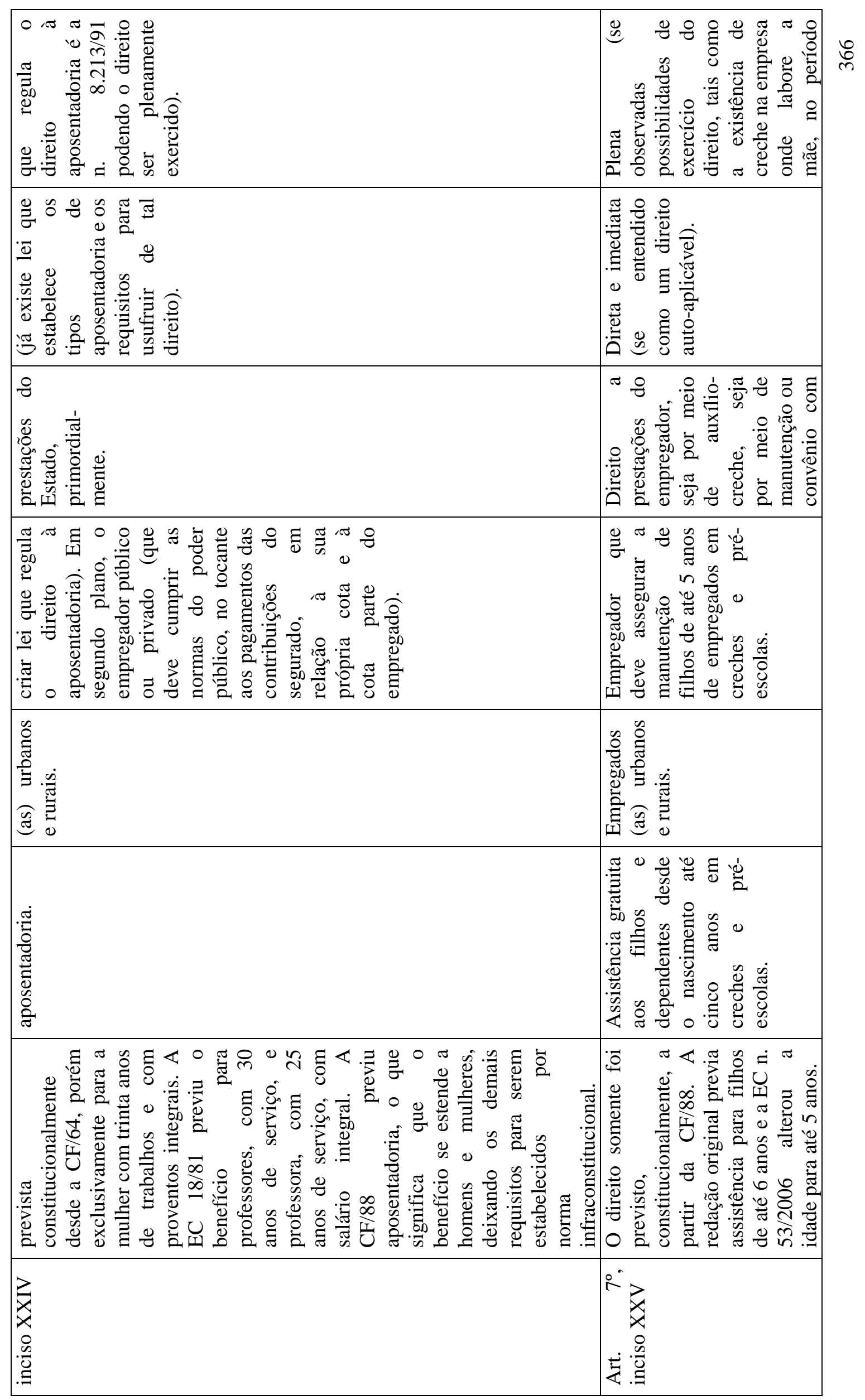




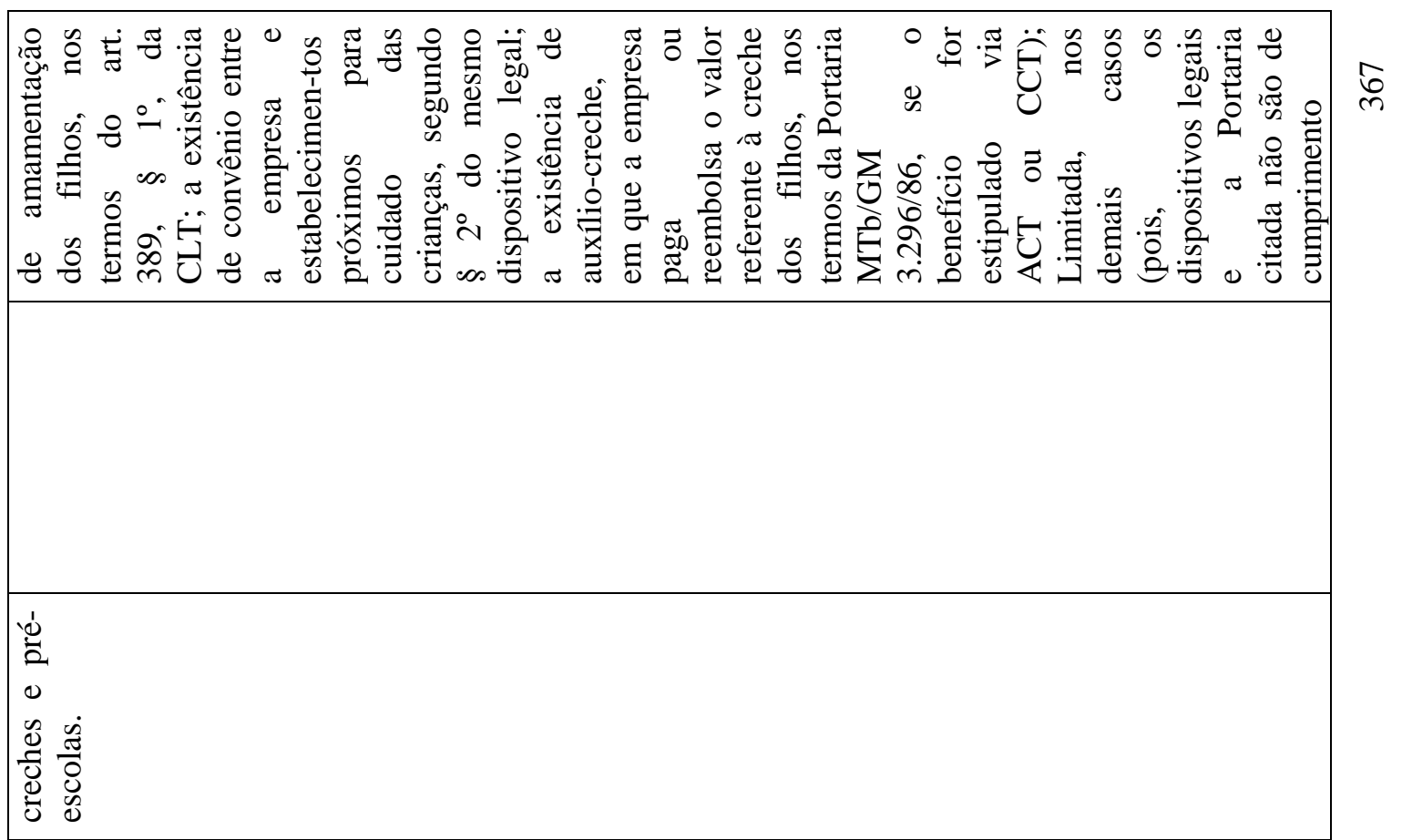




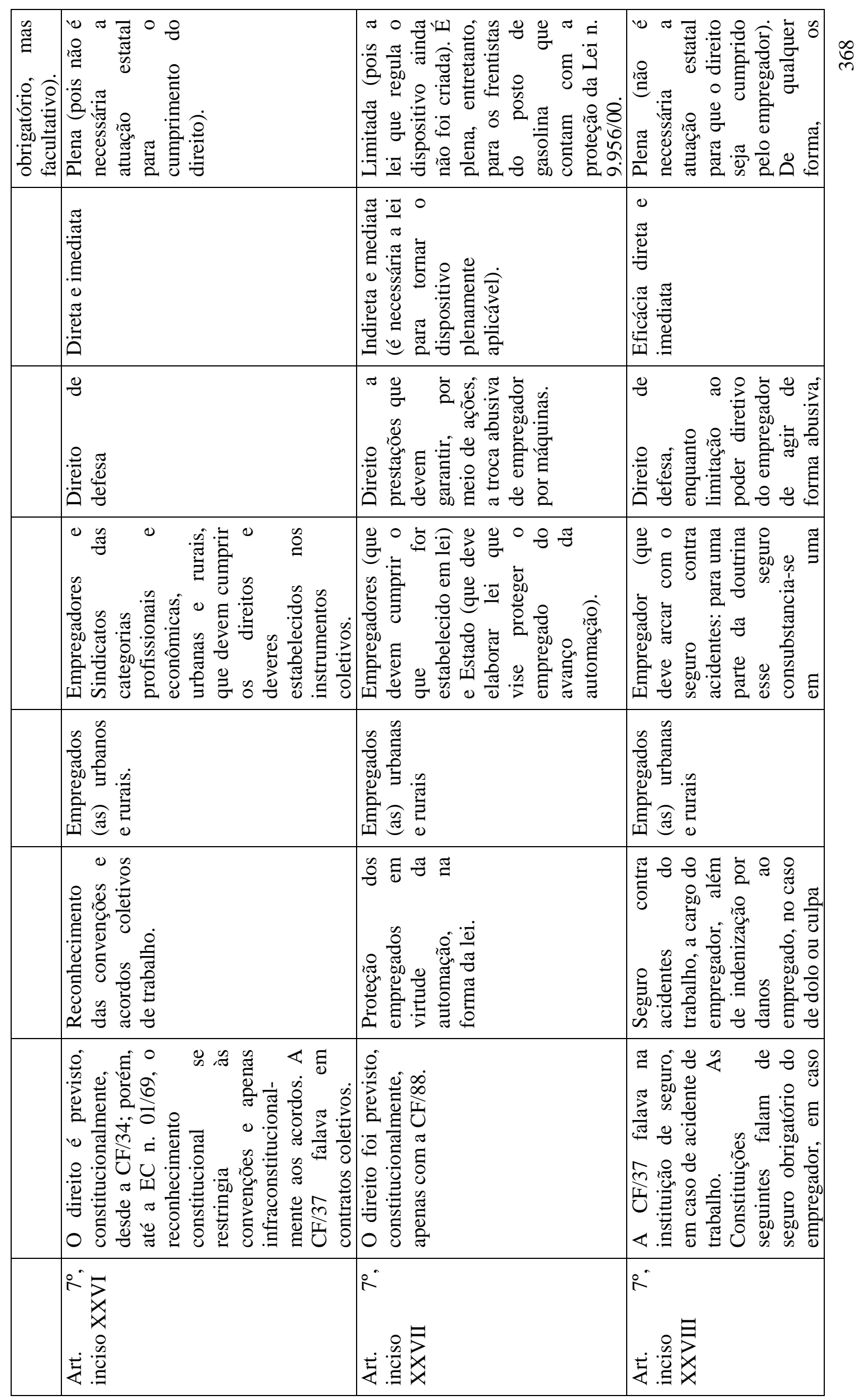




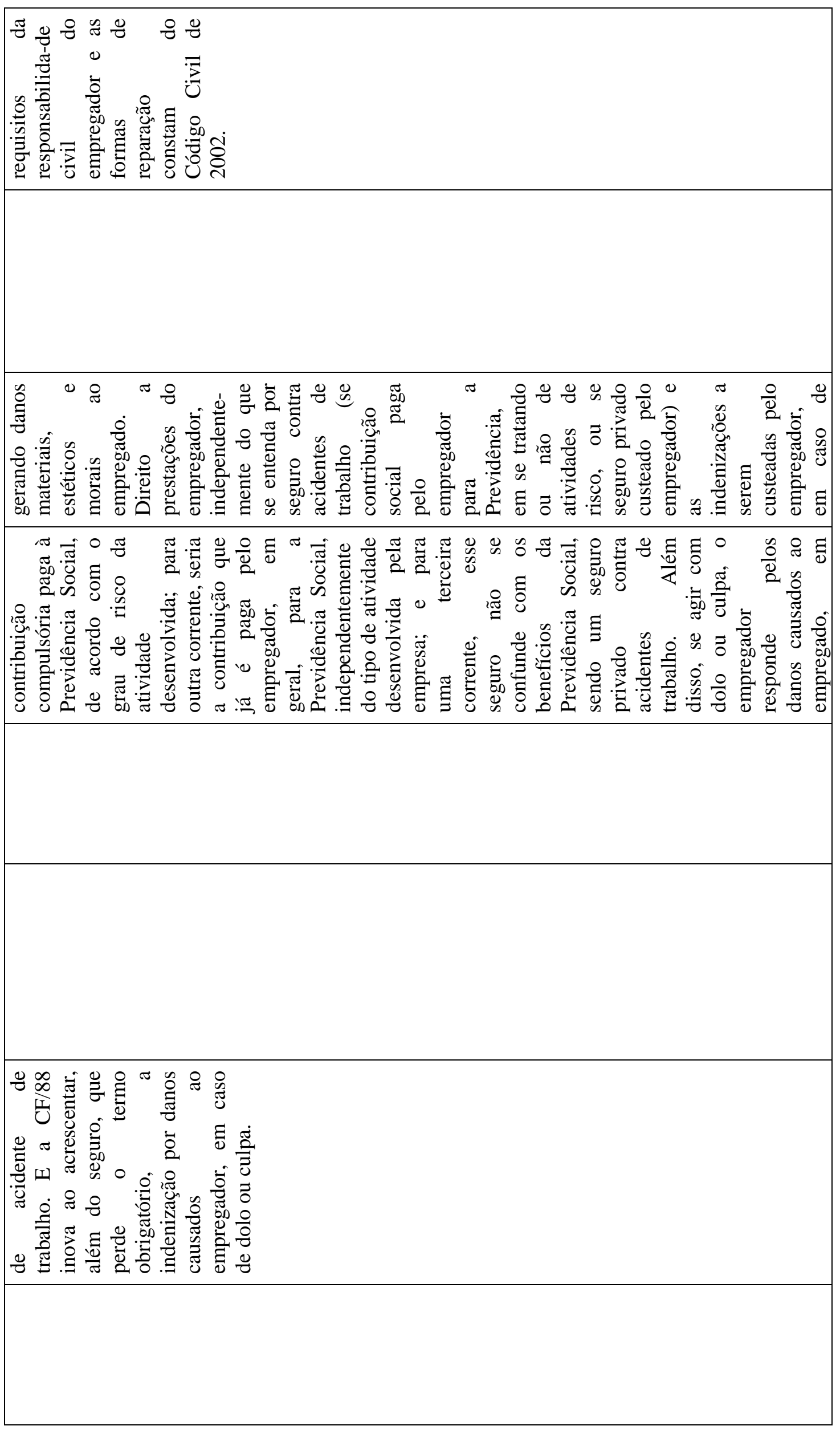




\begin{tabular}{|c|c|}
\hline & 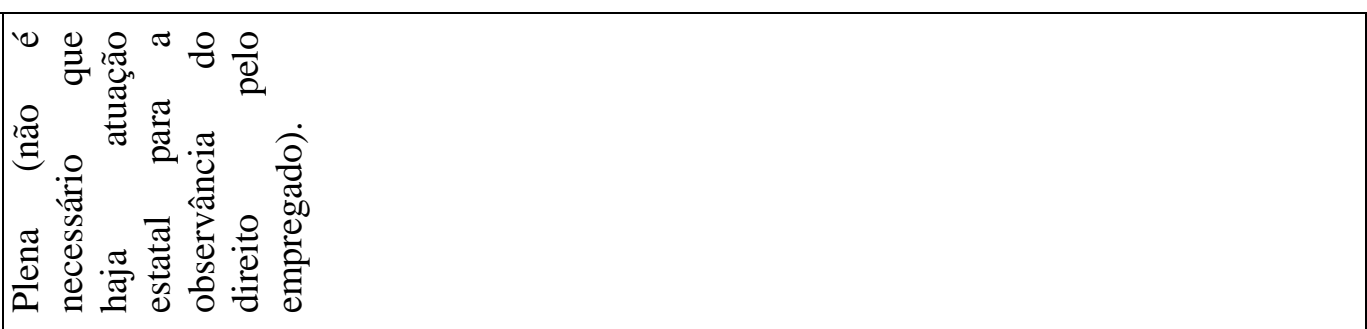 \\
\hline & 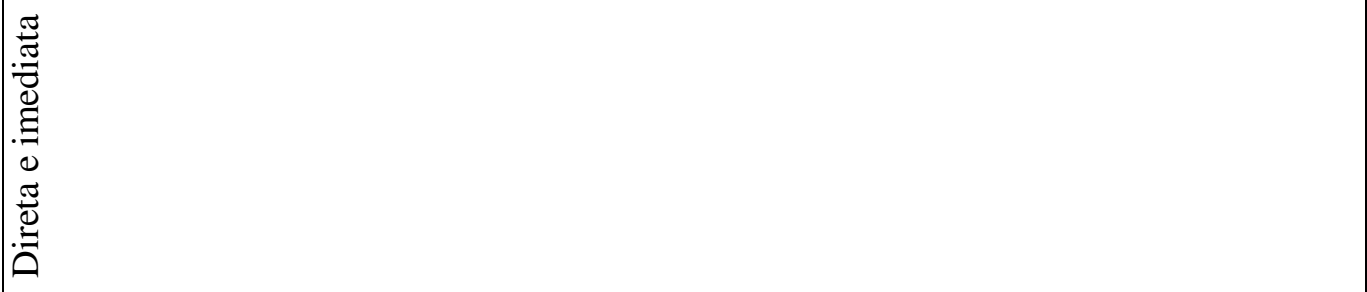 \\
\hline $\begin{array}{l}\frac{0}{0} \\
\frac{0}{7} \\
\overline{0} \\
0 \\
0 \\
0 \\
0\end{array}$ & 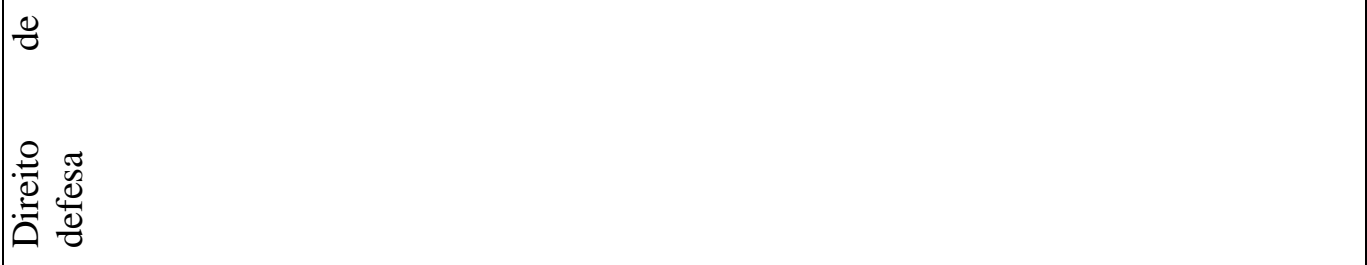 \\
\hline 迎 & 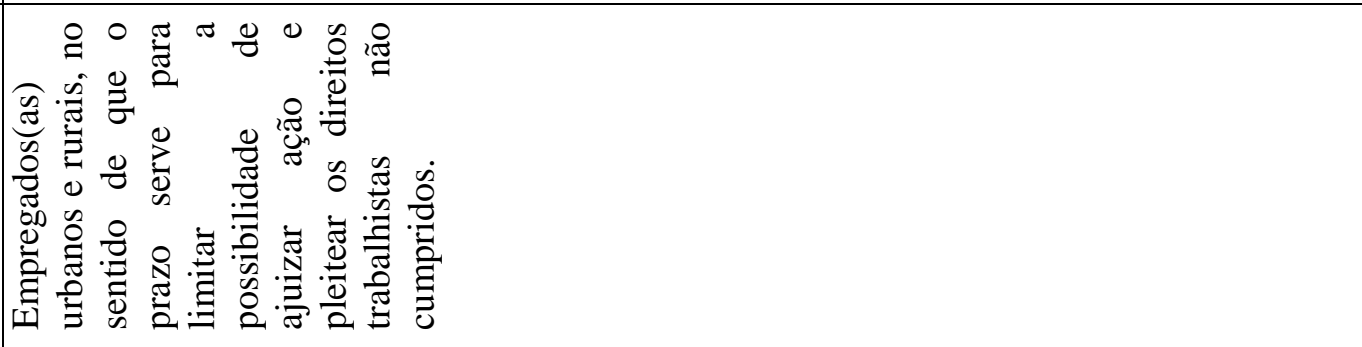 \\
\hline & 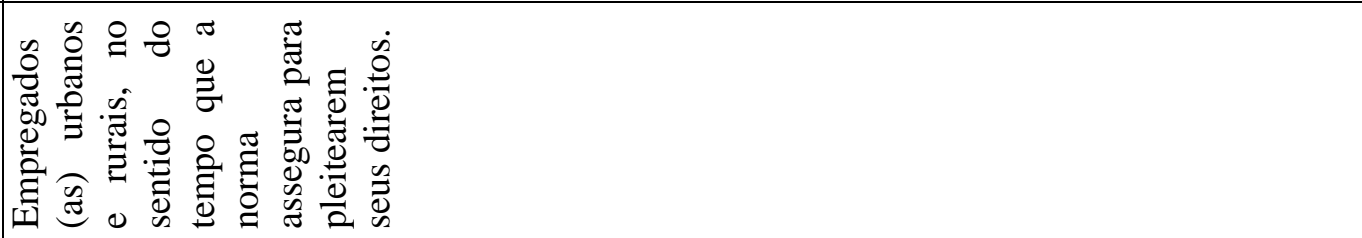 \\
\hline & 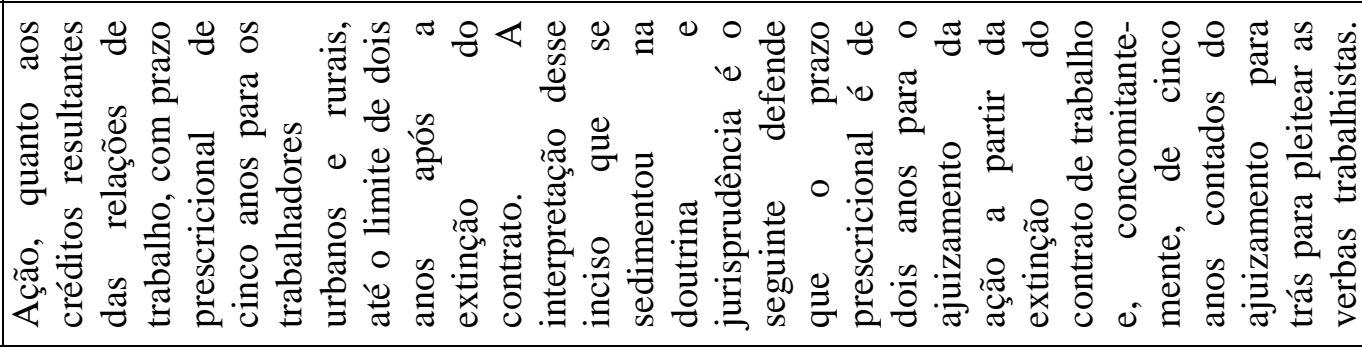 \\
\hline & 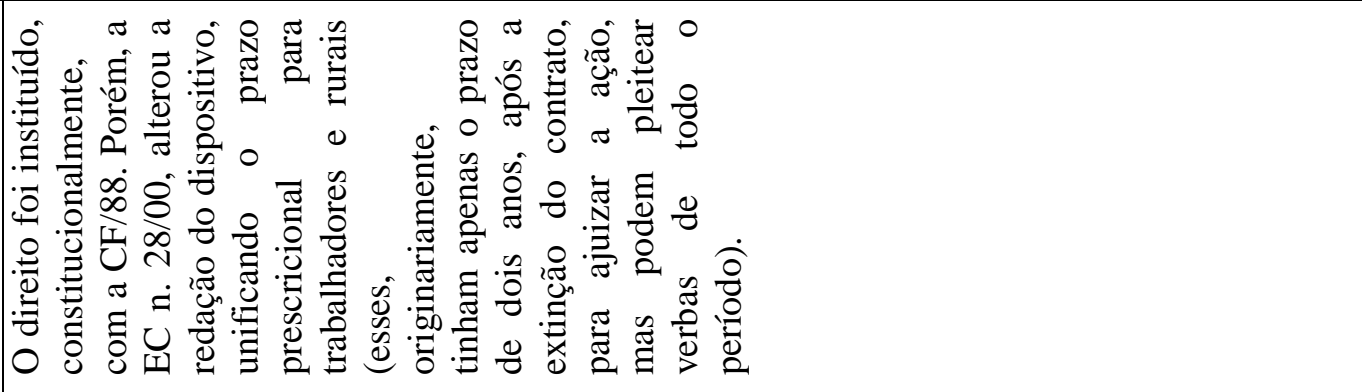 \\
\hline & 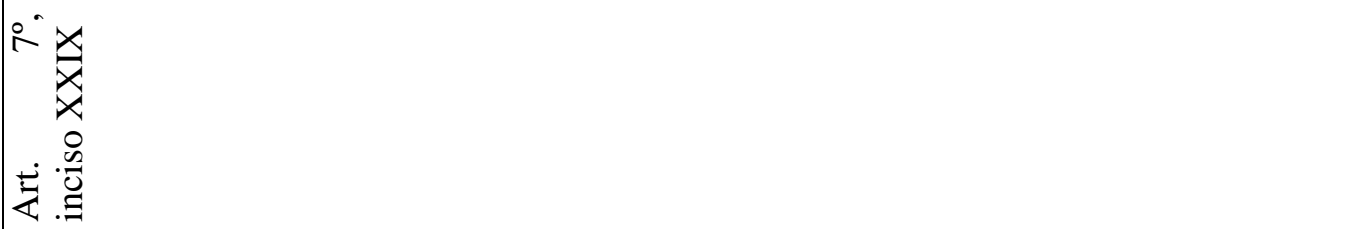 \\
\hline
\end{tabular}




\begin{tabular}{|c|c|}
\hline & 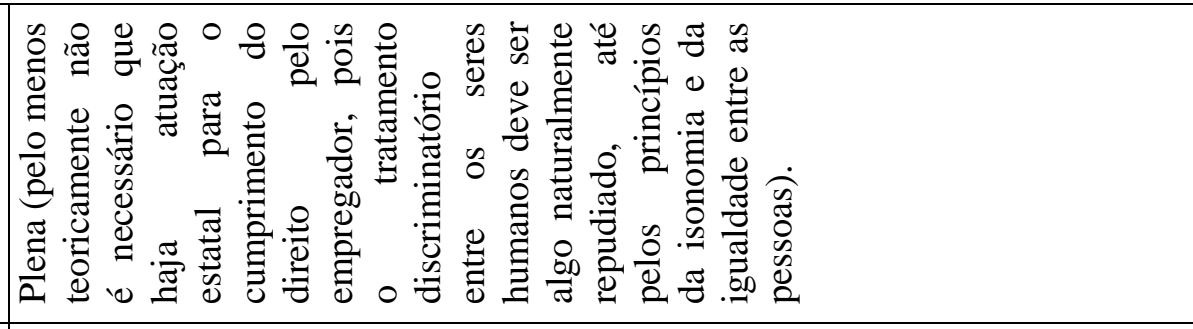 \\
\hline & 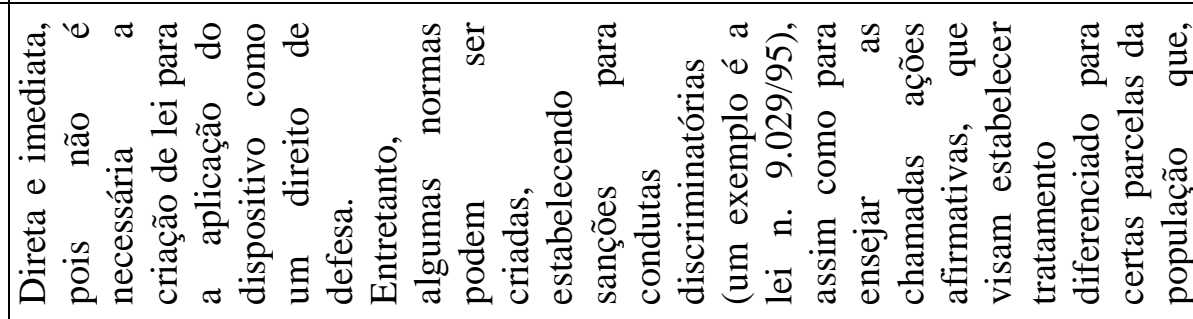 \\
\hline & 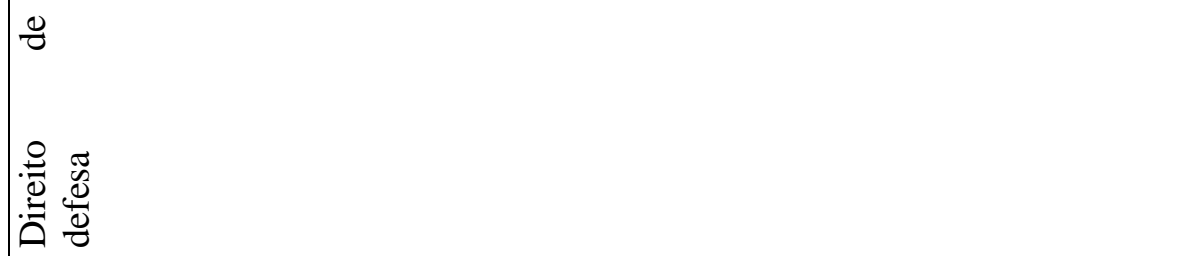 \\
\hline & 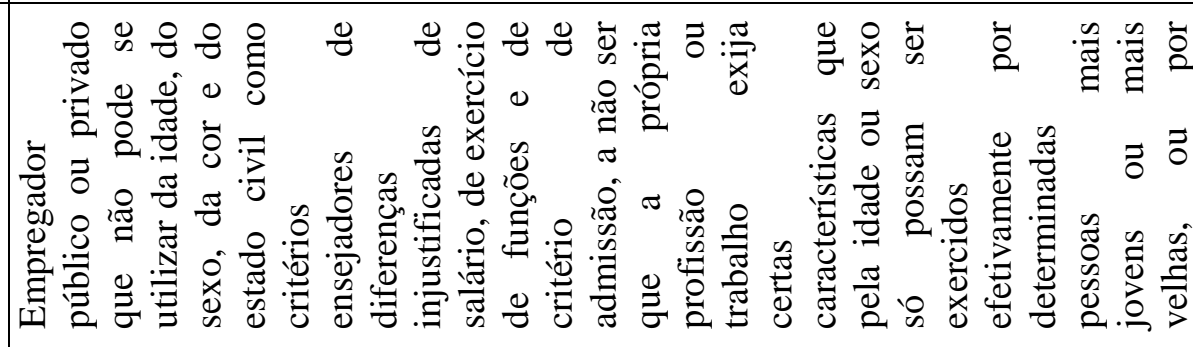 \\
\hline & 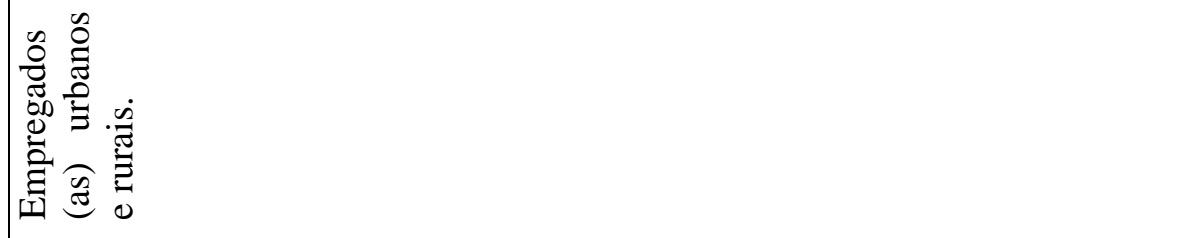 \\
\hline \multirow[t]{3}{*}{ 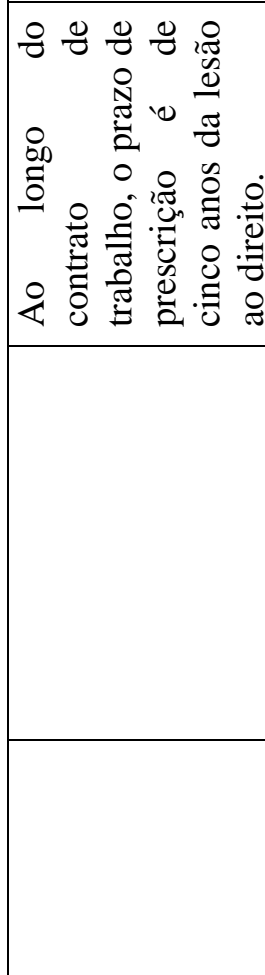 } & 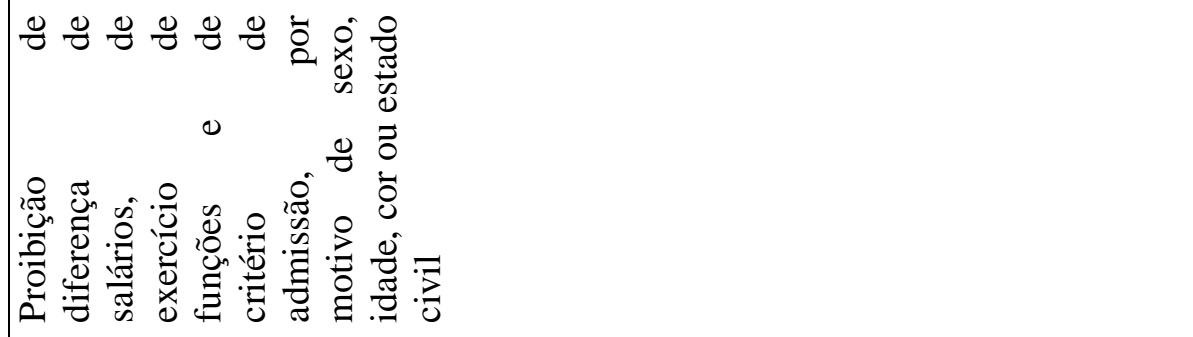 \\
\hline & 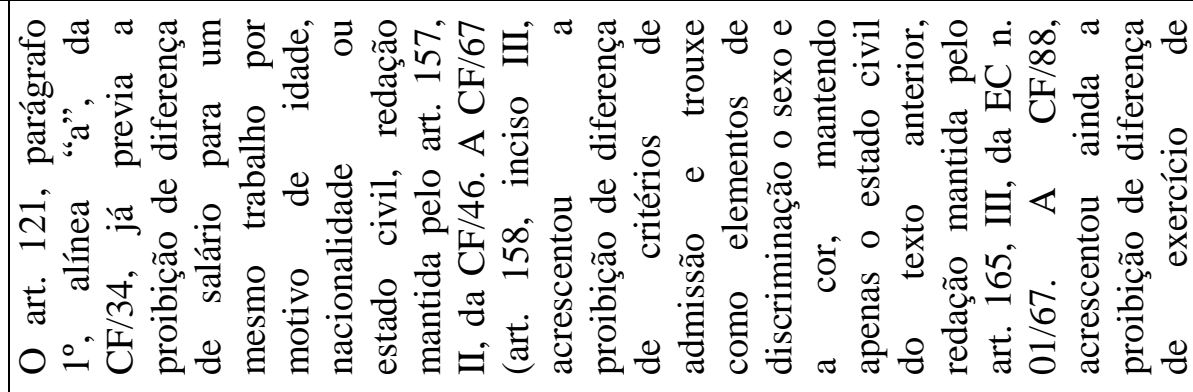 \\
\hline & 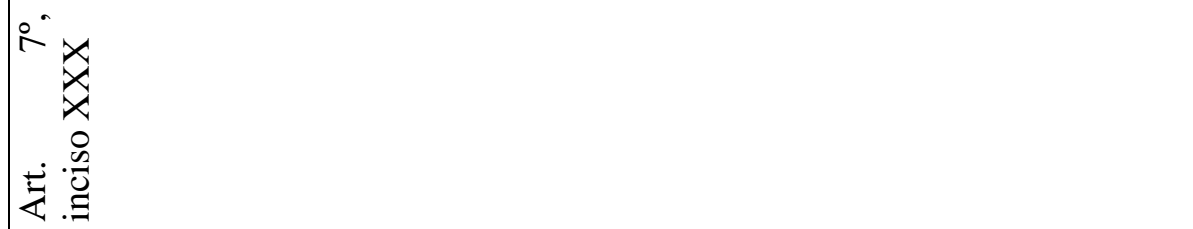 \\
\hline
\end{tabular}




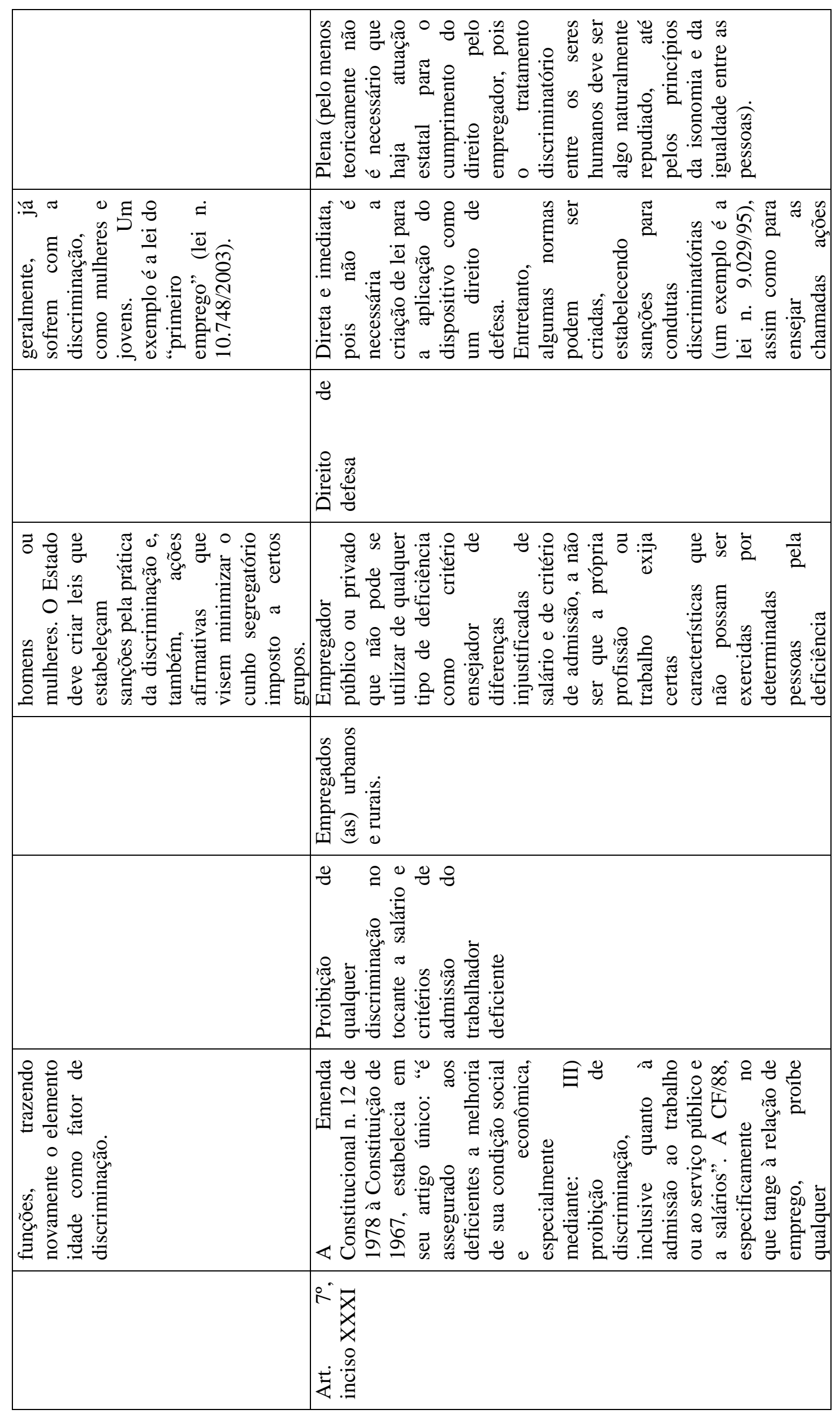




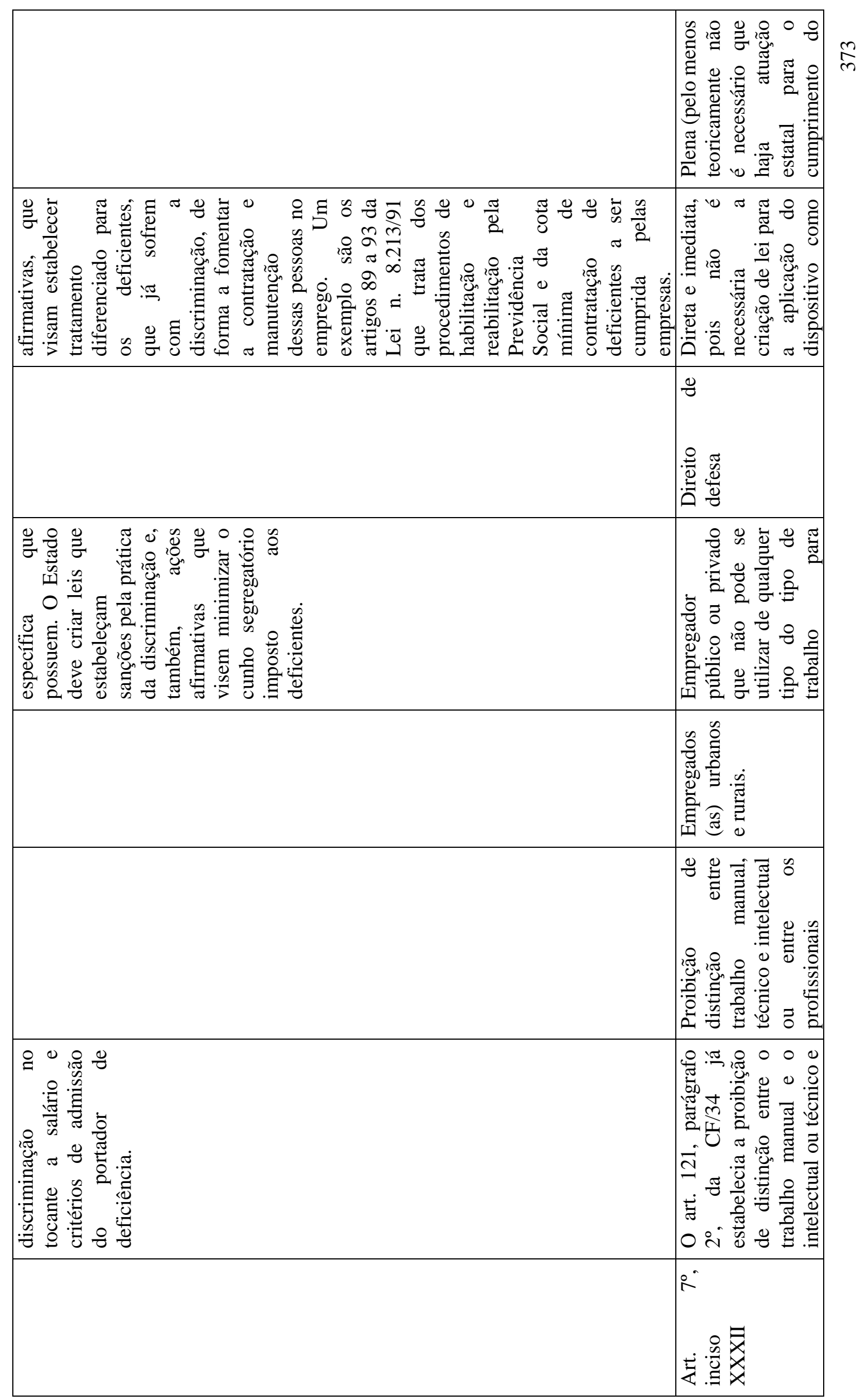




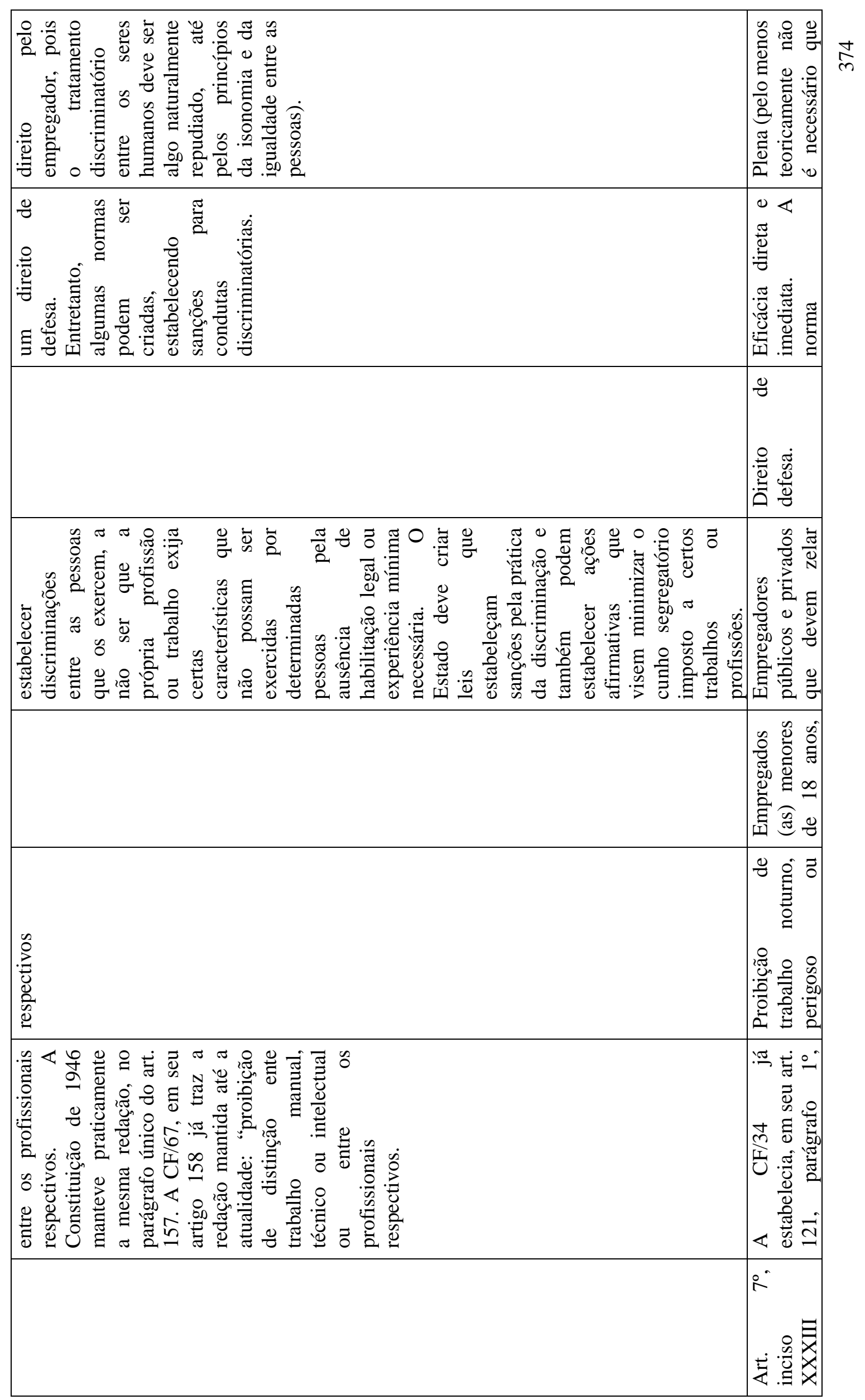




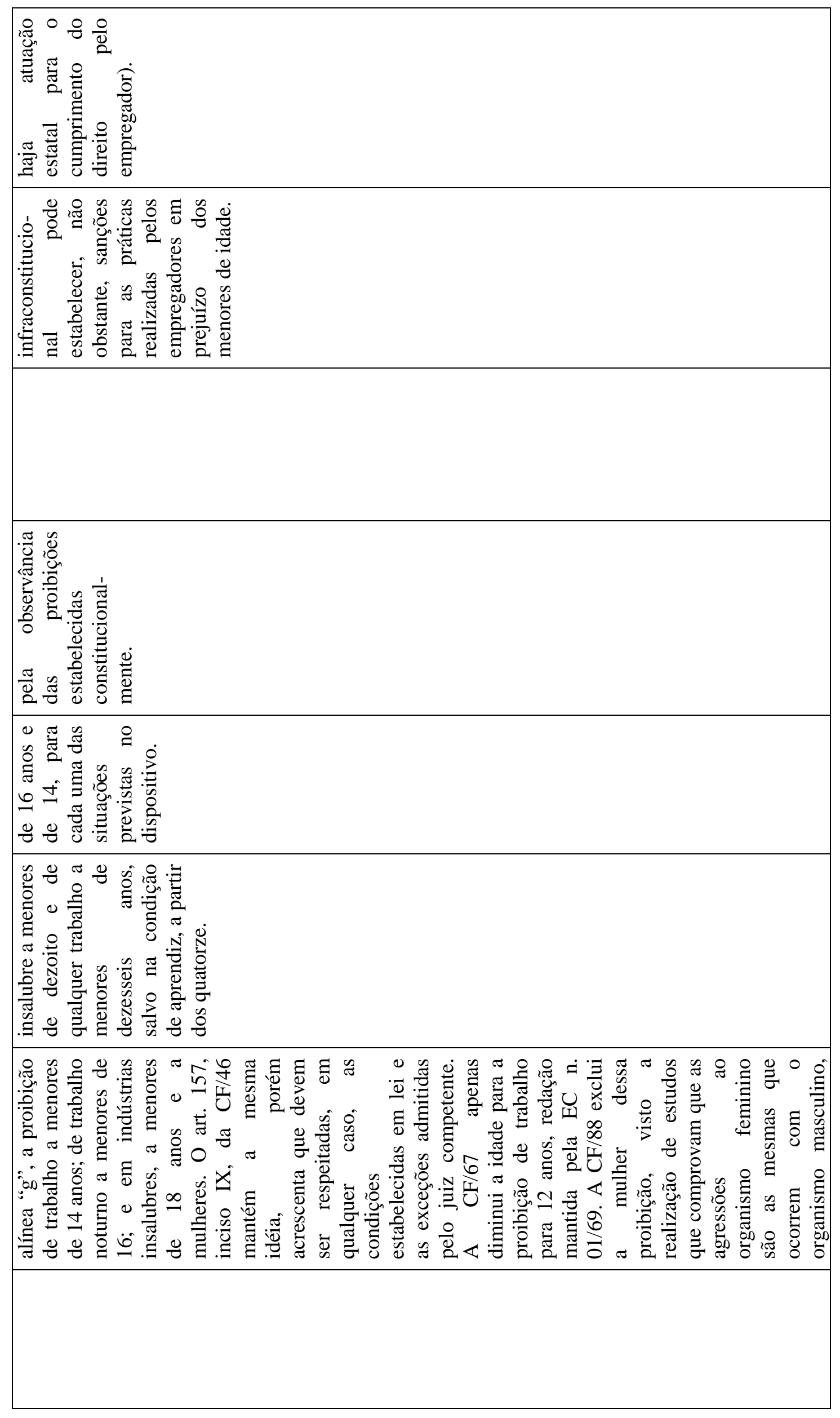




\begin{tabular}{|c|c|}
\hline & 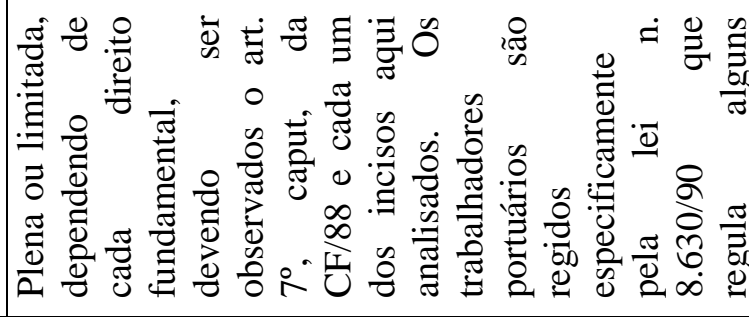 \\
\hline & 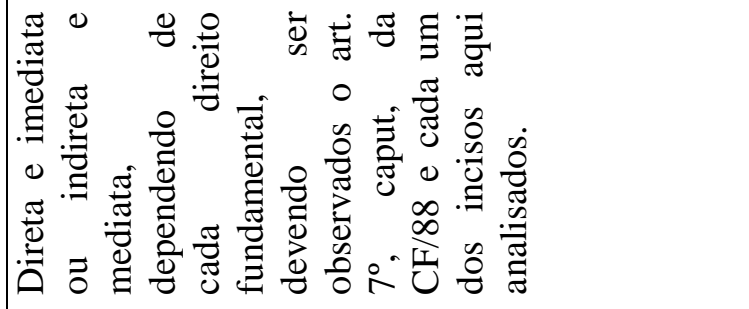 \\
\hline & 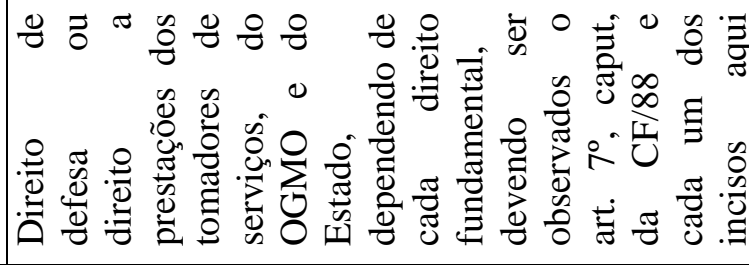 \\
\hline & 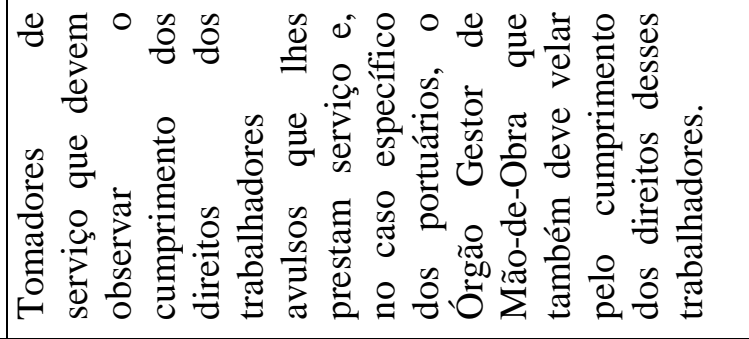 \\
\hline & 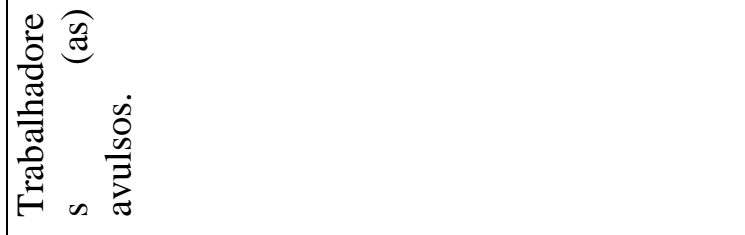 \\
\hline & 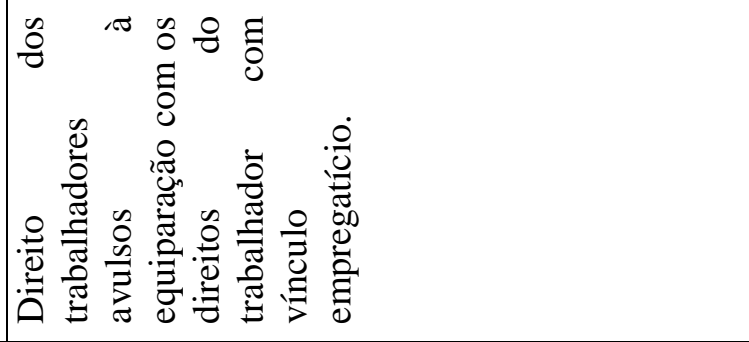 \\
\hline 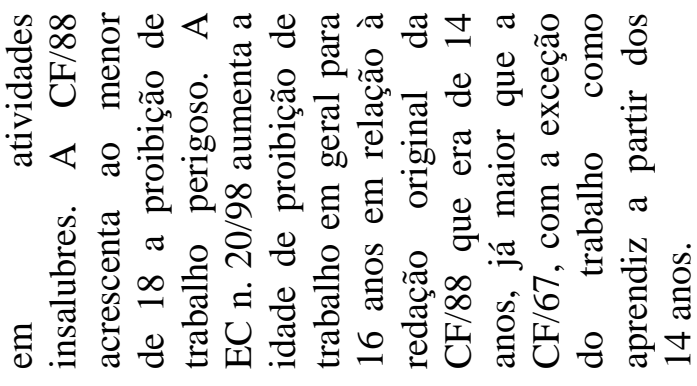 & 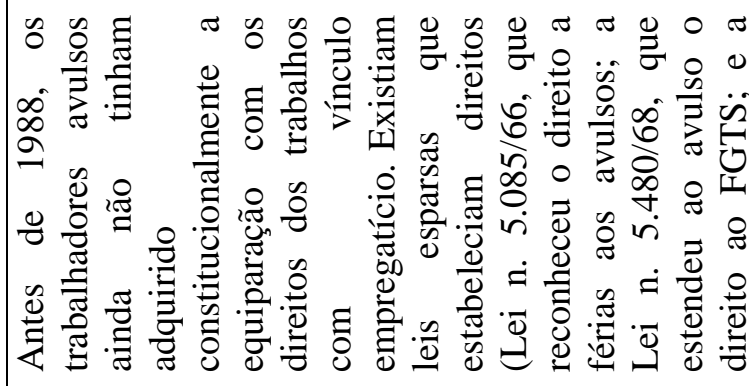 \\
\hline & 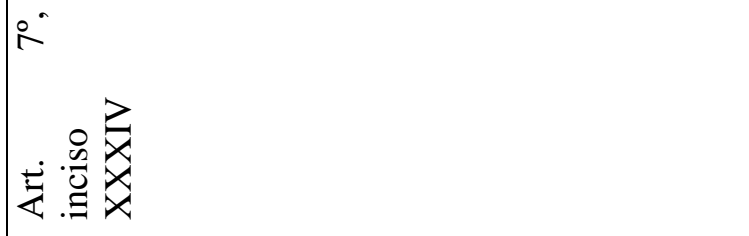 \\
\hline
\end{tabular}




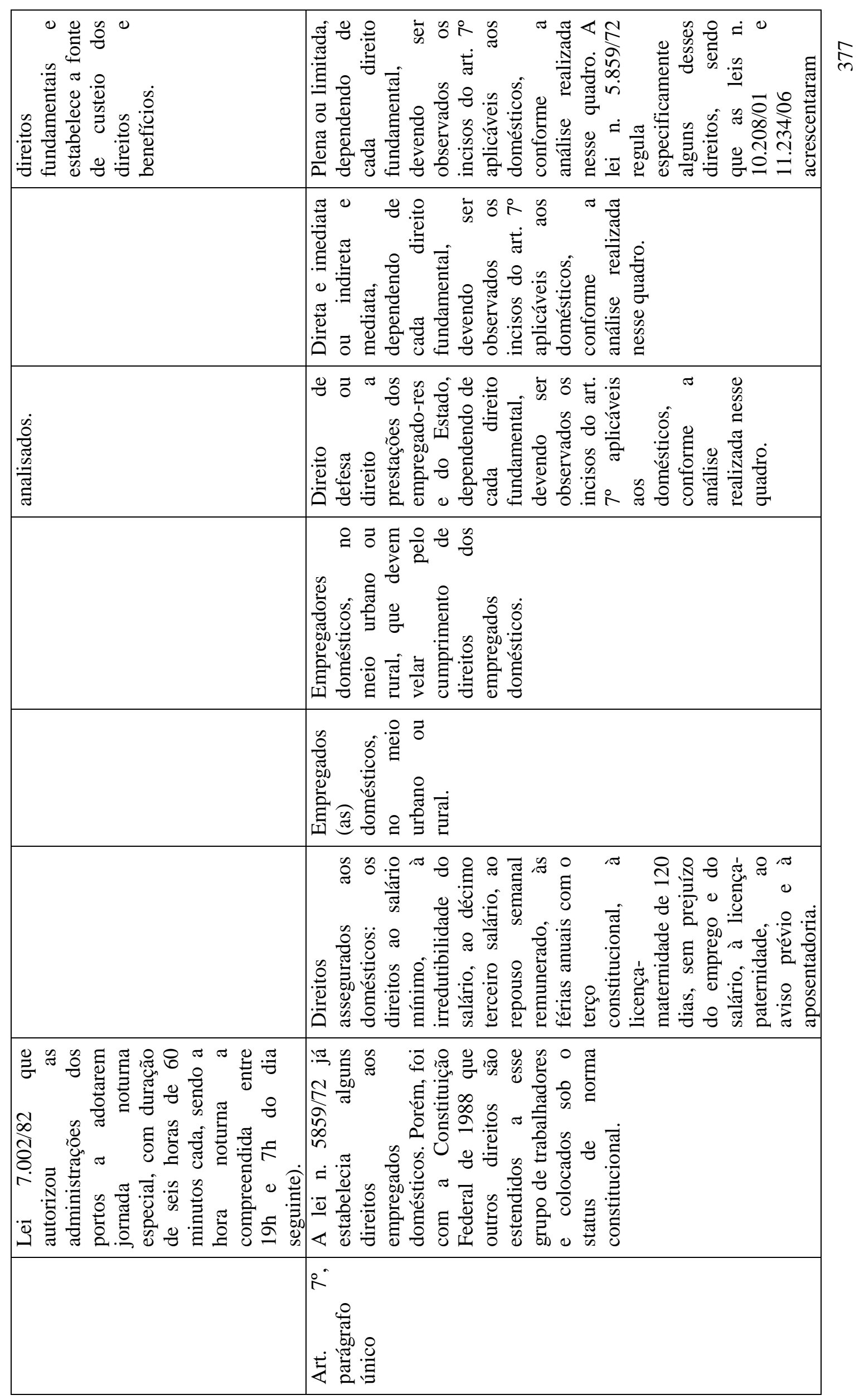




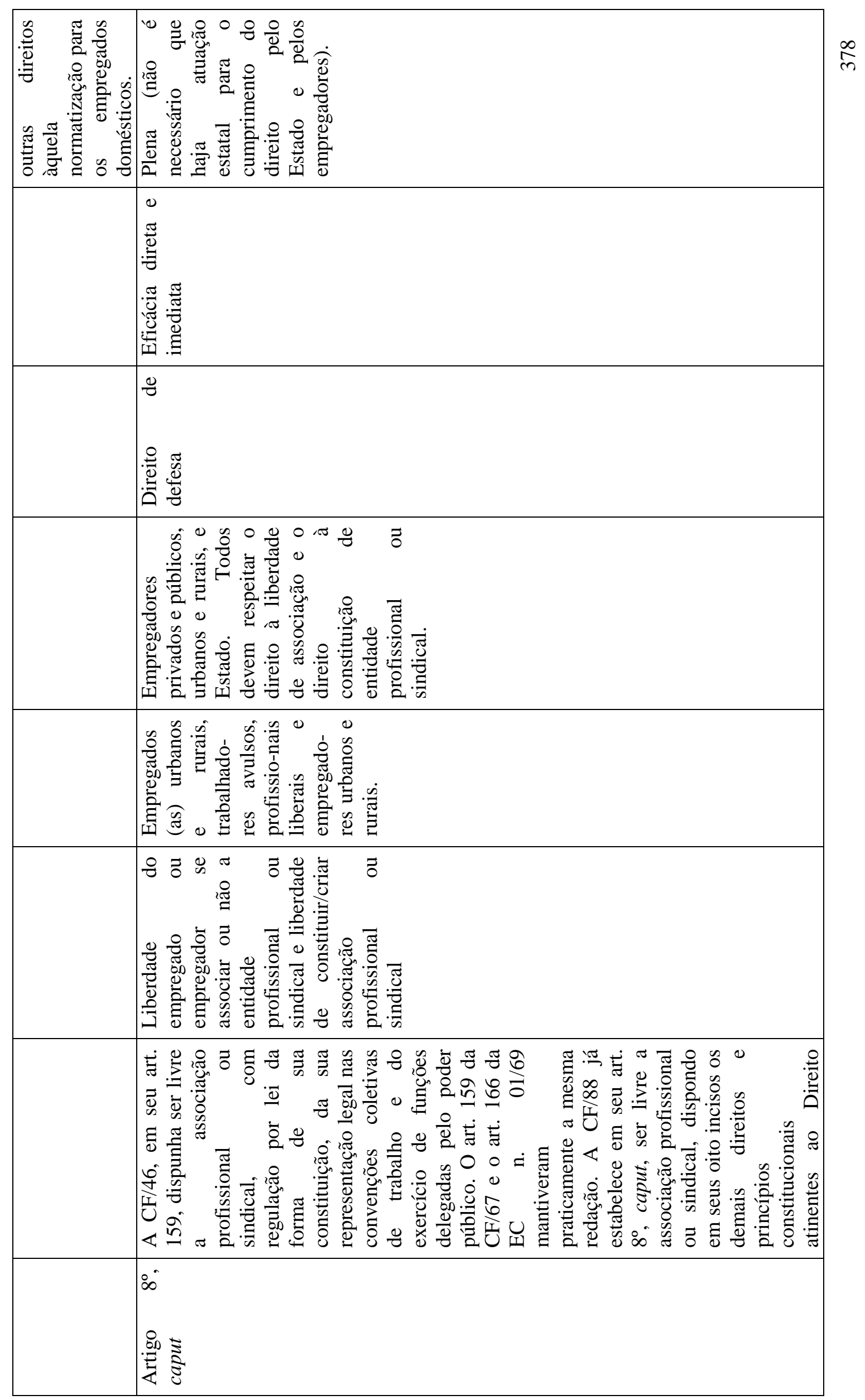




\begin{tabular}{|c|c|}
\hline 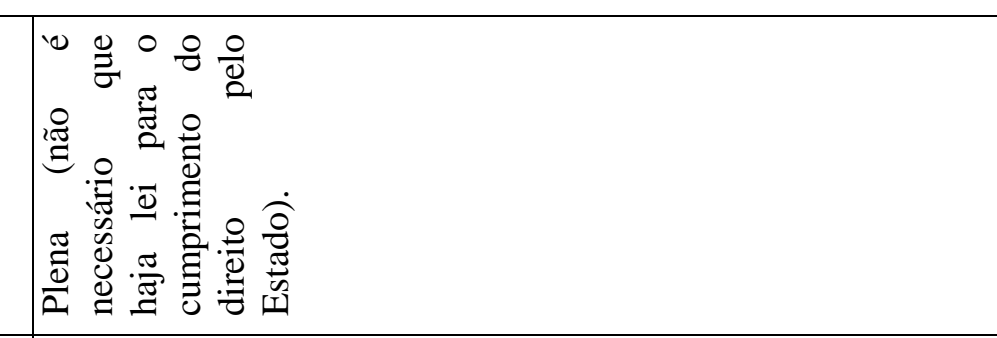 & 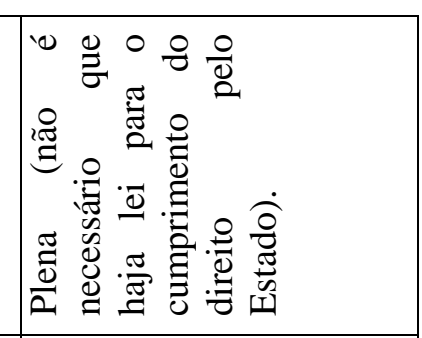 \\
\hline 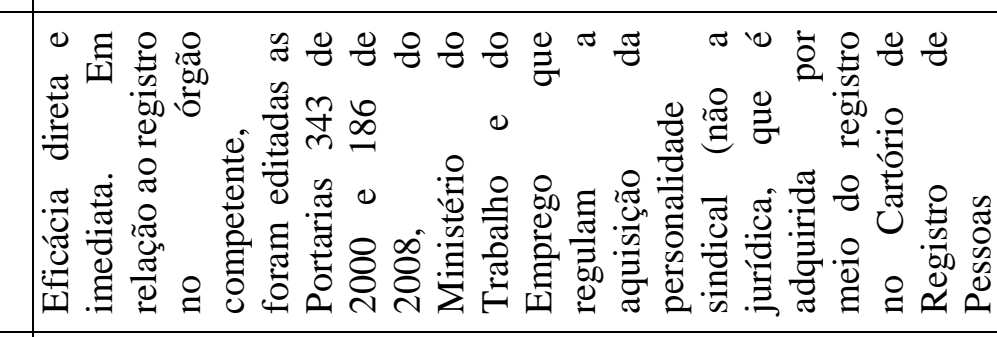 & \\
\hline 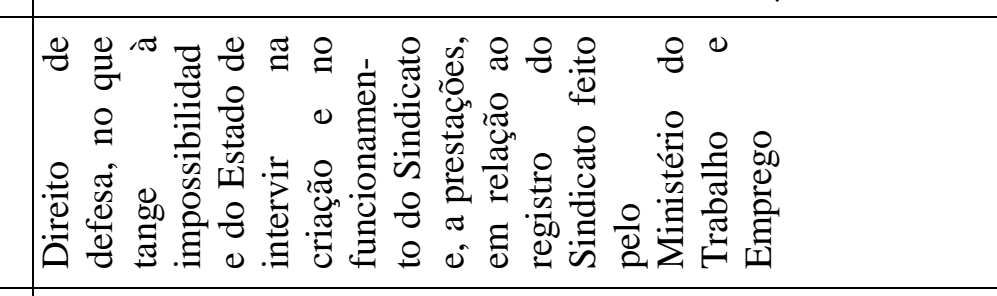 & 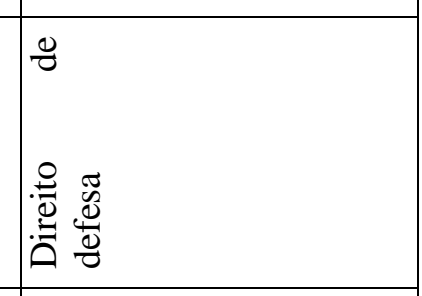 \\
\hline 譄 & 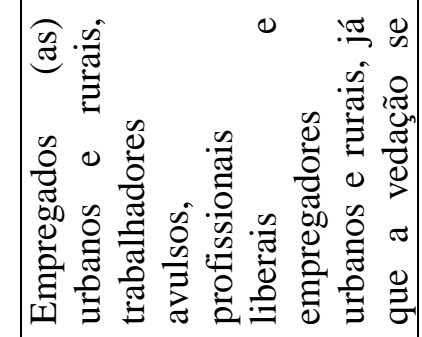 \\
\hline 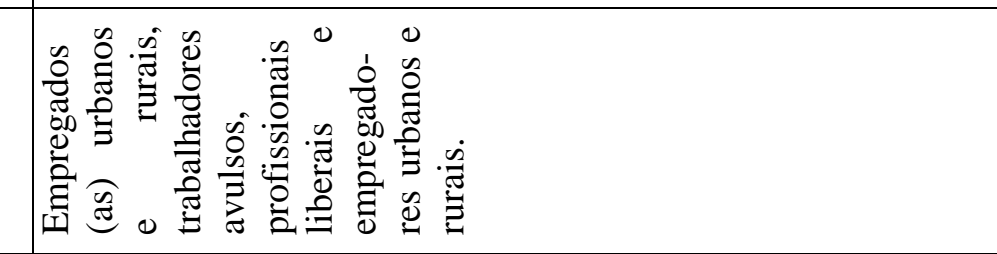 & 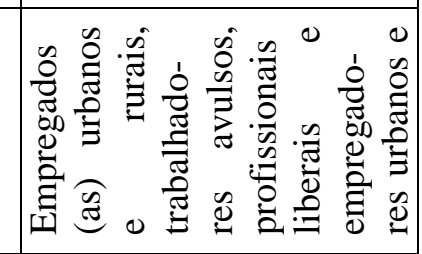 \\
\hline 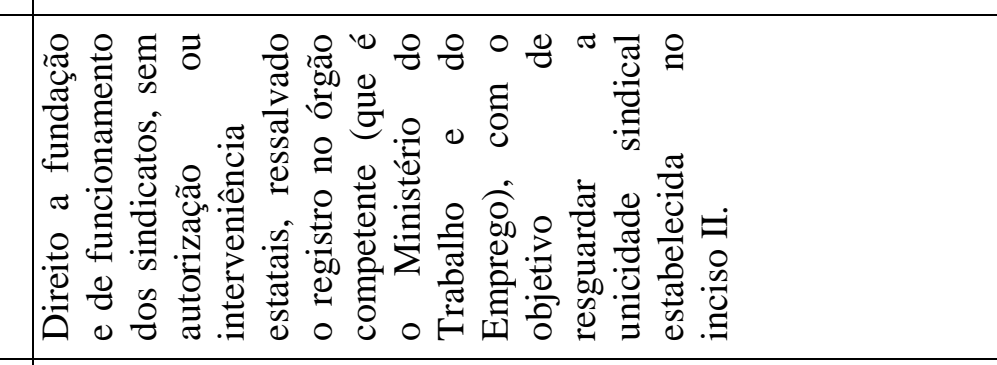 & 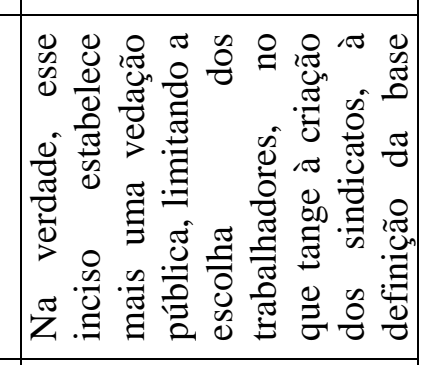 \\
\hline 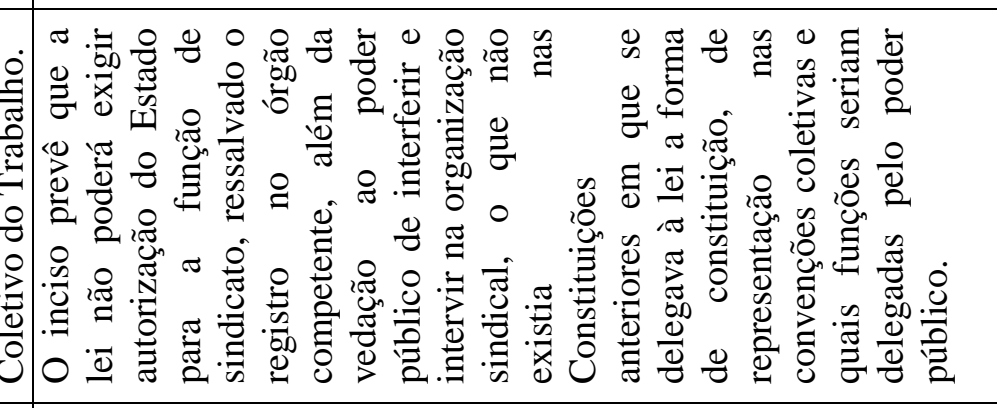 & 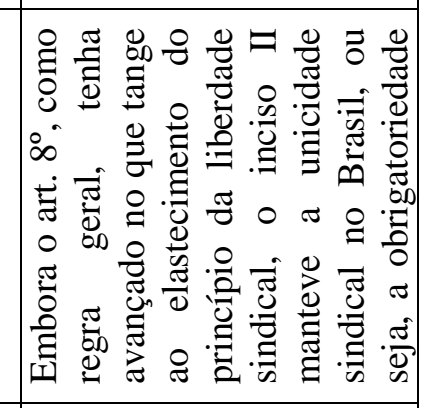 \\
\hline 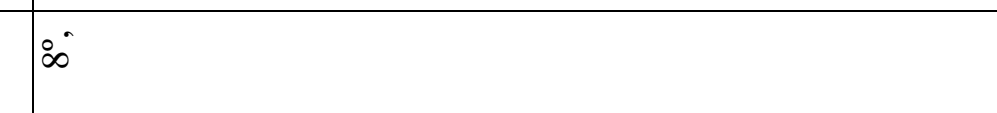 & $\infty$ \\
\hline 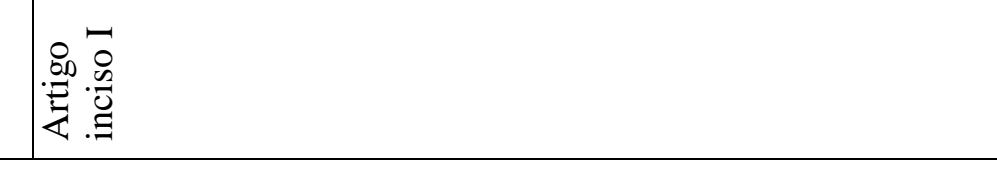 & 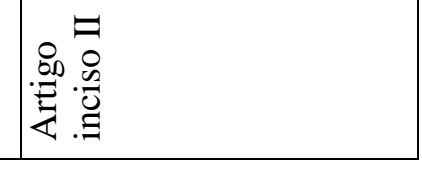 \\
\hline
\end{tabular}




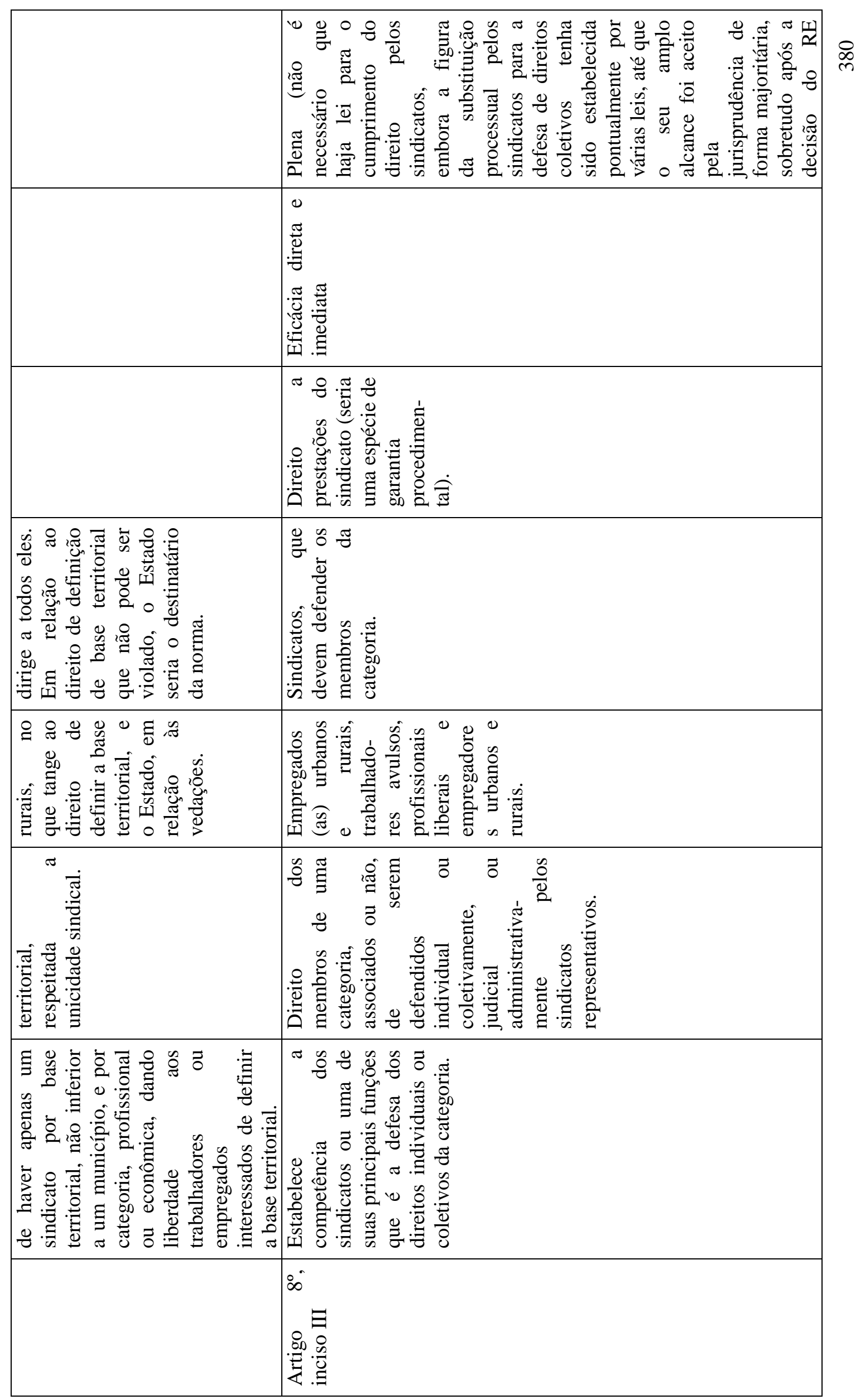




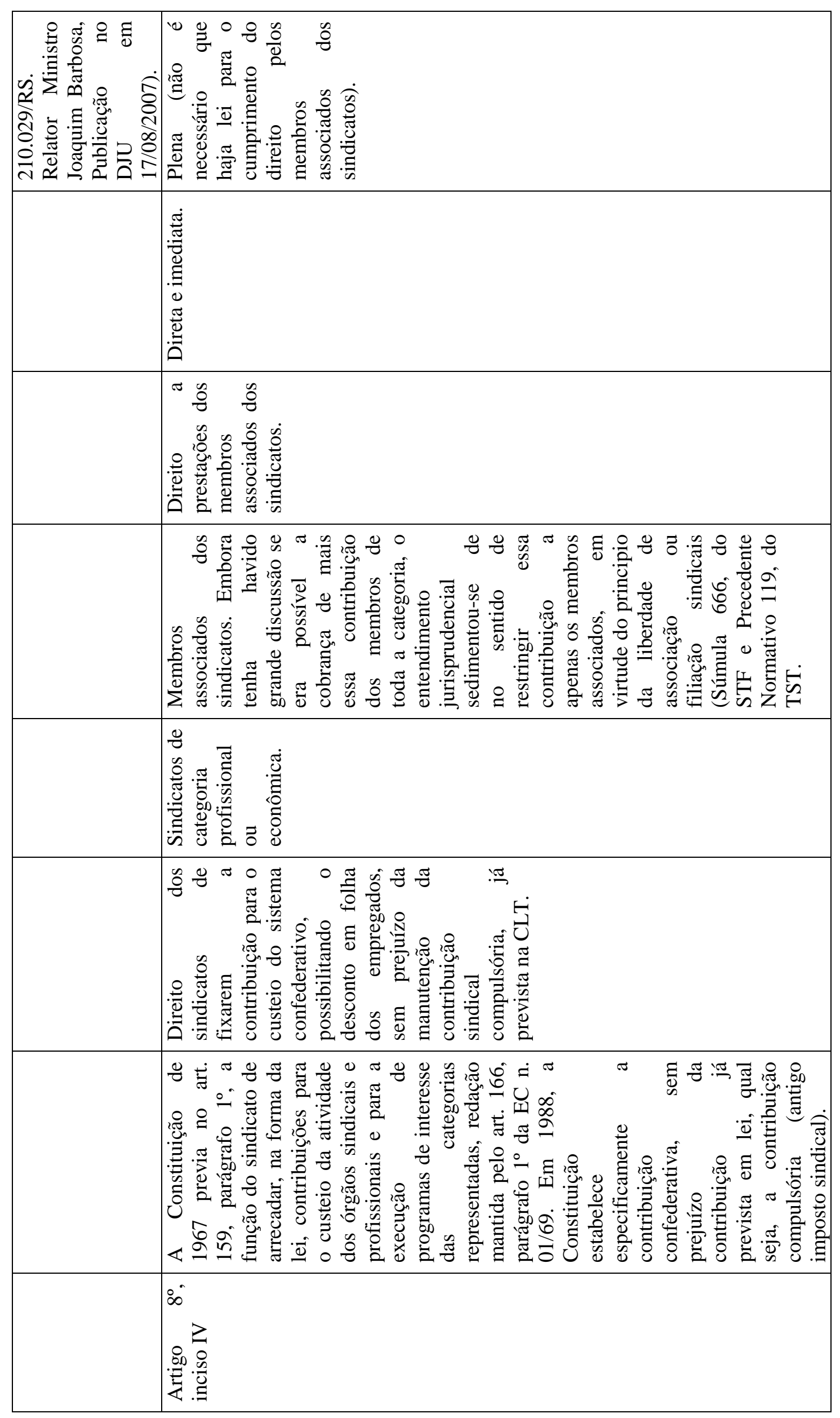




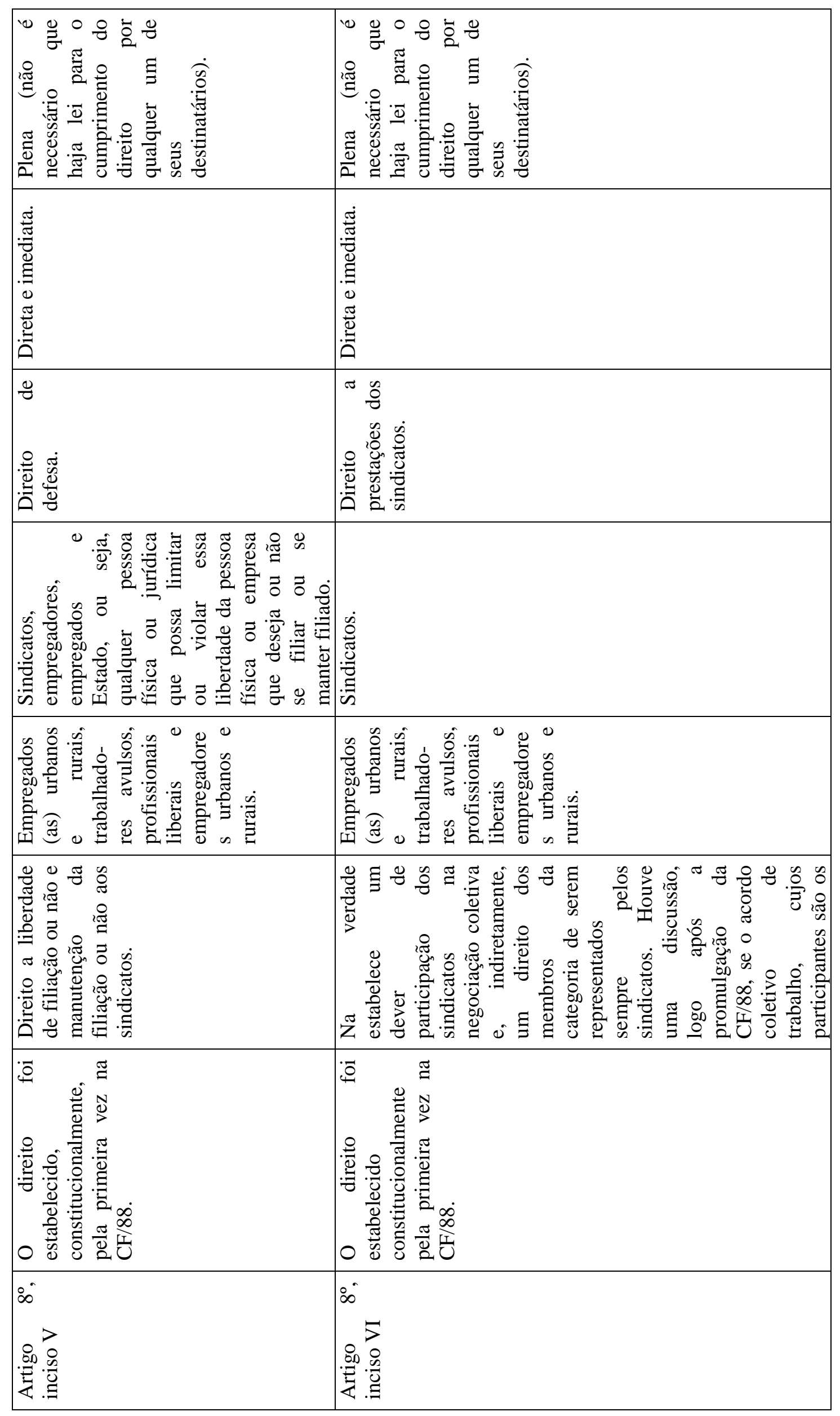




\begin{tabular}{|c|c|c|}
\hline & 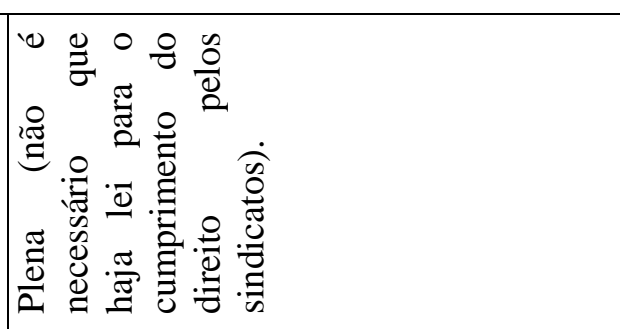 & 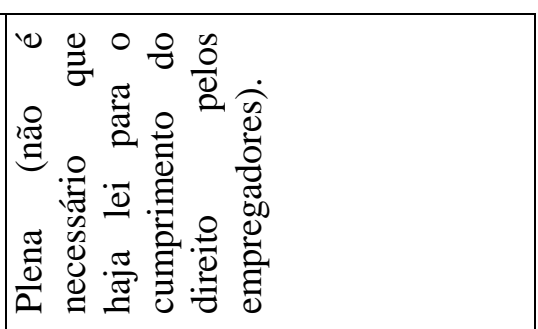 \\
\hline & 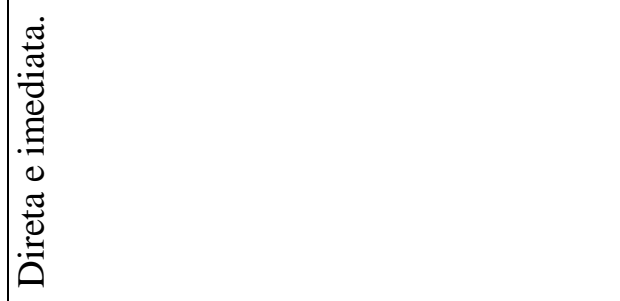 & 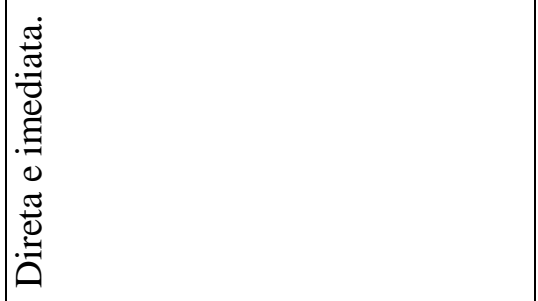 \\
\hline & 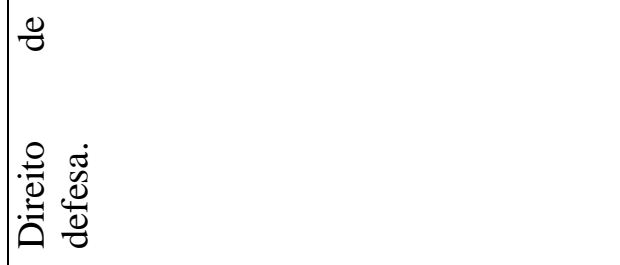 & 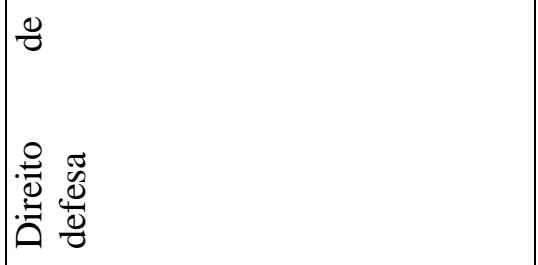 \\
\hline & 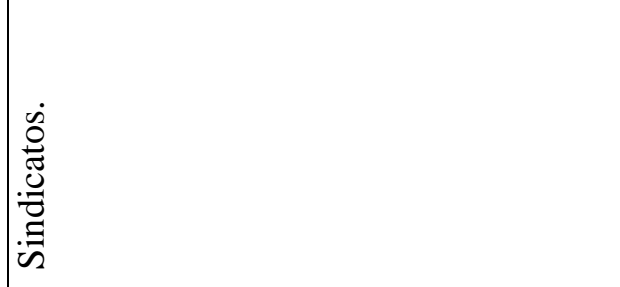 & 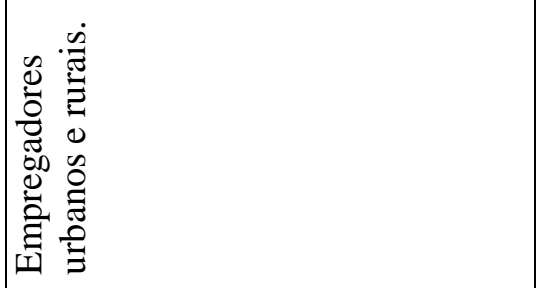 \\
\hline & 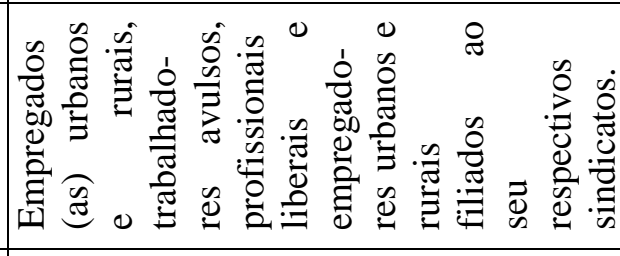 & 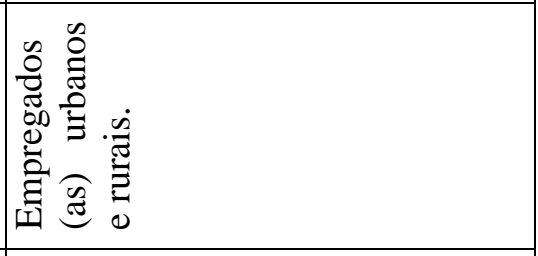 \\
\hline \multirow[t]{3}{*}{ 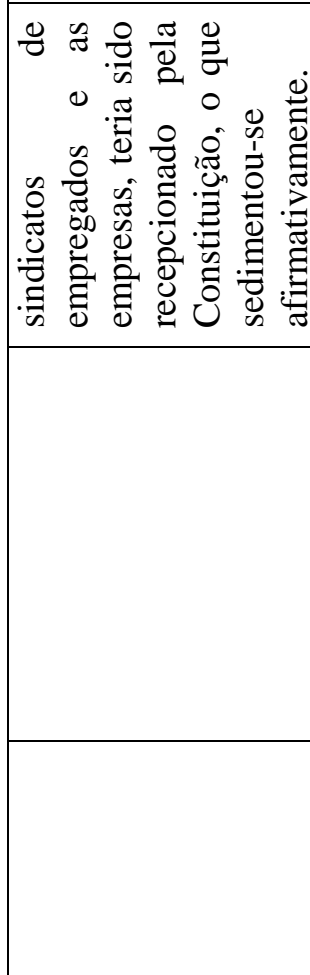 } & 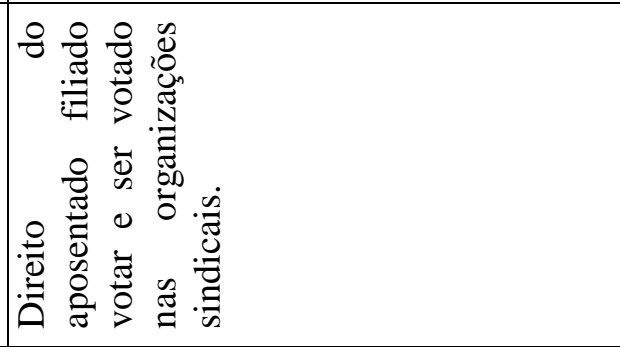 & 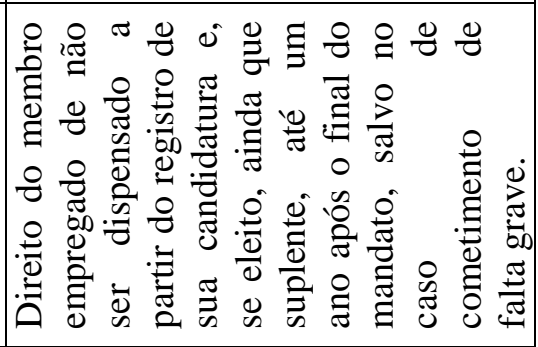 \\
\hline & 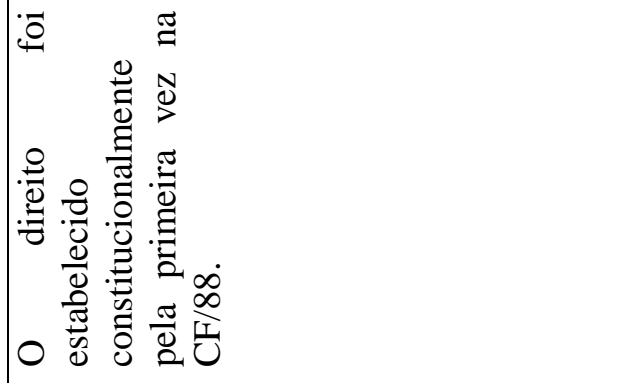 & 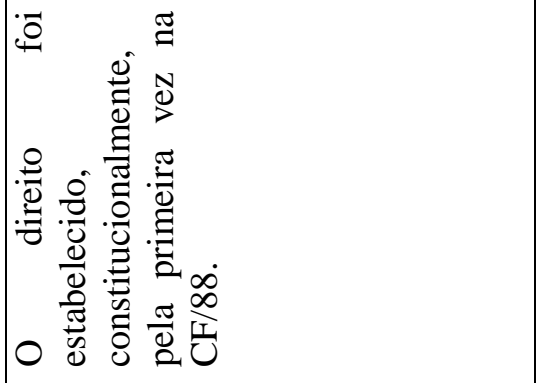 \\
\hline & 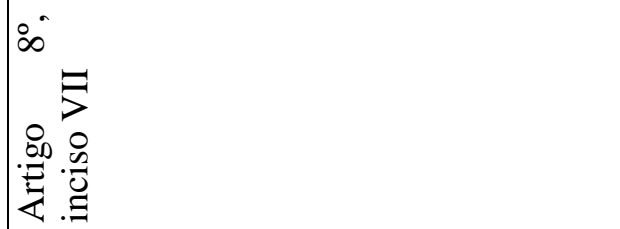 & 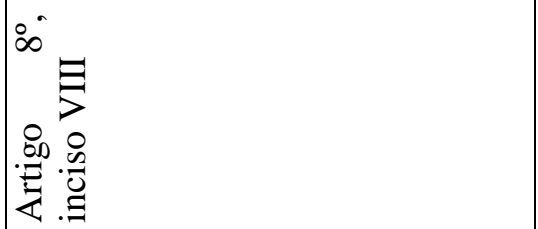 \\
\hline
\end{tabular}




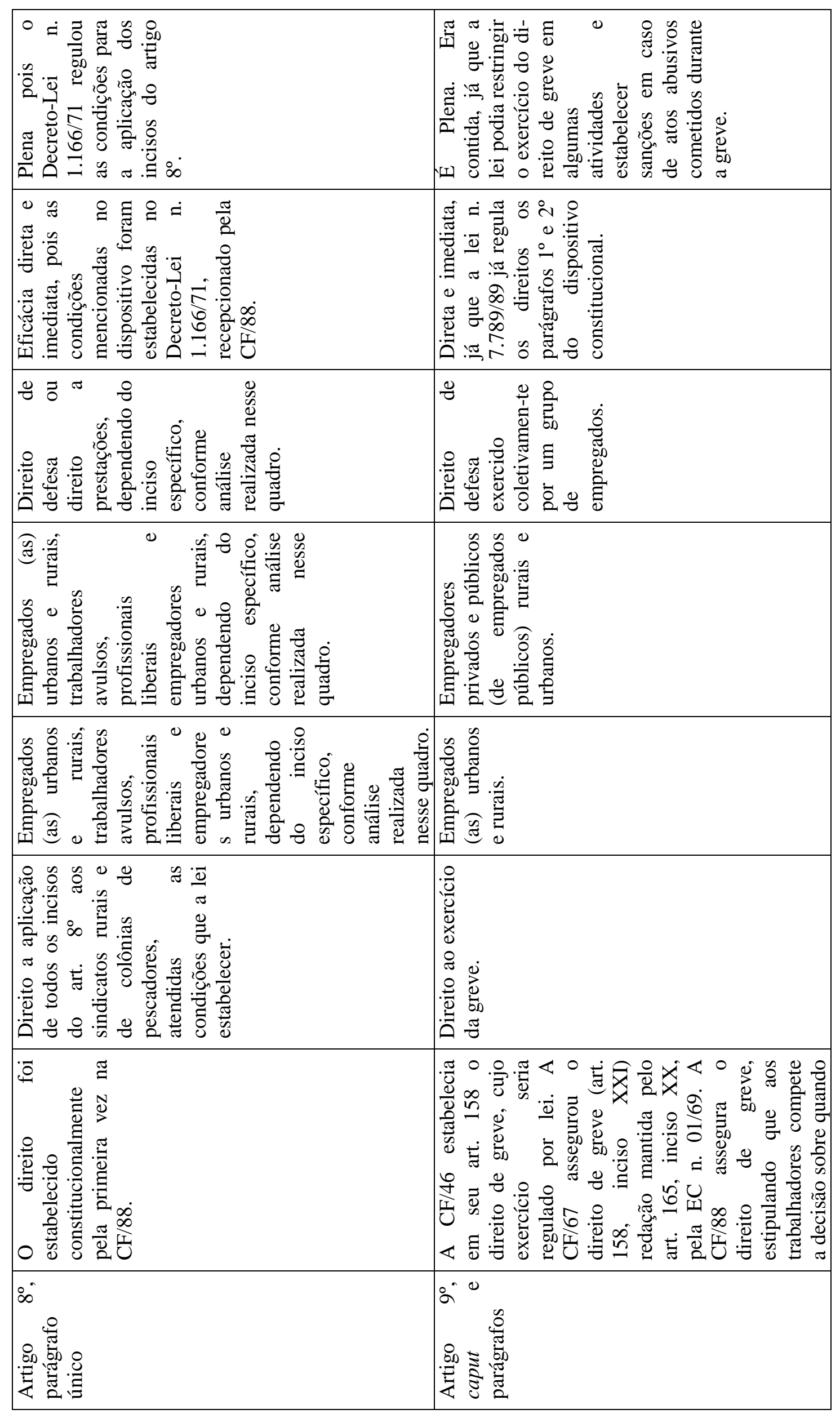




\begin{tabular}{|c|c|}
\hline & 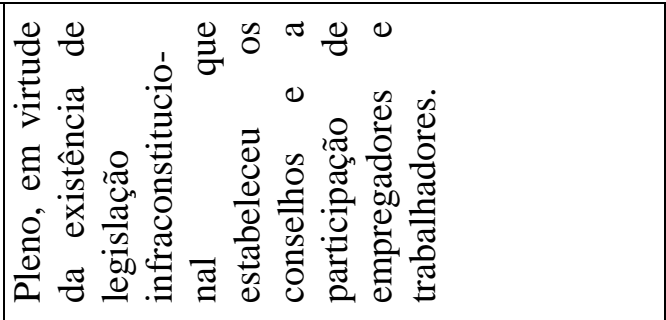 \\
\hline & 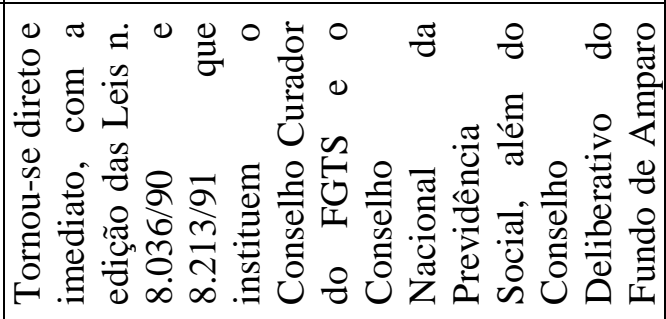 \\
\hline & 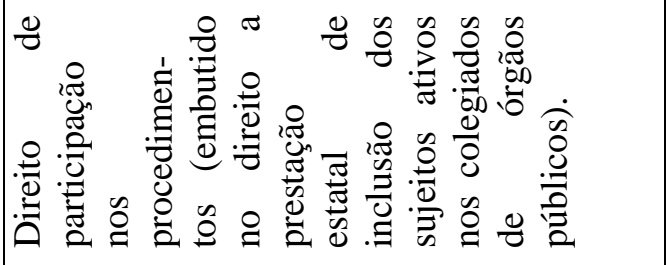 \\
\hline & 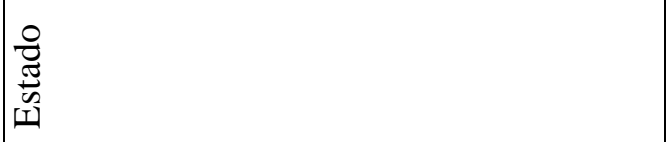 \\
\hline & 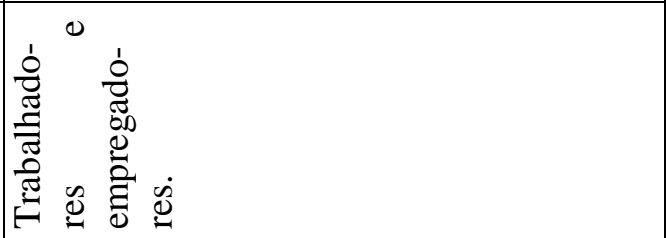 \\
\hline & 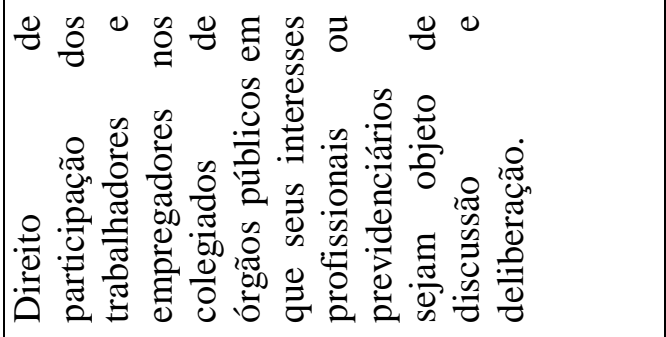 \\
\hline 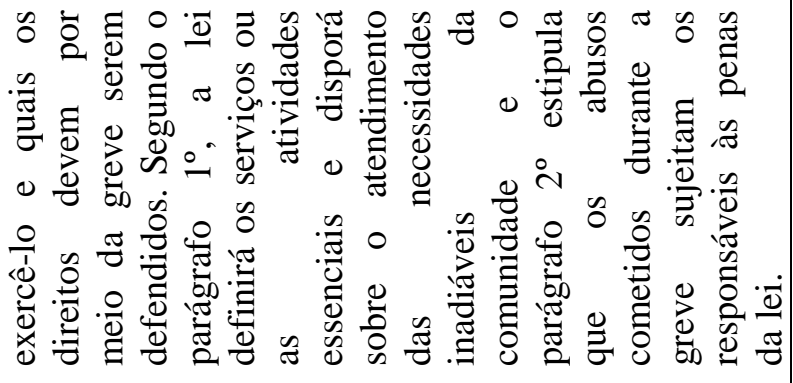 & 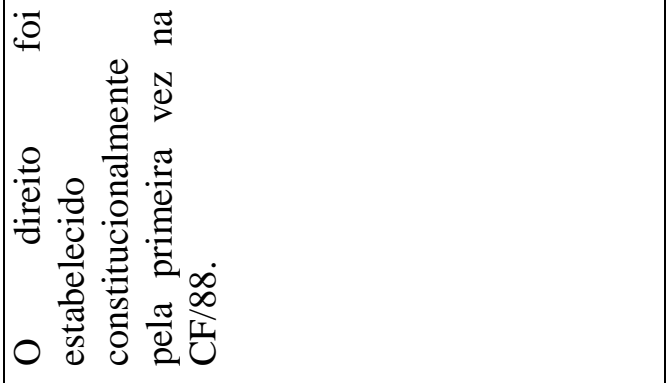 \\
\hline & 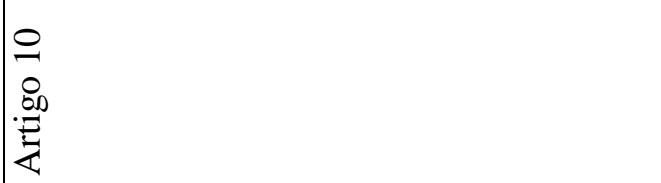 \\
\hline
\end{tabular}




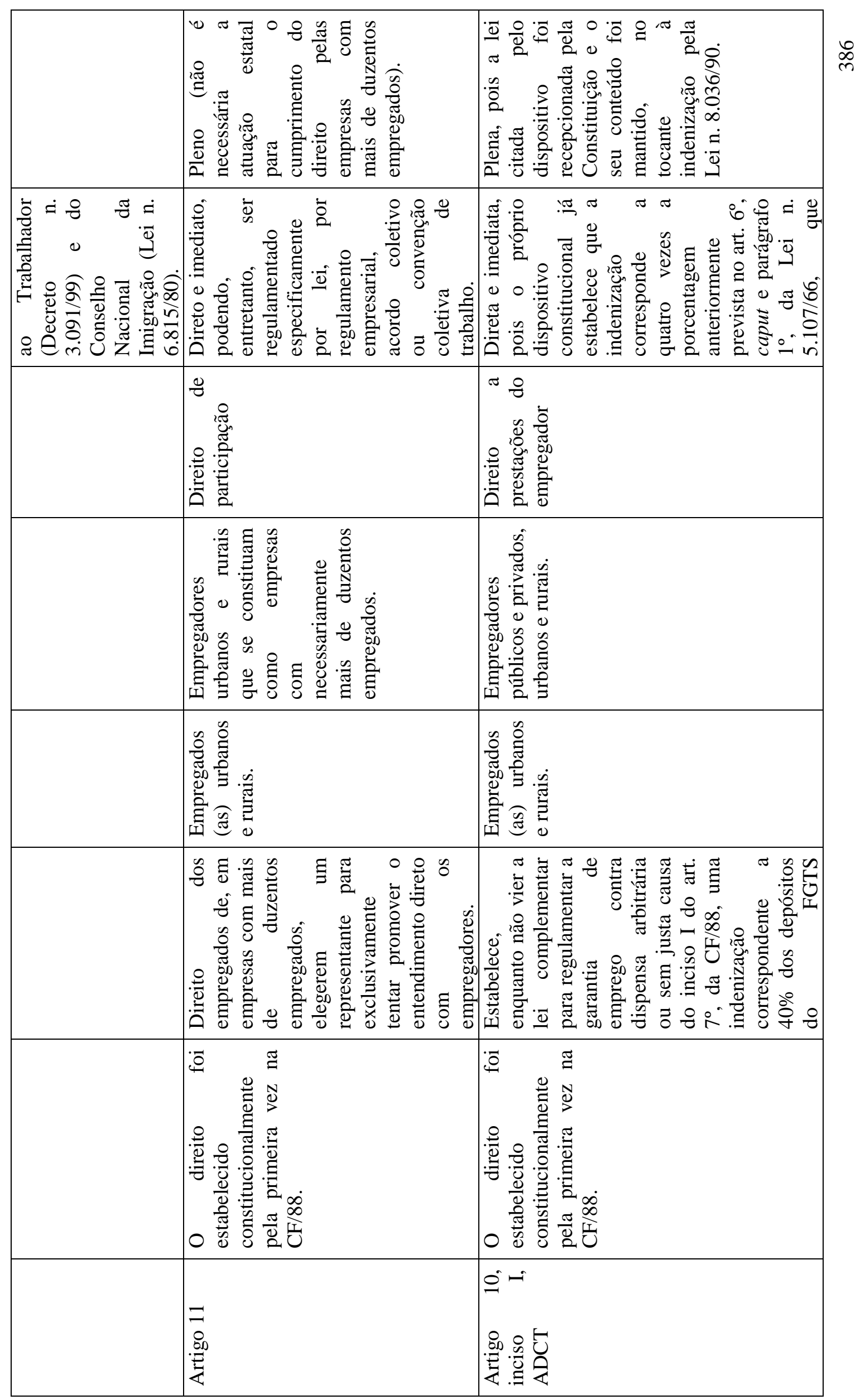




\begin{tabular}{|c|c|c|}
\hline & 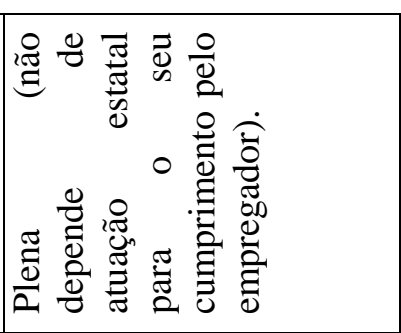 & 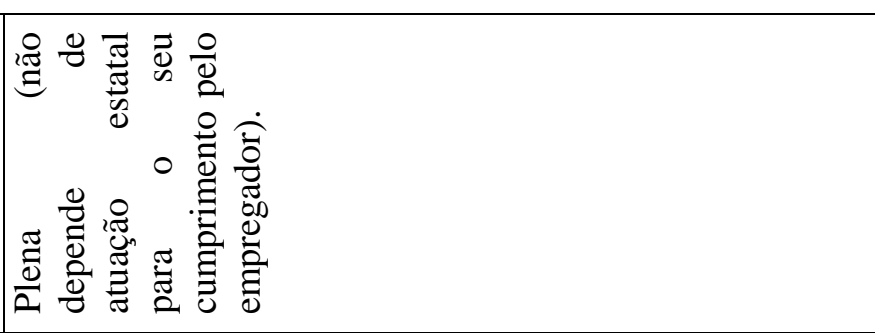 \\
\hline \multirow[t]{4}{*}{ 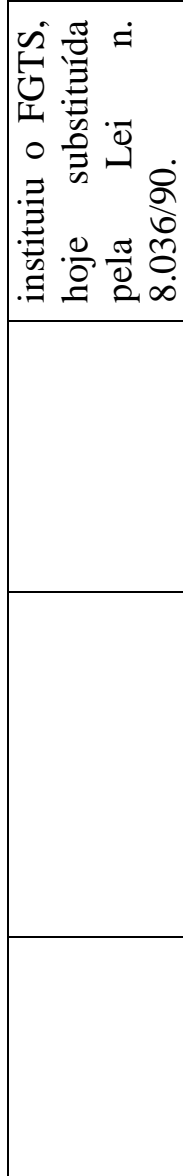 } & 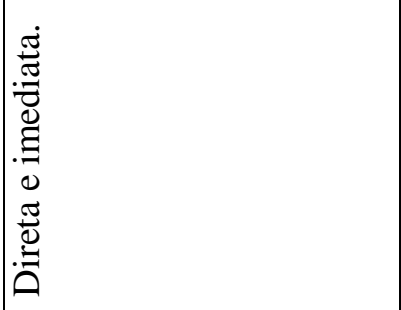 & \\
\hline & 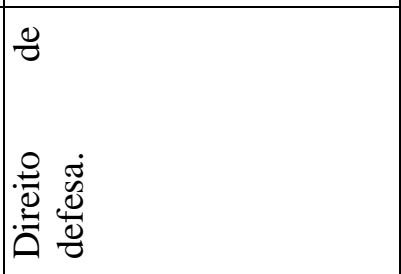 & : \\
\hline & 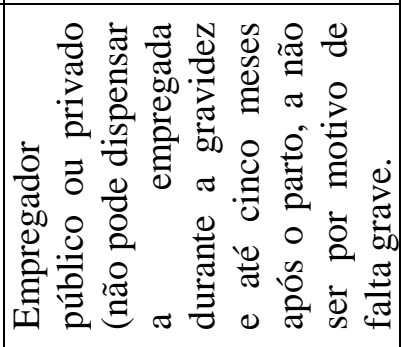 & 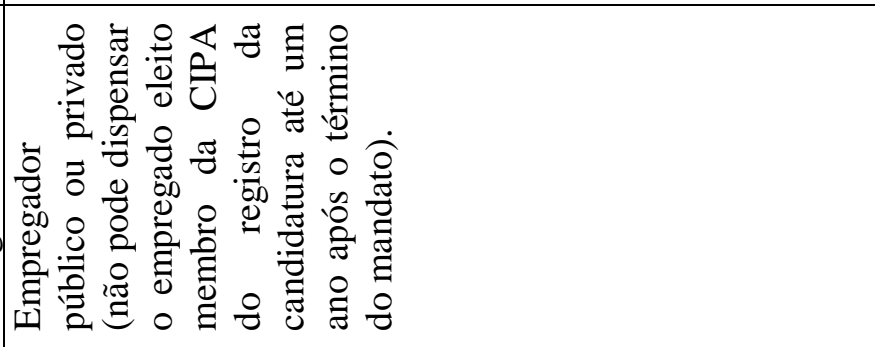 \\
\hline & 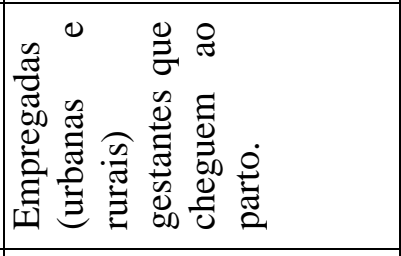 & 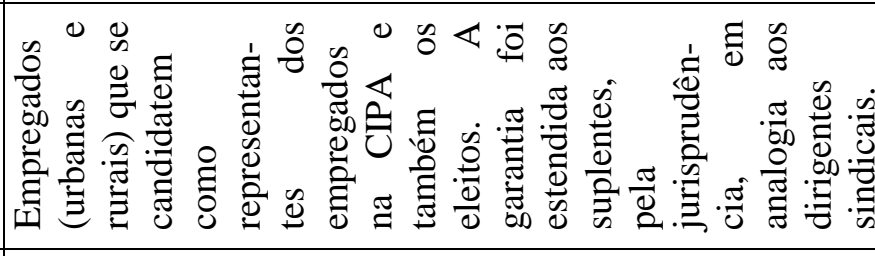 \\
\hline \multirow[t]{3}{*}{$\begin{array}{l}\frac{0}{0} 0 \\
0 \\
0\end{array}$} & 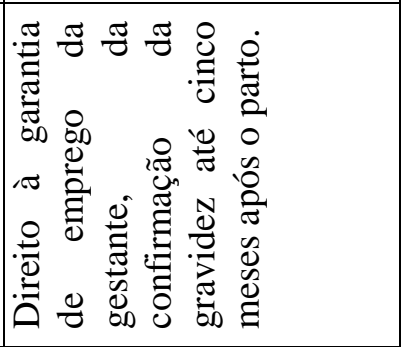 & 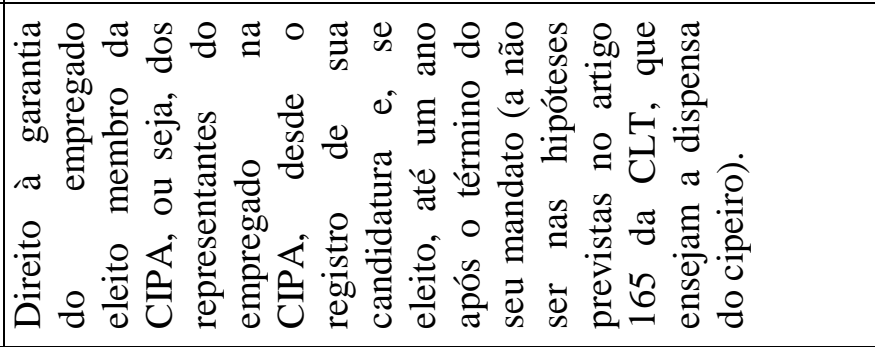 \\
\hline & 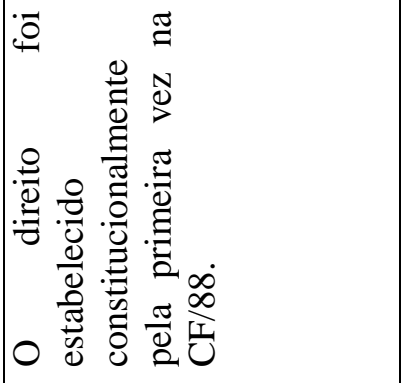 & 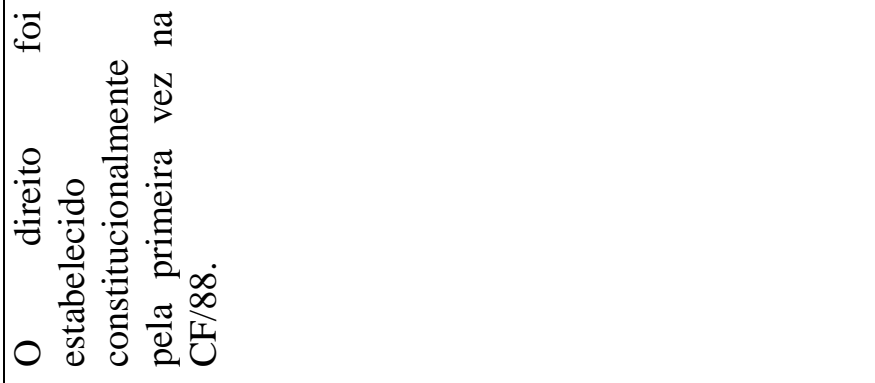 \\
\hline & 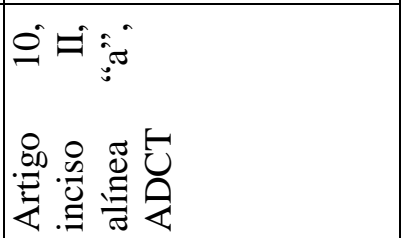 & 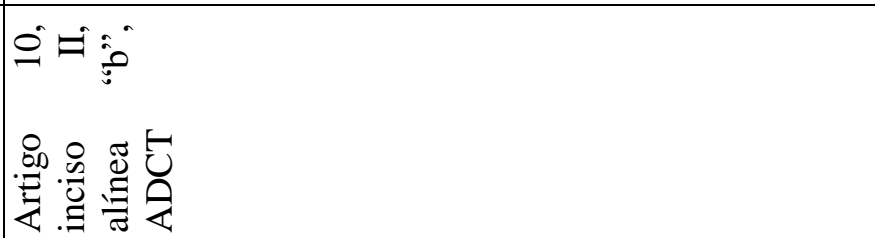 \\
\hline
\end{tabular}


